\title{
PAISAJES EN MOVIMIENTO ESCENARIOS URBANOS DINÁMICOS ENTRE EL ARTE Y LA ARQUITECTURA A FINALES DEL SIGLO XX
}

Ignacio Carbó del Moral 


\section{PAISAJES EN MOVIMIENTO}

ESCENARIOS URBANOS DINÁMICOS ENTRE EL ARTE Y LA ARQUITECTURA

A FINALES DEL SIGLO XX.

AUTOR

IGNACIO CARBÓ DEL MORAL

DIRECTORA DE LA TESIS

PILAR DE INSAUSTI MACHINANDIARENA 
(c) Ignacio Carbó del Moral, 2011

Primera edición, 2011

(c) de la presente edición:

Editorial Universitat Politècnica de València www.editorial. upv.es

ISBN: 978-84-694-6828-9

Ref. editorial: 5502

Queda prohibida la reproducción, distribución, comercialización, transformación, y en general, cualquier otra forma de explotación, por cualquier procedimiento, de todo o parte de los contenidos de esta obra sin autorización expresa y por escrito de sus autores. 


\section{ÍNDICE}

1. Introducción. El paisaje y el movimiento como materiales de proyecto.

2. El paisaje como acontecimiento.

2.1.- Reflexiones en torno al concepto de paisaje. El papel del arte.

2.2. El paisaje como constructo social.

3. El arte de caminar, un recorrido histórico.

3.1.- Peregrinaciones y destierros. Manifestaciones populares entre el arte y la religión.

3.2.- Ejes infinitos. El recorrido en la composición del jardín clásico y barroco.

3.3.- Dentro del laberinto. De Dédalo a Peter Eisenman.

\section{Experiencias entre el arte y el urbanismo en torno al movimiento en el} siglo XX.

4.1.- Urbanismo en movimiento: flâneurs, situacionistas y ciudades nómadas.

4.2.- El dinamismo de la "arquitectura radical" de los años sesenta y setenta.

4.3.- El territorio como paisaje urbano.

4.4.- Arquitecturas fluidas en la segunda mitad del siglo XX.

5. Conclusión: Arquitecturas-paisaje surgidas al hilo del tiempo.

5.1.- Naturalezas urbanas contemporáneas de comienzos del siglo XXI. ... 335

5.2.- Caminando por Paris, un recorrido personal. .................................. 359

5.3.- Un paisaje dinámico: Malas Calles. ................................................. 375

6. Bibliografía. 


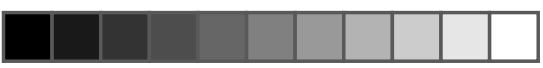

$\oplus$

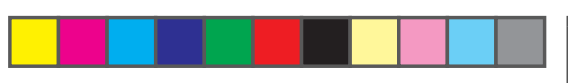




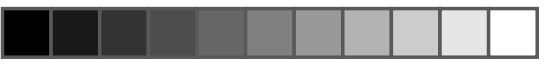

$\oplus$

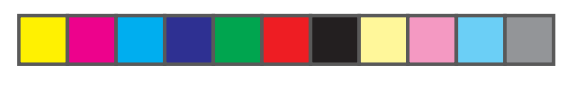

"La obra de arte no se pone en un lugar, es el lugar"

\section{Michael Heizer}



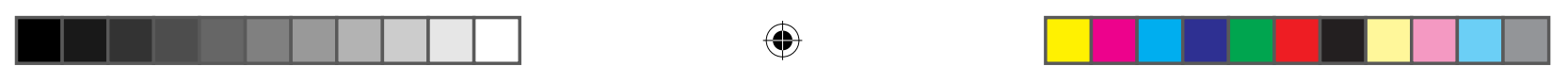

La realización de esta tesis tiene como objetivo fundamental analizar y reflexionar acerca de aquellos escenarios urbanos y arquitectónicos de nueva generación surgidos a finales del siglo XX y principios del XXI que, en mi opinión, están transformando de un modo radical la fisonomía de nuestras ciudades y nuestro territorio. Hablamos de espacios dinámicos que se sitúan entre el arte y la arquitectura, y en los cuales, el movimiento, el recorrido y los procesos son determinantes. Para ello, nos moveremos a lo largo de toda la tesis desde la creación arquitectónica hacia las artes plásticas y viceversa en un diálogo, que espero resulte, fructífero e interesante. Nos aproximaremos a artistas y arquitectos que han reflexionado acerca del entorno que les ha tocado vivir y transformar y quienes han encontrado en el paisaje una valiosísima herramienta de conocimiento. Constataremos, a medida que avancemos en nuestro recorrido, la aparición de profundos cambios en los planteamientos y estudios que tienen como objeto de reflexión la ciudad y el territorio, en tanto que organismos complejos y polifacéticos.

Con este propósito, comenzaremos en el próximo capítulo por fijar nuestra atención en el propio concepto de paisaje, con el ánimo de acotar a qué nos estaremos refiriendo en las siguientes páginas cuando citemos este término. Ya que si consideramos la gran eclosión del término paisaje en los medios como fruto meramente de condicionantes medioambientales o desde el ángulo de los recursos naturales, nos estaremos limitando tan sólo a uno de los múltiples aspectos implicados en este fenómeno, estaríamos cercenando gran parte de la complejidad del problema para permanecer, con toda seguridad, en la superficie de la cuestión. Lo interesante del paisaje es, a mi entender, que necesita de nuestra mirada para llegar realmente a existir como tal. A lo largo de estas páginas, compro- 

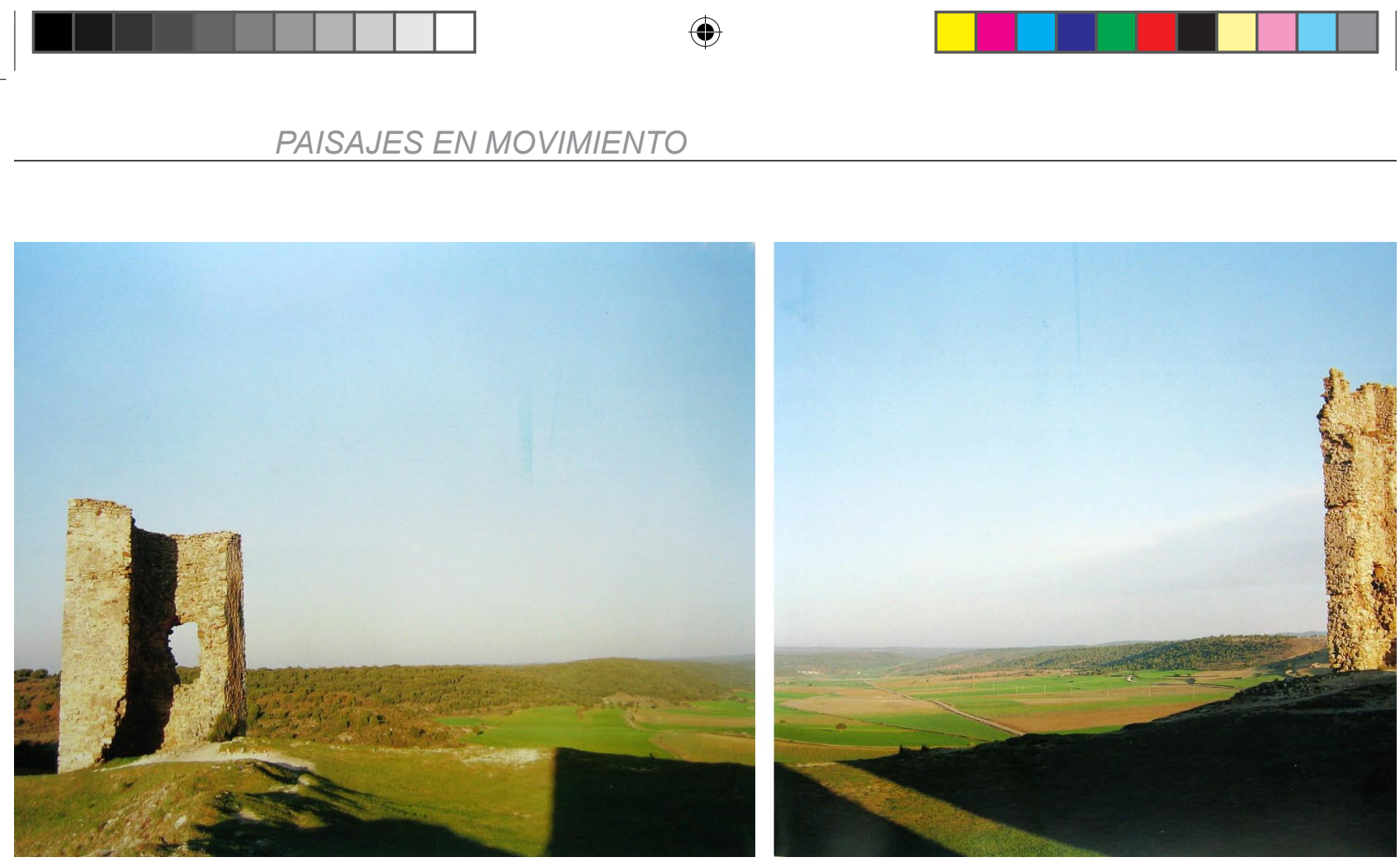

Bleda \& Rosa,Calatañazor en torno al año 1000, 1995.

baremos cómo el paisaje no es sino una mirada al mundo y recordaremos que no existen miradas inocentes o gratuitas, bien al contrario, toda mirada es una construcción cultural, una proyección subjetiva del individuo en el espacio. En este caso es el propio espectador quien se proyecta en un determinado territorio, en un escenario (paisaje) urbano concreto y en dicha proyección hay un elemento clave, primordial: la propia noción que el sujeto tiene de sí mismo y de sí mismo en relación al mundo (antes identificado con la idea de Naturaleza). Este componente de subjetividad ha producido a menudo un vaciado de significado del propio término paisaje pero, en ocasiones, ha supuesto un enriquecimiento del mismo transformándolo en una realidad nueva, estimulante y llena de matices o recursos extraordinariamente sugerentes para arquitectos y artistas.

Nos interesa el paisaje porque éste se ha convertido en los últimos años en una poderosa herramienta de conocimiento en un mundo que ha encogido, que ha reducido su escala de un modo que, en perspectiva, no hace sino asombrarnos. Una reducción de escala del mundo, digamos

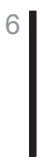



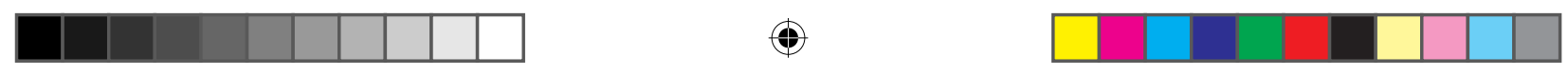

\section{Introducción. El paisaje y el movimiento como materiales de proyecto}

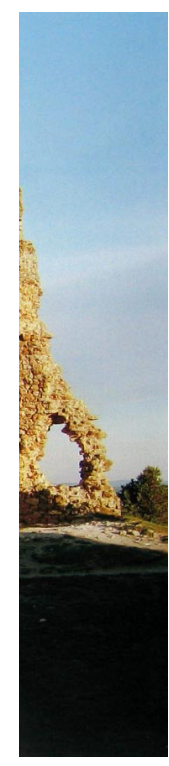

psicológica, que no ha venido acompañada de una disminución en su complejidad. La proliferación en el uso, y en ocasiones abuso, de conceptos como "mundo globälizado" o "aldea global" (cuyo estudio y análisis dejaremos en manos de sociólogos y filósofos), hace referencia a la incapacidad, cada vez más manifiesta, que demuestra el ser humano para comprender e intentar explicar un mundo cada día más diverso, frente al que se encuentra extrañado y en ocasiones perplejo. Es en este contexto histórico y cultural donde encontramos el terreno abonado para que un concepto como el paisaje prolifere y sirva de herramienta, de material de engarce, para la construcción de un renovado edificio cultural (sea por tánto arquitectónico y urbanístico), con el que intentar dar respuesta a dicha realidad.

En la actualidad, al paisaje se le ha liberado del marco, del lienzo, debido, sin lugar a dudas, a la necesidad de ampliar límites y conceptos de modo que éstos nos sean útiles en un nuevo contexto social y cultural. Entender el paisaje pues, como algo estático, como ese punto de vista fugaz, como ese instante breve y fugitivo irrecuperable, si bien no deja de suponer un enorme potencial de gran alcance poético, empequeñece las posibilidades mismas del término, escaqueándonos

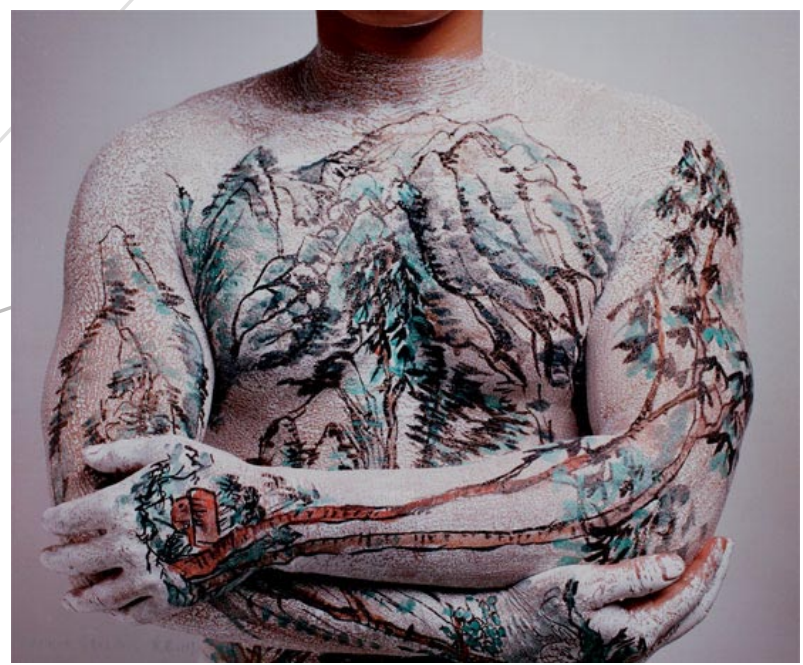

Zhang Huang, Chinese Landscape ,1999. un valiosísimo instrumento de conocimiento y de disección de la realidad. Aferrarnos a viejas definiciones, en ocasiones, no nos deja ahondar en aspectos esenciales del propio término que vuelven más interesante el concepto y más amplias sus posibilidades, enmascarándolos con usos, 

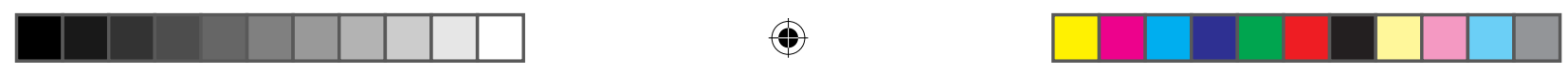

costumbres y lugares comunes adquiridos. Esta intuición y conocimiento de las enormes posibilidades del paisaje está, sin lugar a dudas, en el origen de la mencionada proliferación de escritos y debates acerca del mismo. Así, podemos afirmar, que el paisaje, y por eso partiremos desde él, se encuentra en el núcleo de algunas de las investigaciones más interesantes que se producen hoy en día en torno a la ciudad, el territorio y la arquitectura.

Analizaremos también

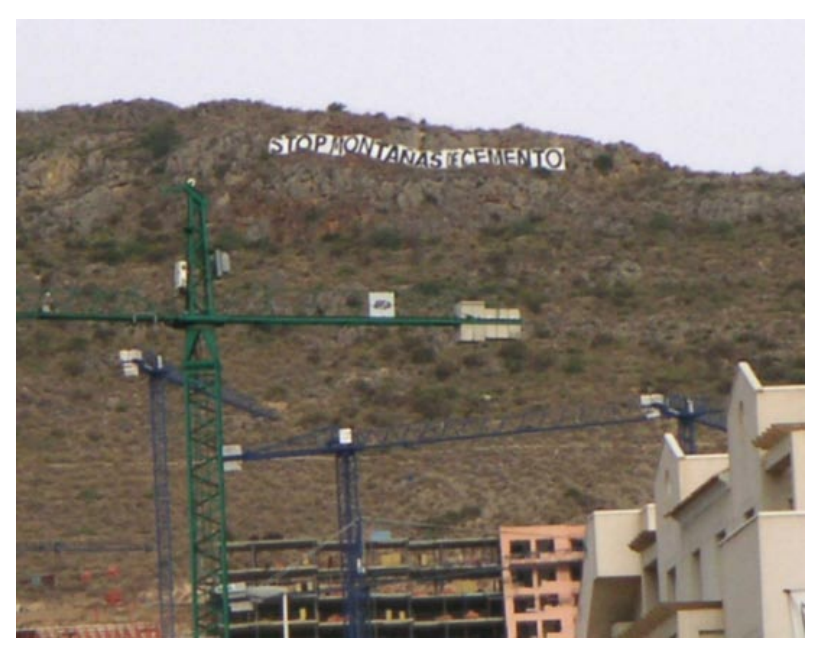

Imagen de una acción llevada a cabo por el grupo Salvemos Mojácar y la costa almeriense para denunciar la destrucción de la costa de Almería. en este primer capítulo a qué es debida (y ésta es una realidad fácilmente reconocible), la existencia de una demanda social cada vez mayor en términos de paisaje. $Y$ es que, en efecto existe, en el cambio de siglo, un incuestionable crecimiento del interés por el paisaje en sectores sociales cada vez más significativos y que antes, si no eran ajenos a dichas preocupaciones, si que adoptaban una posición indiferente frente a ellas. En cambio, hoy en día dichos sectores adoptan una actitud activa, en cuanto usuarios del territorio. Así pues, podemos afirmar que el paisaje resulta más necesario que nunca, y se solicita, cuando no se exige, mejores políticas medioambientales y modelos de desarrollo más respetuosos con el medio ambiente, muy a menudo identificado con éste. Pero a pesar de esta mayor demanda genérica, a medida que intentamos ser más específicos y nos acercamos al núcleo de dicha demanda, el planteamiento se torna confuso y se convierte en un conjunto de reivindicaciones que, sin con- 

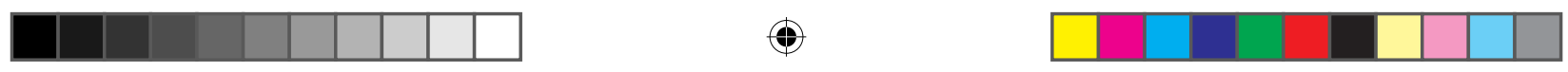

cretarse, se transforman en una visión poliédrica y multifacética. No podía ser de otro modo si intentamos aproximarnos a esta nueva realidad, a la complejidad que encierra el propio término paisaje en nuestros días.

Una rápida sobreexplotación del territorio y el consecuente cuestionamiento de la idea misma de progreso, tal y como se entendía a comienzos del siglo $\mathrm{XX}$, han traído consigo una fuerte oposición, tanto por parte de ciudadanos anónimos, habitantes o usuarios de la ciudad y el territorio, como por parte de sectores cada vez más amplios de profesionales vinculados con su estudio y tratamiento. La conciencia de la escasez de los recursos naturales, que ya no se consideran ilimitados, que ya no son la fuente inagotable e incuestionable de prosperidad que fueron durante siglos, hace que éstos en la actualidad sean contemplados en su justa fragilidad y vulnerabilidad. Esto hace que el número de asociaciones, publicaciones y debates en torno al tema no haga sino aumentar a un ritmo vertiginoso. Decisiones de índole política que hace tan sólo unas décadas, cuando no unos años, se tomaban sin ninguna contestación social e incluso con la complicidad de amplios sectores sociales, en la actualidad son fuente de fuertes controversias.

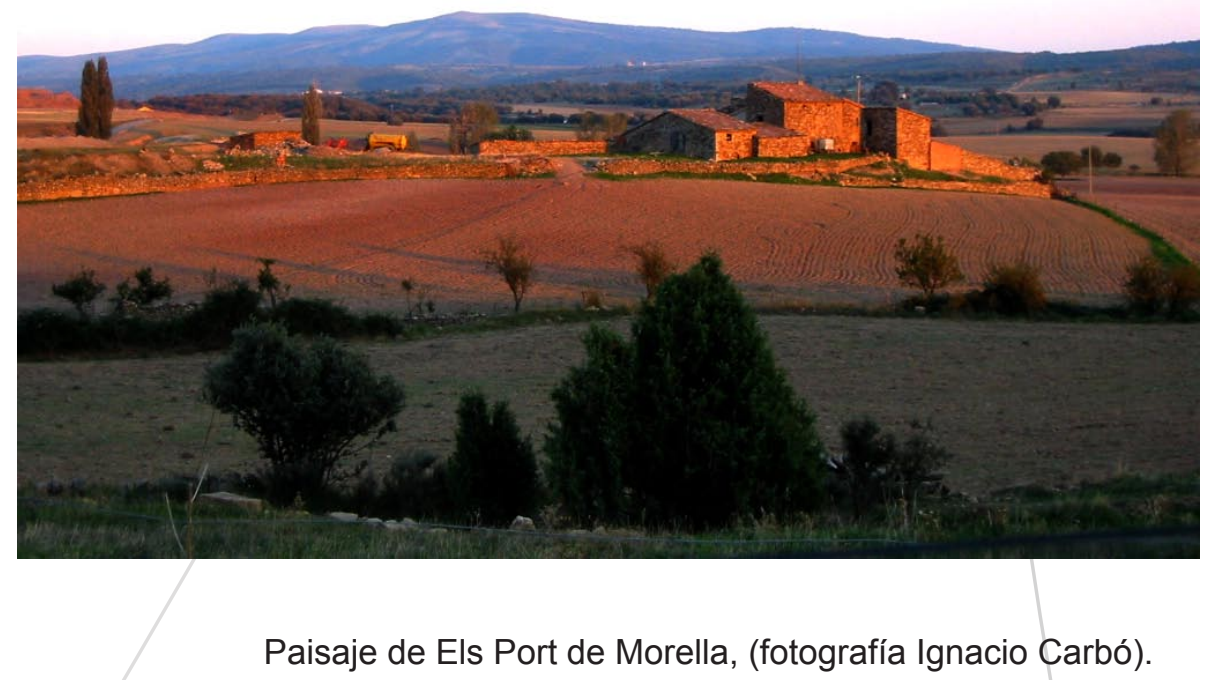



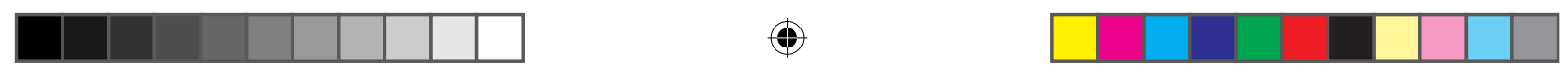

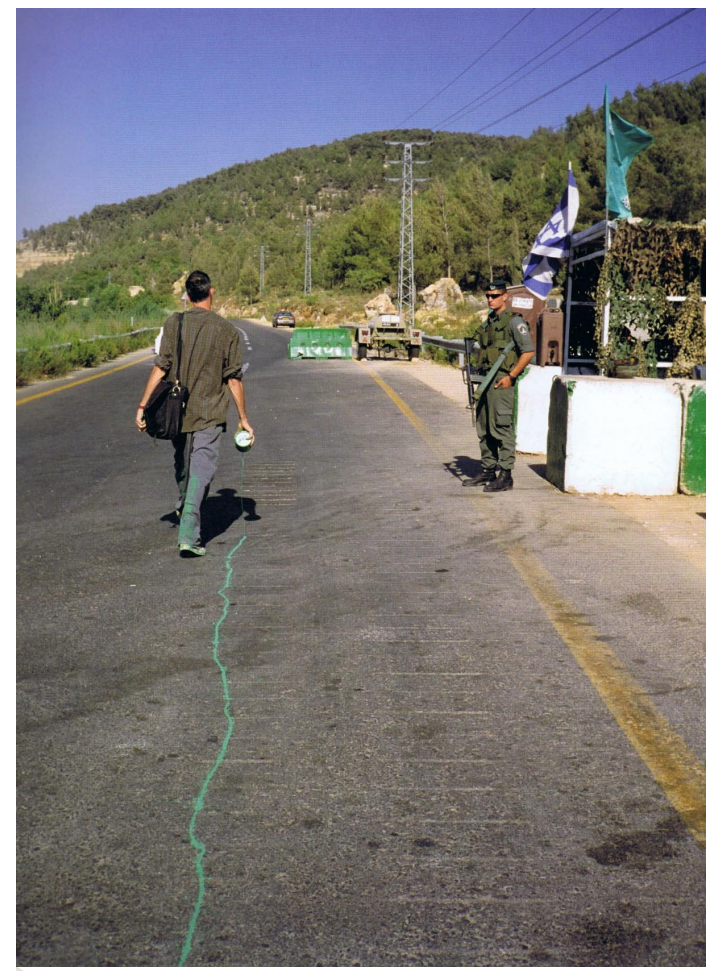

Francis Alys, La línea verde, 2004.
Así, una vez acotado el término paisaje y situados ya de lleno en este ámbito, nos aproximaremos a continuación al movimiento y al recorrido como interesantes y fructíferas herramientas de proyecto, apoyándonos para ello tanto en ejemplos surgidos de diversas situaciones geográficas que ampliarán nuestros puntos de referencia, como en distintos momentos históricos, en mi opinión, especialmente significativos y densos en experiencias y significados. En una primera parte pondremos nuestra atención en el "arte de caminar", el cual nos invitará a echar la vista atrás y recordar el pasado nómada del ser humano, pasado aún presente en algunos puntos del planeta como

Mongolia. El intenso y prolífico diálogo entre el componente nómada (o dinámico) y el componente sedentario (o estático) del ser humano forma el núcleo central del tercer capítulo. La construcción del espacio arquitectónico y del paisaje se produce, en las experiencias que veremos, fundamentalmente en un plano claramente simbólico y referencial. De este modo, analizaremos el nomadismo debido a su enorme capacidad de producción de paisajes metafóricos en transformación constante, producción que se da de un modo muy sugerente en ciertos ámbitos y territoriọs que en el mundo occidental son a menudo olvidados.

El nomadismo nos conducirá hacia las civilizaciones primigenias de Oriente Próximo, con la intención de comprobar la importancia que esta componente dinámica del ser humano todavía tenía en estos pueblos y seguir su rastro en la fascinante arquitectura (y manipulación del

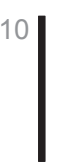




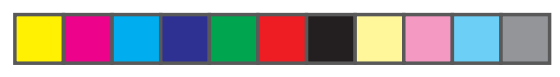

territorio) que produjeron, y que todavía hoy en día sigue interesándonos y seduciéndonos. Tras una pequeña parada en Mesopotamia y sus grandes zigurates y avenidäs procesionales como la del Templo de Marduk, nos acercaremós a Egipto. Aquí, la concepción que tenía el pueblo egipcio de un mundo en constante y perpetuo renacimiento y renovación, de una vida entendida en tanto que "eterno vagar", tuvo una grandiosa plasmación en templos y avenidas que aún podemos recorrer en la actualidad. conoceremos hasta qué punto el movimiento, pensado desde una adecuada cadencia y un correcto ritmo, construía el paisaje y la arquitectura egipcios, al concebir los espacios, tanto exteriores como interiores, para el tránsito y no la permanencia, y simultáneamente, para durar eternamente en un movimiento un millón de veces repetido.

Mesopotamia, Grecia y Egipto nos servirán de preámbulo para aproximarnos a continuación a aquellos paisajes simbólicos surgidos desde una fuerte componente religiosa y cuya manifestación más eviden-

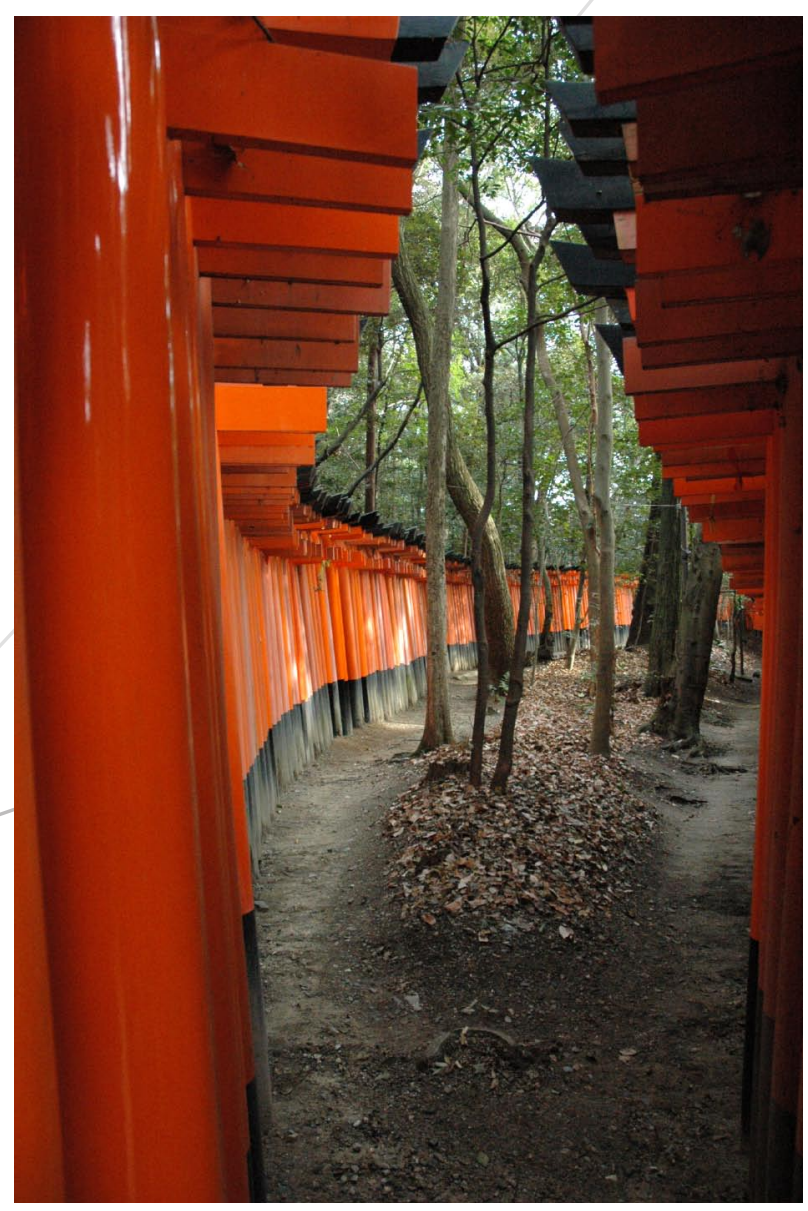

Templo de Fushimi Inari, Kyoto, (fotografía I. Carbó). te es el viaje y el camino. Comenzando en el maravilloso templo sintoísta de Fushimi Inari en Kioto en Japón y tras recorrer sus caminos serpenteantes por las laderas próximas a Kioto (construidos mediante la concatenación de puertas (tori) na- 

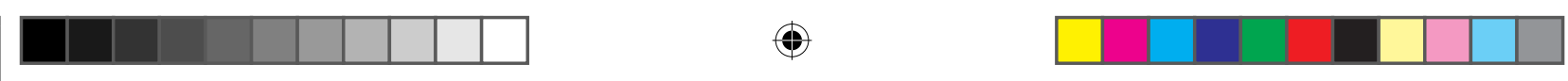

ranjas), avanzaremos después al ritmo de los monjes budistas de Luang Prabang (Laos) en su ruta diaria al alba por las calles de la ciudad, con el ánimo de comprender la rotundidad y la profundidad que puede alcanzar un paisaje que no necesita de construcciones sólidas ni permanentes para demostrar su enorme complejidad, su capacidad sugerente y simbólica. Estas experiencias arquitectónicas-religiosas asiáticas, y las transformaciones que producen diariamente en el paisaje, nos servirán como espejo donde comprobar qué fue del componente nómada del ser
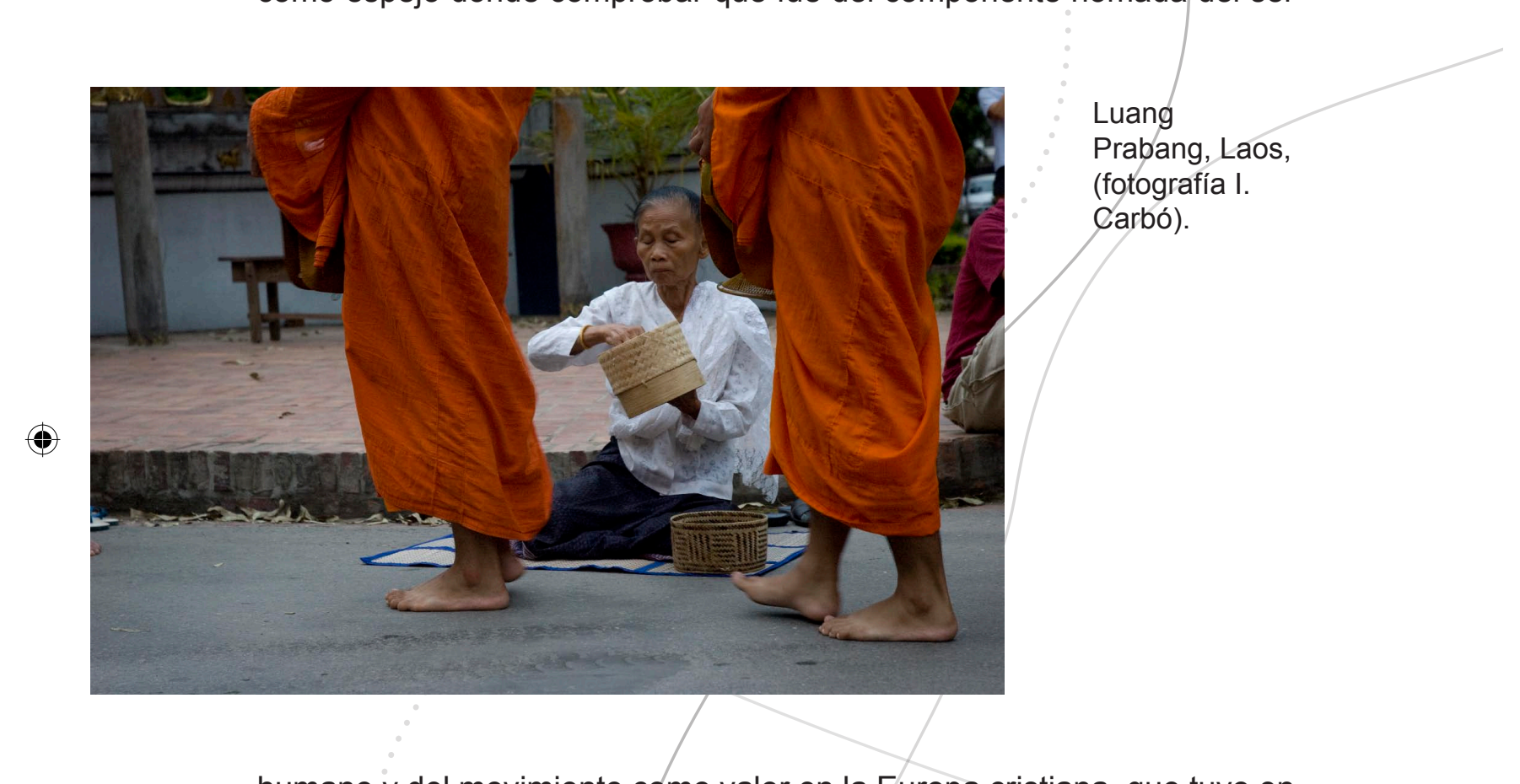

humano y del movimiento como valor en la Europa cristiana, que tuvo en la figura del Homo Viator uha pieza clave de su conformación.

Desde las primeras representaciones de la expulsión de Adán y Eva del paraíso, también la humanidad se encuentra en un caminar perpetuo que no se ha detenido todavía. Así, el deambular del ser humano tomará como metáfora fundamental la figura del peregrino (figura que sirvió, de hecho, para intercomunicar las diferentes culturas de las diversas partes del continente). Las culturas cristianas, en su recorrido por la vida y sus peligros, tendrán como modelo a imitar a Cristo, a quién debe- 

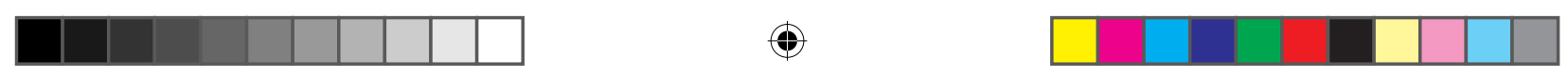

rán seguir los pasos. Caminos procesionales, calvarios ideados para su recorrido litúrgico, o rutas peregrinas son los exponentes vitales de esta cultura de construcción de espacios y paisajes dinámicos pensados para el movimiento y que se activan cuando éste se produce.

Siguiendo el rastro del dinamismo inherente a los paisajes humanos, no nos detendremos en estas experiencias efímeras y simbólicas que acabamos de ver, sino que nos centraremos a continuación en las grandes actuaciones paisajísticas de los siglos XVI y XVII europeos, en el arte de los jardines clásicos y barrocos, con el objetivo de descubrir una doble lectura de los mismos que enriquece la estrictamente formal y compositiva. Con esta intención, haremos antes un alto en el camino para viajar hasta Egipto (al Templo de Hatsepsut) y Camboya (los templos de Angkor) que nos ayudará a entender mejor estos conjun-

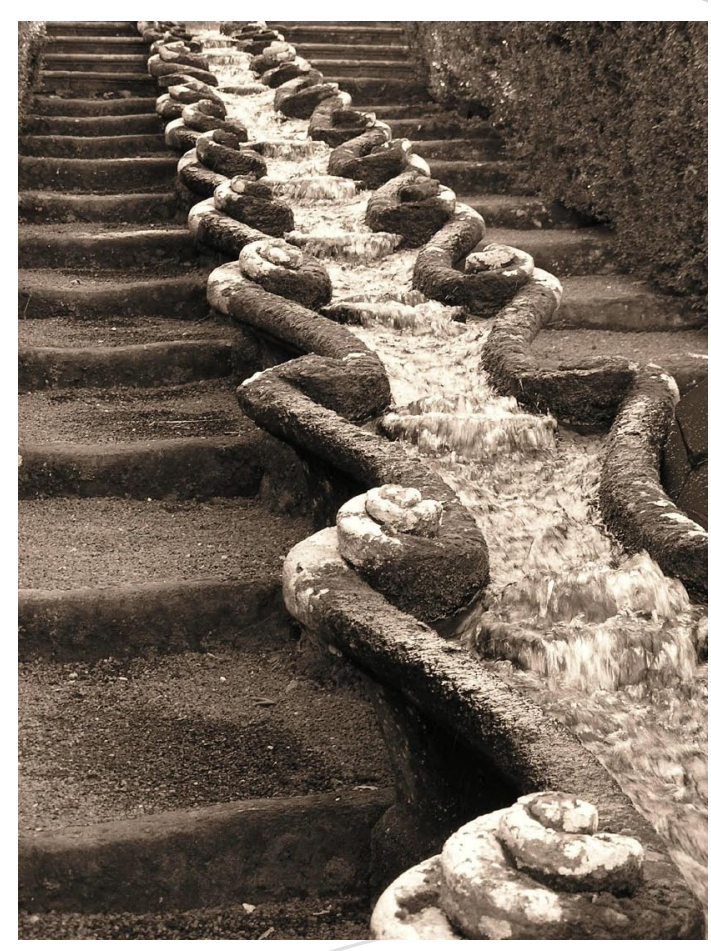

Villa Lante, Bagnaia, Cadena de agua. tos. Recordaremos la enorme importancia que tiene en los jardines clásicos la linealidad y los recorridos, a menudo plagados de sorpresas y divertimentos para sus visitantes, que deben ser descubiertos paseando por ellos, en su justo momento y en su precisa secuencia. No es casual la especial atención otorgada al jardín en este momento, ya que frente a una arquitectura construida con piedra más estricta y coercitiva, se le reconoce su capacidad para sugerir e incorporar significados alegóricos y simbólicos que enriquezcan la realidad de sus promotores y visitantes, (a quién a menudo, los primeros, desean sorprender). La Villa Lante en Bagnaia y el Jardín grande de Caprarola 

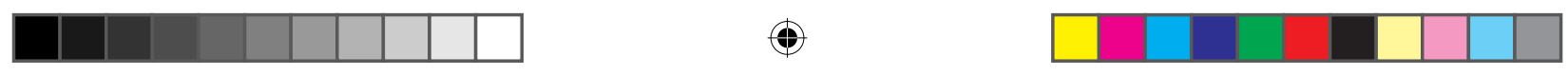

serán los ejemplos paradigmáticos de estas relaciones dinámicas entre la naturaleza y la arquitectura en una Italia que servirá de referencia posterior a Europa entera, mientras que el barroco francés estará ejemplificado en Vaux-le-Vicomte, donde la supuesta estaticidad del conjunto se transforma en mera ilusión óptica a medida que avanza nuestro recorrido, y, cómo no podía ser de otro modo, en el Castillo de Versalles. Aquí será el

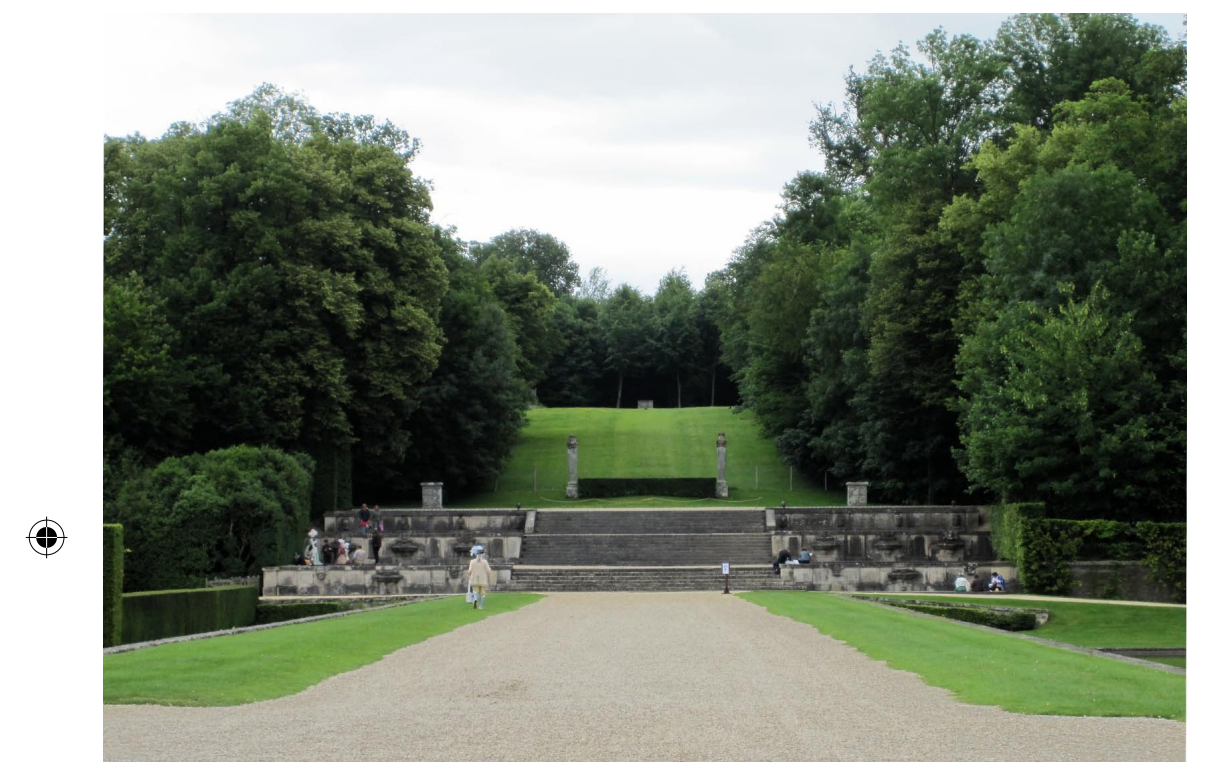

Castillo de Vaux-le-Vicomte, Maincy, (fotografía I.C.).

propio Luis XIV quién nos guiará en el "correcto" recorrido por unos jardines concebidos para la mayor gloria de Francia y su soberano.

Finalmente, haremos en este capítulo una parada en un espacio verdaderamente especial por su propia naturaleza, me estoy refiriendo al laberinto. Ariadna, Teseo y el Minotauro nos acompañaran en este viaje y nos dejarán en la puerta de acceso al laberinto, para que entremos en él y que nos perdamos en su interior, para que experimentemos un espacio concebido netamente para el movimiento, para el recorrido, en el cual, extraviarse y volver a encontrarse, resulta una vivencia personal extraña y 

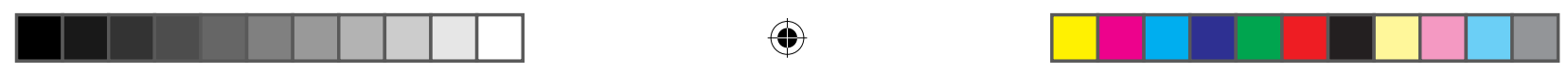

\section{Introducción. El paisaje y el movimiento como materiales de proyecto}

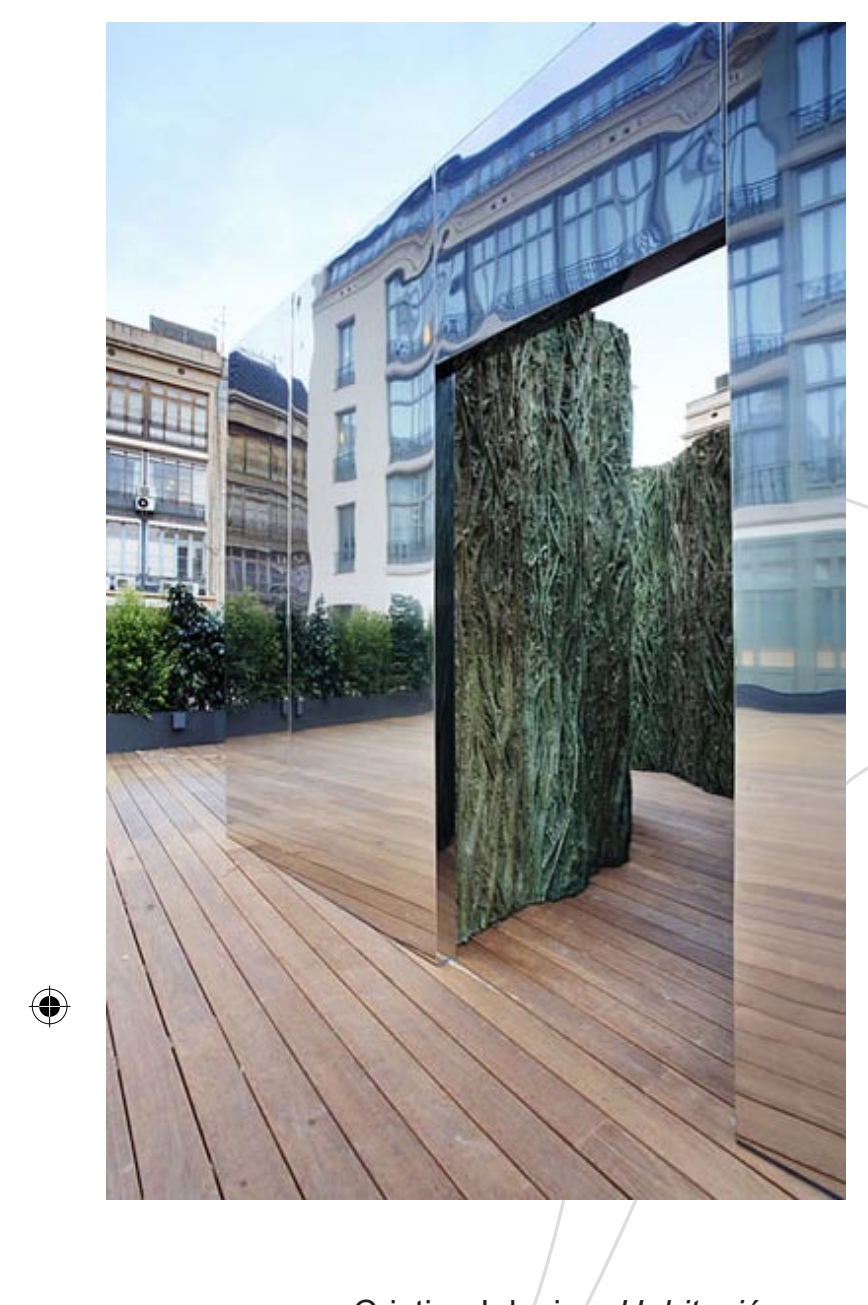

Cristina Iglesias, Habitación verde XV (doble pasaje), 2008. enigmática que conserva intacta toda su capacidad sugerente. Es a nosotros mismos a quién nos enfrentamos cuando nos adentramos en sus límites. Esa "casa hecha para que uno se pierda" tal y como la llamó el escritor argentino Jorge Luis Borges (tal vez quién mejor comprendió los secretos del laberinto), se puede intentar clasificar y tipificar, como veremos de muy diversos modos, como por ejemplo, según el número de posibilidades de elección de recorridos, según los materiales o siguiendo otros parámetros, pero siempre está vinculada a un viaje iniciático, con una fuerte componente mística, filosófica o lúdica según los contextos históricos y culturales de cada momento.

A través de estas primeras, y en cierto modo más genéricas experiencias, llegaremos (en el cuarto capítulo de esta tesis), al siglo $\mathrm{XX}$ y nuestro escenario pasará a ser la ciudad, el espacio urbano. La novedosa lectura que hizo Walter Benjamin de la vida en la ciudad, en cuanto superposición de experiencias fragmentadas y discontinuas, le llevó a la defensa de lo que él denominó el "arte de extraviarse", postulando callejear sin meta aparente, con el fin último de encontrar nuevos caminos y posibilidades. El desplazamiento en el espacio urbano del propio individuo aparece así como generador de nuevos significados. La figura fundamental para entender este contexto y sus inquietudes es el flâneur, quién hace de la ciudad su hogar, caminado sin 

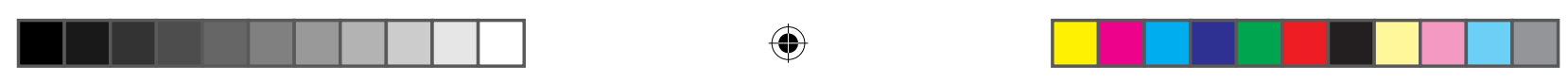

destino alguno, gozando con lo que la gran ciudad le ofrece a su paso. Este personaje clave está, sin duda, en el origen de las experiencias posteriores del grupo DADA. Las "incursiones urbanas" Ilevadas a cabo por este colectivo de artistas e intelectuales por la ciudad de Paris, que debían arrancar con la visita a Sant Julienle Pauvre, desencadena-

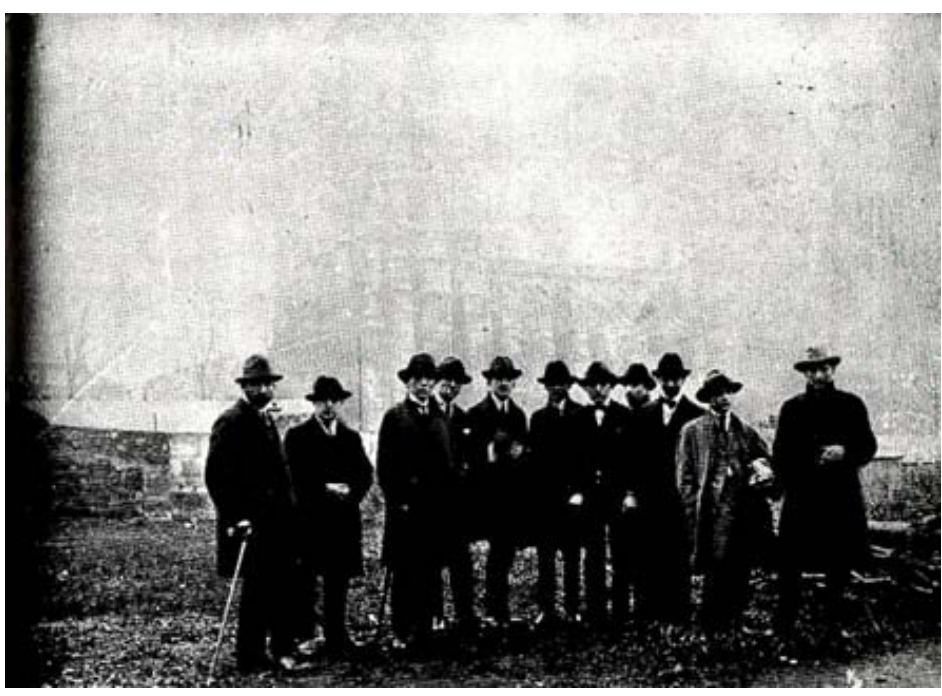

Fotografía del grupo DADA en su visita a Sant Julien-le-Pauvre, Paris, 1921. ron posteriormente en las "deambulaciones" de los surrealistas por el centro de Francia. A pesar de que tanto las incursiones como las "deambulaciones" tuvieron un corto recorrido en el tiempo, el testigo fue recogido posteriormente por la Internacional Situacionista para cuyos miembros, el hecho de perderse en la ciudad ya no conservaba su carácter lúdico y poético sino que se había convertido en una útil herramienta de intervención político-artística. El concepto situacionista de deriva, (cuyo mayor impulsor fue Guy Debord) buscaba evitar dejar huellas físicas en la ciudad, en una clara apuesta por un espacio urbano dinámico y fluido modificado constantemente. Junto a Guy Debod, el miembro más destacado de la Internacional Situacionista, fue Constant, cuya propuesta más conocida e interesante (a la que dedicó muchos años de su vida), New Babylon, nos propone una ciudad nómada que transforma el territorio por el que pasa en un espacio de la memoria.

El proyecto de New Babylon de Constant, resulta fundamental para comprender las experiencias posteriores que se llevaron a cabo en las décadas de los años sesenta y setenta del siglo pasado y que tuvieron

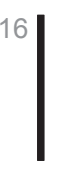



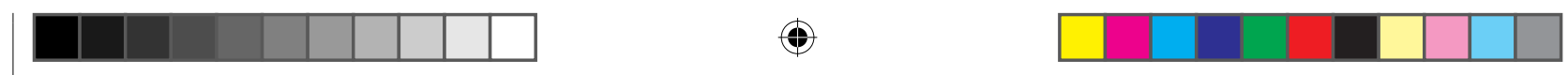

como protagonistas a colectivos de arquitectos (Archigram o Archizoom) y artistas como Kryztoszf Wodiczko. Todos ellos compartieron un profundo deseo de transformación social que debía materializarse en el ámbito de la ciudad. Para llevar a cabo esos cambios, el dinamismo y la movilidad tendrán un papel muy destacado, así como los avances tecnológicos, que suponían, a su entender, una perfecta herramienta de cambio social. Proyectos como Plug-in-city o Walking City, ambos de Archigram, nos hablan de ciudades móviles, que "caminan", que están listas para interactuar con el territorio al que llegan, realizando un urbanismo indeterminado y dinámico que sitúa la ciudad en un ambiente nómada a expensas de la voluntad de sus habitantes. Por su parte, Wodiczko intenta dar respuesta a las necesidades de aquellos sectores olvidados de las grandes ciudades, en concreto a los vagabundos, quienes, casualmente tienen una relación nómada con éstas, que el artista-arquitecto de origen polaco quiere rescatar y poner en valor.

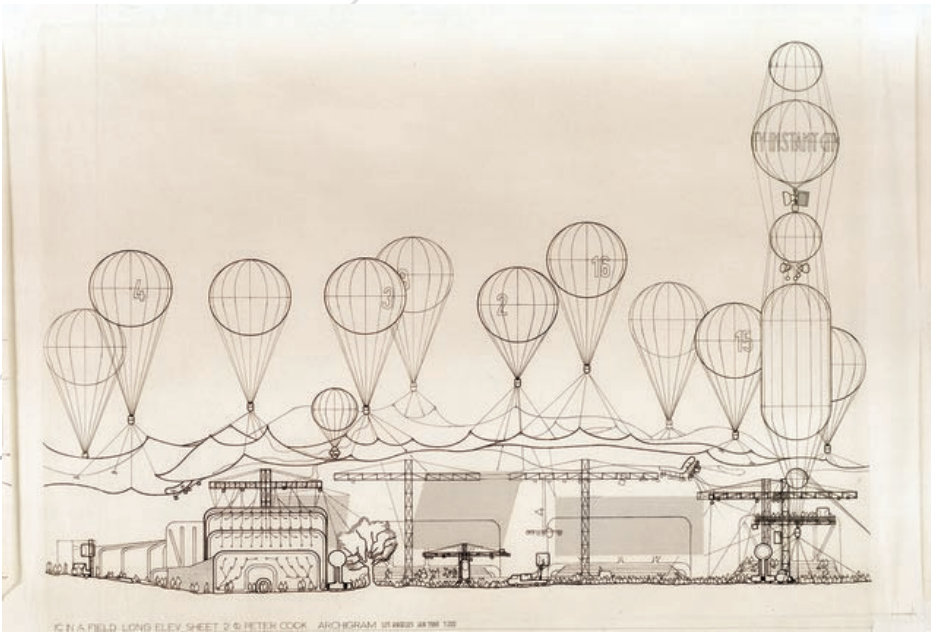

Pero en la segunda mitad del siglo, Peter Cook, Instant City,1969. todo no eran ciudades que caminan o estructuras nómadas listas para ser conectadas. Así, encontraremos interesantes experiencias, sobretodo en el ámbito anglosajón, que tienen la naturaleza como escenario y el caminar como protagonista y que pivotaron en torno a lo que se conoce como Land Art. Los paseos por la naturaleza y la pasión por la idea misma de viaje (propios del Romanticismo) encontrarán dignos seguidores en artistas como Ri- 

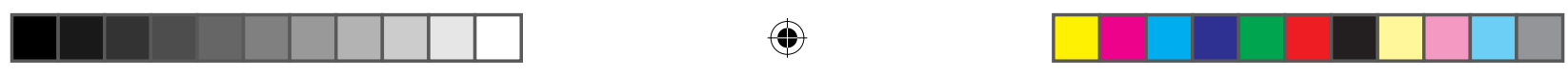

chard Long o Hamish Fulton. Las líneas trazadas al caminar (como en el caso de A Line Made by Walking de Long) o los paseos por una naturaleza prístina vienen a simbolizar todos los senderos que han sido realizados por el ser humano a lo largo de su historia. Por otra parte, el artista
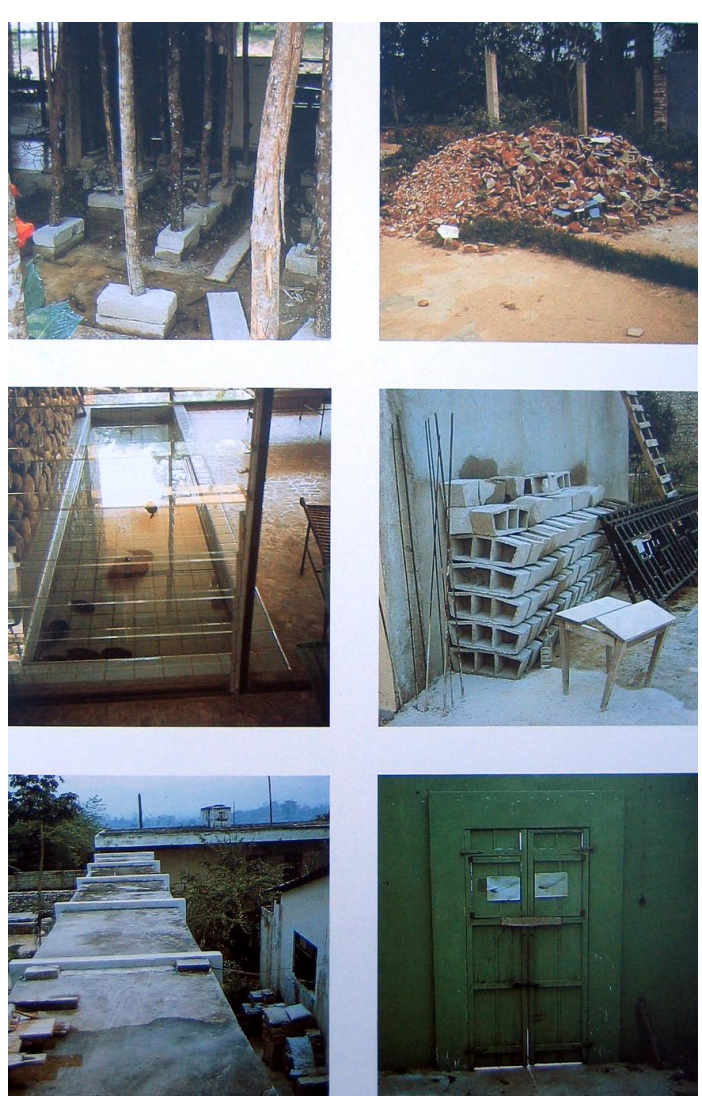

Robert Smithson, Hotel Palenque, Yucatán, México, 1969-72. norteamericano Robert Smithson encontró, en los suburbios abandonados de las grandes ciudades de los Estados Unidos, el escenario perfecto para sus viajes y sus tránsitos cuestionándose la idea de tiempo y lugar, subrayando su papel de verdaderas proyecciones mentales subjetivas. Su Recorrido por los monumentos de Passaic, Nueva Jersey, resulta paradigmático y tuvo una enorme influencia posterior en artistas o urbanistas de todo el mundo, como por ejemplo en el grupo italiano Stalker, con quienes concluiremos el epígrafe.

De este modo llegaremos hasta finales de siglo y comienzos del Siglo XXI, donde nos aproximaremos ya a las arquitecturas fluidas que están transformando nuestros paisajes y nuestras ciudades en la actualidad. La arquitecta anglo-iraquí Zaha Hadid, el grupo holandés NOX o los franceses del colectivo R\&Sie serán, esa vez, nuestros compañeros de viaje. Proyectos, como por ejemplo el Pabellón-puente de Zaragoza, de Hadid, son extremadamente esclarecedores de una forma de entender la

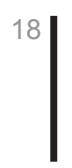



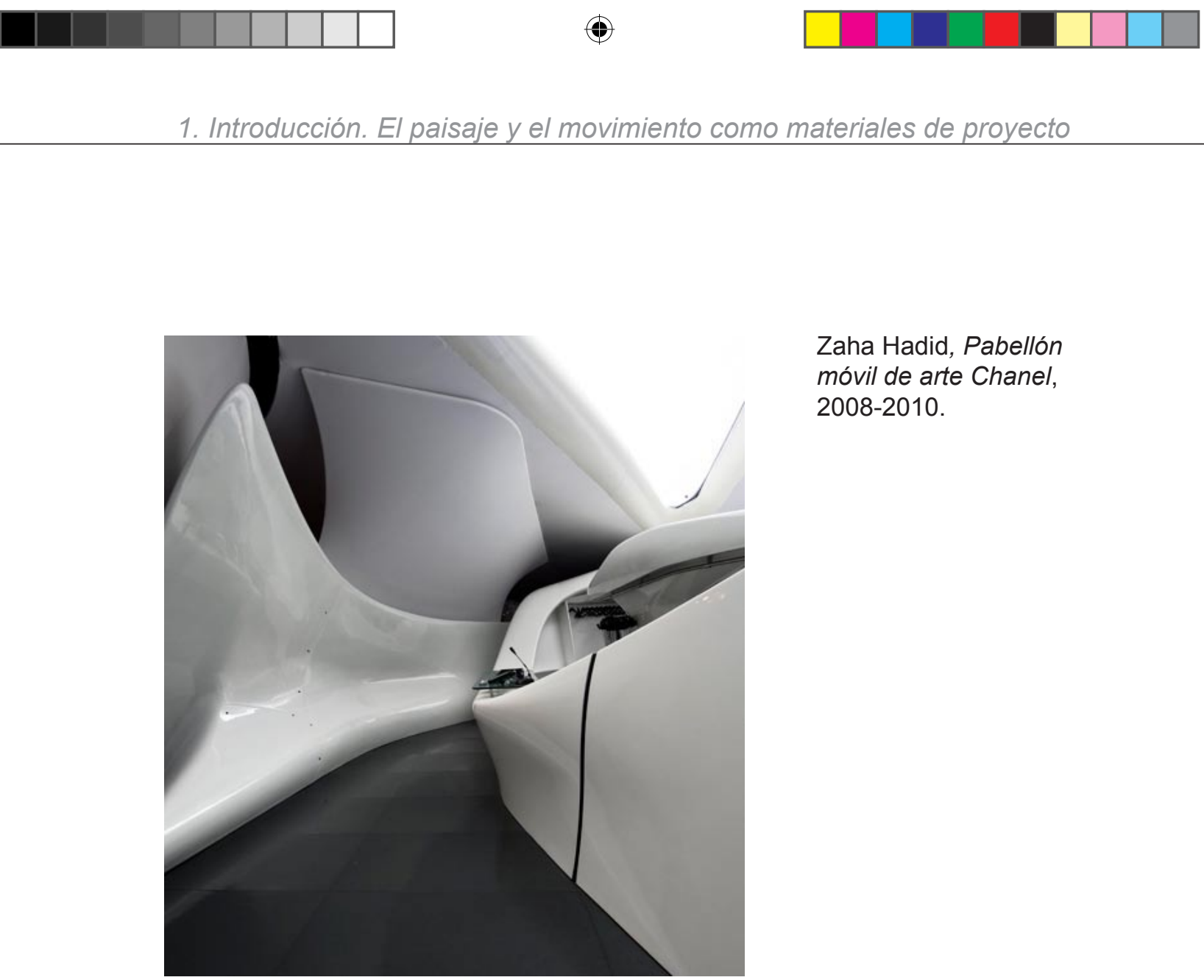

Zaha Hadid, Pabellón móvil de arte Chanel, 2008-2010.

arquitectura y el paisaje como entidades a menudo confundidas e inseparables. Se trata de arquitecturas formalizadas, en unas ocasiones a partir de haces de caminos del paisaje circundante entrelazados, en otras ocasiones desde una transformación de la topografía del lugar, pero que siempre presentan espacialidades fluidas surgidas a partir del estudio atento del entorno y sus relaciones. Son propuestas de una gran flexibilidad y dinamismo que superan las tradicionales dicotomías paisajeciudad o naturaleza-arquitectura y que presentan a menudo una enorme complejidad espacial. Mientras que en el Pabellón de agua dulce de NOX, podremos comprobar la voluntad de disolución del espacio real en un nuevo espacio surgido de diversos vectores siempre vinculados con aspectos de la subjetividad del individuo (tales como los deseos o caren- 


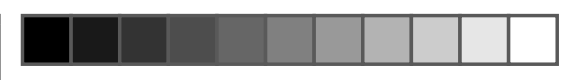

$\oplus$

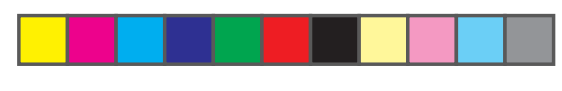

cias), en los proyectos de R\&Sie, (aunque siempre moviéndonos en los mismos parámetros), veremos también el interés de sus autores por sacar a la luz la sofisticación política, social y estética de una sociedad determinada a través de su arquitectura con propuestas cuestionadoras e irónicas como Dustyrelief en Bangkok o Aspiration para la ampliación de la escuela de arquitectura de Venecia.

Finalmente, nuestro viaje nos conducirá hasta las conclusiones, donde comprobaremos la aparición en nuestras ciudades de unas Arquitecturas-paisaje que surgidas al hilo de las experiencias que hemos ido viendo y conociendo, están transformando nuestra realidad. Estas conclusiones/presentarán tres partes bien diferenciadas y que a mi entender son

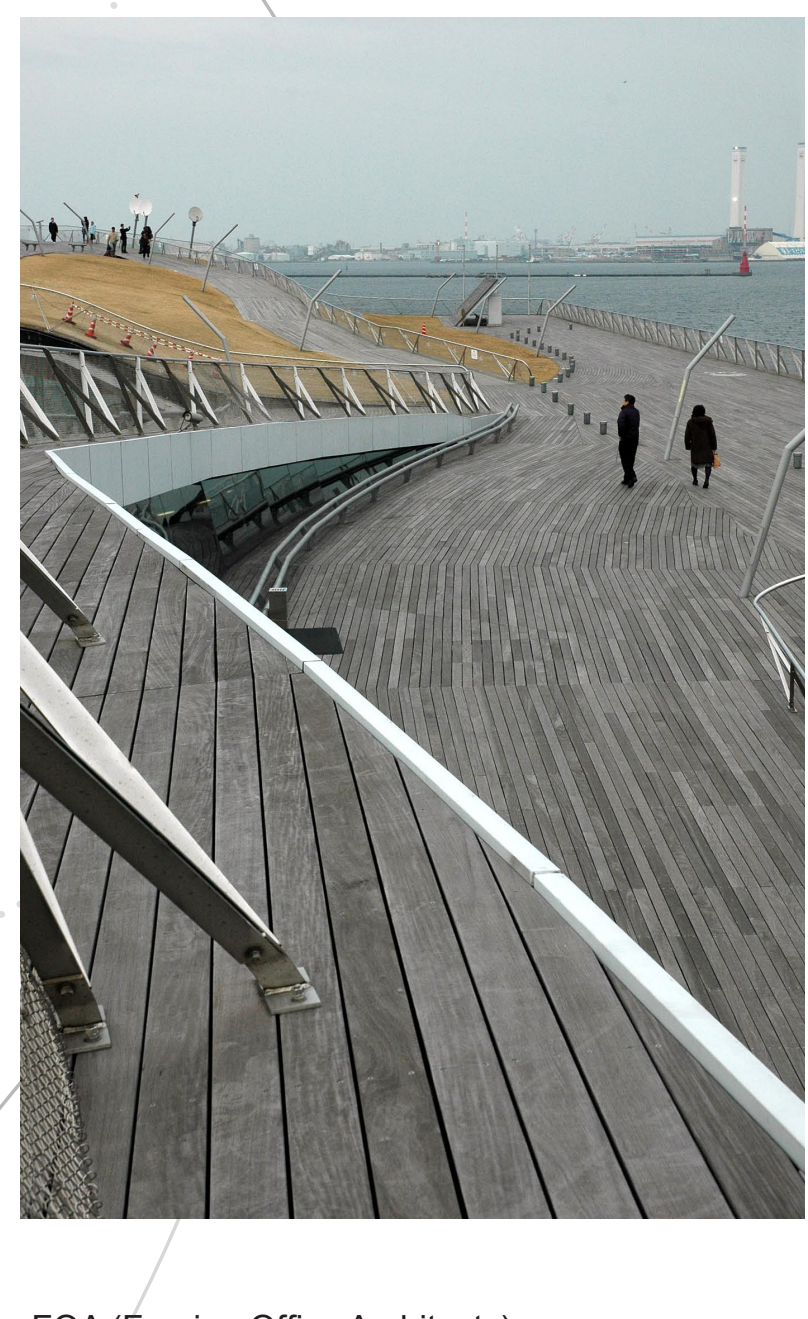

FOA (Foreign Office Architects), Terminal Marítima de Yokohama, 1996/2002, (fotografía I.C.). complementarias: una primera parte de análisis teórico de diversas arquitecturas paradigmáticas de toda la tesis, donde ejemplificaremos cuales son algunas de las claves más importantes de la transformación de cierta arquitectura en lo que creo que podemos denominar más apropiadamente paisajes dinámicos, una segunda parte, que plantea un recorrido personal por la ciudad de Paris, donde de la mano de Walter Benjamin experimenté la posibilidad de crear un auténtico proyecto de paisaje a partir del descubrimiento de la propia ciudad, sin actuaciones físicas ni 


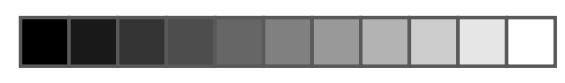

$\oplus$
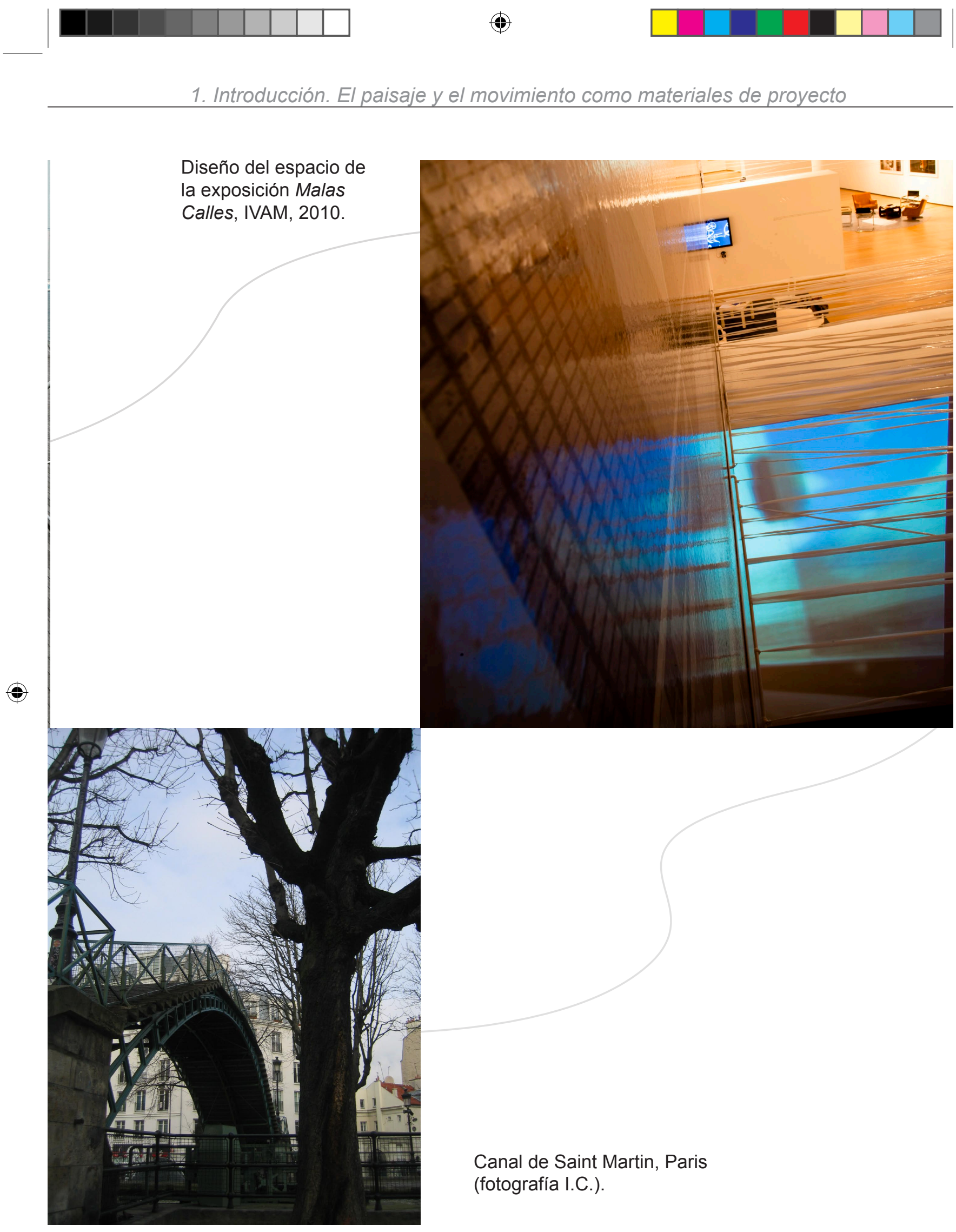

$\theta$

Canal de Saint Martin, Paris

(fotografía I.C.). 

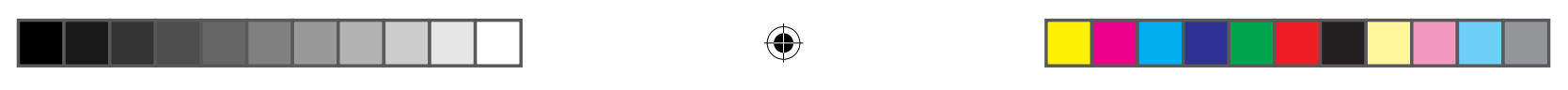

perdurables en el tiempo; y por último, la tesis se completa con la presentación de un proyecto de escenografía realizado este último año, se trata de la creación de un espacio dinámico a caballo entre el arte y la arquitectura donde el paisaje era la pieza clave. Me estoy refiriendo al diseño del espacio para la exposición Malas Calles abierta al público, en el Instituto Valenciano de Arte Moderno (IVAM), desde febrero a junio del 2010. La escenografía para Malas Calles quería hacer partícipe al espectador de un "paisaje en movimiento", con tal propósito creé un recorrido fluido y continuo para la contemplación de las obras de arte.

Así, el espacio y la creación artística formaban un conjunto dinámico y atractivo que acompañaba y guiaba a los espectadores a lo largo del trayecto cronológico inverso propuesto por el comisario. La propuesta realizada para Malas Calles nos demostrará hasta que punto, la tradicional interrelación entre el arte, la arquitectura y el urbanismo se ha visto exacerbada y transgredida en ocasiones, de modo que los límites, las fronteras entre las distintas disciplinas, ayer bien definidas, hoy en día se difuminan cuando no directamente carecen de sentido. Resulta muy estimulante comprobar los diálogos de ida y vuelta, los cruces e interferencias, que se producen entre dichas disciplinas y como todas ellas se entrecruzan y relacionan, en numerosas ocasiones, gracias al paisaje. Todo ello nos demuestra que ya no podemos continuar planteando dichas relaciones mediante alternativas de enfrentamiento o desinterés entre cuestiones imprescindibles y obligadas a entenderse.

Desearía que estos Paisajes en movimiento por los que viajaremos en las próximas páginas, estén llenos de sugerencias para el lector o la lectora, y que la mirada poliédrica, amplia y subjetiva sobre diversos momentos históricos y episodios espaciales que vertebra esta tesis, le invite a crear nuevas asociaciones y le sirva de pequeña ayuda en la invención de sus propios paisajes personales. 


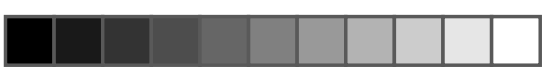

$\oplus$

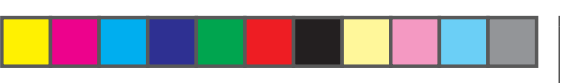




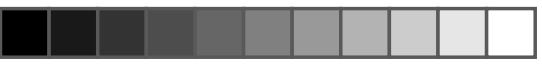

$\oplus$

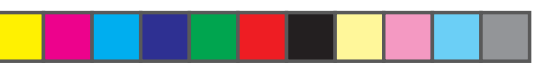

"Antes de contemplar una maravilla ya teníamos de ella noticias y fantaseamos su forma soñándola, soñándola hasta hacerla un imposible."

Federico García Lorca 


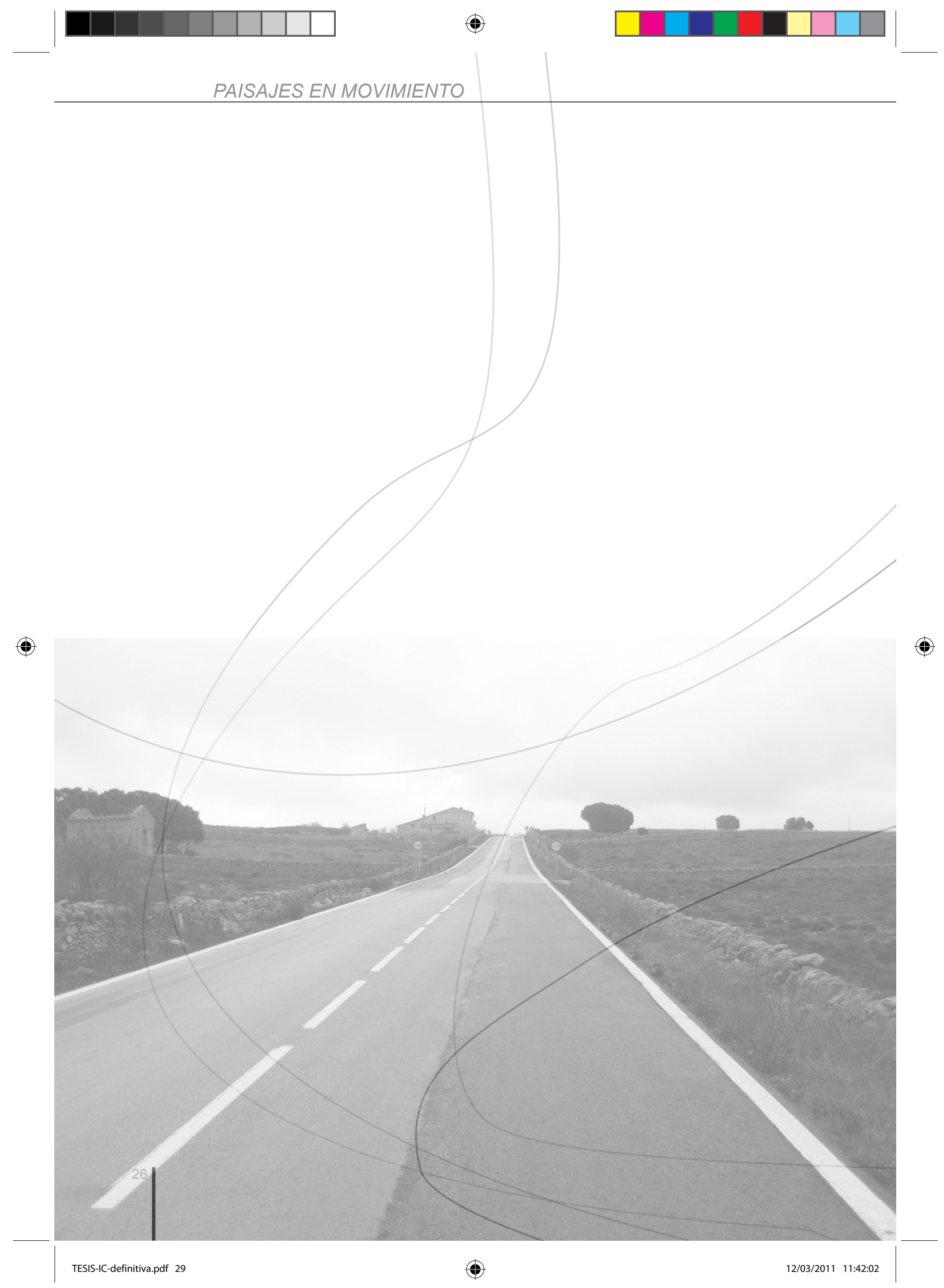



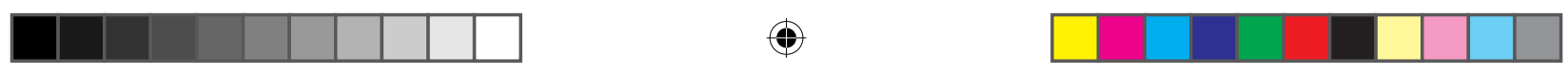

En una investigación cuyo título responde a Paisajes en movimiento resulta inexcusable la concreción ya desde el comienzo de aquello que entenderemos por paisaje en los capítulos siguientes, para evitar de este modo y en la medida de lo posible, confusiones posteriores que se puedan producir en el ámbito de la discusión. Acotar y limitar conceptos previamente es especialmente pertinente en el caso del paisaje, debido a la amplía polisemia del término y a la proliferación de la voz paisaje en el lenguaje coloquial.

Para ello comenzaremos por fijar nuestra atención en la génesis del propio término con el ánimo de ir acotándolo posteriormente. Tanto el término "paisaje", como el término "país", de donde proviene etimológica- 


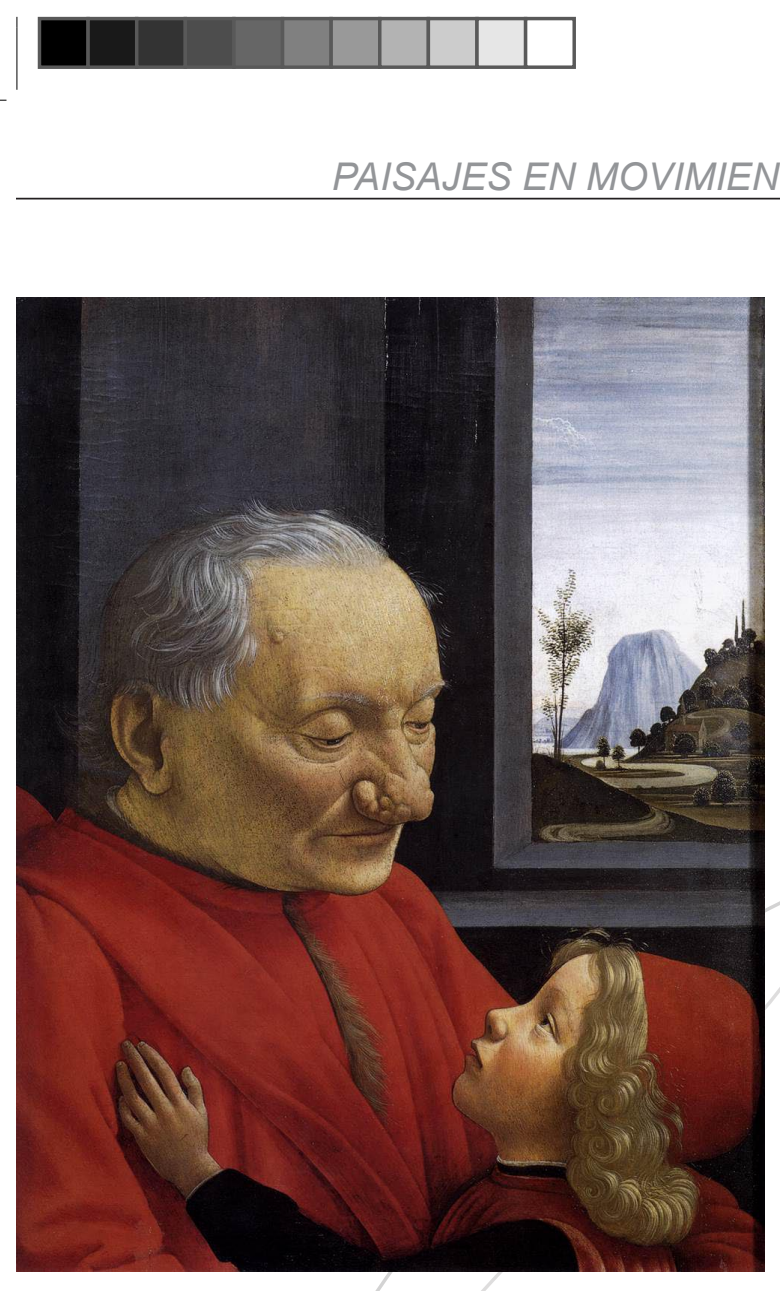

Ghiraldaio, Un hombre viejo y su nieto, 1490, (detalle). mente, proceden de los términos franceses paysage y pays respectivamente. Esto nos conduce rápidamente a una primera reflexión: descubrir cuáles son los mecanismos que producen la transformación de un país en un paisaje. Este fascinante proceso se comprende mucho más fácilmente si descendemos a la lengua materna origen tanto de pays como de "país", el latín.

El término latino que da origen al término castellano es el de pagus. De hecho, en castellano, el término "pago" se mantendrá (según el diccionario de la Real Academia Española de la Lengua) con las siguientes e interesantes acepciones: "1.m. Entrega de un dinero o especie que se debe, 2.m. Distrito determinado de tierras o heredades, especialmente de viñas u olivares." La vinculación del concepto con aspectos utilitarios y productivos, aunque evidente si no perdemos de vista que se trataba de sociedades eminentemente agrícolas y que por tanto dependían de la naturaleza como medio de subsistencia, queda reflejada en la común utilización entre nosotros del término "pagar". Así pues, el salto cualitativo entre el pagus latino y nuestro "país" es un salto extraordinariamente importante para el tema que nos ocupa: mientras que el país permanezca como pago no se puede producir una relación con el entorno que traspase la sumisión a la naturaleza como medio de subsistencia. ${ }^{1}$

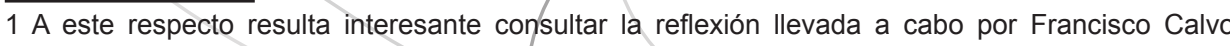
Serraller en "Concepto e historia de la pintura de paisaje" en VV.AA, Los Paisajes del Prado, Nerea, San Sebastián,1993.

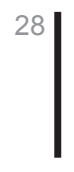



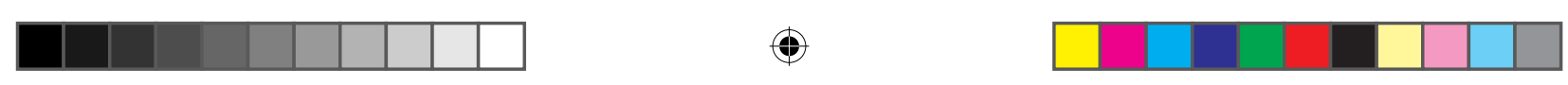

2. El paisaje como acontecimiento.

A medida que el ser humano se libere, en cierto modo, de esta atadura utilitaria, el pago se transformará en país y podremos a partir de este punto comenzar a elaborar paisajes, hablar en términos de paisaje. Hace falta el paso crucial, pongamos a modo de ejemplo, de dejar de ver la lluvia como fecundadora de la tierra donde germinará el trigo con el que haremos el pan, a deleitarnos con el sonido de la lluvia en el tejado, con la chimenea encendida, a salvo nosotros y nuestra economía.

Pero evidentemente, este paso del pagus al país, es tan sólo un primer estadio que todavía no presupone la aparición o el nacimiento del término paisaje en el pensamiento Occidental. Harán falta otras complejas transformaciones, y principalmente la mediación del arte, para que, pasando por la cultura y el pensamiento, el concepto se instale en el lenguaje cotidiano det modo en el que se ha instalado hoy

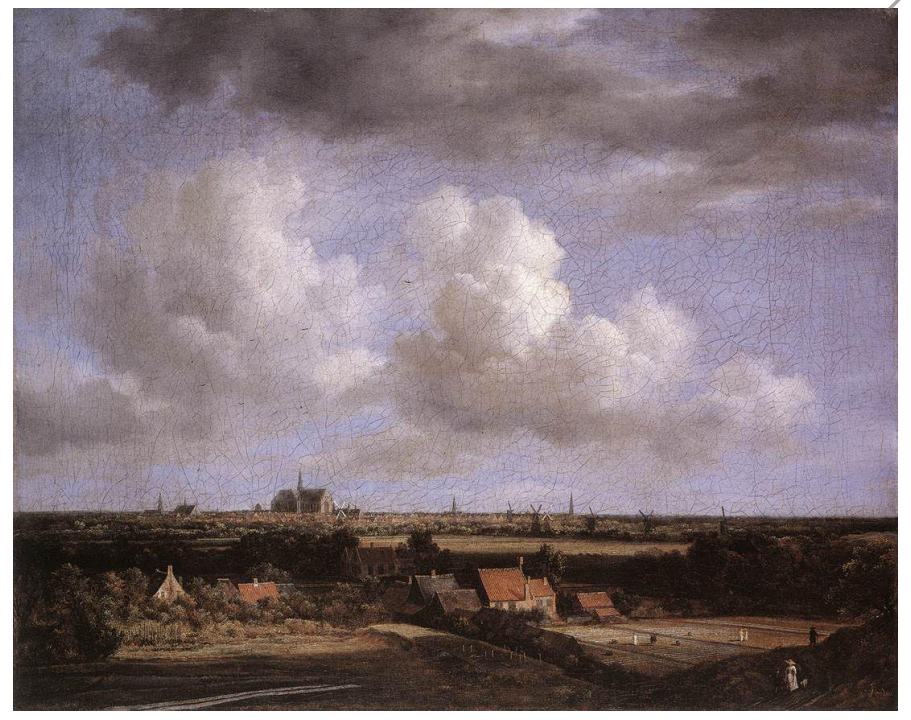

Jacob van Ruisdael, Paisaje con vista de Haarlem , 1610. en día, donde el uso y el abuso han terminado, a menudo, por vaciarlo de significado.

Estaríamos, de hecho en un momento donde sería muy pertinente la pregunta, tan inteligentemente planteada por Augustin Berque, de si: ¿Es que entramos en una nueva era, más rica que nunca en paisajes? ¿O bien al contrario, no hablamos tan a menudo de él sino porque lo habríamos perdido? Sin tomar posición a priori por ninguna de las dos posibilidades,-aún mostrado mayor simpatía por la primera-, de las diferentes líneas de pensamiento que se han planteado el paisaje y han intentado desmenuzar este esquivo concepto, nos acercaremos en este estudio a dos de las, a nuestro 

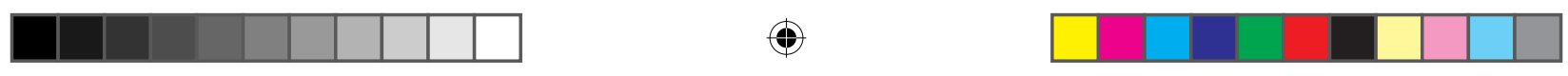

entender, concepciones más interesantes. Son aquellas que bucean en el medio físico y la geografía para buscar, tratando de dislumbrar, algo parecido a una razón del paisaje que nos ayude a manejarnos en un territorio concreto.

Por un lado, encontramos los autores y planteamientos que centran su atención en los aspectos simbólicos que encierra el término, esos estudios que, apoyándose en la pintura, parten de la relación del ser humano como individuo con la Naturaleza. En segundo lugar están, con un enfoque más nuevo pero muy interesante, los autores, como Michel Conan y Joan Nogué, que interpretan el paisaje en términos materialistas, donde el constructo social es la clave necesaria para entender el concepto de paisaje.

Si he seleccionado estos dos planteamientos teóricos y no otros es porque a mi modo de ver ambos enfoques, no solamente no son antagónicos sino que están íntimamente relacionados. En el momento de intentar discernir cómo se construyen los paisajes se debe tener en cuenta la propia complejidad del término, sin evitar contradicciones y algunas veces puntos de vista contrapuestos. No está en el ánimo de este estudio intentar plantear un recetario objetivo de elaboración del paisaje más bien apenas plantear una visión fragmentaria e intencionada sobre el mismo.

Si algo aparece reiteradamente en cualquier aproximación teórica

Asociación Salvem La

Punta,

Documental Tornallom, 2005.

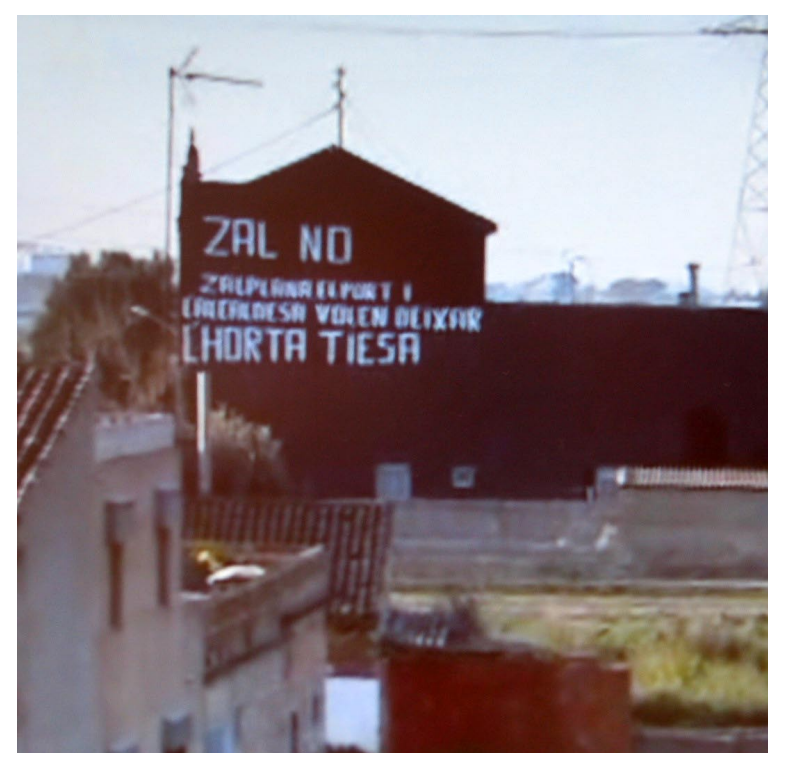


al paisaje es que, en palabras del profesor Pascal Aubry: "Muy rápidamente, nos damos cuenta que inventar paisajes consiste en reconocerse uno mismo en una relación personalizada con el país"2. Cierto, cuando nos adentramos en el estudio del paisaje terminamos tarde o temprano, en nuestro recorrido por el lugar, por encontrarnos reflexionando acerca de aquellos aspectos que nos emocionan o interesan especialmente de aquél territorio concreto y específico y cuestionándonos cuáles son los motivos de ese interés.

Esta evidencia, pues, nos fuerza a plantear un aspecto del término que aún a pesar de parecer evidente es necesario recordar: el paisaje necesita de nuestra mirada, se construye gracias a ella.

Esta mirada que tenemos de nuestro entorno, de la realidad que nos rodea, está en constante construcción, en permanente evolución, gracias a nuestra cultura y conocimiento, a todo aquello que portamos con nosotros y a todo aquello que vamos lentamente incorporando a nuestro bagaje cultural. Se forma, por tanto, a partir de los fragmentos de las miradas que muchos otros antes que nosotros tuvieron sobre el mundo. A partir de estas experiencias, nosotros crearemos subjetivamente nuevas relaciones entre las piezas del tablero creando situaciones y acontecimientos que antes no existían. Esos modelos literarios, pictóricos o cinematográficos que forman parte de nuestra cultura nos acompañan y tiraremos de ellos (aún de manera inconsciente) en la invención de nuestros propios y personales paisajes. Son parte inexcusable de éstos. Así, el paisaje, aún cuando se presenta inseparable de su realidad física concreta, de su objeto, resulta, en palabras de del investigador Augustin Berque, "una entidad relativa y dinámica donde naturaleza y sociedad, mirada y entorno están en constante interacción". ${ }^{3}$ En resumen, el paisaje no existe físicamente, por más que nos empeñemos en denominar paisa-

2 Aubry, Pascal en « De la place de certains documents d'urbanisme dans l'invention des paysages »en Davallon, Jean et Gottesdiener, Hana, « Dossier Musée et Paysages » en Publics \& Musées, PUL, Paris, 2007 p. 53.

3 Berque, Augustin en VV AA, Cinq propositions pour une théorie du paysage, Champ Vallon, Seyssel, 1994. p.6. 

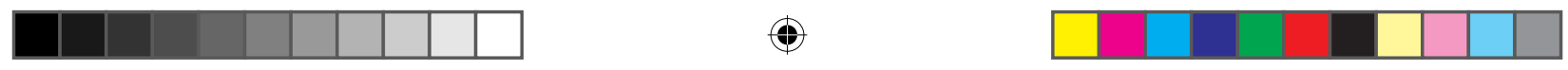

je a un fragmento de naturaleza. Mejor dicho, existe en tanto que realidad física, que es el primer componente necesario pero no suficiente, tendremos pues que inventarlo, para que llegue a constituirse como paisaje.

Esta fascinante tarea no hemos sido capaces de realizarla, o ciertamente y de modo más correcto, no hemos tenido necesidad de ella, hasta que el arte no la ha hecho surgir. Mientras el ser humano vivió en y desde la naturaleza, no hemos visto la naturaleza y el mundo que nos rodea con una cierta pers-

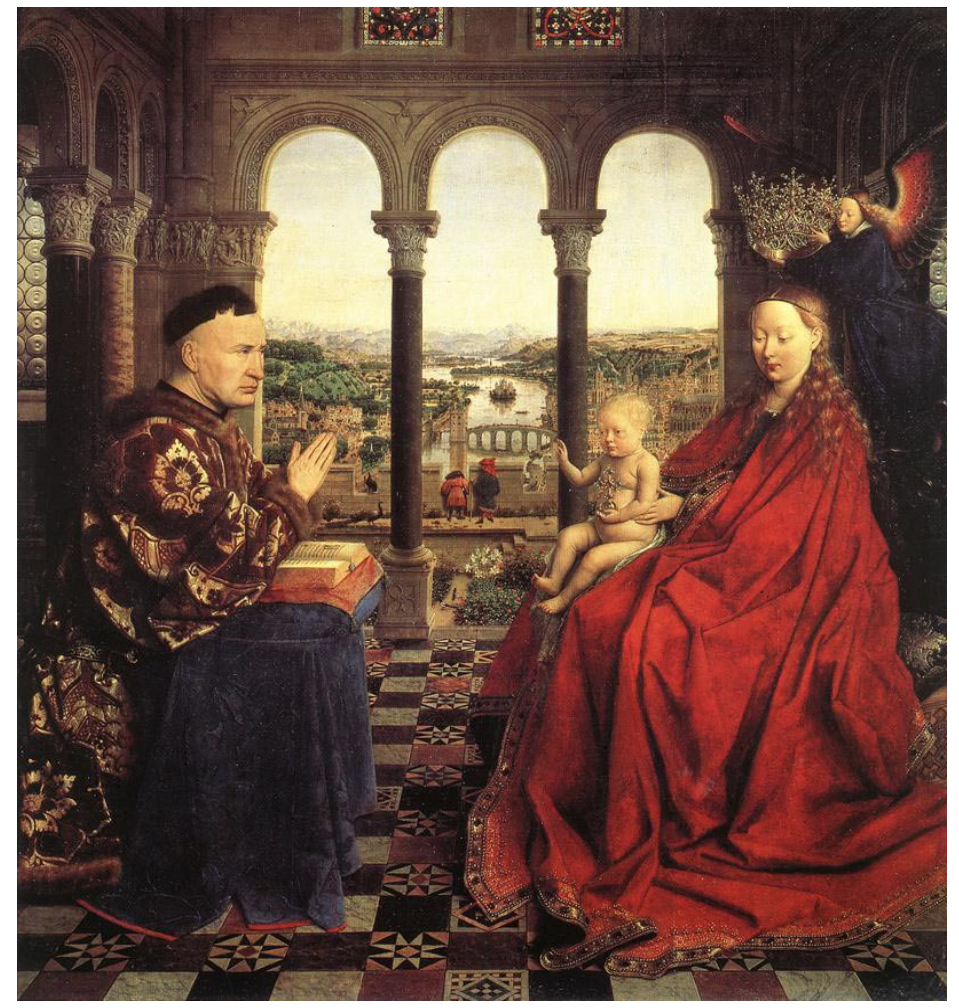

Jan van Eyck, La virgen del canciller Rolin, 1435.

que se convertirá en el primer paisaje. Esta tarea me resulta carente de sentido y se ha demostrado fallida en cada uno de los intentos llevados a cabo. Siempre existirá un nuevo dato, un argumento en contra, que desmienta nuestra afirmación. No es para menos. Cualquier concepto minada mirada cultural y por lo tanto, no hemos tenido la posibilidad de representar el paisaje. Simultáneamente, mientras no hemos podido representar el paisaje no hemos podido contemplar la realidad física desde una mirada cultural, condición necesaria para entrar en la categoría de paisaje.

No trataré en este trabajo de bucear en la historia del arte para encontrar ese momento justo, ese objeto o experiencia concreta pectiva, con una deter1 

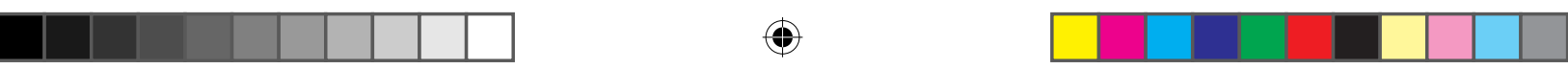

2. El paisaje como acontecimiento.

Jeff Wall, The Thinker,1986.

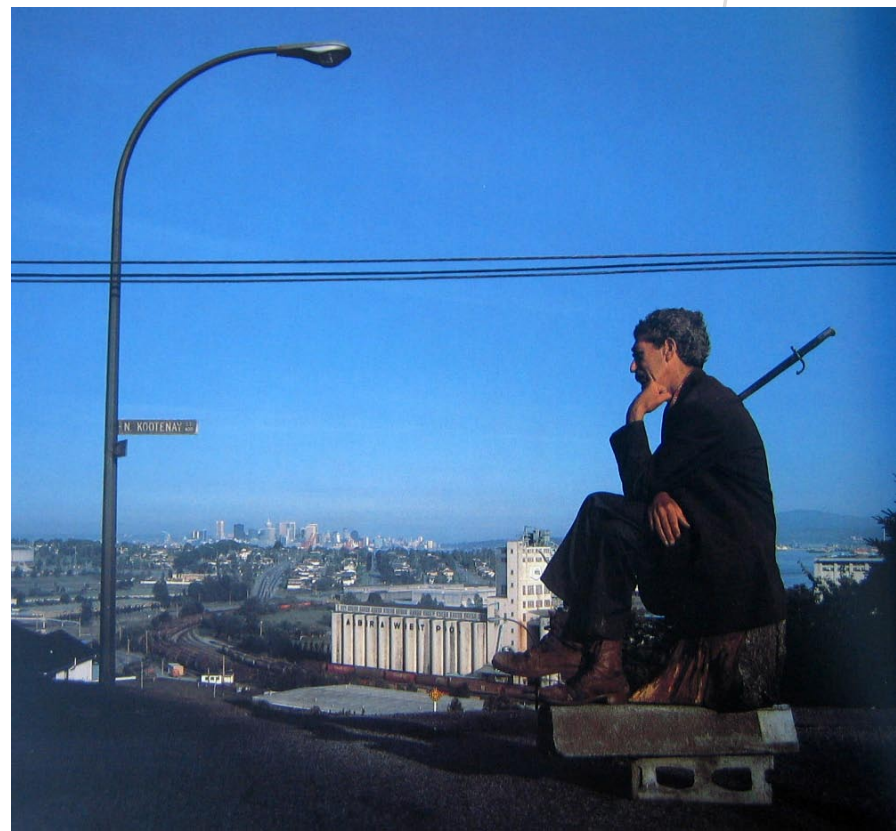

complejo surge de un arduo proceso de destilación y decantación donde poco a poco y con gran esfuerzo, las diferentes relaciones entre elementos se van recomponiendo hasta dar lugar a esa nueva realidad. Cuanto mayor es la complejidad de la noción nueva a investigar, mayor será la dificultad a encontrar el momento y el lugar exacto donde ha sido originada. Tratándose de una entidad tímida y escurridiza como el paisaje no podía ser menos.

El proceso de aparición y consolidación del paisaje ha tenido diferentes velocidades y matices en distintas culturas y momentos históricos. A pesar de que me referiré siempre a la cultura occidental dada mi incapacidad para ver otras culturas si no es a través del filtro de mi mirada (evidentemente occidental), me gustaría, ya que intento mostrar en este epígrafe la mediación del arte en la elaboración de los paisajes, citar, aunque sea sucintamente, la China antigua como, según Augustin Berque, la primera "civilización paisajística". El autor francés plantea ${ }^{4}$ el período de la dinastía Han, en torno al 206 a.C.- 220 a.C., como el primer 4 En su conocida obra Berque, Augustin, Les raisons du paysage : de la Chine antique aux environnements de synthèse, Hazan, Paris, 1995. 

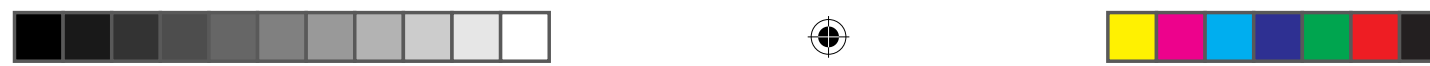

lugar donde rastrear algo similar al concepto actual que tenemos en occidente del paisaje. Para ello se apoya en la existencia de cuatro aspectos clave que, según el autor, definen una estética del paisaje, a saber:

Representaciones lingüísticas, es decir, una o varias palabras para decir "paisaje."

Representaciones literarias, orales o escritas, que canten o describan las bellezas del paisaje.

Representaciones pictóricas cuyo tema sea el paisaje

Representaciones jardineras que traduzcan un apreciación estética de la naturaleza. ${ }^{5}$

Sin entrar a analizar las características del paisaje en la China antigua, (remitiendo para ello al estudioso francés y sus interesantes trabajos al respecto), y no tanto preocupado por su carácter de momento originario sino por lo que de cultural tiene dicho momento, me interesa señalar el contenido de meditación que el paisaje oriental posee en su propia definición, donde la situación del punto de vista del observador desaparece, carece de sentido. Se trata de composiciones que no apelan a la realidad de un mundo físico frente al que nos situamos de un modo también físico sino a un mundo espiritual donde el espectador flota y se desplaza, gracias a unos mecanismos de composición alejados de los que generarán en Europa cientos de años más tarde el paisaje.

Pero volvamos a Occidente: ¿Qué ha ocurrido? ¿Cuándo surge el paisaje tal y como lo entendemos hoy en día? Parece existir unanimidad en considerar que el paisaje como género autónomo surge en la Holanda del Siglo XVI. Como la profesora Anne Cauquelin nos explica: "No existe en los griegos antiguos ni palabra ni cosa semejante de cerca o de lejos a eso que llamamos paisaje."6 Haremos nuestra, pues, la convención establecida de que la aparición del concepto paisaje en Occidente se produce en el Renacimiento. Pero ¿Nos interesa tan sólo la genealogía de un etiqueta pictoricista? Naturalmente que no. En efecto, aunque nos

5 Íbidem p.34.

6 Cauquelin, Anne, L'invention du paysage, Presse Universitaire de France, Paris, 2000, p.35.

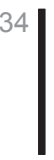




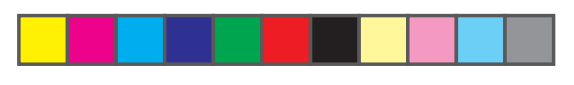

Hsiao Chao, Pabellones en la montaña, (detalle), 11301160.

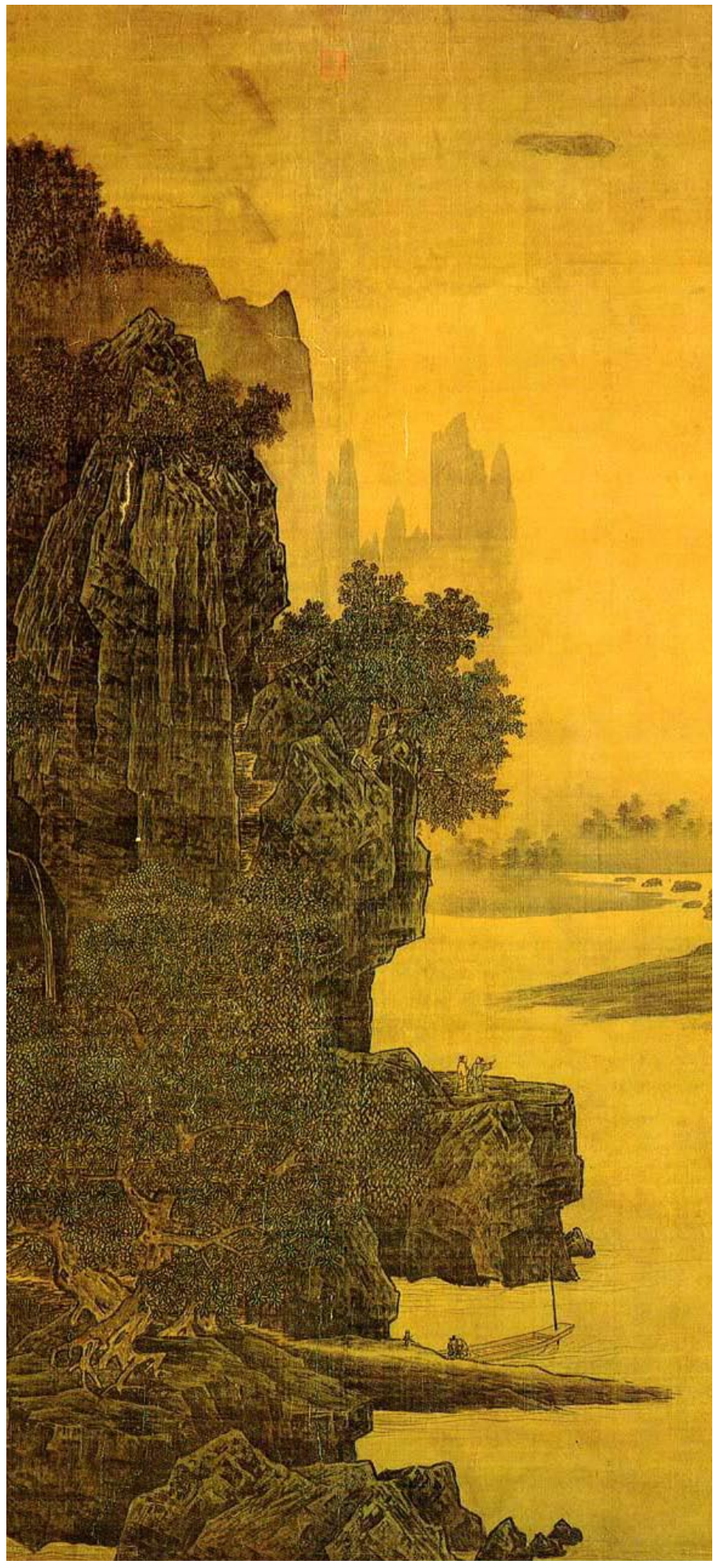



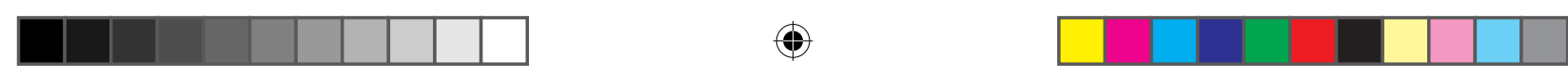

resulta realmente sorprendente la afirmación de Cauquelin, lo que ocurre es que no existe en la Grecia antigua una disociación entre el hombre y la naturaleza, entre el ser humano y su entorno, que permita una toma de distancia que facilite el nacimiento de un concepto como el de paisaje. No se trata tan sólo de que no exista la palabra, sino de que su modo de aproximación al mundo, su mirada, es otra. En consecuencia, aunque pretendamos que los habitantes de aquella época ya conocían el paisaje, la ausencia de concepto para nombrarlo, y nuestra incapacidad para ponernos en su lugar con el objeto de estructurar nuestra realidad del mismo modo que lo realizaban ellos, nos impide plantear que para la los griegos ya existiera el paisaje.

Necesitaremos de un invento de extraordinaria repercusión para que surja en Occidente y tras mucho esfuerzo el nuevo concepto. Un cambio trascendental en nuestra forma de mirar y estructurar el espacio: se trata de la perspectiva. La perspectiva se convierte en una poderosa forma simbólica que une todas las actividades humanas, la palabra, las sensibilidades, los actos, en un nuevo dispositivo óptico y conceptual de primer orden. Con él seremos capaces de conquistar el mundo. La perspectiva se lanza en dirección al infinito, hacia el más allá, hacia lo desconocido.
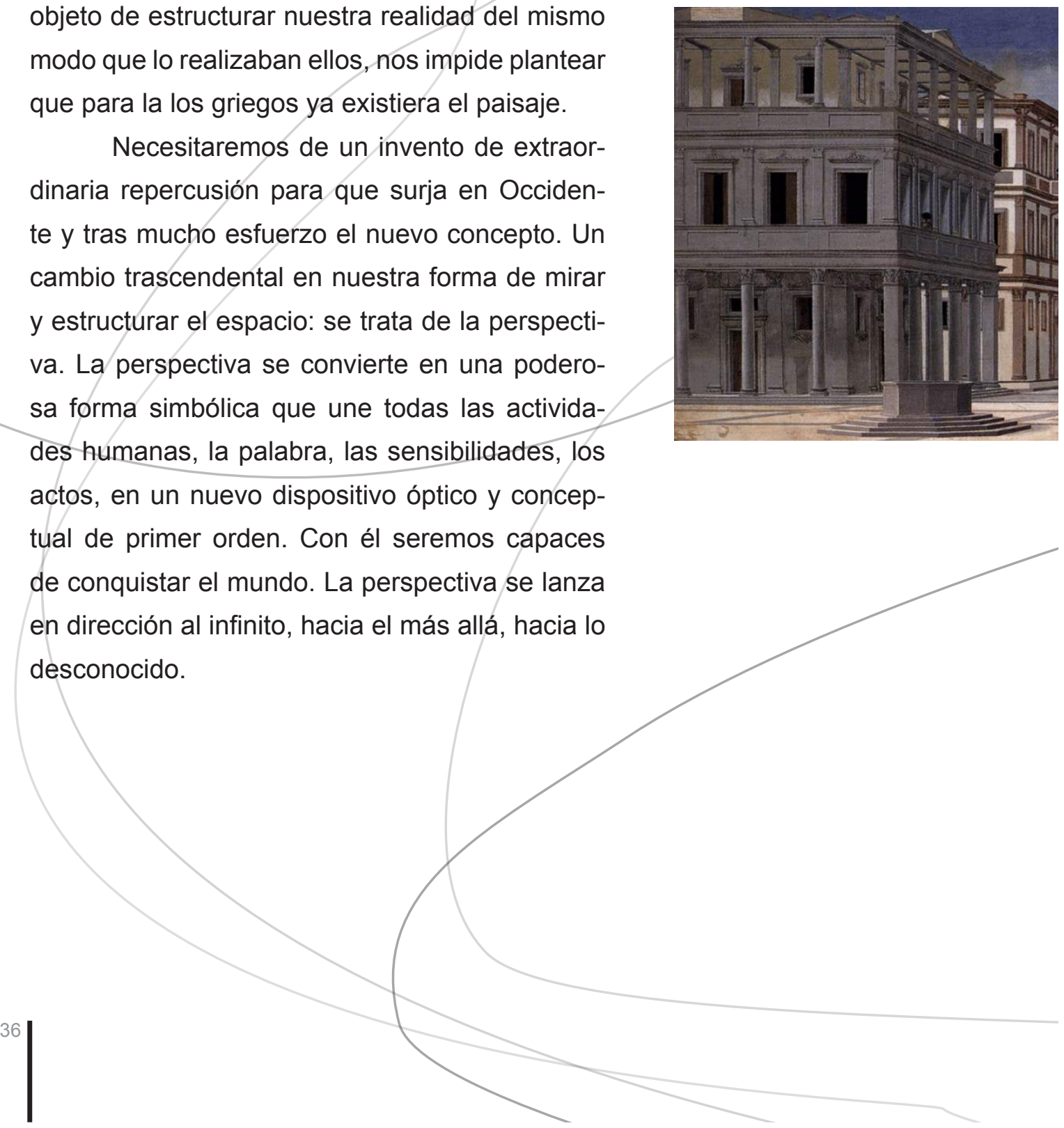

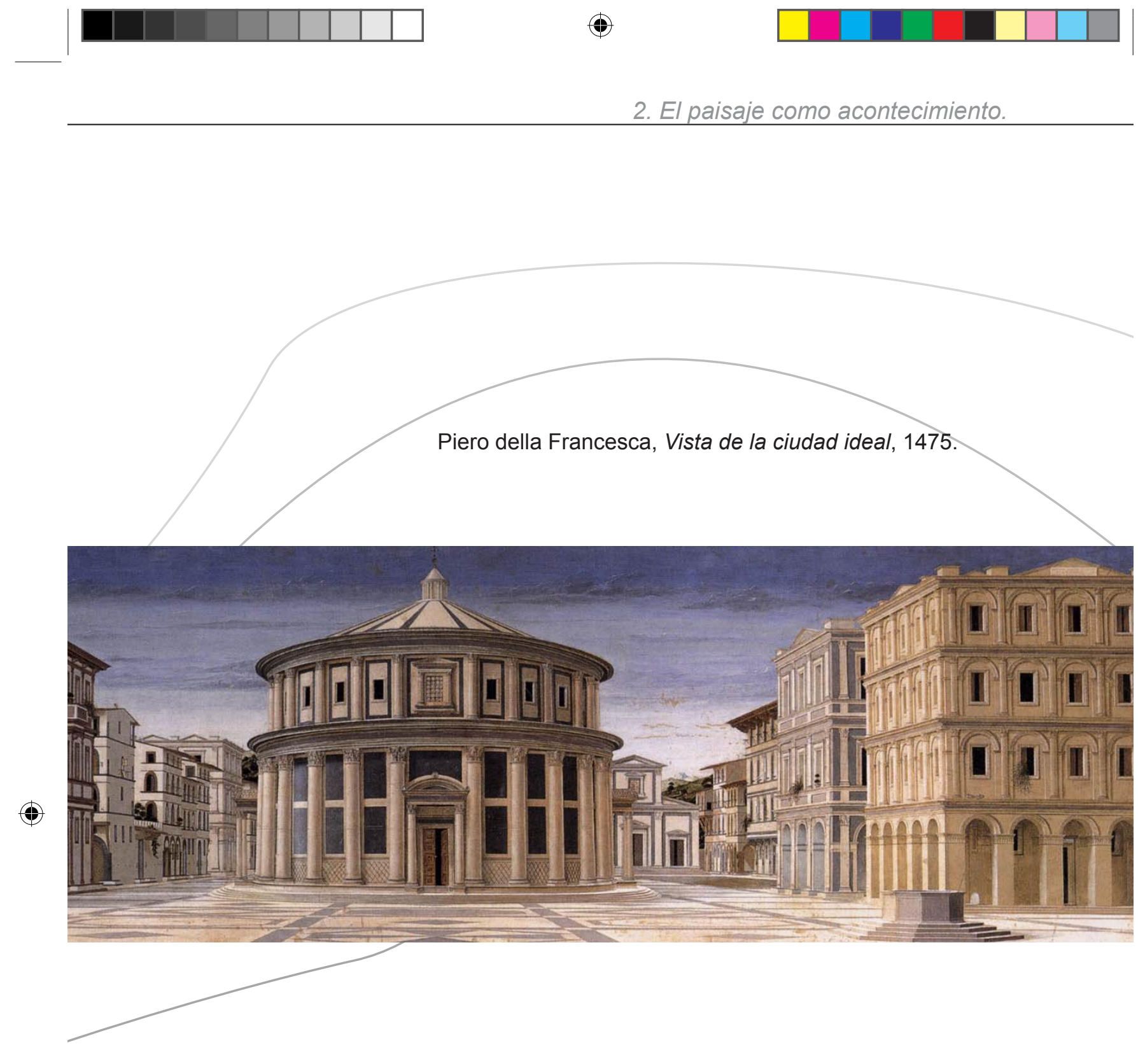

En 1481, el pintor italiano II Perugino en su Entrega de las Ilaves a San Pedro todavía nos cierra la puerta del tempietto pero tan sólo unos años más tarde Rafael nos la abrirá en sus Esponsales de la virgen para que nos interroguemos sobre nosotros mismos, sobre ese lugar soñado que se nos insinúa. ¿Se trata de un vacío? ¿Se trata de un paisaje? Sea lo que Rafael quisiera mostrarnos, el cambio es trascendental.

Sin embargo, múltiples autores no señalan a Italia como la cuna del paisaje sino a los países del Norte de Europa, a Holanda más con- 


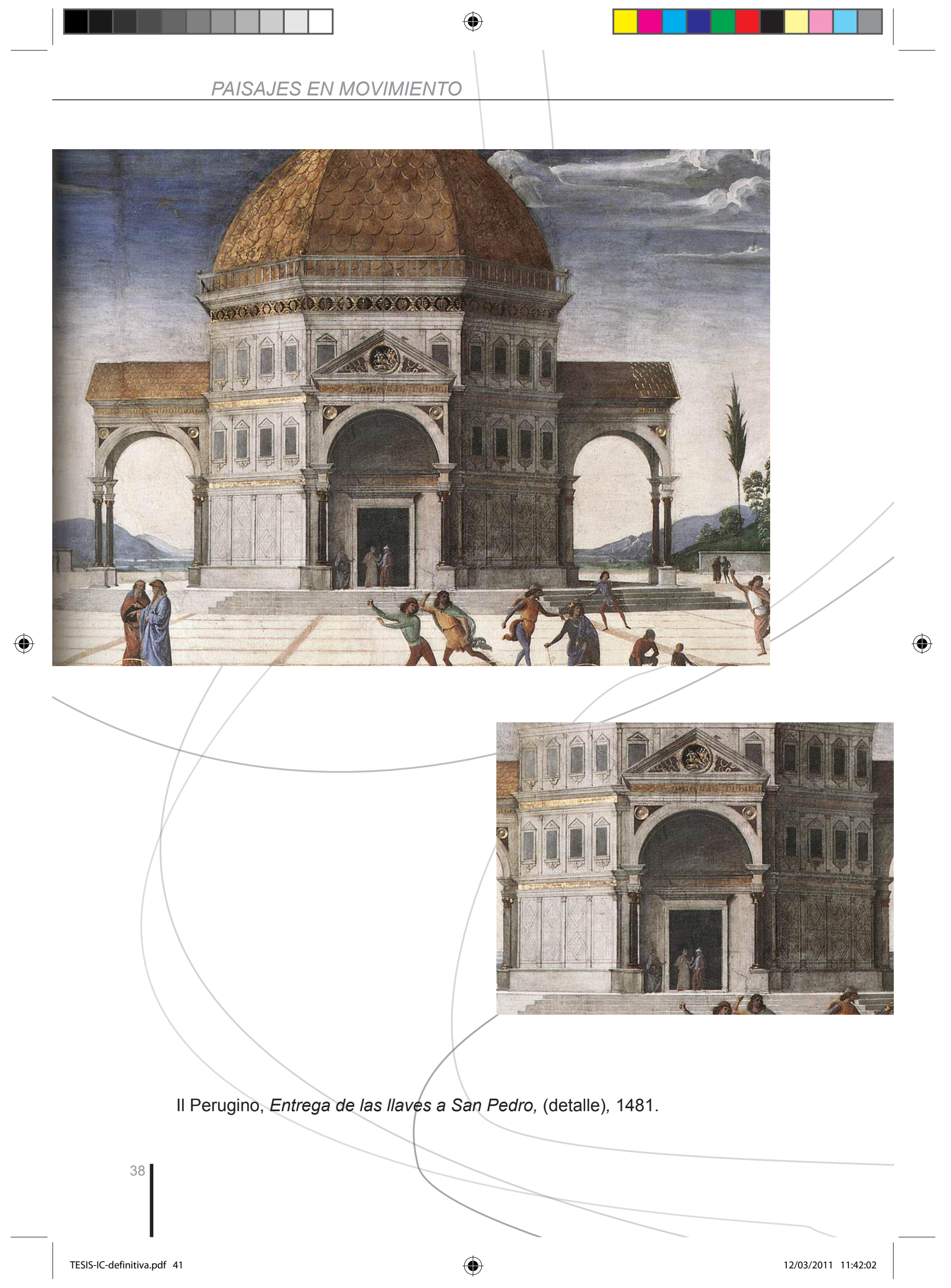




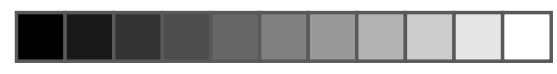

$\oplus$

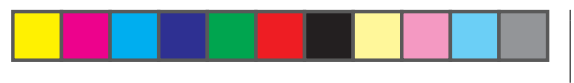

2. El paisaje como acontecimiento.

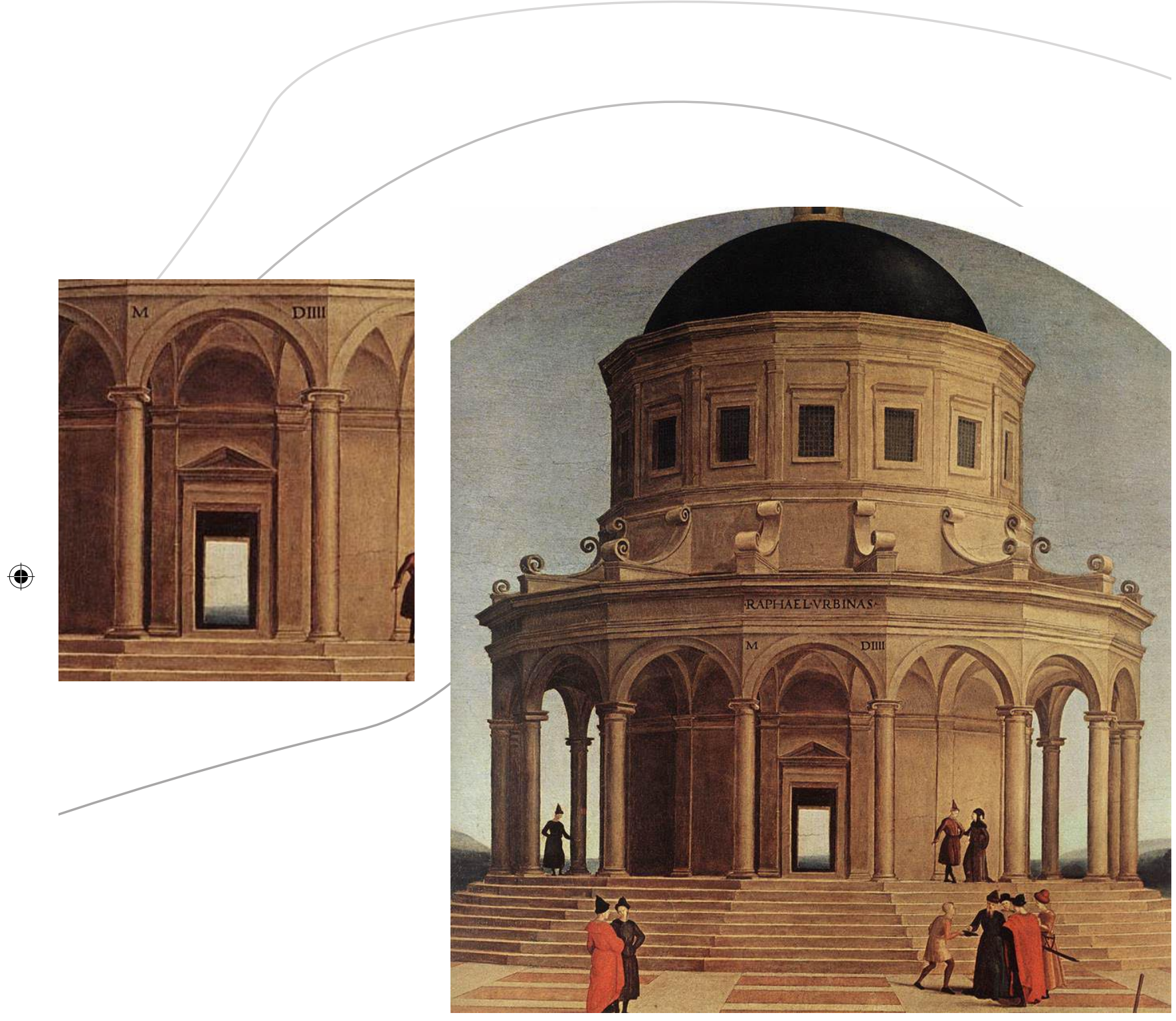

Rafael, Los esponsales de la virgen, (detalle), 1504. 

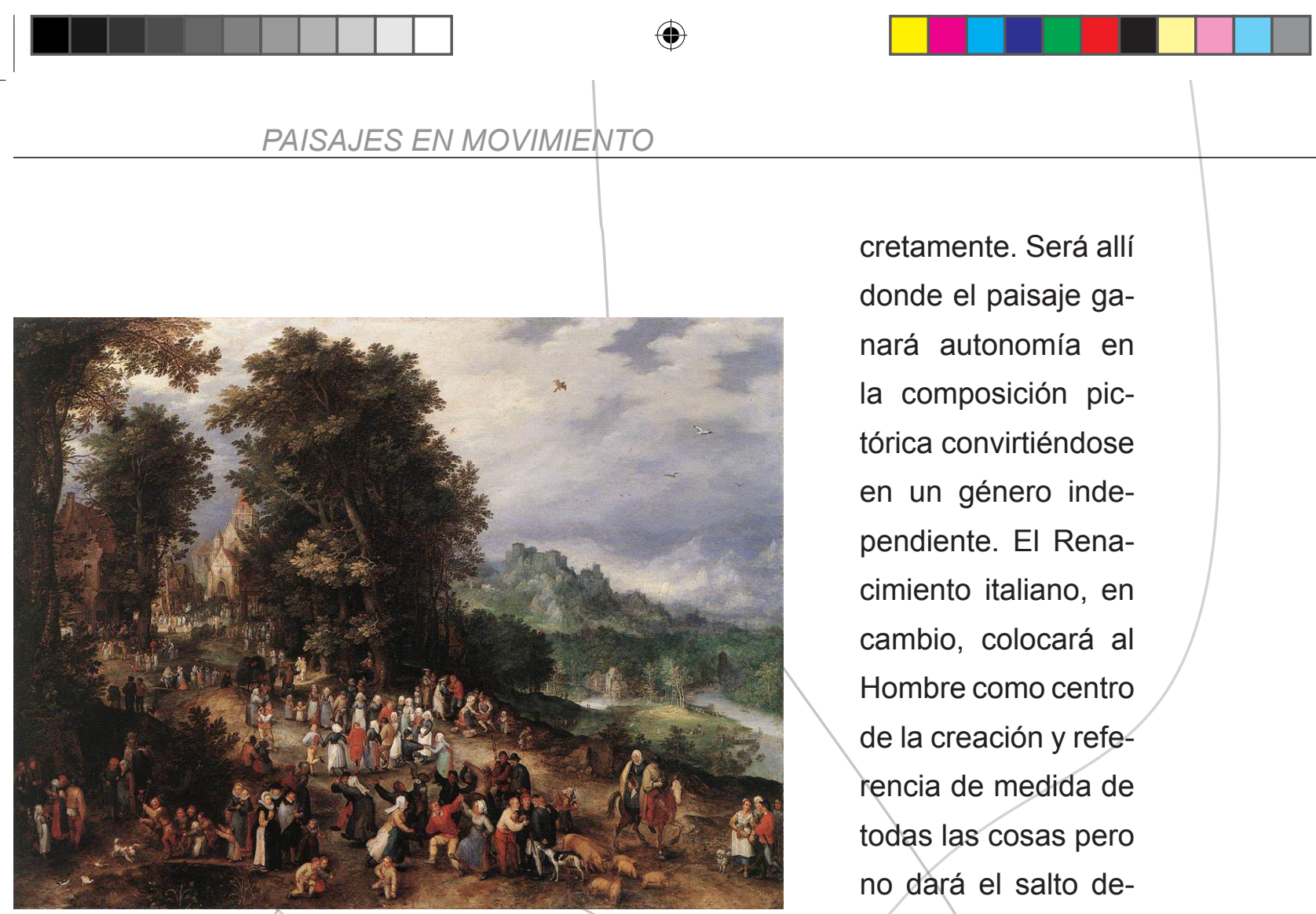

cretamente. Será allí donde el paisaje ganará autonomía en la composición pictórica convirtiéndose en un género independiente. El Renacimiento italiano, en cambio, colocará al Hombre como centro de la creación y referencia de medida de todas las cosas pero no dará el salto definitivo que produzBrueghel el viejo, Feria flamenca, 1610. ca la aparición del paisaje, dejando el testigo al Norte de Europa. De todos modos, este hecho no nos interesa por motivos historiográficos sino por lo extraordinariamente revelador que resulta para entender el proceso conformador del concepto de paisaje. En Italia comienza una progresiva investigación acerca del mundo y el entorno natural pero durante mucho tiempo los "fondos" seguirán como elementos auxiliares del tema principal, invariablemente religioso. No existe una preocupación por los valores naturales, por su representación. La independencia del paisaje no se produce hasta que el cuadro no se libera de la temática religiosa y esto se producirá mucho más al Norte. Es lo que Alain Roger ha denominado la "naturaleza laicizada".

Tal vez Italia hubiera llegado al mismo camino, nunca lo sabremos, pero resulta interesante planteárnoslo si pensamos que la interrupción que sucede en Italia en su investigación se produce en el contexto del Concilio de Trento y la Contrarreforma en su llamada al orden. Como 
nos dice el famoso historiador inglés Anthony Blunt: "Uno de los primeros objetivos de los contrarreformistas fue abolir el derecho del individuo a resolver los problemas relativos al pensamiento y la conciencia según el juicio de su propia razón personal". ${ }^{7}$ Esto llevará al desinterés hacia el mundo exterior y a la destrucción de la mirada hacia el individuo y la sociedad que se llevará a cabo en el ámbito del paisaje en las sociedades reformistas.

\section{Paralela-}

mente, en el Norte de Europa, el nacimiento del paisaje se producirá entre otros factores a partir de la prohibición de Calvino de representar la imagen de Dios y el culto a las imágenes y la aparición de una satisfecha burguesía deseosa de representarse a sí misma. Podemos afirmar pues que el paisaje tiene mucho

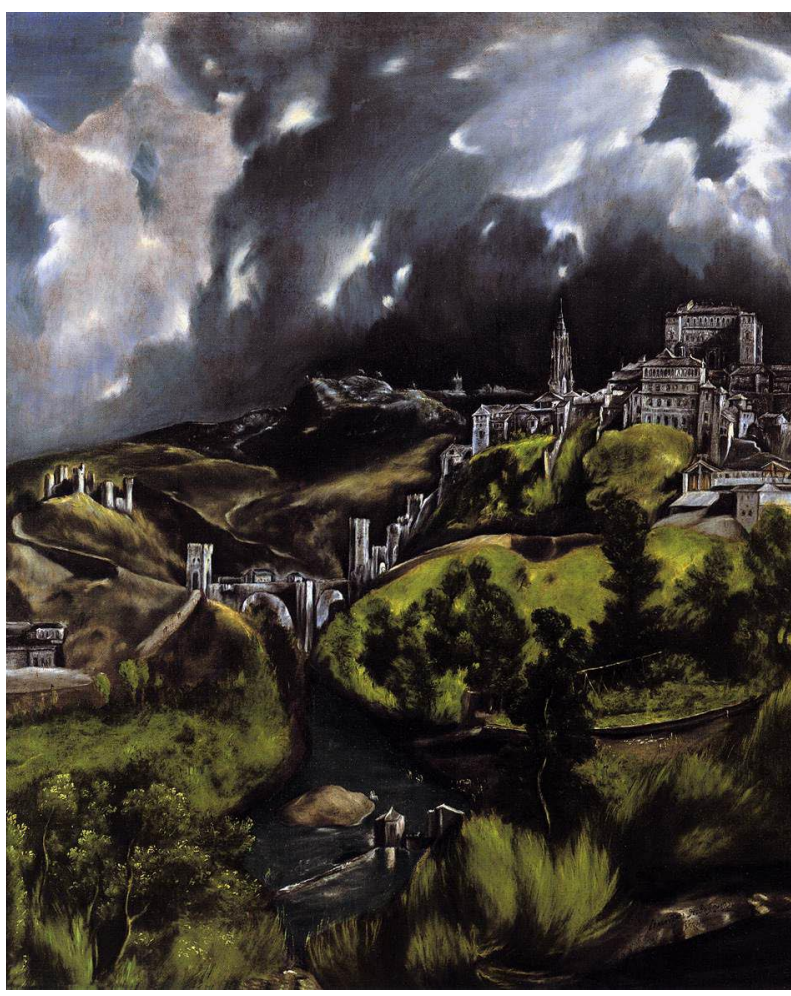

El Greco, Vista de Toledo, 1597-99.

frecuentemente se fomentará el orguIlo nacional a través de la representación de las ciudades, a través del despliegue de posesiones y territorios. Un hecho significativo al respecto

$7 \quad$ Citado por Javier Maderuelo en Maderuelo, Javier, El paisaje, génesis de un concepto, Abada, Madrid, 2005, p.216. 

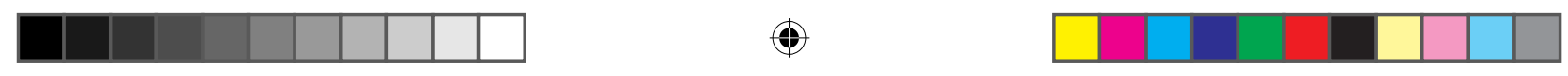

es que los paisajes ya no se pintan por encargo como sucedía con los retratos de la nobleza y el clero, sino que son adquiridos directamente por la población, es decir, por una sociedad que se reconoce a sí misma en dichas obras. Estos paisajes, obviamente, no son tan sólo una mera imitación de la realidad sino que bien al contrario, implica un proceso creativo (por ejemplo, la elección del punto de vista, los elementos que lo compondrán, la luz o el momento del día), que responde a un determinado modelo de belleza, un modelo que refleja e instaura un determinado orden moral. Una visión del entorno físico y la naturaleza que no es mera descripción geográfica sino que es asimilable al modelo italiano $y$ español en cuanto expresión de una religiosidad y moral específicas.

Pero no se produ-

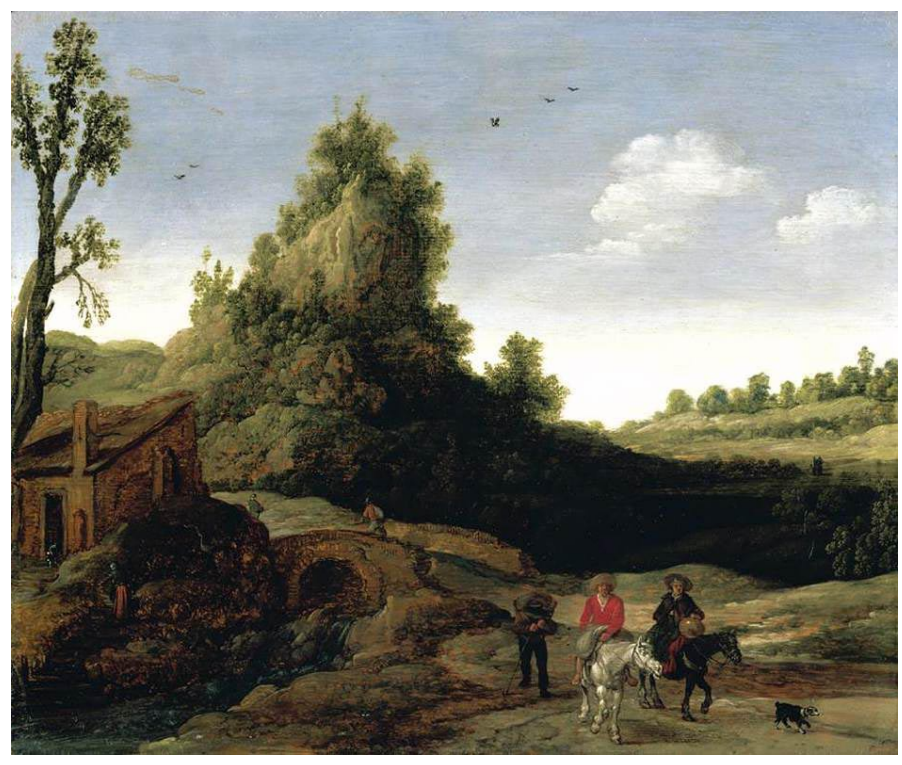
ce la aparición del paisaje autónomo en este contexto Esaias van de Velde, Landscape,1622. únicamente por razones religiosas. El otro gran factor a tener en cuenta, es el enorme aprecio que los holandeses sienten por su país. No en vano el territorio no es algo dado por supuesto, es el fruto de un enorme esfuerzo de desecación de tierras, de canalización de aguas y de grandes infraestructuras para la gestión de esas nuevas tierras generadas. Por tanto, cuando se pintan los paisajes holandeses no se representa una geografía sino un esfuerzo, un regocijo de la población por los logros alcanzados y por su enorme prosperidad. Son la manifestación de la complacencia que la sociedad holandesa siente hacía sí misma. El paradigma de dicho orgullo será la 

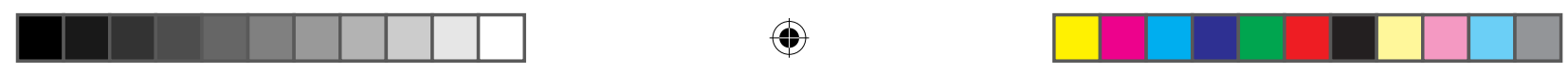

2. El paisaje como acontecimiento.

ciudad de Haarlem, donde se producirán una enorme efervescencia en la representación pictórica de paisajes.

Estamos viendo, pues, cómo el aprecio por la naturaleza no es un hecho intemporal y homogéneo, al contrario, está profundamente ligado a sus diferentes contextos económicos, sociales y culturales. Así, me gustaría mencionar, a modo de ejemplo paradigmático de este carácter fuertemente contextualizado del paisaje, tres momentos históricos concretos distintos donde la lectura de la naturaleza y la creación de paisajes se han producido de modo bien diferente. Para intentar entender cómo nos proyectamos en el entorno hoy en día en nuestras sociedades occidentales, resulta interesante contextualizar los debates y comprobar cómo aspectos que hoy nos resultan indiscutibles no han sido siquiera considerados en otros momentos históricos.

En el primero de ellos, durante el Renacimiento, podemos comprobar cómo no se aprecia la naturaleza en su conjunto, sino únicamente determinados aspectos de la misma. Así, por ejemplo,

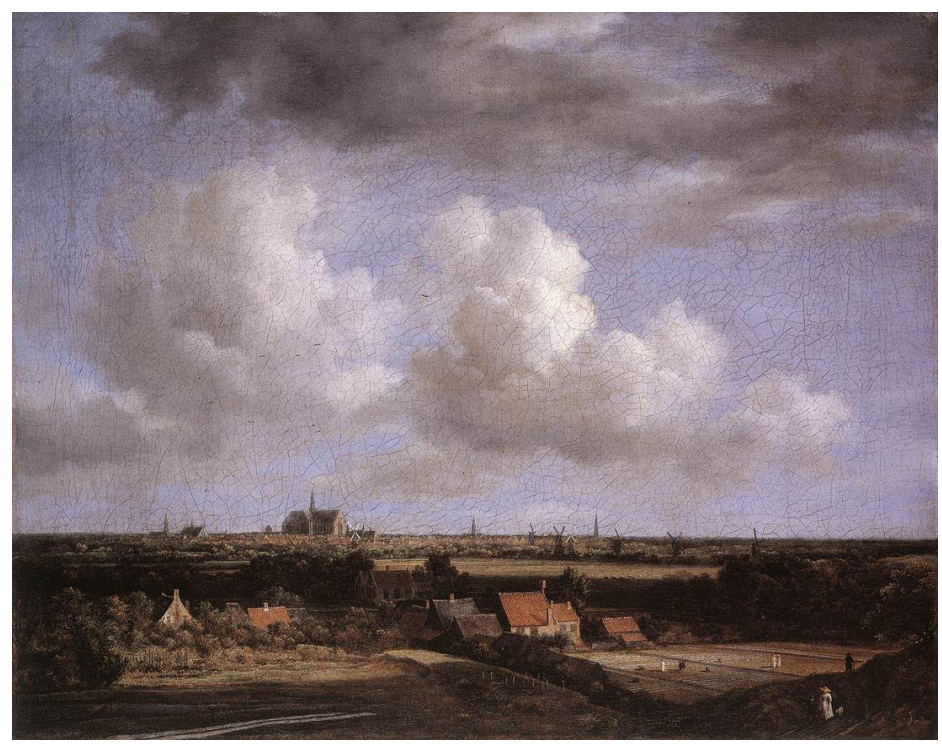
el bosque, el mar o la montaña serán lugares de lo desconocido que Jacob van Ruisdael, Paisaje con vista de Haarlem, 1670.

no solamente no serán valorados sino que producirán rechazo y miedo aún durante mucho tiempo. Los paisajes en este momento reflejan, mayoritariamente, una naturaleza amable, domesticada, cercana a la ciudad. Esta interpretación de la naturaleza tendrá un éxito particular en las 


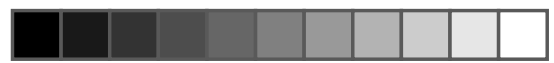

$\oplus$

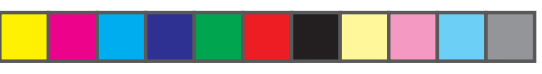

representaciones de la Virgen, donde los fondos de los cuadros son una excusa para reforzar ideológicamente el contenido de la obra mostrando los atributos vinculados a la Virgen Maria. Se trata de representaciones donde lo verdaderamente importante es la transmisión de valores concretos, entre otros, de serenidad y calma, mostrando para ello un campo agrícola productivo y en paz.

$(4$

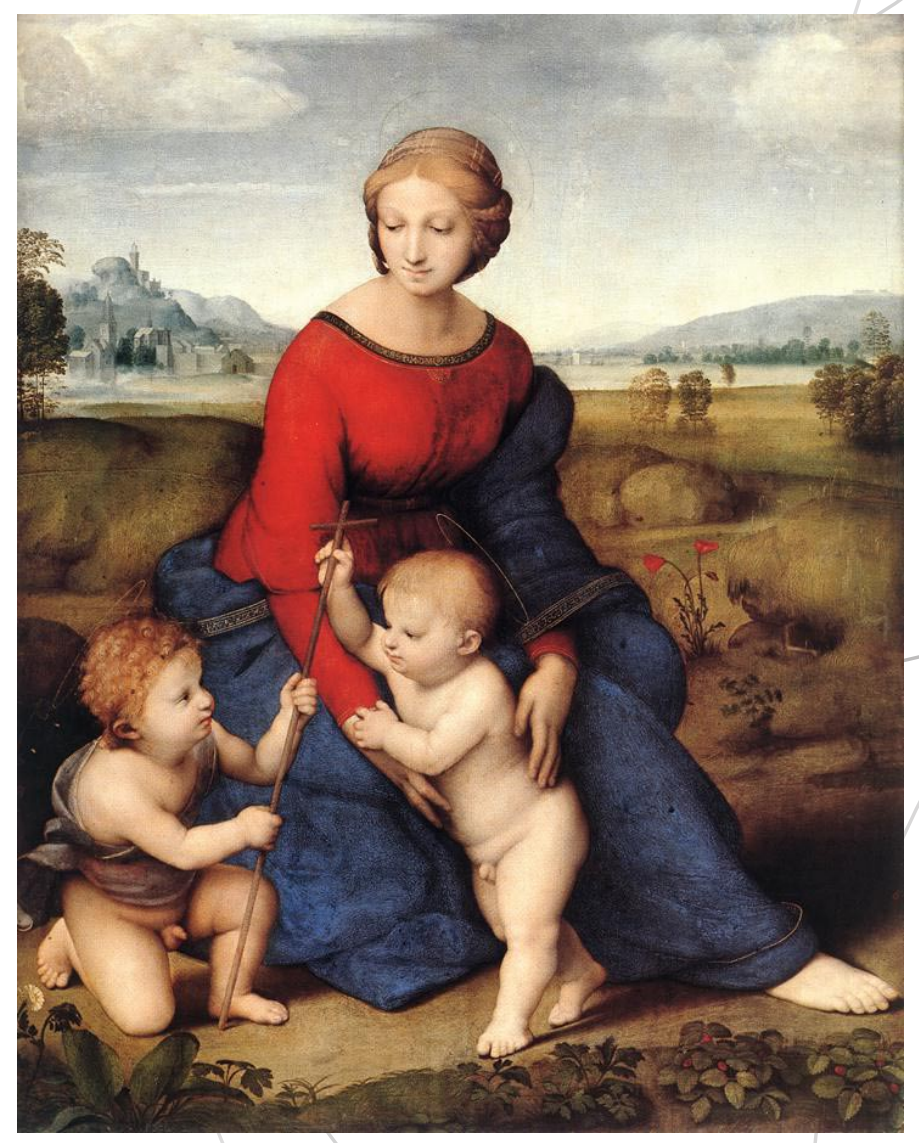

Rafael, Madona del Belvedere,1506.

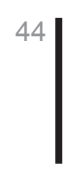



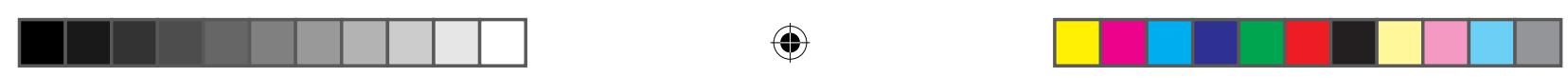

2. El paisaje como acontecimiento.

No me detendré, ya que no es el objetivo de este trabajo, en las diferentes valoraciones de la naturaleza a través de la historia, dejando así pues al margen, numerosos e interesantísimos ejemplos y situaciones de invención de paisajes a través de la historia del arte occidental. Mi interés reside en mostrar cómo el ser humano ha ido creando conceptualmente muy diversos paisajes; así y en muy diferentes lugares, dando un importante salto desde el siglo XVI a finales del S. XIX, deseo mostrar otro caso ejemplar de invención de paisajes: el nacimiento del desierto.

Efectivamente, no encontramos ni rastro de desiertos como lugares dignos de consideración estética durante siglos, bien al contrario, las referencias literarias son profundamente negativas; y sin embargo, aquí están hoy en día los desiertos con un enorme poder de seducción y una fuerza incuestionable. ¿Qué ha sucedido? La primera explicación la podemos encontrar en las expediciones a Egipto del siglo XIX y en las representaciones románticas transmitidas por los fotógrafos de esa época. Con el desarrollo de las técnicas fotográficas, la imagen, la postal del desierto, llegará hasta nosotros para quedarse. Con ellas se inicia un proceso de mitificación, animando al turismo a adentrarse en este lugar de ensoñación, donde apreciar nociones como el silencio o la nada, y

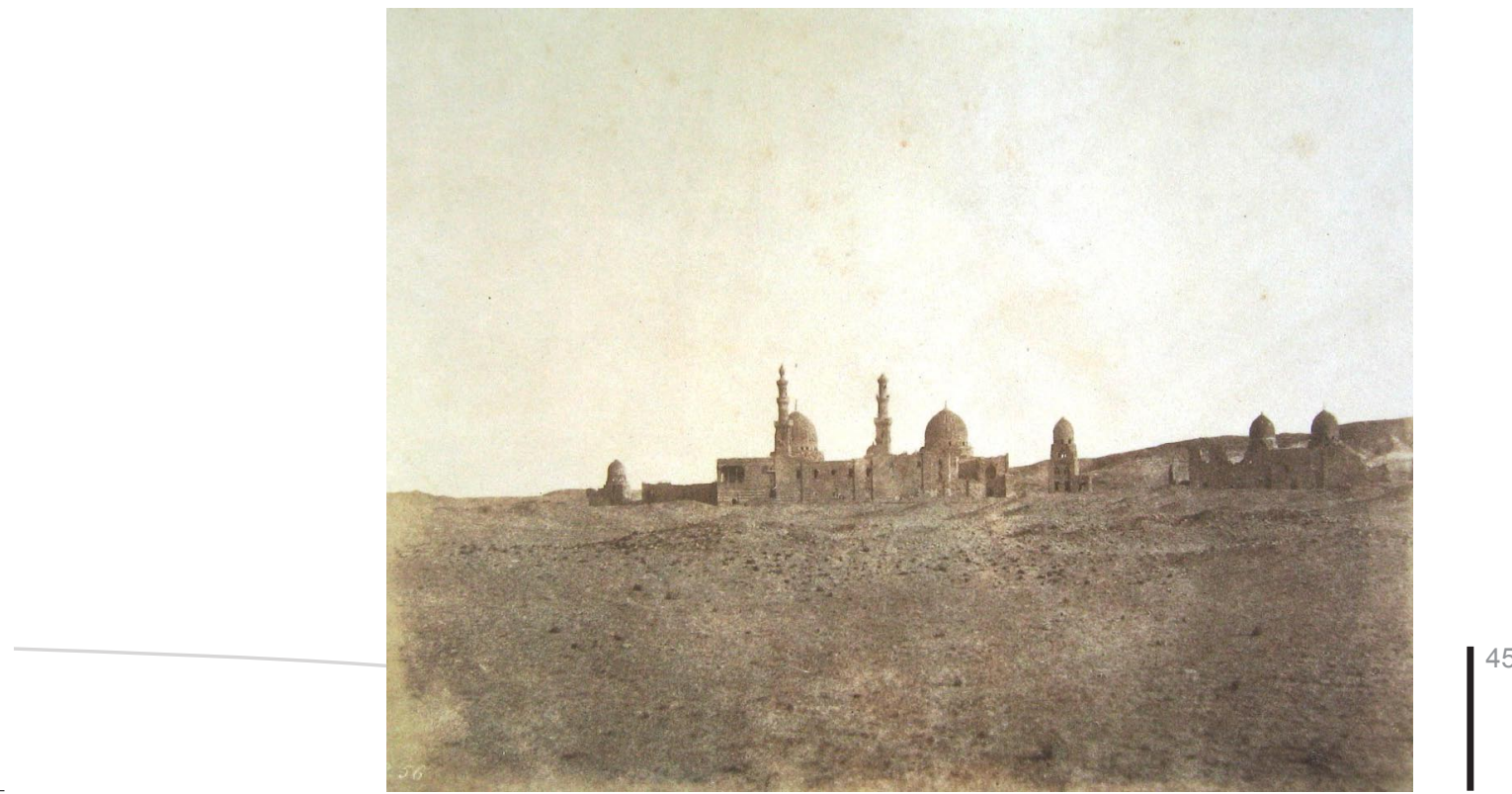



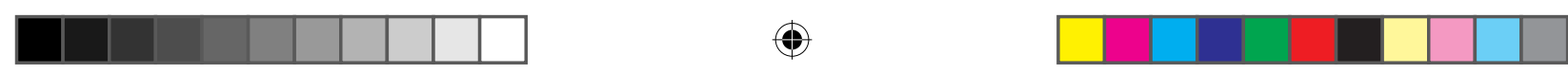

donde interrogarnos sobre nosotros mismos.

Vale la pena destacar que la realidad física del país, el territorio que ha servido de base para la invención del desierto, no responde a lo que casi todos nosotros tenemos en la mente. Como nos recuerda el investigador Michel Roux ${ }^{8}$ aunque el reg (una superficie sensiblemente plana, pedregosa, con algo de arena y limo o arcilla) es inmensamente mayoritario, ha sido el erg (la formación arenosa compuesta por dunas) la que ha calado en el imaginario colectivo. Esto explicaría una experiencia muy esclarecedora al respecto que tuve hace unos años en el desierto del Gobi.

El viaje al desierto del Gobi al sur

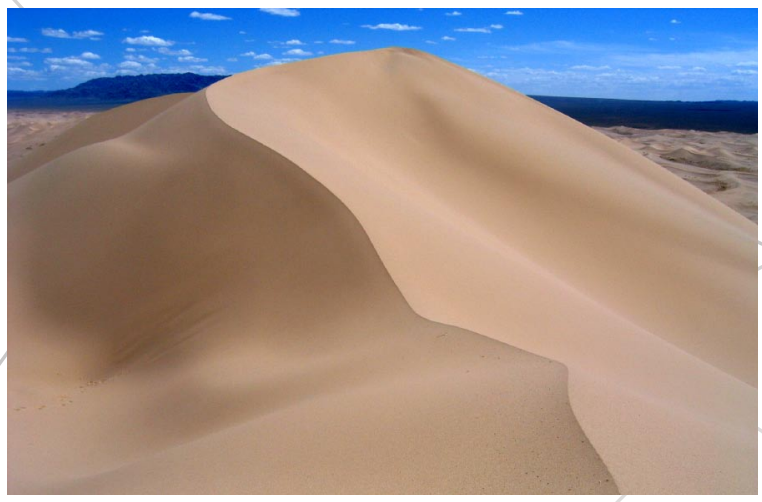

Desierto de Gobi, Mongolia, (fotografía I.C.). de Mongolia y frontera con China se proyectó como el viaje a un lugar soñado, mítico, no visto pero sí repetidamente imaginado. Así, resulta reveladora mi actitud casi ridícula por encuadrar con mi cámara fotográfica un mar de dunas que apenas terminaba en el borde la fotografía. Le estaba negando la condición de paisaje al desierto de piedra que nos rodeaba. La fotografía resulta, por tanto, una completa invención ya que dicho encuadre solamente se obtuvo después de días de recorrido por kilómetros y kilómetros de desierto de enlosado de piedra y grava que en ese momento no se acomodaba a las expectativas creadas de lo que "debía" ser el desierto del Gobi. Estaba reproduciendo, comparativa e inconscientemente, aquella

8 Citado por Alain Roger en Roger, Alain, Breve tratado del paisaje, Biblioteca Nueva, Madrid, 2007, p.117.

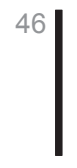



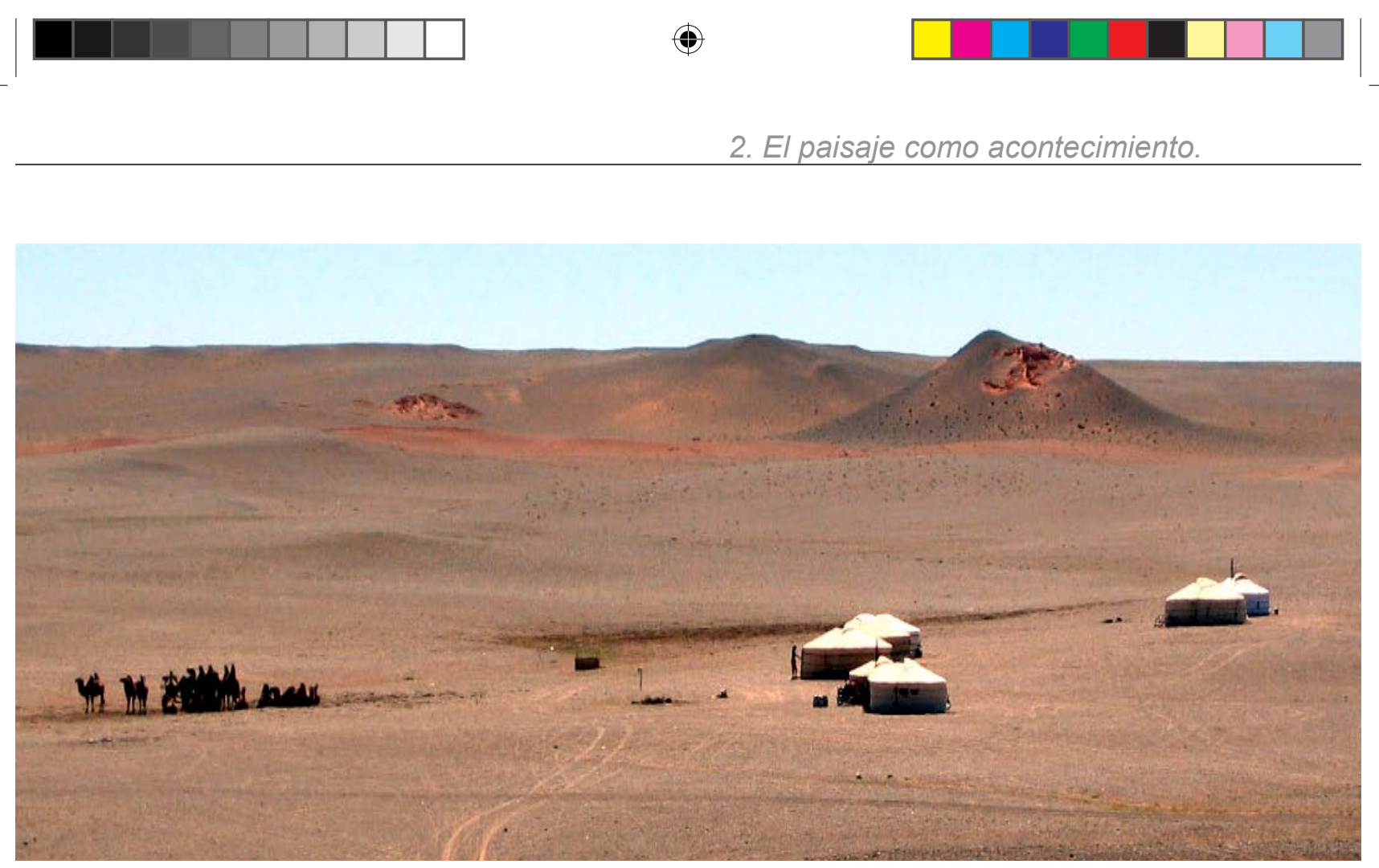

Desierto de Gobi, Mongolia, (fotografía I.C.).

preocupación, por entonces desconocida, de los primeros fotógrafos del desierto cuya principal inquietud consistía en buscar lo sublime intentando borrar cualquier presencia humana que fuera más allá de la ruina del Egipto faraónico. Pero lo que obtuve fue algo diferente a un paisaje: únicamente una duna, un elemento más o menos atractivo pero sin rastro de paisaje. Hizo falta, partiendo del auténtico desierto de piedra, la incorporación de otros elementos de referencia como los gers (las tradicionales yurtas mongolas), y los camellos para hacer surgir algo similar a un paisaje, a uno de los paisajes del desierto del Gobi. Siempre me he interrogado sobre el porqué de la seducción que producen los desiertos ¿Se debe, tal vez, a qué ningún paisaje como el desierto nos posiciona frente al mundo? ¿Es esa la misma fascinación que produce la puerta abierta del tempietto de Rafael? Preguntas difíciles de contestar, o mejor aún, imposibles de responder dado el carácter profundamente íntimo de nuestra relación con el paisaje.

Finalmente, no quisiera terminar esta parte de la introducción sin 

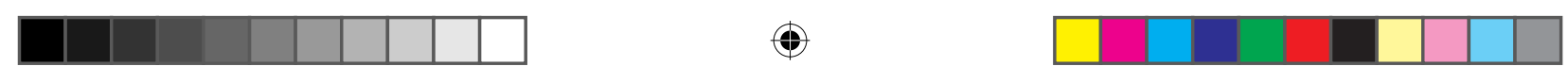

mostrar, aunque sea de un modo breve, cómo la invención del paisaje a través del arte es un proceso abierto y fluctuante que se sigue produciendo hoy en día. El paso del país al paisaje a través del arte no se debe entender como un fenómeno del pasado, bien al contrario, el arte contemporáneo y el cine siguen investigando y creando nuevos y sugerentes paisajes. Con ello, me refiero al tercer ejemplo de contexto histórico que deseo citar. En 1984, el director Win Wenders, comenzará su película Paris Texas con una serie de travellings del desierto de Arizona acompañados por la extraordinaria banda sonora de Ry Cooder para presentarnos a un personaje extraviado, errante por el desierto. La combinación de imágenes y música crea un paisaje que actúa con una enorme fuerza y capacidad expresiva, reforzando la idea de soledad y abatimiento de un personaje de quién descubriremos poco a poco que ha perdido el rumbo en la vida, que ha olvidado por qué se encuentra en ese lugar y que no recuerda ni siquiera su propia identidad. El desierto natural, se nos presenta, como poderosa metáfora del desierto interior del personaje.

Otro ejemplo, éste aún más reciente, de utilización del paisaje como herramienta expresiva y vehículo de significado donde una naturaleza real es mucho más que sus condiciones físicas u objetivas y se convierte en un paisaje, esta vez de libertad y de opresión al mismo tiempo, nos lo ofrece Ang Lee en Brokeback Mountain (2005). El film, que narra la "imposible" historia de amor entre dos cow-boys norteamericanos homosexuales en la década de los años sesenta y setenta, presenta una naturaleza profundamente cargada de significado. En un contexto social fuertemente hostil, el único lugar donde los protagonistas podrán expresarse y ser felices es en un entorno salvaje sin rastro de presencia humana. Así, cuando en la escena donde Ennis del Mar (Heath Ledger) le confiesa a su compañero Jack Twist (Jake Gyllenhaal) que nunca dejará su doble vida, a Jack Twist le basta con contemplar aquellas montañas para comprender que ellas serán toda su esperanza, que sólo allí podrá ser libre. Borrado así cualquier atisbo de relación con la montaña basado únicamente en la belleza de sus árboles o en la claridad de sus riachue- 


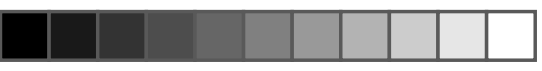

(†)

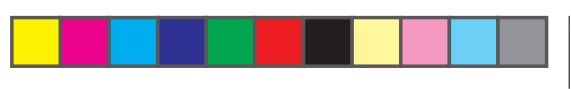

2. El paisaje como acontecimiento.

$\oplus$
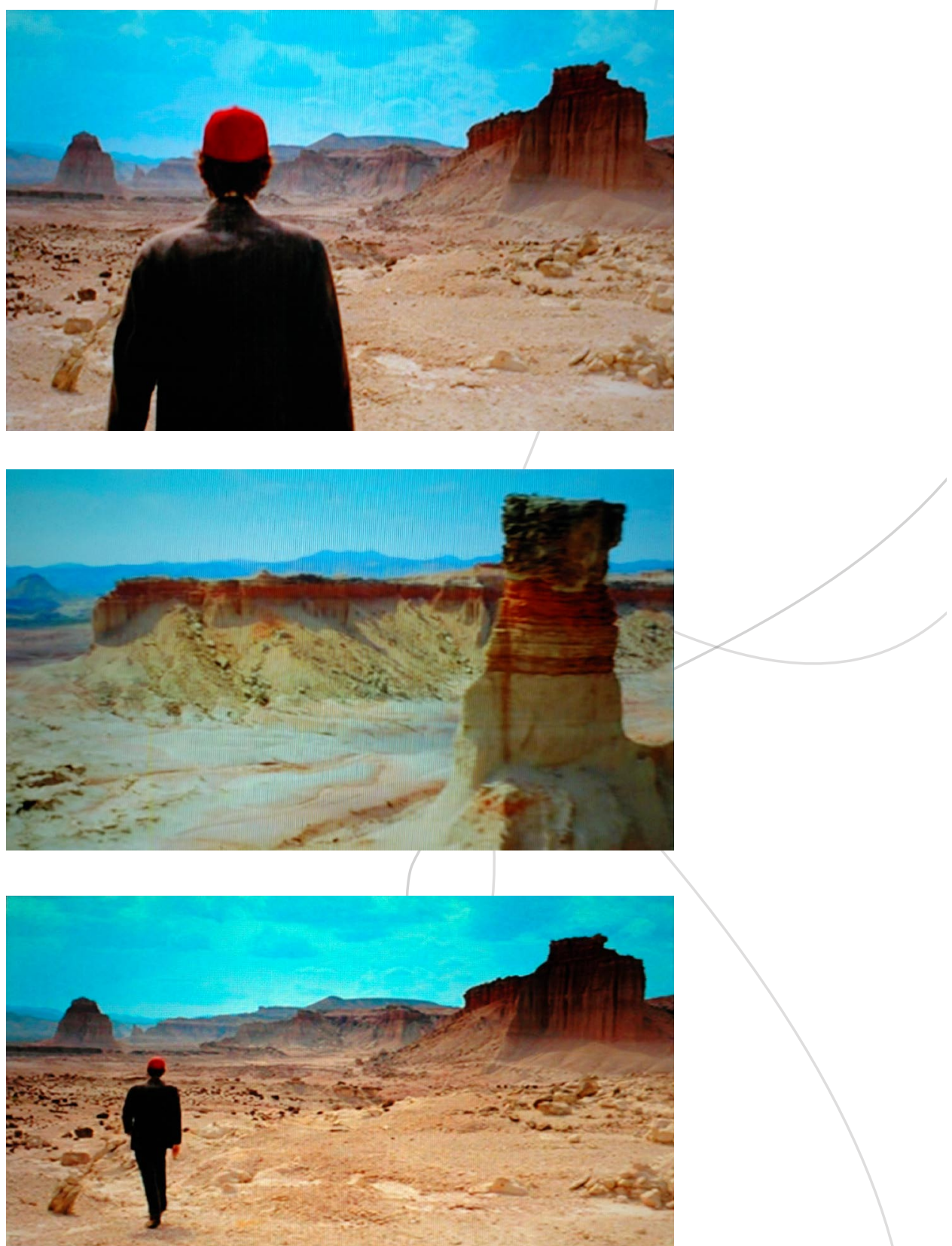

Win Wenders, Paris Texas, 1984.
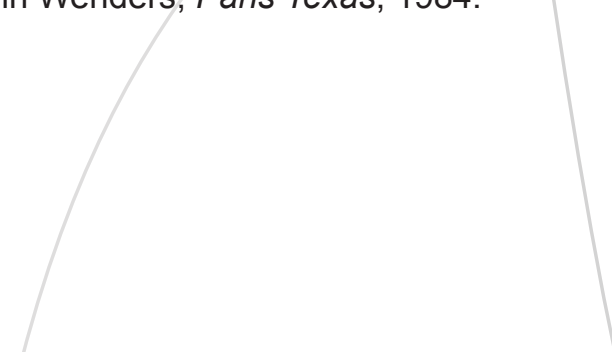

$\oplus$ 


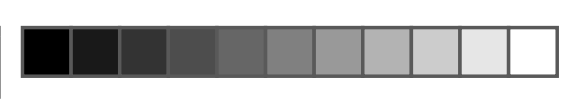

$\oplus$
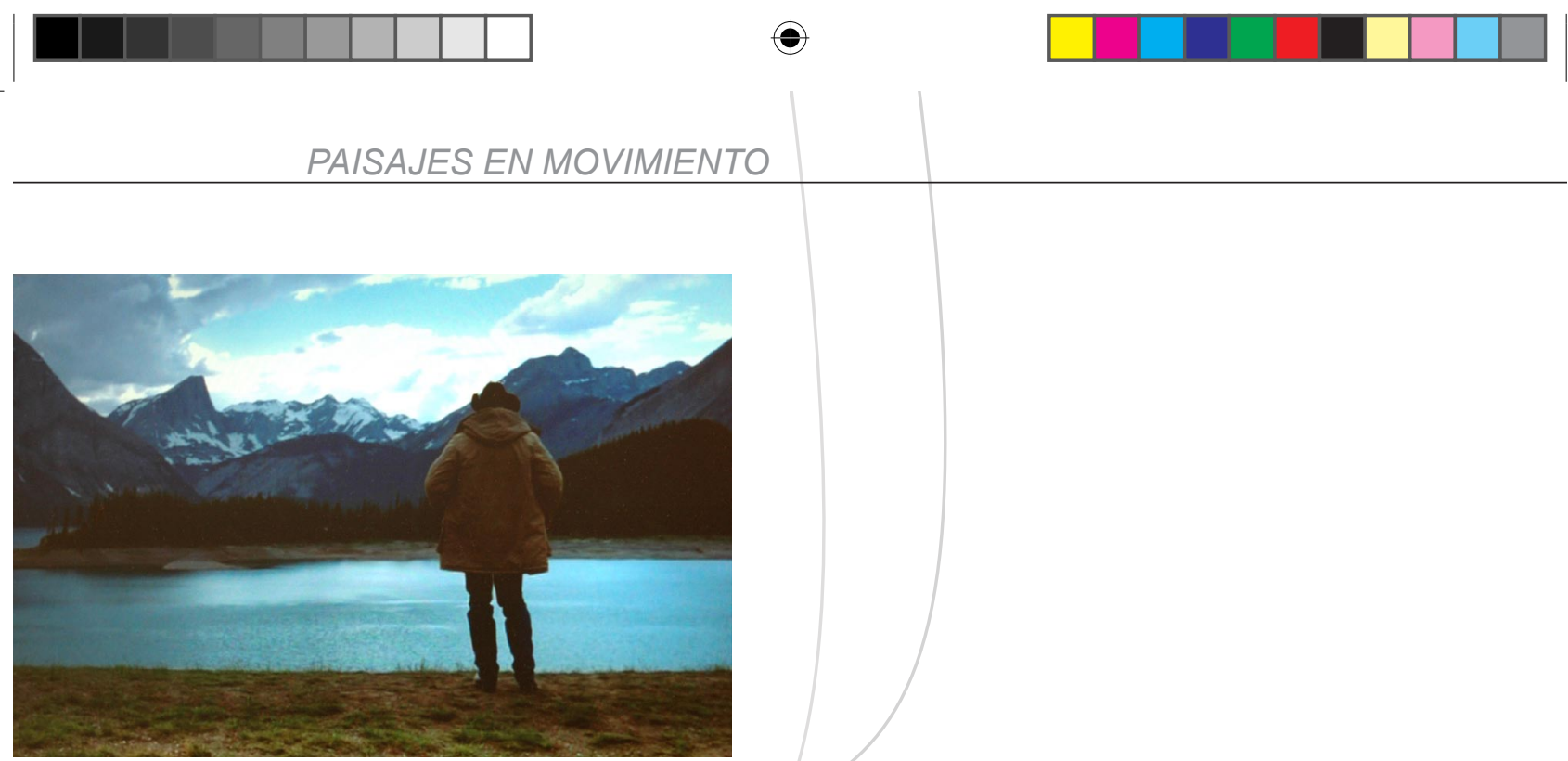

$\oplus$
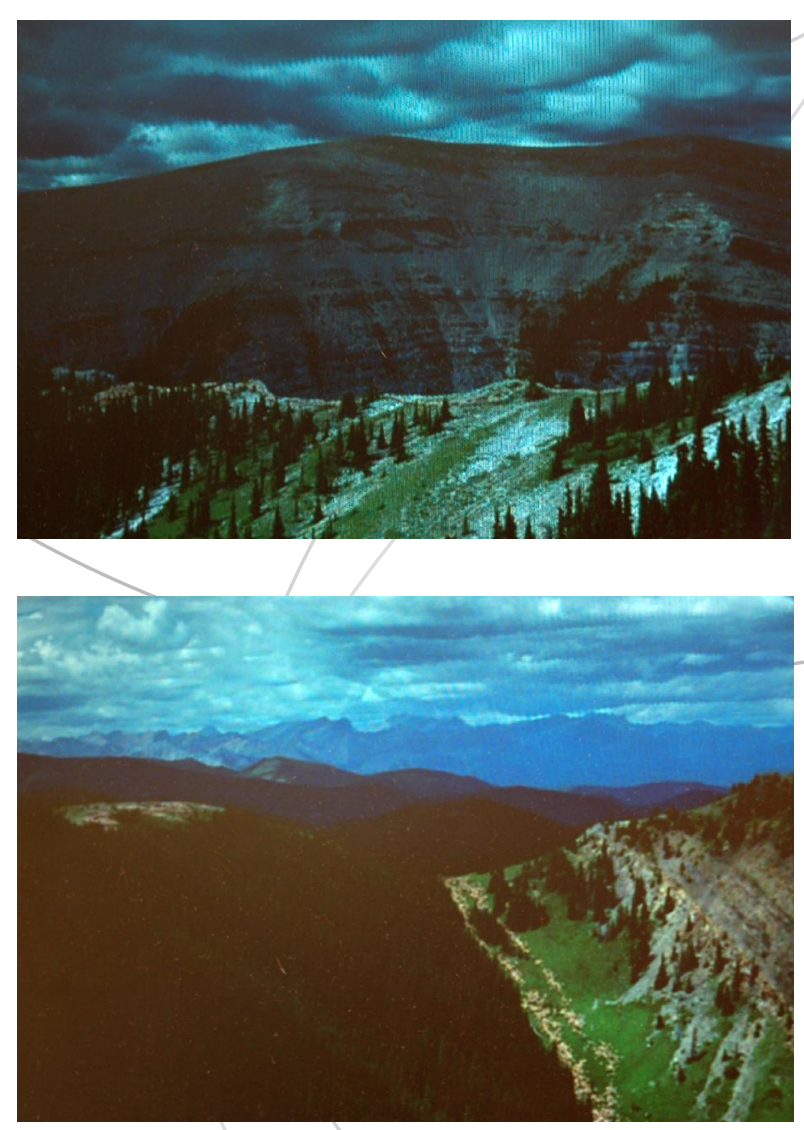

Ang Lee, Brokeback Mountain, 2005.

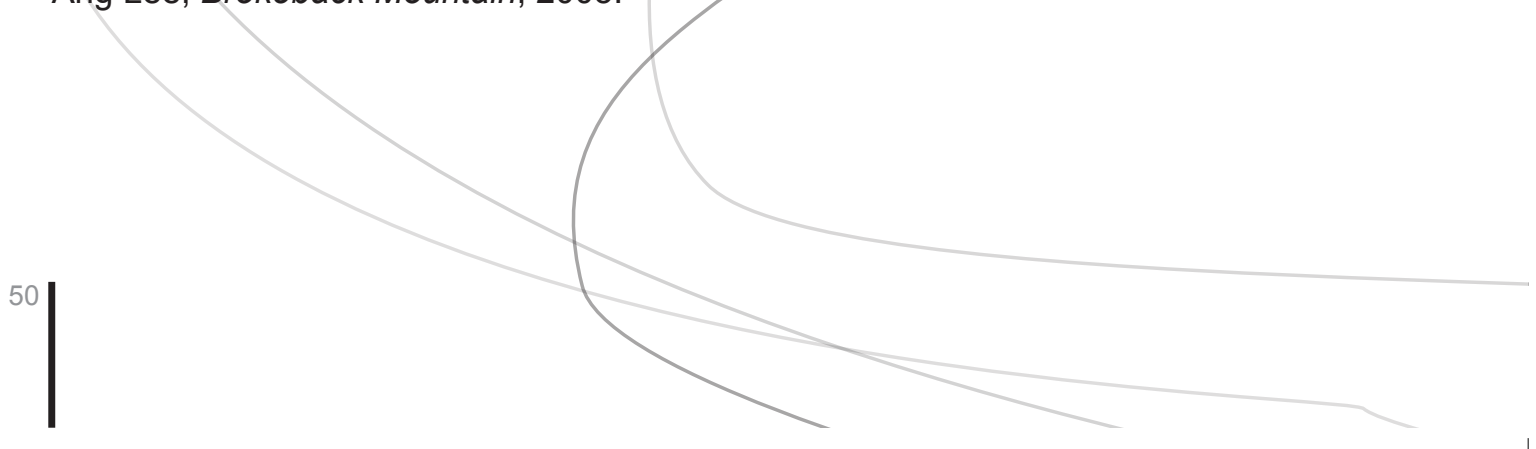



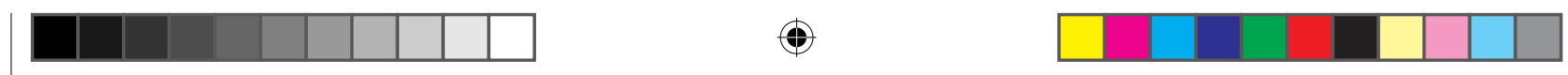

2. El paisaje como acontecimiento.

los. La montaña de Brokeback no es tan sólo una formación geológica, es mucho más, es una construcción sociopolítica, una invención cultural gracias a la mirada del arte.

Naturalmente no es la única montaña en la historia de la Cultura Occidental construida desde y gracias al arte, ha habido muchas otras de muy diferente significado. Por ello, me gustaría en este momento recordar otra montaña de gran trascendencia en la historia del paisaje: el monte Ventoux. De este modo, aprovecharé un episodio que muchos autores consideran como, nada más y nada menos, que el origen del concepto mismo de paisaje en la cultura occidental para concluir esta introducción resumiendo y fijando el "paisaje" de Paisajes dinámicos. Se trata de la ascensión por parte de Francesco Petrarca al monte Ventoux en torno a 1336. $Y$ me interesa traer aquí esta anécdota interesada, para llamar nuestra atención sobre lo significativo de que precisamente se hable de nacimiento del término paisaje a colación de una excursión, de una ascensión, en definitiva, de una acción dinámica y todas sus complejas implicaciones.

En efecto, poco podía imaginar Petrarca cuando inició su andadura hacia la cima del monte Ventoux, cerca de Aviñón, en pleno siglo $X I V$, que aquella extravagante excursión supondría, para muchos historiadores posteriores, el comienzo de un nuevo concepto, el paisaje. Un concepto que habría de hacer su aparición en el Renacimiento para quedarse en la Cultura Occidental hasta comienzos, al menos, del siglo XXI, donde recobrará un fuerte impulso y vitalidad. Si bien resulta innegable que datar en una fecha tan concreta y específica el origen de un concepto tan complejo y múltiple como el de paisaje resulta demasiado simple, es interesante fijarse en el por qué de la atención puesta en esa fecha por gran parte de la historiografía del paisaje. 

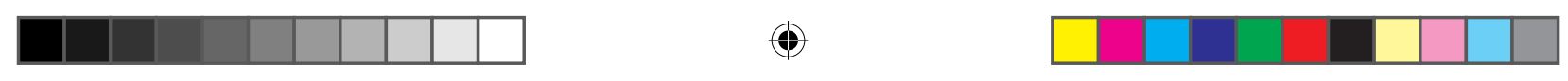

Hagamos memoria:

Petrarca decide comenzar la ascensión al Monte Ventoux "impulsado únicamente por el deseo de contemplar un lugar célebre por su altitud."9 Nos detendremos, por el momento, en esta primera exposición de sus motivaciones. El interés por parte del poeta toscano en ascender dicho monte, no surge, evidentemente, de manera espontánea. Como él mismo nos confiesa, antes de comenzar el relato propiamente dicho de los avatares de la cami-

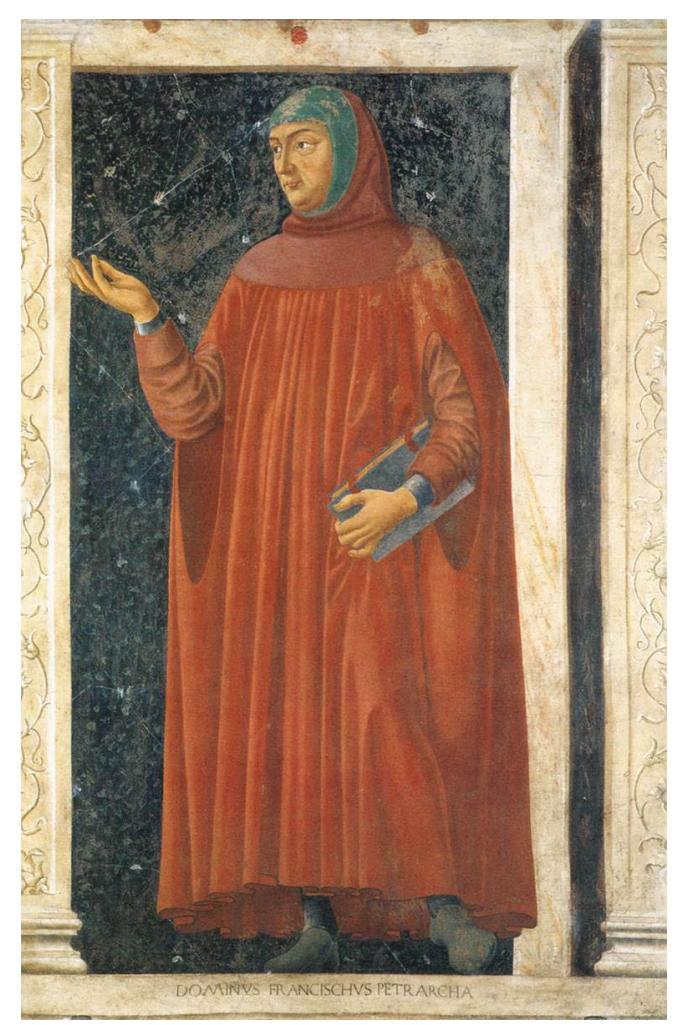

Andrea del Castagno, Petrarca, c. 1450. nata, hacía muchos años que dicha ascensión estaba en su ánimo y se decide a acometer un viaje largamente postergado después de releer a los clásicos, en concreto, la historia romana de Tito Livio y el ascenso del Monte Hemo por parte de Filipo rey de Macedonia. Es decir, encontramos aquí la primera clave del texto: en la contemplación del panorama desde la cumbre y en su ánimo durante la ascensión existe una intencionalidad, Petrarca busca un lugar ya soñado. Nunca pues, sus ojos verán una mera geografía con una mirada llamemos objetiva o científica, sino que contemplará una naturaleza con resonancias históricas, algo que trasciende la realidad física del entorno.

Así nos narra el momento fugitivo de emoción estética que se

9 Todas las citan que hacen referencia a la ascensión al Monte Ventoux se encuentran en Petrarca, Francesco, Manifiestos del Humanismo, Península, Barcelona, 2000, entre las páginas 25 y 35.

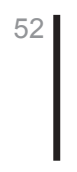



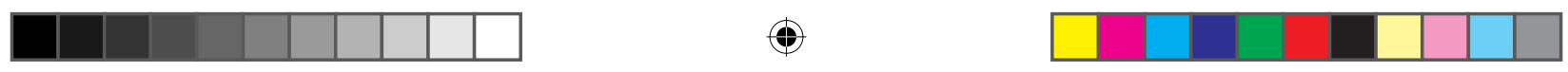

produce a su llegada a la cima: "Primeramente, alterado por cierta insólita ligereza del aire y por el escenario sin límites, permanecí como privado de sentido. Miré en torno a mí: las nubes estaban bajo mis pies y ya me parecían menos increíbles el Atos y el Olimpo mientras observaba desde una montaña de menor fama lo que había leído y escuchado acerca de ellos." Pero el relato todavía va un paso más allá.

Cuando Petrarca, una vez alcanzada la cima del monte, descansa y ya repasada la geografía circundante en busca de nombres y lugares conocidos, decide extraer un pequeño volumen de la Confesiones de San Agustín que lleva "siempre a mano" y abrirlo al azar para extraer alguna enseñanza de sus páginas se detiene en el siguiente fragmento: "Y fueron los hombres a admirar las cumbres de las montañas y el flujo enorme de los mares y los anchos cauces de los ríos y la inmensidad del océano y la órbita de las estrellas y olvidaron mirase a sí mismos". A continuación nos explicará: "Me quedé estupefacto lo confieso." Para concluir, algo más adelante: "Entonces, contento, habiendo contemplado bastante la montaña, volví hacia mí mismo los ojos interiores, y a partir de ese momento nadie me oyó hablar hasta que llegamos al pie; aquella frase me

Vista del Monte Ventoux en la actualidad.

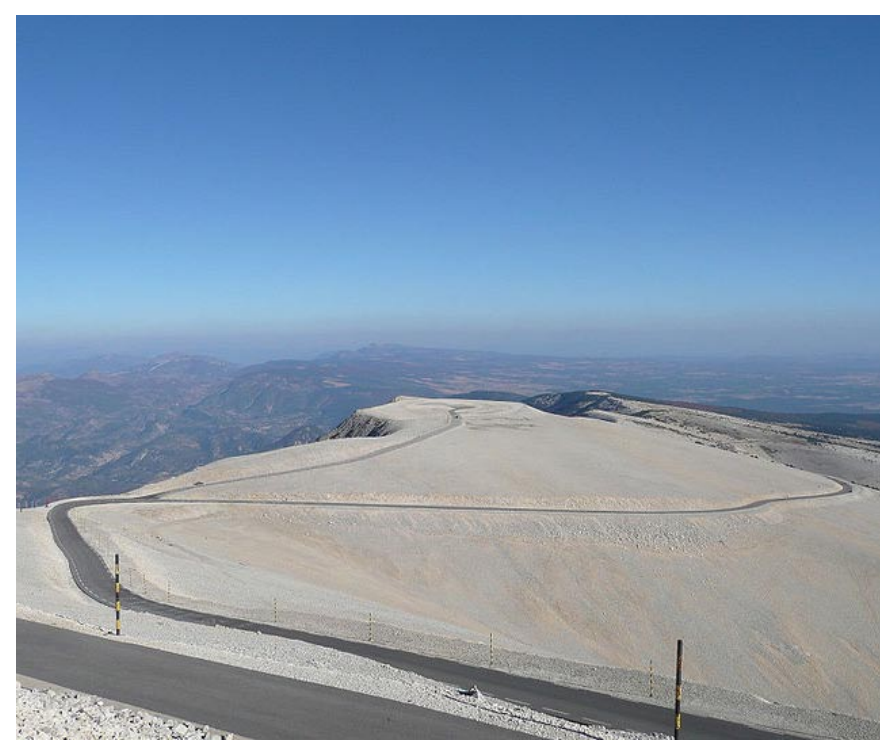



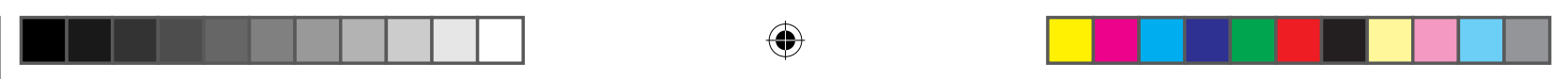

tenía suficientemente ocupado en silencio."

Tenemos, en estos fragmentos del hermoso relato de Petrarca dos claves que con infinitas variaciones y matices, nos permitirán construir paisajes en el mundo Occidental: una, la contemplación de la naturaleza como algo que va más allá de la utilidad práctica que se pueda extraer de ella; dos, la emoción estética surgida de dicha contemplación, entendida dicha emoción estética, por supuesto, en un sentido amplio y mutante a través de los siglos y la obligada referencialidad de dicha mirada, bien a cuestiones de carácter histórico, personales o de distinta índole. Todo ello trabado e interrelacionado gracias a la mirada hacia nosotros mismos. En definitiva, como nos recuerda Petrarca, el paisaje como suma de la contemplación exterior de la naturaleza más la mirada de los "ojos interiores" hacía nosotros mismos. 


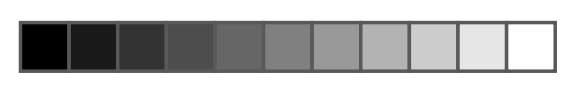

$\oplus$
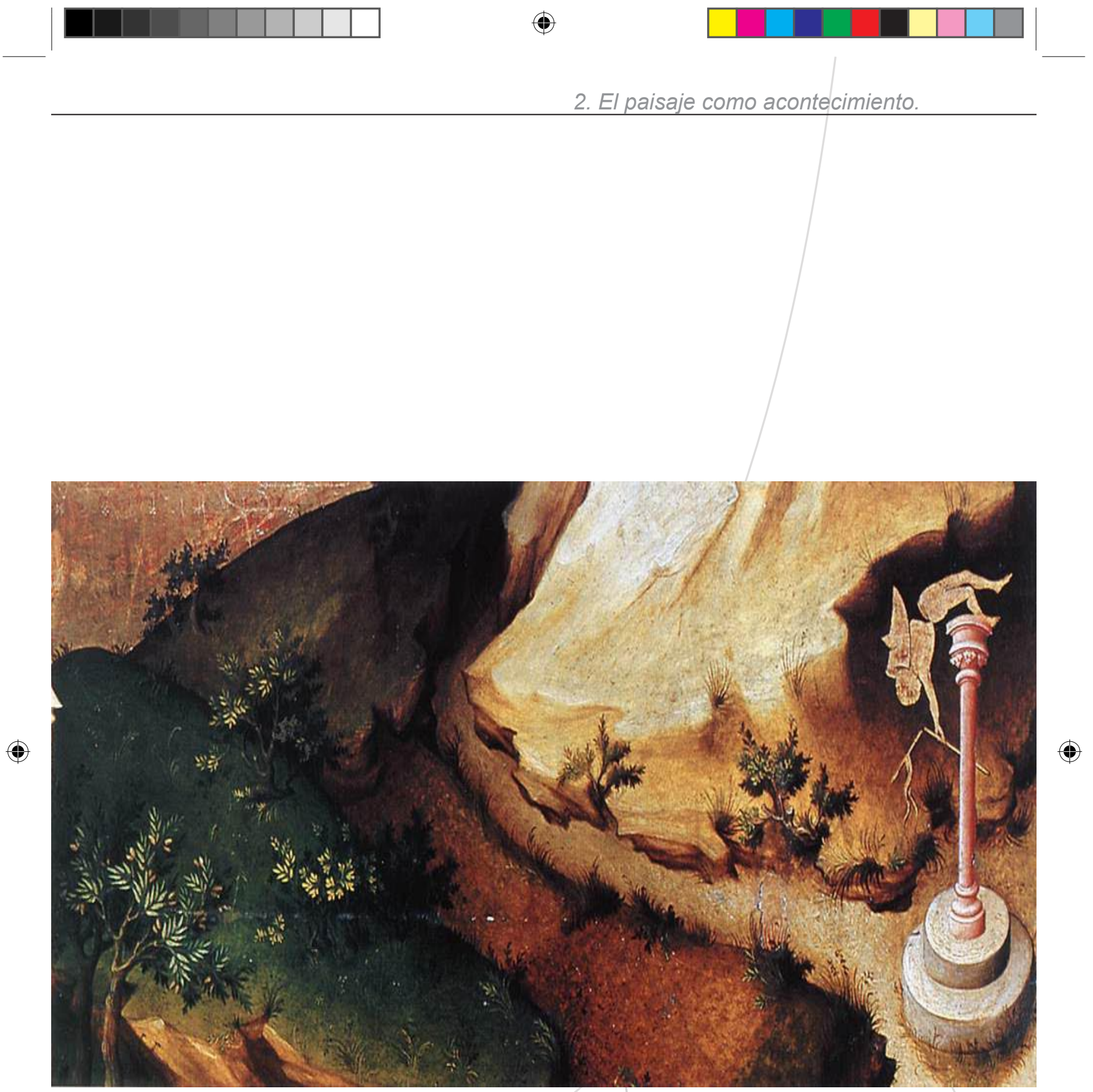

Melchior Broederlam, Huida a Egipto, 1393-99, (detalle).
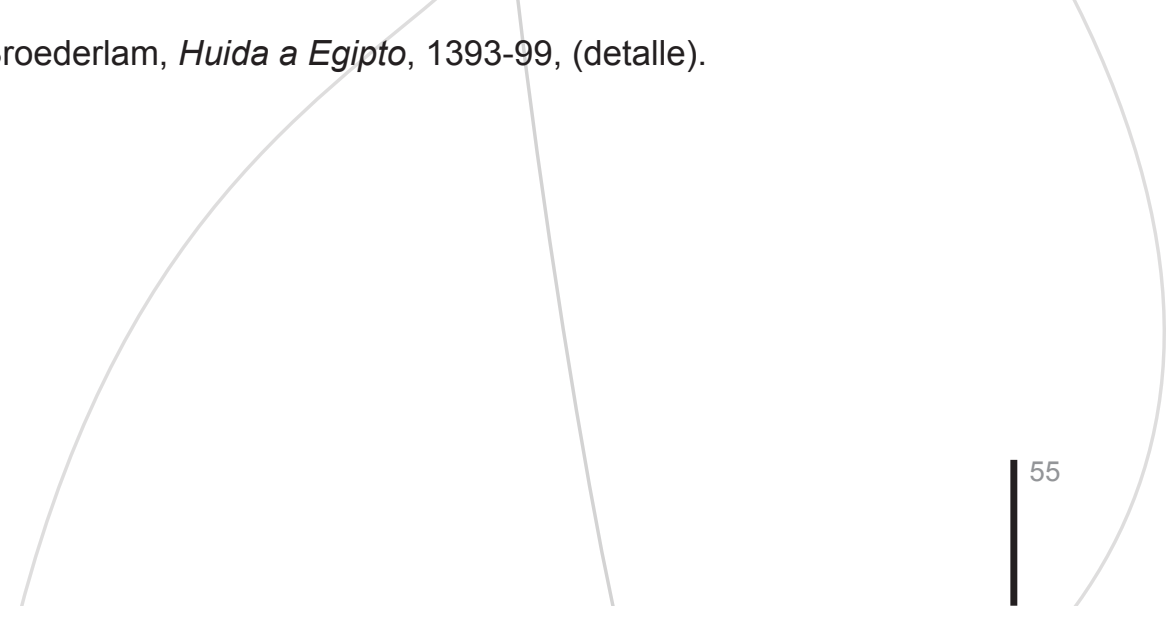


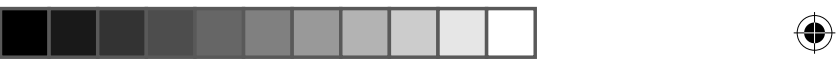

$\oplus$
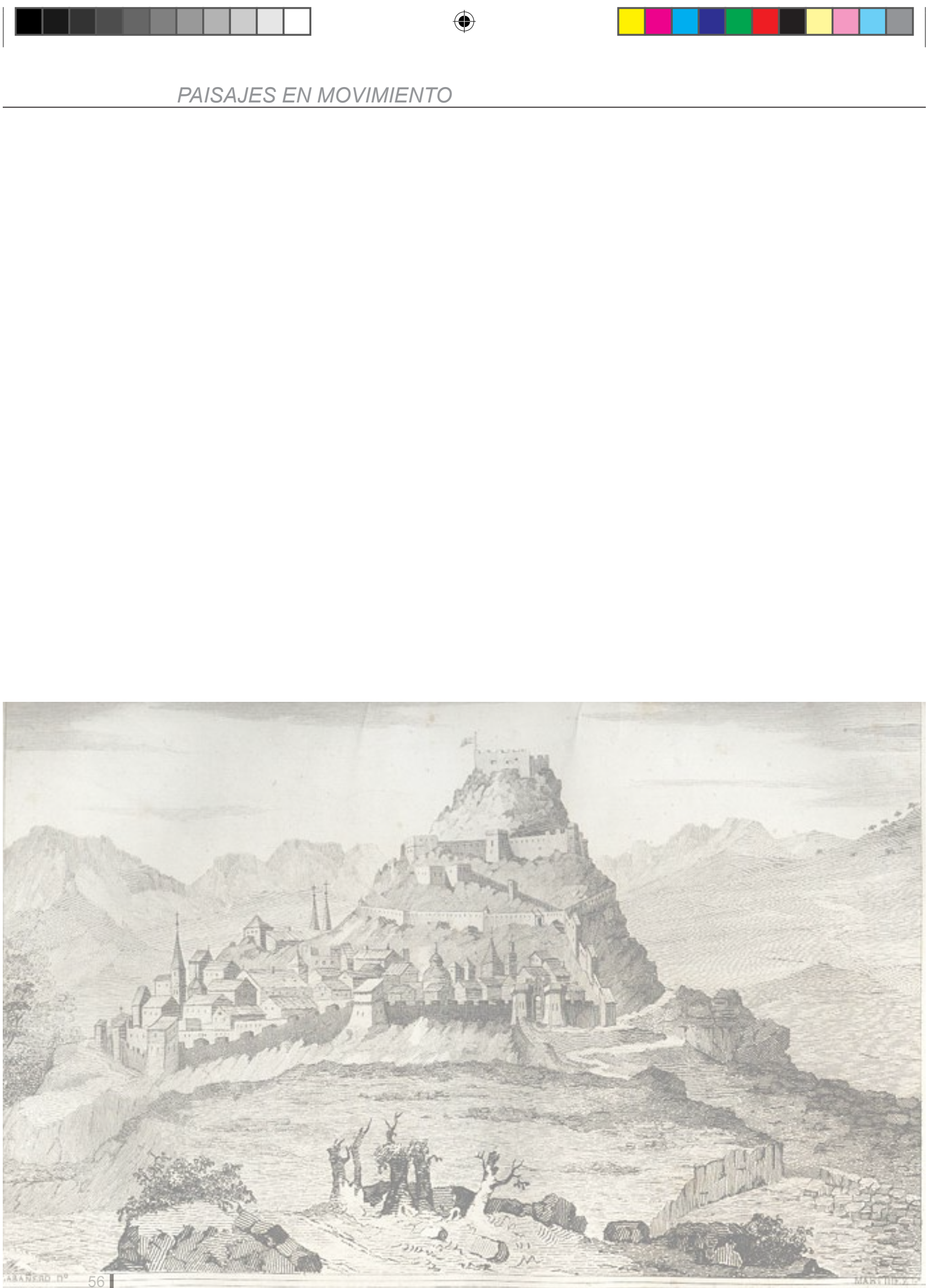

\section{VISTA DE MORELLA.}

Ctomada de la cambera de Aragon 

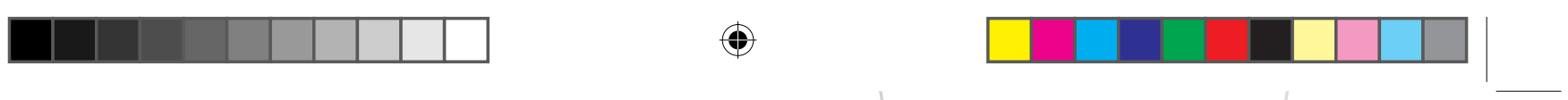

2.2.EL PAISAJE COMO CONSTRUCTO SOCIAL

Como veíamos en la introducción, pensar el paisaje es hoy más necesario que nunca. Las sociedades actuales plantean una cada vez mayor demanda en términos de desarrollo territorial y planteamientos como "protejamos nuestros paisajes" o "por un desarrollo sostenible" son reivindicados por un gran número de colectivos sociales. Se solicita, cuando no se exige, mejores políticas medioambientales y modelos de desarrollo más respetuosos con el paisaje. Pero a pesar de esta mayor demanda genérica, a medida que intentamos ser algo más específicos, el planteamiento inicial se difumina para convertirse en un conjunto de demandas que, sin concretarse, se transforman en una visión poliédrica y compleja. No podía ser de otro modo si intentamos tratar los paisajes. 

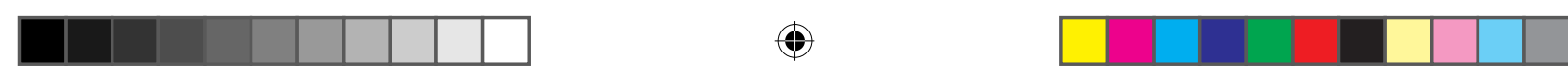

Como hemos visto, el paisaje necesita de una mirada para existir. El paisaje es una mirada. Y no existen miradas inocentes, gratuitas. Toda mirada es una construcción, una proyección subjetiva en el espacio. En este caso, será el propio observador quién se proyecta en un determinado territorio y en esa proyección hay un aspecto clave, primordial: la propia noción del sujeto o grupo social, como elemento situado en un contexto sociocultural concreto y específico, de la idea de Naturaleza en tanto construcción cultural. ${ }^{10}$ Un hecho que no hace sino subrayar y evidenciar el carácter nada arbitrario de la mirada hacia la naturaleza es cómo, históricamente, se ha utilizado ésta como herramienta para legitimar determinados planteamientos ideológicos. Por traer tan sólo algunos de los numerosísimos ejemplos que la Historia nos brinda citaremos dos bien alejados en el tiempo: Confucio en el año 500 a.C. ya planteaba: "es ley natural que la mujer esté sometida al dominio del hombre"11 y mucho más recientemente George W. Bush en su discurso de bienvenida a Benedicto $\mathrm{XVI}$ en su reciente visita a tos EE.UU (reproducido por los principales medios de comunicación mundiales) le planteará: "Aquí en Estados Unidos encontrará una

Ares del Maestre, Castellón, (fotografía I.C.). nación que acoge el papel de la religión en la plaza pública. Cuan-

10 Para una mejor aproximación al concepto de Naturaleza, véase: Albelda, José, Saborit, José, La construcción de la Naturaleza, Valencia: Generalitat Valenciana, 1997.

11 Ibídem, p.31.

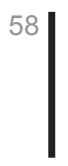



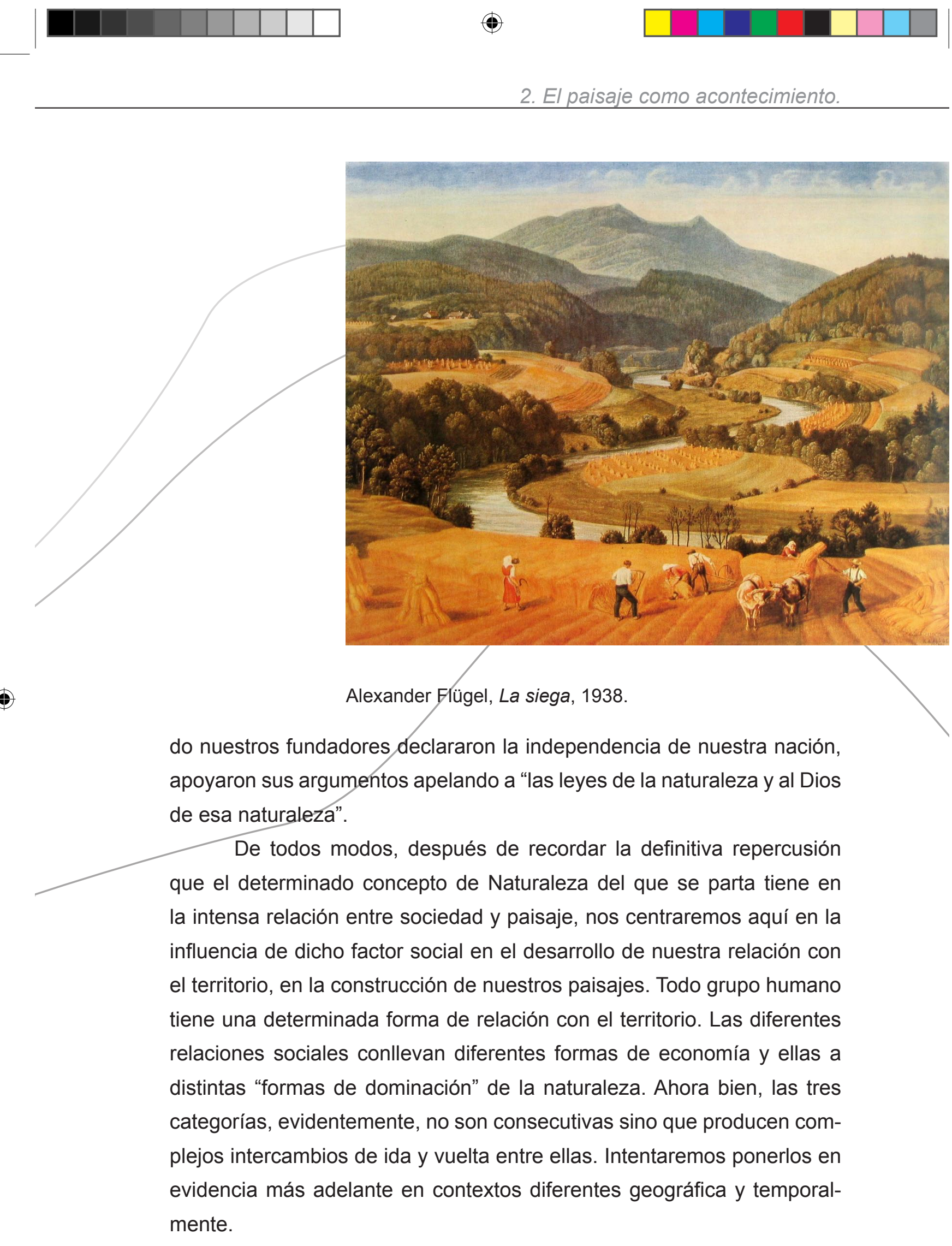

do nuestros fundadores declararon la independencia de nuestra nación, apoyaron sus argumentos apelando a "las leyes de la naturaleza y al Dios esa naturaleza.

que el determinado concepto de Naturaleza del que se parta tiene en la intensa relación entre sociedad y paisaje, nos centraremos aquí en la el territorio, en la construcción de nuestros paisajes. Todo grupo humano tiene una determinada forma de relación con el territorio. Las diferentes elaciones sociales conllevan diferentes formas de economía y ellas a plejos intercambios de ida y vuelta entre ellas. Intentaremos ponerlos en mente. 

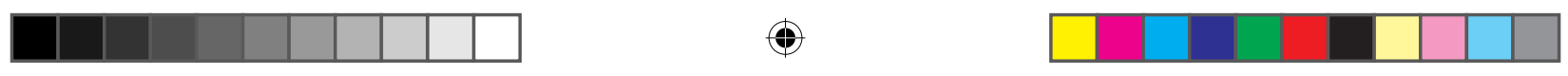

Vamos a partir pues de una premisa bien sencilla que complemente la visión dada en el epígrafe anterior, entender el paisaje como la proyección de un grupo social en un espacio natural o urbano, para tratar de mostrar los complejos mecanismos de interrelación que operan entre el grupo social y "su" paisaje, que actúan en la formación de la identidad colectiva.

Ahora bien, no podemos olvidar cómo históricamente la invención del paisaje la ha llevado a cabo un determinado grupo social dominante, con la suficiente capacidad para hacerlo, esto es, con el control de los resortes culturales y de poder, entendido éste en un sentido amplio del término, necesarios. Estos grupos se han permitido la apropiación ritual de la naturaleza, frente a otros grupos sin la capacidad para expresarse en términos de paisaje. Como nos dice el geógrafo Denis Cosgrove "la idea de paisaje representa un modo de visión por el cual ciertos europeos se han representado y han representado a otros el mundo a su alrededor y sus relaciones con él, y a través del cual han dicho algo de las relaciones sociales." 12

Frederick E. Church, Autum on the Hudson ,1856.

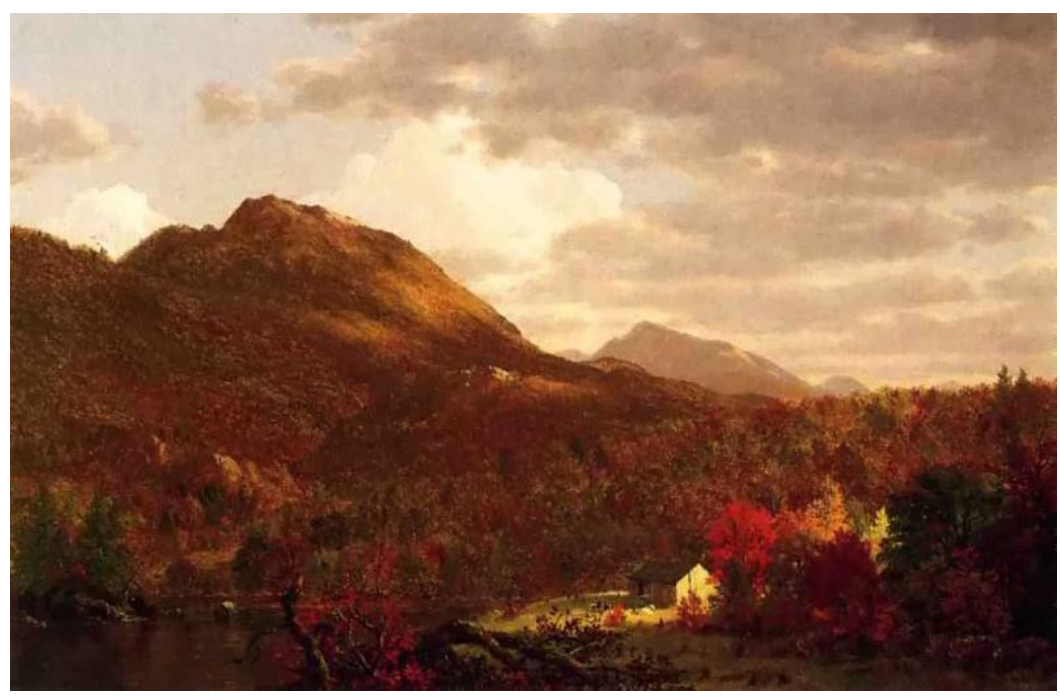

12 Cosgrove, Denis, "Social Formation and symbolic landscape » en VV.AA., Carnet du paysage n8, Paris, 2002, p.30. 


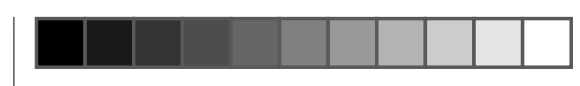

De acuerdo con estos planteamientos, dichos grupos se representan a menudo a sí mismos en un país mítico donde no existen los conflictos, donde los problemas y contradicciones, y mucho menos los elementos disonantes o disidentes no tienen cabida. En dichos casos el arte ha servido para la representación del grupo a través del paisaje, convirtiendo los ideales del grupo en un paisaje. Veamos de cerca, a modo de ejemplo paradigmático, la apropiación ritual de la naturaleza por parte de los ideólogos del nacional-

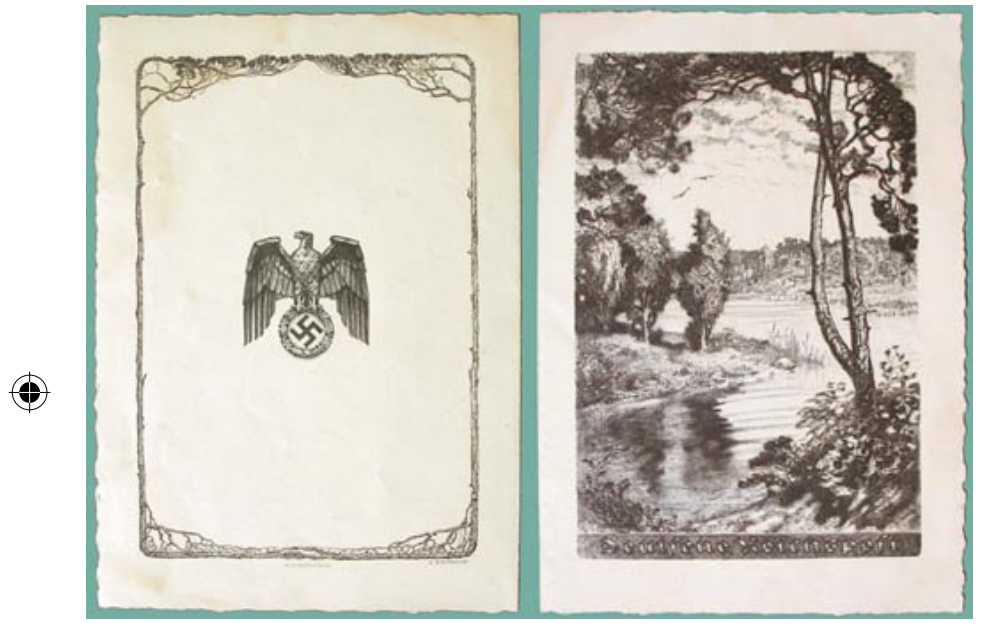

Anverso y reverso de un telegrama nacionalsocialista, circa 1940. socialismo alemán a comienzos del siglo XX.

Partiremos para ello de una escena de la película Cabaret de Bob Fosse (1972), basada en la novela de Christopher Isherwood Adiós a Berlín que enmarca el argumento con el telón de fondo del auge del nazismo. La escena comienza con la escapada de dos de sus protagonistas, Bryan (Michael York) y Maximilian( Helmut Griem) al campo, en lo que pretendía ser una inocente jornada. En el transcurso de la comida un joven muchacho de las Juventudes Hitlerianas se alza y comienza alegre un canto titulado Tomorrow belongs to me (el mañana me pertenece). Significativa es la localización de la escena: frente a un Berlín, rodado casi en su totalidad en interiores, donde reina una situación caótica llena de personajes de dudosa moralidad como prostitutas, editores de revistas pornográficas o cazafortunas, el ama- 


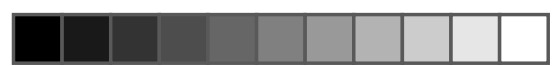

$\oplus$
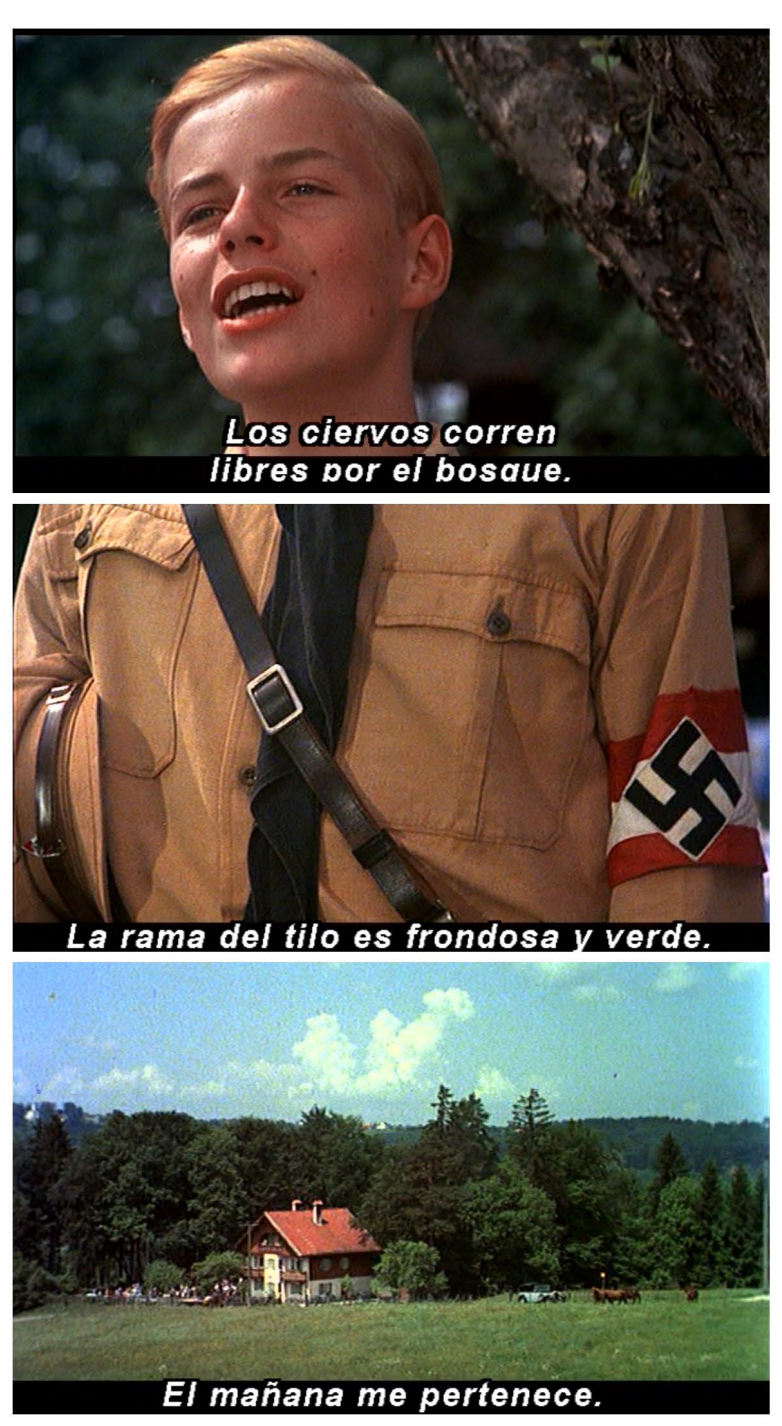

Bob Fosse, Cabaret, 1972. necer de un nuevo tiempo solamente se puede producir en la naturaleza y desde ella.

La canción que entona el prototípico joven hitleriano (rubio, de ojos azules y atractivo) comienza con una estrofa que describe un bucólico y típico paisaje alemán:

"Cae un sol de estío sobre la pradera, los ciervos corren libres por el bosque pero se reúnen para recibir la tormenta"

Tras el grandilocuente estribillo "El mañana me pertenece", a continuación, en la segunda estrofa y mientras se ensalzan elementos identitarios del paisaje alemán como los verdes y frondosos tilos o el Rin como gran figura paterna y de prosperidad, la cámara desciende para descubrirnos la terrible verdad,

bajo esa dulce apariencia de loa a una naturaleza bienhechora se esconde el monstruo que se avecina, el nacionalsocialismo, que todos los espectadores ya conocen lo que traerá consigo. En el instante final de la escena, el director, inteligentemente, inicia una apertura de campo que permite ver la huida apresurada de los protagonistas de regreso a Berlín,

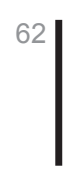



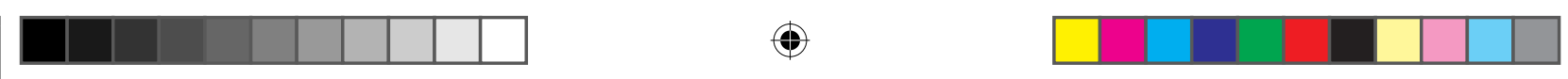

al tiempo que construye una fuerte metonimia entre el pintoresco paisaje de la Selva Negra con típica casa de campo de factura germánica incluida y el movimiento ideológico que se sustentará en él, en una relación biunívoca entre la construcción de la identidad nacional apoyada en un paisaje que la legitima y le representación del paisaje apropiado para los valores éticos y morales supuestos al pueblo alemán.

Un elemento a no menospreciar en la escena es el intercalado de fotogramas donde, con la canción de fondo, se retrata a una sociedad alemana profundamente satisfecha de sí misma. Esto nos remite a un componente del paisaje del que ya hemos hecho mención anteriormente, la relación afectiva que se establece entre el observador y el paisaje. Podríamos decir a riesgo de simplificar en exceso y tomando el ejemplo que nos brinda Bob Fosse, que el afecto por los paisajes propios tiene mucho de ejercicio de autoestima social, autoestima ligada, en tantas ocasiones, con el nacionalismo e incluso con el totalitarismo.

Como proclamaba el estudioso Erhard Mäding en su Regeln für die Gestaltung der Landschaft (Reglas para la organización del paisaje) "Los alemanes serán el primer pueblo occidental en crear, mediante el

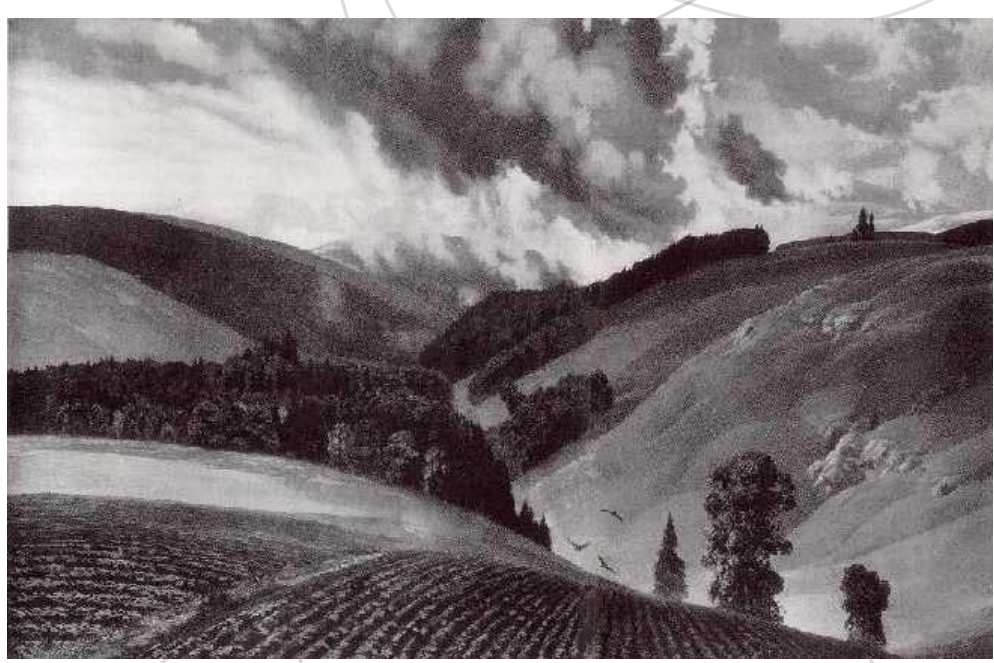
paisaje, un entorno espiritual (seelische unwelt) produciendo así, por primera vez en la Historia de la humanidad esa forma de vida que permite a un pueblo determinar plena y conscientemente el medio favorable a su bienestar físico y 

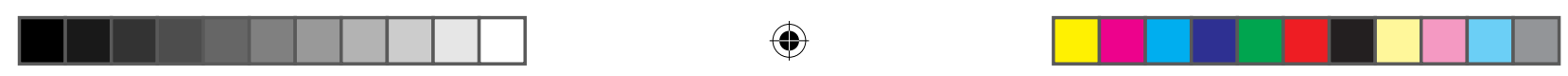

espiritual." Un poco más adelante, en 1943, Mäding recalcará: “la relación con la naturaleza representa para el hombre germánico una profunda necesidad vital."13 En el caso que acabamos de ver, el nacionalsocialismo alemán ha dado el paso del país al paisaje mediante la apropiación simbólica del mismo como vertebrador de la identidad alemana. ${ }^{14} \mathrm{El}$ paisaje se ha convertido en símbolo, en el emblema del pueblo alemán, que es el único con la capacidad para valorarlo en su justa medida, al tiempo que sirve para la representación del colectivo nacional.

Ahondando un poco más en la relación entre sociedad y paisaje nos encontramos con otra interesante vuelta de tuerca, la relación histórica entre el concepto de nación y el de paisaje. Múltiples son los países que han utilizado el paisaje como elemento de gran calado en el imaginario colectivo para hacer surgir el germen de la nación. Citaremos, de entre

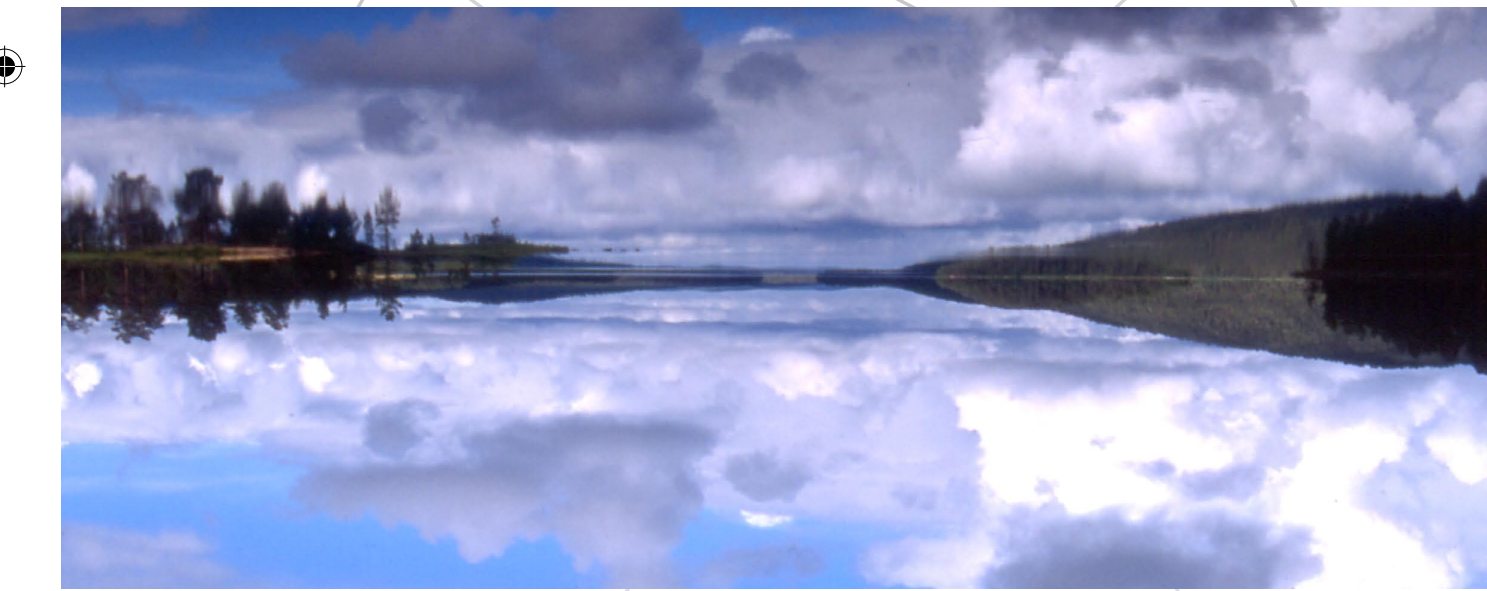

Parque Nacional Lemmenjoki, Finlandia, (fotografía I.C.).

13 Citado por Gröning, Gert, en Grôning, Gert, « Y a-t-il un changement dans la compréhension du paysage? Sur les recommandations pour éviter la culture des plantes étrangères en Allemagne au XX siècle », en Roger, Alain y Guery, François (dir.), Maîtres et protecteurs de la nature, Champ Vallon, Seyssel, 1991. p.82.

14 Al mismo tiempo, se produce un claro ejemplo de utilización del paisaje como instrumento de dominación social. Se llegará a solicitar el acondicionamiento adecuado de los territorios tomados a Polonia para el "saneamiento" del paisaje "enfermo" de modo que el hombre germánico se sienta a gusto y está dispuesto a defender su nueva patria.

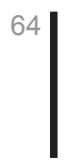




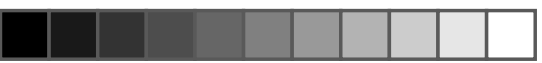

(1)

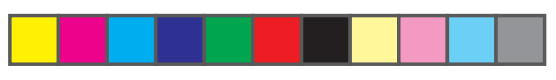

otros muchos, el caso finlandés y sus infinitos bosques de abedules "de belleza incomparable". Sintomáticamente, la obra de dos de sus genios nacionales, el arquitecto Alvar Aalto y el compositor Jean Sibelius, son un claro ejemplo de la identificación de los finlandeses con su paisaje. No podremos entender dicha obra desligada de esos paisajes de horizontes

Lago Inari, Finlandia, (fotografía I.C.).

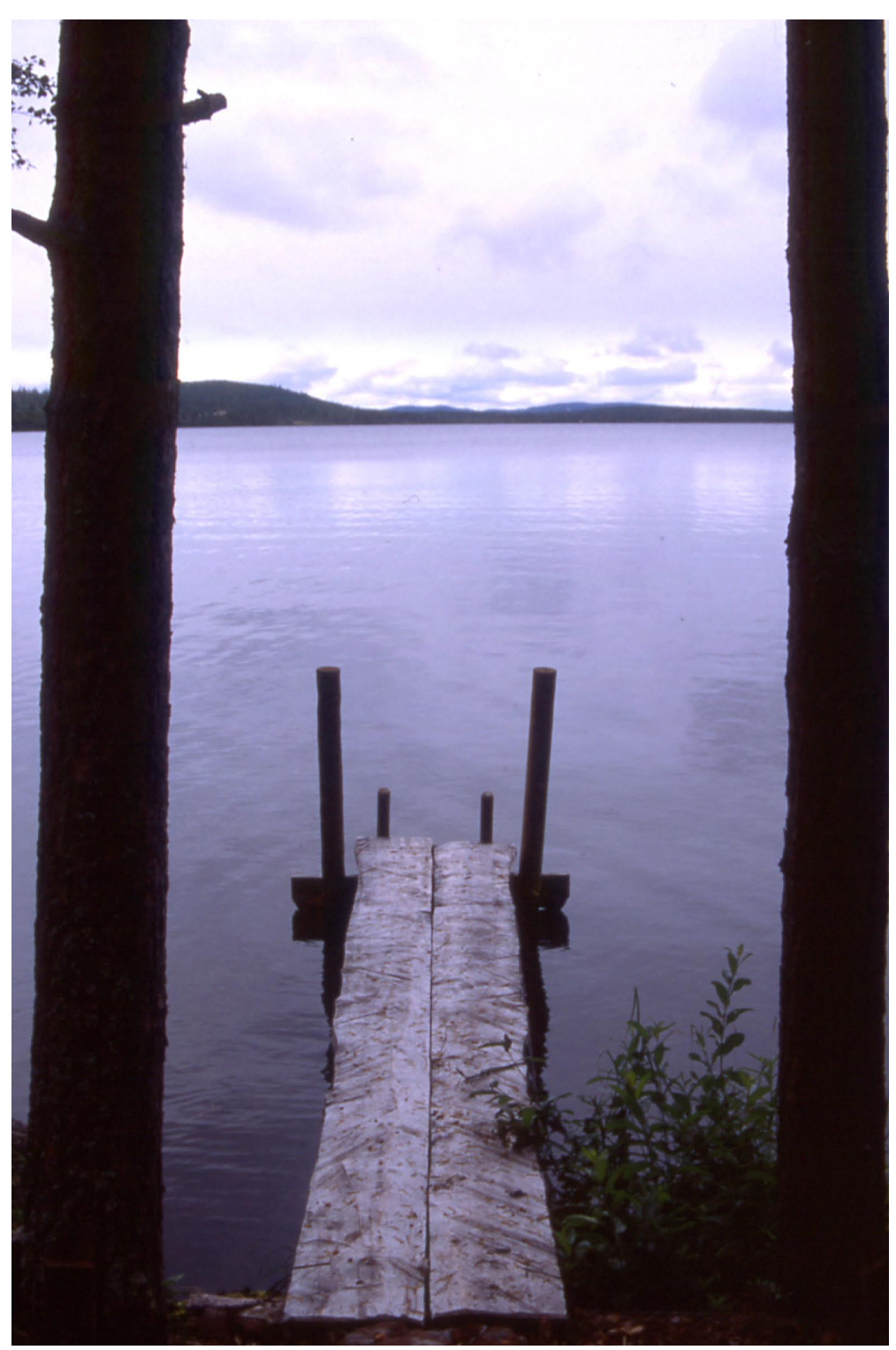



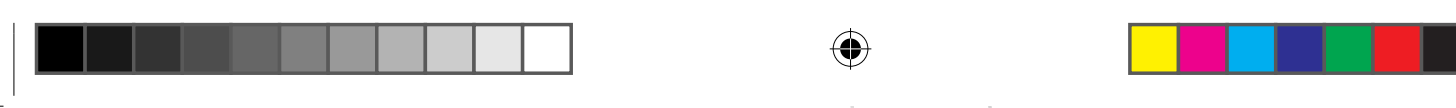

infinitos y cielos inabarcables donde el silencio es estremecedor.

Pero de entre los muchos casos paradigmáticos de la utilización del territorio, y la vinculación entre él y sus habitantes en términos de paisaje, como herramienta de construcción nacional, nos fijaremos más detenidamente en la génesis de los Estados Unidos de Norteamérica como nación moderna. En efecto, se inventará un paisaje como componente de primer orden en la forja de una identidad nacional todavía por conformar, quedando patente la estrecha vinculación que naturaleza y nación han tenido en los EE.UU desde sus orígenes coloniales. Los primeros europeos que desembarcaron en Norteamérica con el ánimo de colonizar ese territorio, los pioneros, lo hacían movidos por grandes ideales (aunque en el fondo en muchos casos no fuera sino el hambre y la desesperación). Dejaban sus lugares de origen en busca del "paraíso perdido", en busca de una "tierra prometida" donde poder establecerse y crear comunidades alejadas de los problemas y conflictos del continente que les vio nacer y que se convertiría en el viejo continente en relación a ese mundo nuevo que ellos estaban fundando. Es el momento de la construcción del mito del "noble salvaje" 15 y la archiconocida conquista del Oeste, término éste último que no en vano hace referencia a una coordenada geográfica.

En pleno auge de los nacionalismos en el ámbito europeo, los norteamericanos necesitaban, en un momento determinante de su propia construcción nacional un rasgo identitario que, necesariamente, tenía que diferenciarse de aquellos que alcanzaban gran eco en los medios europeos de la época. Cómo no, se fijarán en el paisaje. Y encontrarán una pieza clave en la construcción de la identidad nacional norteamericana, se trata del concepto de wilderness, que podríamos traducir por "lo salvaje". En efecto, frente a un continente europeo con sus paisajes bucólicos, domesticados y extraordinariamente antropizados, los nuevos habitantes de los EE.UU encontrarán en la naturaleza salvaje la piedra angular de la identidad nacional. Pieza de gran éxito a juzgar por la gran profusión

15 Para un acercamiento al mito del hoble salvaje, véase la publicación VV.AA., El Salvatge europeu, Centre de Cultura Contemporánea de Barcelona, Barcelona, 2004. 

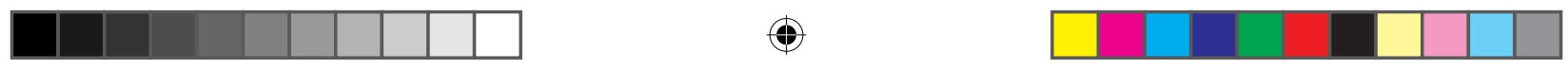

\section{El paisaje como acontecimiento.}

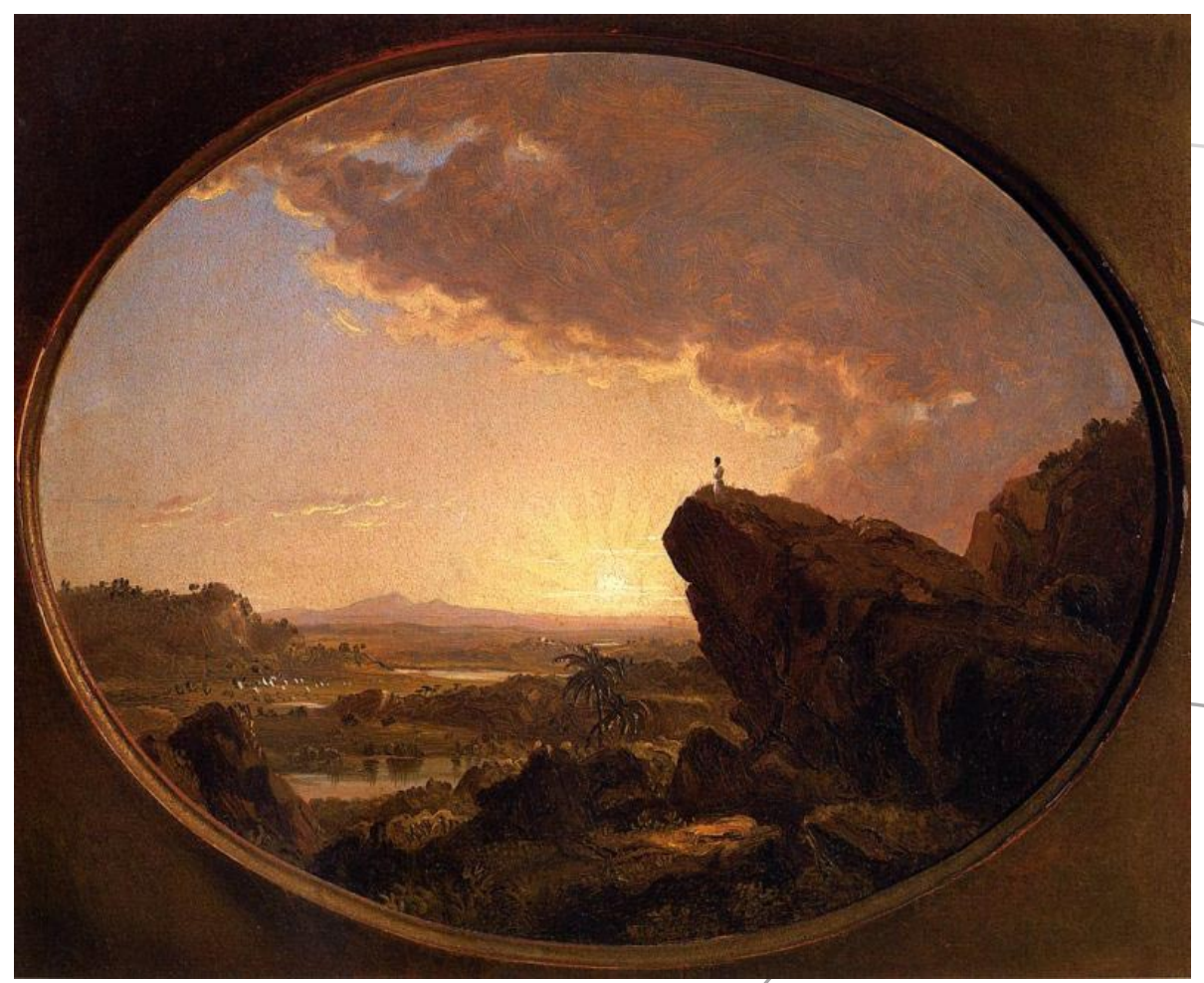

Albert Bierstadt, Moises contemplando la tierra prometida, 1850.

posterior que ha tenido, tanto en la literatura como en ese poderosísimo instrumento de divulgación que es el cine. La importancia del cine será de primera magnitud gracias a la industria de Hollywood y el gran alcance que ésta tiene.

Algunos de los paisajes retratados en esta primera época por pintores como Albert Bierstadt o Frederick Church estaban de hecho habitados pero ellos los representaban vacíos de presencia humana. $Y$ no solamente los pintores evocan esa naturaleza salvaje, en 1820 el libro Picturesque views of the American Scene (Vistas pintorescas de la escena americana) proponía mostrar: "nuestras altas montañas... la magnitud sin precedente de nuestras cataratas, el esplendor salvaje de nuestros bosques occidentales, inigualado por cualquiera de los paisajes de los 


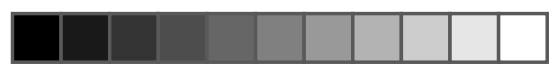

$(\varphi$

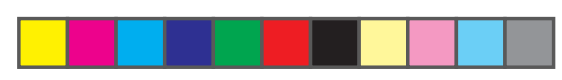

que otros países alardean"16

En esta invención del paisaje norteamericano tendrá un papel destacado el American Conservation Mouvement (Movimiento Americano de Conservación), un movimiento surgido como reacción de ciertas élites a la perdida de lo salvaje, a la conquista de la última frontera. Sus miembros más activos son una significativa amalgama de caballeros exploradores, hombres imbuidos de una profunda religiosidad -los transcendentalistas- y cazadores de caza mayor. Muchos de ellos verán en "lo salvaje" el escenario, el paisaje, apropiado donde poner a prueba y en definitiva mantener su virilidad cazando, acampando y explorando nuevos territorios que satisfagan sus ansias de conquista. Igualmente, aparecerán en este momento las reservas indias, que en muchos casos no surgen sino de la inquietud por preservar dicha escena salvaje, donde los

16 Macy, Christine y Bonnemaison, Sarah, Architecture and nature, creating the American landscape, Routledge, Londres, 2003, p.2.
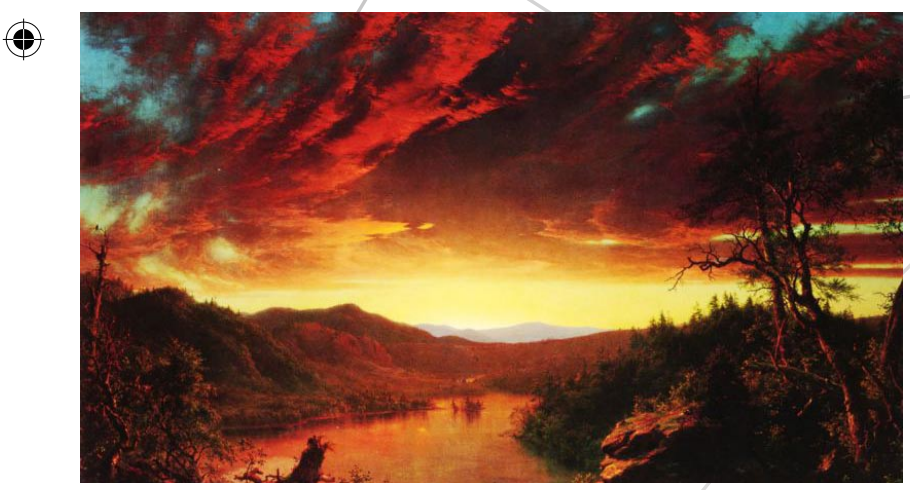

Frederick E. Church, Resplandor en lo salvaje, 1860.

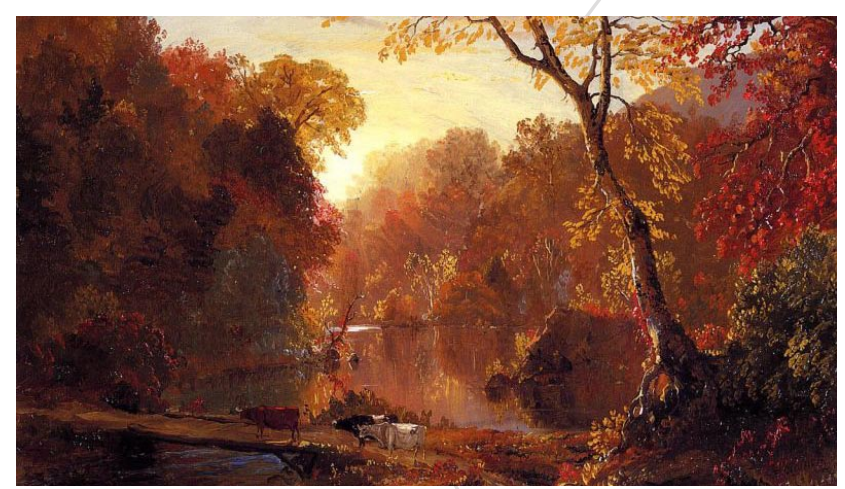

Frederick E. Church, Otoño en Norteamerica, 1856.

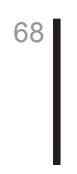



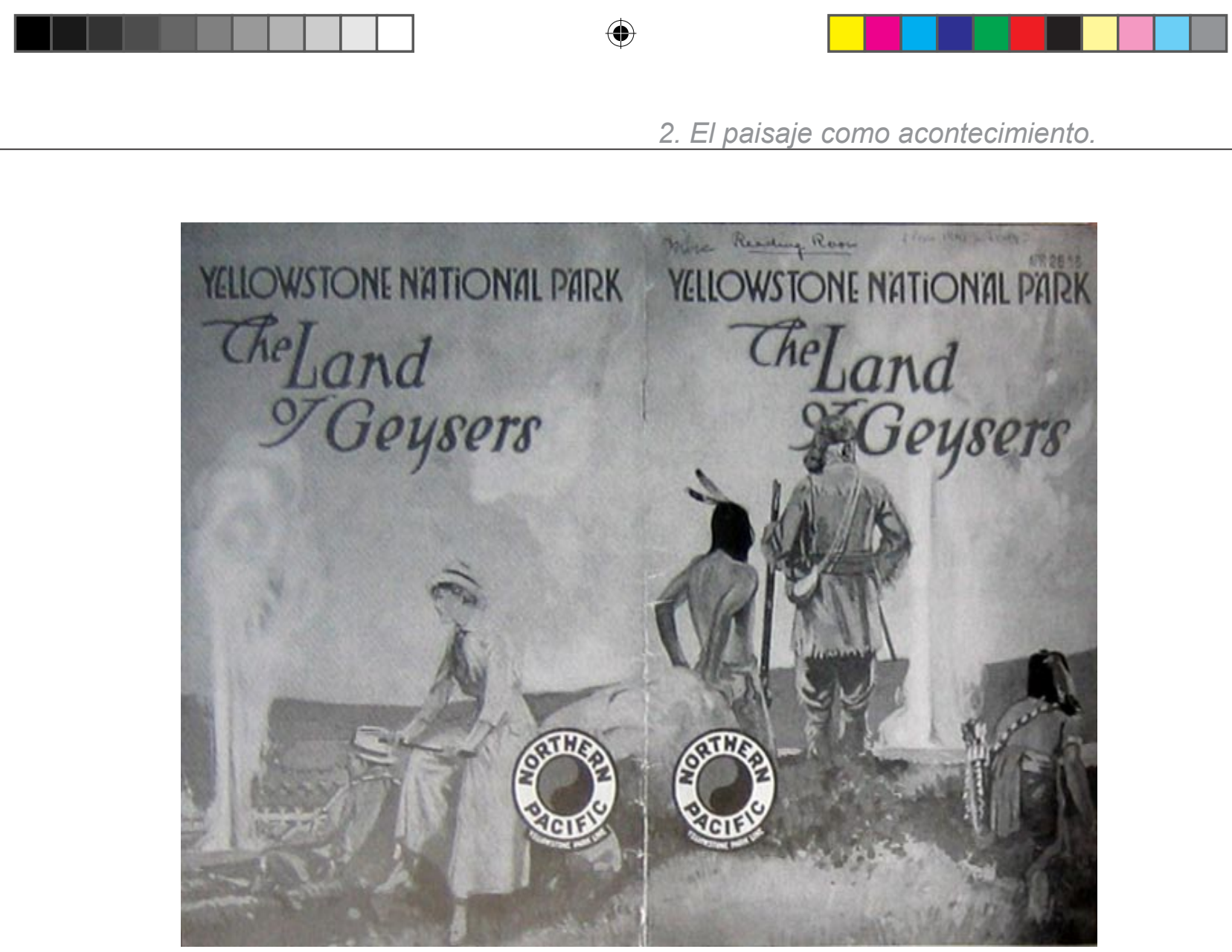

Folleto turístico de Northern Pacific, ca. 1910.

indígenas norteamericanos no serán más que un elemento más, meros actores de ese paisaje norteamericano por excelencia.

La estrecha relación de los habitantes de EEUU con el paisaje no se diluirá con el paso de los años, la podemos rastrear a lo largo de todo el siglo XX y comienzos de éste. Al igual que en el caso que citábamos antes de Alvar Aalto en Finlandia, el conjunto de la obra del gran arquitecto norteamericano por antonomasia, Frank Lloyd Wright, está muy dfeterminada por el paisaje de los Estados Unidos. Un buen ejemplo de ello son el conjunto de viviendas unifamiliares que éste proyectó y construyó y que se conocen bajo el nombre de prairie houses (casas de la pradera). Si bien toda la obra la obra de Wright está, como decimos, embebida de una fuerte vinculación con el lugar, esta estrecha relación con el paisaje 

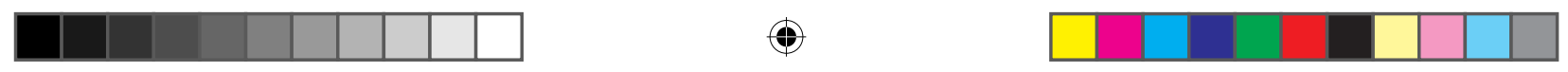

Frank LLoyd Wright, Casa Robie, 1909.

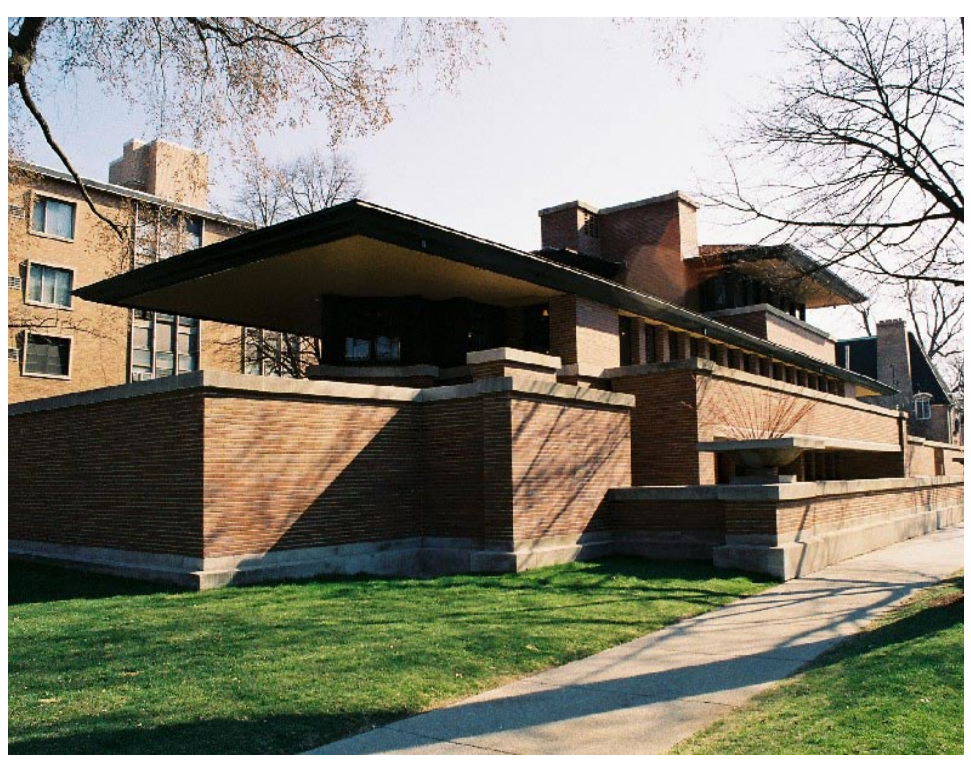

circundante resulta especialmente explícita en estas casas, y su manifestación quizá más evidente sea una marcada horizontalidad.

Son muy numerosos los ejemplos como este, aunque citaremos solamente uno que nos resulta especialmente interesante. Es el caso del conocido artista contemporáneo Lothar Baumgarten. De su obra, que gira principalmente entorno a la memoria y la profunda relación que se establece entre los pueblos (especialmente centroamericanos), y su realidad física nos gustaría recordar las fotografías de su serie Carbon (1989) que trata los paisajes norteamericanos surcados por dos líneas ferroviarias que surcan el país. Se trata de imágenes de exquisita calidad en blanco y negro que muestran paisajes indómitos donde la presencia humana se rastrea mediante la aparición de signos claramente identificables con la idea de progreso y conquista tecnológica. En entornos de extraordinaria belleza natural investiga en la invención del paisaje norteamericano diseccionando los rasgos fundamentales de la identidad nacional, propo- 


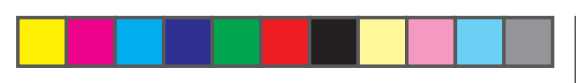

$\oplus$

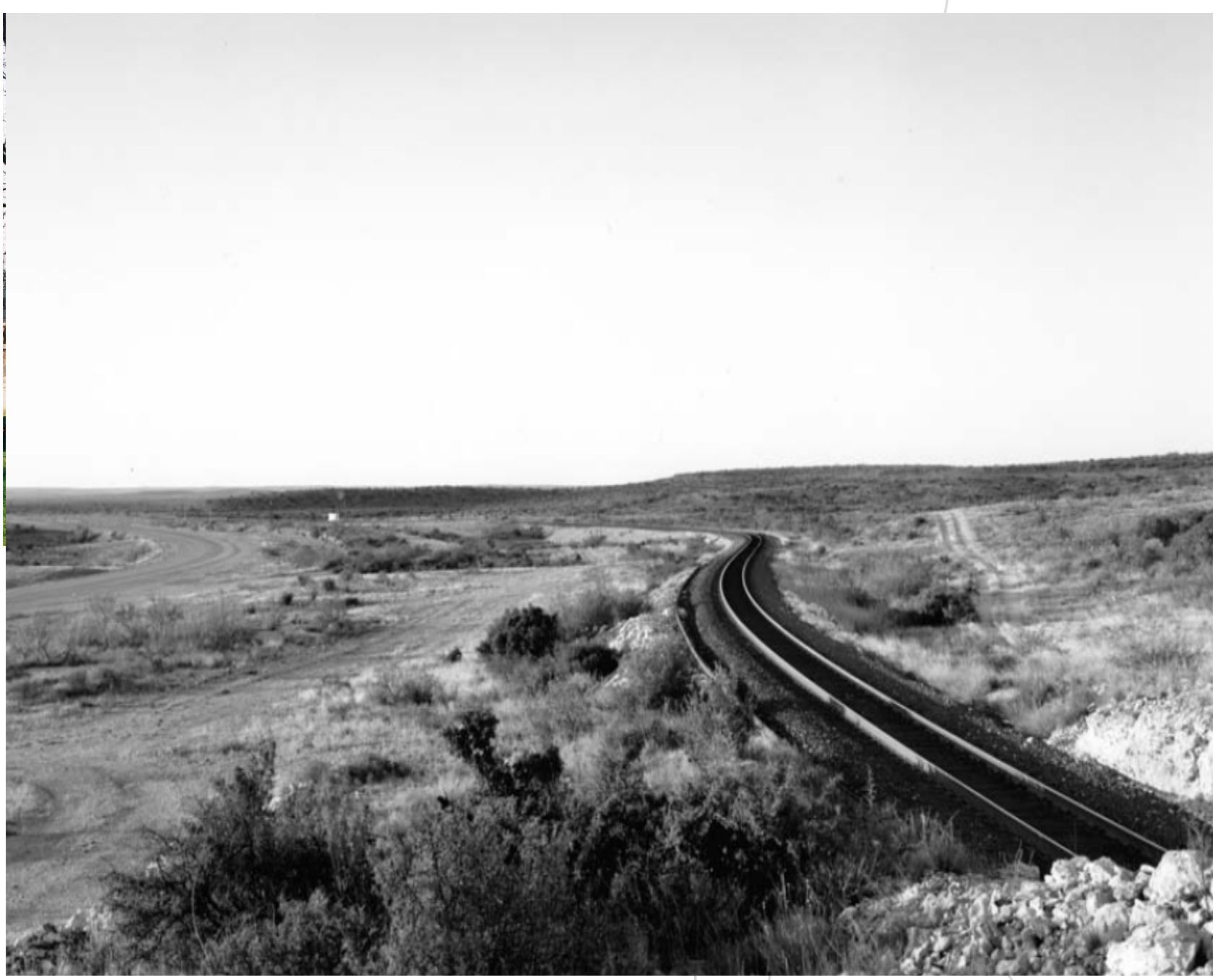

Lothar Baumgarten, Southern Pacific Transportation Co. and Amtrak's Sunset Limited, Val Verde County Texas, 1989, (Serie Carbon), 1989.
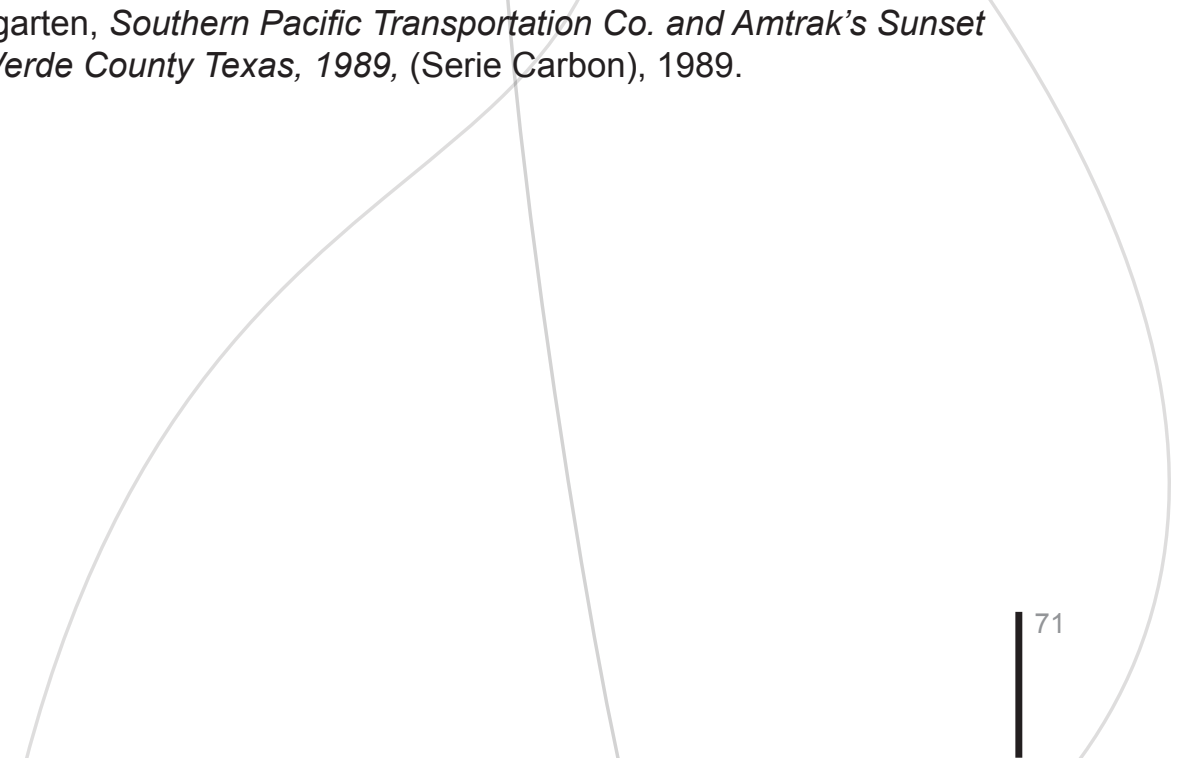

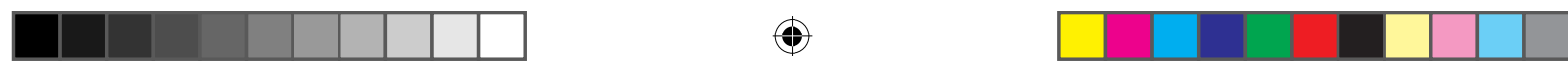

niendo al espectador un diálogo de relaciones múltiples que le sirve para reflexionar sobre sí mismo y su propia identidad.

Por último me gustaría mostrar la vigencia que éstas lecturas tienen en la cultura norteamericana en la actualidad y para ello daremos un salto de las galerías y museos de arte contemporáneo a las salas de cine comercial, donde el conocido actor Sean Penn, en su quinto largometraje tras las cámaras, Into the Wild (2007) (traducida en España por "Hacia rutas salvajes"), nos propone una supuestamente progresista historia que reivindica la libertad individual como bien supremo. Se trata de una historia basada en hechos reales, aspecto en el que se insiste desde las instancias de promoción de la película, donde un muchacho, Christopher McCandless, lo deja todo para encontrarse a sí mismo en la soledad de la naturaleza salvaje de Alaska. La película supone un verdadero recorrido por los paisajes más representativos de los EE.UU, desde las verdes praderas sin fin al Cañón del Colorado, resultando muy significativa la estrecha identificación que se establece entre el plano visual, con una presencia constante del paisaje exquisitamente fotografiado, y el plano conceptual, con un machacón mensaje que nos habla de estrictos códigos morales de conducta que presenta una sociedad enferma de la que el joven necesita escapar. La infelicidad del joven, producida por una familia desestructurada le empuja a abandonar una prometedora y acomodada vida, descubriendo que después de vagar errante enfrentándose a múltiples situaciones, solamente es capaz de encontrar la felicidad en el pleno contacto con una naturaleza indómita, sumergido "Into the wild" (en lo salvaje). 

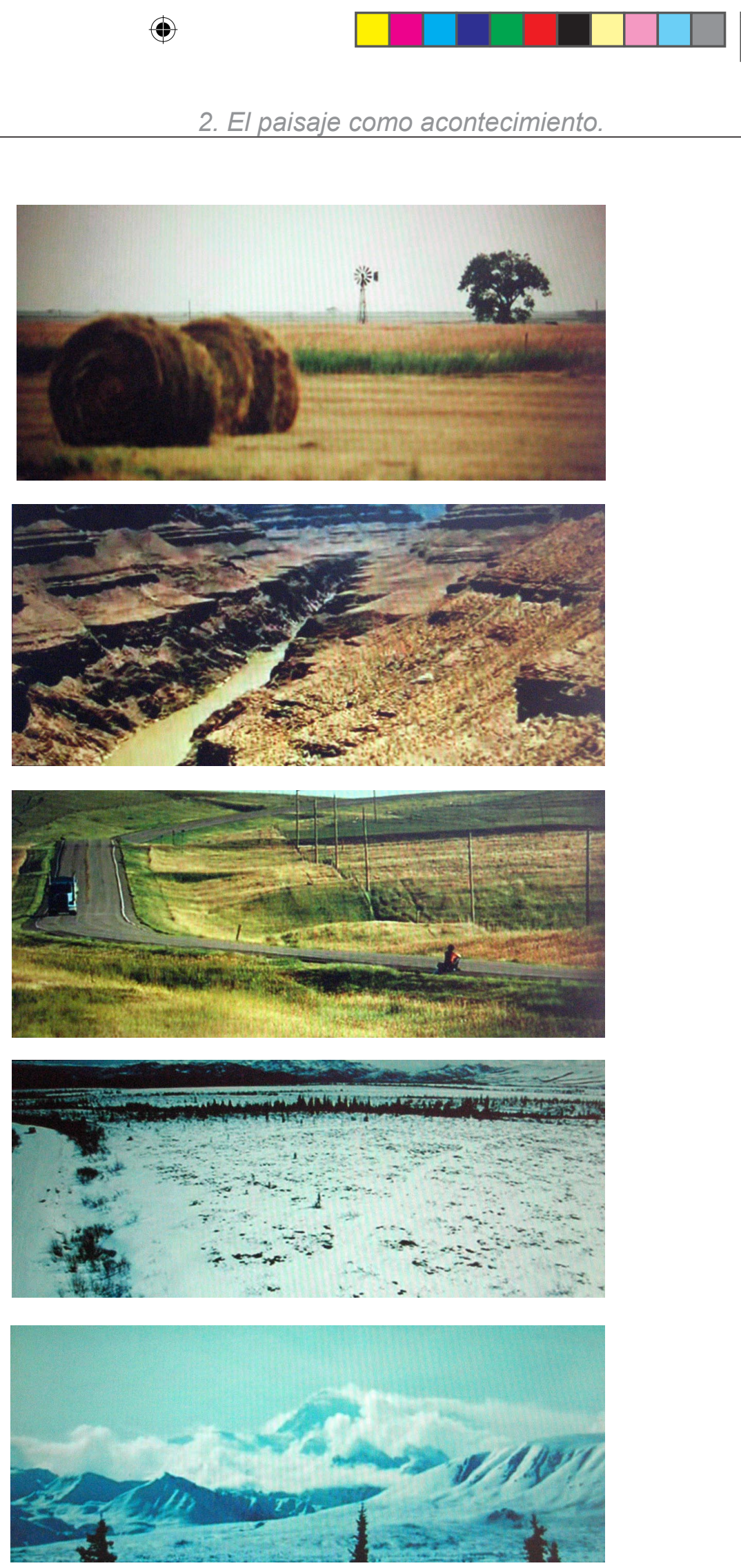

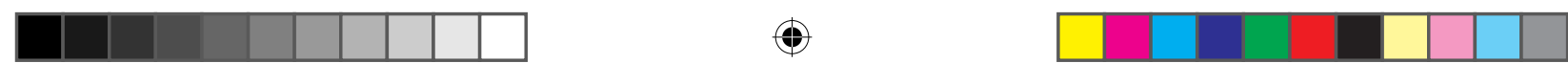

Como vemos, la historia del paisaje no es sino otro capítulo más en la historia de las sociedades, una muy útil herramienta para la mejor comprensión de las mismas. Mediante el paisaje, en tanto que objeto y simultáneamente su representación, se están reconociendo ellas mismas, por lo cual no podemos ver los paisajes más que como la expresión de sus objetivos y anhelos. Sus formas de apropiación de la naturaleza, sus formas rituales, se proyectan en el lugar haciendo surgir una nueva categoría rica y compleja como es el paisaje. Huidas románticas como la de Christopher McCandless o discursos de construcción y exaltación nacional mediante la dominación de la naturaleza, son tan sólo algunos de los innumerables capítulos de esa mirada a la naturaleza, de esa reflexión sobre nuestra posición relativa en el mundo que es el paisaje.

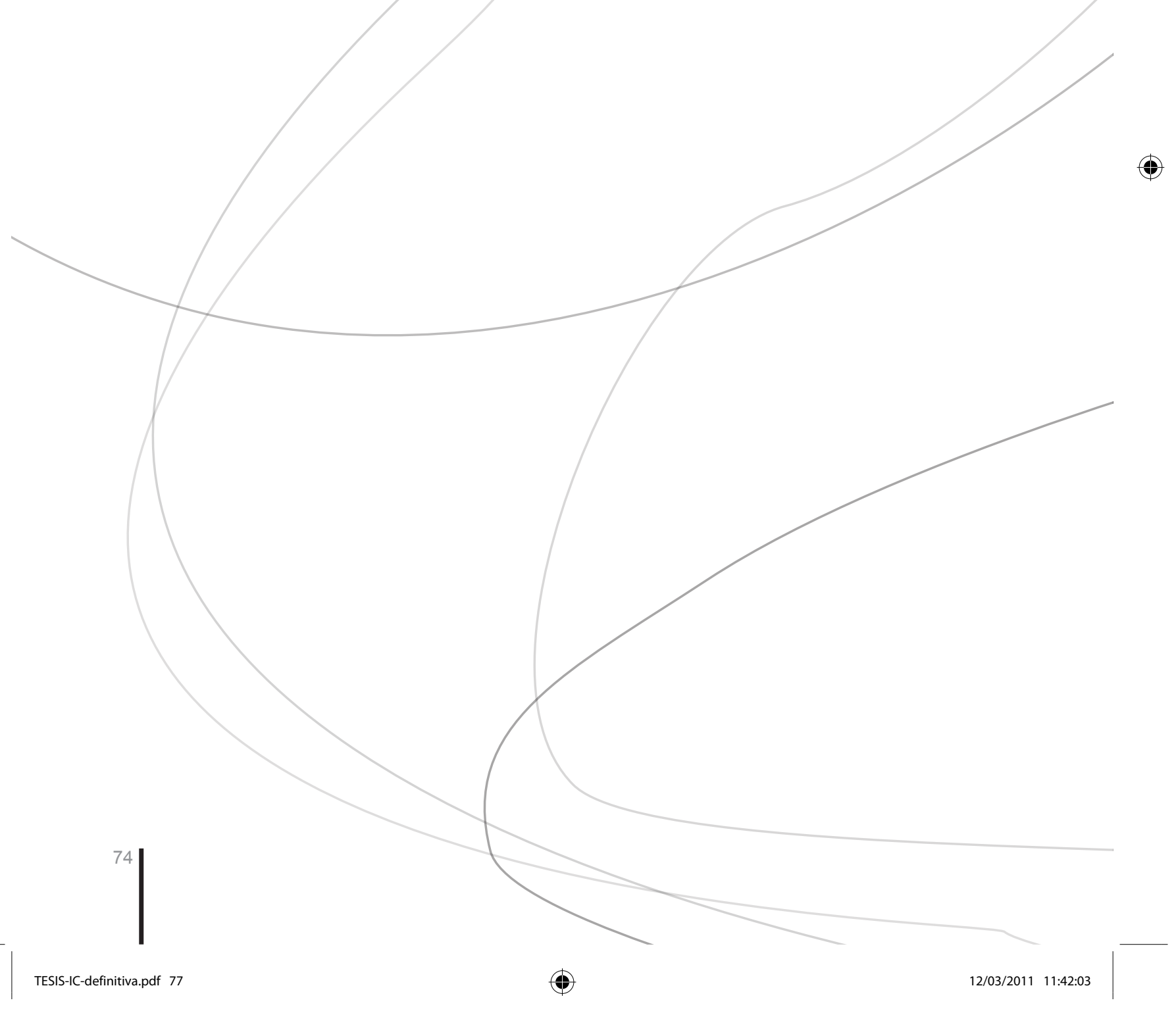




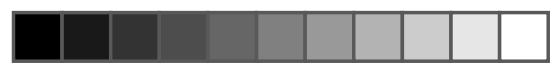

$\oplus$

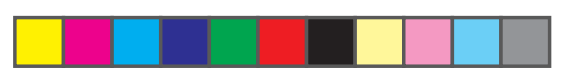

2. El paisaje como acontecimiento.

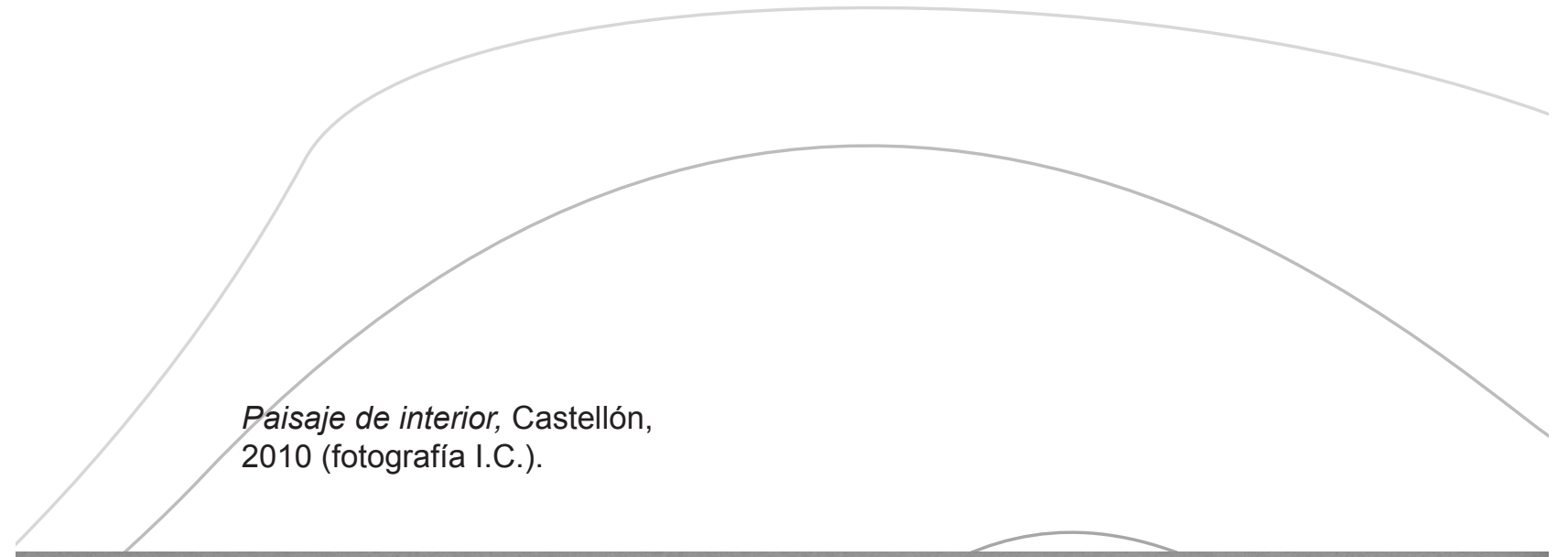

$(\oplus$
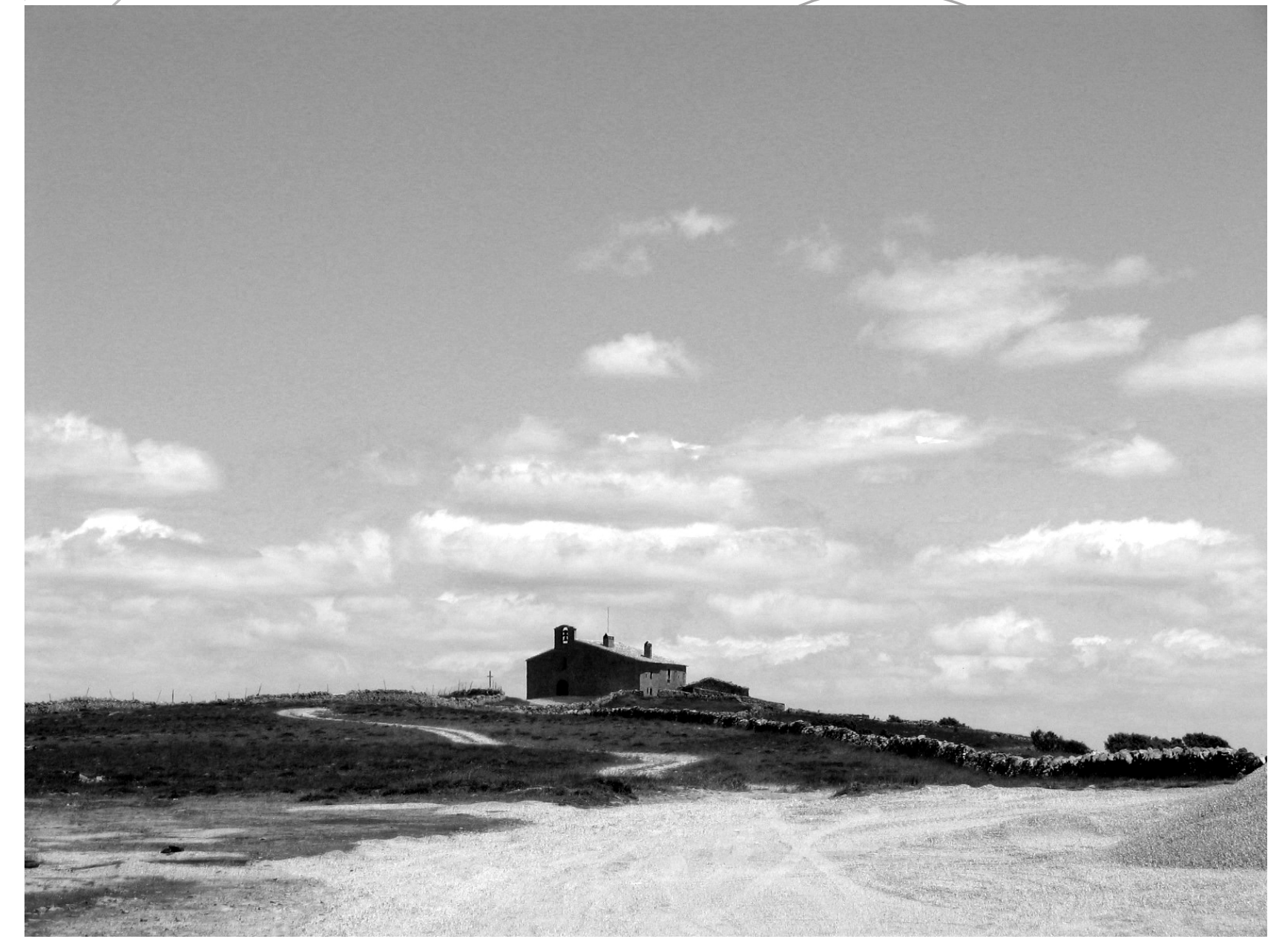

$\left.\right|^{75}$ 


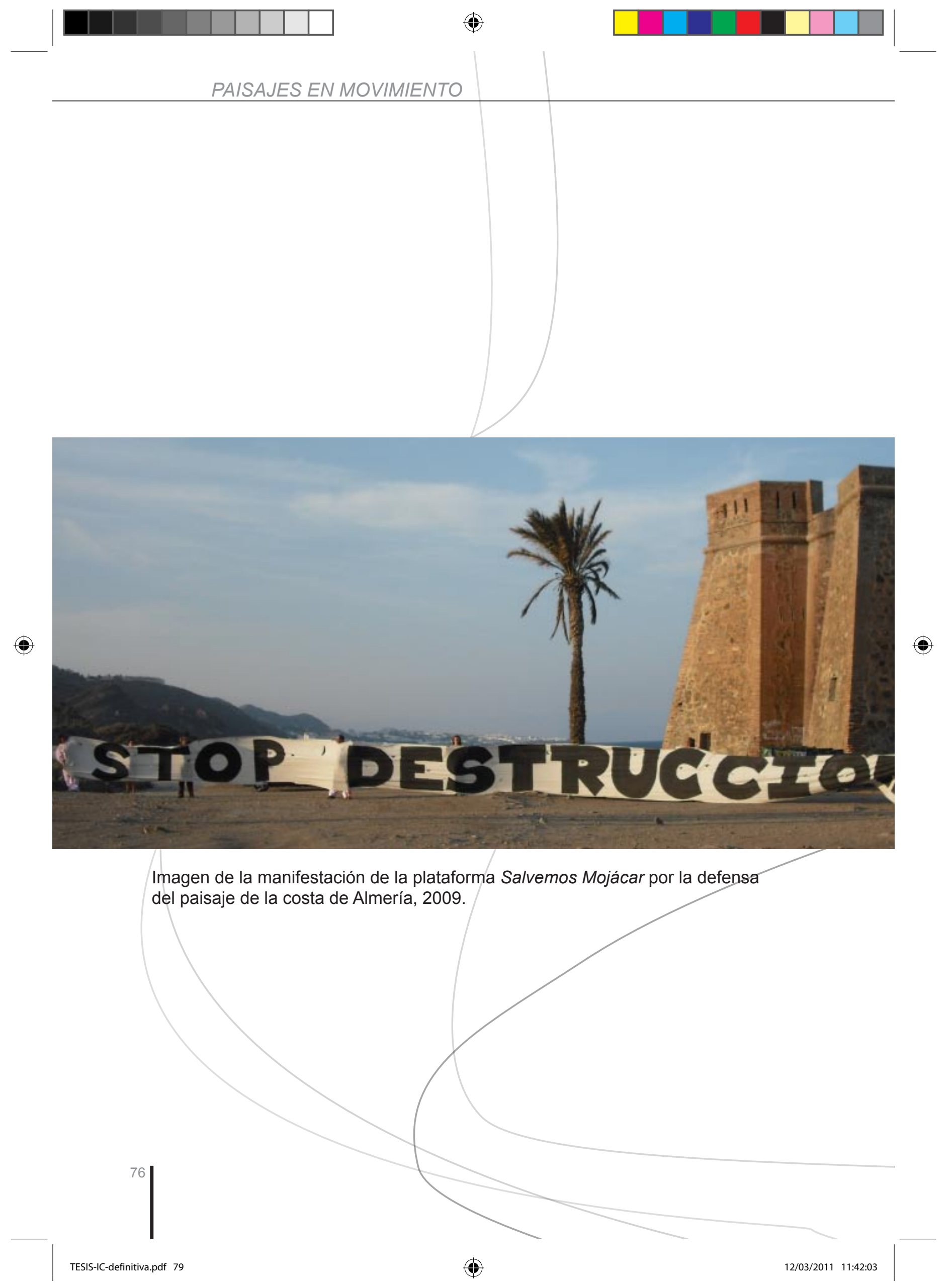



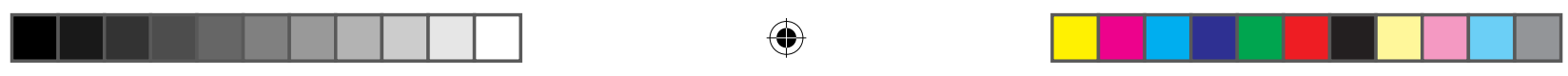

Finalmente, para intentar comprender el momento en el que nos encontramos actualmente, hablando en términos de paisaje, y acotar algo más el tránsito que se produce para convertir un país en un paisaje nos fijaremos en la relación que se produce en el ámbito del paisaje entre el campo y la ciudad, entre lo rural y lo urbano. Para ello comenzaremos poniendo nuestra atención en un factor de gran importancia que no debemos pasar por alto y que tiene una vigencia enorme hoy en día: el turismo.

Continuemos en los EE.UU. y situémonos en el momento de aparición de los Parques Nacionales. En este momento, la naciente industria del turismo encontrará un filón para hacer dinero gracias a la oferta de 

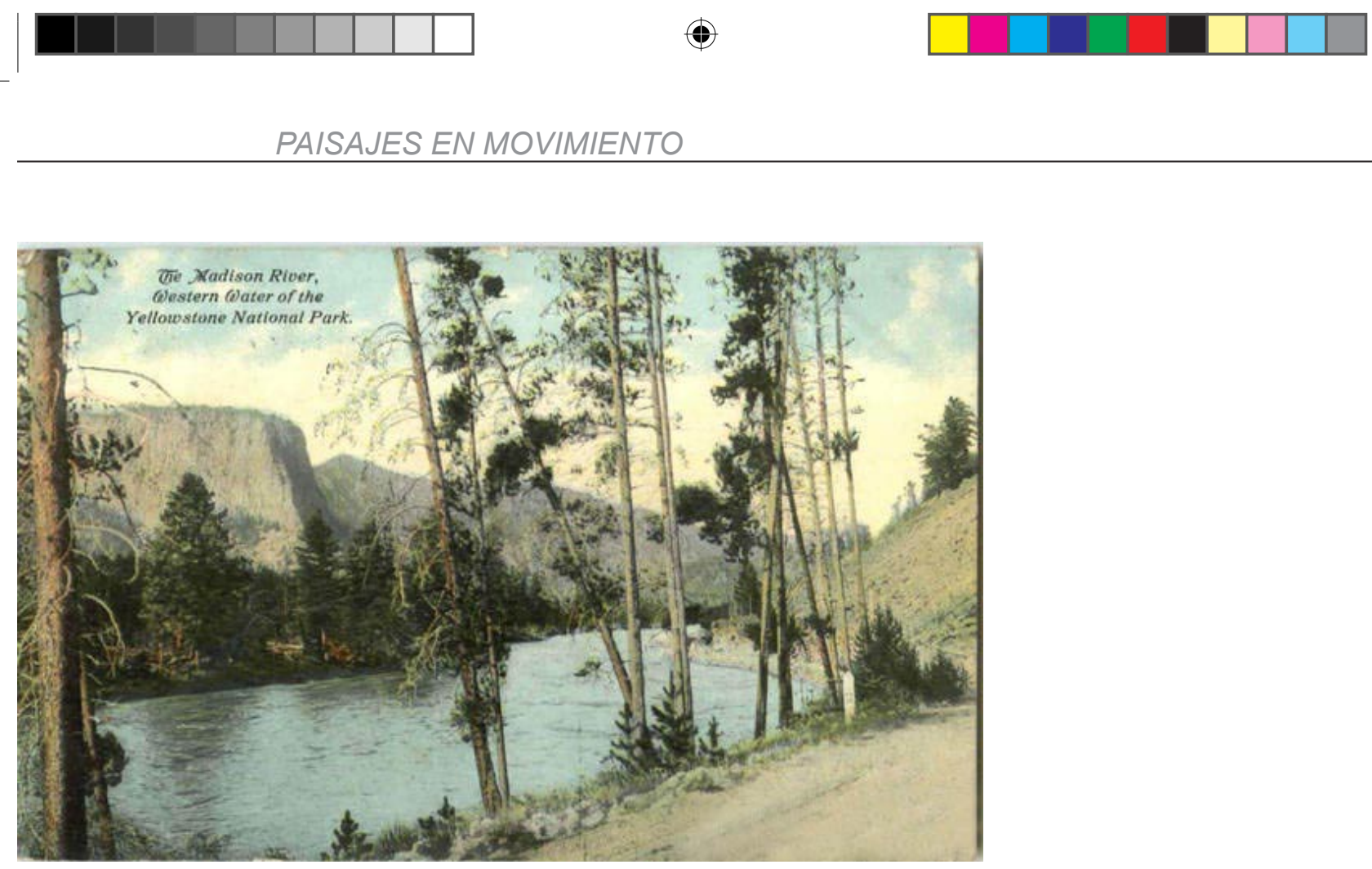

Tarjeta postal del Parque Nacional de Yellowstone, EE.UU,1909.

inmersión en una naturaleza salvaje pero al mismo tiempo domesticada para uso y disfrute, desde la comodidad y la seguridad, de la cada vez mayor clase media-alta norteamericana. Se vende a una sociedad cada vez más autocomplaciente y satisfecha de sí misma la posibilidad de visitar las maravillas del país.

En un instante de extraordinaria industrialización y urbanización se produce un cambio tremendamente importante en los ritos de apropiación de la naturaleza y en los mecanismos de invención de paisajes. Se produce una transformación en la mirada hacia la naturaleza que implica unos cambios que todavía hoy encontramos, y en situaciones también espacialmente mucho más próximas a nosotros, en los turistas que se aproximan a entornos naturales de gran valor, cámara fotográfica o de vídeo en mano, listos para "llevarse a casa" esas vistas que han encontrado ya fotografiadas en los folletos de las agencias de viaje y en los que se ofrece el paisaje como un objeto de consumo más. El fenómeno del turismo tiene una gran incidencia en la conformación del paisaje en la ac-

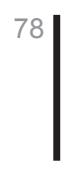



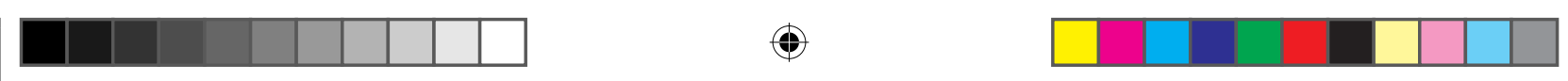

tualidad y está en el corazón del conflicto habitual que se produce entre la población del lugar, que hemos denominado "campesinos" y aquella que llega a él en busca de un ideal, los "urbanitas". Estos exigen de la Naturaleza, en multitud de ocasiones, que se adapte a la imagen preconcebida que se habían elaborado de ella. Hacer esta adaptación es el papel del guía turístico, por ejemplo, que se encarga de escoger los miradores, los recorridos y las paradas que mejor respondan a las expectativas de los turistas de su grupo, pues si la panorámica no responde a lo esperado se quedaran decepcionados.

Resulta interesante relacionar este fenómeno tan actual con un planteamiento desarrollado por autores como Anne Cauquelin o Michel Conan que se cuestionan si el paisaje no es sino una invención de los habitantes de la ciudad. Ya Horacio en el siglo I a.C. se lamentaba de su condición de ciudadano, ensalzando la vida campestre como antídoto de

Folleto turístico de Halcón

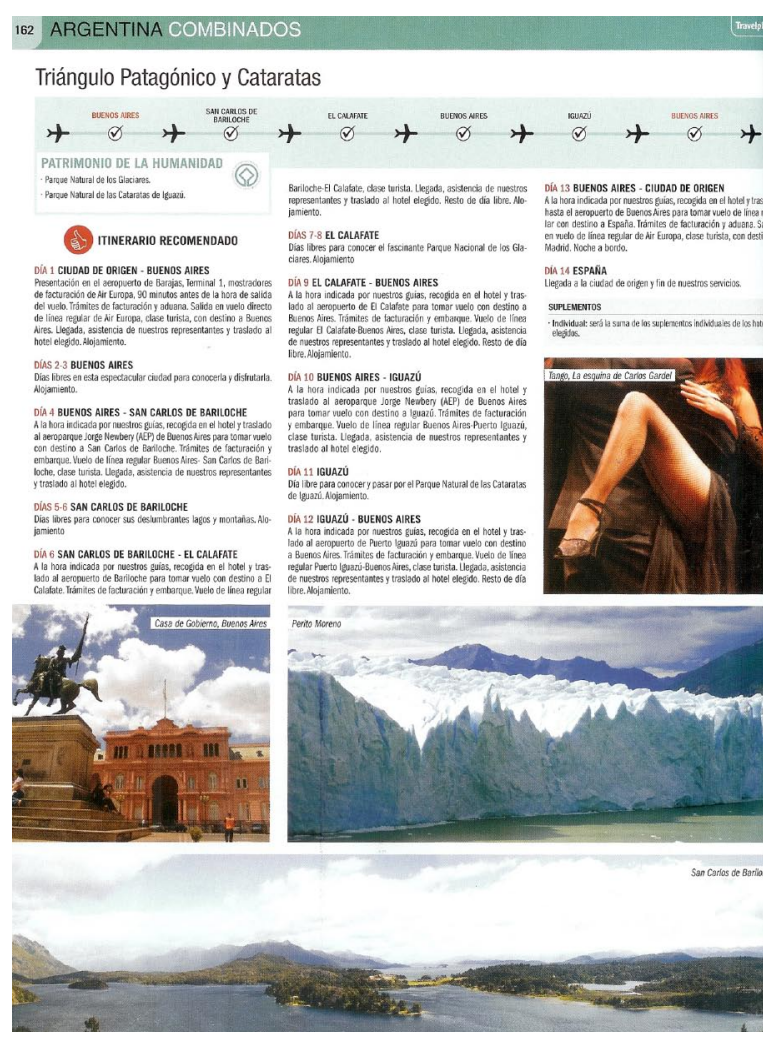
viajes, 2007. 

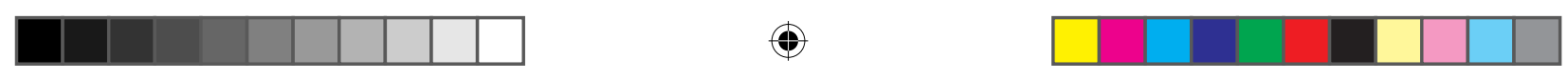

todos los males que le acontecían al habitante de la ciudad. El campo era el lugar donde disfrutar del merecido descanso, eso sí gracias a la satisfacción de observar la productividad de sus fincas agrícolas. ${ }^{17}$

En efecto, resulta obvio que el habitante de una determinada comarca rural, no "ve" los mismos paisajes en las laderas de sus montes de donde a menudo extrae el sustento con mucho esfuerzo y trabajo que el urbanita que sale de la ciudad de algún modo huyendo de los conflictos que ésta le genera. Para unos, simplificando en extremo, unos

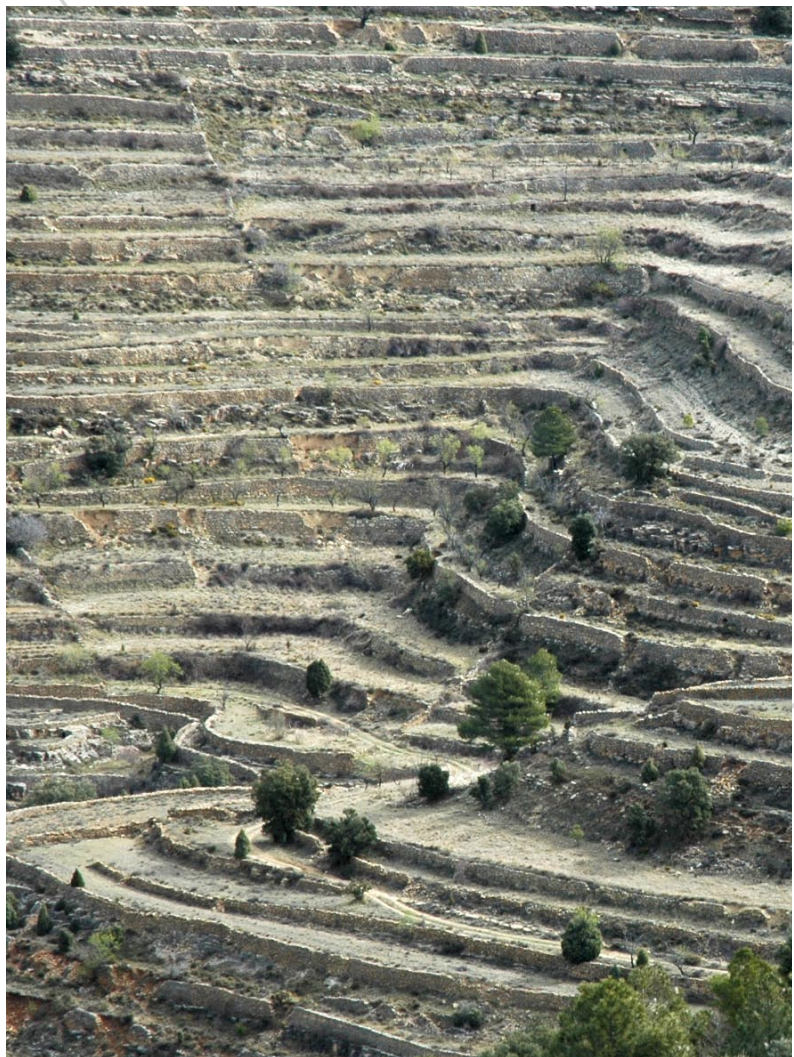

Bancales de cultivo cerca de Castellfort, Castellón, (fotografía I.C.). determinados bancales serán el fruto del duro esfuerzo y el trabajo, para los otros un motivo de goce y deleite estético. La apropiación de la naturaleza es diametralmente opuesta y la invención del paisaje se producirá necesariamente también de modo diferente. Serán otros los gestos, las palabras y las prácticas que producirán paisajes. Será el urbanita quién frente a un peñasco invoque las gestas de la alta montaña o quién al observar una población encaramada sobre la ladera valorará lo pintoresco de la vista. Esa aproximación diferente está en el origen de habituales problemas surgidos en el desarrollo del territorio. Los diferentes "ri-

17 Respecto a Horacio y la relación entre el ser humano y la naturaleza en el mundo romano, resulta muy interesante consultar Cauquelin, Anne, L'invention du paysage, Presse Universitaire de France, Paris, 2000.

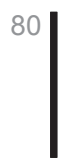




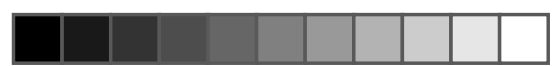

$\oplus$

\section{El paisaje como acontecimiento.}

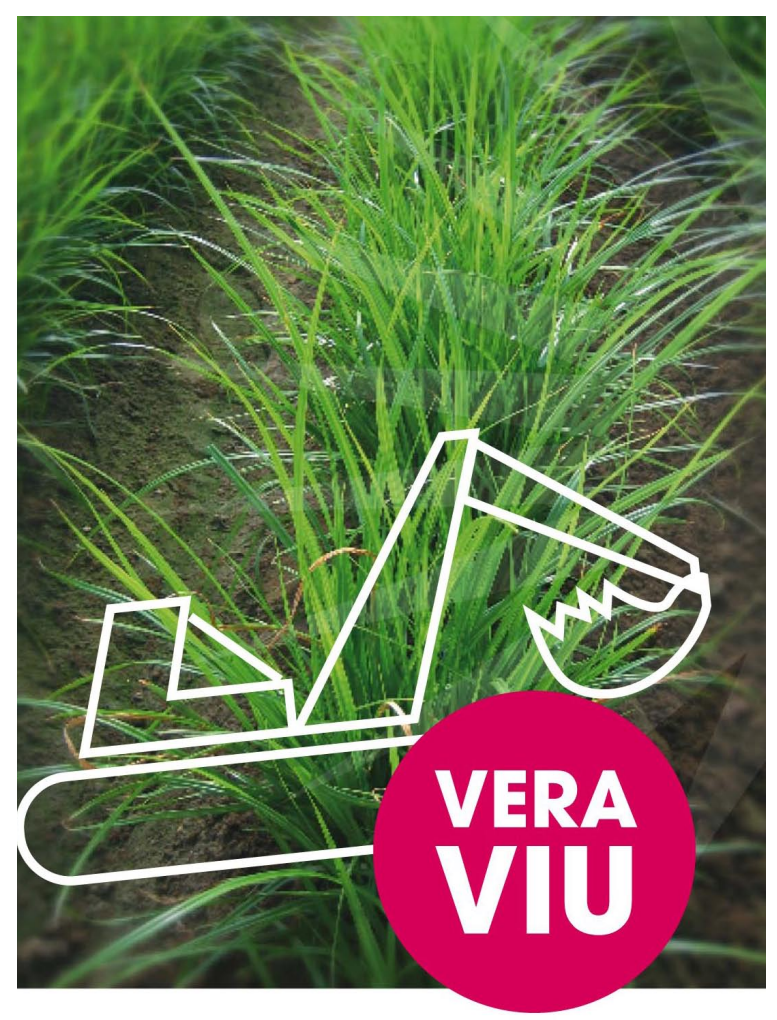

ASOCIACIÓN SALVEM L'HORTA DE VERA-ALBORAIA

Cartel de la Asociación Salvem L'Horta de Vera-Alboraia. tos de apropiación"18 llevados a cabo por distintos grupos sociales suelen propiciar, en múltiples ocasiones, un conflicto de intereses. Respecto a un mismo territorio un sector social puede sacarle una utilidad económica mientras que otro le encontrará una función científica o política o simplemente le aplicará un valor estético y de placer a través del paseo o la contemplación. Vemos como el mismo territorio suele definir variados paisajes. De este modo puede llegar incluso el caso en el que un determinado sector o grupo social llegue a convertir ese paisaje en emblema de una determinada identidad.

Estaríamos, sirva como ejemplo bien conocido, en el caso de los "Salvem", plataformas ciudadanas surgidas en el entorno metropolitano de la ciudad de Valencia, que tomando un determinado paisaje- Salvem L'Horta, por ejemplo- como emblema de grupo, lo utilizan como elemento identitario, como aglutinador capaz de fortalecer la idea de grupo y hacer surgir una voluntad conjunta donde antes existían voces discordantes caminando en distintas direcciones con intereses a menudo contrapuestos y que son fagocitados con el fin de superponer un bien superior, un determinado paisaje con una fuerte carga simbólica para los miembros del grupo: "La comarca de L'Horta es mi paisaje sentimental más primario. Su evocación tiene todavía regusto de tierna infancia." ${ }^{19}$ Estos movimien-

18 Concepto desarrollado por Conan, Michel en « L'Invention des identités perdues » en VV. AA., Cinq propositions pour une théorie du paysage, Champ Vallon, Seyssel, 1994.

19 Mollà, Antonio, "Per L'Horta" en El País Comunidad Valenciana, Viernes 18/04/2008, p.4. 
tos, surgidos en diferentes contextos, siempre tienen aspectos en común como son: un reflujo en la confianza en el progreso como garante de bienestar y una fuerte demanda de escucha a los ciudadanos.

El conflicto surge pues a menudo cuando la mirada del que está se encuentra con la mirada del que llega. El campesino, demanda servicios y desarrollo que aún asocia con el bienestar y la ciudad, y el urbanita defiende una conservación del territorio para que responda a unas expectativas que (en ocasiones) va en perjuicio de los propios habitantes del lugar. Este es uno de los grandes retos en el acondicionamiento de áreas sensibles en términos de paisaje. Escuchar y entender las sensibilidades de los distintos grupos sociales que se relacionan de diverso modo con el territorio, es una de las tareas fundamentales de los arquitectos y paisajistas que se enfrentan al proyecto del paisaje. 


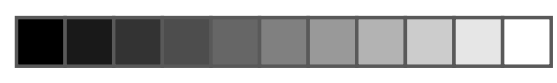

$\oplus$

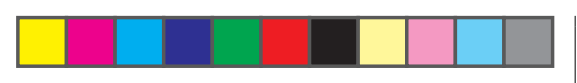

2. El paisaje como acontecimiento.

Imagen de L'Albufera, Valencia, 2009.

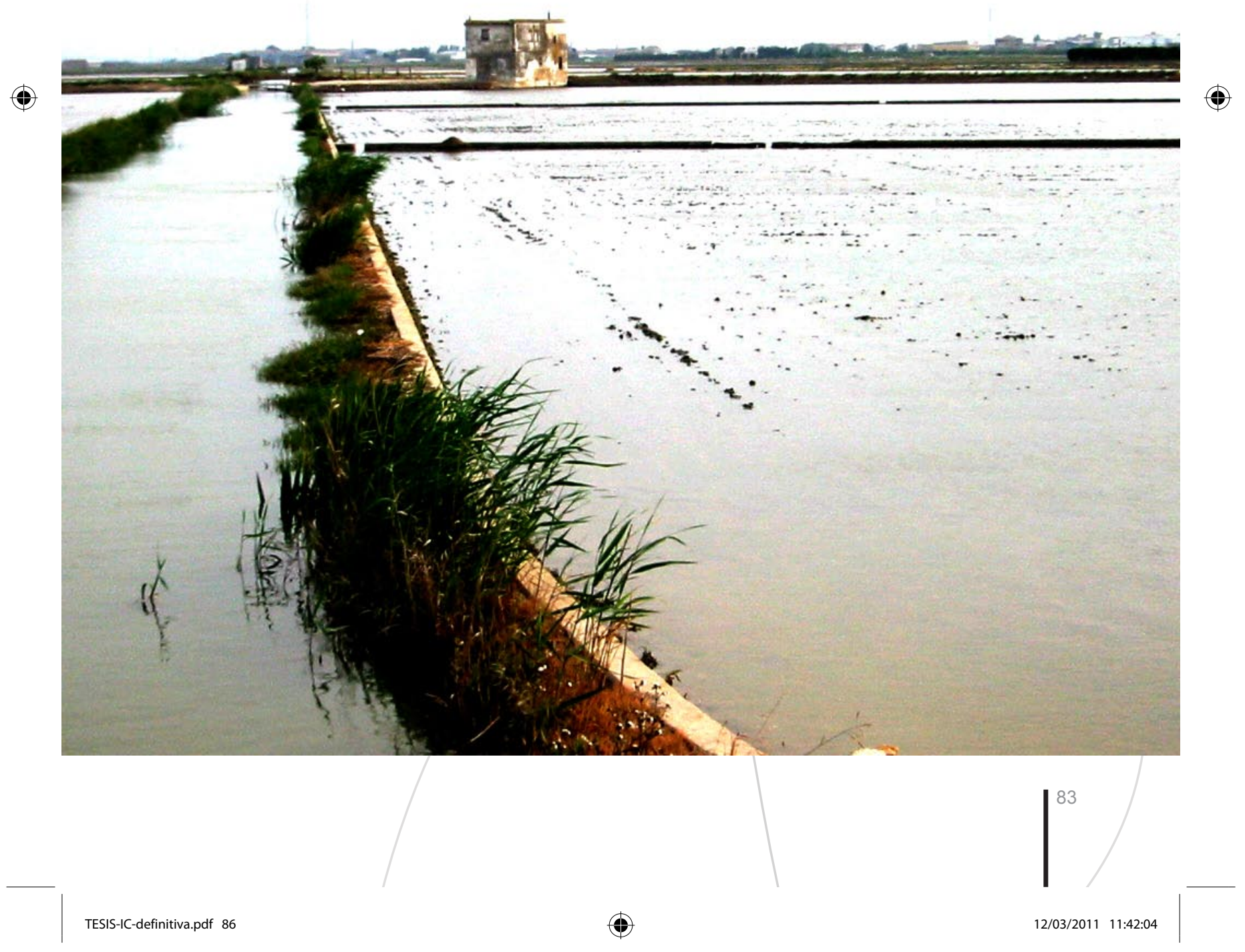



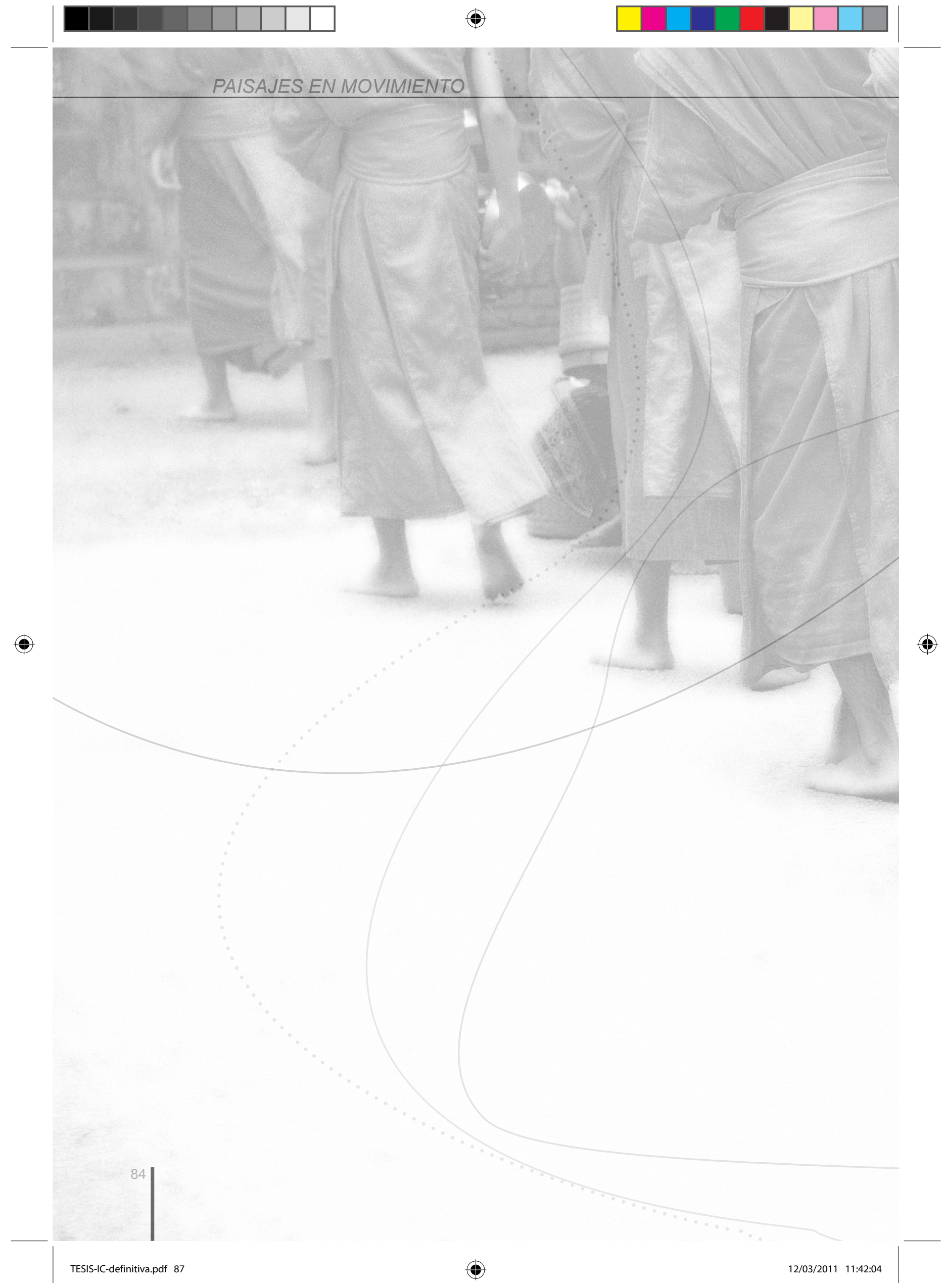


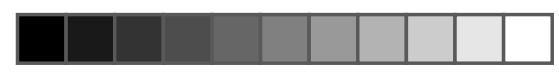

$\oplus$
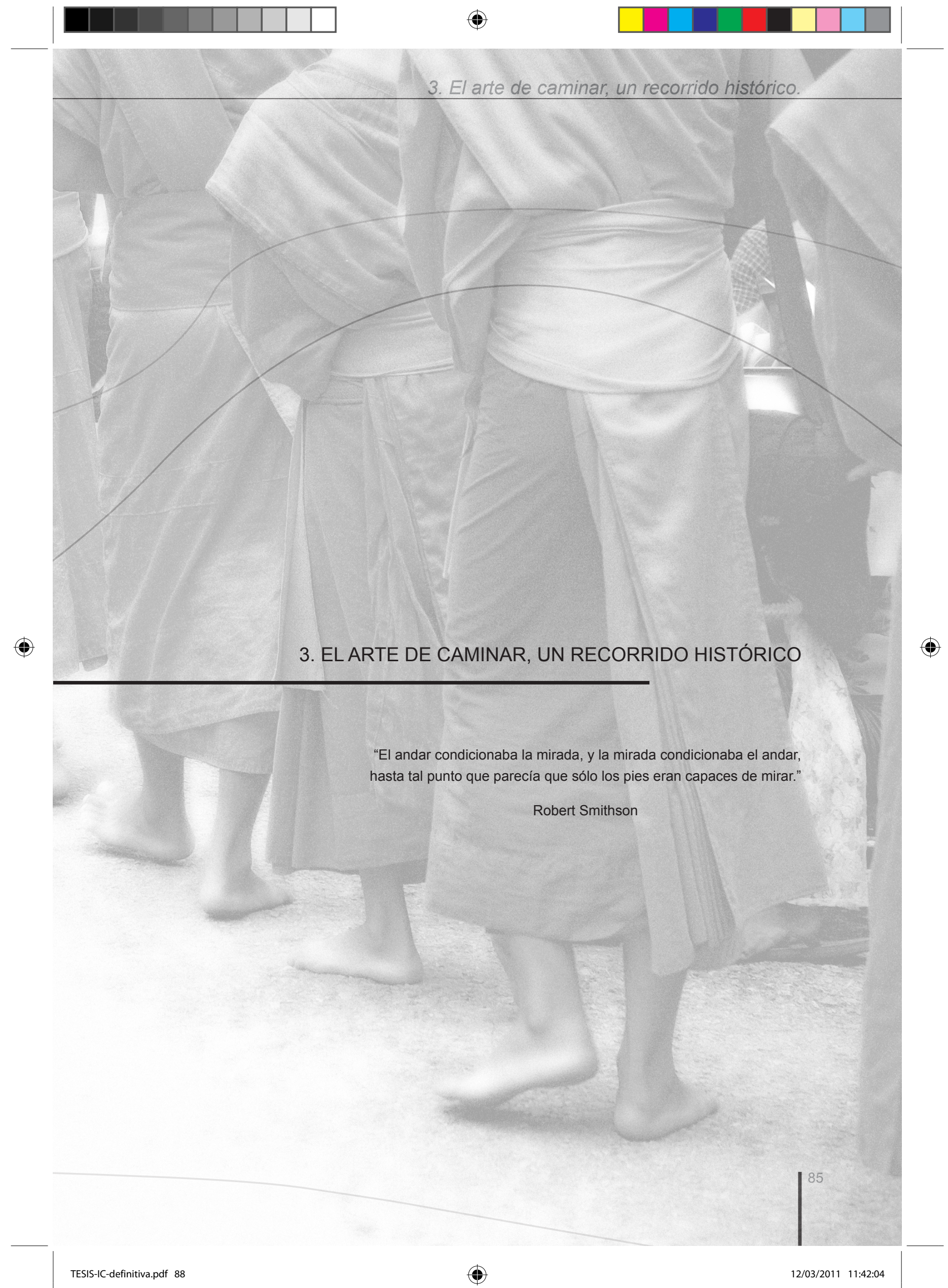


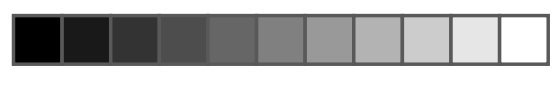

$\oplus$

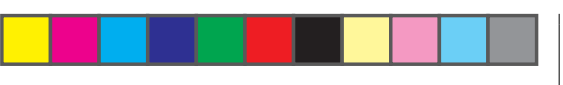

PAISAJES EN MOVIMIENTO

$(\varphi$

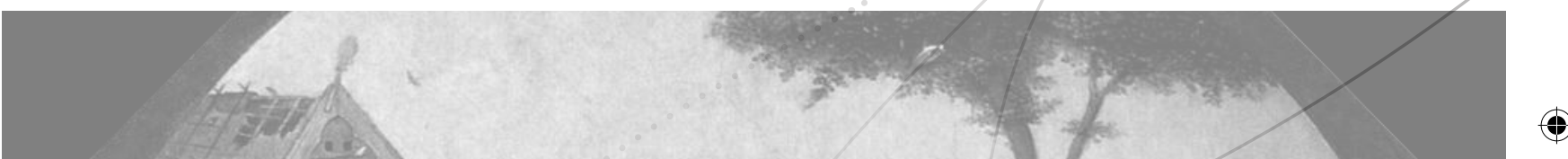



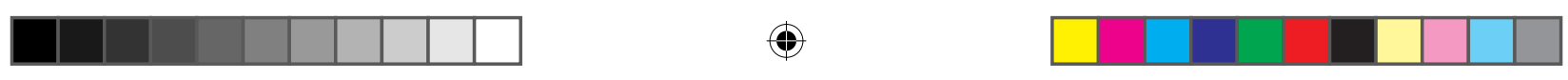

3.1. PEREGRINACIONES Y DESTIERROS. MANIFESTACIONES POPULARES

ENTRE EL ARTE Y LA RELIGIÓN

Ya desde sus orígenes, el ser humano ha establecido una estrecha relación con el entorno a través del movimiento del propio cuerpo. Los vínculos del ser humano con su mundo inmediato son pues indisolubles de este movimiento en el espacio. Son estas profundas raíces, a través de la cultura y la civilización, las que irán transformándose en las acepciones que utilizamos en la actualidad para referirnos al desplazamiento del ser humano en el espacio tales como andar, pasear, caminar, moverse,...., Por lo tanto, resulta evidente que el movimiento, asimilable a una posición referencial en constante transformación, y un complejo sentido del espacio y del tiempo ligado al movimiento están en el núcleo de la construcción de la arquitectura y de la ciudad y por extensión del 

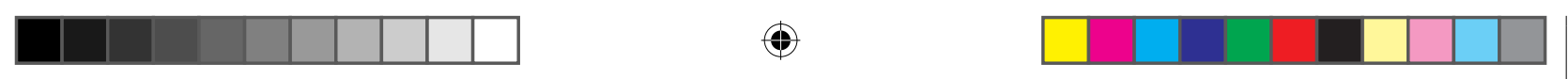

paisaje en tanto en cuanto constructo cultural humano.

Este aspecto, llamémosle primigenio, del movimiento autoreferencial como elemento vertebrador de la relación del ser humano con el mundo nos lleva a descender a los incipientes orígenes de la civilización para interrogarnos acerca del nomadismo y sedentarismo como aspectos aún implícitos en el ser humano y acerca de la interesante relación que se establece entre ellos en el modo que el hombre y la mujer tienen de enfrentase a su entorno. Francesco Careri, en su conocido ensayo Walkscapes $^{1}$ plantea ampliamente esta interesante relación entre nomadismo y sedentarismo como

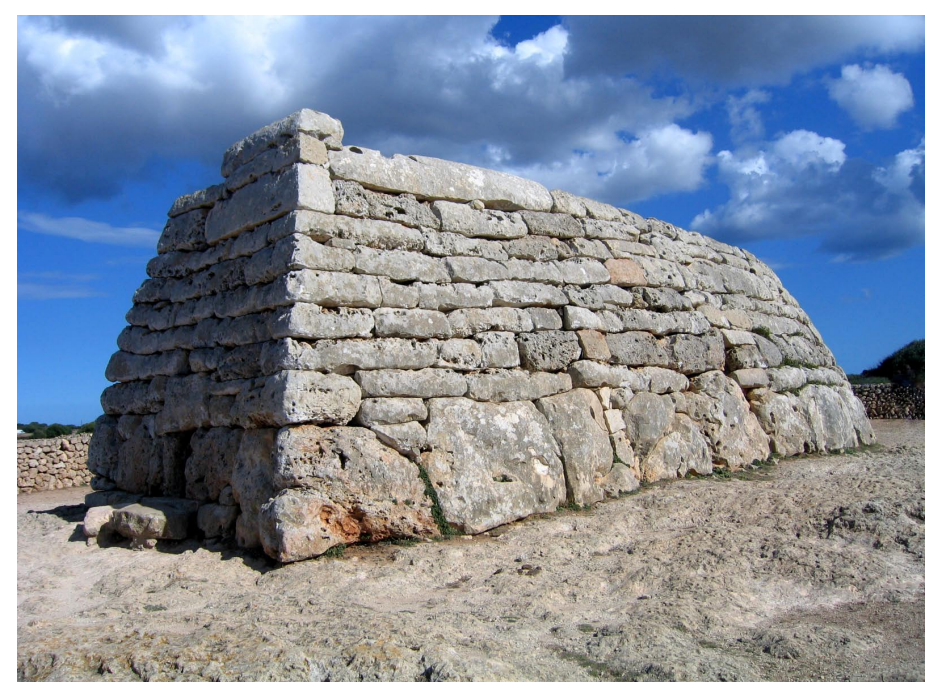

Naveta, Menorca, 2007 (fotografía I. C.). aspectos aún implícitos en el ser humano, surgidos a partir de dos actividades primarias de subsistencia como fueron en origen la caza y la recolección que darían lugar posteriormente al pastoreo y la agricultura respectivamente. Son por lo tanto dos aspectos relacionales del ser humano con su entorno que adquieren forma a través de aspectos tanto estáticos como dinámicos. El conflicto surgido entre ambos aspectos, que se remonta naturalmente a los orígenes de la civilización, no está en absoluto resuelto y es (como desarrollaremos más adelante) en este conflicto y gracias a él donde fructificarán algunos de los ejemplos más interesantes de la producción arquitectónica y paisajística de finales del siglo $\mathrm{XX}$.

1 Careri, Francesco, Walkscapes. El andar como práctica estética, Gustavo Gili, Barcelona, 2003. 

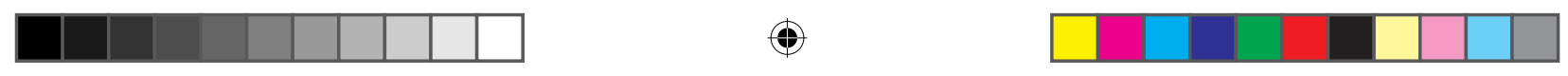

En efecto, el nomadismo hace aflorar la necesidad de la construcción simbólica del paisaje. Si para el ser humano sedentario los espacios nómadas son, a menudo, espacios vacíos, para los nómadas dichos vacíos no lo son en absoluto, bien al contrario, están repletos de huellas, de trazos invisibles que cargan de significado el territorio. El nómada transforma el vacío en lugar de la memoria, surcado de signos que enriquecen y construyen el paisaje con múltiples significados. Hoy por hoy, uno de los lugares en el mundo más interesante donde experimentar el paso del ser humano desde el nomadismo al sedentarismo (en la relación con el territorio) es con toda seguridad la actual Mongolia. Cuando llegamos a este país desde un contexto tan fuertemente urbanizado como el nuestro, donde la tradicional dicotomía campo-ciudad ha sido superada por un territorio ampliamente explotado donde la ciudad se expande sin solución de continuidad, enfrentarnos a un territorio escaso en núcleos urbanos e infraestructuras nos devuelve a un mundo donde el ser humano se considera aún nómada, vive como tal y se siente orgulloso de serlo.

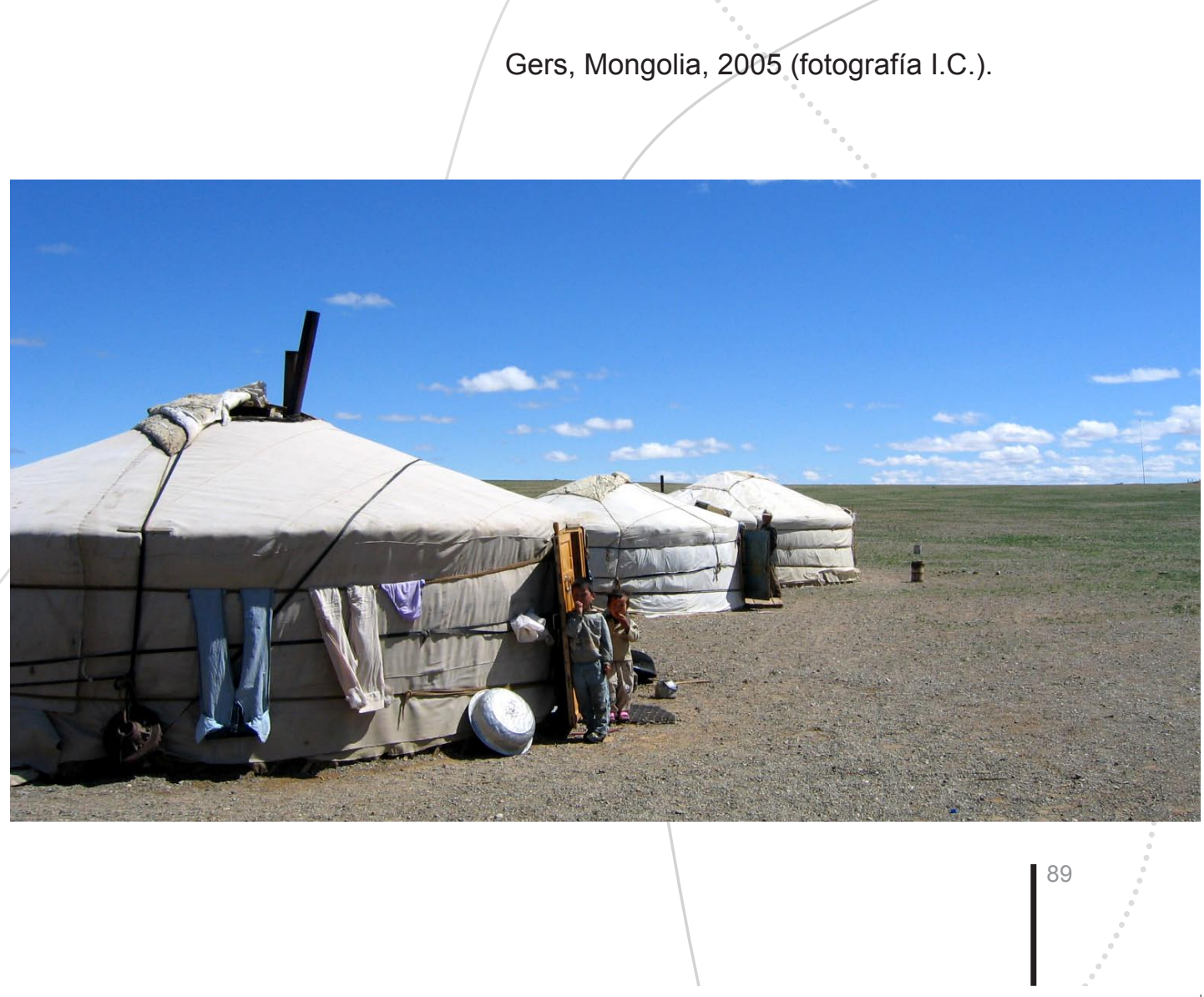



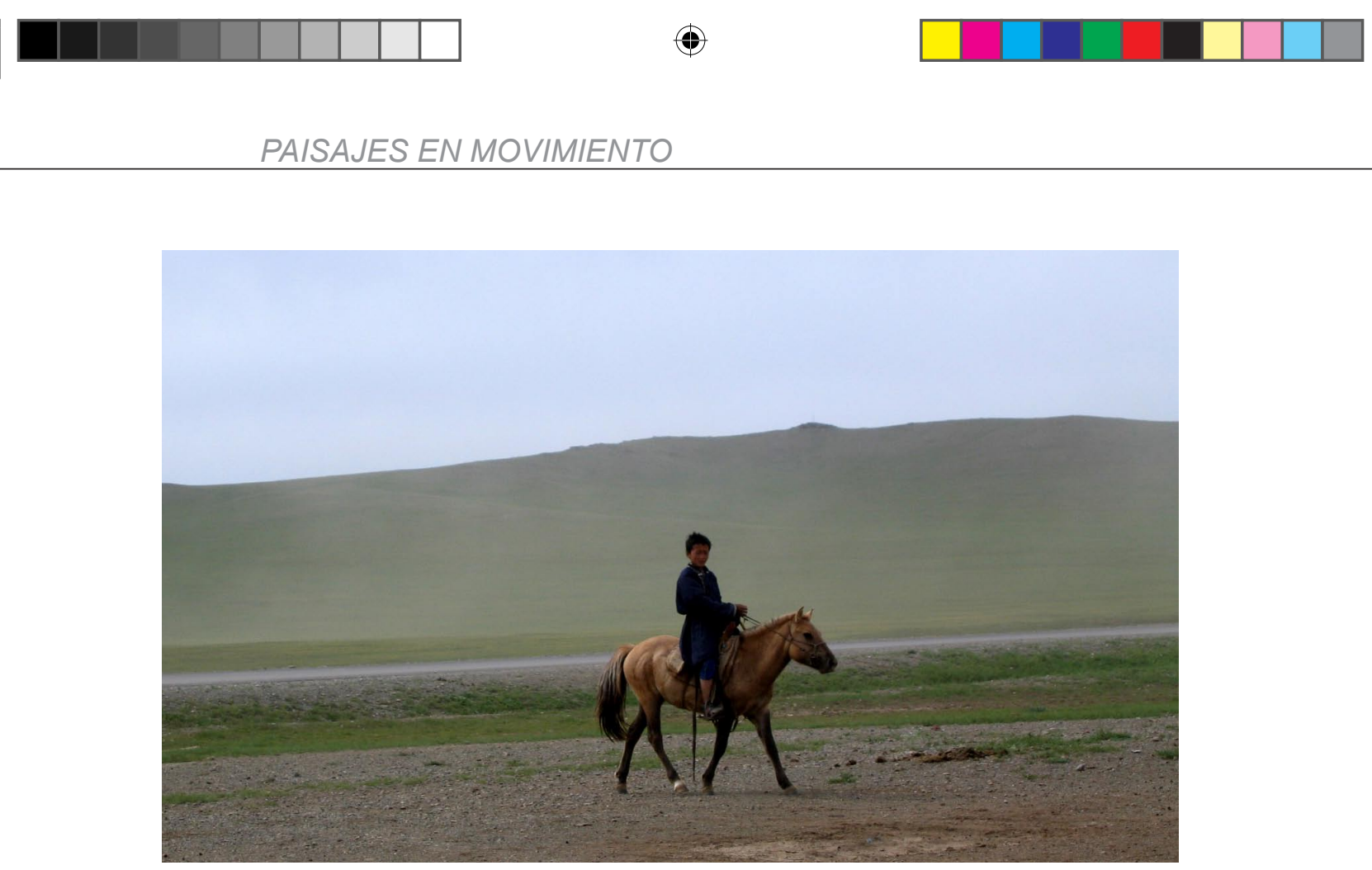

Jinete nómada, Mongolia, 2005 (Fotografía I.C.).

Este cambio de perspectiva no resulta en absoluto evidente y pronto comprobamos nuestra ausencia total de respuesta ante un territorio tan "vacío" de signos aparentes, donde nos faltan las claves y las referencias a las que estamos acostumbrados y que nos resultan imprescindibles en nuestro contexto socio cultural habitual. Nos sentimos desprotegidos ante la escala abrumadora de este paisaje al que, prácticamente de modo instantáneo, dotamos de un significado bien diferente de aquella que le otorgan los habitantes nómadas que montan y desmontan sus viviendas (los gers) una y otra vez para aprovechar los pastos y la climatología a lo largo del imperturbable cambio de las estaciones. Los jinetes mongoles descifran cotidianamente, aún hoy en día, un complejo sistema referencial de huellas y signos en un territorio mudo para el viajero occidental que queda, de este modo, sin referencias y abrumado ante su propia soledad frente al paisaje.

Esta diferente relación con el territorio que encontramos en la actual Mongolia se fundamenta en que, como nos recuerda Careri: "Sólo la presencia del hombre [...] así como la variación de las percepciones 


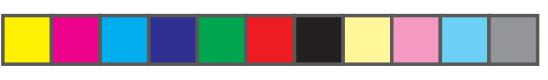

que recibe del mismo cuando lo atraviesa, constituyen ya formas de transformación del paisaje que, aunque no dejan señales tangibles, modifican culturalmente el significado del espacio y, en consecuencia, el espacio en sí mismo."2Esta radical diferencia en nuestra aproximación al mundo se sitúa en un estadio de nuestra conciencia todavía inexplorado suficientemente pero sin lugar a dudas sus implicaciones para la cultura del ser humano y su manifestación en el urbanismo y el paisaje son de enorme valor.

Aún en los albores de la civilización, Gilgamés el "hombre en una cuarta parte y dios en las restantes tres cuartas partes" se lanzó a un viaje agónico producto de la zozobra y la desesperación que le causara la muerte de su amigo Enkidu. Gilgamés, enloquecido por la muerte de su amigo y espantado ante la visibilidad

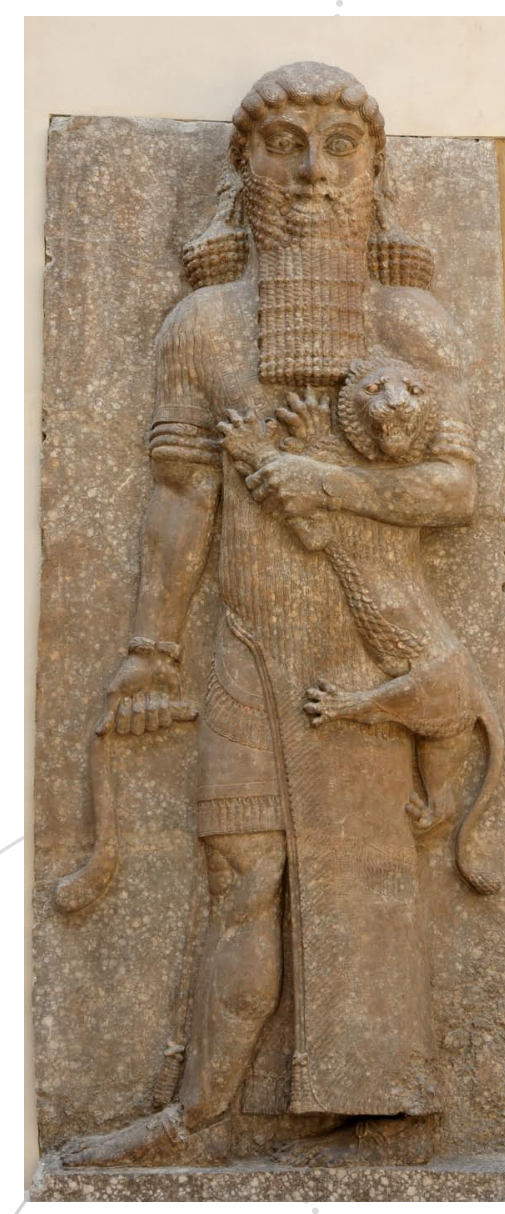

Héroe dominando un león.

(También conocido como Gilgamesh), Siglo VIII a.C., Museo del Louvre, Paris. y constatación de su propia caducidad y vulnerabilidad consagrará su vida a un viaje en búsqueda de la planta de la vida eterna. ${ }^{3}$ Este hermosísimo mito acerca del destino humano tiene extraordinarias similitudes con mitos pertenecientes a otras religiones, como por ejemplo la egipcia. El viaje, aparece ya con un papel fundamental en la primera tragedia conocida acerca de la existencia humana.

2 Ibídem, pág.51

3 Cuando Gilgamés finalmente ha encontrado la ansiada planta en el fondo del océano, una serpiente, emergiendo de las aguas, se la come mientras aprovechando que éste se está bañando. 


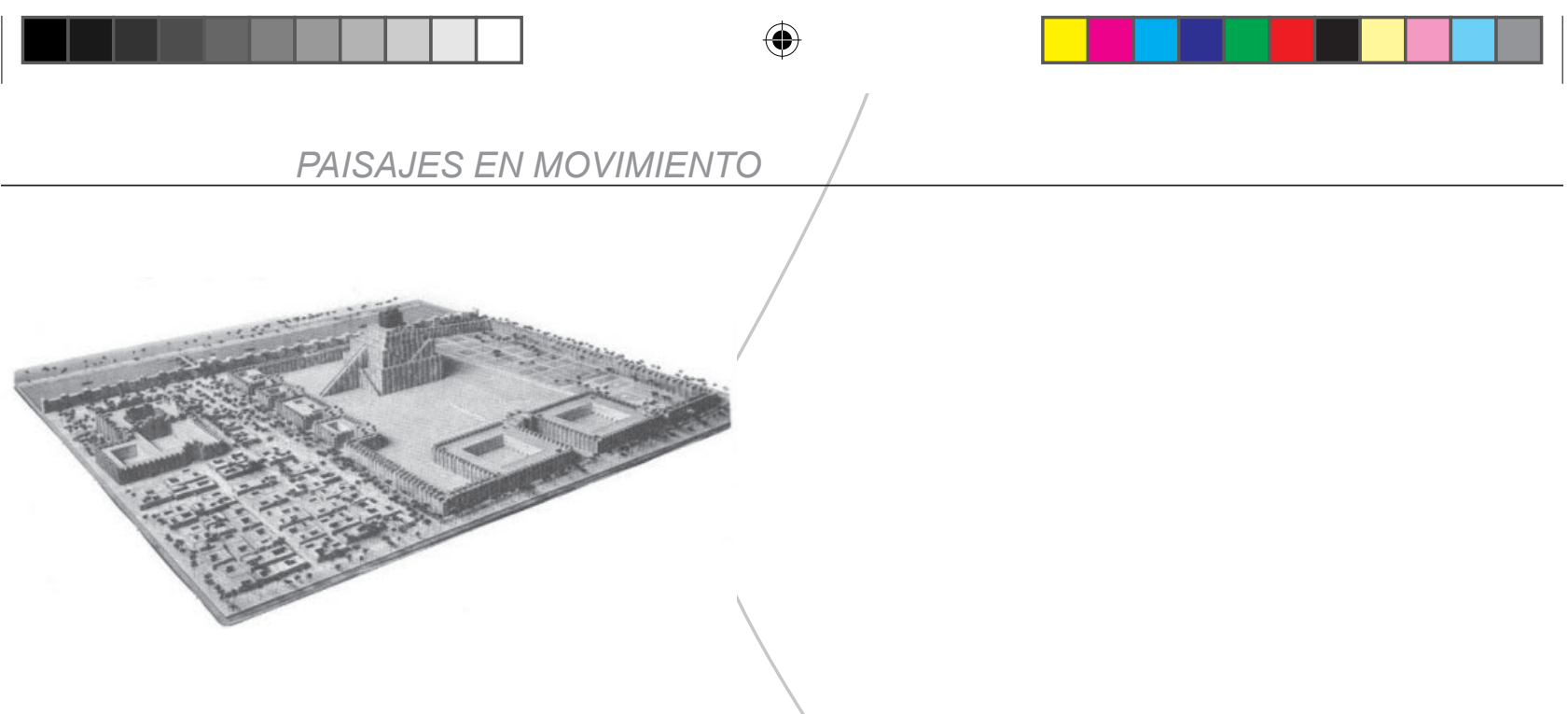

Maqueta de Esagila, el templo del dios Marduk, Museo del altar de Pérgamo, Berlín.

La ambivalencia de las relaciones entre constancia y cambio como aspectos esenciales del ser humano encontró una primera y temprana contraposición entre las civilizaciones de Egipto y Sumeria. Mientras que para los egipcios la vida posterior a la muerte era un lugar de renovación y renacimiento, explicitado hasta el infinito en innumerables relieves y papiros, la visión sumeria del otro mundo presentaba a éste como un lugar totalmente hostil a la vida, un lugar de miseria y desesperanza. Para los egipcios, el movimiento diario del sol desde el amanecer hasta el ocaso equivalía, en su mito más conocido, al viaje del dios Ra en su barca solar quien se adentraba en la noche para renacer cada mañana después de vencer a las fuerzas de la muerte perpetuando así el ritmo de la vida. ${ }^{4}$ Para los sumerios, en cambio, el otro mundo más allá de la muerte es la morada de los muertos, un lugar del que no hay retorno posible y tan sólo excepcionalmente será posible interrogar al espectro de algún personaje importante. ${ }^{5}$ Algunos historiadores como Kurt Sethe o Sigfried Giedion han interpretado en esta contraposición entre ambas culturas el mantenimiento por parte del pueblo egipcio de unos vínculos más estrechos con su pasado nómada, vinculado a las primeras civilizaciones arcaicas. De

4 Sobre este mito y otros mitos fundamentales de la religión egipcia véase: Armour, Robert A., Dioses y mitos del Antiguo Egipto, Alianza Editorial, Madrid, 2004

5 Acerca de otras visiones de los mitos sumerios se puede consultar: Asimov, Isaac, «Los acadios, los nómadas conquistadores». El Cercano Oriente, Alianza Editorial,Madrid,1986.

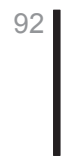



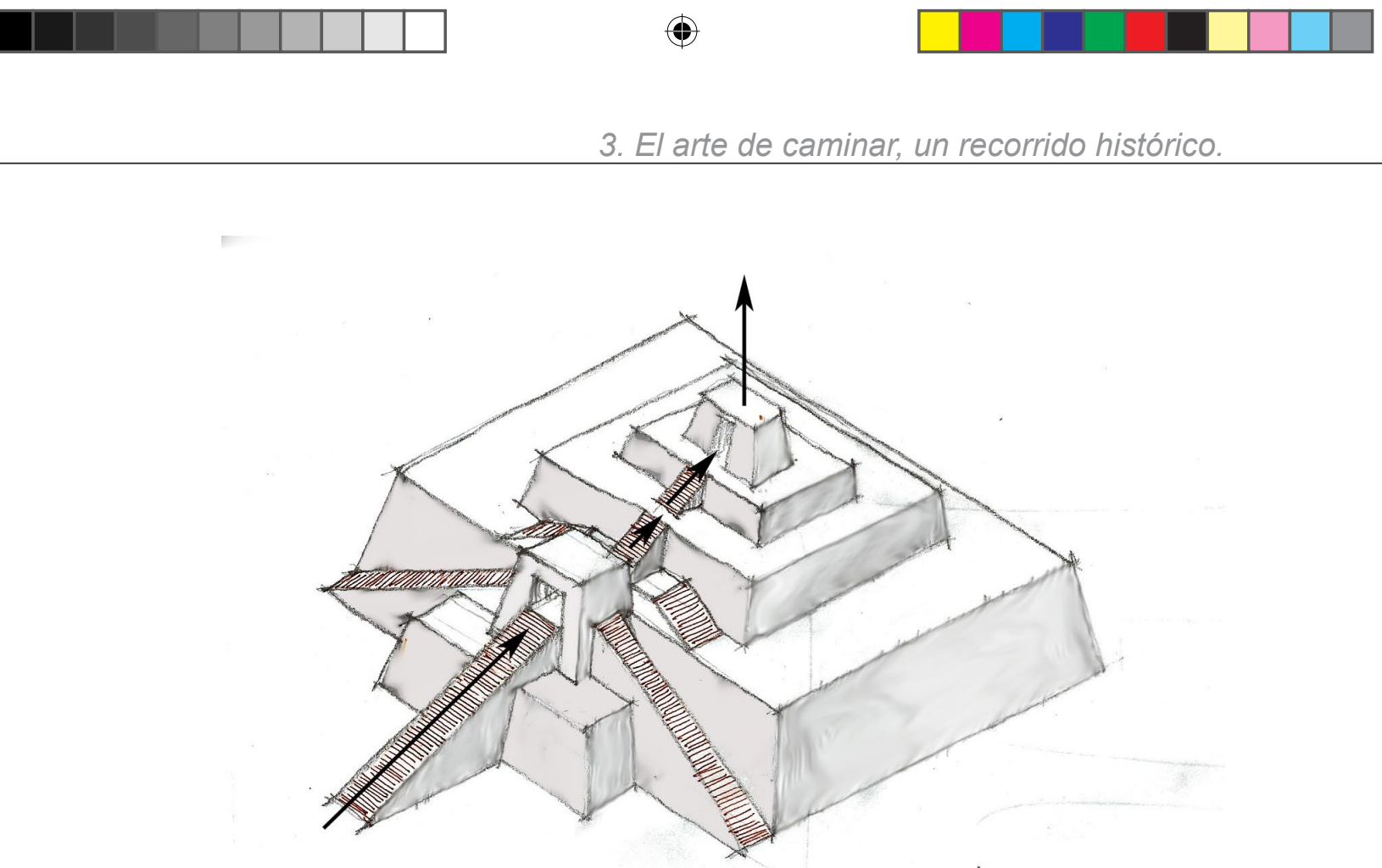

Representación esquemática del zigurat ideal y su secuencia de recorrido y espacial (dibujo I.C.).

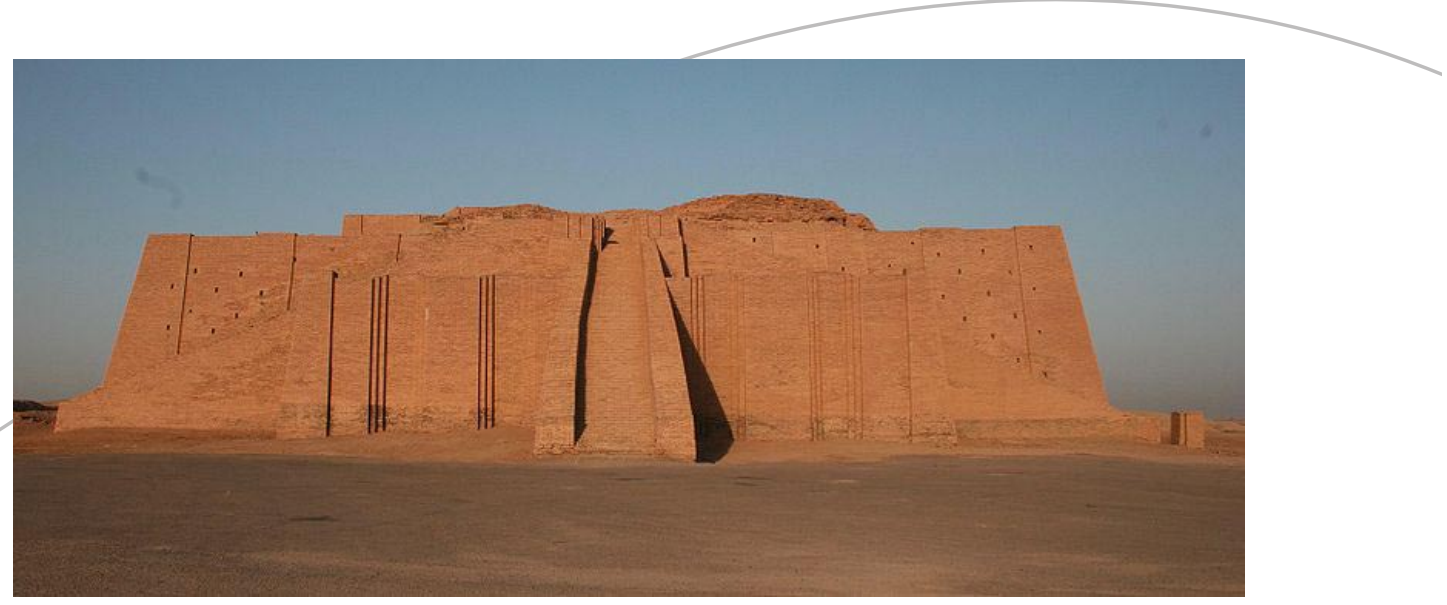

El famoso Zigurat de Ur, cerca de Nasiriya (Irak) en la actualidad. 

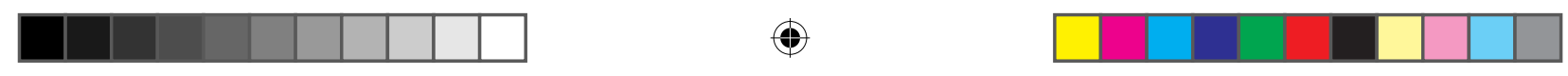

hecho, si admitimos como validas la mayoría de las interpretaciones realizadas en el siglo XX acerca de los zigurats sumerios, éstas nos remiten al deseo de unión con la divinidad por parte del ser humano. Partiendo de esta hipótesis, podemos interpretar con cierta facilidad los zigurats como meras estructuras necesarias para la confección, para la construcción, del verdadero elemento principal de la arquitectura sumeria: la escalera monumental. Escalera erigida para, gracias a su recorrido, (aspecto éste fundamental) producir la anhelada identificación con la divinidad.

El zigurat sirve pues como una ingente escenografía, como una necesaria y grandiosa estructura para la edificación de la aportación fundamental de Sumeria a la historia de la arquitectura universal: la escalera monumental mesopotámica. Los zigurats son, pues, estructuras necesarias para la erección del posiblemente más dinámico de los elementos arquitectónicos: la escalera. Y a una escala que implicaba directamente al territorio y en consecuencia al paisaje mesopotámico. La escalera principal del zigurat, que asciendecontra la pared noroeste, se encontraba flanqueada por dos escaleras simétricas opuestas que apoyadas en dicha pared noroeste, desciendes majestuosas hacia el patio del templo. La escalera principal, colocada estratégica y simbólicamente en el eje del conjunto, sobresalía del volumen principal y se reunía al nivel de la primera terraza, en un punto coronado con un pórtico, con las dos escaleras secundarias laterales. A partir de este punto, solamente continúa la escalera central, que reduce su sección y conduce, tras algunos tramos más hasta la plataforma superior donde se culmina con un templo, en lo que supone el remate a una magnífica escenografía para las procesiones sacerdotales. Arquitectura dinámica al servicio de una estudiada y sofisticada coreografía de tránsito que celebra la unión del ser humano con la divinidad. El zigurat de Etemenanki se considera tradicionalmente como la famosa Torre de Babel bíblica, causante del castigo de Dios ante la soberbia de los hombres que pretendieron alcanzar el cielo. ${ }^{6}$

6 Génesis, XI

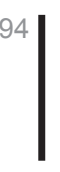



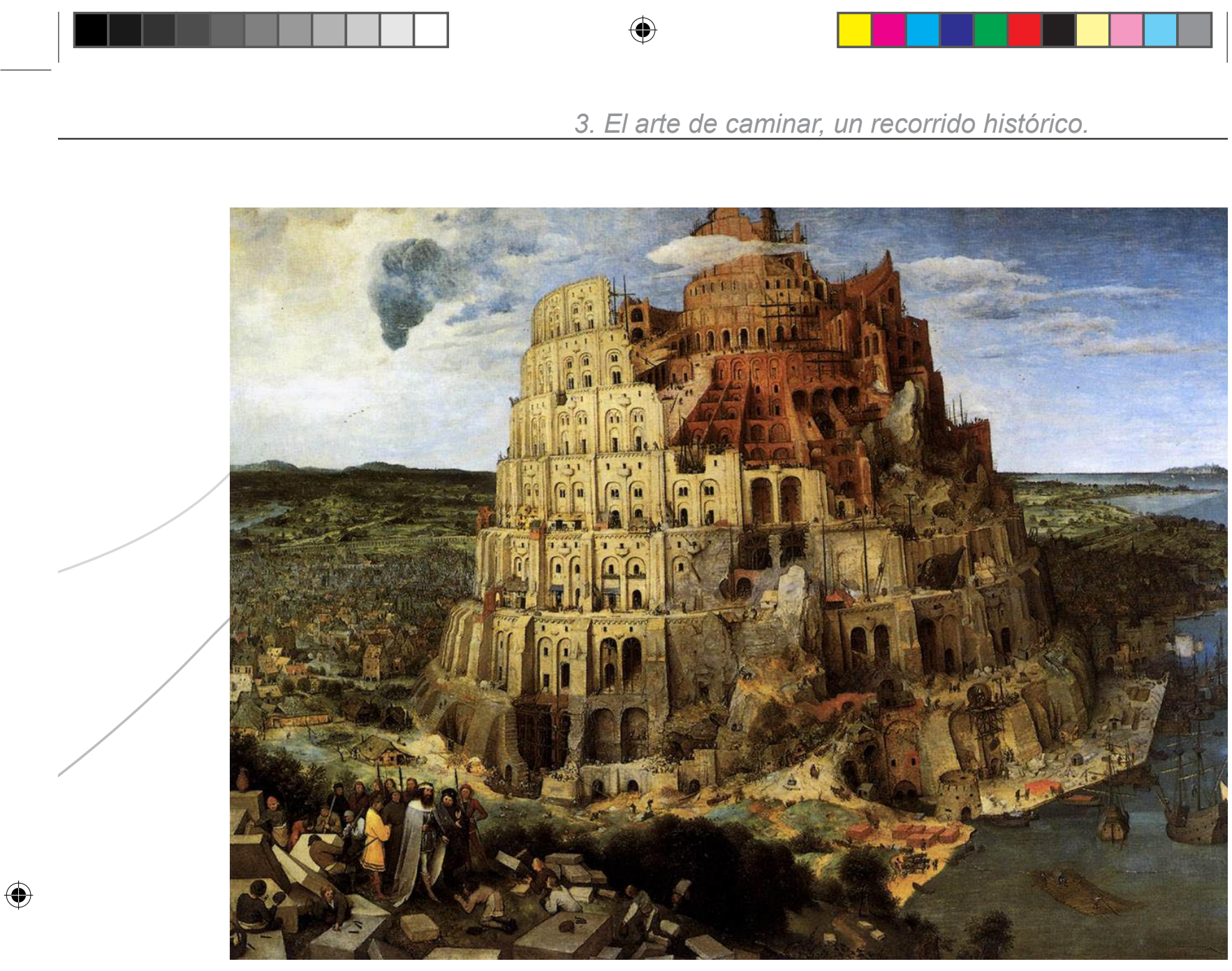

Pieter Bruegel el viejo, La Torre de Babel, 1563.

Del conjunto formado por este zigurat paradigmático y el templo de Marduk comenzaba el que probablemente sea, según diversos autores, el camino procesional más largo y ostentoso que se haya construido en la historia de la humanidad. Esta vía sacra de dimensiones magníficas, construida para la celebración de las fiestas de Año Nuevo, que tenían lugar en el equinoccio de Otoño, atravesaba la magnífica puerta de Istar para alcanzar un pequeño templo donde se celebraban los ritos correspondientes a la festividad. 


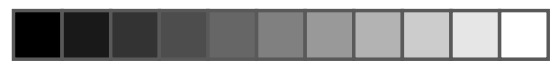

(
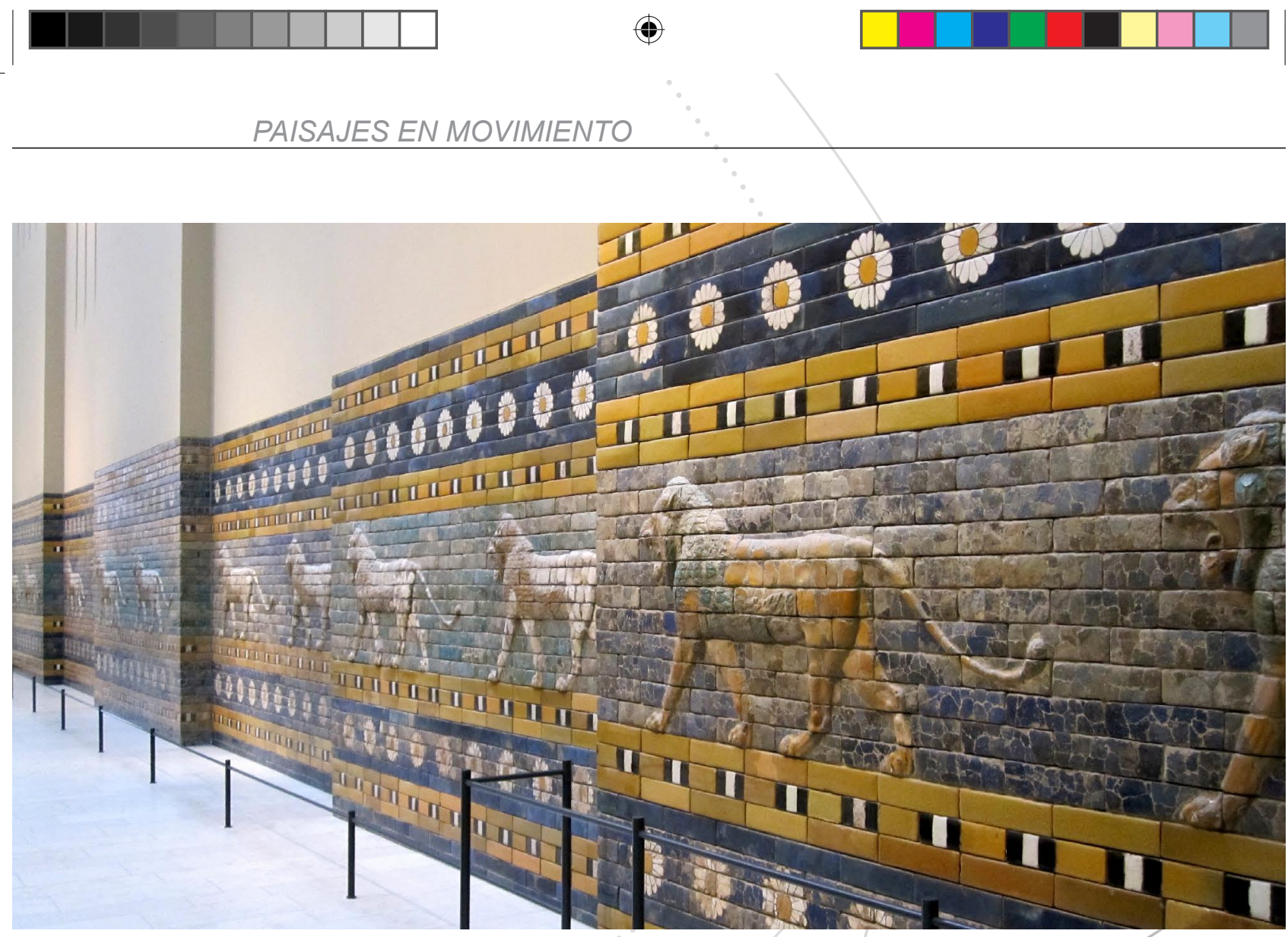

$\oplus$

Cerámica vidriada perteneciente al Camino procesional del Templo de Istar,

Babilonia, circa 575 a.C. Museo del Altar de Pérgamo, Berlín (fotografía I. C.).

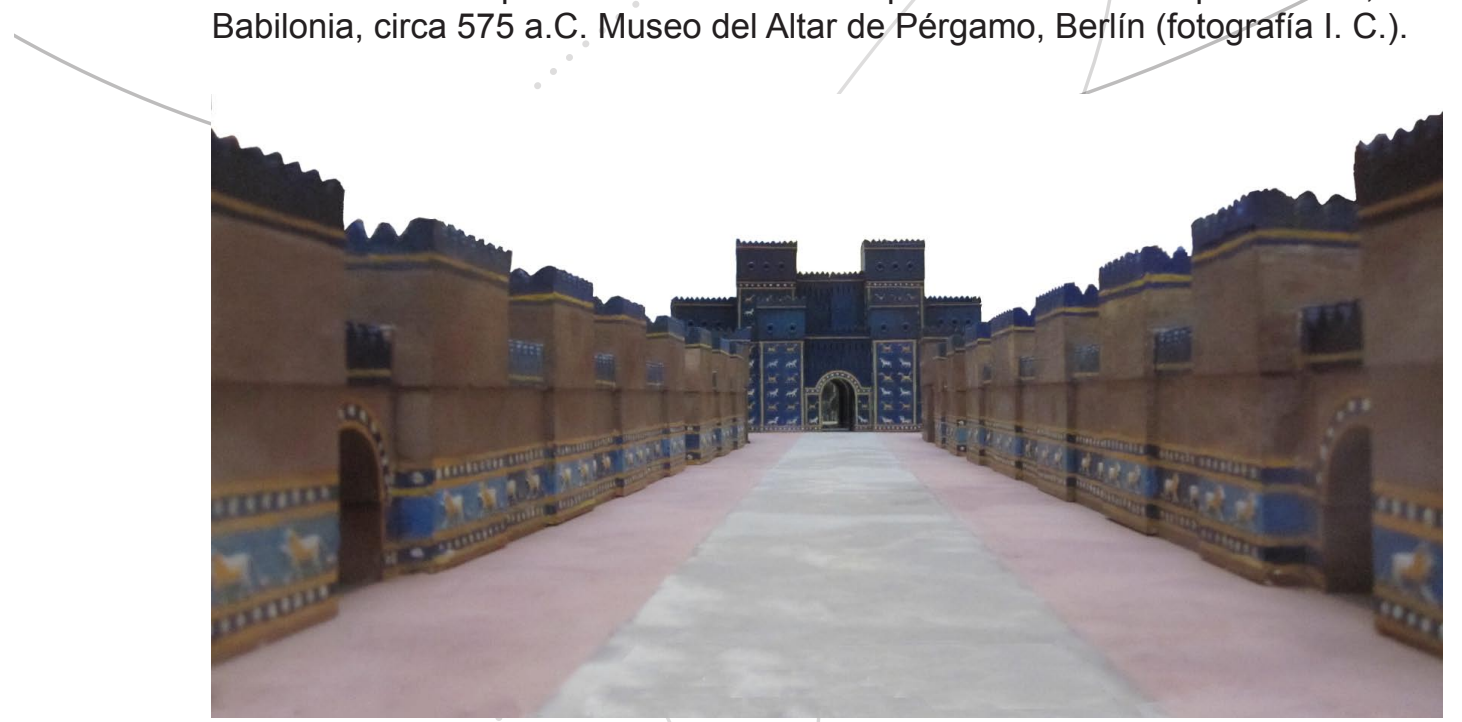

Reproducción espacial del Camino procesional del Templo de Istar, Babilonia, (a partir de la maqueta existente en el Museo del Altar de Pérgamo, Berlín).

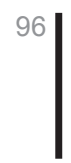



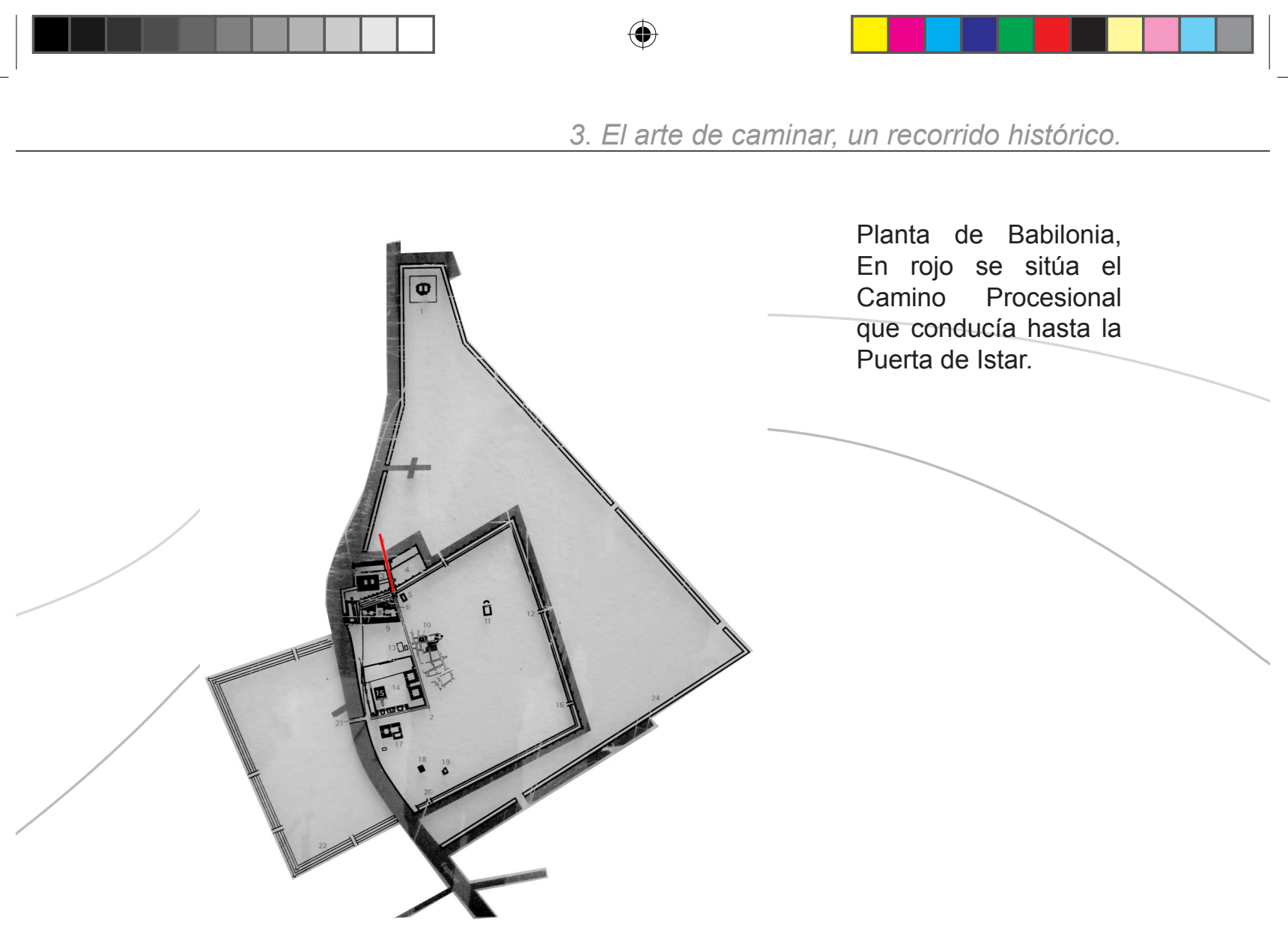

No obstante, tendremos que fijarnos en una civilización enclavada algo más al Oeste para poder encontrar, gracias a la aparición de la arquitectura en piedra, restos verdaderamente notables y en buen estado de conservación de arquitecturas y paisajes pensados con un fuerte componente dinámico. La aparición en Egipto de la arquitectura en piedra está íntimamente relacionada con la singular relación establecida por el pueblo egipcio entre la vida y la muerte, o más correctamente, entre la vida antes y después de la muerte. Como muy bien nos recuerda el profesor Giedion ${ }^{7}$ fue su anhelo de eternidad el que llevó a los primeros egipcios a la búsqueda de un material que cumpliese sus deseos, y para ello, la piedra, a pesar de su dureza y del necesario y arduo trabajo que comporta, colmaba sus aspiraciones. Fue esta dificultad en el trabajo de la piedra lo que produjo un gran desarrollo de las destrezas necesarias para darle la forma deseada. Esta íntima vinculación de la piedra con la muerte queda

7 En su fundamental obra al respecto: Giedion, Sigfried, El presente eterno: Los comienzos de la arquitectura, Alianza Forma, Madrid, 1986. 

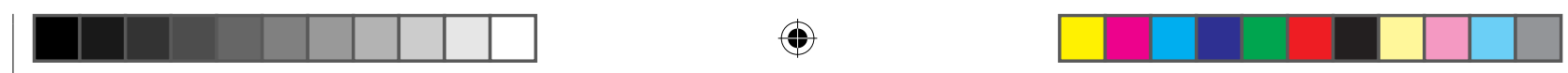

patente en el hecho de comprobar cómo en un principio la piedra era un material reservado únicamente para las tumbas, prohibiéndose su uso en otro tipo de construcciones. Un buen ejemplo de ello es el extraordinario complejo funerario para el rey Zoser en Saqqara, considerado como una de las primeras construcciones en piedra de la historia de la humanidad.

Todo el conjunto de edificios construye un elaborado escenario creado para el movimiento del $\mathrm{ka}^{8}$, en este caso del ka del rey Zoser, fundador de la III Dinastía. "El recinto sagrado de la pirámide escalonada de Zoser es en todos sus aspectos un viaje hacia lo desconocido bajo el impulso de una fe inquebrantable y poderosa en la existencia del ka." ${ }^{\prime 9} \mathrm{El} k a$ es un complejo y sofisticado concepto religioso egipcio que podemos asi-

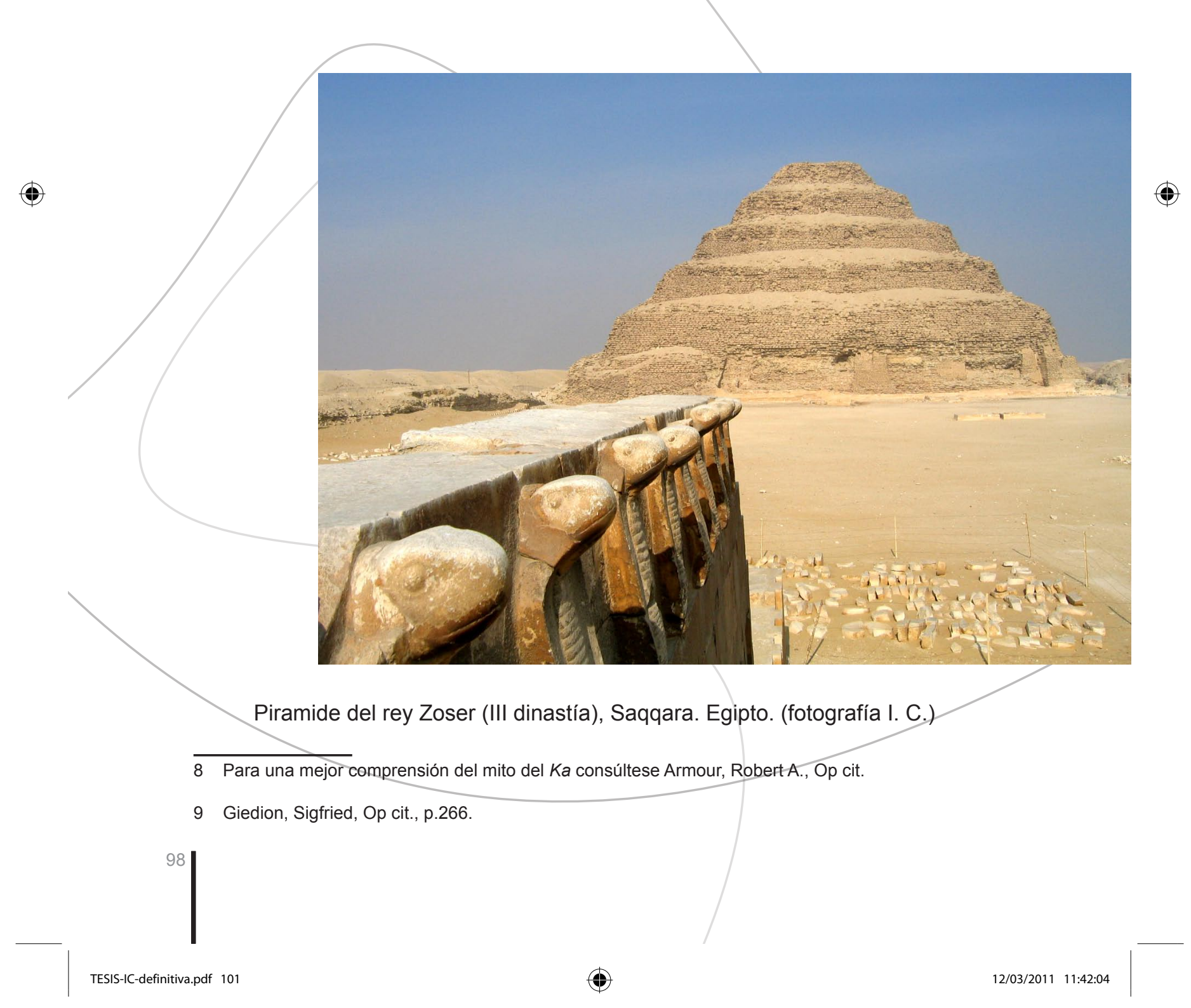



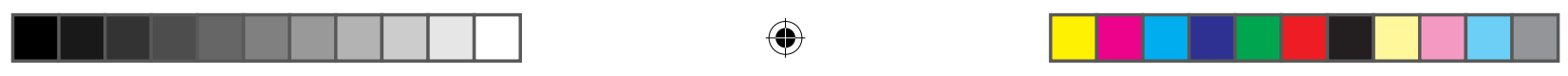

3. El arte de caminar, un recorrido histórico.

milar (de un modo excesivamente simplista pero suficiente para el caso que nos ocupa) con una fuerza vital, con un doble de la personalidad que podía separase de ésta cuando quisiese. El ka emanaba del dios hacia el faraón, que de este modo era hijo y también dios. El rey era el único mortal que poseía esta gracia divina y cósmica, esta doble naturaleza y podía
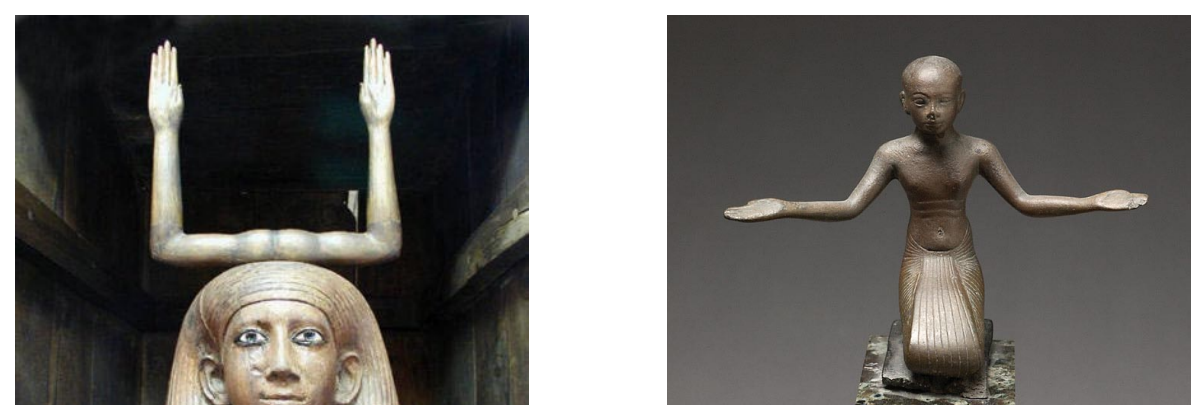

Dos representaciones del concepto del Ka egipcio.

dispensarla a sus súbditos a voluntad. Todo el complejo de Saqqara está edificado como morada del ka del rey Zoser. "Era el ka del rey el que residía en las cámaras subterráneas del palacio, el que daba las órdenes en el edificio gubernamental, corría la carrera ceremonial en el amplio patio en la época de las fiestas jubilares, erraba a través de todo el recinto, cerrando tras de sí las puertas de piedra labradas, siempre abiertas, que conducían a las capillas y a otros edificios, y salía para viajar a través de las muchas puertas fingidas de la alta muralla."10

La concepción dinámica de Saqqara no termina, sin embargo, en sus referencias al deambular eterno del ka. Los egipcios nunca se interesaron en la elaboración del espacio interior en sus construcciones y aquí en Saqqara, muchos de los edificios del complejo se reducían a sus fachadas. Es decir, se trata de autenticas escenografías, decorados de teatro en piedra, para lo realmente importante: los movimientos que se

10 Giedion, Sigfried, Op. cit., p. 268. 

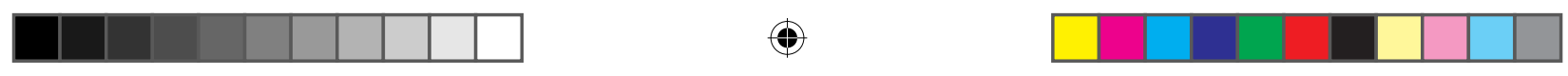

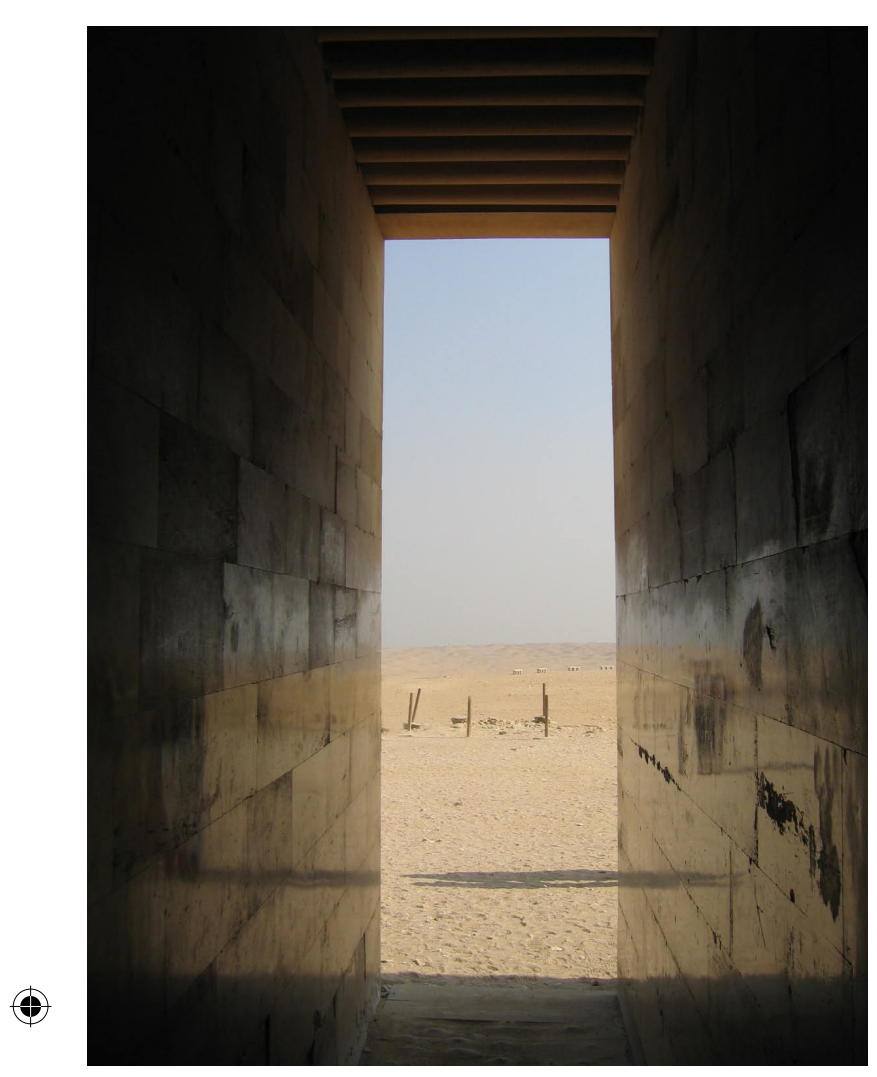

Acceso al recinto sagrado de la piramide del rey Zoser (III dinastía), Saqqara.

Egipto (fotografía I. C.)

Sección longitudinal del Gran templo de Amón. Karnak,Egipto. producían dentro del conjunto. Éstos podían ser, bien los movimientos del rey Zoser en su carrera ceremonial anual como los de su doble, de su "fuerza vital", el ka, en su eterno vagar. La presencia, por ejemplo, de numerosas puertas falsas no se puede entender sino desde la voluntad de dotar de una amplia libertad de movimientos al ka del rey. Paralelamente, en dicha ceremonia anual, el rey renovaba periódicamente su naturaleza divina y en consecuencia su vitalidad como monarca, asegurando el equilibrio del cosmos, la renovación de las armoniosas relaciones entre el cielo y la tierra y alejando de este modo el fantasma del caos primordial que tanto atemorizaba a los egipcios. El propio rey corría literalmente una carrera

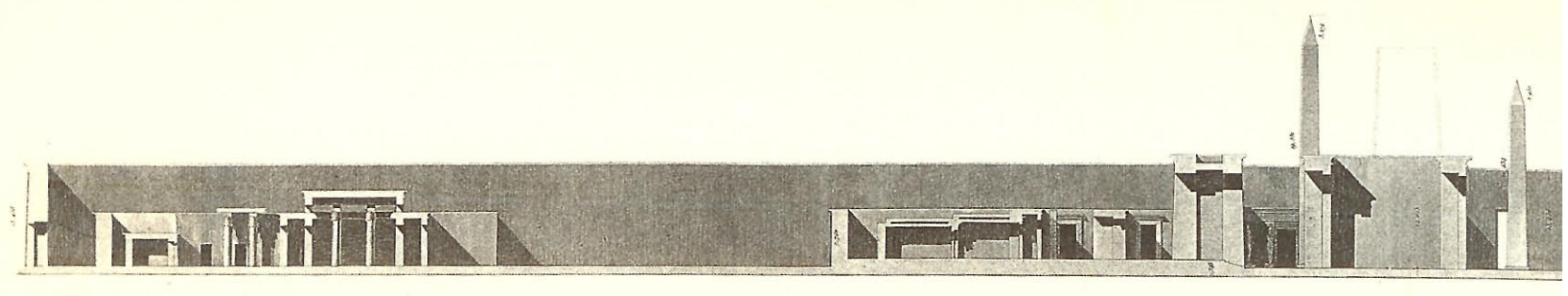



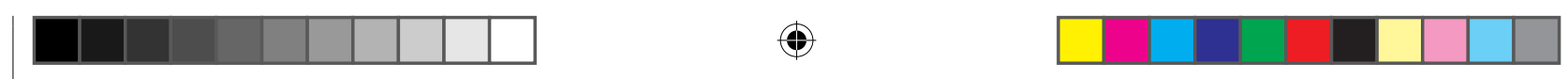

ceremonial entre dos piedras que aún podemos encontrar en el amplio patio. Esta carrera se consideraba una verdadera danza ritual sobre el campo que aseguraba la fertilidad, en un acto estrechamente vinculado con antiguos ritos de la fertilidad que concernían a la diosa Hathor en su forma de buey sagrado.

Este interés principal por espacios y concepciones arquitectónicas dinámicas más que por espacios estáticos y cerrados, se confirma al comprobar el hecho de que el único recinto, el único espacio interior de todo el conjunto verdaderamente elaborado e interesante, es la sala procesional que se encuentra a continuación del acceso principal. Este acceso, el único para los vivos de todo el conjunto, permanecerá perpetuamente abierto. A partir de aquí, se accede a una gran sala de $54 \mathrm{~m}$. de longitud flanqueada por veinte columnas entregas de caliza, en su día pintadas de rojo. Finalmente, la salida del corredor desemboca en una estancia espacialmente ampliada por un recinto cubierto a modo de sala hipóstila. Esta sala procesional, que da la pauta para todo el conjunto, con su sutil iluminación oblicua a través de las altas ventanas horizontales practicadas en los muros da la perfecta idea de un espacio interior sagrado en tanto en cuanto "sala de paso". Este concepto de sala, de camino procesional, perdurará en el resto de la arquitectura egipcia posterior y más concretamente en las grandes salas hipóstilas (como por ejemplo en el templo de Karnak), así como la elevación de la nave central para introducir una tenue luz en el conjunto. La sala procesional y el complejo

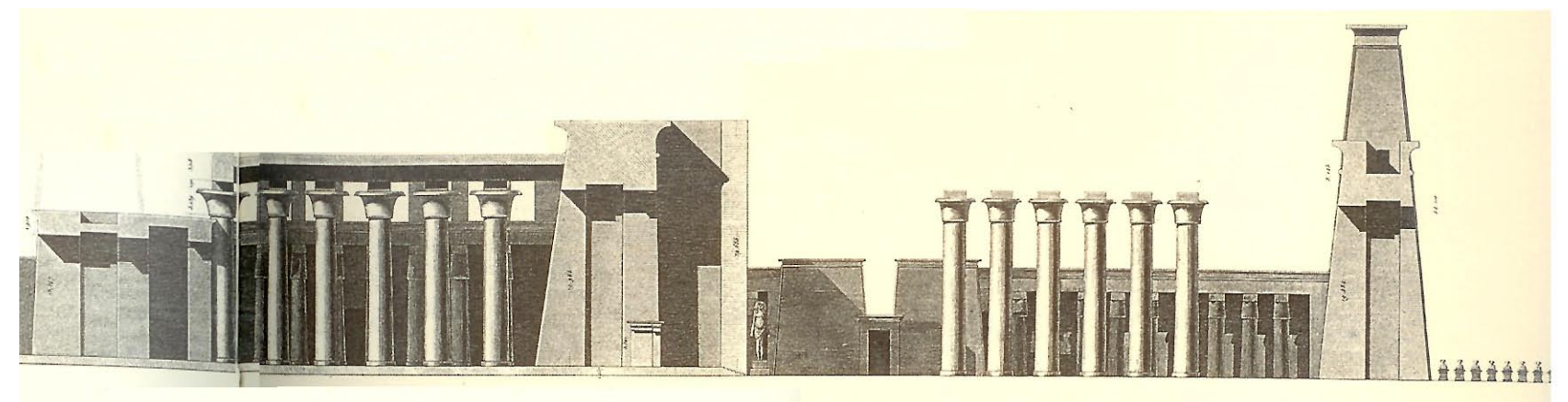



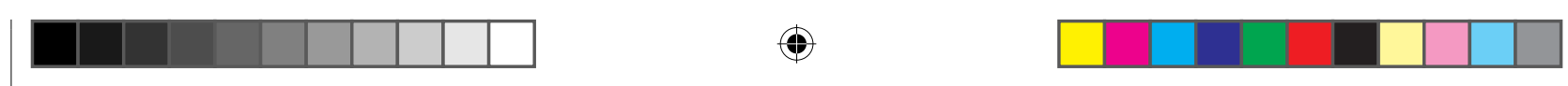

de Saqqara en su conjunto no pudieron surgir más que de una profunda convicción en la continuidad inmutable entre la vida antes y después de la muerte, entre la vida terrenal y la vida en el más allá.

Esta idea del eterno vagar, la creencia de que la vida en sus etapas nunca permanecía estática, reafirmaba la necesidad de una constante y eterna renovación que alcanzó una concreción espacial y paisajística de gran elaboración en los grandes templos del Imperio Nuevo, donde la idea básica del templo se conservaría durante miles de años. Las abrumadoras construcciones que admiramos hoy en día como reflejo del esplendor de los antiguos templos del Imperio Nuevo fueron creadas como paisaje pertinente para las procesiones que se desarrollaban en su interior, se erigieron como testigos elocuentes de la compleja visión egipcia de una vida en constante cambio cuya duración total era mucho más dilatada y extensa que la de la corta vida humana.

El tipo más habitual de templo repetirá un esquema tripartito que comienza en el acceso a través de una sala hipóstila cubierta para acceder a continuación a un patio cercado que separa el mundo exterior del mundo interior del templo. Los monumentales pilonos marcan claramente esta frontera. Así pues, la morada del dios, el verdadero espacio completamente interior, el santuario propiamente dicho, se encontraba al final del "camino" y tenía su acceso cerrado. En sí misma, esta disposición ya lleva implícita la idea de viaje. La apertura de la puerta sagrada mediante el rito de la rotura del sello tan sólo podía ser llevada a cabo por el faraón en ocasión de las grandes procesiones, enormes dispositivos de cuidada escenografía espacio temporal que permitirán la realización de tal acto. La imagen del dios correspondiente será posteriormente traslada durante dichas procesiones mediante una barca sagrada a la cual se le habilitará una antesala dentro del conjunto del templo. Como no podía ser de otro modo, vemos cómo el desarrollo del templo egipcio responde a sus más profundas convicciones religiosas. Son fiel reflejo de unas creencias que no reconocían interrupción entre la vida antes y después de la muerte. Su concepto del mundo, estaba estrechamente ligado a las crecidas del Nilo, 

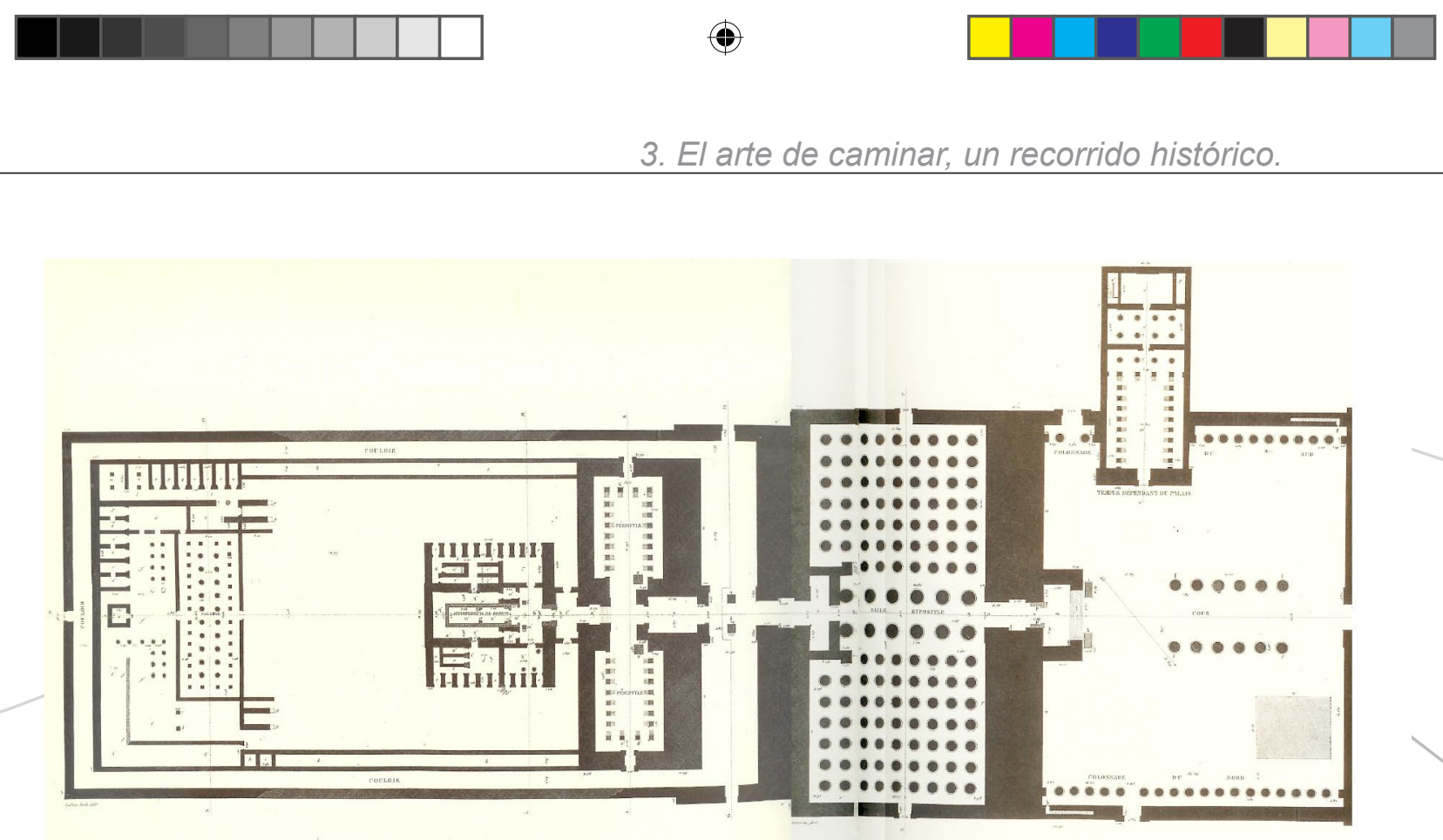

Planta del Gran templo de Amón, Karnak, Egipto.

que con su crecida anual fertilizaba la tierra y aseguraba las cosechas en un ciclo perpetuo de armonía de las fuerzas del cosmos que deberá tener su plasmación en la arquitectura egipcia. Esta concepción del mundo, entre la constancia y el cambio, esta asunción del eterno vagar humano y cósmico, se consolidaba en la erección de cada nuevo templo."Miraban el templo como miraban su propio cuerpo, como algo que vive, que crece, que decae y que vuelve a vivir de nuevo."11 Es esta concepción de constante movimiento, lo que explica las sucesivas extensiones de los templos, así como el hecho de que se hayan encontrado restos de templos anteriores colocados estratégicamente en los cimientos de templos nuevos como elementos simbólicos de renacimiento y regeneración.

Naturalmente, esta concepción fluida y dinámica de la vida como vagar eterno no afectó únicamente a los templos en sí, es decir a su interior. Existe un nivel de conexión física entre los templos que dejó unas profundas huellas en un territorio que se transformó, gracias a numerosos caminos sagrados, en un paisaje lleno de referencias simbólicas y colmado de significados, muchos de ellos perdidos para nosotros en 11 Íbidem, p. 333 . 

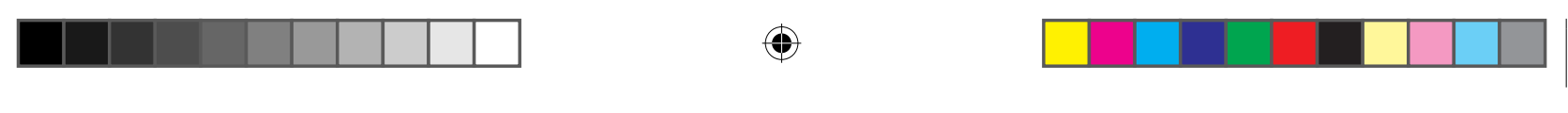

la actualidad. El desierto, mudo en gran medida para nosotros, se transforma, producto de la estrecha relación establecida entre cada templo egipcio y los templos situados a su alrededor, generando una compleja y fascinante red de caminos sagrados que articulaban y estructuraban el territorio a través de diferentes relaciones visuales y espaciales que lo transformaban en un denso paisaje trascendente.

En esta producción de paisaje y arquitectura dinámica tenían una posición clave las grandes procesiones ceremoniales y el complejo de ritos y arquitecturas ligados a ellas. Estas procesiones transportaban, en su núcleo central, la imagen del dios en la barca sagrada desde su santuario (situado en un templo) a otro templo próximo y necesitaban en cada momento de los espacios adecuados para la realización de los ritos pertinentes. La barca se conservaba, de acuerdo a su estatus, en la parte más sagrada del templo. Entre otros espacios, el camino de la barca sagrada necesitaba de paradas, de templos especiales diseñados para el descanso de la misma. La sofisticación y el grado de virtuosismo alcanzado en algunos de los relieves que decoran estas capillas hacen pensar en la complejidad de los ritos de acompañamiento que se realizaban en estos lugares en ocasión de las procesiones ceremoniales. El número y tamaño de los relieves de los muros de los grandes templos que hacen referencia a estas procesiones es abrumador, lo que da buena cuenta de la importancia capital que tenían para el pueblo egipcio y en su liturgia.

Un magnífico ejemplo de estos caminos sagrados fue la red de vías que unieron el templo de Amón en Karnak con distintos templos y lugares sagrados cercanos tales como el templo de Mut (consorte de Amón), el templo de Jonsu (su hijo) o el lago próximo; parada necesaria para algunos de los ritos relacionados con el agua o el propio Nilo, presencia siempre principal en la cosmogonía y los ritos egipcios. Además el eje del templo de Amón nos conduce directamente y con enorme precisión hasta el templo de Hatsepsut situado en la otra orilla del Nilo. Inscripciones en el pilono de Amenofis III de este templo nos indican que el Magno Festival de Opet se celebraba, en tiempos de la reina, por tierra 

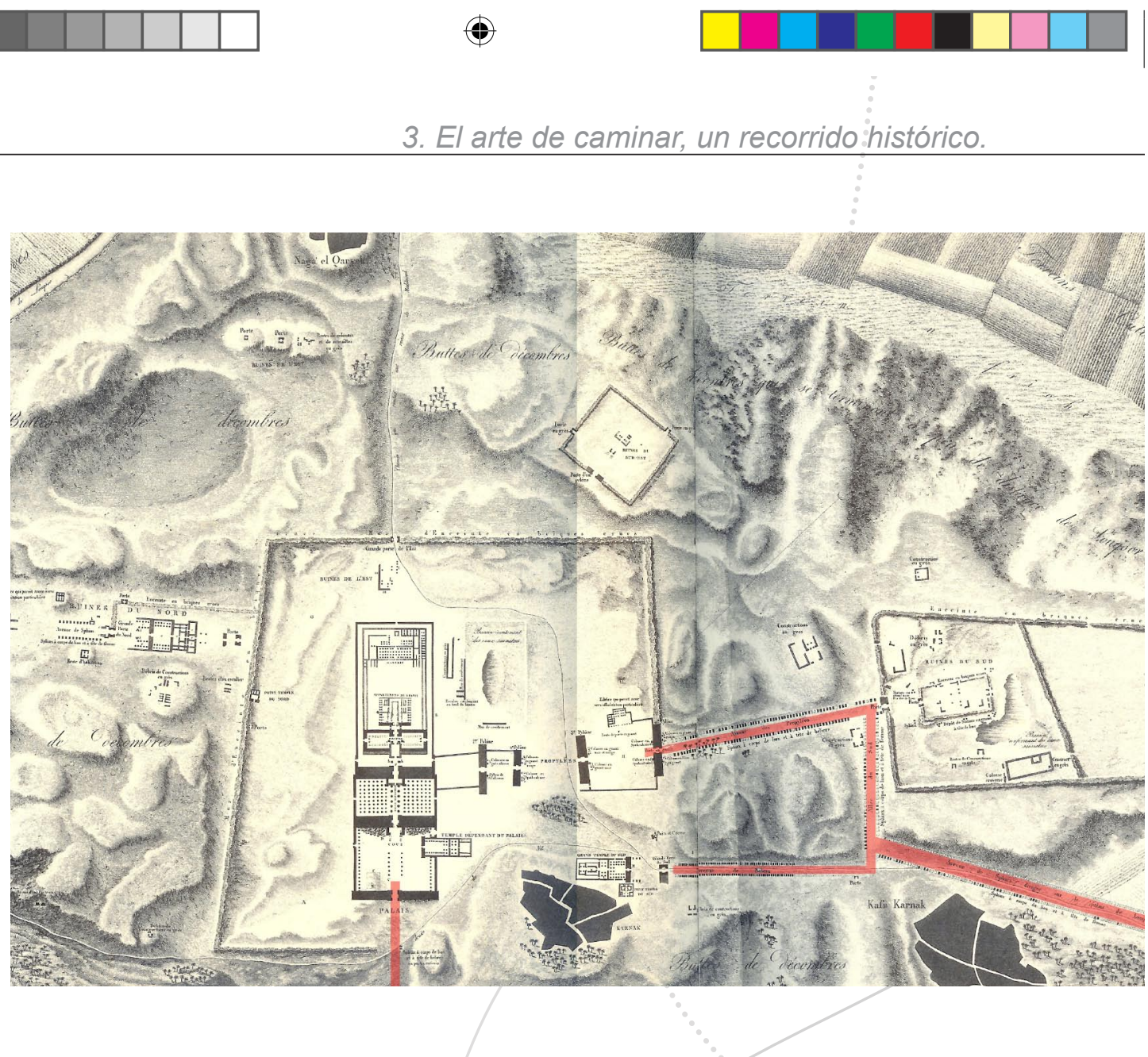

Red de caminos sagrados en torno al templo de Amón. Karnak,Egipto.

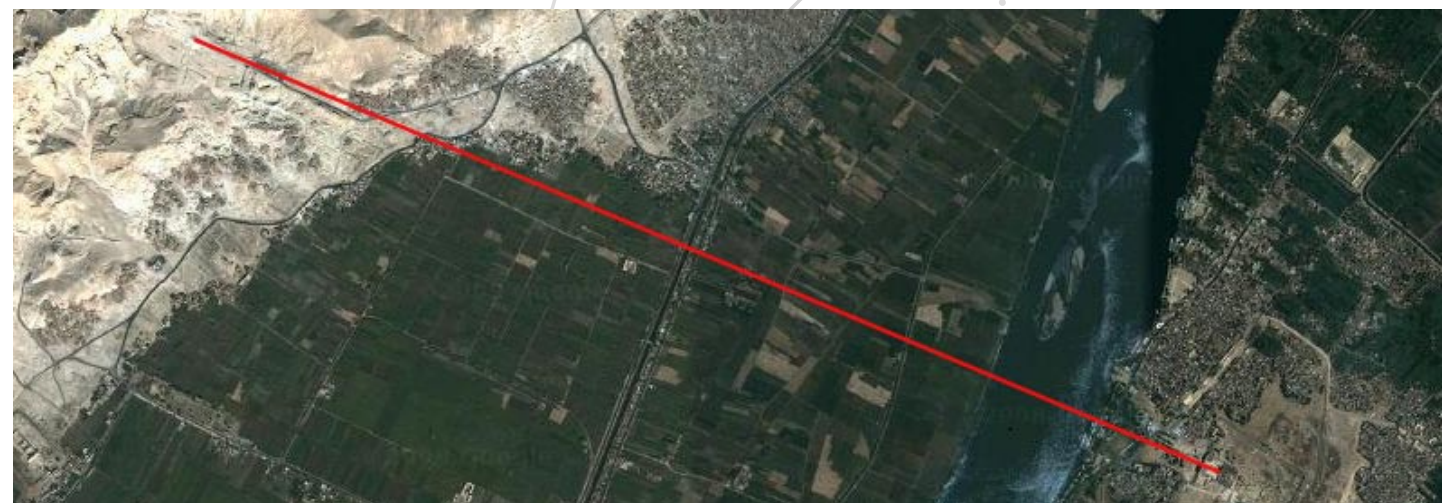

Relación espacial entre el eje del templo de Amón en Karnak y el templo de la reina Hatsepsut, Egipto. 


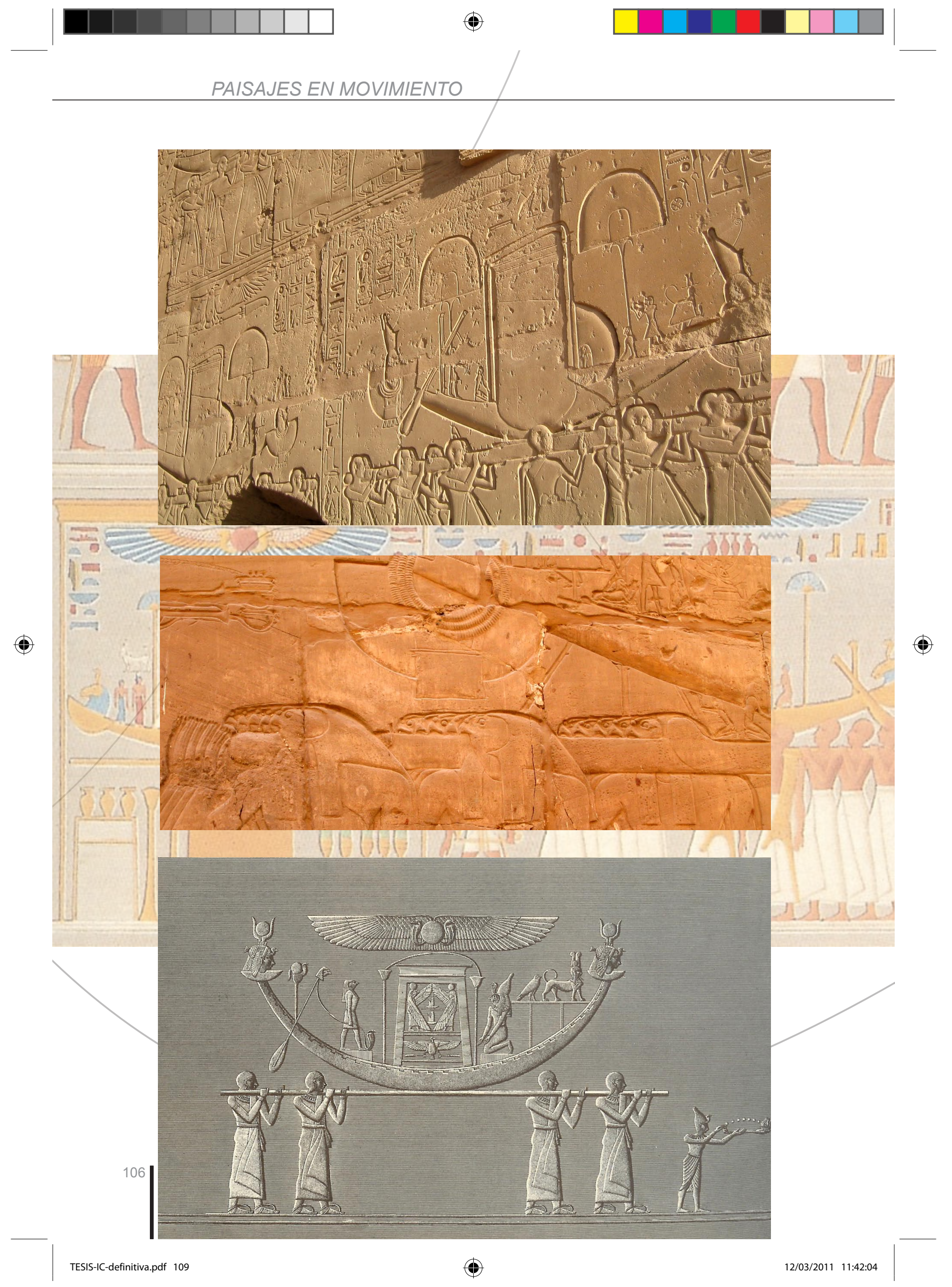



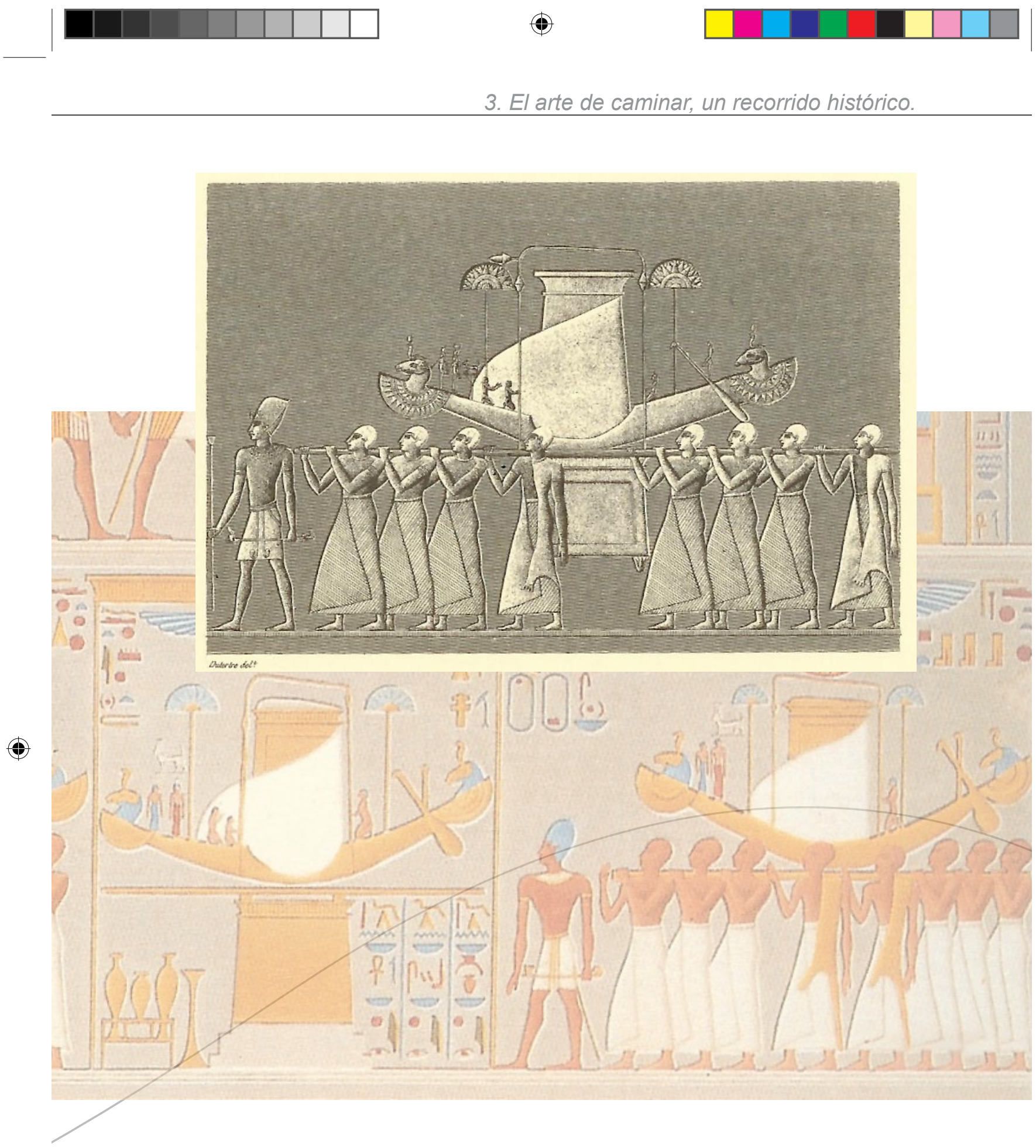

Diversas representaciones de la barca procesional.

Los bajorrelieves en los cuales se muestran las procesiones donde se porta la barca sagrada aparecen en incontables ocasiones en los muros de los templos egipcios.

(Los grabados que aparecen en estas páginas están extraídos del Description de l'Égypte. Publiée sous les ordres de Napoleón Bonaparte. Las fotografías son de I.C). 

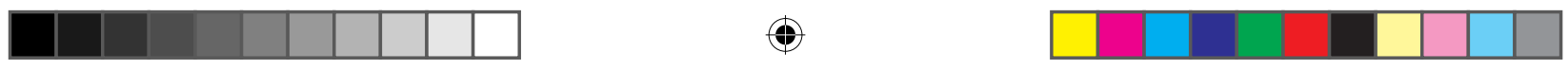

desde Karnak hasta Luxor, descansando para ello en las capillas ya mencionadas anteriormente. Extraordinarios relieves explican todos y cada uno de los aspectos y ceremonias que comprendían estas procesiones, todos y cada uno de los pasos y ritos celebrados por el faraón en el transcurso de los festivales.

En estos relieves, el elevado número de barcas sagradas representadas resulta muy elocuente, lo que hace patente la obsesiva idea de viaje que impregna toda la concepción y realización de estos templos y caminos procesionales. En el templo de Luxor, encontramos un friso a lo largo de la sala hipóstila que comprende a lo largo de 46 metros las diferentes etapas del viaje de Amón desde el recinto sagrado de Karnak hasta la cella del templo de Luxor en un viaje de ida y vuelta. Podemos ver tallados en la piedra: la ofrenda del rey frente a las barcas en el templo de Amón en Karnak, el viaje de las barcas sagradas hasta el Nilo a hombros de los sacerdotes, el viaje de las barcas por el Nilo hasta Luxor, la procesión de las barcas por tierra hastael templo de Amón en Luxor, etc. Como podemos ver, la barca es omnipresente en todo el ritual.

Ahora bien, aunque la concepción de un mundo en constante re-

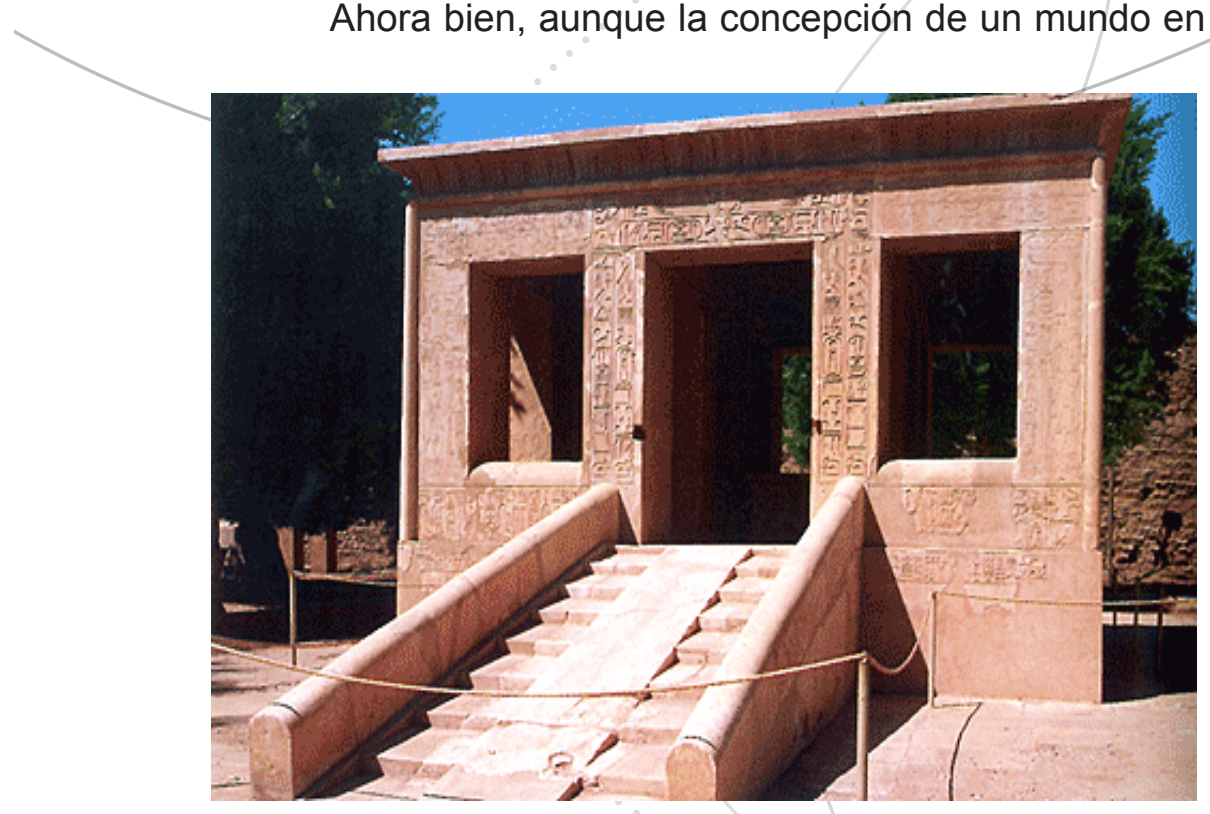

Pabellón de Sesostris I (XII Dinastía) para el descanso de la Barca Sagrada. 

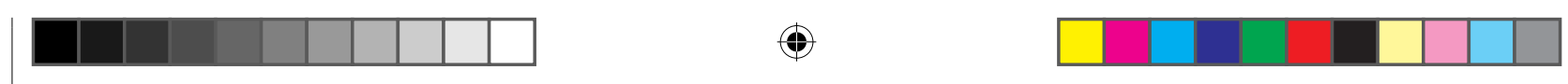

novación y renacimiento y de la vida como un eterno vagar no llegó a grados de similar intensidad en civilizaciones coetáneas, estos rituales y procesiones, que comprometían una visión dinámica del paisaje y la arquitectura no fueron, en la antigüedad, una excepción propia del pueblo egipcio. Ya hemos visto ejemplos muy significativos en Mesopotamia de arquitecturas dinámicas pensadas y experimentadas desde el movimiento pero tampoco la civilización griega más tardía rompió con el antiguo significado ritual del viaje como símbolo de primer orden y con un fuerte carácter sagrado. El cambio fundamental que se produjo en Grecia respecto a Egipto fue el hecho de que ahora ya no es la deidad la que se desplaza de un templo a otro mediante elaborados ritos y pautas sino que en Grecia será el pueblo, serán los fieles, quienes harán el viaje. Paralelamente, la naturaleza, mucho más generosa en esta orilla del Mediterráneo que en el árido desierto egipcio, será incorporada plenamente en los diferentes ritos.

De entre las procesiones que se producían en la ciudad de Atenas ( $y$ en todo el mundo griego), con toda seguridad, la más conocida es la gran procesión de las Panateneas. Este festival, lleno de significado para la ciudad de Atenas, tenía lugar cada cuatro años en agosto y poseía, posiblemente, (como los otros ejemplos que hemos visto) un fuerte carácter agrícola vinculado a ritos de fertilidad de la tierra relacionados con la cosecha. Mediante la procesión, la ciudad rendía homenaje a su propia fundación y a sus dioses, especialmente a Atenea, de quién tomó el topónimo. Cuando la ciudad aún carecía de nombre, la diosa venció a Poseidón en una competición por su protección. Mientras Poseidón golpeó la tierra con el tridente haciendo brotar una fuente de agua salada, Atenea les ofreció un olivo, que proporcionaría a sus habitantes aceite, madera y alimento. ${ }^{12}$ La procesión, que entraba en la ciudad por la puerta de Dipilon, llegaba hasta el templo de Atenea en la Acrópolis, configurando la morfología del ágora de Atenas.

12 Para una mayor información sobre la fundación de la ciudad de Atenas véase: Grimal, Pierre, Diccionario de mitología griega y romana, Paidós, Barcelona,1994. 


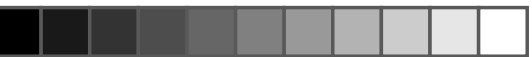

$\oplus$
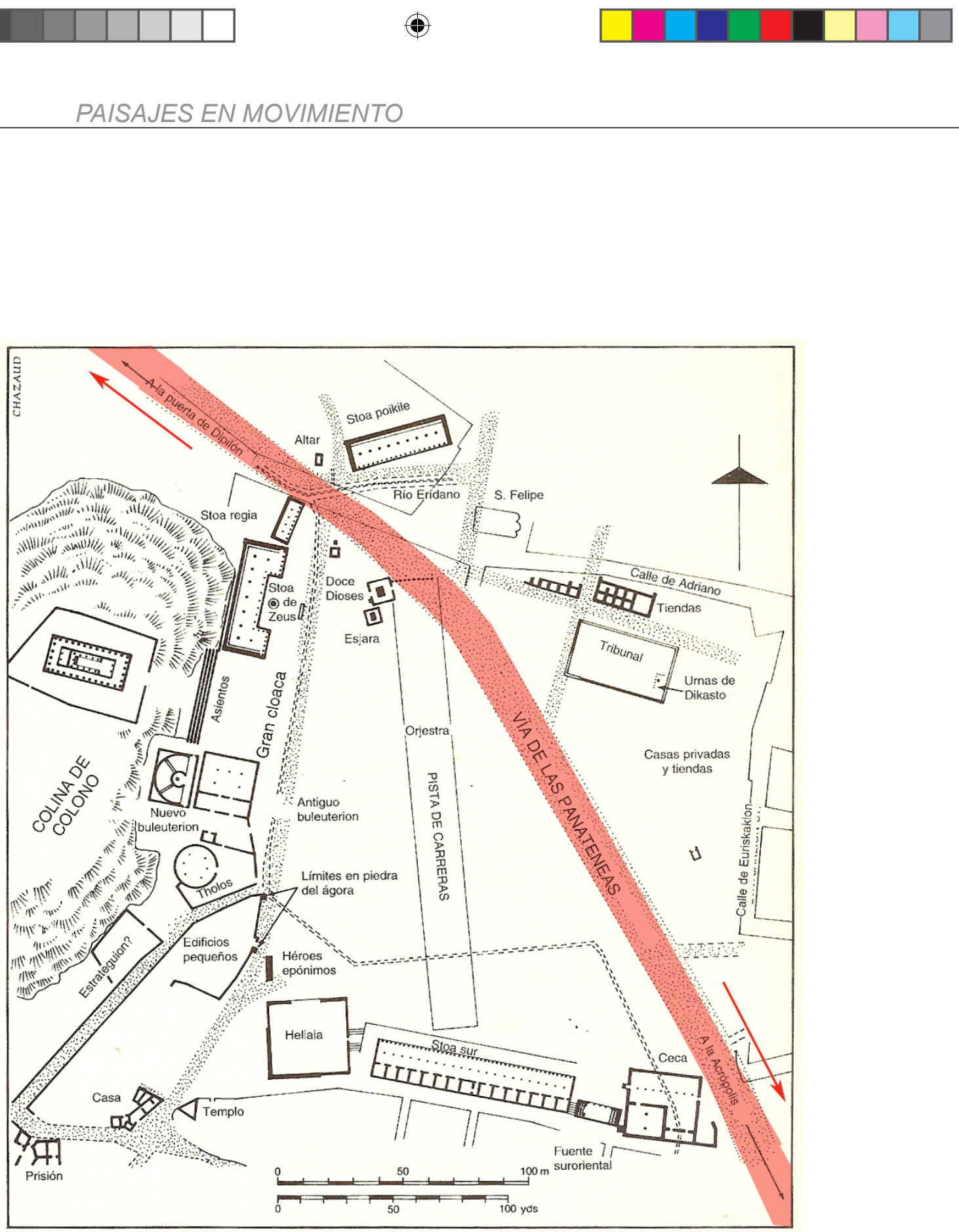

Plano de situación aproximada de la Vía de Las Panateneas, Atenas.

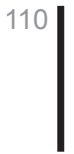



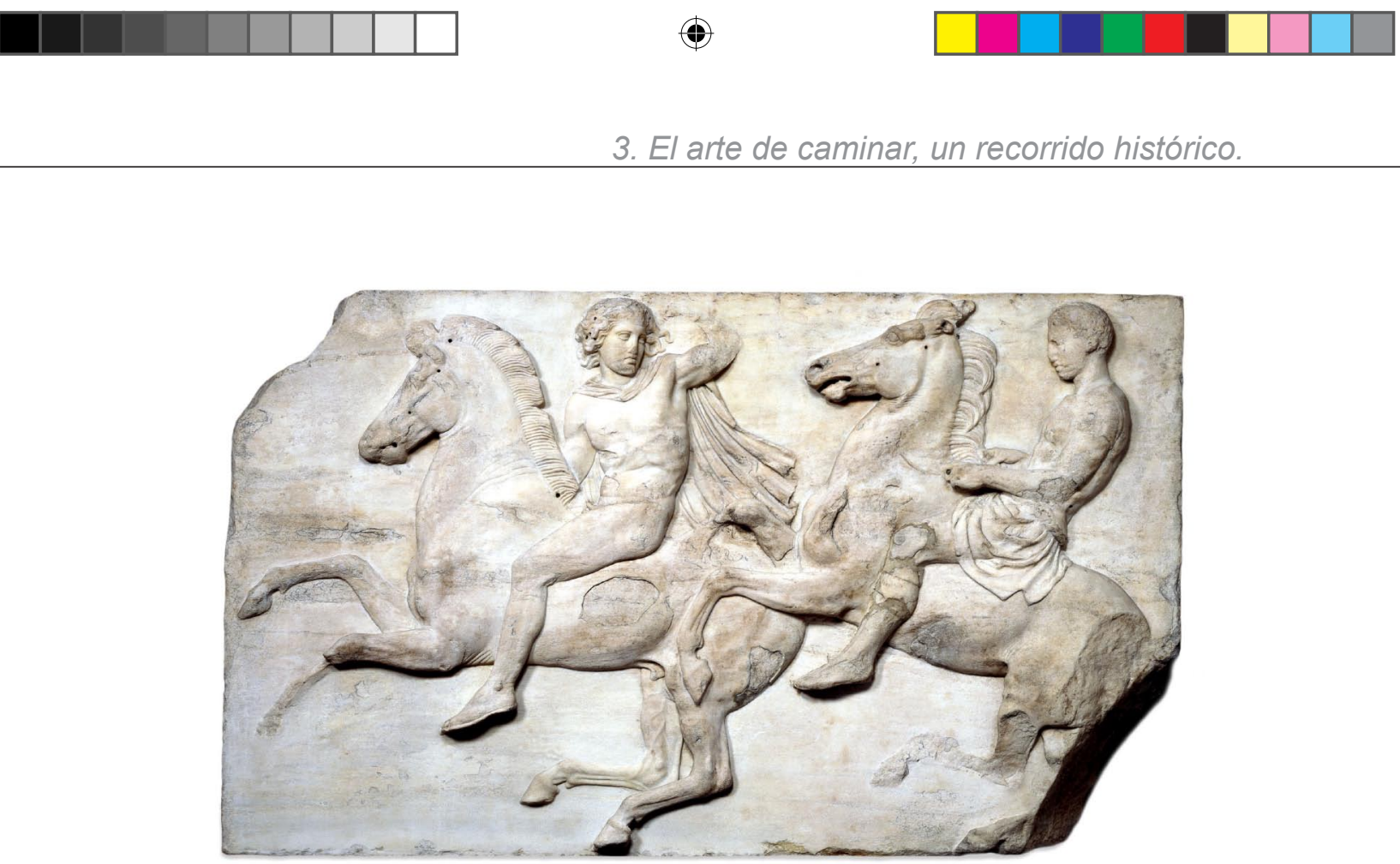

Metopa del friso del Partenón, 443-438 a.C., cuyo conjunto representa el gran desfile de Las Panateneas, British Museum, Londres.

El lugar privilegiado que ocupa la representación de esta procesión en el friso del Partenón y la calidad de los relieves nos demuestran la enorme importancia que estos festivales tuvieron para la ciudad. El vívido movimiento y el brillante ritmo de las figuras en movimiento esculpidas por Fidias en las metopas del Partenón, presentan una multitud en tránsito, entre lo humano y lo divino, donde los seres humanos se encuentran a gusto entre los dioses. Así pues, los cuerpos desnudos, jóvenes e idealizados trasgreden la división entre seres humanos y los dioses, aún a riesgo de terribles consecuencias.

Aunque en este caso el movimiento se relega a la piel exterior del templo, es necesario recordar que esto es inseparable de la interpretación que los griegos hacen de la arquitectura y el espacio y de la escasa importancia que otorgaron a los espacios interiores frente a los dispositivos espaciales exteriores construidos de volúmenes y recorridos. Así, la gran procesión de las Panateneas, no solamente configuró la arquitectura del Partenón y de la Acrópolis sino que fue vehículo transformador del 


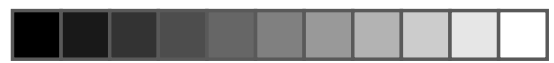

$\oplus$

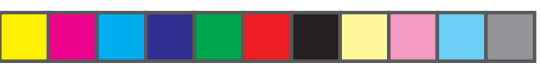

territorio y del tejido urbano. Los Propileos, por citar un ejemplo urbano más concreto, no fueron sino una grandiosa puerta digna de dichas conmemoraciones, un acceso triunfal al recinto sagrado de la Acrópolis.

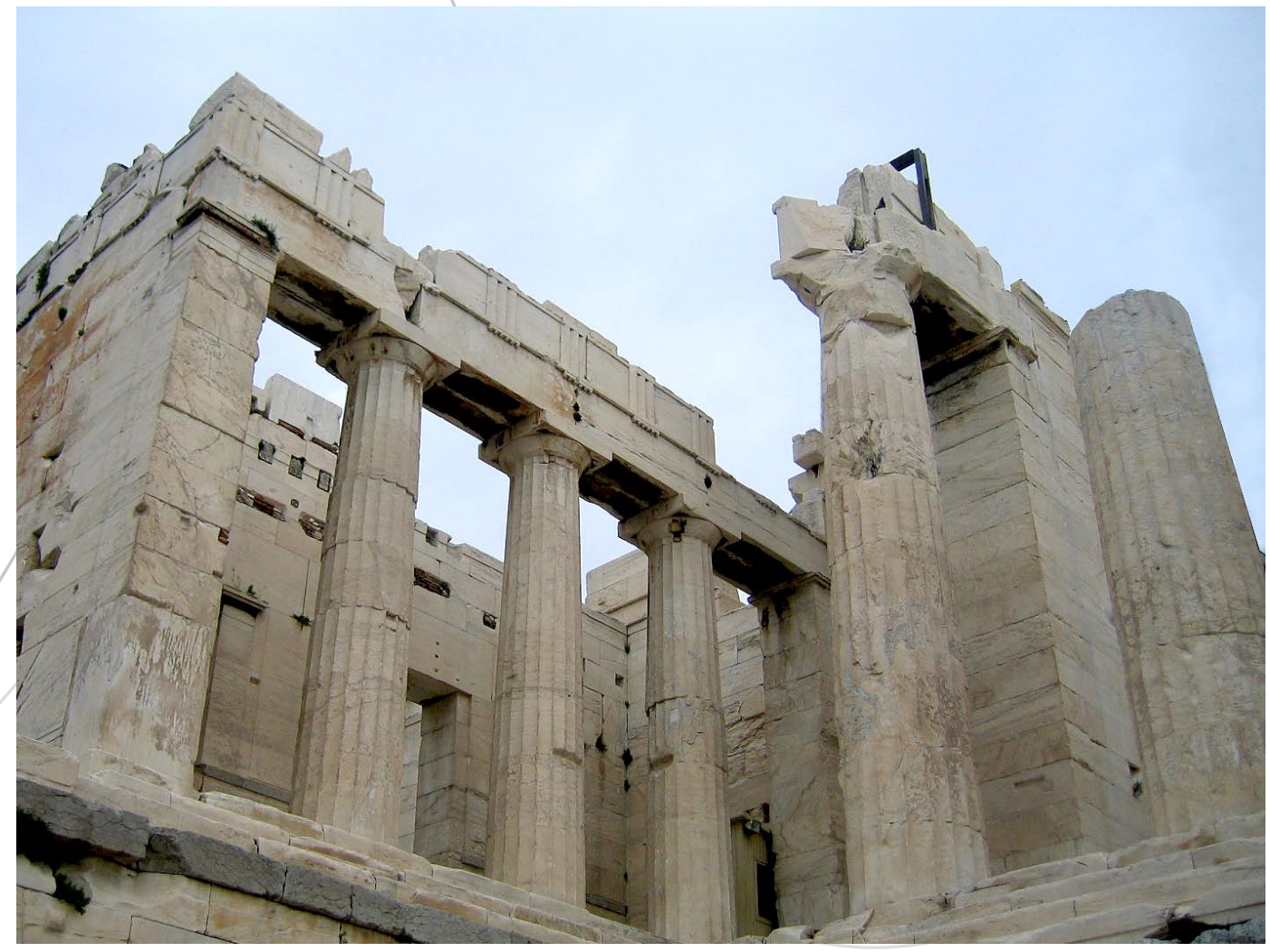

Los Propileos, 437 a.C., Atenas (fotografía I. C.).

Acabamos de realizar un somero recorrido, a través de Mesopotamia, Egipto y Grecia, por momentos clave en dichas civilizaciones y que dieron lugar, además de a transformaciones simbólicas y dinámicas del espacio y el paisaje a importantísimos hitos arquitectónicos en su aspecto más estático y edificado.

Pero conviene en este momento recordar que no se producen únicamente transformaciones del espacio en aquellos casos donde se

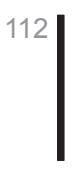



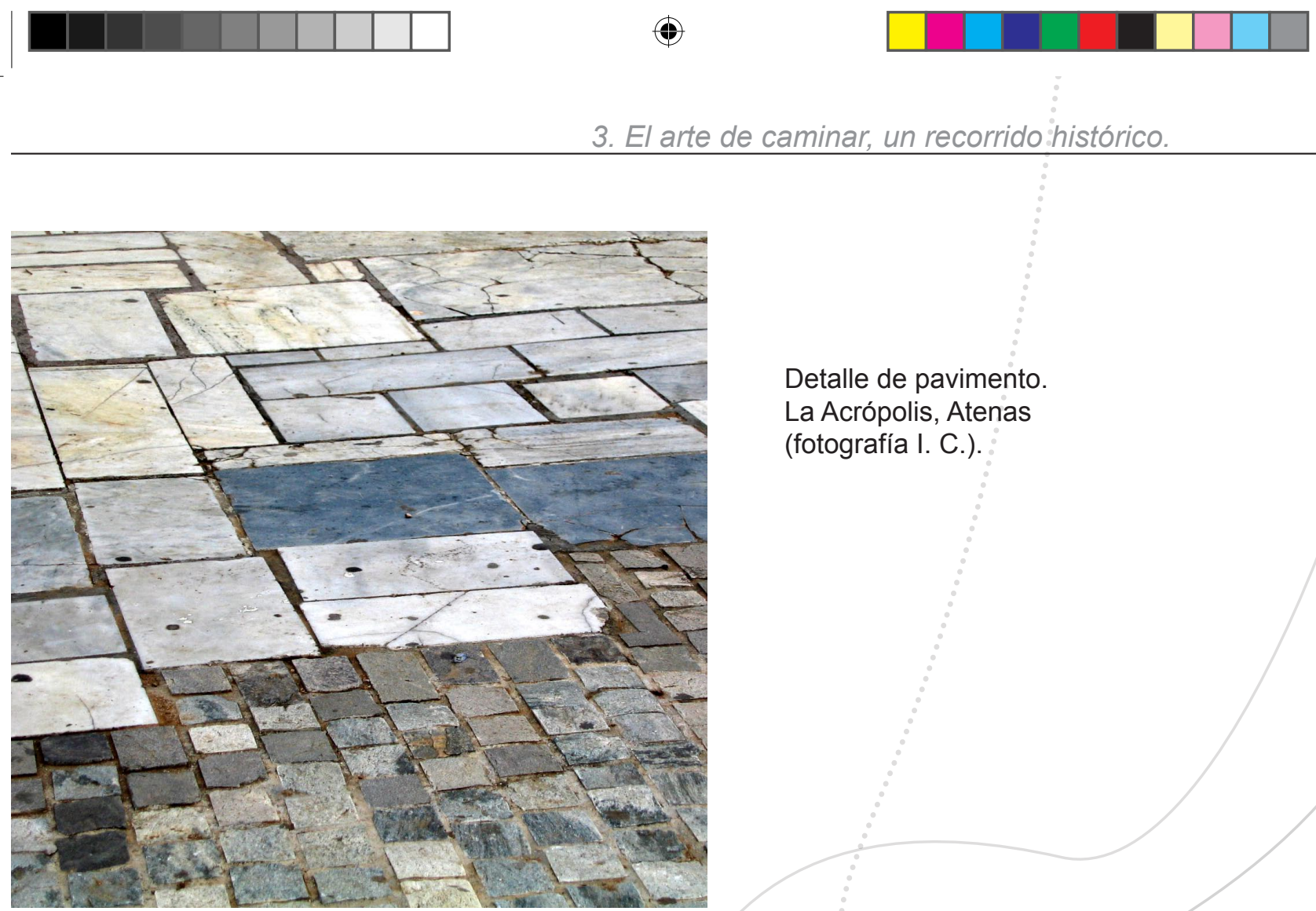

Detalle de pavimento. La Acrópolis, Atenas (fotografía I. C.).

realizan cambios físicos en el mismo sino también en aquellas ocasiones en las que los cambios se plasman a través de alteraciones simbólicas que modifican el espacio transformando su significado y construyendo paisajes nuevos y sugerentes.

Tradicionalmente, en el ámbito religioso han surgido un gran número de estas experiencias en las que se han producido y aún producen, modificaciones del espacio a través de modificaciones de su significado simbólico. Así pues, a lo largo de la historia del ser humano, las peregrinaciones y procesiones han constituido un modo de invención y reinvención del espacio y del paisaje de primer orden. Aunque a menudo estas transformaciones han sido despreciadas cuando no negadas por interpretaciones más materiales de la arquitectura y de lo que se supone constituye una verdadera transformación paisajística vinculada a una intervención directa y construida. Estas peregrinaciones y procesiones (no necesariamente, como veremos, ligadas a la liturgia) han supuesto unos poderosos vehículos de transmisión patrimonial y cultural. 

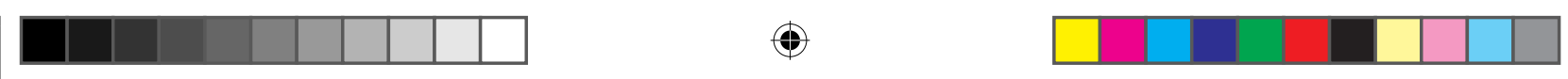

En ocasiones estos recorridos dejarán tras de sí en el territorio unas huellas permanentes, con ansias de eternidad aún en su materialidad efímera. Como maravilloso y paradigmático ejemplo me gustaría citar el Templo de Fushimi Inari en Kyoto (Japón) y sus extraordinarios caminos por las laderas de alrededor del templo. No en vano, la manifestación religiosa por antomonasia en Japón, fuertemente ligada al pensamiento y al carácter japonés es el sintoísmo. Este implica la adoración de los kami, que podemos asociar a espíritus de la naturaleza. Algunos de ellos son locales, (tratándose en este caso de genios del lugar concreto), mientras que otros representan manifestaciones más amplias de la naturaleza. Se trata, en definitiva, de una manifestación religiosa asimilable a una forma sofisticada de animismo naturalista con una importante veneración por los antepasados y la naturaleza.

Es en este contexto donde surgen por todo el territorio japonés las famosas torii, puertas ceremoniales que marcan el paso entre el mundo finito de los mortales y el mundo infinito de los dioses. Estas puertas, formadas tradicionalmente por un pórtico de madera, son donadas por personas que han tenido éxito en sus negocios y asuntos. No es de extrañar que sea precisamente en el templo dedicado al espíritu de Inari (a

Templo de Fushimi Inari, Kyoto, Japón (fotografía I. C.).

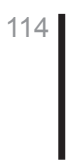

TESIS-IC-definitiva.pdf 117

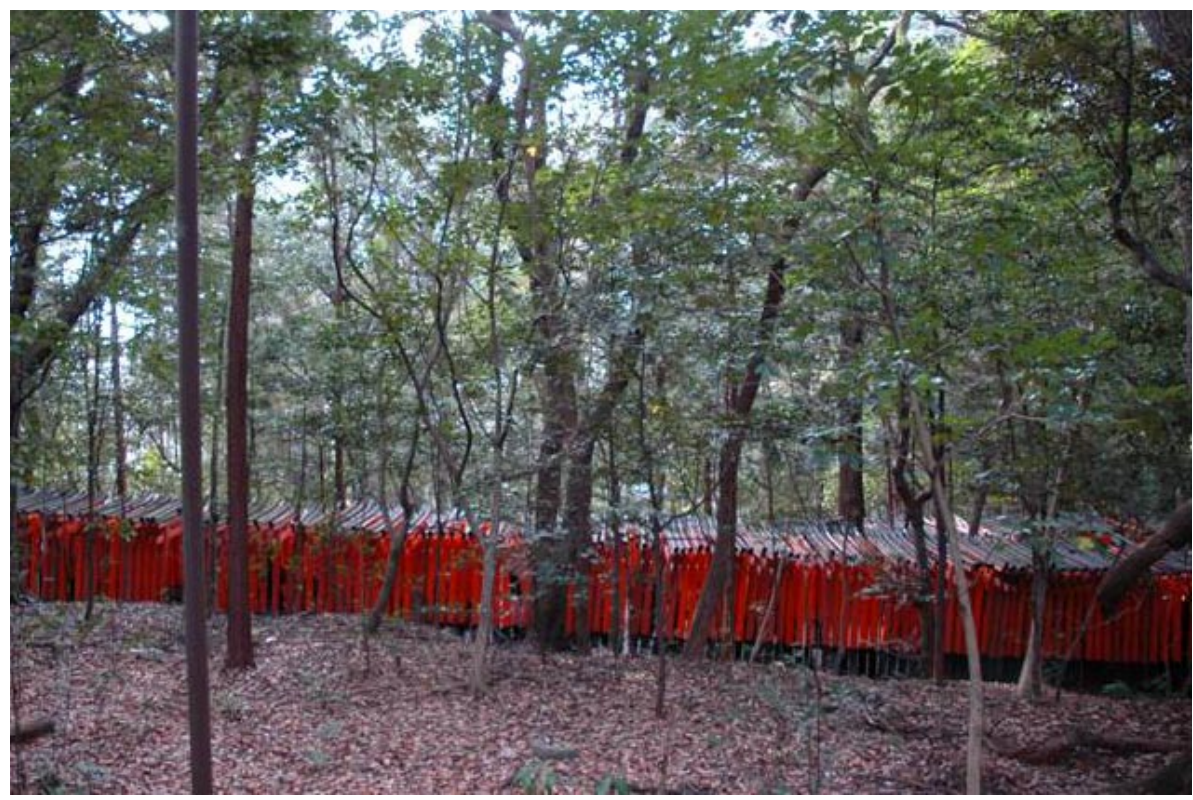

$12 / 03 / 2011 \quad 11: 42: 05$ 

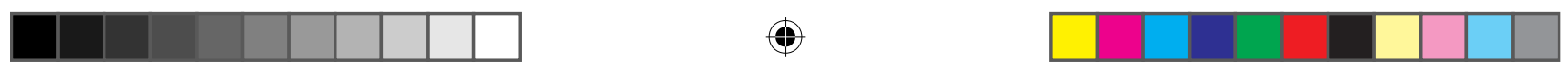

3. El arte de caminar, un recorrido histórico.

quién se considera como protector de las cosechas, especialmente del arroz, y que por lo tanto ha sido asociado históricamente con la riqueza) donde se ha levantado cientos de ellas. Aquí, la sucesión de torii pintadas de negro y naranja y adosadas las unas a las otras, ha creado una red de caminos sagrados entre la vegetación de gran significado simbólico y cuyo recorrido no únicamente supone objeto de gran veneración por los creyentes sintoístas sino una experiencia espacial y estética profundamente atractiva. En ocasiones las torii se aprietan unas contra otras donde apenas si cabe una brizna de aire,

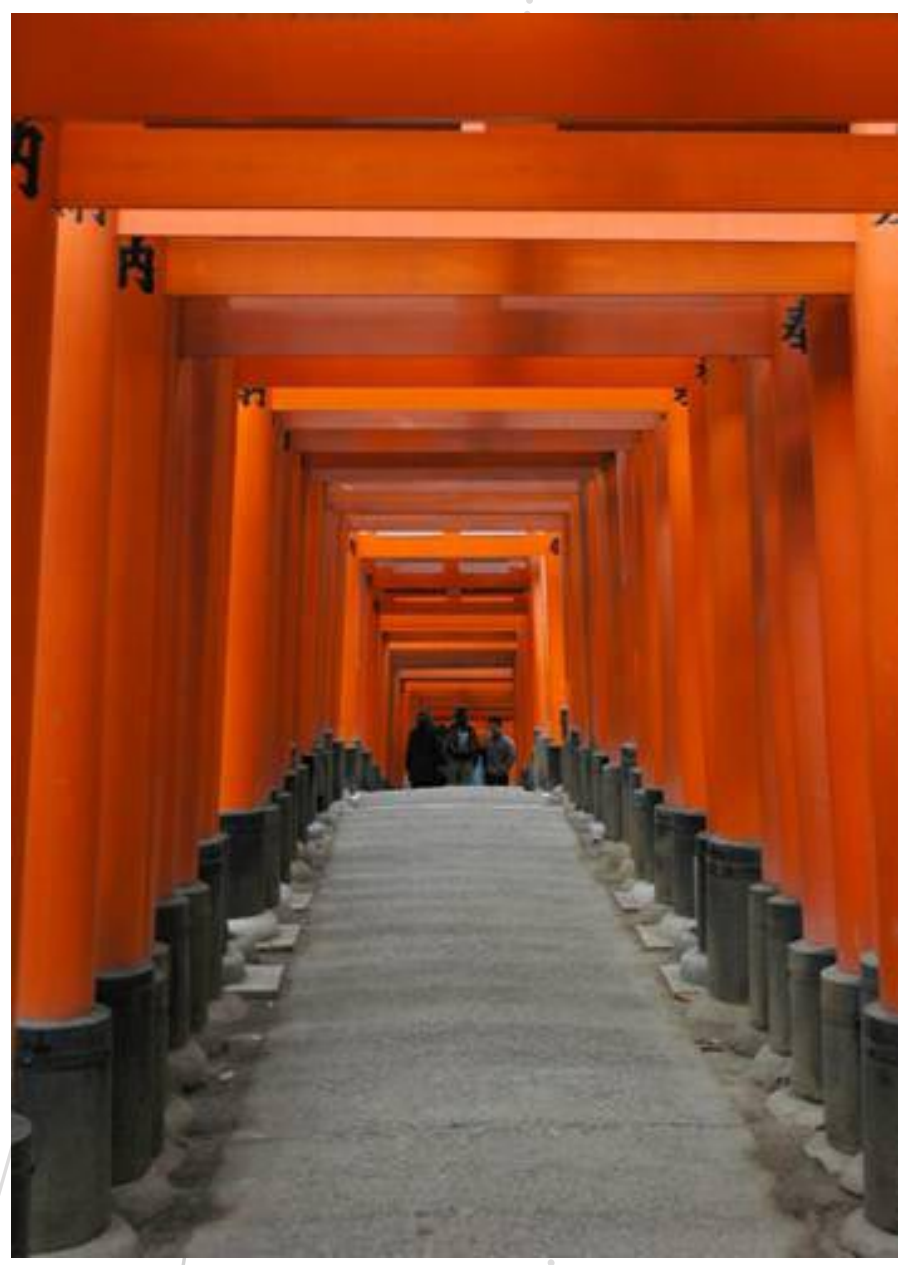
en ocasiones se separan dejando filtrar el verde los árboles cercanos. En algunos tramos han incorporado textos y solicitudes en sus pilares, en otros el naranja brilla con especial intensidad.

En definitiva se trata de caminos porticados pensados para ser recorridos y que alcanzan todo su sentido y su potencial visual, estético y paisajístico en y desde el recorrido de los mismos. Bien bajo sus dinteles, bien al desembarcar en sus "capillas" naturales formadas a través 

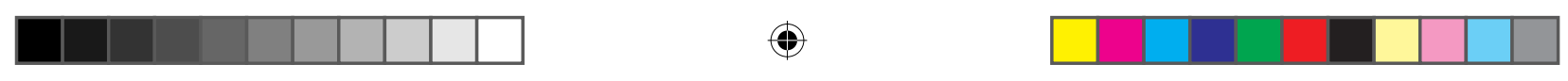

de colocación de ofrendas en elementos naturales, tales como árboles y rocas.

De todos modos, de algún modo seguimos manteniéndonos en cierto ámbito de lo construido, nos queda dar un paso más para llegar a manifestaciones creadoras de paisaje a partir de transformaciones simbólicas de significado que no alteran la realidad física. Actuaciones en el paisaje, si se me permite la expresión, efímeras, tranquilas, sutiles aun-

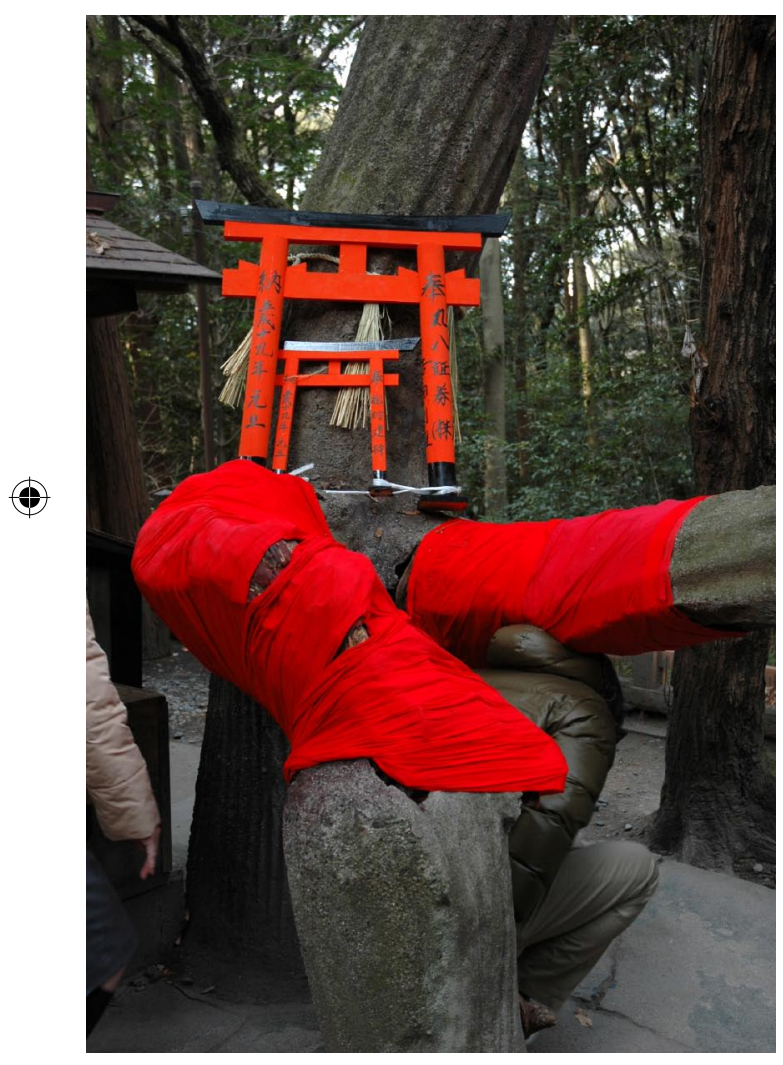

Templo de Fushimi Inari, Kyoto, Japón, 2008 (fotografía I. C.).

que no espontáneas. Tomaré esta vez como ejemplo los recorridos de los monjes budistas de Luang Prabang (Camboya) al romper el alba.

Cada día, al salir el sol, las hermosas y desiertas calles de la antigua capital del Reino de Lan Xang se transforman de un modo verdaderamente asombroso. Poco a poco los habitantes de la ciudad, recién levantados, van saliendo de sus casas en un escrupuloso silencio. Portan tan sólo unos pequeños cuencos con arroz, una humilde estera y algún que otro objeto personal. Pausadamente se van posicionando en las calles, en ciertas calles, aparentemente en puntos sin localización exacta. Se están preparando con gran solemnidad para un momento sin duda muy sagrado e importante para ellos. A medida que la niebla, habitual a esas horas debido a la proximidad del Mekong, se levanta vemos aparecer a lo lejos el motivo de toda la liturgia que acabamos de presenciar. Sin perturbar el silencio, se aproximan, en perfecta formación, cientos y cientos de mon-

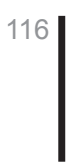



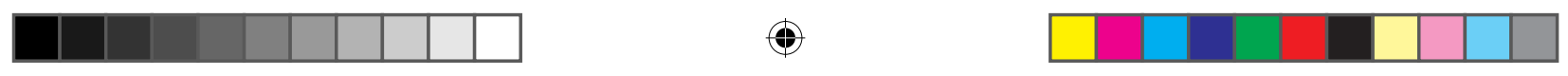

3. El arte de caminar, un recorrido histórico.

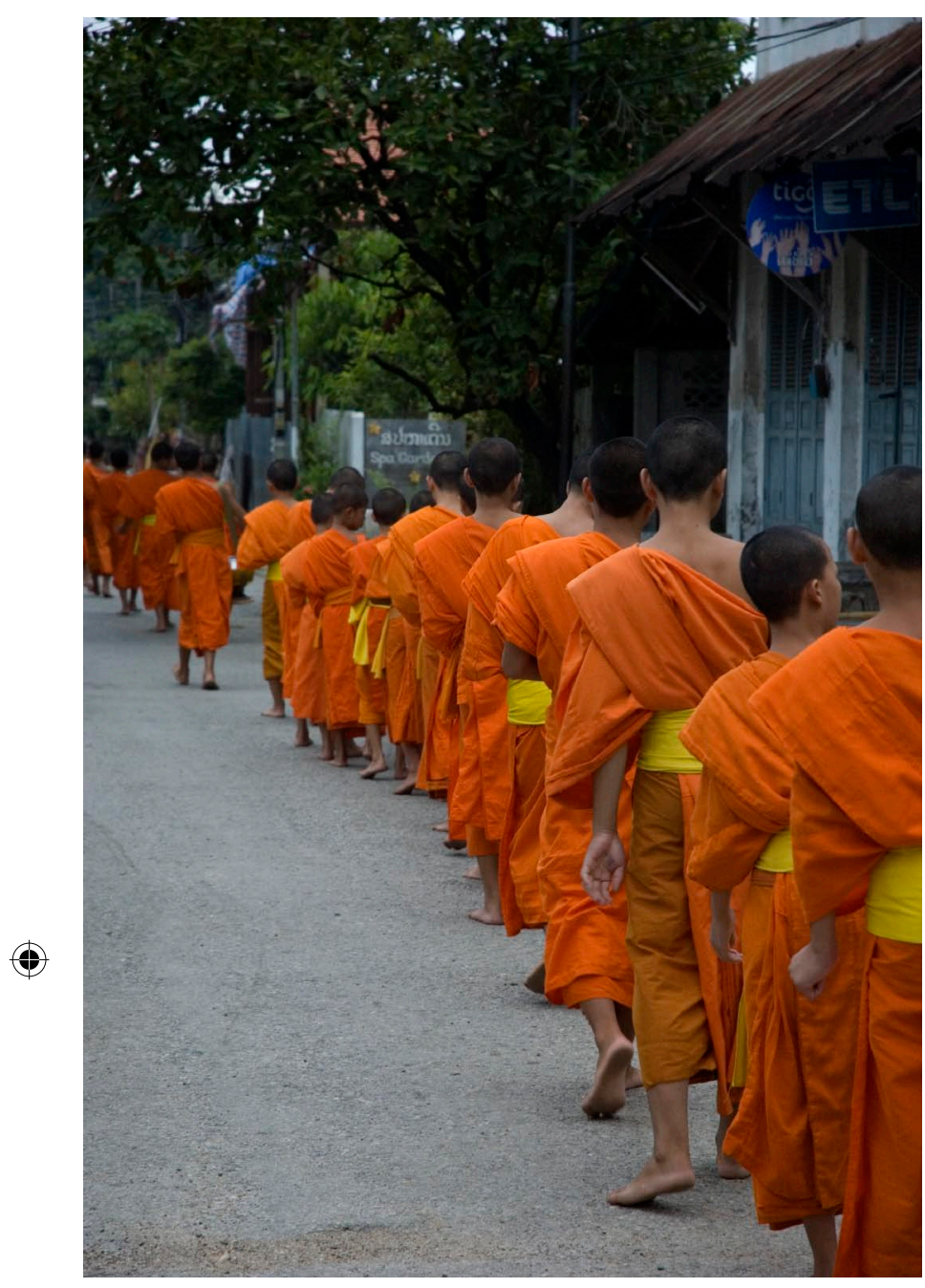

Monjes pidiendo la lismosna al alba. Luang Prabang, Laos, 2009 (fotografía I. C.).

jes budistas con sus túnicas de azafrán y sus cestos de laca sujetos al cinto, dispuestos a recoger las ofrendas de los habitantes de la ciudad. Lo que hace unos minutos eran calles vacías y mudas se transforman en reguero de monjes solícitos y silenciosos venidos de las decenas de templos de la ciudad que recogen la devoción de los habitantes de Luang Prabang en forma de unos puñados de arroz al vapor. La rotundidad del naranja y la hermosura de los gestos y los objetos han transformado radicalmente el espacio de Luang Prabang. Se produce, durante los minutos que dura la ceremonia callejera, una alteración que no necesita de elementos fijos o permanentes. Bien al contrario, el movimiento de los gestos, la cadencia del andar de los monjes y de la recogida de las ofrendas, las relaciones que se producen, hacen surgir un paisaje en movimiento, un escenario urbano dinámico y efímero de una gran intensidad y complejidad. 


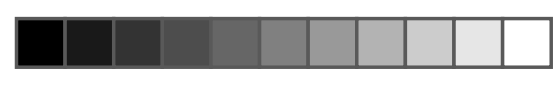

$\oplus$
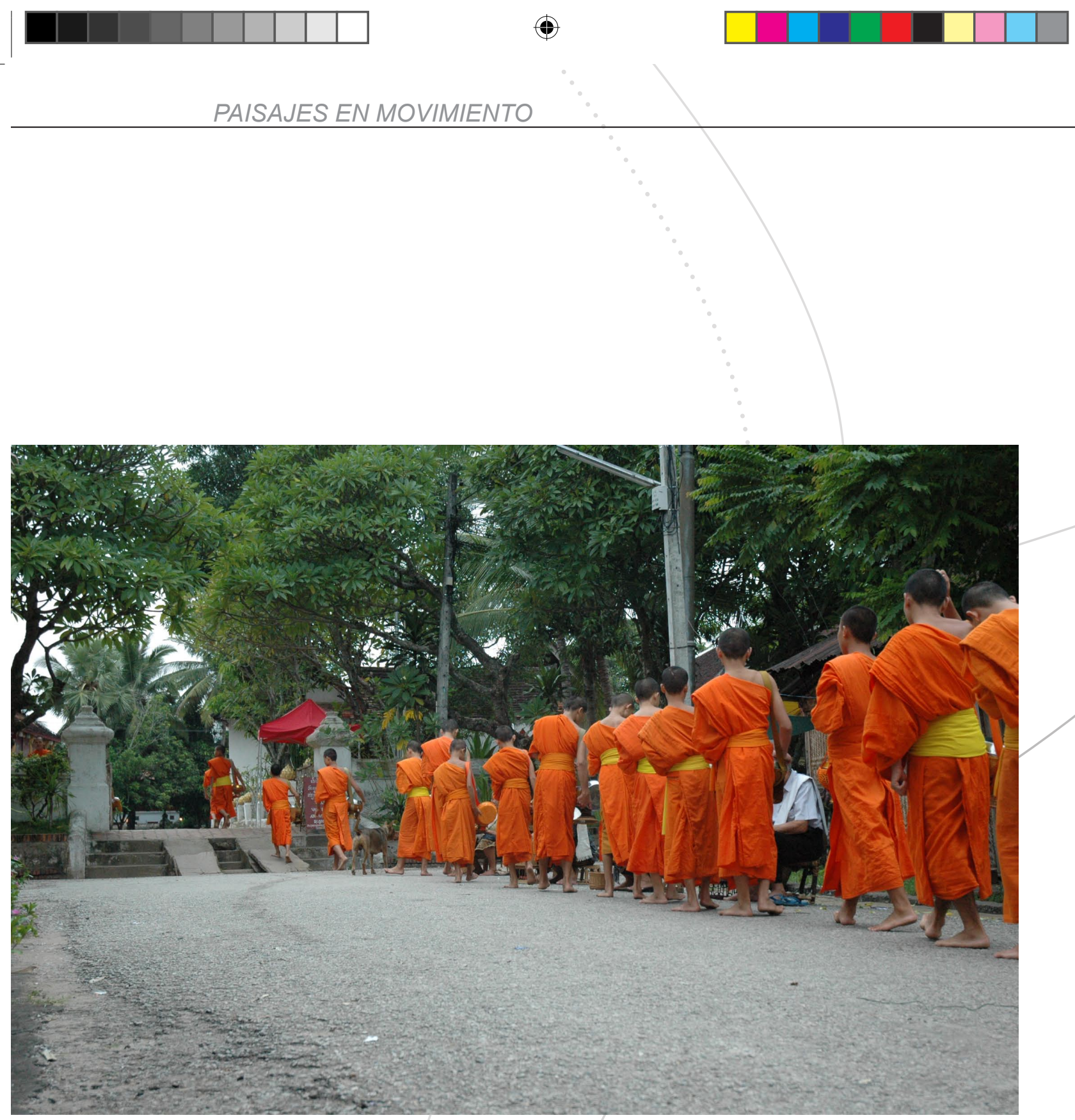

Monjes pidiendo la lismosna al alba, Luang Prabang, Laos. +07:40 horas

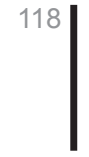

TESIS-IC-definitiva.pdf 121 $\oplus$

$12 / 03 / 2011 \quad 11: 42: 05$ 

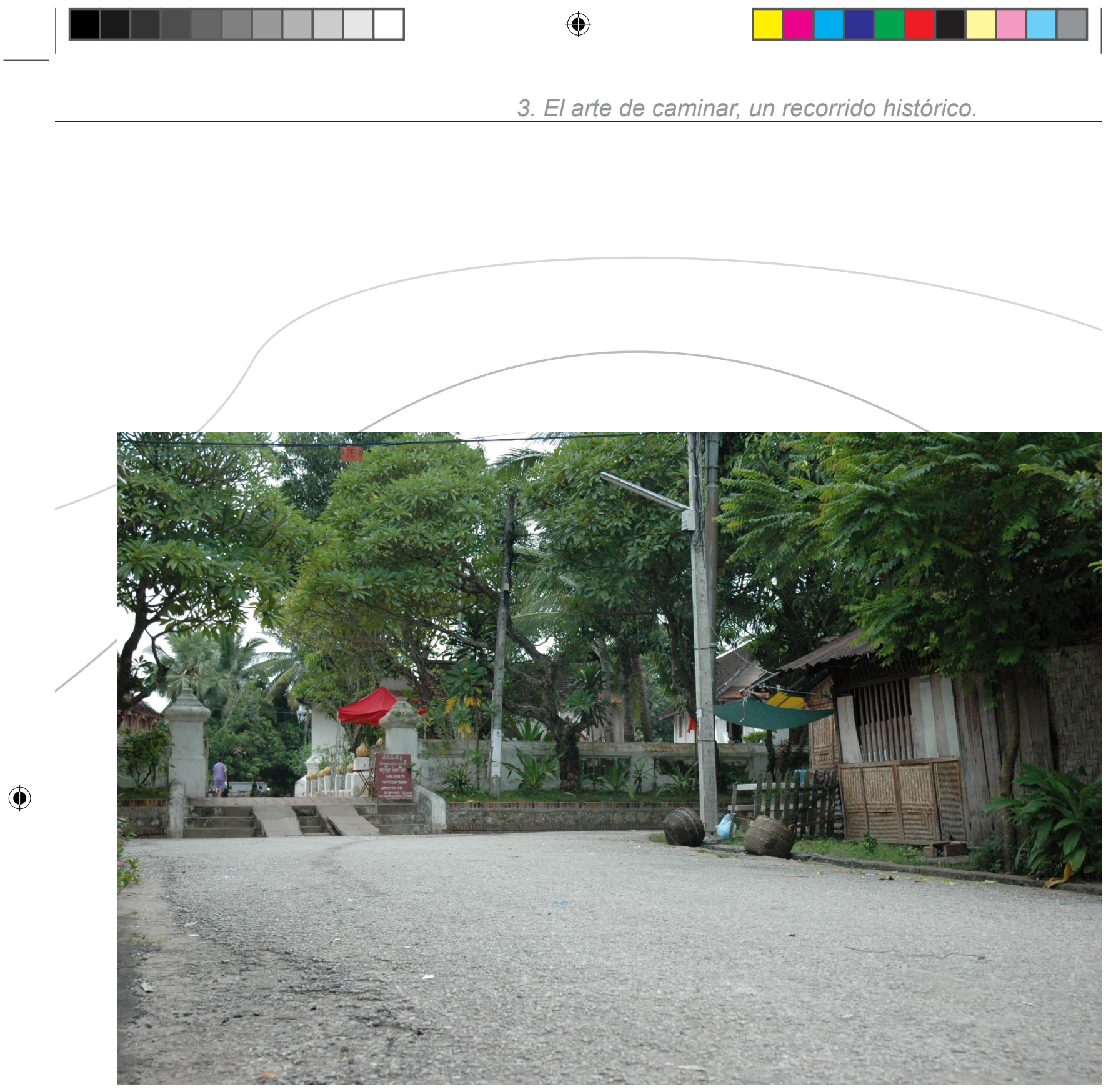

Monjes pidiendo la lismosna al alba, Luang Prabang, Laos. +07:44 horas (fotografías I. C.).

( Como se puede apreciar, las fotografías fueron tomadas desde el mismo punto de vista exactamente, durante y después del paso de los monjes, con el objetivo de captar la transformación espacial efímera producida). 

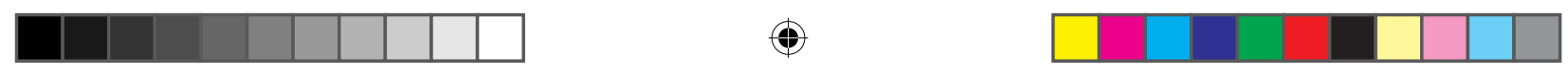

Hemos hecho hasta ahora un recorrido por experiencias lejanas a nosotros en el tiempo o en la distancia pero esas mismas transformaciones del paisaje de las que hablamos a propósito de Kyoto o Lung Prabang las podemos encontrar, ya en nuestro contexto sociocultural, en muchas de nuestras procesiones y peregrinaciones; como la que se lleva a cabo desde Les Useres hasta el santuario de Sant Joan de Penyagolosa en Castellón de la que

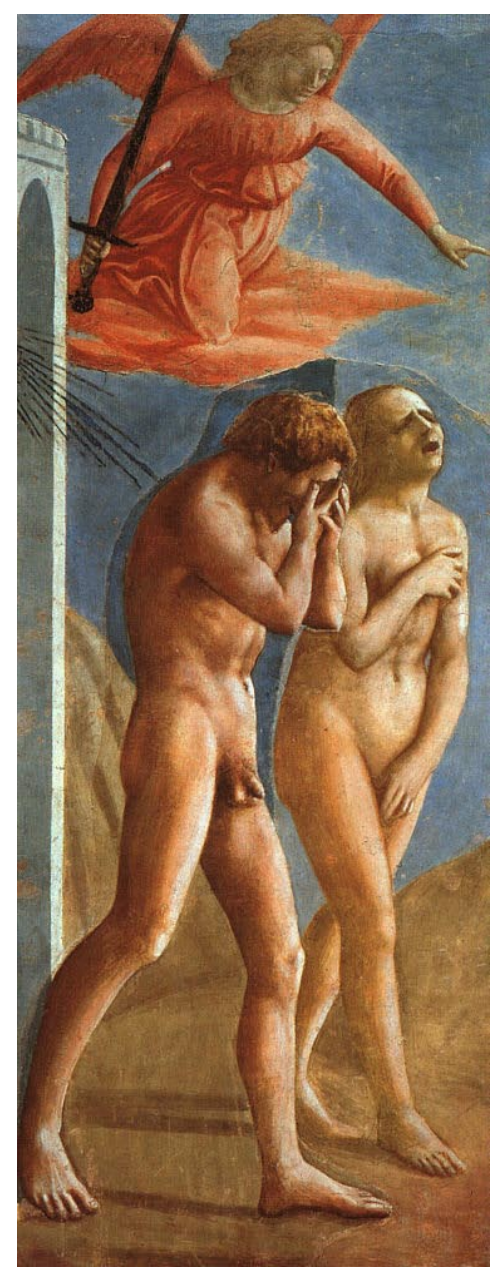

Masaccio, Expulsión del paraíso,1426-27. hablaré más en detalle posteriormente.

Estas manifestaciones que hemos visto, aparentemente lejanas, nos enseñan valiosas lecciones acerca del componente dinámico que siempre ha estado presente en la construcción del paisaje del ser humano, de sus ciudades y de su arquitectura. Sin embargo, la cultura del movimiento en relación al espacio y la arquitectura llegará hasta nosotros a través del tiempo reinterpretada por la cultura judeo-cristiana.

De este modo, en nuestra cultura occidental serán Adan y Eva quienes con su expulsión del paraíso instauraran un caminar de la humanidad que no se ha detenido aún. No ha de extrañarnos pues, el enorme éxito que la representación del momento mismo de la expulsión del Edén ha tenido históricamente en la pintura, sobre todo del Renacimiento italiano, momento de grandes cambios y transformaciones y, por tanto, de gran dinamismo. Los numerosos ejemplos que podemos encontrar de este motivo pictórico nos evidencian la fascinación que produjo, y aún produce, este momento del comienzo del caminar (culturalmente hablando) del ser humano. Massacio, con su maravillosa visión de la expulsión del paraíso, (que 


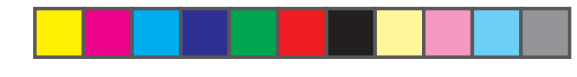

sirvió de modelo a la correspondiente escena pintada por Miguel Angel en la Capilla Sixtina) nos muestra un ser humano en camino, andando; un hombre y una mujer llevando sobre sus espaldas todo el peso de su humanidad recién adquirida, afligidos por su nuevo y terrible desamparo. No hay vuelta atrás ni final posible a ese camino iniciado, lo que queda por delante es un "eterno vagar".

Se inaugura con este gesto una extensa peregrinación del ser humano por la vida hasta el momento final, donde se producirá el reencuentro con el creador. Cuando, y según los términos medievales, abandonará la "ciudad terrestre" para alcanzar, al final de camino, la "Jerusalén celestial", modelo de ciudad ideal. Este tema, abordado en particular por San Agustín en "La ciudad de Dios" está en el corazón de la espiritualidad cristiana. Se trata de la concepción de una humanidad en exilio en la Tierra, donde hombres y mujeres son extranjeros viajando en el tiempo de la Historia hasta el día del Juicio Final que, como su propio nombre indica, supone el fin, el momento de conclusión de la Historia, donde el ser humano se presentará ante Dios para rendir cuentas por sus acciones. Se concibe un ser humano cual peregrino afligido y vencido por el peso de la vida, como el personaje pintado por El Bosco en la guarda izquierda de, precisamente, su Tríptico del Juicio Final. Tal y como escribió el monje dominico Jacques de Voragine en torno a 1250 en su obra La leyenda dorada: "el tiempo de la peregrinación es aquel de la vida presente, en la cual nosotros estamos siempre combatiendo y viajando."13

Estamos tratando, nada más y nada menos, que de la entrada del ser humano en la Historia, en una Historia que ya la tradición judía planteó en desarrollo inacabado pero progresivo: "En un principio...." ${ }^{14}$ Estamos, por lo tanto, en un momento nuevo de revolución en las artes y donde la pintura y la arquitectura comenzarán a dar carta de naturaleza al mundo que rodea a la figura humana. Un mundo abierto a la acción del ser humano y que se transformará paulatinamente de país en paisaje

13 Citado por Daniel Arasse en VV. AA., Les figures de la marche, Réunion des musées nationaux, Paris, 2000, p. 40.

14 Génesis, I,1 


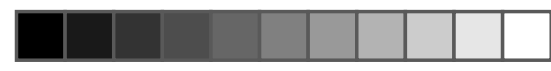

$\oplus$
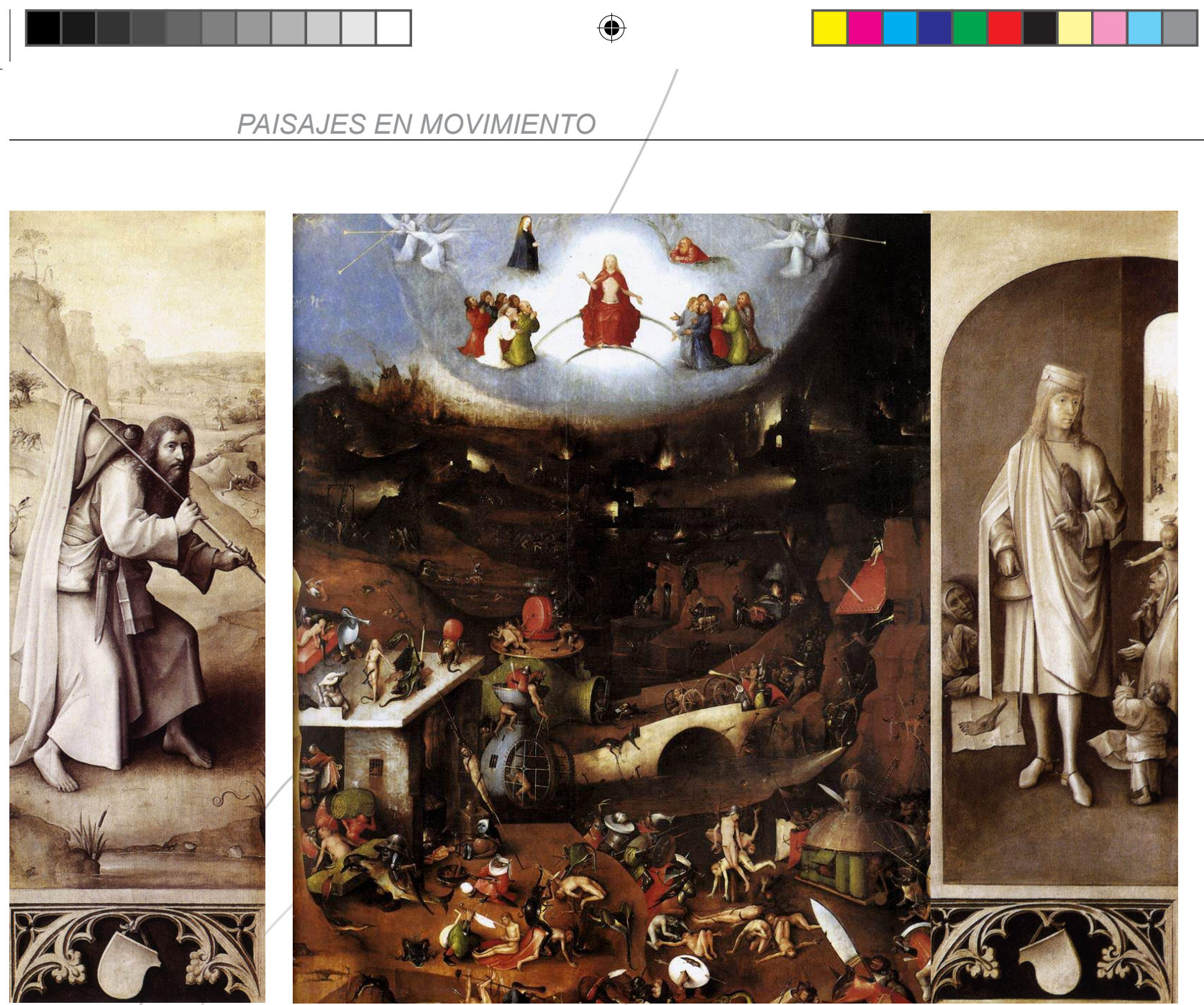

El Bosco, Tríptico del Juicio Final, circa 1482.

por la propia interacción física y simbólica de éste. Además y de un modo significativo, no solamente el paisaje tuvo su momento inaugural en el Renacimiento sino que el movimiento propiamente dicho será uno de los grandes temas de investigación de la pintura renacentista.

Paralelamente, la idea del "camino de la vida", del camino a recorrer que representa la vida humana, se irá consolidando progresivamente en la cultura cristiana occidental. Un buen ejemplo nos lo brinda de nuevo El Bosco, quién trató el tema de la vida como viaje y combate en el magnífico tríptico El carro del Heno, conservado en el Museo del Prado. En esta obra encontramos representado, en la tabla lateral izquierda, el momento inaugural del acceso del ser humano a la Historia, del comienzo

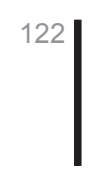



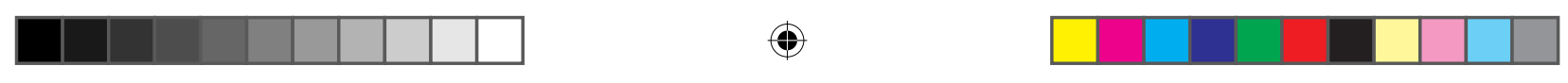

del camino mediante la expulsión del paraíso. En la tabla central El Bosco situó el carro de heno, símbolo de los vicios y bienes terrestres que nos dirigirán directamente a un infierno poblado de tormentos y monstruos, representado en la tabla de la derecha. Elocuentemente, cuando el tríptico se cierra, las puertas configuran El camino de la vida. Esta escena, cuyo título no deja lugar a dudas, nos presenta a un peregrino con la espalda doblada por el arduo trabajo de cargar con el heno, un personaje que avanza con dificultad, temeroso ante las pruebas y engaños a los que la vida le somete. Mientras avanza por el camino se debe enfrentar apenas sin fuerza a un perro rabioso y amenazador, en el momento que debe cruzar un frágil puente, significativamente colocado justo antes del próximo paso del viajero, mientras que la muerte permanece como una presencia insoslayable, amenazadora, en el fondo de la escena. Será gracias a esta figura del peregrino que el caminar se convertirá en motivo pictórico autónomo merecedor de atención particular. Se trata de la representación, mediante esta fascinante figura, de la peregrinación colectiva de la humanidad, producto del castigo divino y representación y símbolo, al fin y al cabo, de un proceso de búsqueda personal.

El Bosco, Tríptico del Juicio Final, circa 1482. (abierto)

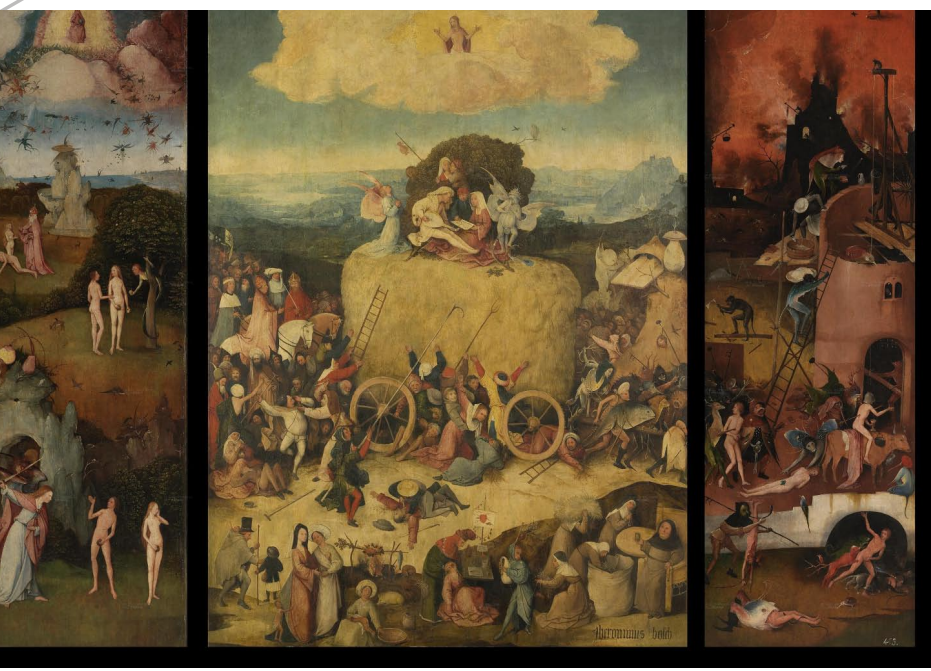



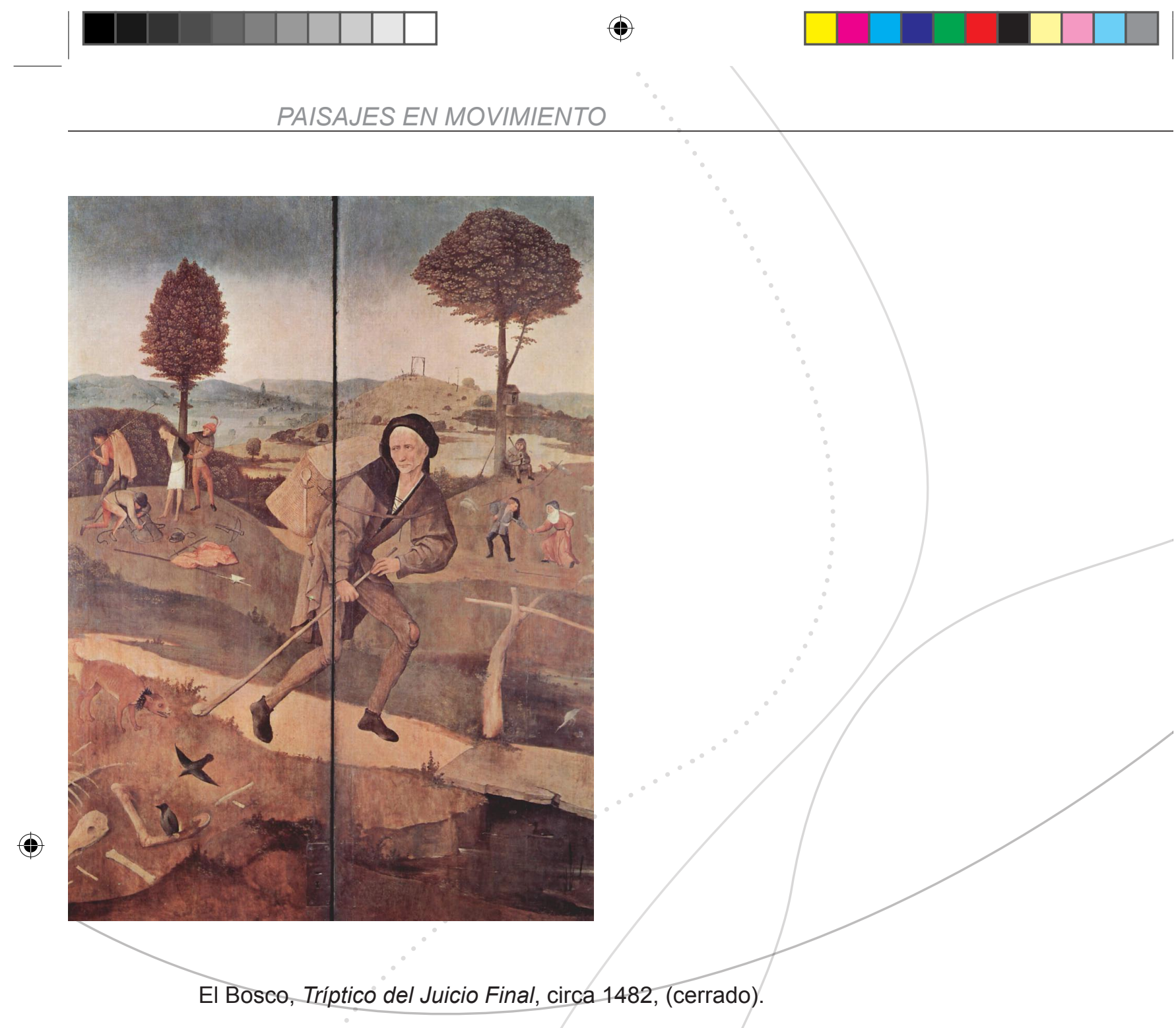

Otro ejemplo especialmente interesante de representación del camino a transitar por el "homo viator", esta vez tratado formalmente de un modo cómico es La parábola de los ciegos de Pieter Brueghel el viejo. Como sucede a menudo con la comedia, se trata aquí de una doliente y profunda reflexión sobre la condición humana y su destino. Guiado por ciegos, el ser humano se enfrenta a un destino fatal en su discurrir por la vida. Una vida que se presenta llena de obstáculos y amenazas antes las cuales el destino del hombre en marcha es sucumbir más temprano que tarde. Esta célebre e interesante representación del ser humano en movimiento nos muestra a un ciego ya caído, mientras cae ya el siguiente sobre él. Ya vemos, ya sabemos, cual es el destino de aquellos que vie-

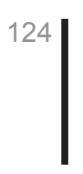




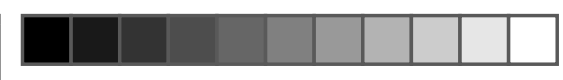

$\oplus$

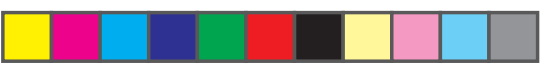

3. El arte de caminar, un recorrido histórico.

nen detrás caminando, confiando su suerte a un ciego como guía. Poco importa si la intención del pintor fue tan solo la de divertir, como sugieren algunos autores. El propio título, referente a la parábola de Jesucristo, nos invita a interrogarnos sobre las verdaderas intenciones del pintor y nos invita a bucear en el verdadero contenido de la obra.

El recuento de iconografía sobre el caminar individual o colectivo sería inabarcable y excede el interés de este trabajo pero su estudio profundizaría en los valores y enseñanzas que traen consigo dichas representaciones y que tienen el viaje y la marcha como vehículo y símbolo. Por citar solamente algunos de los más célebres ejemplos del Antiguo Testamento, recordemos cómo tras la expulsión de Adán y Eva, también Caín será condenado a vagar eternamente tras su crimen fraticida ${ }^{15} \mathrm{o}$

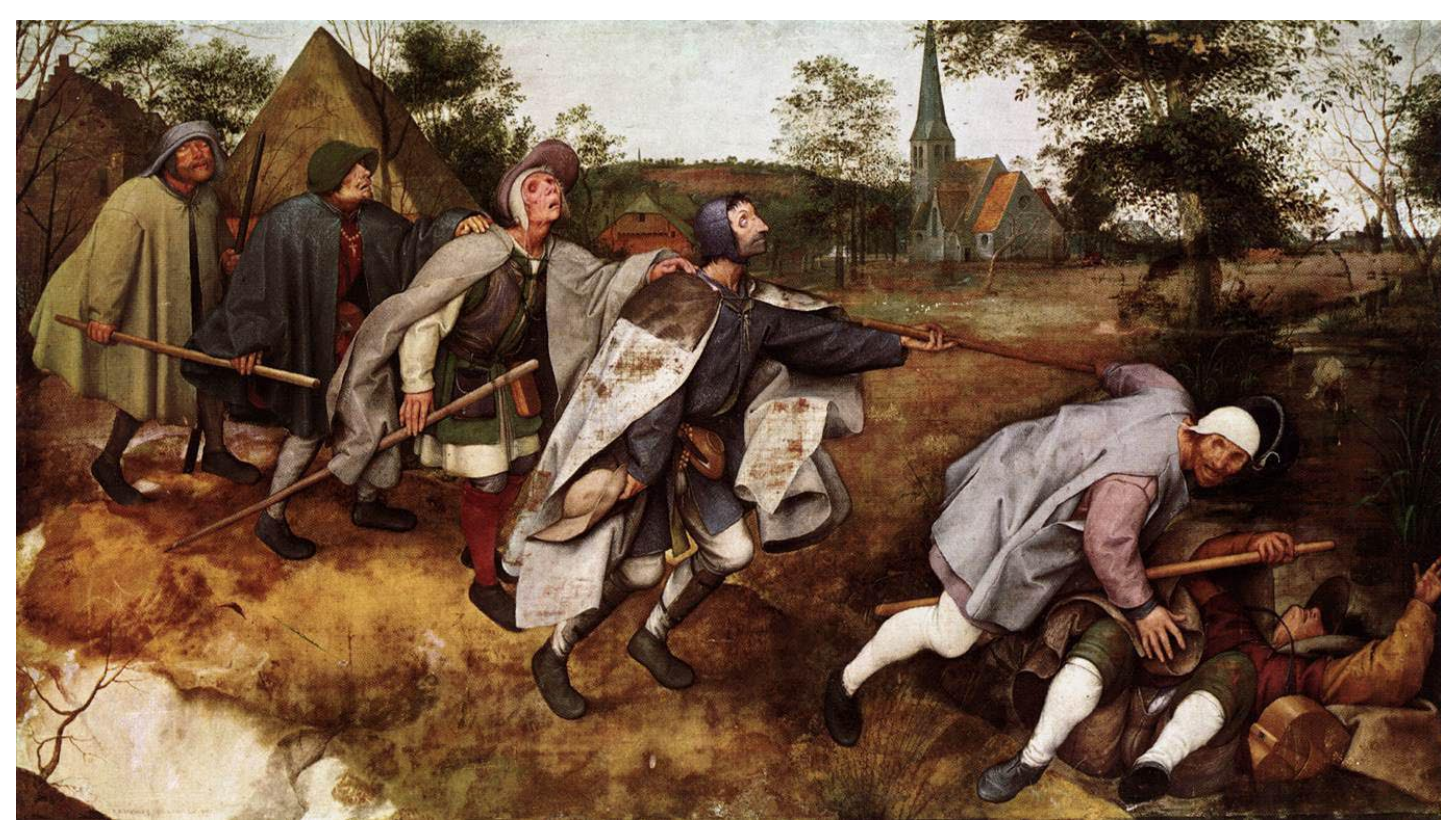

Pieter Brueghel el viejo, Parábola de los ciegos, circa 1568.

15 En referencia a Caín y la muerte de Abel, es muy interesante la reflexión llevada a cabo por Careri, Francesco, Walkscapes. El andar como práctica estética, Gustavo Gili, Barcelona, 2003. p.29 y siguientes. 

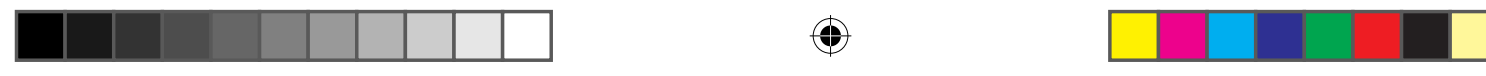

el relato del éxodo del pueblo judío, guiado por Moisés, que podemos interpretar como una clara alusión al mito del eterno vagar al que está condenada la humanidad. En la antigüedad clásica, Orión, Sísifo, Diógenes o Ulises son personajes que también nos transmiten sus enseñanzas gracias al viaje.

Será Jesucristo, sin embargo, el modelo a imitar en el mundo occidental posterior. De este modo, recorrer el camino de la vida se asimila a seguir los pasos de Cristo ("Yo soy el camino, la verdad y la vida.") ${ }^{16}$ La presencia de los pies desnudos en la iconografía cristiana revela la importancia otorgada por ésta al caminar y por extensión al movimiento humano y el papel de éste en la propia configuración del espacio urbano, arquitectónico y paisajístico del ser humano. Si los pies desnudos de Cristo son utilizados como símbolo revelador de su naturaleza humana, podemos entender rápidamente la importancia del caminar en la propia configuración cultural del ser humano. En la representación de los apóstoles, por ejemplo, la puesta en valor de los pies desnudos atestigua la sinceridad y la fortaleza de su compromiso en seguir el camino representado por Jesucristo. Es el mismo motivo que lleva, por citar solamente un hermoso ejemplo, a Caravaggio a colocar en primer plano de su Madona di Loreto (también conocida como Madona de los peregrinos) los pies estropeados y sucios del personaje arrodillado, que de este modo se identifica con la figura de un peregrino. De este modo, esos pies, en un sentido más amplio remiten a su condición humana. A su condición de ser humano que camina por la vida en búsqueda de esperanza y sentido. Esperanza que encontrará en esta obra de Caravaggio en su acceso y conocimiento de la Virgen María. El realismo del motivo no hará sino reforzar una idea espiritual y conceptual bien establecida: encontrar el sentido de la vida se identifica con seguir el camino de Cristo.

Resulta muy interesante que Jesucristo, precisamente, termine sus días en un camino que le llevará hasta la muerte en el Monte Calvario. Aunque diferentes recorridos y viajes salpican su ministerio e inundan

16 Juan $14: 6$.

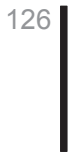



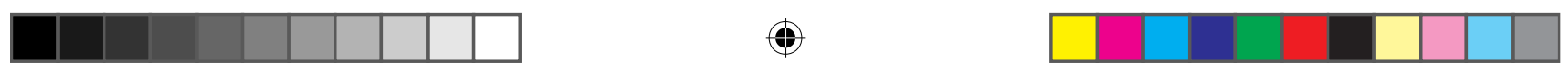

Caravaggio, Madona di Loreto, 1603-05. Detalle de los pies sucios y fatigados del peregrino debido al polvo del camino recorrido.

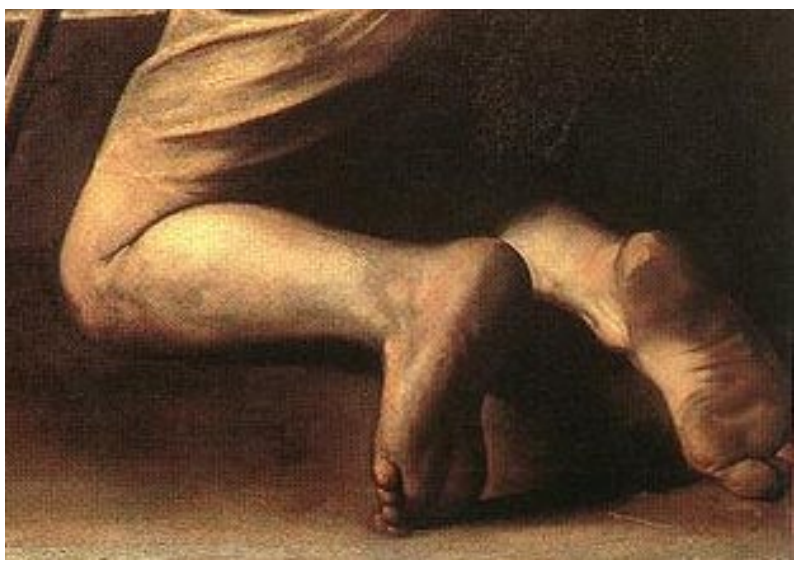

los evangelios, será en una dolorosa ascensión como culminará la semana de pasión que le conducirá a la muerte en la cruz. Este camino del calvario será recordado en la tradición cristiana en una serie de capítulos o "estaciones" que son reconstituidos y conmemorados en todas las iglesias cristianas. El camino del Calvario, exterior a la iglesia y fuertemente vinculado con el tejido urbano y paisajístico ha creado extraordinarios paisajes de denso contenido y gran plasticidad y belleza, en lo que podríamos considerar como verdaderos proyectos de paisaje. Singulares realizaciones que conjugando arquitectura, simbolismo y naturaleza han transformado lugares y territorios en complejas y sofisticadas instalaciones que buscan a través de la liturgia específica, recordar y reforzar la idea de la vida como seguimiento del camino emprendido por Cristo; intentando así, dar respuesta a la búsqueda del sentido de la vida para el creyente cristiano cuya metáfora más potente es el camino de la cruz. 

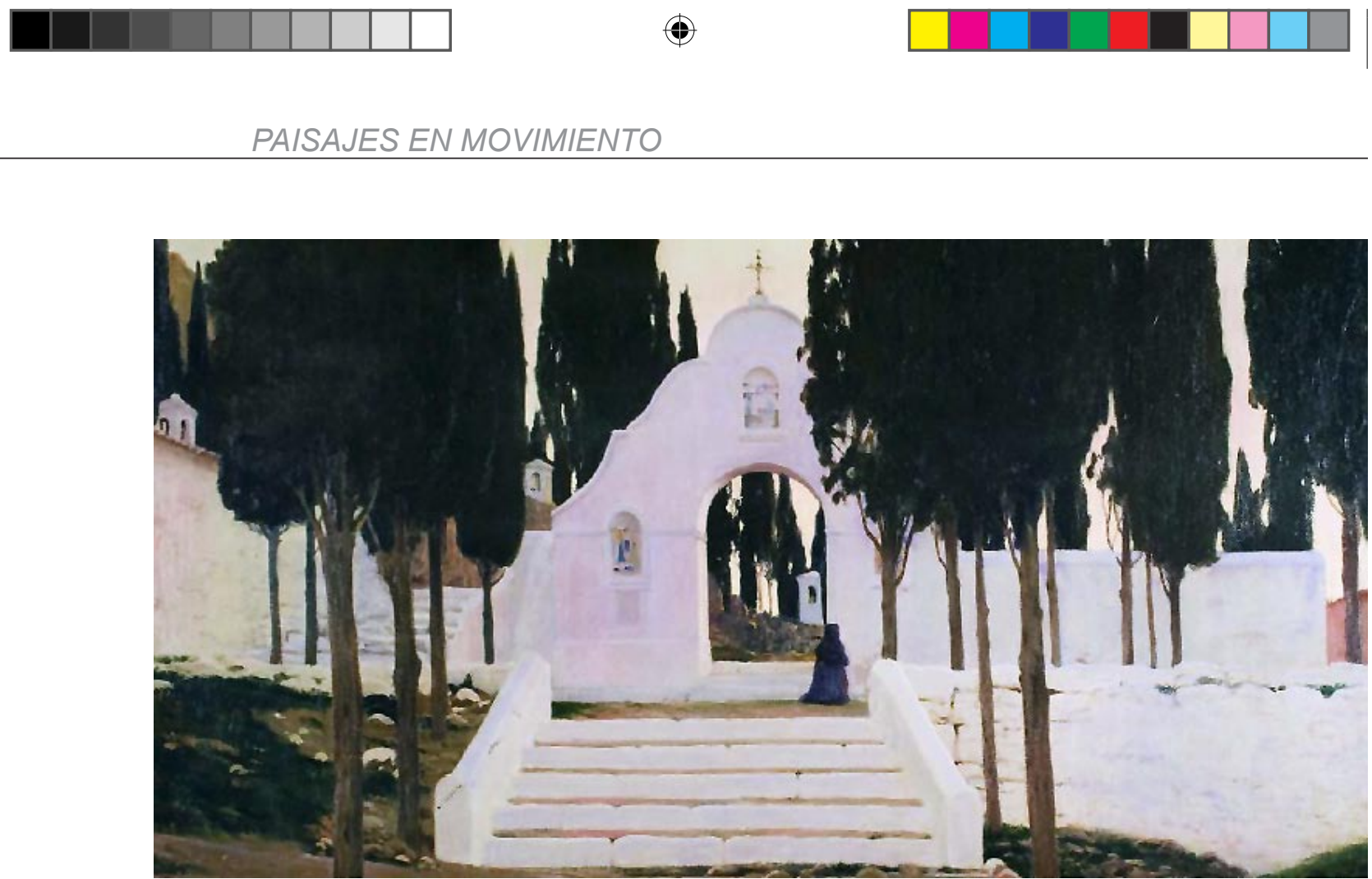

Santiago Rusiñol, Calvario de Sagunto, 1901, (detalle).

Este mismo sentimiento está en el origen de numerosas procesiones y peregrinaciones que jalonaron la historia y de algunas que todavía hoy podemos encontrar en diferentes lugares transformando el territorio en paisaje y vinculando, muchas de ellas, naturaleza y ciudad. Ritos del movimiento que crean paisaje no ya desde la intervención directa de transformación física y permanente sino desde el propio caminar, desde el simbolismo y la culturalización de un determinado territorio. Un ejemplo paradigmático de estas peregrinaciones que todavía tienen lugar actualmente es la que se lleva a cabo desde Les Useres hasta el santuario de Sant Joan de Penyagolosa en Castellón y que es conocida popularmente como Els peregrins de Les Useres.

El camino de la peregrinación, cuando atraviesa el núcleo urbano se construye tan sólo a partir de una efímera alfombra de retama que marca la ruta que pisarán los pies desnudos de los peregrinos y que altera de modo temporal, pero profundamente cargado de significado, el espacio urbano. Esta línea confeccionada de naturaleza surcando las pétreas ca- 

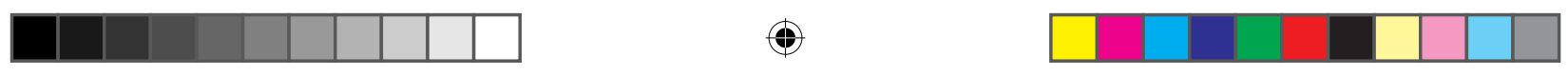

lles de la localidad crea un interesante diálogo entre naturaleza y ciudad, entre geometría e informalidad. Cuando el camino sale del casco urbano, son los mismos masoveros que habitan esos montes los que lo limpian de piedras, adornándolo con guirnaldas y flores y alfombrándolo de retama o follaje de sabina, en un acto paisajístico en sí mismo de enorme belleza y potencial simbólico. Son experiencias éstas que cuestionan la tradicional mirada del campesino hacia ese territorio que le sirve de sustento para transformarlo en paisaje. Sin necesidad de salir de él, sin necesidad de ser extranjero, sino a través de la experiencia de introspección que se produce gracias al camino. Además, en cuanto a Els Peregrins de Les Useres específicamente, es muy interesante la relación que se establece entre camino y música a partir de la elementalidad polifónica de dos voces y el ritmo lento marcado, por supuesto, por el caminar, generando un paisaje sonoro que complementa al físico y que expande el entorno circundante produciendo una profunda

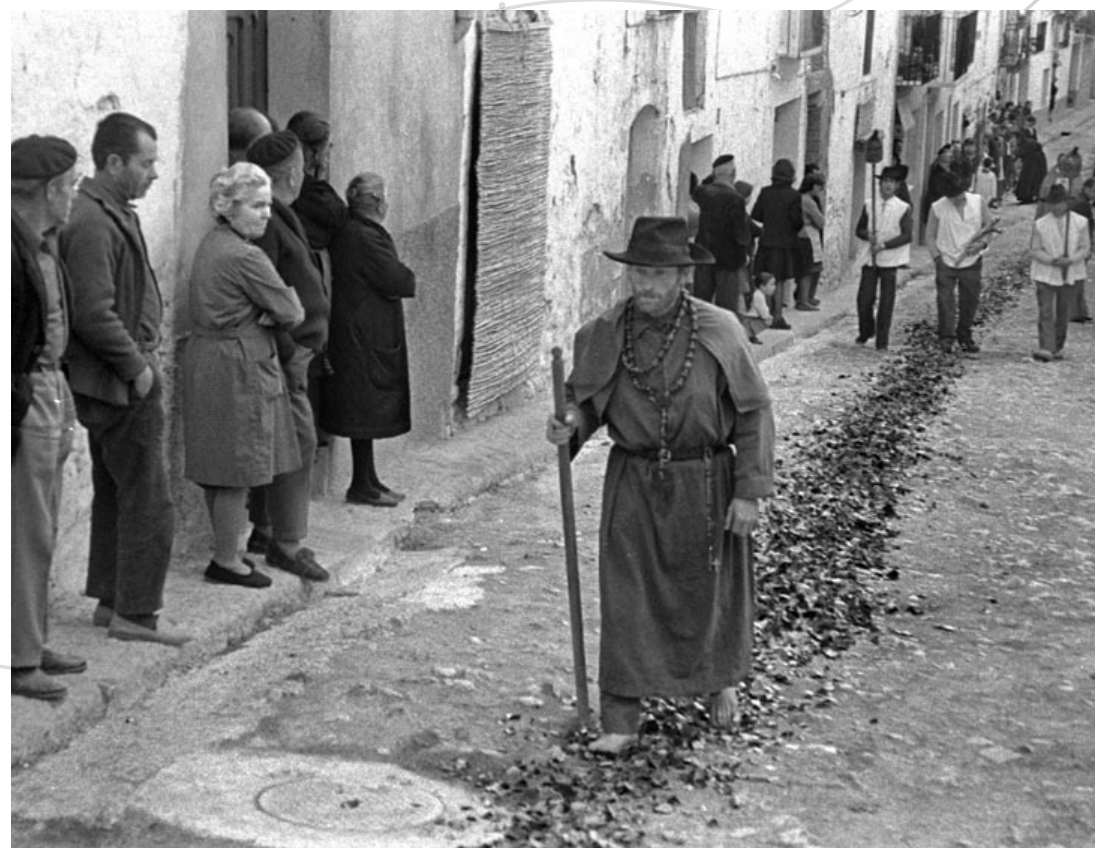
impresión estética.

Els Peregrins de Les Useres, Castellón, 1982 (fotografía Manuel Cruzado). 
Si recuperamos aquí el relato/de Petrarca al que hacíamos referencia hace unas páginas, encontraremos múltiples referencias explícitas de la relación metafórica y simbólica entre el camino de la ascensión al monte y el camino de la vida, asimilando las dificultades del camino a la búsqueda la virtud: "La vida beata está situada en un lugar excelso y, como dicen, es angosta la vida, la vía, que conduce hasta ella. Asimismo, se interponen muchas colinas y es necesario avanzar de virtud en virtud, por preclaros peldaños.(...) En la cima se halla el final de todo y el término del camino al que nuestra peregrinación se orienta." ${ }^{17} E s t e$ texto, vinculado al nacimiento mismo del concepto paisaje, no puede por tanto ser más interesante desde el punto de vista que nos ocupa ya que, en efecto, se escribe en un momento de enorme efervescencia cultural y paralelamente se relaciona de lleno con el tema cristiano del camino de la vida y con el fundamento de las procesiones y peregrinaciones que transforman periódicamente nuestros paisajes a través del movimiento del ser humano.

De todos modos, conviene señalar que las transformaciones paisajísticas de las que hablamos, no se dan únicamente ligadas al entorno natural. También el paisaje urbano ha estado y está ligado a modificaciones efímeras vinculadas a manifestaciones religiosas donde procesiones y actos públicos se apropian del espacio para construir nuevas entidades de carácter paisajístico y urbano. En 1496, Gentile Bellini nos dejará un interesantísimo testimonio de una de estas procesiones en la ciudad de Venecia. (Procesión en Venecia, 1496). La obra muestra la puesta en escena de la sociedad veneciana con la excusa de una ceremonia religiosa teniendo como espectacular "decorado" la Plaza de San Marcos. Las fachadas de la plaza, sus casas, la misma catedral de San Marcos, pasan a ser elementos de segundo orden y el despliegue de los habitantes de Venecia en el espacio vacío de la plaza se convierte en el auténtico y fundamental episodio urbano con una transformación del espacio, que aunque efímera, deja sin duda huella en la percepción del mismo por par-

17 Petrarca, Francesco, Manifiestos del Humanismo, Península, Barcelona, 2000, p.26. 
te de la sociedad veneciana. Se trata de una fuertemente estructurada y organizada coreografía que a través del ritmo y el movimiento convierte la Plaza de San Marcos en un paisaje dinámico y fluido que va más allá de las fábricas de los extraordinarios edificios de su perímetro y de la exquisita proporción del vacío urbano de la plaza para llevarnos a un espacio urbano entre el arte y la arquitectura cuyo carácter pasajero y efímero no resta un ápice de interés. Bien al contrario, completa y enriquece la percepción del entorno urbano gracias precisamente a esa componente temporal.

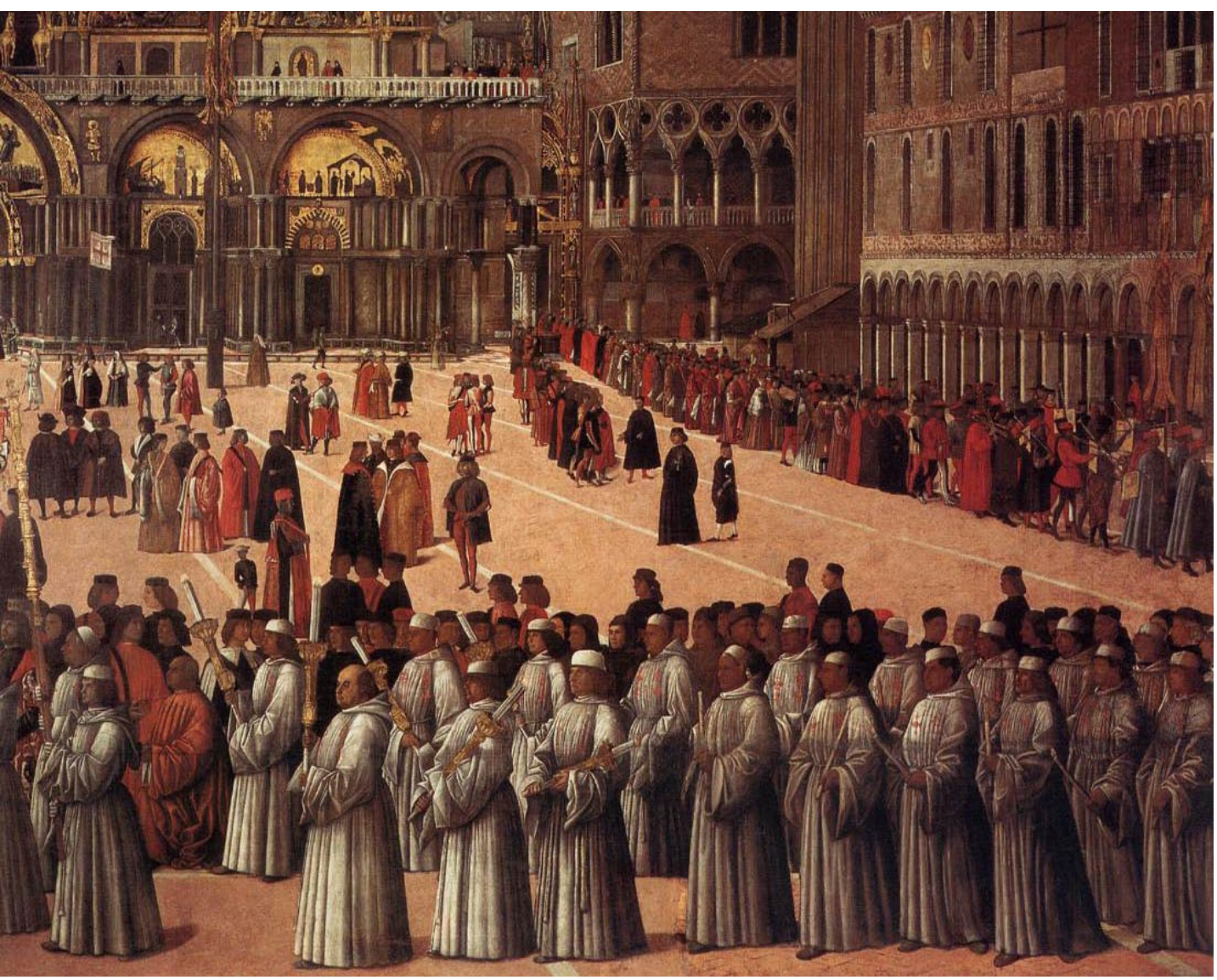

Gentile Bellini, Procesión en la Plaza de San Marcos, 1496 (detalle). 


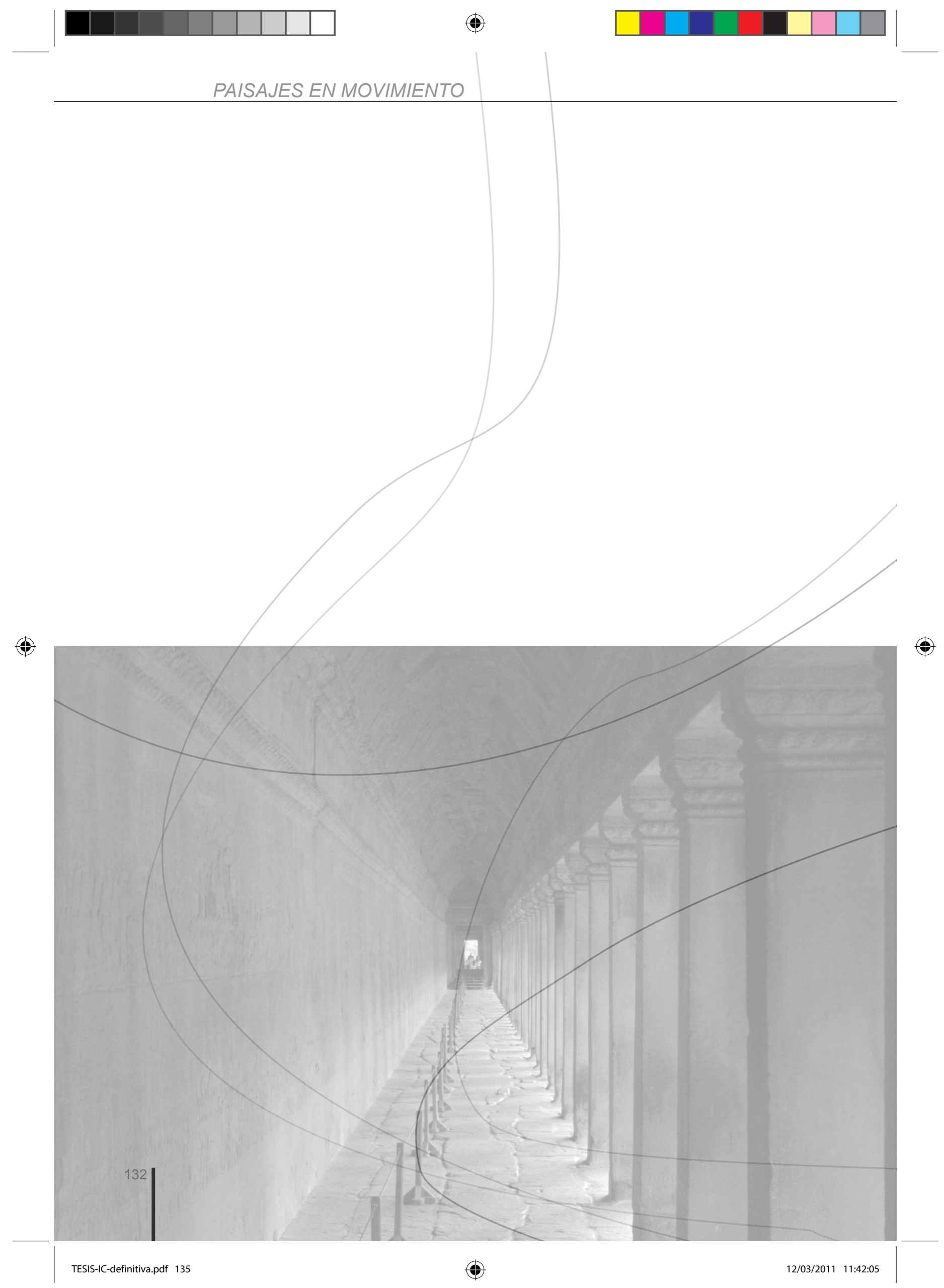



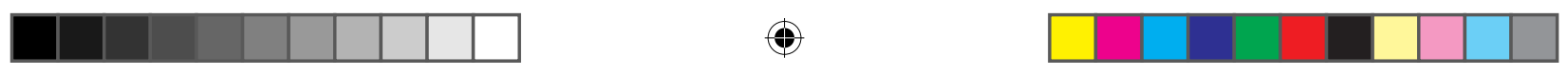

Para acercarnos a la experiencia del movimiento como uno de los componentes esenciales en los jardines clásicos y barrocos europeos, para tratar de entender los mecanismos que activan los elementos más dinámicos y ambiguos de estos jardines (siempre articulados, como veremos, a partir de la construcción y el recorrido de ejes omnipresentes), me gustaría arrancar el tratamiento de estos "ejes infinitos" volviendo la vista atrás, a otras culturas y distintos períodos históricos.

Así pues, regresaremos ahora de nuevo al Egipto de los faraones, y más concretamente a Deir el-Bahari, en la ribera occidental del Nilo, frente a la antigua ciudad de Tebas (Luxor actualmente). Allí se alza el extraordinario templo de Hatsepsut. Este conjunto arquitectónico, atribuido 


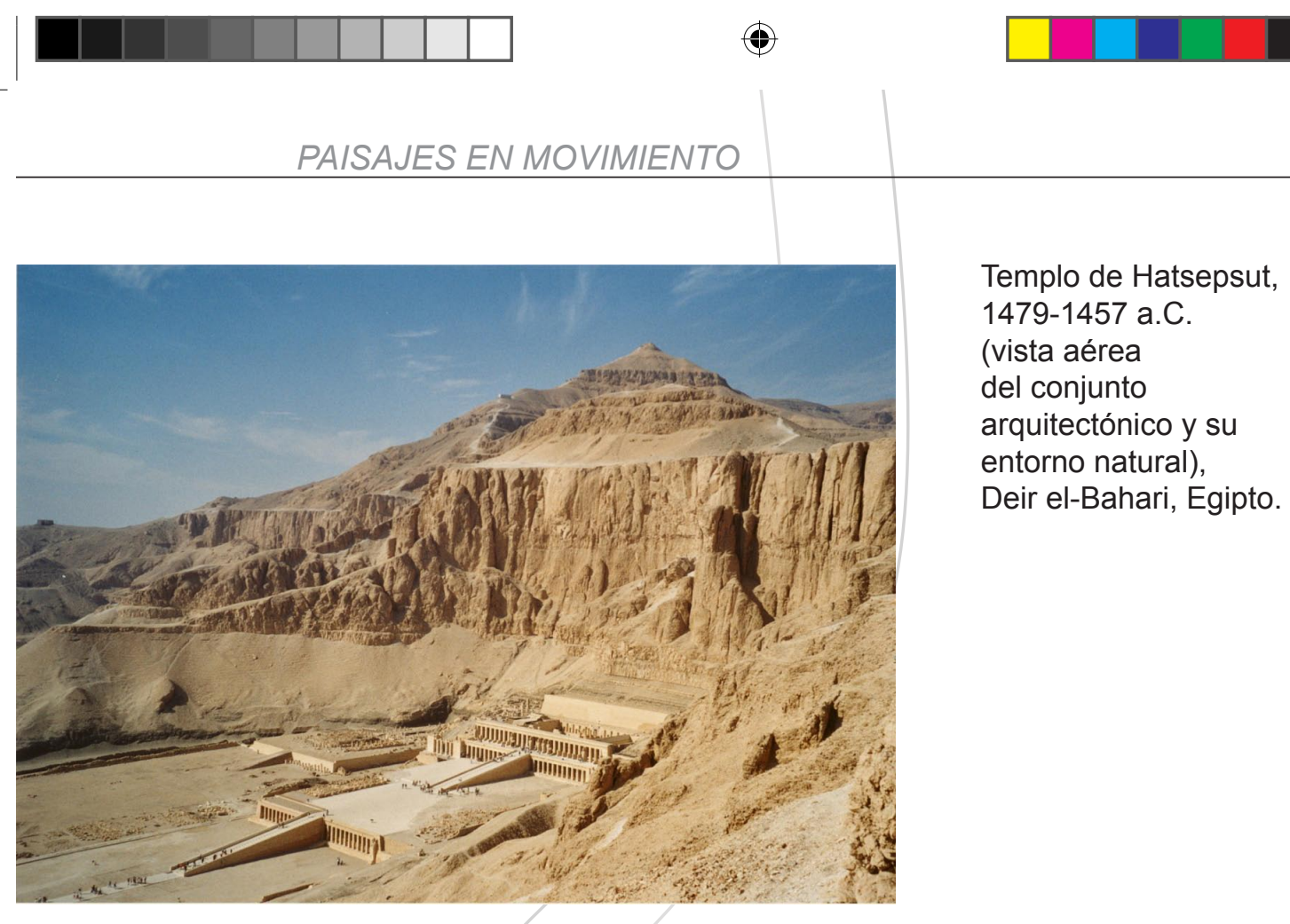

a Senemut y levantado para la reina que dirigió la XVII dinastía del 1479 a.C. al 1457 a.C. es un magnífico ejemplo, y necesario antecedente, para adentrarnos en el diálogo entre arquitectura y naturaleza a través de dispositivos espaciales y visuales dinámicos, que tendrá un gran desarrollo en nuestra cultura occidental a partir de la aparición del jardín clásico una vez arrancada la Eda Moderna en Europa.

Dicho templo surge de una concepción lineal que partiendo desde el valle (junto a Nilo), se prolonga por la calzada ascendente hasta el templo funerario y, finalmente, desde éste hasta la capilla fúnebre excavada en la propia ladera de la montaña. Las amplias y elegantes rampas unían cada terraza con la siguiente creando un fuerte y atractivo sistema aseendente. La gran libertad espacial del conjunto, debido fundamentalmente a las magníficas terrazas, a las diferentes relaciones entre éstas y a las columnas pilastras, no responde en modo alguno a un planteamiento estático del conjunto sino todo lo contrario. El sistema perspectivo funcionaba en un doble sentido: en sentido descendente, desde las amplias terrazas se domina visualmente la cuenca del Nilo, creando un mecanismo de apropiación simbólica del paisaje que se abre frente al templo y que al- 

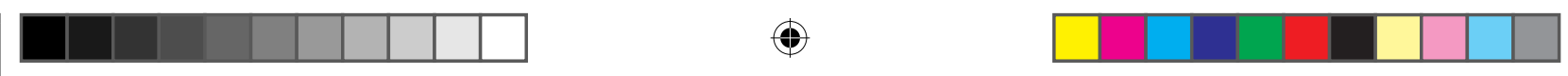

3. El arte de caminar, un recorrido histórico.

canza al templo de Karnak, en la otra orilla del río; en sentido ascendente, el templo dibujó, complementado por el paisaje natural del valle, la escenografía perfecta para acompañar los complejos ritos funerarios egipcios. Un sobrecogedor telón de fondo donde la relación entre arquitectura y naturaleza alcanzó uno de los capítulos más vibrantes de la historia de la humanidad. Un lugar donde las estribaciones rocosas que acompañan el templo no hacen sino empujar, lanzar, la mirada hacia arriba, hacia lo trascendente, hacia la vida que continúa más allá de la muerte. Una vida que viene del Nilo y continúa su recorrido ritual hasta esconderse entre los muros del templo y finalmente desaparecer en las entrañas de la montaña inmortal. La secuencia de rampas y terrazas del templo de Hatsepsut expresan con enorme claridad el concepto de vida como viaje que vertebra toda la religión egipcia y su visión del mundo. Su constante y serena progresión ascendente hacia las entrañas del majestuoso circo

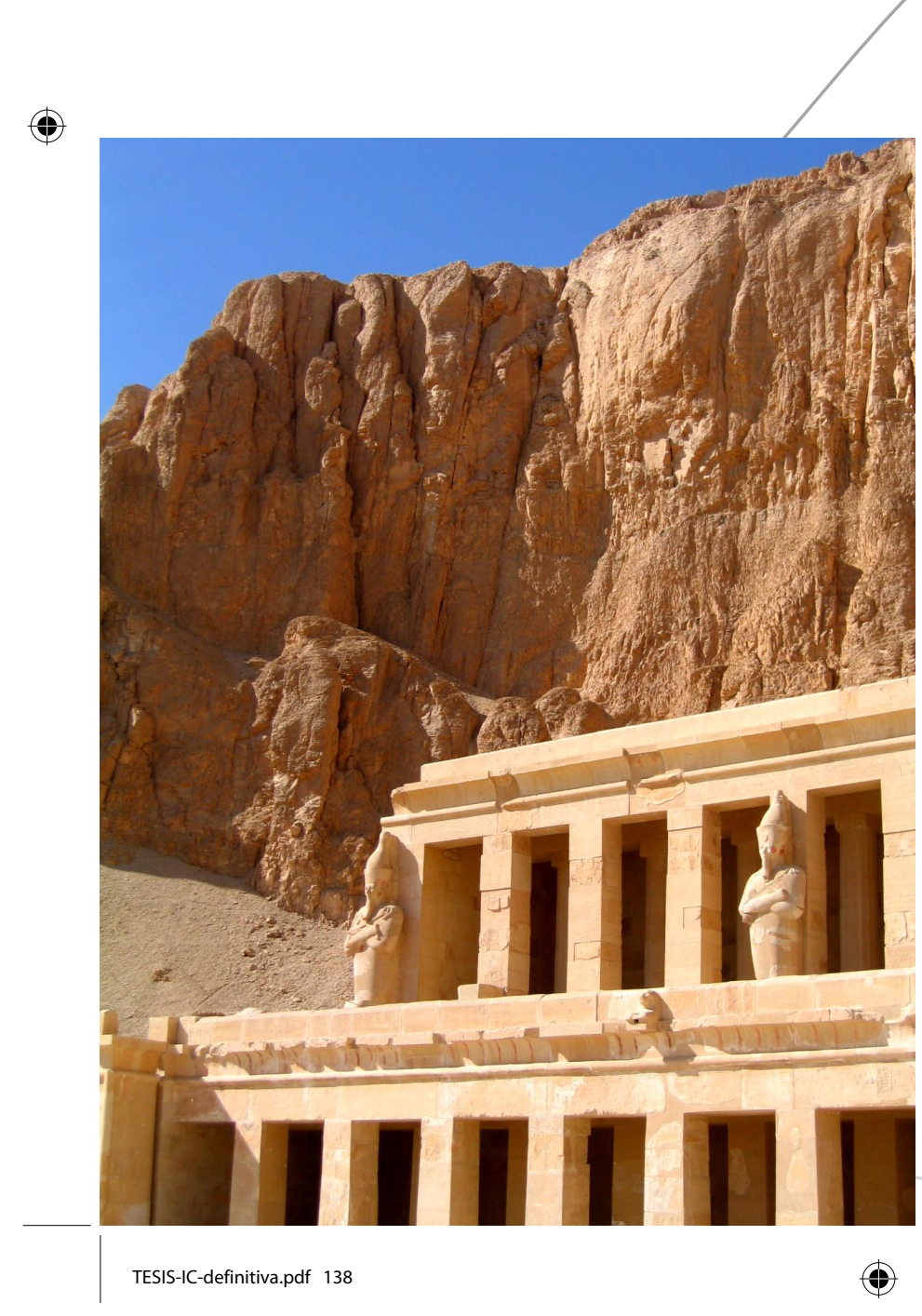
rocoso (que protege y completa el conjunto) constituye uno de los caminos procesionales más majestuosos jamás concebido y edificado. El templo se convierte así, desde un planteamiento progresivo y dinámico, y gracias a su articulación en la naturaleza, en un prodigioso paisaje. Como nos sugiere el profesor Giedion; "El templo hacía pensar en un jardín de placer para la eternidad. Todo es luminoso y alegre [...] desde la entrada hasta el

Templo de Hatsepsut, Deir elBahari, Egipto. (fotografía I.C). 

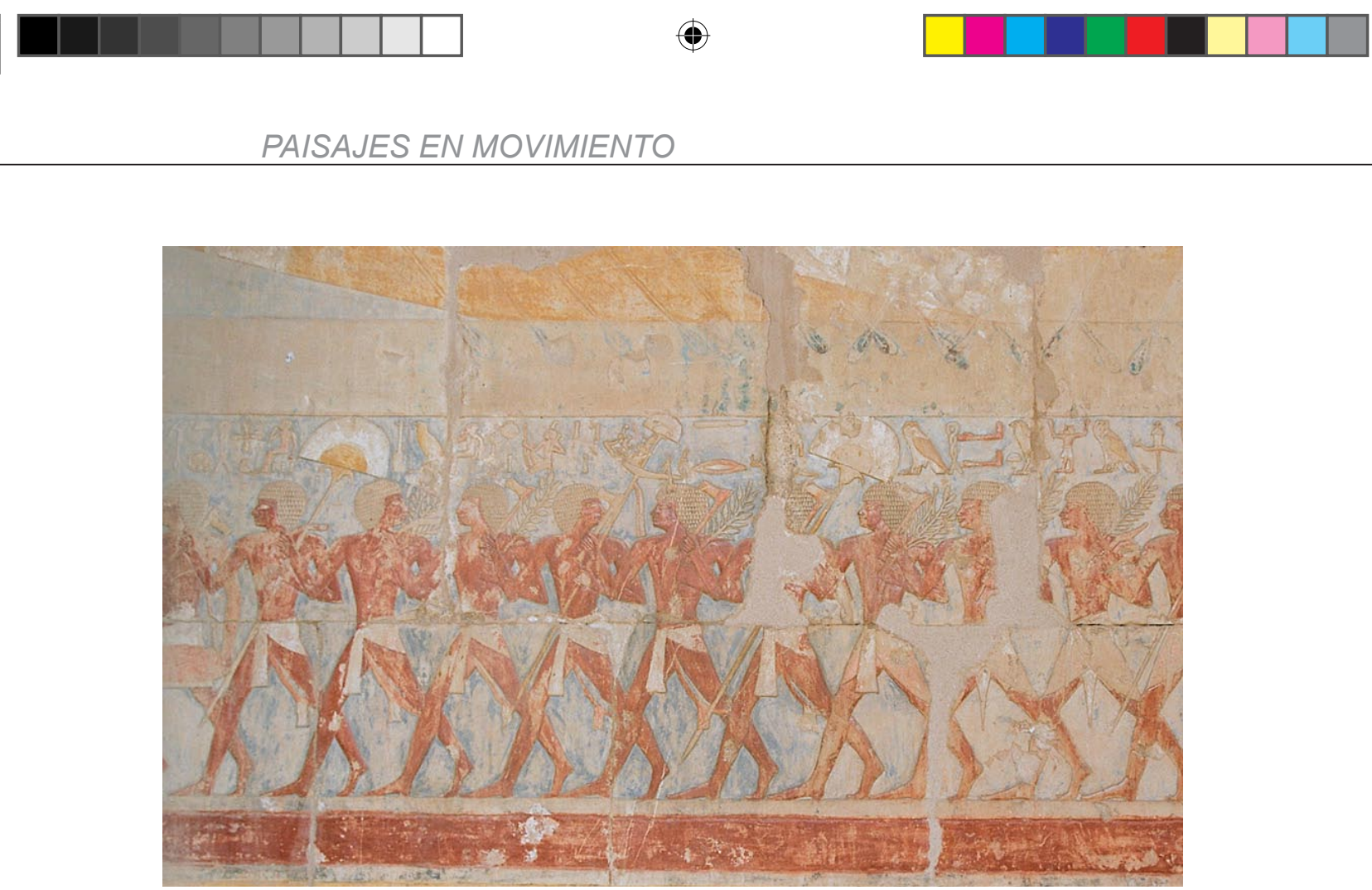

Relieve en el Templo de Hatsepsut, Deir el-Bahari, Egipto. (fotografía I.C).

santuario más alto al que da frente la fila de figuras osiríacas."1 De hecho existen indicios de presencia vegetal en las terrazas, así como de láminas de agua donde se desarrollaban los papiros, tan queridos y tan cargados de simbología para los egipcios.

El fructífero diálogo establecido entre la horizontalidad de las terrazas y la verticalidad de la pared rocosa articulado gracias a las rampas ascendentes y la cuidada y estudiada estatuaria nos ha legado un extraordinario episodio de intensa relación entre arquitectura y naturaleza, de arquitectura en cuanto paisaje dinámico.

Aún a pesar de lo sublime del templo "del millón de años" de Hatsepsut, la audacia en la confrontación entre arquitectura y naturaleza virgen, no resulta en absoluto un hecho aislado si ampliamos el campo de visión a otras civilizaciones bien alejadas en el tiempo y el espacio y que responden, por tanto, a otros parámetros socioculturales. Un acercamiento a la cultura Khemer nos permitirá ampliar la visión y traer aquí 1 Giedion, Sigfried, El presente eterno: Los comienzos de la arquitectura, Alianza Forma, Madrid, 1986, p.409. 


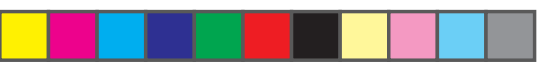

extraordinarios paisajes en movimiento creados por el ser humano que enriquezcan nuestra visión a menudo un tanto eurocentrista.

La civilización Khemer floreció en la península de Indochina desde el siglo IX al XIII y construyó en Angkor la capital de su imperio. Los khemer supieron transformar la inmensa llanura de que disponían en una increíble y colosal red de ingenios hidráulicos donde embalses, campos de arroz y canales aseguraban la supervivencia de su pueblo. El centro neurálgico de la ciudad de Angkor estaba basado en un conjunto de complejos sagrados cuyo epicentro y razón de ser era un templo piramidal a modo de representación simbólica de la montaña

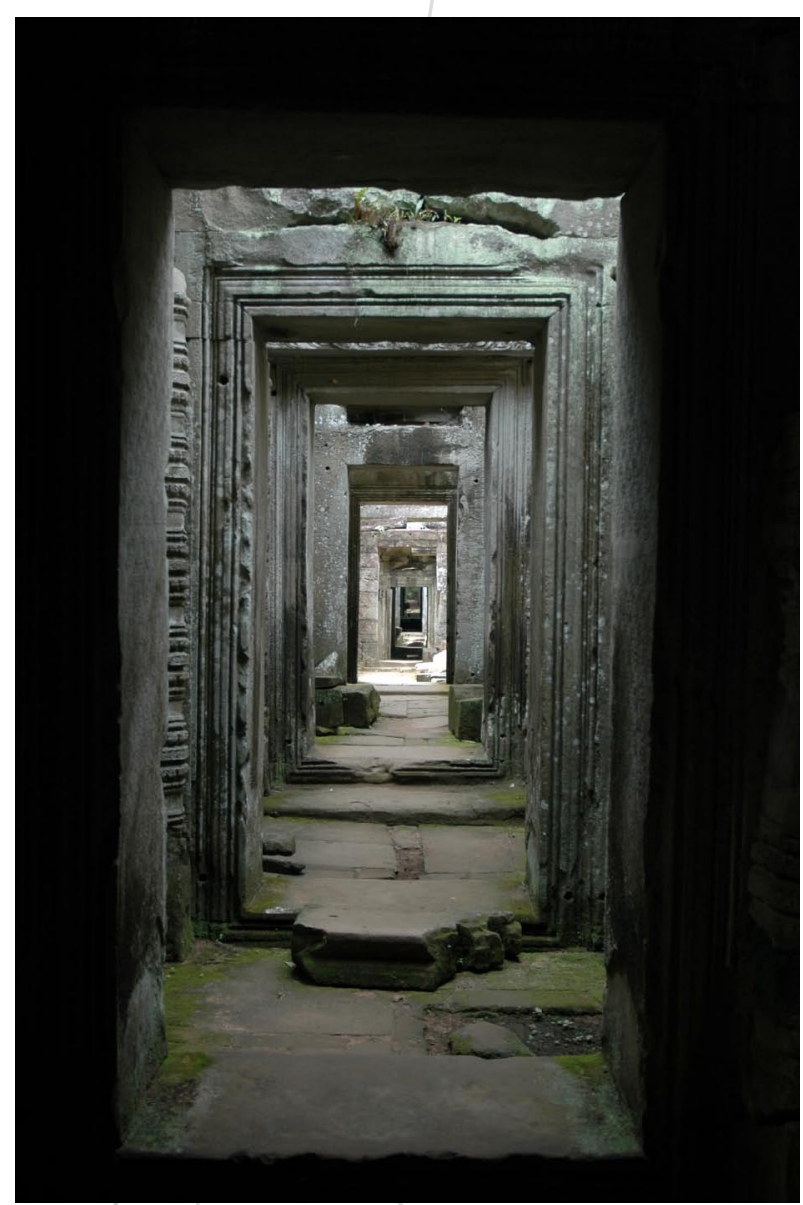

Templo de Preah Khan, Angkor, Siglo IX-XIII, Camboya. (fotografía I.C). cósmica, Meru. ${ }^{2}$ Estos templos y las distintas relaciones que se establecían entre ellos forman un complejo y sugerente conjunto que aún hoy sobrecoge al visitante.

Cada templo se rodea de un canal o se refleja en un embalse que simboliza el océano primordial, mito fundamental para la religión hindú, surgiendo como resultado una inmensa lámina de agua entrelazada

2 En la cosmogonía hindú, el monte Meru es la montaña mítica, con forma de cono truncado muy alargado y situada en el centro del mundo conocido. Las referencias a ella son constantes en diferentes textos sagrados. Para algunos hinduistas el monte está por el contrario formado por ciento nueve picos. 

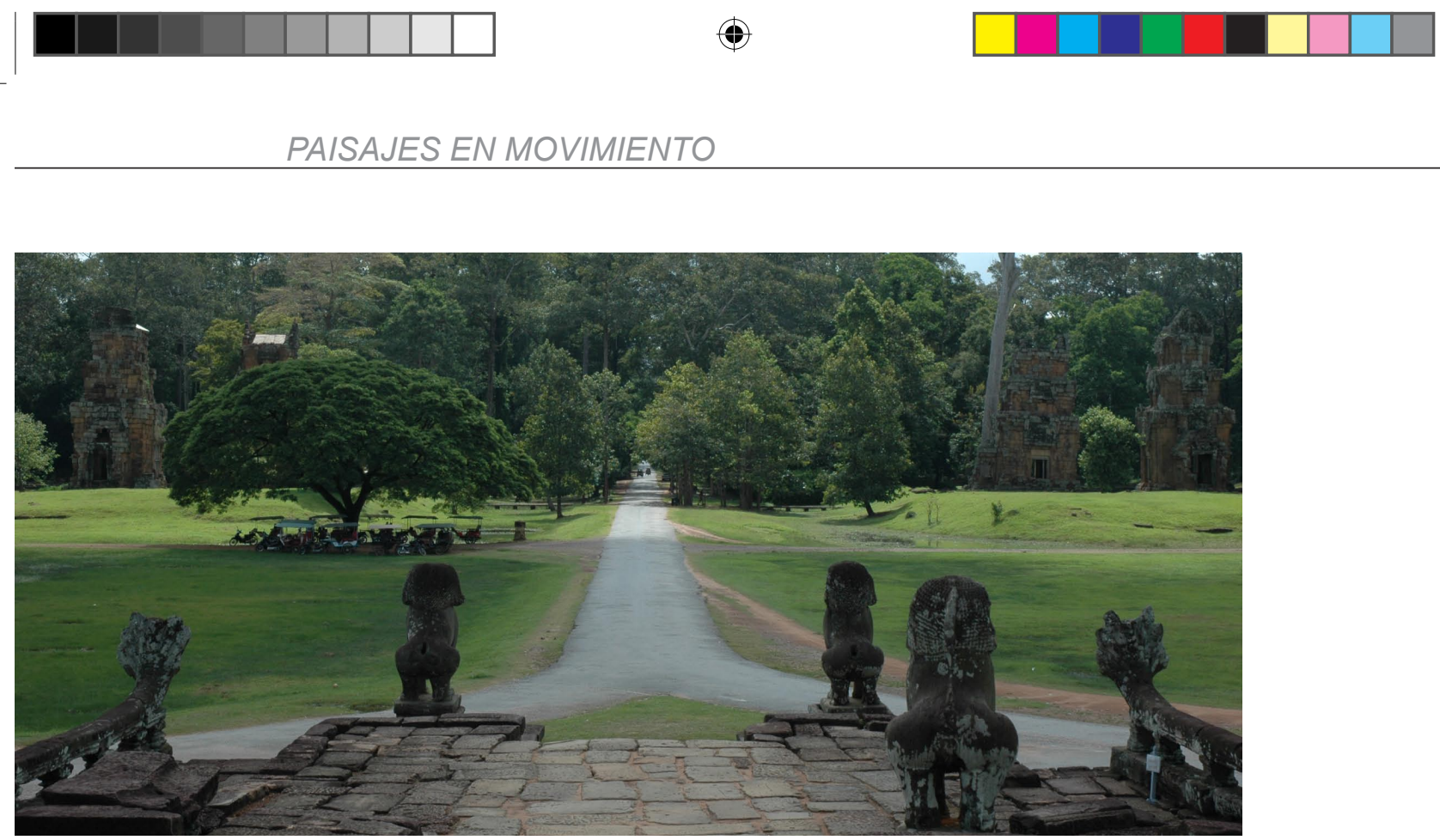

Recinto de Angkor Thom, Angkor, Camboya. Vía que conduce hasta la puerta de la Victoria (fotografía I.C).

con caminos y praderas y salpicada de templos. Los interminables ejes que surcan Angkor en su conjunto constituyen un irrepetible paisaje del movimiento donde todos y cada uno de los elementos está en su lugar adecuado y lo está en relación a los elementos de su entorno próximo y lejano al mismo tiempo. Los ejes se vuelven infinitos cuando se alejan adentrándose en la densa selva que rodea los templos. Las puertas (como por ejemplo la Puerta de la Victoria), unen unos conjuntos con otros al tiempo que marcan la pauta en la aproximación reverencial y litúrgica a los templos-montaña. Cualquiera de los cientos de templos que aún podemos visitar hoy en día se entiende desde el recorrido que propicia y organiza. A pesar de la estaticidad aparente de sus pesados muros, que sin duda no reflejan gran virtuosismo constructivo, todo en los templos remite al movimiento si nos fijamos con atención. Las puertas ceremoniales, por ejemplo, marcan (de nuevo) el tránsito entre lo sagrado y lo profano. Como nos dice el antropólogo Mircea Eliade: "El camino sagrado es arduo, está sembrado de peligros porque de hecho es un rito del paso de lo profano a lo sagrado; de lo efímero y lo ilusorio a la realidad 

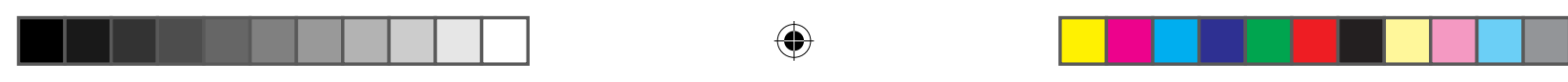

y la eternidad; de la muerte a la vida; del hombre a la divinidad."

Una vista aérea del conjunto de Angkor Wat, tal vez el ejemplo más imponente y conocido de Angkor, revela la importancia otorgada en el conjunto a todos aquellos elementos construidos para trabajar y "texturizar" la llegada procesional y simbólica al "centro", al templo-montaña,

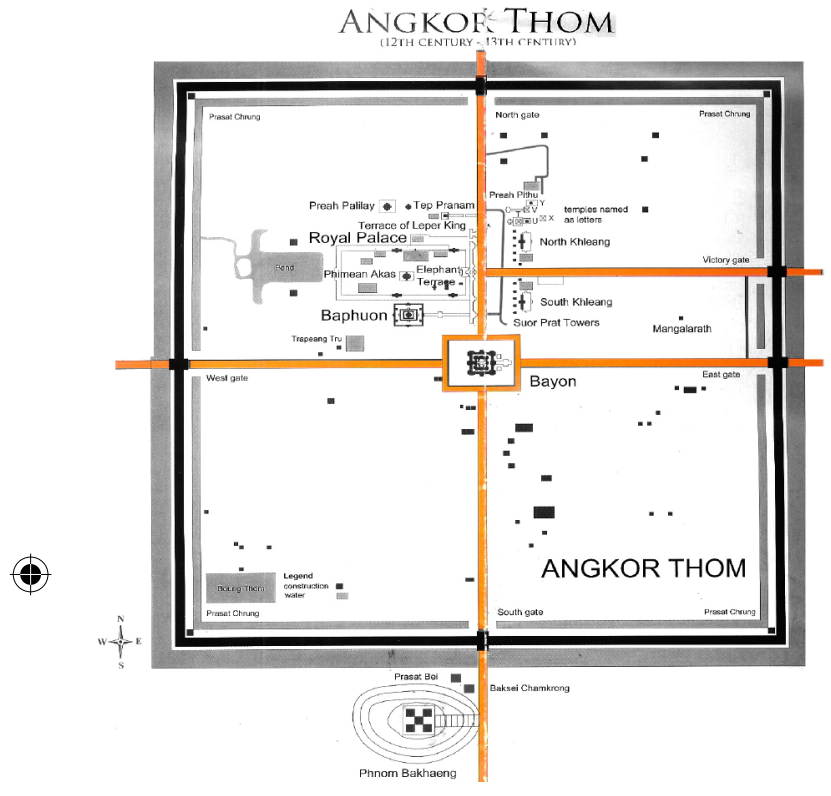

Estructura de ejes de Angkor Thom, Angkor, Camboya. al prasat central. Cada uno de los cuatro ejes, orientado perfectamente con los puntos cardinales, tiene una gopura, una puerta ritual que marca, tal y como veíamos, la transición entre lo sagrado y lo profano, justo en el punto de intersección con el canal que cierra el cuarto recinto.

La presencia de las nagas, ${ }^{4}$ serpientes míticas de cinco o siete cabezas en las balaustradas de los canales y plataformas del templo refuerza la idea de tránsito o de transición (según el punto de vista) entre la zona secular y el área sagrada del templo ya que las nagas se asimilan aquí a la figura del dragón de las aguas, animal mágico que trae la lluvia y es símbolo del arco iris que une el cielo y la tierra. La experiencia de los infi-

nitos ejes de Angkor no termina en las gopuras de acceso a los templos; por el contrario, sus interiores son un conjunto de ejes superpuestos e interconectados que invitan a recorrer los patios, las terrazas, ascender las escalinatas y alcanzar los prasats, los templos-montaña, símbolos del centro del Universo.

Pero Angkor es también un paisaje en movimiento que nos ofrece experiencias y enseñanzas en un sentido bien diferente y sin duda único

3 Eliade, Mircea, El mito del eterno retorno, Alianza Editorial, Madrid, 2008, p.25.

4 Las nagas proceden, como a mayoría de la iconografía y el simbolismo del conjunto de Angkor de la India y su tradición religiosa y filosófica hinduista. 


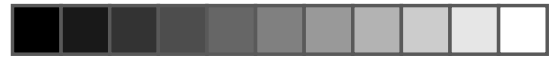

$\oplus$

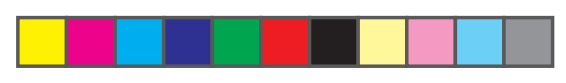

en el mundo en cuanto a su intensidad y plasticidad. La absorción de los conjuntos arquitectónicos por parte de la vecina selva a lo largo de los siglos ha creado una fusión única entre arquitectura y naturaleza donde el movimiento, si bien imperceptible al ojo humano, es un factor determinante. Nunca se visita el mismo Angkor, las raíces avanzan a su ritmo imperturbable, la naturaleza crece y muere enroscada a los bloques que tallaron los artistas y artesanos khemeres de modo que muchas piedras mudan de emplazamiento al ritmo de las estaciones. Los templos de Angkor ya no serán nunca más un conjunto de elementos arquitectónicos aislados, autónomos y rodeados por una selva mantenida al margen,

(4)
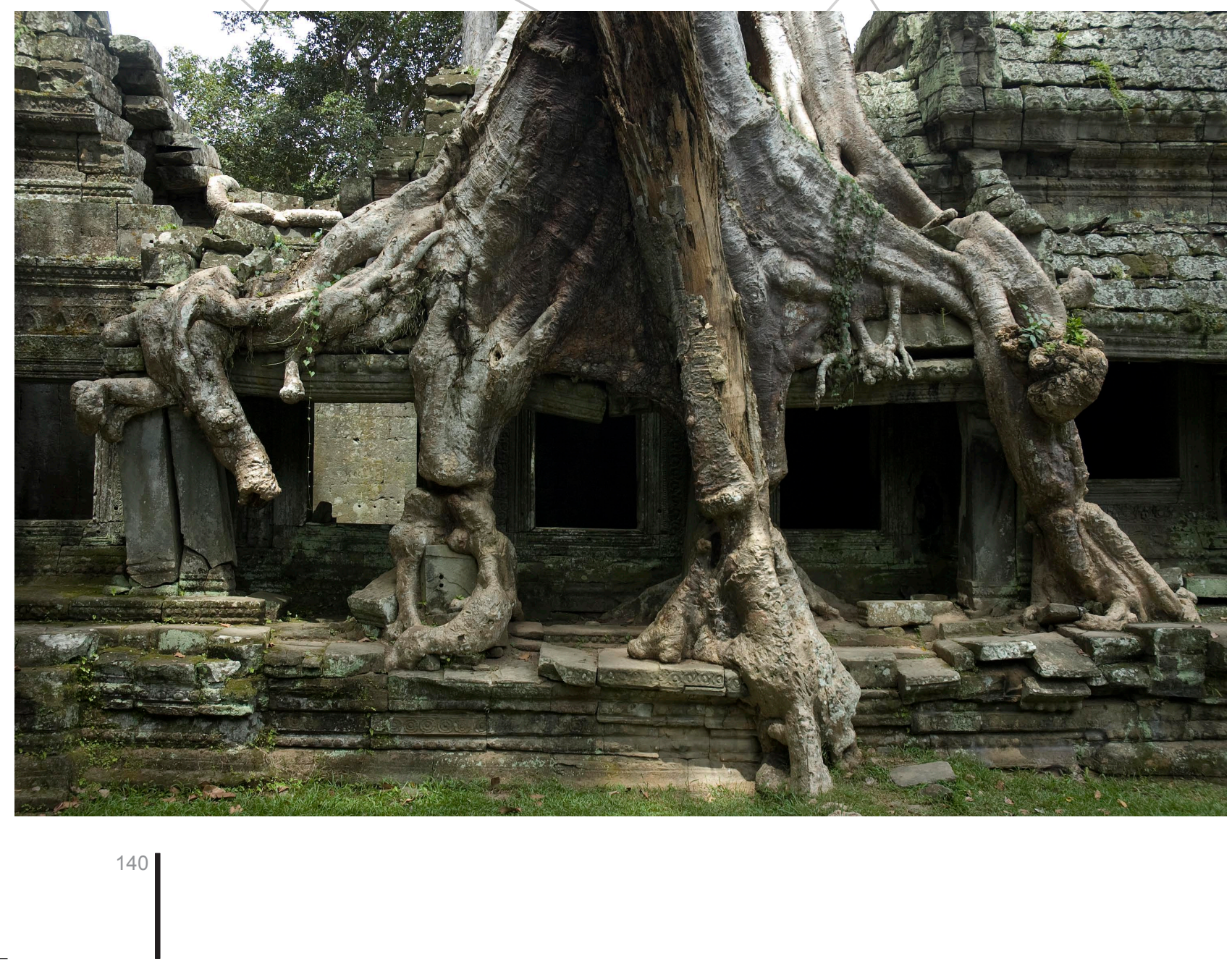

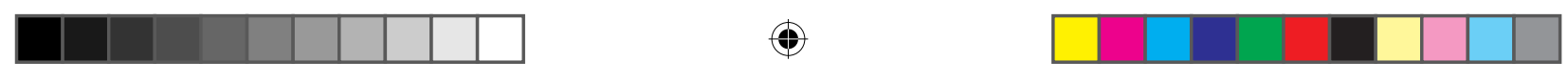

cuidada y vigilada. Los límites entre los elementos vivos e inertes se encuentran completamente en entredicho. El avance y retroceso de la selva transforma segundo a segundo el paisaje de Angkor, creando una de las fusiones más intensas que se han producido entre la naturaleza y la obra del ser humano; de tal modo que naturaleza, arte y arquitectura crean a cada instante un paisaje efímero situado entre la cultura y la exuberancia de la vida que conforma la selva de la planicie de Angkor.

Después de recordar estas dos obras tan significativas, y que nos enseñan claves tan interesantes para la construcción del paisaje dinámico, regresamos a nuestro contexto para comprobar de qué modo coexiste en Europa en los siglos XVI y XVII, y especialmente en Italia y Francia, una fuerte linealidad en las secuencias con la presencia de movimientos superpuestos vertebradores y generadores de paisaje. Este interés por los aspectos más dinámicos, por las facetas más efímeras y cambiantes de los jardines, resurgirá pues con fuerza, como decimos, en los jardines del Renacimiento italiano para llegar a su apoteosis en los grandes dispositivos de los jardines del Barroco francés.

En efecto veremos de qué modo, a partir del Renacimiento italiano, con la progresiva pero determinante irrupción de la perspectiva en tanto que herramienta de escrutinio de la realidad y de apropiación simbólica del entorno y por extensión del mundo, poco a poco, los proyectos de jardinería asociados a distintas actuaciones arquitectónicas se tornan más complejos y sofisticados. Como bien nos recuerda Leonardo Benévolo en su conocida obra La captura del infinito, hasta ese momento, durante los siglos que conforman lo que hoy conocemos como Edad Media, el objeto arquitectónico no mantendrá, a partir de una determinada distancia ( trescientos metros en concreto), su carácter individual, volviéndose parte de la continuidad del fondo paisajístico de las obras. No en vano, la proyección del ser humano en el territorio que le rodea ocupa un puesto destacado en las grandes transformaciones sociales y culturales ocurridas al comienzo de lo que los historiadores han dado en denominar la Era Moderna. En este momento, la arquitectura abandonará la tradicional 


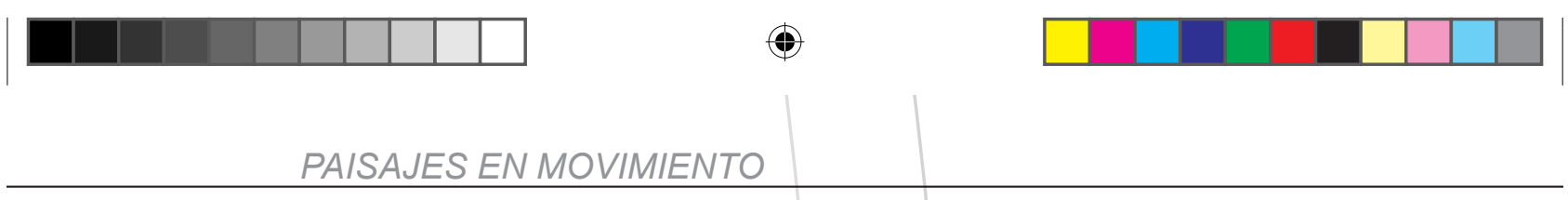

ocupación espacial interior (habitual durante años anteriores), empequeñeciendo de este modo la antes insalvable distancia existente entre la arquitectura y el paisaje. El ser humano, en su devenir en la vida y en su recorrido por el mundo, se lanza a la captura del horizonte en busca del infinito.

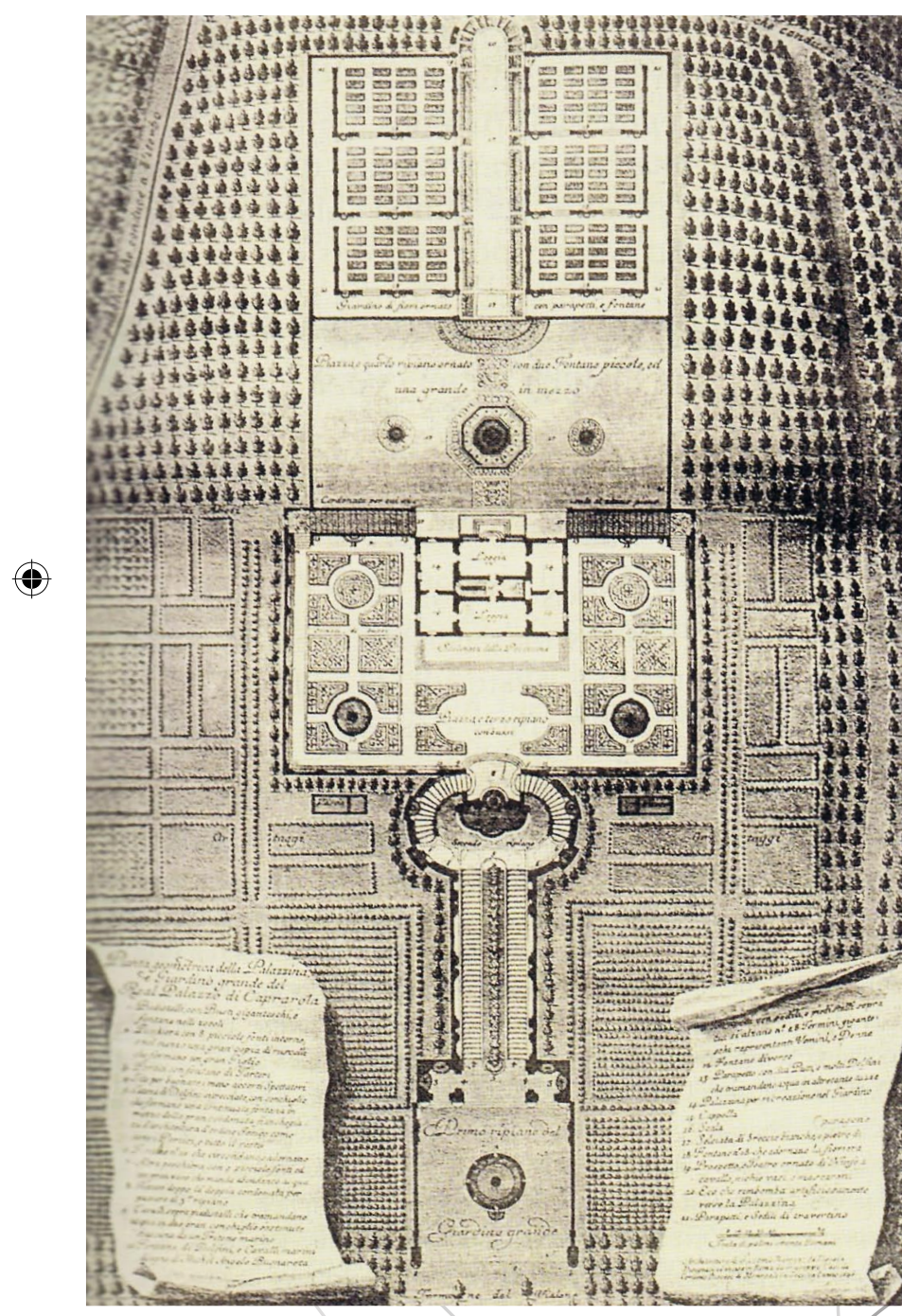

Planta del Jardin Grande de la Villa/Farnese en Caprarola, circa 1550, Italia.
Es por tanto consecuencia lógica, la especial atención prestada al jardín en este momento, ya que se le reconoce su capacidad para incorporar significados y estructurar y configurar la realidad con al menos igual o incluso mayor intensidad que la arquitectura de piedra. El carácter, a priori azaroso y gratuito, del jardín lo convierte en un espacio de lo posible, con un alto grado de libertad y de experimentación. Los trazos y recorridos esparcidos antes por el territorio o las transformaciones espaciales de carácter popular y religioso, pasan al ámbito de la esfera del poder $y$, en cierto modo gracias a su incorporación al jardín, se organizan, es decir, se suman a la esfera de lo doméstico. Se produce un interesante 

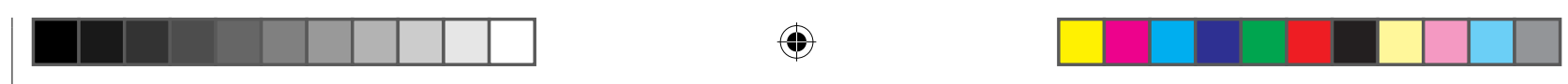

cambio de escala y de escenario en la representación y el ejercicio del continuo fluir de la vida humana. Aún cuando por supuesto no se abandonan las prácticas que hemos visto el capítulo anterior, pues éstas coexisten con los nuevos, o mejor dicho reencontrados, mecanismos que ya veíamos en el templo de Hatsepsut y que se vertebran a partir de la experimentación y en definitiva del reencuentro dinámico con los elementos de los distintos dispositivos paisajísticos. Tradicionalmente, en el estudio de este período se ha relegado a un segundo plano (en el mejor de los casos) el fundamental aspecto experimental y dinámico de los jardines debido a la fascinación que la composición de sus plantas y la delicadeza de la decoración han ejercido en arquitectos e historiadores. Pero, sin lugar a dudas, es recorriendo estos jardines el mejor modo en que podemos completar, si no llegar a entender, uno de sus planos de análisis, plano que encierra una enorme carga simbólica.

Acercándonos a Villa Lante en Bagnaia analizaremos de qué modo se estructuran algunos de los mecanismos que activan el movimiento subyacente en estos jardines clásicos aparentemente estáticos. A esta villa próxima a Viterbo (atribuida a Vignola por algunos autores), se accede desde tres calles que ascienden desde el núcleo medieval de Bagnaia hasta la puerta de acceso principal. A partir de aquí, se tiene una visión longitudinal del eje que vertebra en planta toda la composición y distribuye de este modo los jardines, que ascienden por la ladera en dirección Sur.

La composición comienza en un plano inferior formado por un cuadrado de setenta y cinco metros de lado que incluye en su interior un jardín de cuadros cerrados por setos bajos y árboles frutales distribuidos por sus correspondientes caminos. Este jardín actúa, a modo de vestíbulo, como presentación refinada en su ornamentación y composición que sirve al tiempo de recepción y de representación. Como fondo de este jardín de "inicio" aparecen, en contra de lo habitual, dos casinos en esquina. Este episodio arquitectónico resulta fascinante ya que se puede interpretar como el fraccionamiento del casino, habitualmente en posición 

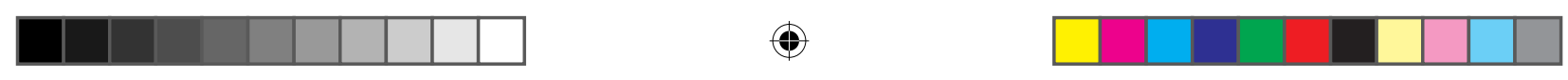

central, en dos mitades. Supone un cierto sacrificio de la arquitectura construida en piedra para que podamos avanzar en nuestro recorrido a través del eje sin ser interrumpidos por la edificación. Este eje de recorrido del jardín, elemento principal de todo el conjunto, está fuertemente estructurado merced al juego de planos que organizan el terreno $y$ en consecuencia el desnivel. Se trata de un sutil juego compositivo entre planos horizontales e inclinados. Los primeros aco-

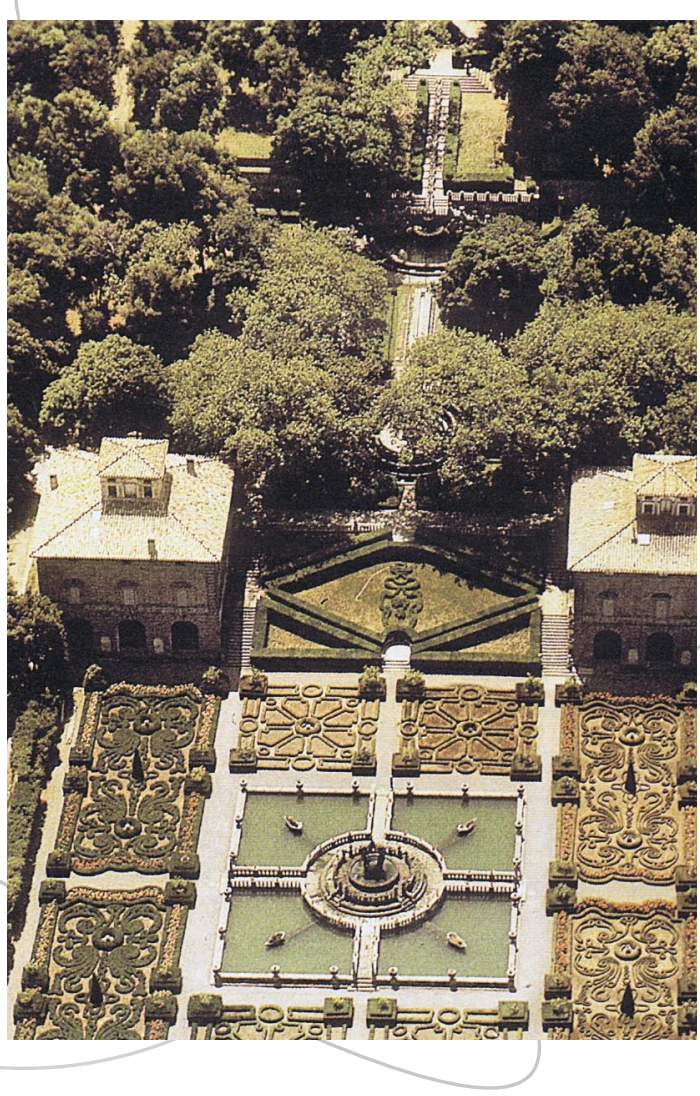

Villa Lante, Siglo XVII, Bagnaia, Italia. tarán, como no podía ser de otro modo, espacios más estáticos asociados a los casinos laterales, con dimensión suficiente y cuidados frentes arquitectónicos. Resulta interesante destacar que en el centro de estos muros no encontramos ninfeos ni ábsides sino fuentes escalonadas que sobresalen en semicírculo. Es decir, no aparecen elementos compositivos que impliquen una absorción, un final de una visual o un recorrido sino que, por el contrario, las fuentes que encontramos nos invitan a continuar el recorrido, nos susurran con sus juegos de agua que prosigamos ascendiendo en nuestro caminar por el eje que articula la villa entera.

Frente a estos planos horizontales, los planos inclinados están concebidos, contrariamente, como dinamizadores del recorrido. Es en

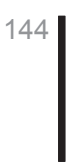



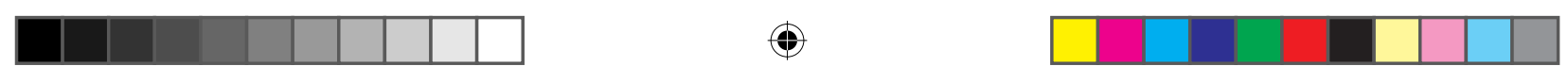

3. El arte de caminar, un recorrido histórico.

estos planos donde se articulan las rampas que incluso en el primer tramo están colocadas en diagonal, enfatizando aún con mayor intensidad si cabe su potencial dinámico. En Villa Lante no encontramos un belvedere, no existe ni al inicio ni al final del recorrido un punto donde obtener una visión de conjunto. Lo que nos ofrece Villa Lante es un recorrido a través del eje central en el que la sistematización de los jardines nos proporcione una perspectiva dinámica construida a partir de la cuidada secuencia de visuales. Sucesivamente, se mostrarán partes del jardín que antes quedaron ocultas o semiocultas. La imagen completa y nuestra experiencia del jardín se irán transformando a medida que avancemos y a partir de la modificación de las sucesivas vistas.

A medida que ascendemos por las rampas diagonales del primer talud aparecen los elementos de la primera terraza horizontal, inmediatamente, la fuente de Las Lucernas nos invita a continuar ascendiendo. Al alcanzar la segunda terraza aparecen las figuras de La Sirena y Los Ríos ante la mirada asombrada del espectador. Este efecto sor-

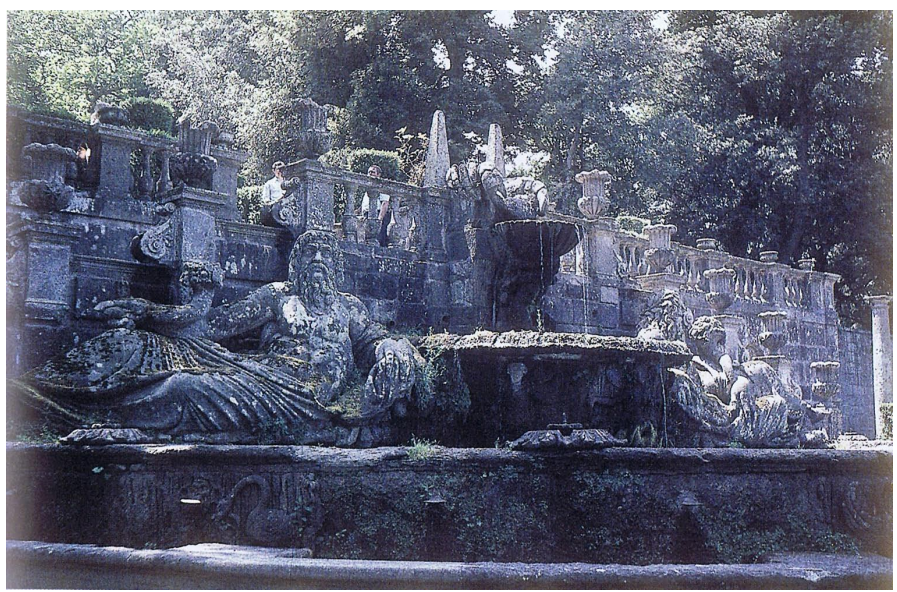

Villa Lante, Bagnaia, Italia, Fuente de las Lucernas. presa, buscado de modo constante en la composición de estos jardines, requiere necesariamente de un fuerte dinamismo del jardín ya que es solamente al alcanzar el punto pertinente y tras una secuencia lógica e inteligente cuando la reacción deseada será alcanzada. Volveremos a ver a menudo este buscado efecto de sorpresa e impresión en el espectador en los jardines que trataremos más adelante. 

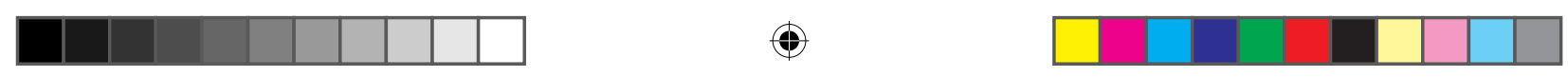

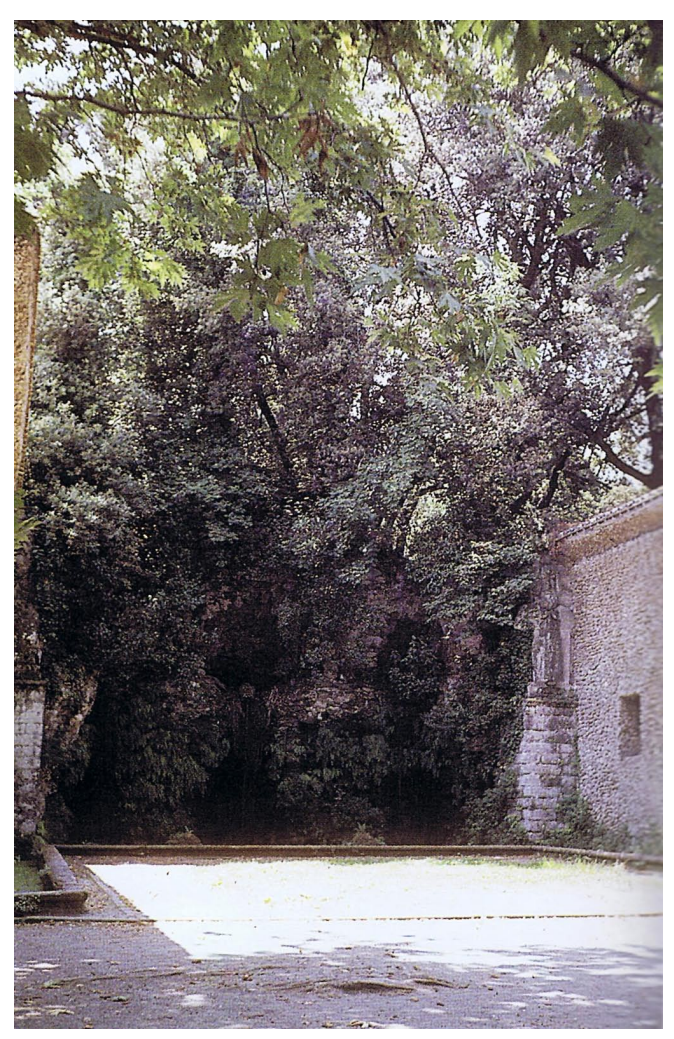

Fuente del Diluvio, Villa Lante.
El pabellón vegetal es, aparentemente, el final del recorrido a través del eje central. Una vez alcanzado éste, y situados en su umbrío interior, refrescado por una delicada fuente, descubrimos, de nuevo para nuestra sorpresa, un último dispositivo que completa, esta vez sí, el recorrido ascendente y la perspectiva del conjunto: la fuente del Diluvio. Flanqueada por la logias y las pajareras, y enmarcada por la arquitectura, parece la oquedad oscura y húmeda de la naturaleza, supuestamente virgen. De nuevo un intenso y apasionante diálo-

go entre la naturaleza y la arquitectura hace surgir un paisaje de enorme capacidad sugerente.

Pero ciertamente el recorrido del jardín no tiene un único sentido ni es la fuente del Diluvio un final definitivo y cerrado. En sentido descendente el movimiento se acelera, se precipita, nunca mejor dicho, gracias al fluir de la cadena de agua. $Y$ es interesante hacer notar que la aceleración del movimiento no es sin embargo constante. El agua que mana de la oquedad de la fuente del Diluvio, desciende por la cadena, salta desde la bocina de la Sirena al vaso de los Gigantes, atraviesa la mesa del cardenal (para refrescar de este modo las bebidas en fiestas y banquetes) y reaparece después en la fuente de las Lucernas, se desacelera y remansa finalmente en los estanques que configuran el jardín de cuadros 

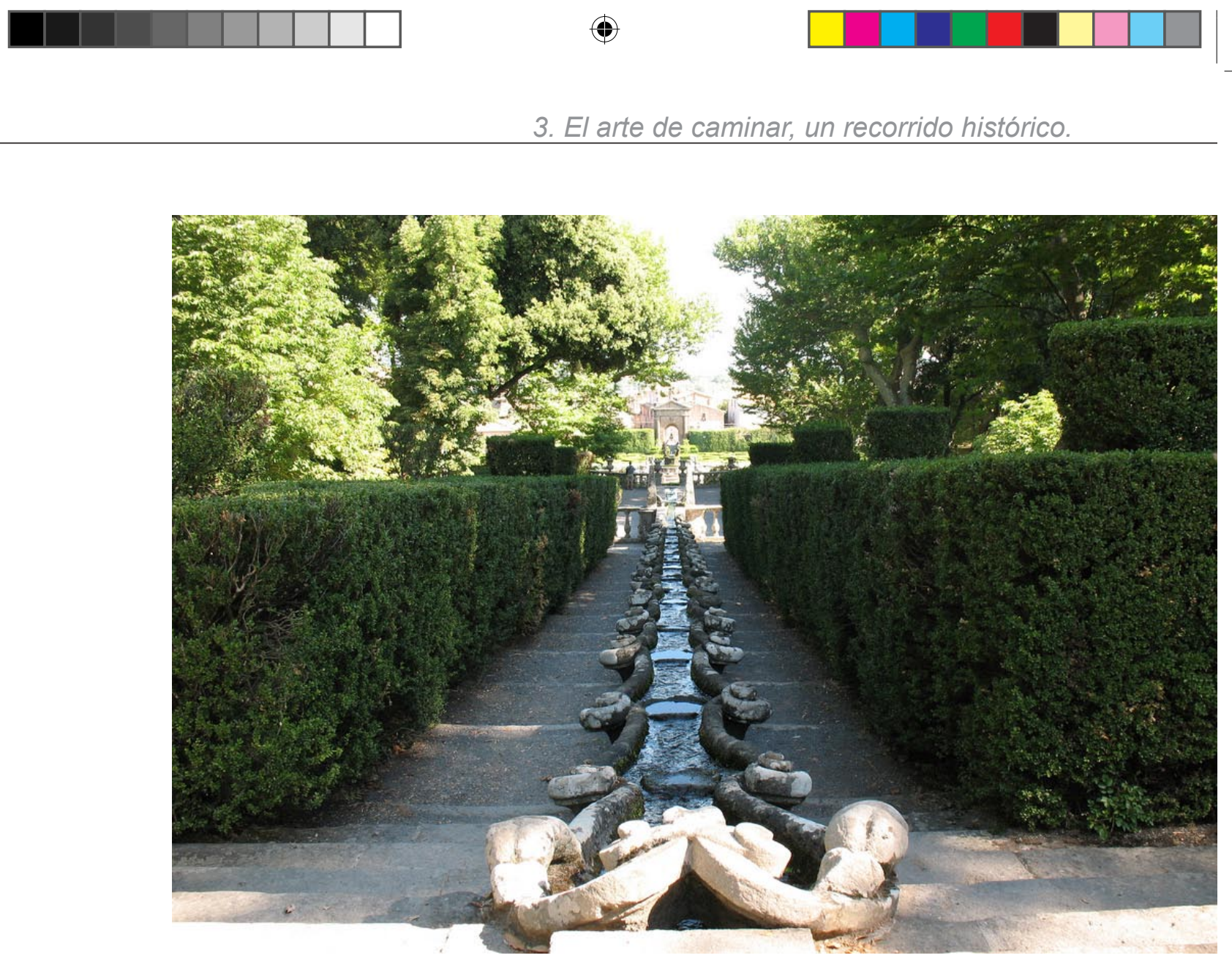

Cadena de Agua, Villa Lante.

del inicio de recorrido. La cadena otorga un papel protagonista al movimiento del agua en la composición del jardín en su conjunto, obligándola a cambios de velocidad, aumentando y disminuyendo ésta rítmicamente. Las distintas velocidades durante el recorrido del agua están íntimamente relacionadas con diferentes ritmos en los desplazamientos del visitante de la villa. La forma de las piezas que organizan el fluir del agua organiza también el complejo juego de relaciones establecido entre los elementos vegetales, tectónicos y acuáticos. Esta interrelación entre elementos de diversos ámbitos plantea la disolución de las fronteras entre paisaje y arquitectura, entre naturaleza y artificio. Esta composición que vemos en Villa Lante, resultado de la integración de su fuerte axialidad con su correspondiente escalonamiento, la encontramos en innumerables ejem- 

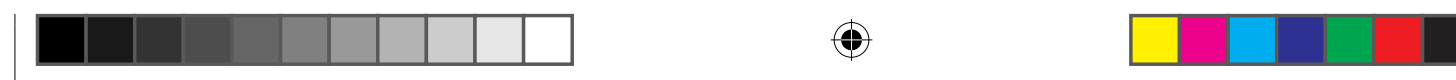

plos de jardines clásicos italianos de la época. Este esquema de jardín de tipo aterrazado se completa tipológicamente mediante la prolongación en profundidad y la diferenciación en tres sectores consecutivos.

Los componentes básicos que ponen en relación el eje y el desnivel son, como hemos visto, las terrazas y los taludes. Por ello, vale la pena incidir de nuevo en la dualidad existente entre ambos elementos. Las terrazas, correspondientes a los tramos horizontales, son los espacios del "estar", los ámbitos estáticos donde realizar/actividades tales como actuaciones de teatro o banquetes y celebraciones. Son lugares pensados para la permanencia y no para el tránsito. En cambio, pensados desde y para el movimiento se confeccionan los taludes, los planos inclinados, que son los que más nos interesan para el tema que nos ocupa, en cuanto espacios dinámicos generadores de espacios del desplazamiento y el fluir de propios y extraños. Estos planos dinámicos incluyen fundamentalmente líneas de recorrido: rampas con mayor o menor desarrollo, caminos por tanto ascendentes y descendentes, escaleras tanto en su vertiente más modesta como en la más monumental, transformadas ya en escalinatas. Éstas últimas de las más variadas formas y escalas.

A menudo los planos horizontales e inclinados se distribuyen y separan mediante muros de contención, frentes arquitectónicos cuya acumulación y superposición produce verdaderas fachadas dinámicas que se transforman a medida que avanzamos y que cambiamos, en consecuencia, de punto de vista. Centrar nuestra atención únicamente en los episodios o capítulos puntuales con significación especial dentro del dispositivo del jardín nos resta la experimentación del dinamismo producido en todo el conjunto gracias al desplazamiento de th punto a otro del sistema.

Los muros de contención se colmatan, a su vez, de elementos que dinamizan su superficie y producen una vibración llena de sugerencias y una fuerte capacidad evocadora de tiempos pasados o míticos con referencias reiteradas a la antigüedad como tiempo portador de prestigio. La enorme importancia otorgada al tratamiento escultórico y plástico de 

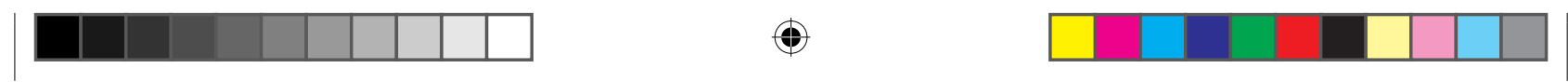

dichos elementos de transición y de límite tales como escaleras y rampas, así como a las balaustradas, no hacen sino llamar nuestra atención sobre el papel que jugamos nosotros en calidad de visitantes y por tanto experimentadores del espacio, es fundamental nuestra interacción con ellos para crear en cada ocasión distintos vínculos efímeros y dinámicos, nuevas y estimulantes relaciones con el jardín en su conjunto. Es precisamente en estos puntos singulares donde se concentran gran parte de los elementos arquitectónicos y escultóricos que emplean el agua como recurso expresivo. Sin duda, el movimiento propio del agua, ya que casi nunca se trata de albercas ni aguas quietas, refuerza y potencia el carácter dinámico de estos artefactos, en ocasiones verdaderas folies pensadas para el goce estético y el divertimento de las clases en el poder. Cascadas, canales en pendiente Planta de la Villa Farnese, circa 1550, Caprarola, Italia.

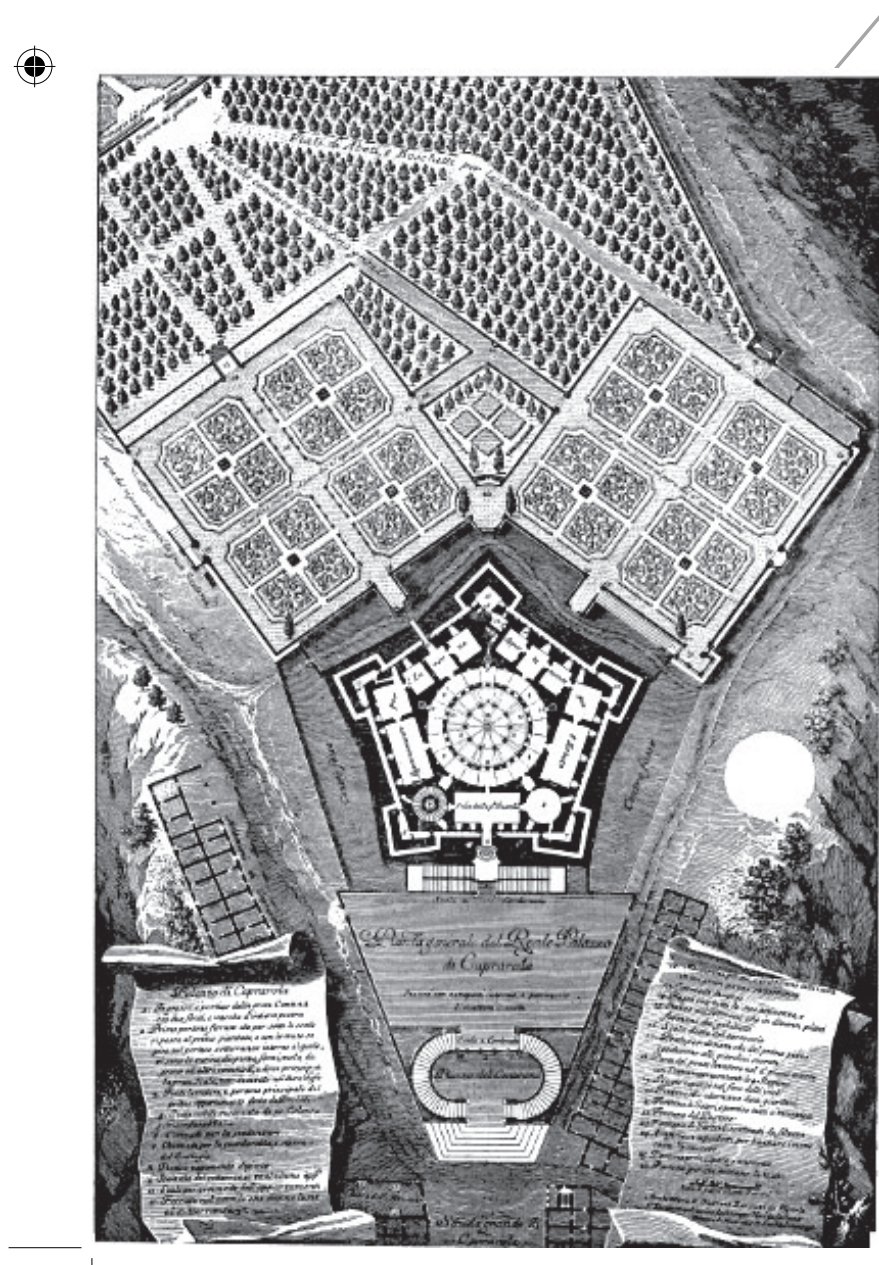
asociados a rampas, escaleras con caídas de agua entre los parapetos laterales, también denominadas en ocasiones como "escaleras de agua", fuentes murales adosadas a los paramentos verticales o acopladas en escalinatas. Todo un catálogo de movimientos y juegos de agua que influyen directamente en la velocidad de la visita y en el ánimo en la experimentación del propio dispositivo y, por extensión, de todo el conjunto del jardín o de la villa.

Otro caso interesante dentro de las mismas coordenadas culturales e históricas del jardín clásico italiano y que completa y enriquece la visión de Villa Lante es, sin duda, 

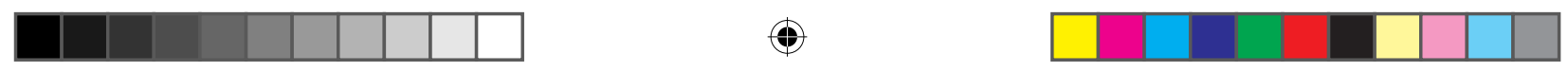

el complejo de la

Villa Farnese en Caprarola.

El palacio

construido para

la familia Farne-

se en Caprarola

se sitúa al final

de una calle que

surge rectilínea

desde el cen-

tro de la pobla-

ción y que con

una pronunciada

pendiente ascen-

dente nos lleva

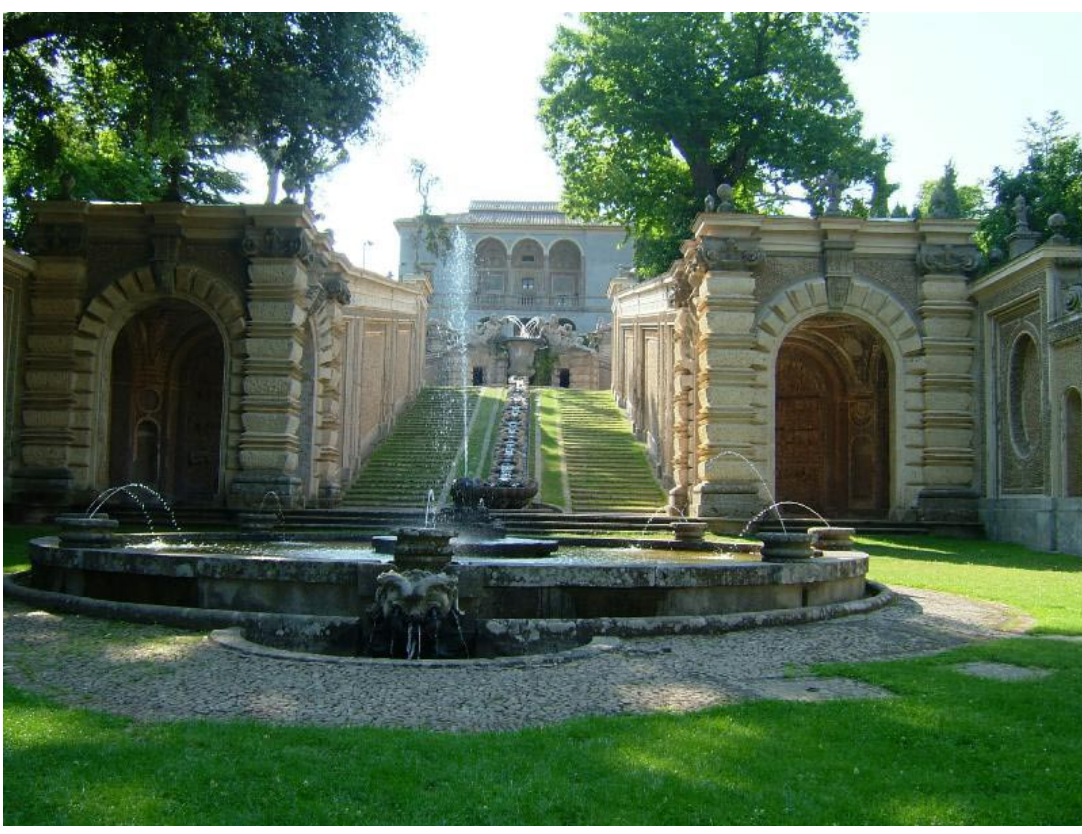

hasta el palacio

Vista hacia la fuente de Los Gigantes, Villa Farnese.

que sirve de este modo de cierre de perspectiva. Las sucesivas rampas, escalinatas y taludes que ascienden hasta el pabellón de acceso no pretenden tanto entablar una relación con la población como establecer, tal y como nos señala Miguel Angel Anibarro: "una distancia insalvable con ella, enfatizando el alejamiento del palacio y fijando un itinerario procesional destinado a suscitar el reconocimiento de la condición superior de sus habitantes." 5

Ya en el interior del parque llegamos, tras recorrer una avenida flanqueada por abetos y en ligera pendiente descendente al denominado Jardín Grande de Caprarola. Esta avenida nos ha conducido hasta un pequeño claro delimitado lateralmente por muros que descienden de cota hasta unos pedestales en el testero. En el centro se sitúa una fuente circular que marca el punto focal de arranque del recorrido, a partir de

5 Anibarro, Miguel Ángel, La construcción del jardín clásico. Teoría, composición y tipos, Akal, Madrid, 2002, p.215.

150 
este punto se activa el sofisticado sistema perspectivo que despliega el casino y el jardín en su conjunto a medida que ascendemos. Enmarcada la perspectiva por los pórticos laterales de la rampa, los muros laterales acuciados por el fluir del agua fugan precipitadamente hacia la fuente de Los Gigantes y la logia del casino. La pareja de "ríos" recostados que forman la fuente de Los Gigantes se convierten en metáfora de la vida misma en cuanto rio $^{6}$. A medida que ascendemos, irán apareciendo las escaleras curvas laterales y se amplía el plano del fondo. Al tiempo, las escaleras perimetrales nos invitan a continuar ascendiendo.

La rampa sube hasta la primera plataforma, de forma ovalada, con límites dinámicos dibujados por cuatro fuentes alojadas en los muros de cierre. Estos muros acompañan sendas escalinatas que siguiendo su curvatura ascienden hasta la siguiente plataforma, a la que accedemos tras superar unos pequeños escalones a la altura de los gigantes de la fuente. Sin embargo, la posición centrada del casino le resta rotundidad y aceleración al movimiento, contrariamente a lo que sucedía en Villa Lante, donde lo prioritario era el eje y su recorrido. Serán necesarias dos escaleras perpendiculares a nuestro ascenso para sortear el casino, lo que interrumpe la fluidez del ascenso y frena la velocidad del visitante. El movimiento acelerado por el fluir del agua en la cadena de agua de la parte inferior se tranquiliza y ralentiza en la parte superior y posterior al casino. El eje termina en una exedra abierta formada por cuatro pilares entre los cuales se sale al bosque y se fugan las visuales.

Ahora bien, esta terminación del eje que recorren aquellos que visitan el jardín viniendo a pie desde el palacio supone por el contrario el comienzo para aquellos que llegan al conjunto a caballo o en carruaje. La villa se recorre pues en dos sentidos bien distintos y con velocidades diferentes. Viniendo desde el palacio, la villa se entiende, se lee y experimenta como un lugar de solaz respecto a la vida en palacio, más estricta

6 La aparición, muy extendida, de estatuas y grupos escultóricos referentes a diferentes ríos, sean éstos míticos o locales, hace hincapié en el enorme éxito en este período de una concepción de la vida entendida como un eterno vagar, como un transcurrir nunca estático, que va desde el nacimiento hasta la muerte. 
y ordenada. Desde el parque, la edificación se reconoce como un pabellón de caza. El jardín Grande de Caprarola nos enseña de qué modo la misma forma arquitectónica es percibida y reconocida de modo bien distinto según el movimiento del propio espectador, según la secuencia de aproximación. Para ello se han puesto todos los mecanismos formales y espaciales a trabajar para alcanzar un conjunto con múltiples lecturas y enriquecido por las diferentes velocidades de aproximación y los flujos que recorren todo el conjunto, desde el antiguo núcleo medieval hasta la puerta de carruajes situada en el extremo opuesto del jardín.

Tanto Villa Lante como el Jardín Grande de Caprarola nos muestran la presencia de una fuerte componente dinámica en el jardín clásico a la italiana y nos ayudan a reconocer el verdadero papel protagonista que el movimiento tiene en estos jardines, desplegando todo el potencial arquitectónico, plástico y paisajístico de las villas italianas de los siglos $\mathrm{XVI}$ y el XVII.

La experimentación italiana llevada a cabo estos años, alcanzará nuevas cotas, en ocasiones llevadas al paroxismo, en los grandes complejos franceses posteriores tales como Vaux-le-Vicomte y Versalles, obras ambas que contaron con la participación de un personaje de excepción: André Le Nôtre. En estas residencias, como en obras similares del período, el arte de los jardines era una pieza clave con la que trasmitir, presentado en un envoltorio majestuoso, un mensaje claro y nítido: el poder del comitente y su interés por el arte y los ideales humanistas. Inquietudes, de hecho, que no hacen sino reafirmar su preeminente posición social. La racionalización de los recursos a veces juzgados inagotables en aras del discurso del arquitecto paisajista para crear todo tipo de artificios que prolongan y enriquecen la arquitectura construida no pierde de vista nunca este objetivo. Como nos dice el arquitecto y paisajista francés Bernard Jeannel, "era, sin embargo, muy consciente (...) de que si se recurría a su talento era para disponer el decorado de una escenificación que podía llegar sobre todo con ocasión de las grandes fiestas, hasta el extremo de una coreografía ritual, síntesis tan sabia como hábil de los mitos de la 

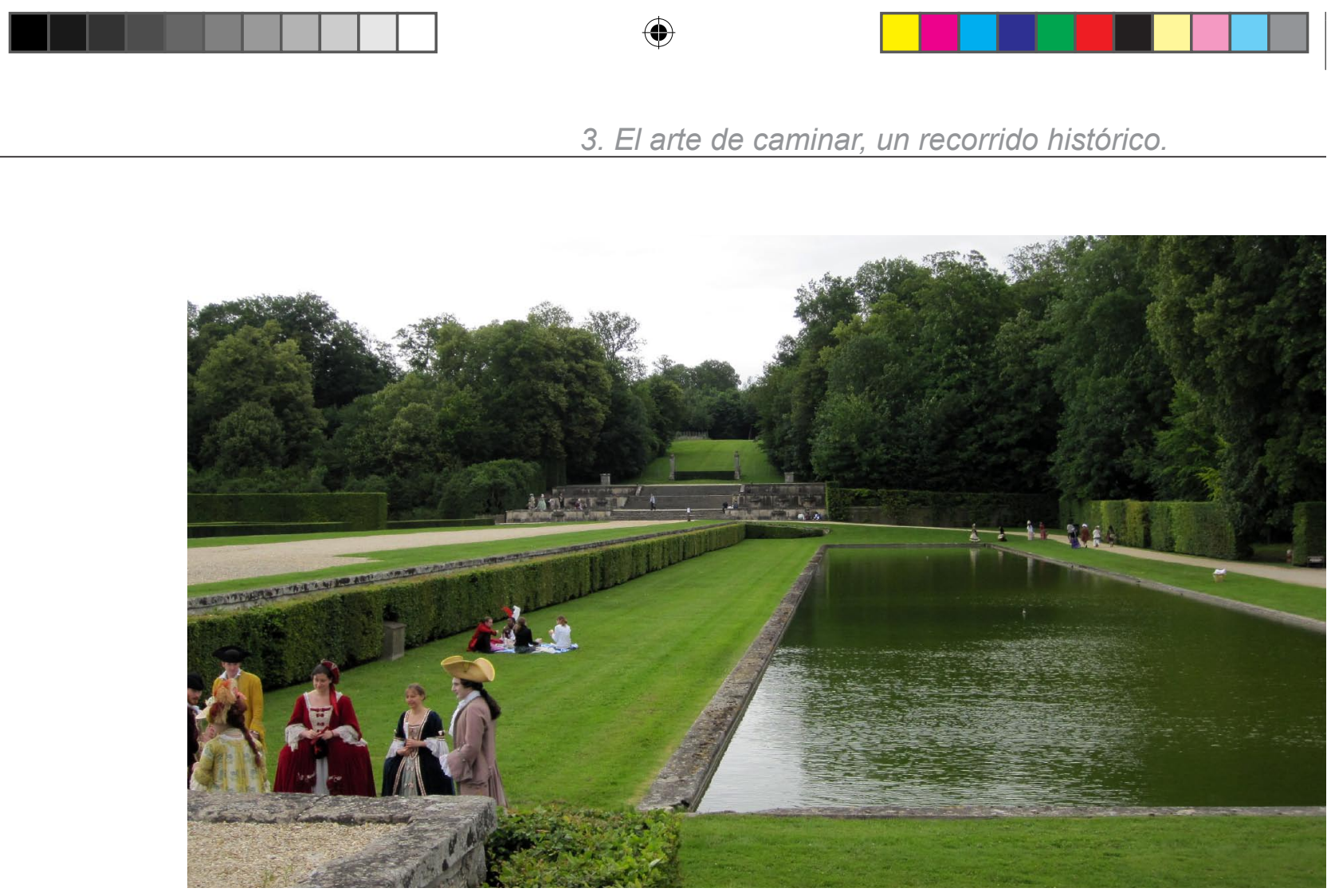

Castillo de Vaux-le-Vicomte, 1656-61, Maincy, Francia, (fotografía I.C).

creación, base del poder y de su religión."7

El palacio de Vaux-le-Vicomte, edificado para Nicolas Fouquet, superintendente de finanzas de Luis XIV, alberga el que podemos considerar primer jardín monumental francés, heredando las experiencias italianas y ampliando sus conquistas espaciales. El hecho excepcional de que se partiese de una casi total ausencia de preexistencias significativas otorga al conjunto su fuerte carácter unitario y un alto grado de libertad que permitió al arquitecto Charles Le Brun y al paisajista André Le Nôtre ejecutar una obra sin renuncias dignas de consideración. La alteración del lugar se produjo en aras del dominio y la domesticación de la naturaleza en un deseo de proyección narcisista y una elevada ansia de eternidad. Desde la misma posición del palacio hasta el grado de declive de parterres y taludes o la longitud de los canales de agua, todo está pensado y ordenado mediante un sabio juego de compensaciones de las deformaciones visuales propias de las leyes de la perspec-

7 Jeannel, Bernard. Le Nôtre, Akal, Madrid, 2003, p.9 

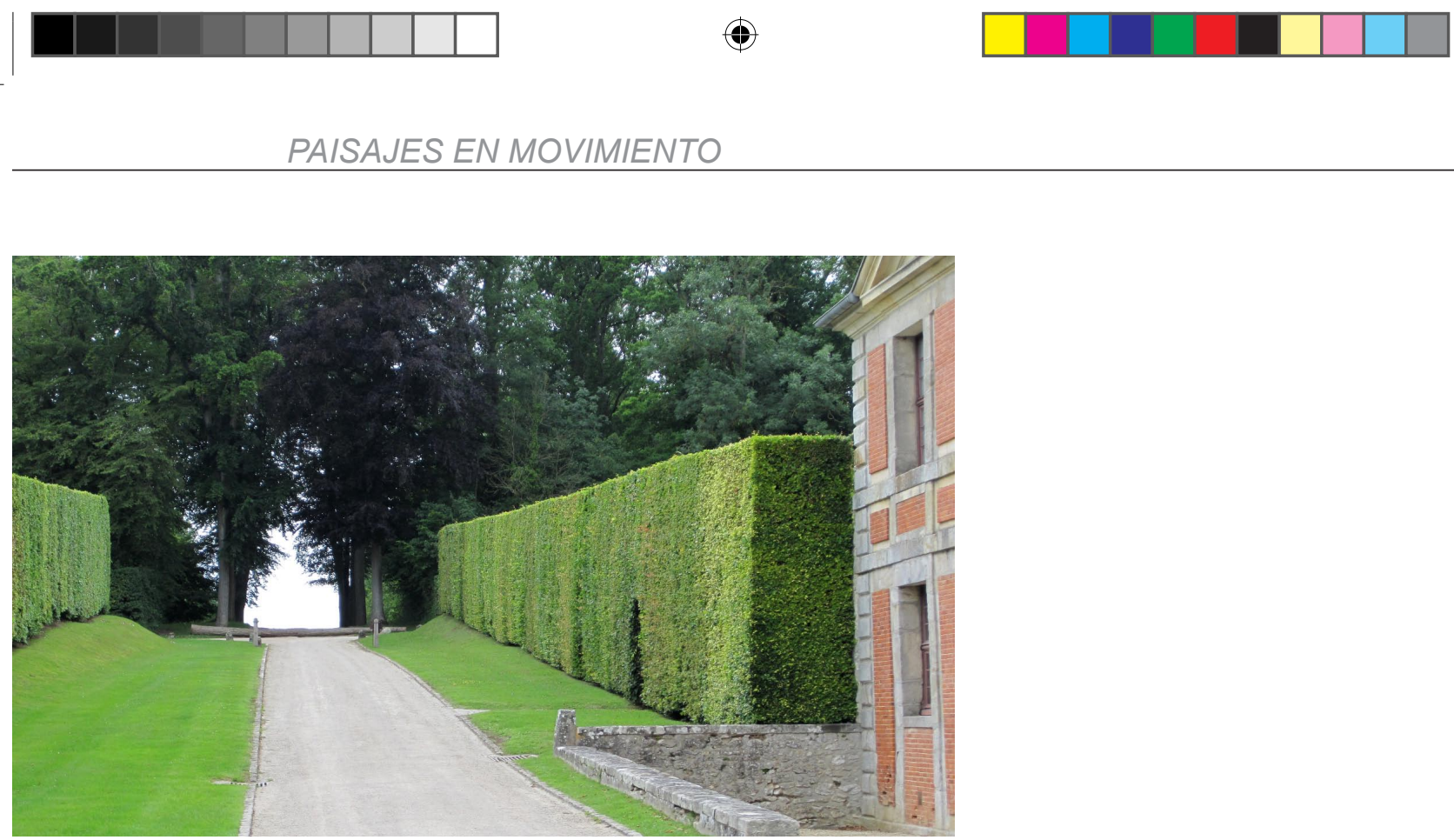

Acceso lateral, Castillo de Vaux-le-Vicomte (fotografía I.C).

tiva que llevaban décadas conociéndose y perfeccionándose. Todo ello para transmitir, como veíamos, un deseo de trascendencia, una ilusión de eternidad. Vaux supone en cierto modo un progreso respecto al modelo italiano ya que aun siguiendo los mismos cánones y métodos ya vistos, es extremo el rigor de los mecanismos de perspectiva y la inteligente utilización de los "efectos sorpresa" que producen una fuerte impresión en el espectador que queda maravillado ante lo que descubre a cada paso en su paseo por los jardines. Estos "efectos sorpresa" son presentados y posteriormente explicados durante el recorrido mismo, de modo que la lectura de las claves de tales acontecimientos supuso un gran divertimento a los visitantes del jardín hecho que les dio una gran notoriedad, ya en su época, a los autores.

En Vaux-le-Vicomte, la aparente estaticidad del conjunto, que en planta parece simple y evidente, se transforma en ilusión a medida que se recorren los senderos del jardín. El movimiento del espectador es, de nuevo, clave para alcanzar a comprender toda la complejidad e interés de los jardines que André Le Nôtre construyó para Nicolas Fouquet. 

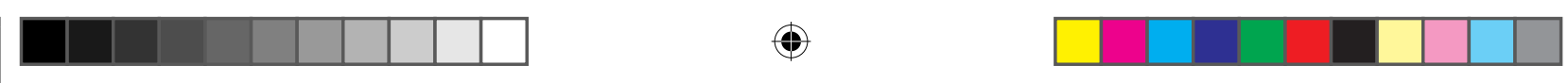

Desde su llegada, ya el visitante queda atrapado por una dinámica que le obliga avanzar por la monumental avenida procesional de plátanos que conduce al acceso principal del palacio, una imponente verja con su reja de forja y pilastras de Hermes. Aquí se produce un divertido juego de interacción entre los motivos de la

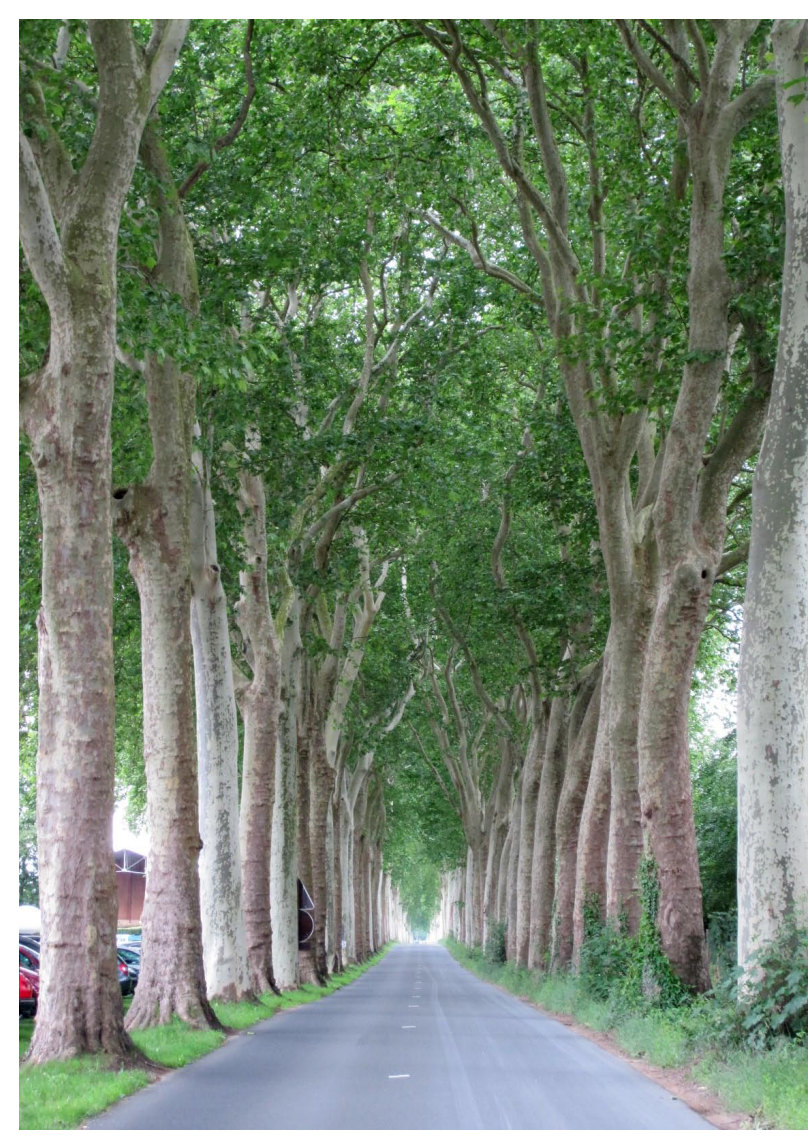

Acceso principal, Castillo de Vauxle-Vicomte (fotografía I.C). reja de entrada y aquellos motivos similares de la fachada del palacio que queda detrás, juego que hace bascular la relación figura fondo creando un movimiento inesperado y sorprendente en la propia percepción de la fachada, haciendo avanzar y retroceder la masa de la edificación. A medida que avanzamos a lo largo del eje, las relaciones entre los distintos elementos cambian constantemente dejando en evidencia la supuesta estaticidad del conjunto. El divertido juego que se establece entre el exquisito adorno de forja de la puerta en un primer momento con la fachada del palacio, a continuación entre ésta y el frontón del pabellón central, posteriormente con el tejado y finalmente explotando en el cielo sobre las cubiertas, tal y como lo hacían los fuegos de artificio con ocasión de las fiestas que allí se celebraban, actúa a modo de preludio de los mecanismos que rigen todo el conjunto.

Los elementos están dispuestos, como no podía ser de otro modo, en relación los unos con los otros, pero también y sobre todo, en función de la secuencia de aproximación, del espacio y del tiempo que media en- 


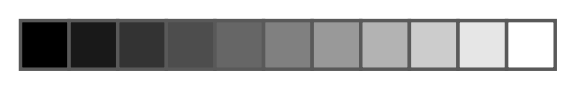

$\oplus$
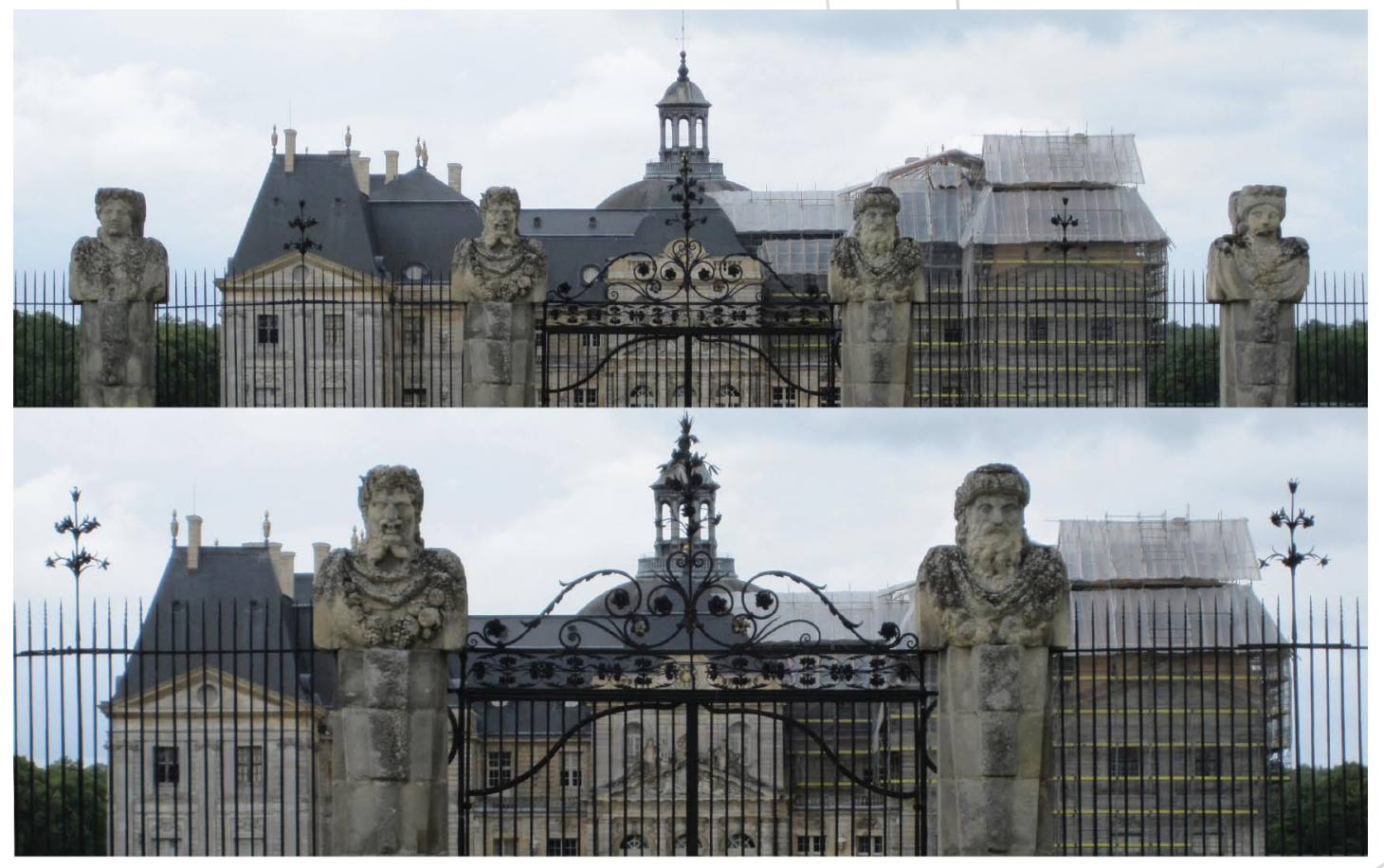

$(\varphi$

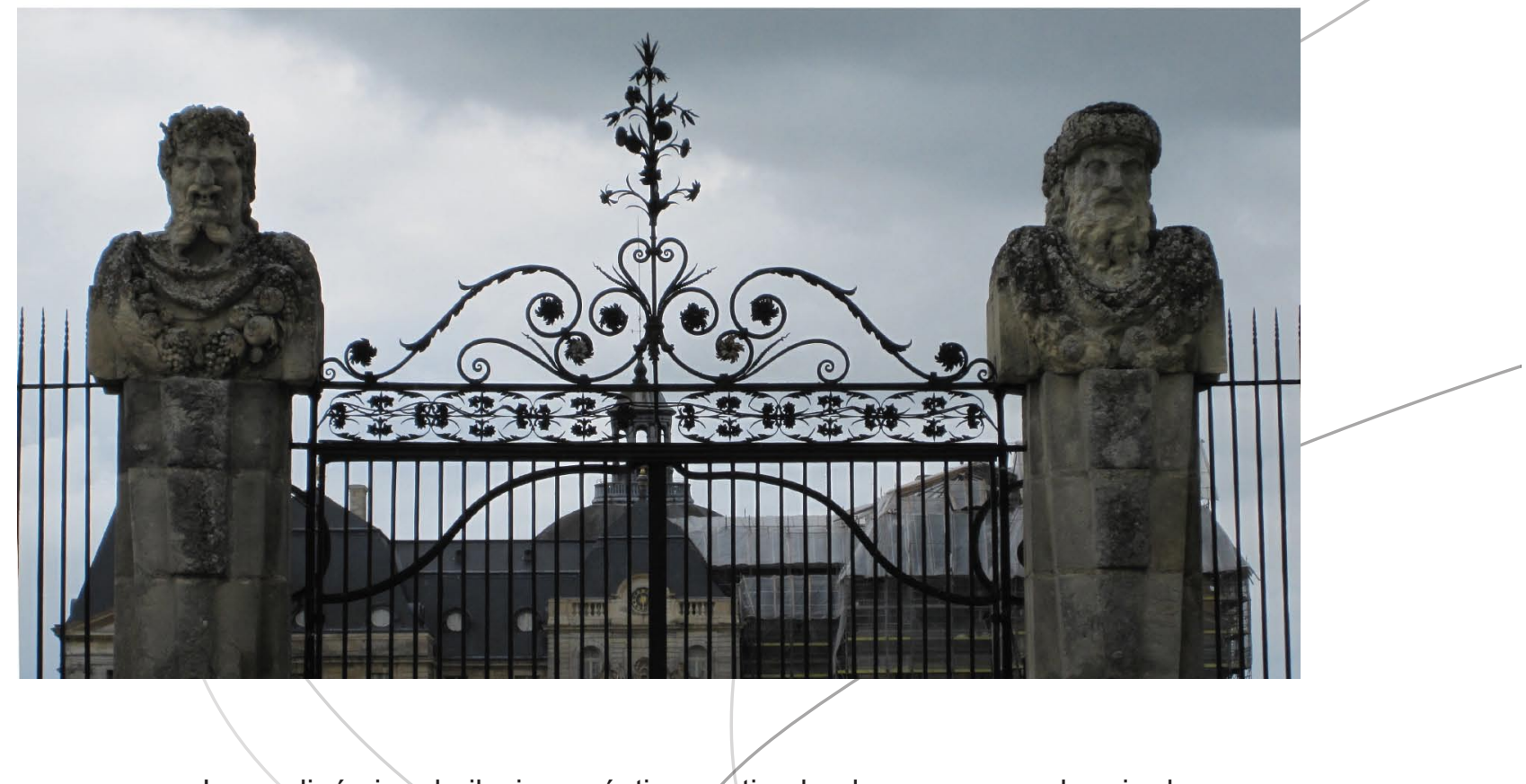

Juego dinámico de ilusiones ópticas activado al acercarnos a la reja de acceso al palacio. Las relaciones y las distancias entre el observador y el palacio varían según avanzamos, transformando/la escala perceptual del conjunto.

Castillo de Vaux-le-Vicomte (fotografías I.C).

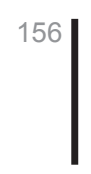



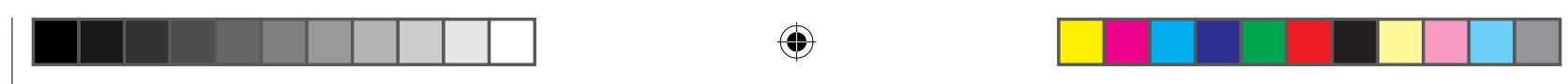

tre el espectador y la obra, de los desplazamientos ópticos de los motivos gracias al desplazamiento del visitante. La ligera pendiente del terreno produce un contrapicado del conjunto arquitectónico que enfatiza la monumentalidad del palacio, acentuando el movimiento inverso y acelerando la fuga visual. La balaustrada más próxima a la fachada del palacio acentúa, gracias a su mayor altura, la progresión dinámica que conduce al palacio. Aquí, la posición del edificio corta el eje, al contrario de lo que sucedía en Villa Lante, pero no para detener el movimiento sino para provocar un ritmo, una cadencia alterada y sinuosa que obliga a descubrir episodio a episodio las sorpresas y las maravillas de Vaux. Éste no se contempla en su magnificencia (aún) sino que debe de recorrerse para ser aprehendido, para dejar al visitante admirado por el control aparentemente total de la naturaleza y el dominio de la tecnología (sobretodo hidráulica) que permite los juegos de sorpresas que jalonan sus jardines.

La visión velada del jardín desde las ventanas del palacio acelera el movimiento, deseoso de conocer aquello que ahora tan sólo se le deja entrever. Es, una vez pasadø el vestíbulo y atravesado el salón oval, ya en las gradas que conforman la terraza, donde se despliega una visión global de los jardines de Vaux que deja boquiabierto al visitante del palacio. Premeditadamente, esta visión no es (aunque lo pueda parecer) completa sino que muestra algunas piezas y esconde sabiamente otras que se irán descubriendo durante el propio recorrido del jardín. La perspectiva que aquí se ofrece al espectador está inteligentemente cerrada allí donde interesa al autor. Por ejemplo lateralmente, donde los muros vegetales ralentizan el recorrido obligando al visitante a concentrarse en el punto central, único punto donde la perspectiva queda abierta. Así pues, la fuga en su conjunto se prolonga hasta alcanzar la figura de Hércules y luego más al fondo para proyectarse, para lanzarse, al infinito. El efecto está reforzado verticalmente por el talud verde que con su acusada pendiente ascendente produce un fuerte dinamismo vertical que ralentiza el movimiento visual hasta detenerlo en la estatua que corona y reina sobre la línea de horizonte: la mencionada estatua de Hércules., situada a la altu- 

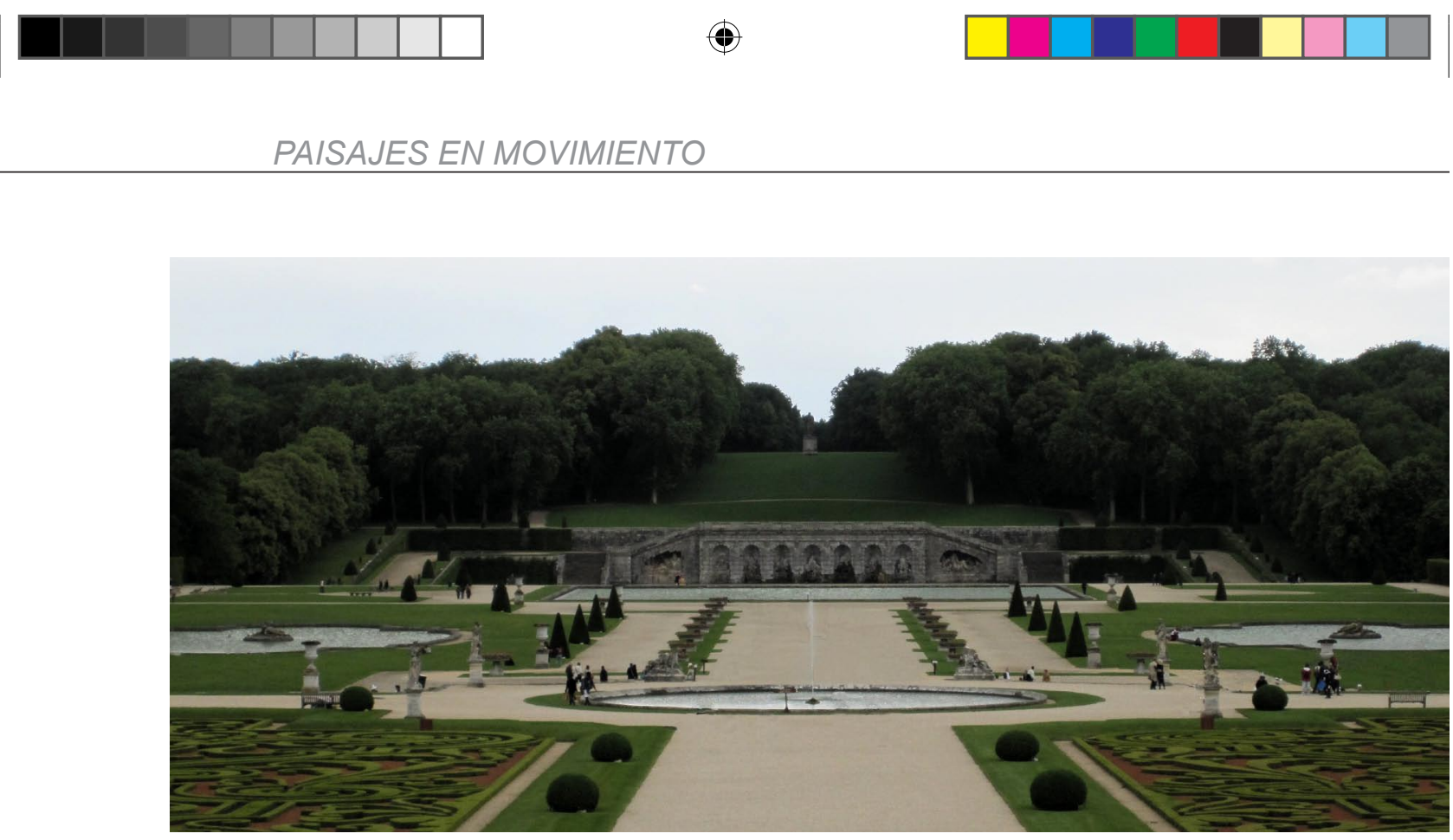

Vista de los jardines desde la terraza del palacio. Castillo de Vaux-le-Vicomte (fotografía I.C).

ra visual del propietario del palacio que queda de este modo en parangón con la figura mítica, con el famoso héroe hijo de Zeus y Alcmena.

En este momento el jardín se nos aparece sensiblemente plano, será caminado por él del modo en que iremos descubriendo y comprendiendo los diferentes niveles existentes en Vaux-le-Vicomte. Una vez superados los estanques transversales, avanzamos por el eje central a través de la allée d'eau (avenida de agua), un paseo bordeado de surtidores de agua cuya altura constante quedaba a modo de dinámica balaustrada siempre en movimiento. A partir de este punto nos sorprendemos de la rapidez a la que se suceden los cambios en las relaciones entre los diferentes elementos del jardín, relaciones que creíamos conocer y controlar desde la terraza y que ahora devienen inestables por sorprendentes. La gruta que parecía elevarse por encima del estanque cuadrado ha desaparecido y nos encontramos ante una zona deprimida donde aparecen visibles ahora las Grandes Cascadas. Aquí el agua se vierte por máscaras grotescas espumeando y deslizándose por vasos y demás elemen- 

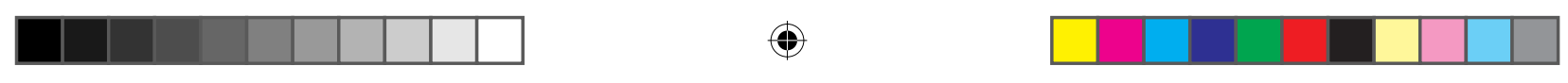

3. El arte de caminar, un recorrido histórico.

tos escultóricos hasta alcanzar el estanque rectangular de su base. La avenida de agua no hace sino guiar nuestros pasos, prepararnos, para la sorprendente innovación técnica y para el consecuente deleite estético que suponía la contemplación de tal cantidad de agua en movimiento.

En toda esta estudiada puesta en escena el sonido jugaba, sin lugar a dudas, un papel de primer orden, tejiendo una idea de misterio que suponía una componente vital para el éxito del recorrido y la experimentación del jardín. Un sonido inaudible desde el palacio y que iba in crescendo, aumentando en intensidad y capacidad sugerente, a medida que

el visitante se acercaba

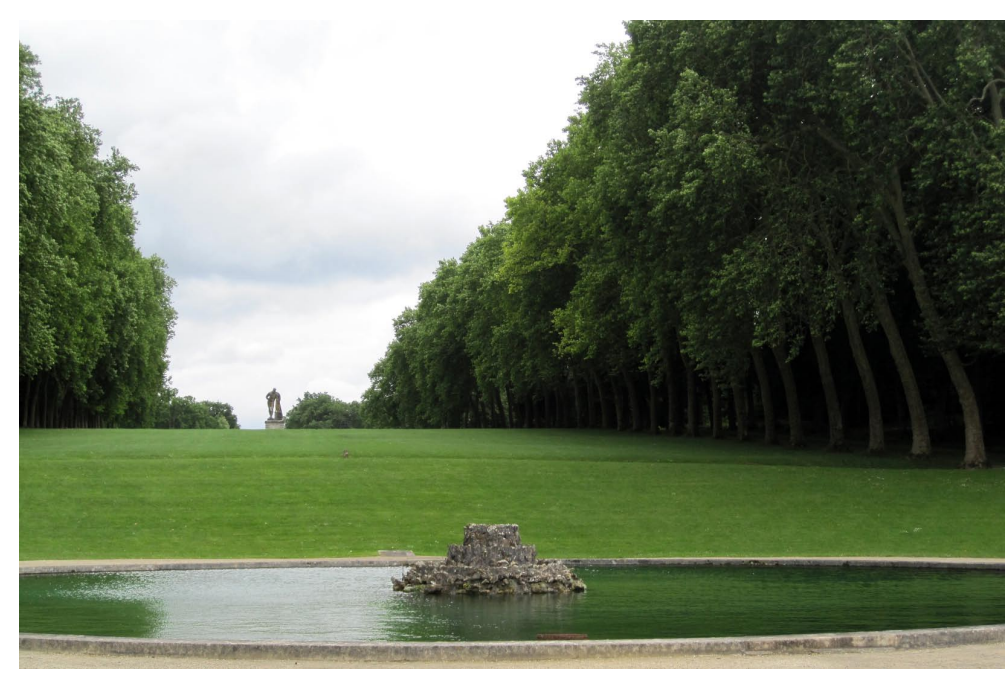

Terraza de La Gerbe, con la estatua de Hércules al fondo, Castillo de Vaux-le-Vicomte (fotografía I.C). a las cascadas.

Una vez alcanzada la estatua de Hércules al final del recorrido del eje longitudinal, ya en la terraza de la Gerbe, tras subir dos juegos de rampas y dos escaleras monumentales simétricas hasta la parte superior y continuar franqueado por dos avenidas laterales de plátanos que dan la réplica a aquella del acceso, el eje se despliega en tres direcciones multiplicando así las fugas hacia el infinito y ampliando, en consecuencia, la sensación de infinitud del conjunto. ${ }^{8}$

En este punto, si volvemos la vista atrás hacia el palacio, los diferentes elementos del conjunto se colocan en una relación nueva y distinta

8 Esta sensación hoy en día ha desaparecido debido a los cambios sucedidos en las inmediaciones del dominio de Vaux-le-Vicomte. 

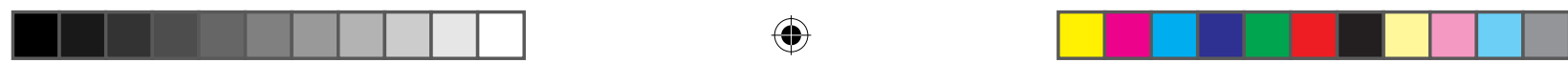

los unos con respecto a los otros. Las fugas de las diferentes líneas que componen el jardín crean un fuerte efecto de armonía visual ahora que contemplamos el palacio situado en el centro, gracias al inteligente trabajo de niveles. Estas ilusiones ópticas son puestas en marcha a medida que nos desplazamos según las coordenadas planteadas por Le Nôtre y por tanto no se pueden pensar aisladamente, sino en la medida en que la experiencia y la interacción del espectador en movimiento las activa. En la base de la escultura de Hércules, el espectador comprende el cambio que ha experimentado la ordenación del jardín desplegado ante sus ojos. Ahora nos encontramos en la cima de una pendiente pronunciada contemplando un jardín que antes pensábamos plano y que ahora se ha convertido en el magnifico zócalo del palacio. La fluctuación de líneas horizontales y verticales pone en funcionamiento todas las fugas de los diferentes elementos del jardín.

A medida que descendemos, el juego de relaciones se transforma y se establecen nuevos diálogos, aunque siempre con el palacio como protagonista indiscutible. A pesar de la rigidez formal del esquema organizativo, los cambios y transformaciones del conjunto son prácticamente constantes. El palacio parece acercarse por momentos para alejarse a continuación y ello sin solución de continuidad en un movimiento construido por Le Nôtre mediante ilusiones ópticas y que alcanzó en Vaux-leVicomte cotas extraordinarias.

La continuación, y en bastante grado la culminación, de las experiencias llevadas a cabo en Vaux fueron las transformaciones llevadas a cabo por el paisajista francés en el castillo de Versalles para adecuarlo a las necesidades de representación que tenía el poder real en la Francia

Secuencia espacial de aproximación al palacio desde la estatua de Hércules, Castillo de Vaux-le-Vicomte (fotografías I.C). 

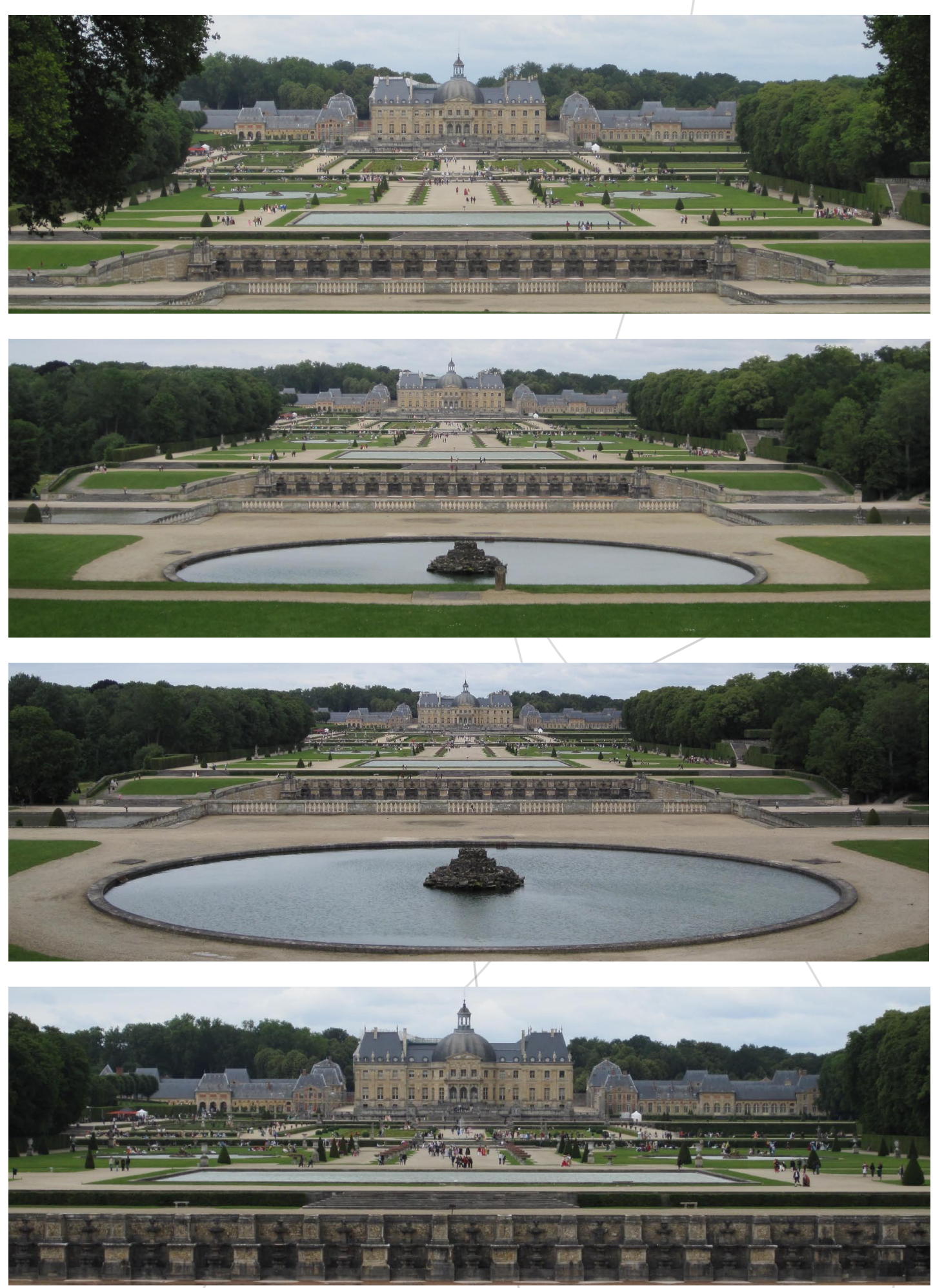


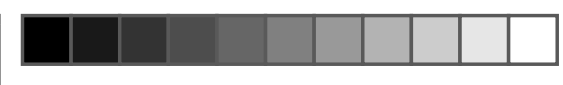

del siglo XVII, especialmente la figura que apostó por Versalles contra todo pronóstico: Luis XIV ${ }^{9}$.

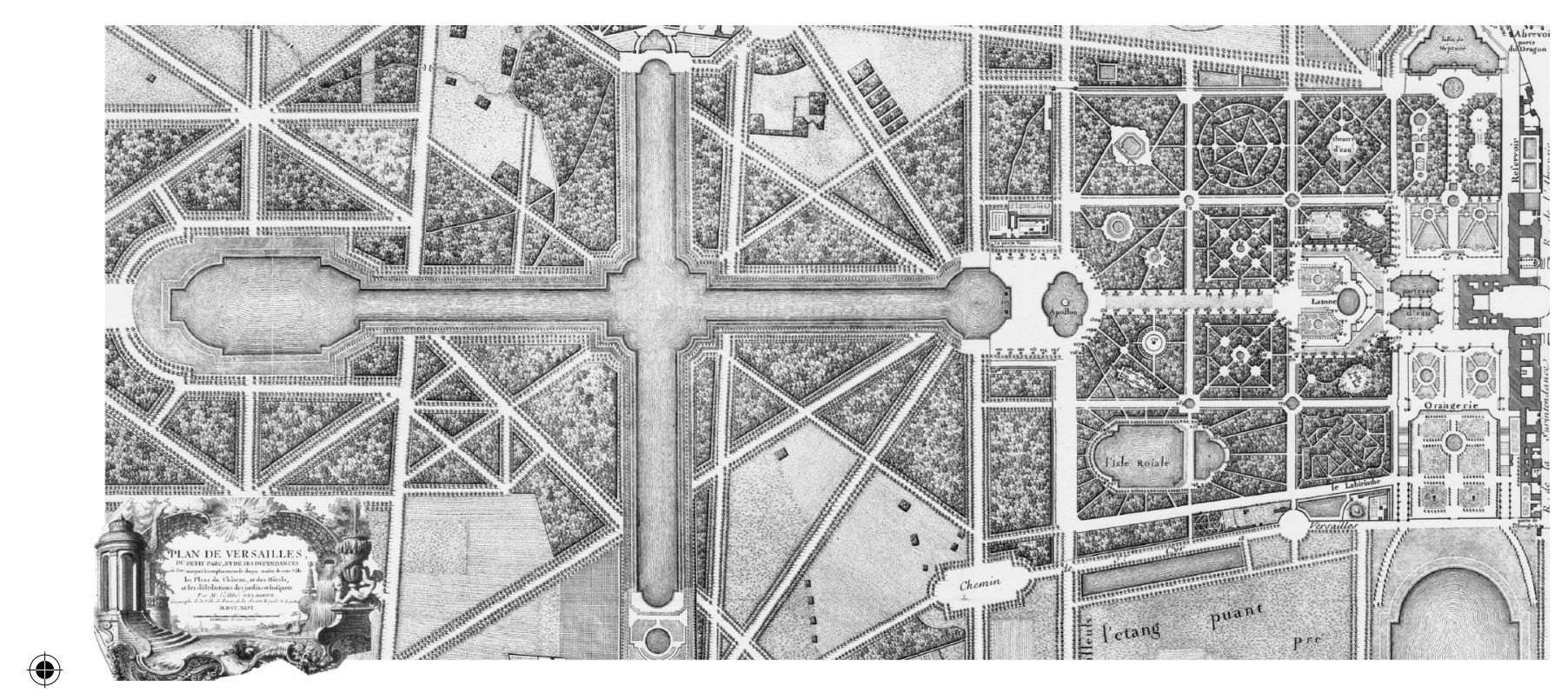

Plano de Versalles del abad Jean Delagrive, (1746).

Los jardines de Versalles son una pieza clave del palacio, al crear un gran dispositivo con un profundo carácter alegórico reconocido en el hecho que, de modo excepcional, el propio rey redactase de su puño y letra unas instrucciones para el "correcto" recorrido del jardín, de tal modo que de este recorrido se pudiesen extraer las enseñanzas que el monarca deseaba, desvelando el sentido oculto del jardín y dejando al visitante boquiabierto ante su magnificencia (especialmente si éste era extranjero). Versalles está repleto de juegos de ilusión perceptiva, de ajustes geométricos y formales al modo que veíamos en Vaux. Así, los juegos acuáticos de Versalles, al igual que sucedía en Villa Lante o en Vaux-le-Vicornte, eran parte activa fundamental ya desde su concepción.

9 Conocida es la oposición de Colbert, quién en una carta de 28 de septiembre de 1665 le dice a su soberano: "iOh qué lamentable sería que el más grande rey fuese medido por el rasero de Versalles! Y sin embargo es de temer tal desgracia." Jeannel, Bernard, Op cit, p.46. 

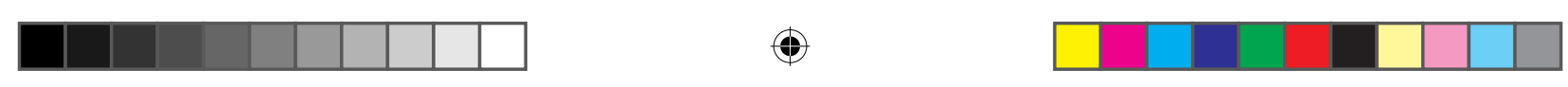

Por la escala de la actuación, por la densidad de los temas tratados en Versalles y debido a la profundidad de los planteamientos de una obra tan inconmensurable (y tan ampliamente tratada en la bibliografía) como ésta, realizar un exhaustivo re-

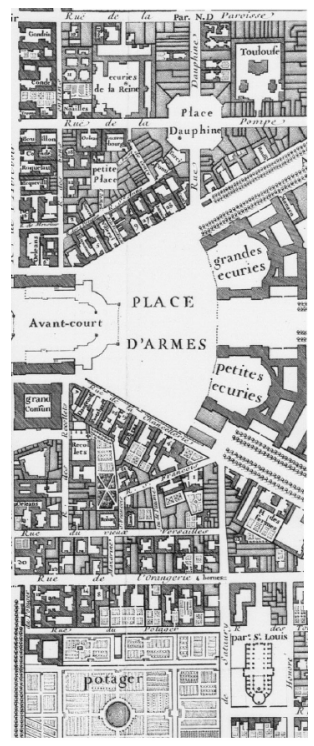
corrido por Versalles excede el objetivo de este estudio. A pesar de ello, sí me gustaría dar algunas pinceladas que ayuden a completar nuestra visión del jardín francés de la época según las claves que estamos desarrollando, claves que vamos también a encontrar, cómo no, en Versalles. Para ello comenzaré por aproximarme a uno sólo de los numerosos ejemplos de estos juegos acuáticos que activaban los elementos del jardín haciéndolos vibrar en ocasión de los grandes acontecimientos y de las visitas del rey. Para entender algunos de los mecanismos dinámicos de Versalles, nos acercaremos al desaparecido Téâtre d'eau (Teatro de agua), junto a los bosquecillos del Marais. Aquí, como su propio nombre indica, la protagonista indiscutible es el agua, pero en movimiento. El acceso se producía a través de un único punto con lo que se controlaban las visuales $\mathrm{y}$, lo que es más importante, las sensaciones e impresiones fruto de estas visuales, A partir de aquí, la zona circular estaba dividida en dos partes; una en semicírculo, limitada por tres niveles de bandas forradas de césped destinadas a los espectadores, la otra mitad destinada a los ac-

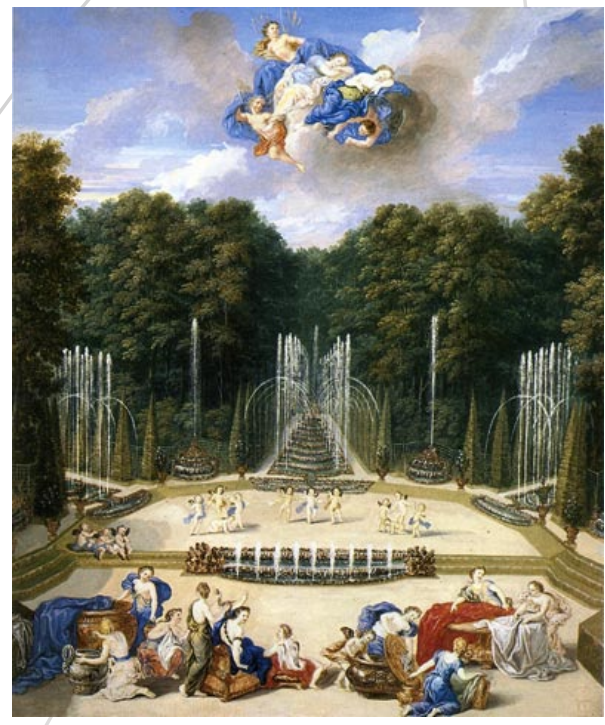
tores. Todo aquí está dispuesto Jean Cotelle, Teatro del agua, 1693. 


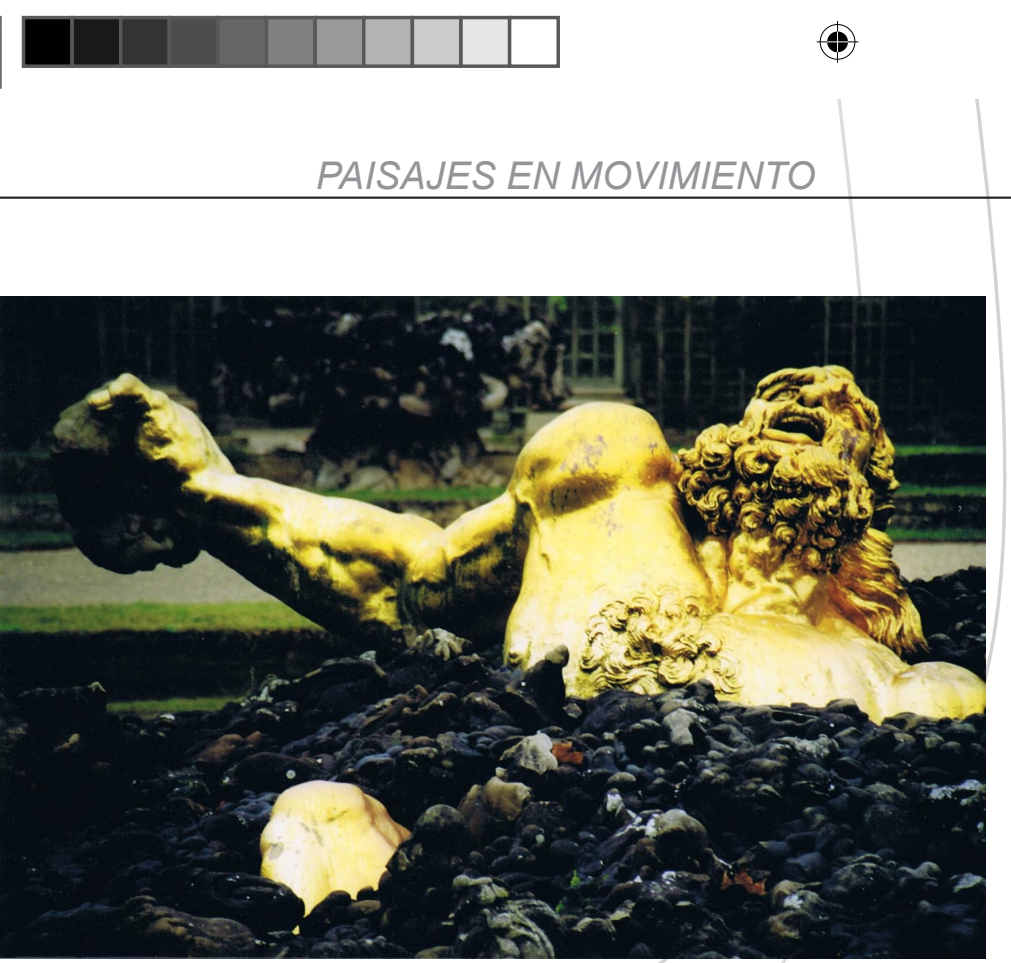

Palacio de Versalles, Siglo XVII, Fuente de Encélado (detalle) (fotografía I.C).

no para actuaciones teatrales (que de hecho no tuvieron lugar nunca), sino para el disfrute del espectáculo de las fuentes y surtidores en funcionamiento. La pendiente natural del terreno es aprovechada por André Le Nôtre para presentar mejor los juegos acuáticos. El conjunto lo completan tres avenidas de agua que partían directamente de la escena y que estaban formadas por sucesivos niveles superpuestos.

En todo caso, más allá de planteamientos formales o de juegos y divertimentos al modo de Vaux-le-Vicomte, (donde vimos dichos mecanismos más ampliamente), Versalles nos resulta un ejemplo especialmente interesante, debido a los textos que, ya desde los comienzos de la actuación, se escriben sobre el palacio y sus jardines. La importancia de dichos textos radica en que, como nos recuerda Juan Calatrava: "lejos de desempeñar un pasivo papel de mero "comentario", contribuyen activamente a la construcción ideal de la arquitectura regia, hasta el punto de que puede decirse que las más de las veces el palacio y sus jardines no eran directamente "visitados", de manera inocente sino "leídos" a través de la mediación de tales textos." ${ }^{10}$ Versalles supone un importante hito en cuanto a la importancia otorgada al recorrido para la total comprensión

10 Calatrava, Juan, "Introducción" en VW.AA, Manera de mostrar los jardines de Versalles, Abada editores, Madrid, 2004, p.10.

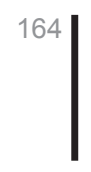



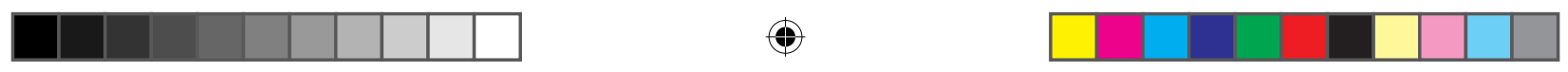

3. El arte de caminar, un recorrido histórico.

del jardín de un modo consciente y premeditado. La manière de mostrar Versalles no son sino las instrucciones dadas por el propio rey para visitar sus jardines de modo que el objetivo de los mismos y de su visita sea legible a los ojos profanos, con el claro propósito de dar cuenta del poder y la magnificencia del monarca. El hecho de que existan distintos recorridos

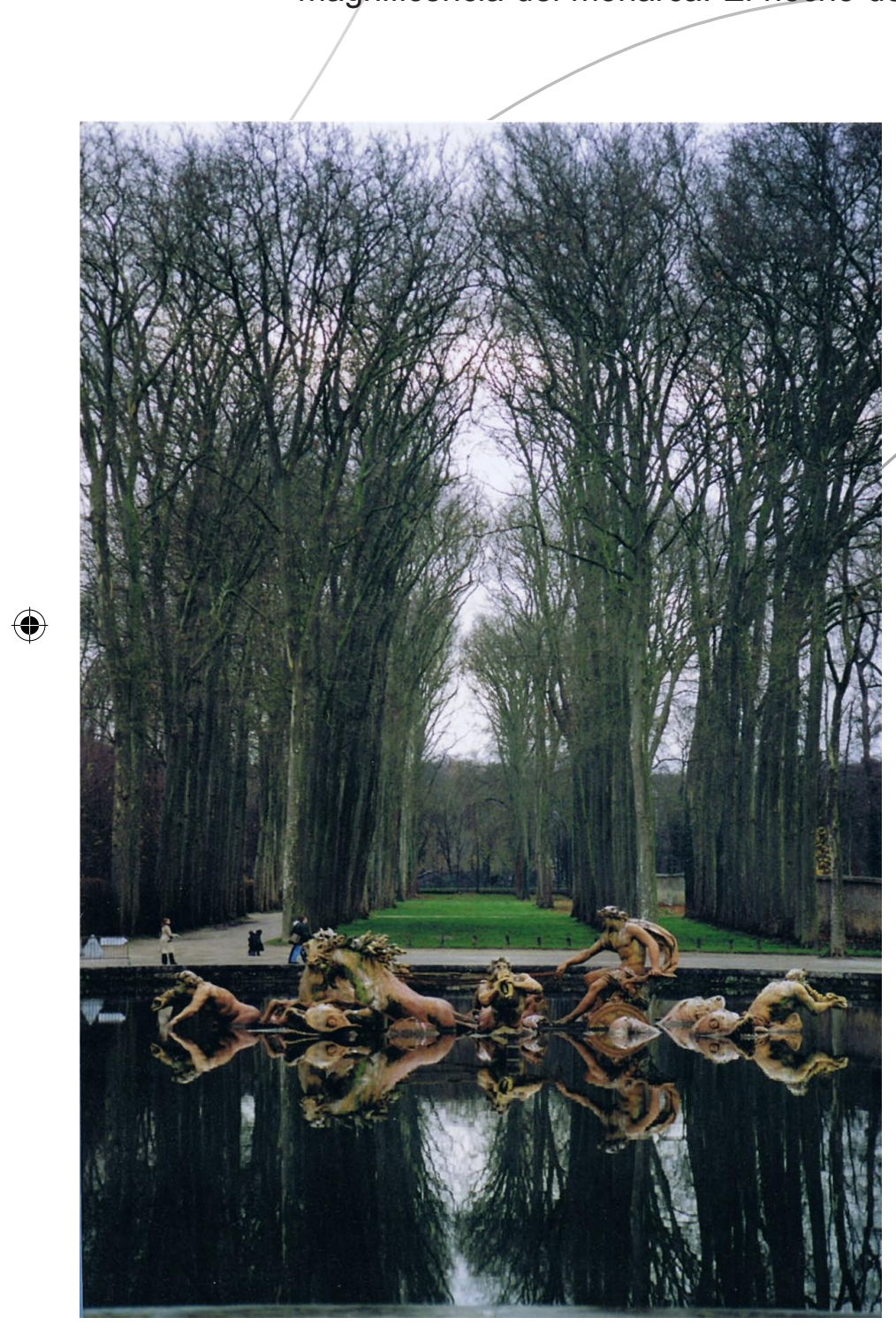

Palacio de Versalles, Fuente de Apolo (fotografía I.C). o "maneras" de visitarlo que proponen un determinado orden de experiencia incide en el reconocimiento del sentido alegórico del jardín, (que no puede de otro modo salir a la (uz), al tiempo que pone en evidencia que el recorrido en sí mismo crea contenido, transforma por tanto el espacio simbólicamente $y$, en consecuencia, genera paisaje y arquitectura.

Un aspecto fundamental de dichos recorridos es la correcta elección de los puntos de contemplación (y por tanto estáticos) que se activan correctamente si están bien situados en la secuencia espacio temporal. No resulta en vano pues, que el rey, el amo y señor del los jardines, se erija en el conocedor, en el demiurgo que posee las 

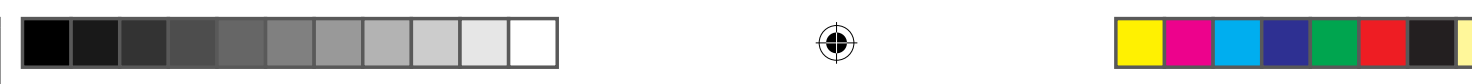

EI monarca Luis XIV nos dejó varios itinerarios par recorrer sus jardines, que suponen un testimonio excepcional. Abajo se preproduce las instrucciones relativas al Itinerario del 19 de julio de 1689 y su situación sobre el plano del abad Jean Delagrive.

19 DE JULIO DE 1689

LOUIS XIV

- Al salir de los baños, ir al centro de la Orangerie; después, hacer una pausa cerca del Laberinto para contemplar los naranjos y el palacio.

- Pasar por el alto de Latona, hacer allí una pausa, ir al Pantano, donde habrá fruta y helados.

- Descender a Ceres y a Flora.

-Entrar en los baños de Apolo, rodearlos.

- Ir al Encélado, salir por abajo para ir a la sala del Consejo.

- Pasar de nuevo por Flora.

- Entrar en la Montaña.

- Ir al teatro pasando por Ceres.

- Pasar de nuevo delante del pantano, sin entrar en él.

- Ir a las tres fuentes por la parte alta, donde habrá helados preparados.

- Bajar par ir a Neptuno, rodear el Dragón.

- Entrar en el arco de triunfo.

- Pasar de nuevo por Neptuno, rodearlo por el exterior, ir al encuentro de las carrozas en la verja que conduce al Trianon. 

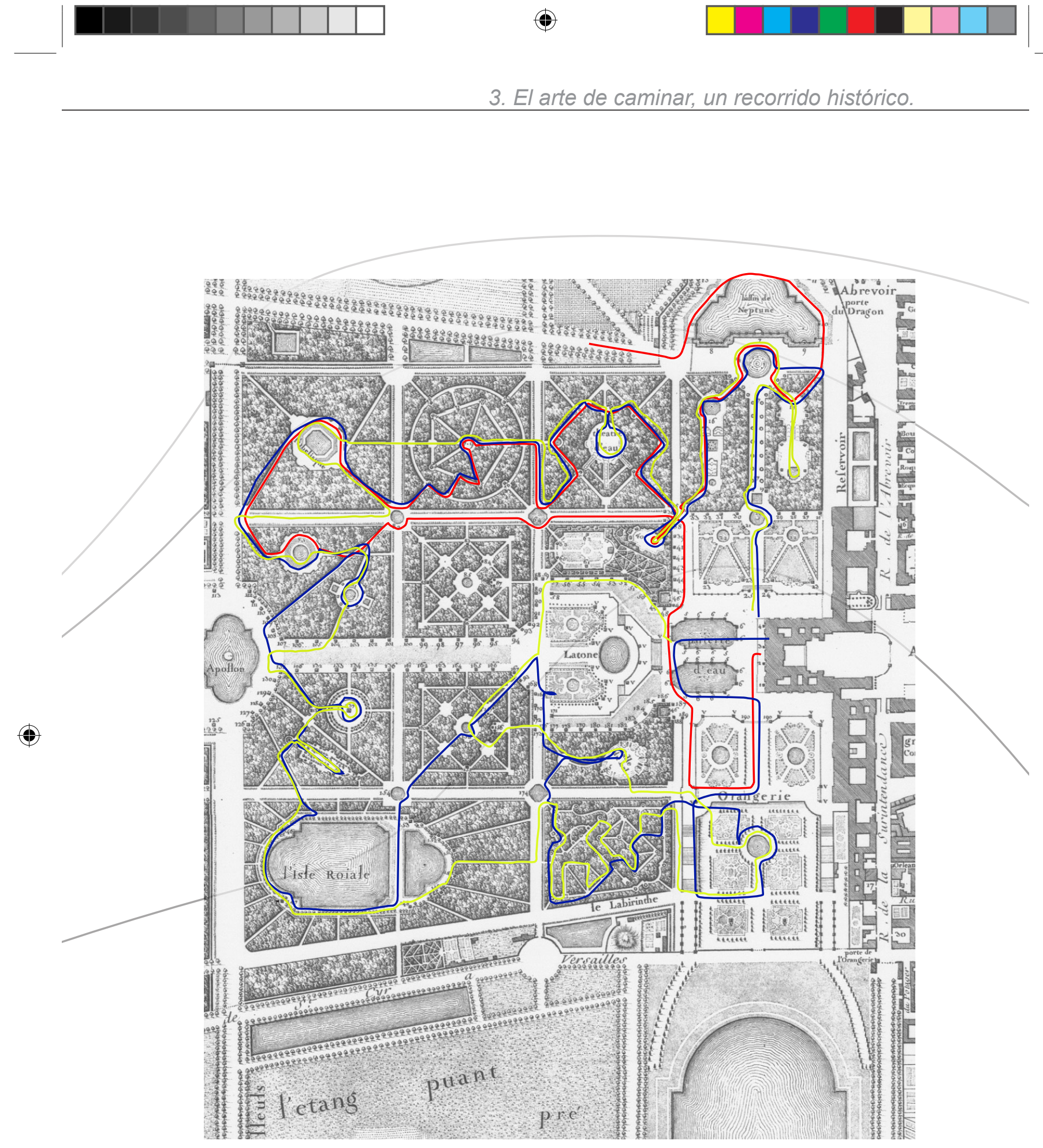

Itinerario fechado en 19 de julio de 1689

Itinerario fechado entre 1691 y 1695

Itinerario fechado a partir de 1702 


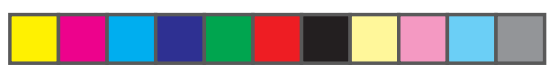

claves y las desvela de acuerdo a sus intereses políticos. Resulta especialmente significativo que el eje del Gran Canal, el eje áulico simbolizado por la fuente de Apolo, se cruce y contemple pero nunca se recorra. ${ }^{11}$ Así pues, la mayor parte de la visita que se "debe" hacer transcurre periférica al gran eje.

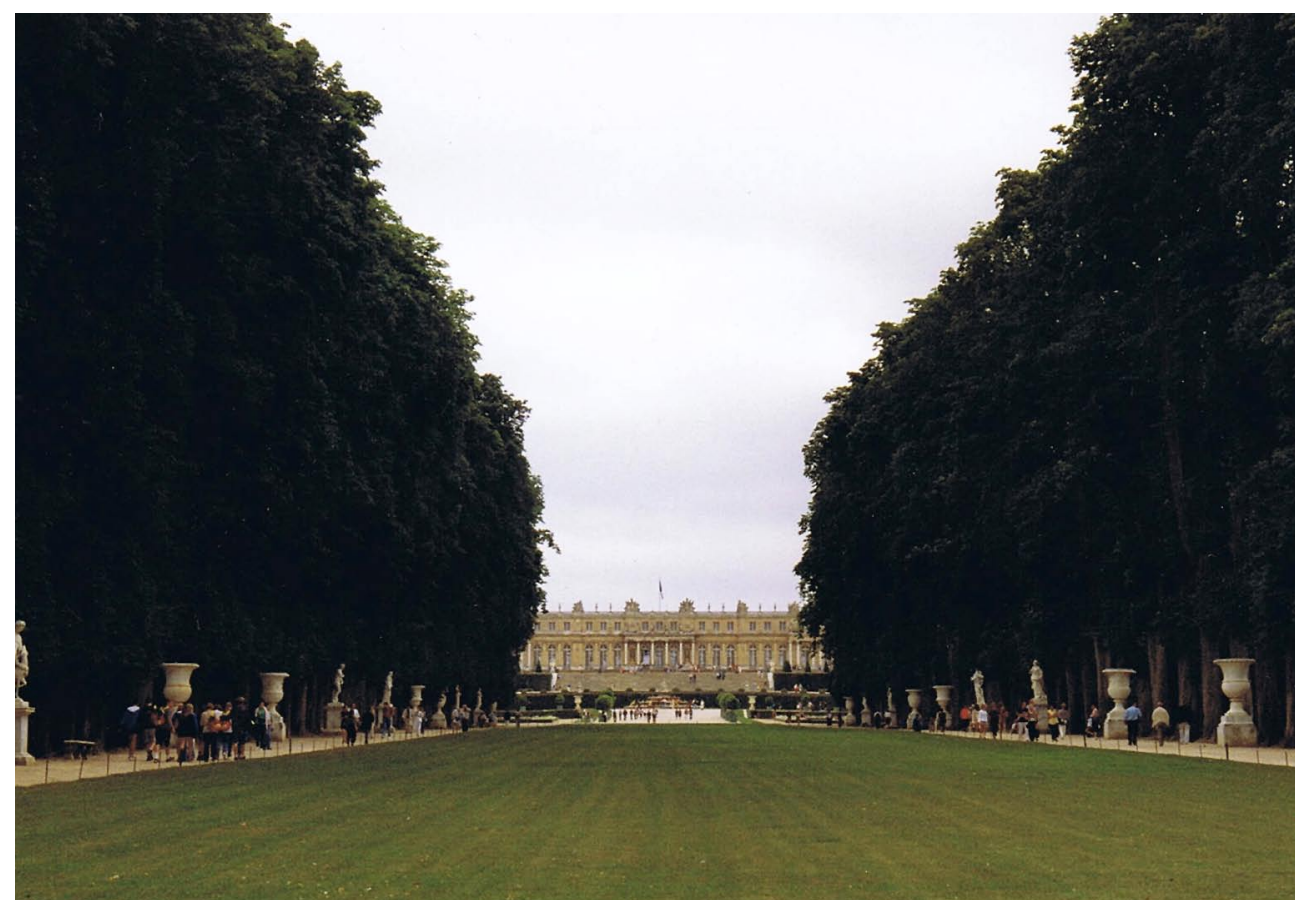

Palacio de Versalles, Gran Eje (mirando hacia el palacio), (fotografía I.C)

De igual modo, la famosa fiesta que se celebró en Versalles el 18 de julio de 1668 y que marcó un hito en la historia del palacio no tiene, significativamente, un escenario fijo sino que se trata de un recorrido por el jardín en el transcurso del cual se van sucediendo hechos extraordinarios tales como banquetes, juegos de agua, representaciones de tea-

11 Hoy en día, por el contrario, prácticamente todos los visitantes realizan el recorrido descendiendo a través del eje directamente desde el palacio, algo completamente ajeno a la forma de mostrar los jardines del rey y que por tanto no sólo desarticula la carga simbólica del jardín sino que sin lugar a dudas hubiera enojado profundamente a Luis XIV. 

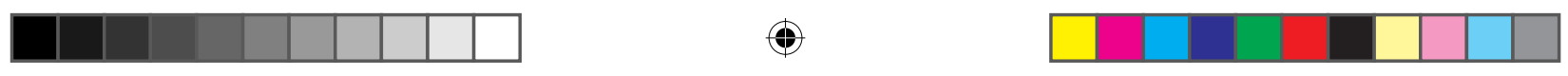

tro,... Así, los juegos de agua, los surtidores y estanques, se convierten en pieza clave de la puesta en escena de ese movimiento de visitantes y objetos al servicio del monarca francés.

Efectivamente, espejos de agua, cascadas y especialmente surtidores, ponen en movimiento el jardín en su conjunto para el goce de sus

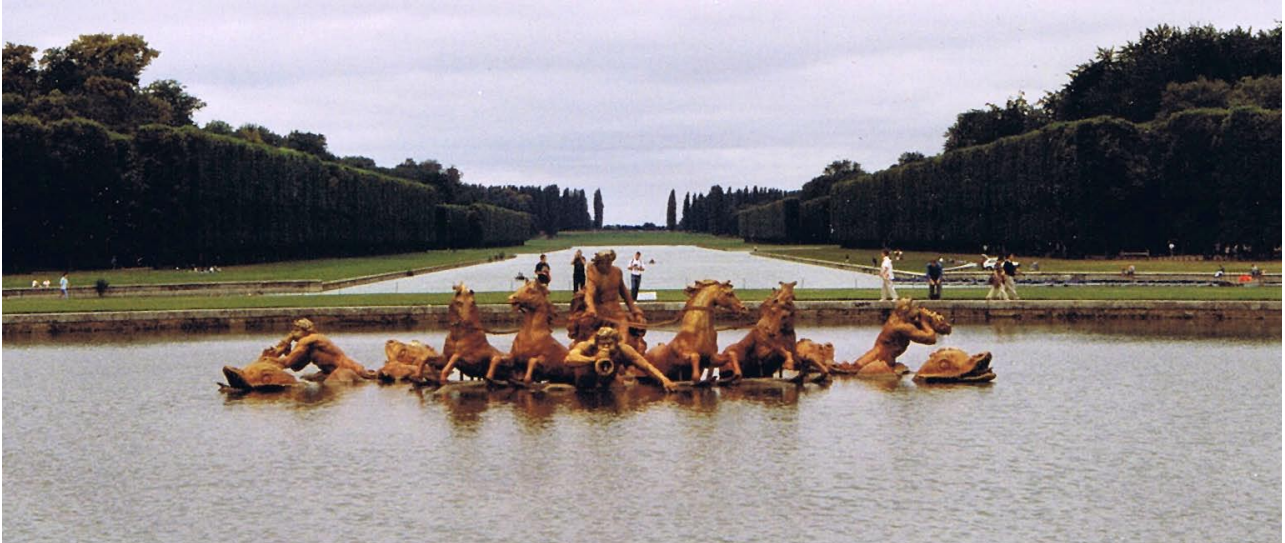

Palacio de Versalles, Gran Eje (mirando hacia el horizonte), (fotografía I.C).

habitantes y, sobretodo, para el asombro de sus invitados. Los jardines se multiplican en espacios previstos para representaciones teatrales, ballets y comedias de diversos tipos. Por esta razón, tanto Vaux-le-Vicomte como Versalles pueden ser leídos como escenarios grandiosos, grandilocuentes, para la mise en scène del poder real y aristocrático en la Francia del siglo XVII.

Pero, es la representación de la vinculación del poder real con la 


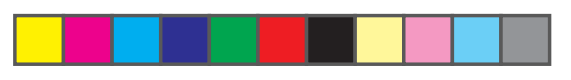

eternidad la que creó uno de los episodios más extraordinarios de Versalles; la creación del Gran Canal, "una abertura prodigiosa que atrae y sosiega, que calma el espacio y que al mismo tiempo lo extiende." ${ }^{2}$ De igual modo a como sucede en el templo de Hatsepsut, donde la arquitectura se proyecta hacia la naturaleza, hacia la montaña, creando un paisaje del tránsito en busca de eternidad, Versalles bascula en torno al Gran Canal, a esa sobrecogedora abertura hacia el infinito. La figura de Apolo, envuelta en un portentoso juego de surtidores, surgiendo de entre las aguas en un movimiento eternamente detenido, dominando el aquí y el ahora pero también el siempre y en todo momento, explicita una vinculación entre naturaleza y eternidad a través del paisaje en movimiento que nos remite al mencionado templo egipcio y al modo en cómo éste se funde entre las rocas para acompañar a la reina en su vida tras la muerte en un recorrido nunca detenido.

12 Jeannel, Bernard. Le Nôtre, Akal, Madrid, 2003, p.72.

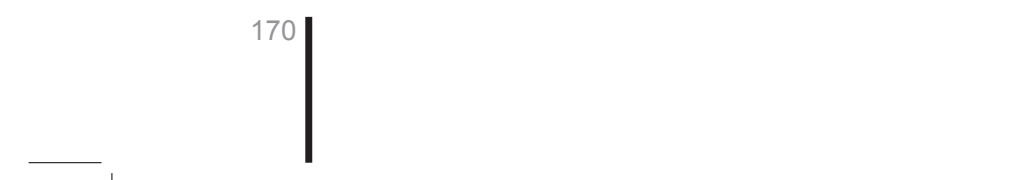




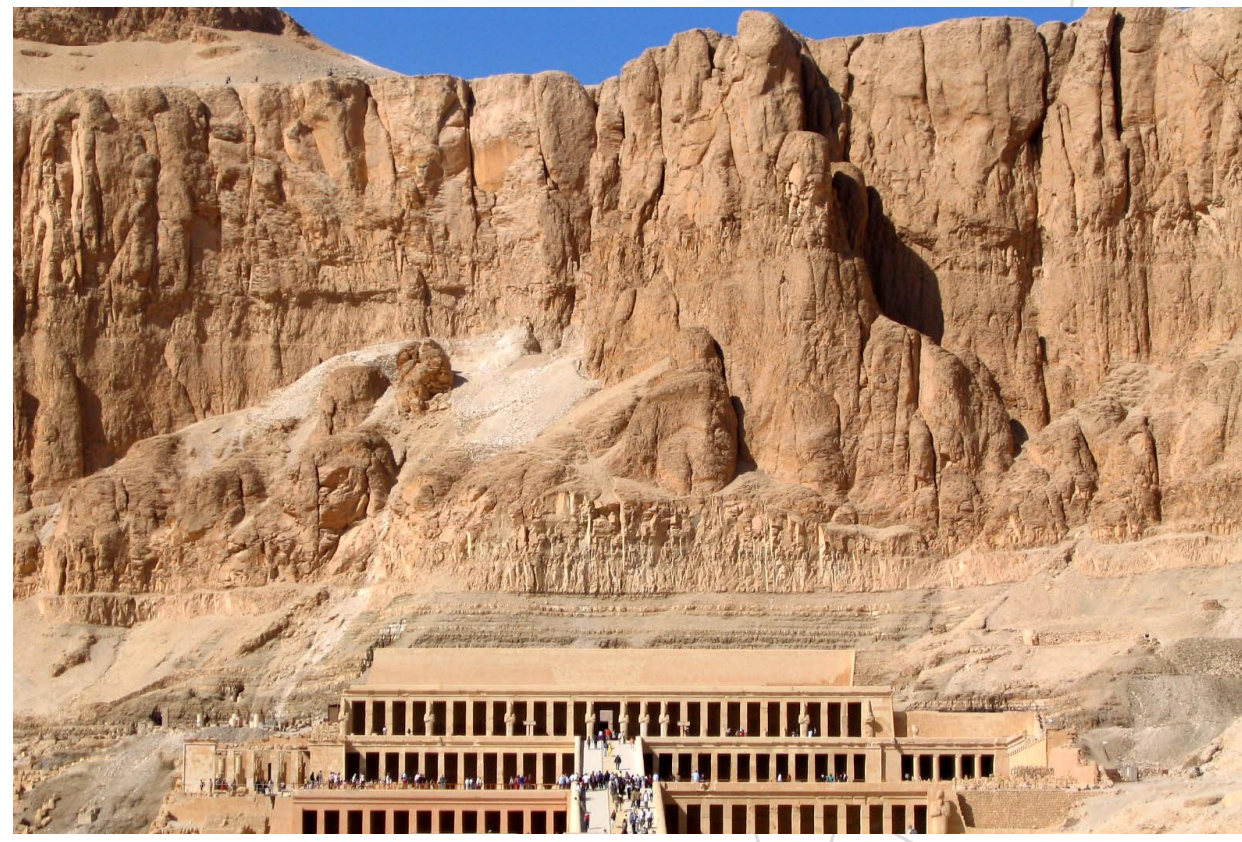

Templo de Hatsepsut, vista de conjunto (fotografía I.C).

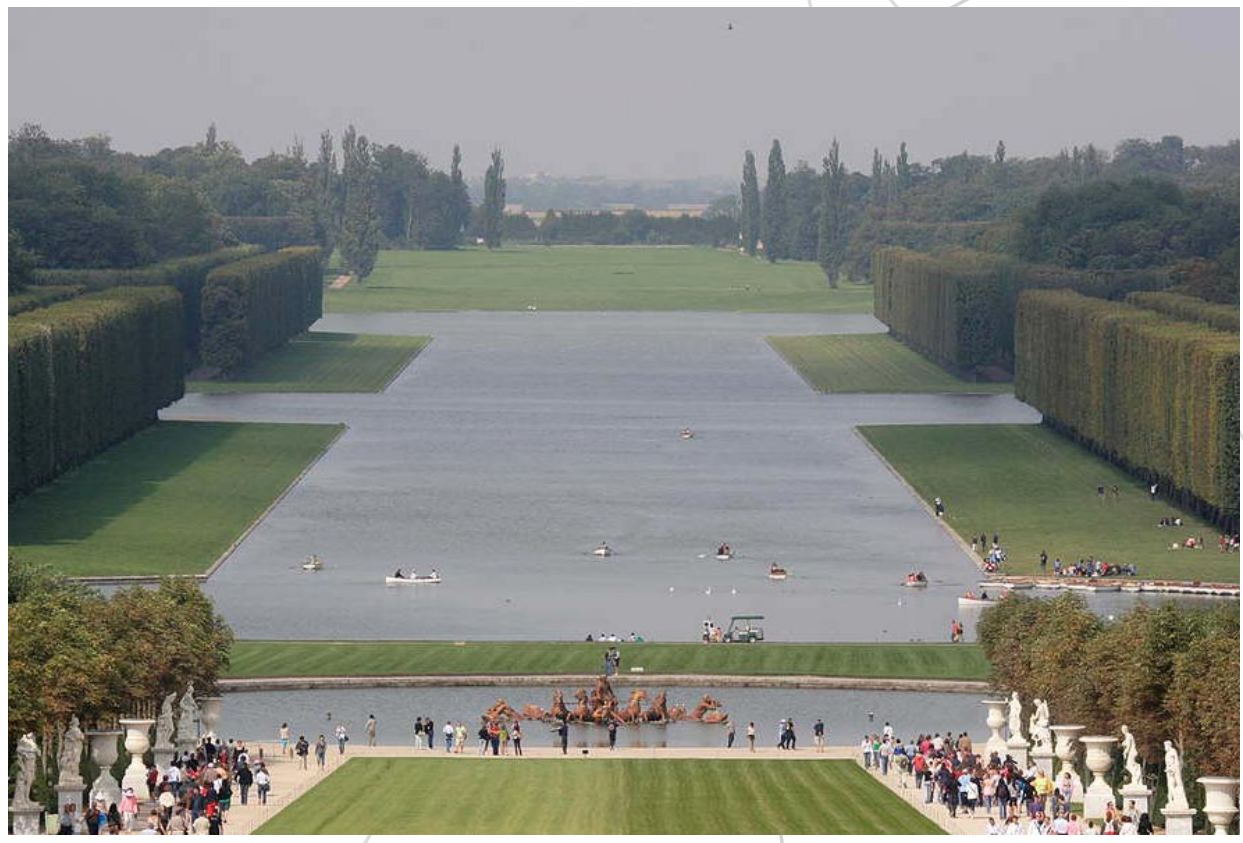

Palacio de Versalles, Gran Eje áulico. 


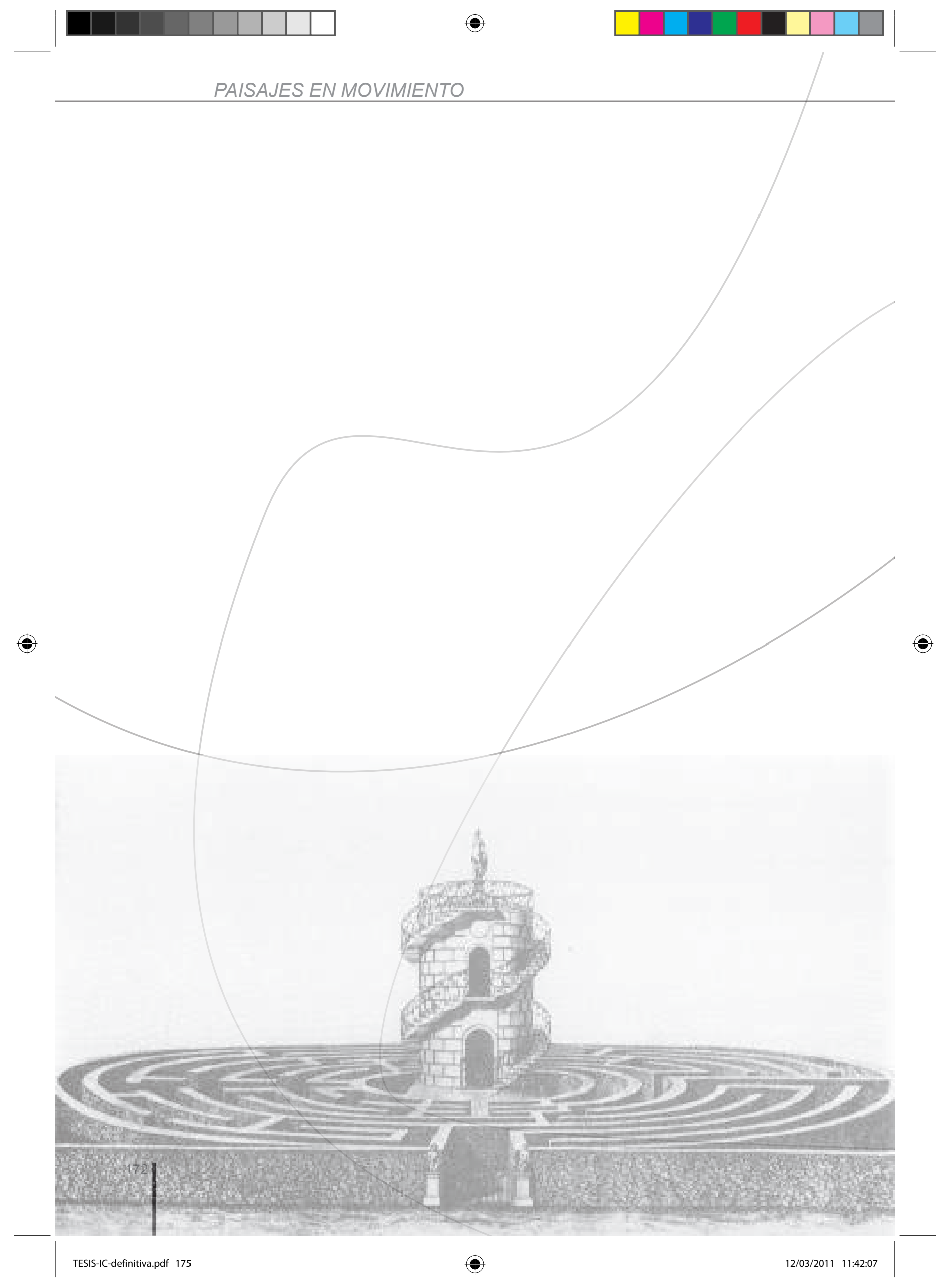



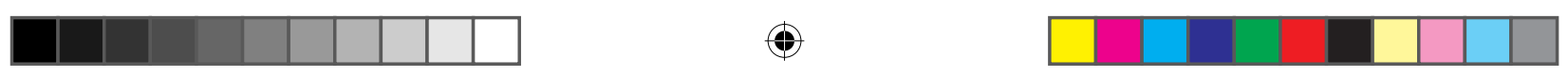

3.3 DENTRO DEL LABERINTO. DE DÉDALO A PETER EISENMAN

Históricamente el laberinto, exitosa figura del imaginario colectivo, ha supuesto un capítulo aparte en cuanto al pensamiento, y en ocasiones la posterior construcción, de lugares que gracias a una fuerte componente dinámica han dado lugar a lo que estamos denominando "paisajes del movimiento". El laberinto, no obstante, no es una figura del pasado sino que continúa hoy en día excitando nuestra imaginación, resultando por lo tanto indispensable un acercamiento a él para comprender de un modo más completo algunas de las experiencias arquitectónicas y urbanas más interesantes del siglo $\mathrm{XX}$.

Tal y como haríamos si accediéramos al laberinto por su entrada, comencemos nuestro recorrido por el mismo acercándonos al diccionario 


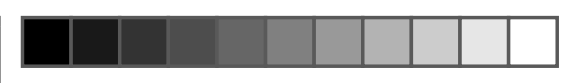

y buscando la entrada "laberinto" intentando extraer alguna consideración al respecto. Según el diccionario de la Real Academia Española, el laberinto, en su primera acepción es un "(1.m.) Lugar formado artificiosamente por calles y encrucijadas, para confundir a quien se adentre en él, de modo que no pueda acertar con la salida." Comparativamente, y sin ánimo de estudiar todas y cada una de las distintas definiciones que podemos encontrar, en el Diccionario de uso del español Maria Moliner, éste es un "lugar donde hay muchos caminos que se entrecruzan, de modo que es muy difícil orientarse para salir de él. Toma nombre del famoso de Creta. Se construyen a veces en parques o jardines para distracción."

Así pues, si atendemos a estas y otras definiciones enciclopédi-

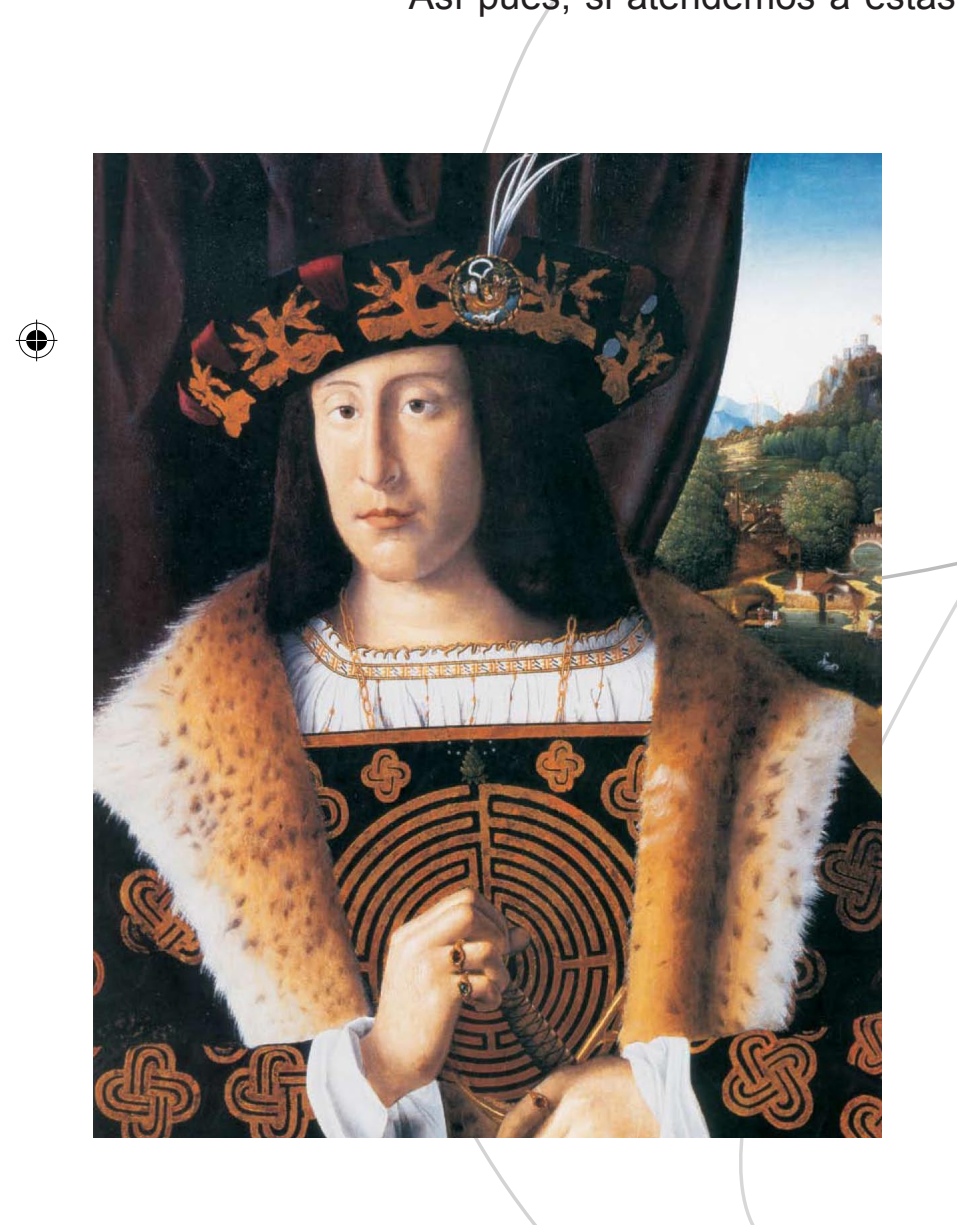

Bartolomeo Veneto, Retrato de un hombre, circa 1510. cas, la experiencia del laberinto es, sin lugar a dudas, la vivencia de un espacio que tiene lugar a través del movimiento, del recorrido del visitante; sea éste un movimiento simbólico, metafórico, representacional o, por el contrario, real y físico en el espacio. Se trata, conviene no obstante destacarlo, de un movimiento de fuerte naturaleza dubitativa (son constantes las referencias en distintas lenguas y diccionarios a cruces y encrucijadas), ansioso y en ocasiones angustiado. Dentro del laberinto han desaparecido los grandes ejes con estructuras claras y legibles, los recorridos con objetivos anunciados y deseados y etapas o capítulos placenteros 

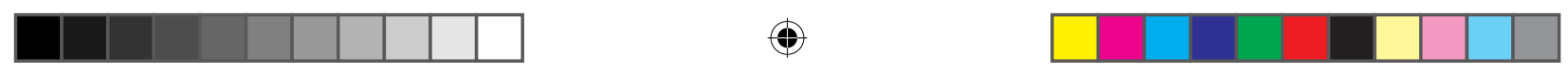

3. El arte de caminar, un recorrido histórico.

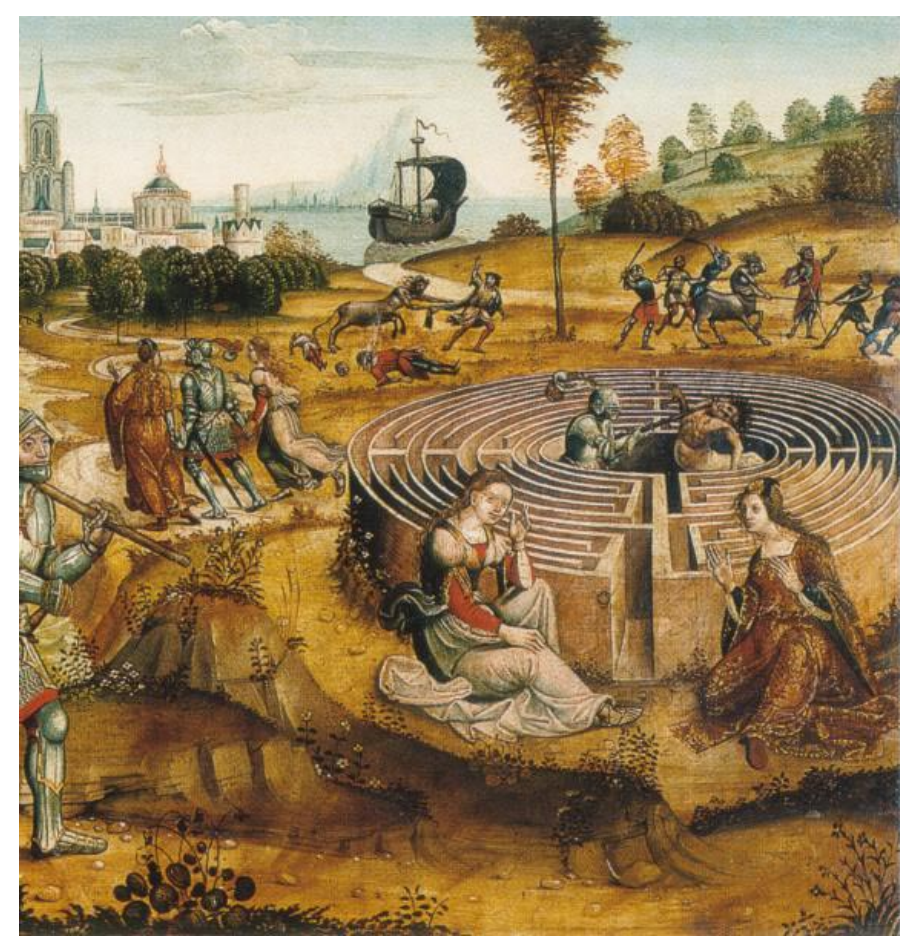

Maestro de Cassone Campana, La leyenda de Teseo y el Minotauro, circa 1515, (detalle). y a menudo sensuales, los caminos señalados y celebrados, edificados a menudo simbólicamente. Somos los visitantes quienes nos enfrentamos a nosotros mismos cuando nos adentramos entre sus límites. Esta pérdida de referencias en su interior supone un potente elemento dinamizador del espacio que nos obliga a huir hacia adelante (o hacia atrás) pero nunca a permanecer parado. Esta ausencia de elementos estabilizadores, de reposo, nos empuja a movernos en una búsqueda constante. No tiene cabida la pausa en el interior del laberinto. Se trata un lugar pensado desde y para el movimiento y donde sin embargo no encontramos elementos referenciales que nos guíen en ese recorrido. En sentido amplio, como veremos, el laberinto es la imagen de la angustia del hombre ante un mundo que le sobrepasa (el pecado, en los laberintos medievales; el amor en los laberintos de amor renacentista...).

Buena muestra de este sentimiento de pérdida, de angustia, nos la da el escritor argentino Jorge Luis Borges, quién entendió de modo excepcional la singular naturaleza de los laberintos. En su obra, la fascinación por estos espacios es constante, de modo que referencias explícitas e implícitas al laberinto trufan sus cuentos. Tal vez la más hermosa (y quizás también la más reveladora) sea aquella donde el escritor argentino relacionó la casa y el laberinto mediante esta inestimable descripción: “La 


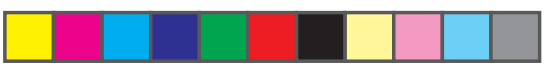

idea de una casa hecha para que la gente se pierda es tal vez más rara que la de un hombre con cabeza de toro, pero las dos se ayudan y la imagen del laberinto conviene a la imagen del Minotauro. Queda bien que en el centro de una casa monstruosa haya un habitante monstruoso."1

Pero, ¿De qué monstruo nos habla Borges?, ¿Quién fue el Minotauro, según el mito clásico que sirve de origen a la palabra laberinto y a una extensa tradición cultural ligada al mismo?

Nos cuenta la leyenda que

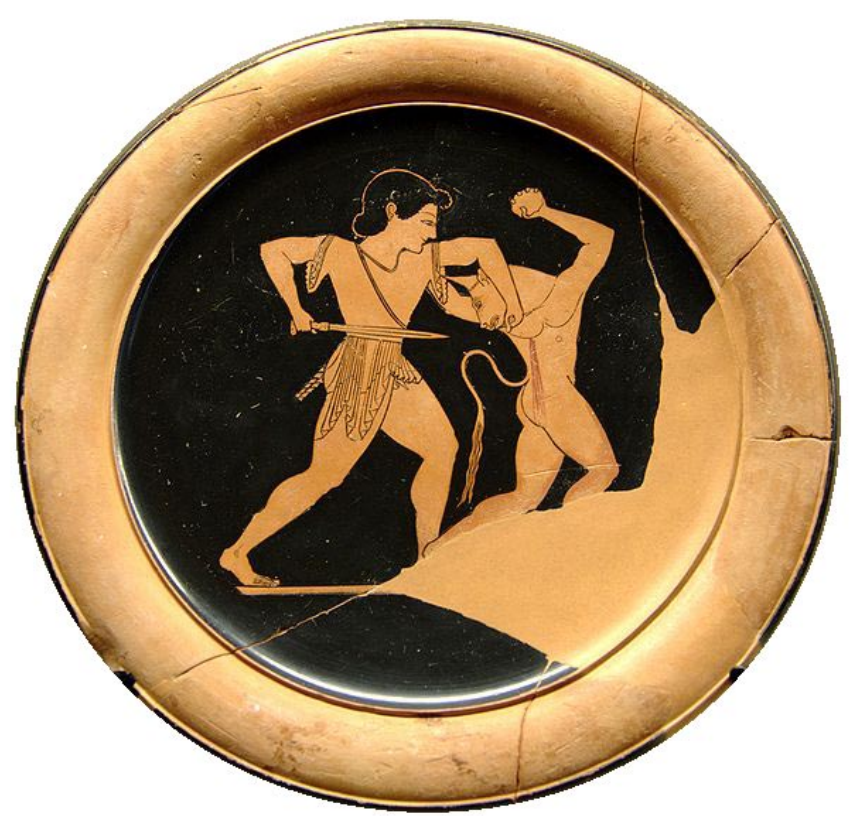

Teseo y el Mlnotauro, Vaso ático, 520-510 a.C, Museo del Louvre. el rey Minos, en reclamación por el trono de Creta, pactó con el dios Poseidón la aparición de un toro desde el fondo del mar a quién Minos rendiría honores. Una vez surgido éste del fondo del mar y debido al incumplimiento de su promesa, un castigo de los dioses produjo que Pasifae, esposa del rey, cayera locamente enamorada del toro surgiendo del amor entre ambos un ser monstruoso, mitad hombre mitad toro, a quién pusieron de nombre Asterión y a quién, debido a su doble naturaleza, conocemos hoy en día como el Minotauro. Minos, enloquecido de ira demandó a Dédalo un palacio de complicados corredores donde encerrar a Asterión, quién a partir de este momento perdería su nombre. ${ }^{2}$

Así pues, el mito cretense del laberinto que encerraba al terrible Minotauro en su interior surge ligado a un arquitecto, Dédalo, quién con-

1 Borges, Jorge Luis, El libro de los seres imaginarios, Bruguera Alfaguara, Barcelona, 1979, p.162.

2 La unión entre Pasifae y el toro se produjo gracias a una vaca falsa, construida por Dédalo, donde la reina se escondió para dar rienda suelta a sus deseos por el toro. Podemos observar de qué modo, el protagonismo por parte de Dédalo el arquitecto en el mito es considerable ya que son varios los prodigios e ingenios que se le atribuyen a lo largo del mito. 


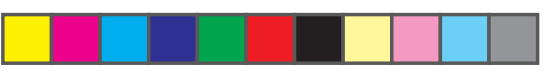

cibió un lugar tan extraordinario que incluso él mismo tendría posteriormente problemas para encontrar la salida. Dédalo, desterrado de Atenas debido a un horrible crimen ${ }^{3}$ huyó a Creta donde pasó, debido a su talento, a ser el arquitecto del rey Minos, para quién construyó el que se convertiría en el más famoso y reconocido laberinto. Fue Dédalo también, quién, cómplice de Ariadna, le mostró a ésta la argucia con la que ayudar a Teseo a vencer en su combate contra el Minotauro y posteriormente conseguir salir del laberinto. La idea era utilizar un ovillo que, desenrollado, le ayudase a "dibujar" el camino de regreso. ${ }^{4}$

Descubrimos, de la lectura atenta del mito, una primera característica primordial del laberinto. Estamos ante un espacio al que se accede y en el que ya desde el mismo momento del/ingreso estamos buscando la salida. Es decir, un lugar en el que se entra y se sale (con mayor o menor dificultad), pero en el que no se permanece intencionadamente. Por lo

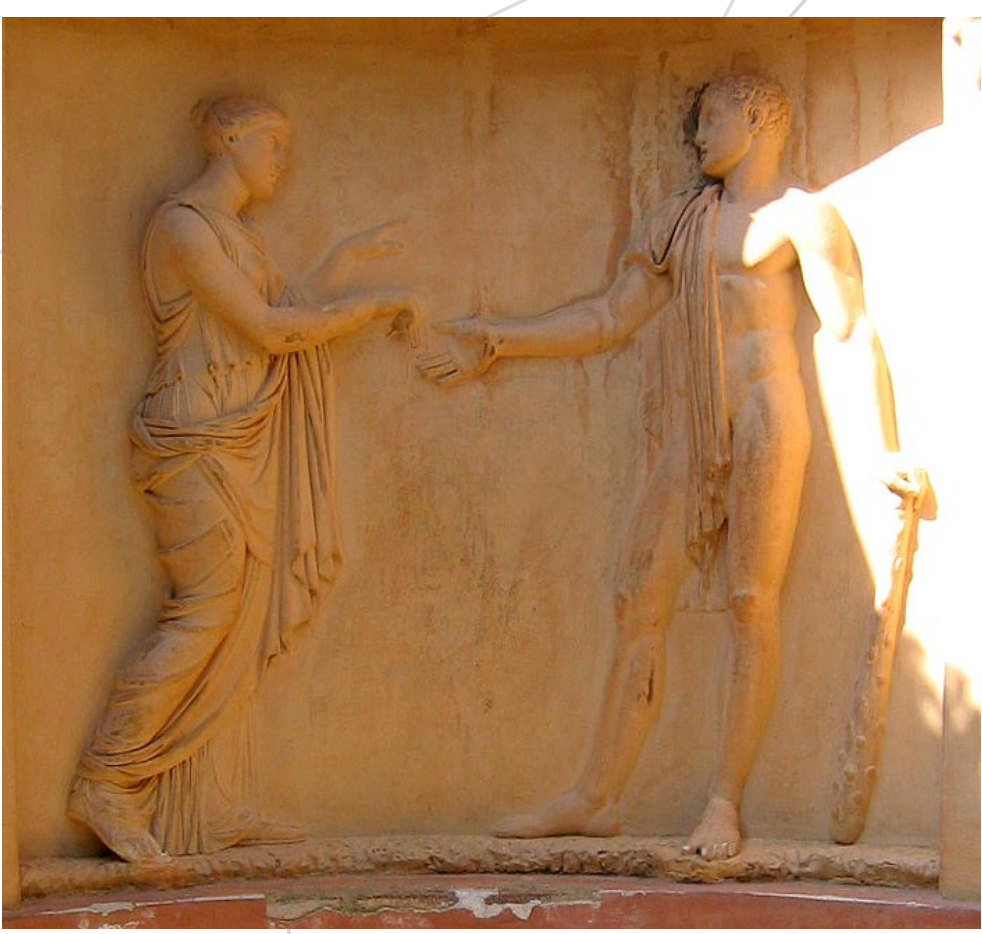

Ariadna entregando el hilo aTeseo, s/f, entrada al laberinto de Horta, Barcelona.

3 Dédalo asesinó a su sobrino y discípulo Talo, hijo de su hermana Pérdix, debido a los celos que experimentó el día que Talo, inspirándose en la mandíbula de una serpiente inventó la sierra, crimen por el que fue castigado por el Areópago.

4 Posteriormente, Minos, conocedor del engaño y de la ayuda del arquitecto, encerró al propio Dédalo y a su hijo en el laberinto, quienes lograron huir ayudados de alas de cera, episodio que daría lugar a otro interesante y hermoso mito. 

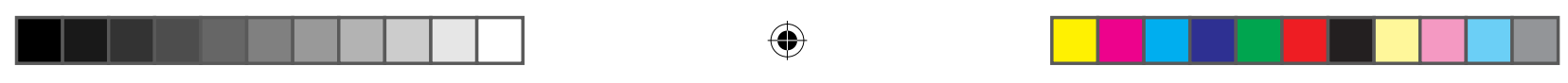

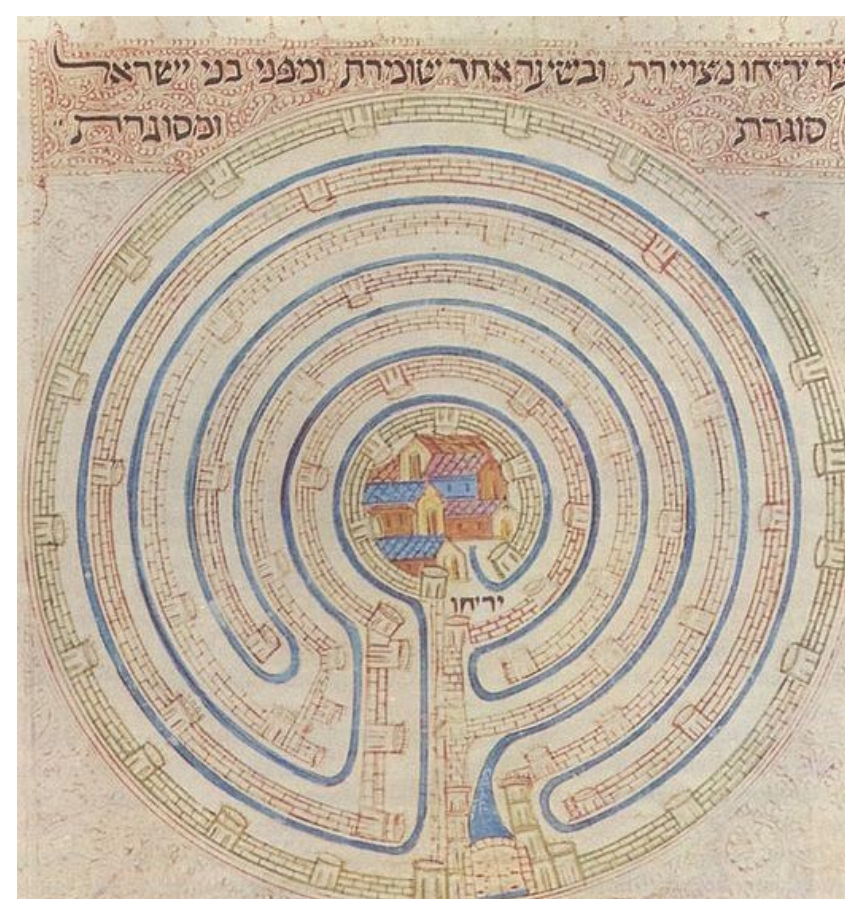

Mapa de Jericó, Biblia Farhi, Siglo XIV. Ejemplo de laberinto unicursal. tanto, existe siempre un objetivo en el recorrido del mismo.

Esto nos lleva a una primera y somera clasificación de los laberintos en función del objetivo de este recorrido pudiendo distinguir entre "inextricables"; si el objeto es encontrar la salida al mismo o en "impenetrables" si por el contrario nuestro objetivo es, gracias a su inteligente recorrido, llegar al centro. Pero tanto en unos como en los otros, independientemente del objeto final, lo fundamental es el recorrido en sí mismo, bien sea éste de entrada, bien de salida. Esta clasificación nos lleva directamente a la otra gran diferenciación entre los distintos tipos que podemos encontrar, los llamados laberintos "unicursales" o laberintos "multicursales".

La característica fundamental de los primeros, que han llegado hasta nosotros gracias a la tradición literaria proveniente del relato mitológico, es que están diseñados y pensados con la intención de alcanzar el ansiado centro, que no es sino el premio al esfuerzo, a la paciencia y la constancia en el empeño en el recorrido del laberinto. Este tipo de laberinto supone en cierto modo un rito iniciático, pues pone a prueba la paciencia y la constancia del visitante en su voluntad por alcanzar el centro. En palabras de la profesora Penelope Reed Doob, se "enfatiza la sumisión del creyente que se sabe sujeto a un poder que le sobrepasa." ${ }^{5}$

5 Doob, Penelope Reed, The Idea of the Labyrinth from Classical Antiquity through the Middle Ages, 

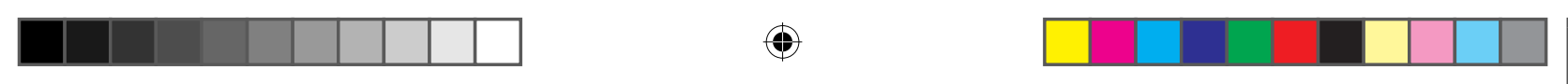

Como vemos, los laberintos suponen la concreción, en un espacio limitado y acotado, de los paisajes de peregrinación que veíamos en el epígrafe anterior. Se trata de un movimiento, de un recorrido a través de un itinerario simbólico que nos lleva desde la oscuridad a la luz, de lo profano a lo sagrado; es decir, de la periferia al centro. El avance en el laberinto supone un proceso de aprendizaje destinado a conducirnos desde la ignorancia, a través de peligrosos caminos, hasta alcanzar el conocimiento, colocando al individuo y su propio desplazamiento como único referente espacial.

Es este esfuerzo físico y espiritual el que, simultáneamente, nos conducirá al éxito, a alcanzar el deseado centro. No es casualidad por tanto que, como conviene recordar, este concepto de laberinto ha sido prácticamente el único existente hasta el siglo $\mathrm{XV}$, más allá de diferentes concreciones físicas construidas o representadas ya que el laberinto ha conocido un éxito formidable en cuanto expresión y metáfora del mundo.

La vinculación entre paisaje y peregrinación que leíamos en el capítulo anterior, y que no es sino expresión del deambular del ser humano por la vida siguiendo los pasos de Cristo, cristalizó con gran popularidad en la proliferación de representaciones del laberinto asociados al concepto de peregrinación y que se materializaron consecuentemente en textos y luga-

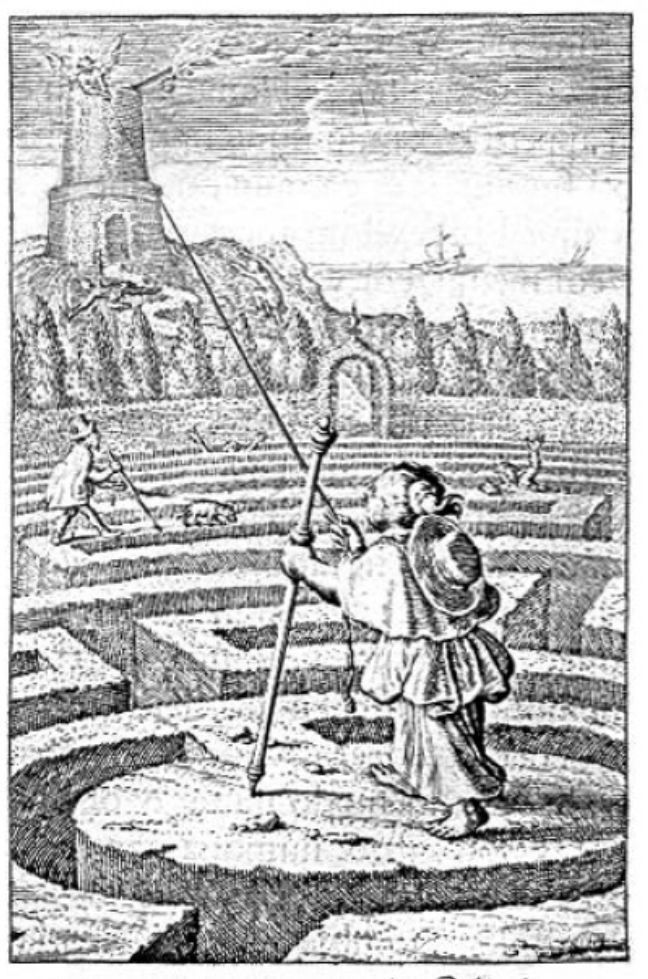

Vtinam drigantur vir mea ad cusfodiendas instificationtes tuas! Psal. us.

Hermann Hugo, llustración del Salmo 119 en Pia Desideria, 1624.

Cornell University Press, Nueva York, 1990, p.122. 

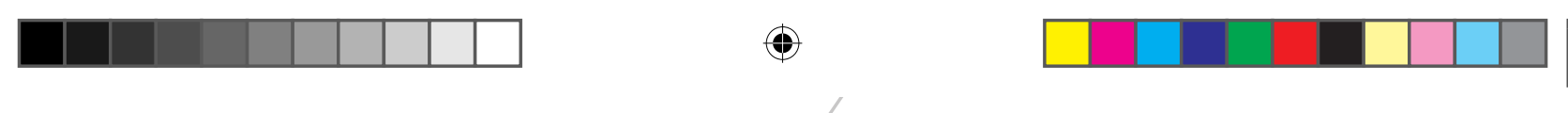

res sagrados. En 1624, el jesuita Hermann Hugo publicó en Anvers su Pia Desideria. En uno de sus salmos el autor acompaña el texto de una ilustración donde podemos ver el alma humana representada con el hábito de un peregrino que alcanza, en el centro del laberinto, la gracia representada como el "hilo de Ariadna" que un ángel le tiende desde la torre del cielo. Observamos aquí de modo explícito, cómo el centro es el objetivo y es aquí donde, después de sortear las pruebas y peligros de la vida, alcanzamos la comunión con lo sagrado. Resulta interesante señalar, como bien observa el historiador de arte Daniel Arasse ${ }^{6}$, que en este ejemplo, los muros que habitualmente encierran el camino en la representación del laberinto se han convertido en insalvables simas donde el alma puede caer en cualquier momento, (tal y como demuestran las figuras representadas justamente en el momento de extraviarse y perecer por causa del pecado).

Por esa razón, los laberintos proliferan durante la Edad Media en las iglesias de toda Europa, ya que se presentan asociados al camino de la vida en tanto que camino de virtud cuyo objetivo y recompensa es Cristo. De hecho la casi totalidad de laberintos construidos durante esta época (la mayor parte de ellos situados en Francia e Italia) se han hallado en el interior de iglesias y no en edificios civiles, bien fueran éstos palacios o residencias más humildes.

Los diversos ejemplos que podemos encontrar en estos dos países abarcan desde los doce metros y medio de diámetro y 294 metros de longitud total de camino desarrollado del laberinto existente en el pavimento de la nave central de la catedral de Chartres, en Francia, realizado hacia 1200 y uno de los más elaborados y famosos ejemplos, a los apenas cincuenta centímetros de diámetro del situado en una de las columnas del pórtico de la Iglesia catedral de San Martino en Lucca, uno de los más hermosos de Italia.

El laberinto de la catedral de Chartres es seguramente uno de los

6 Véase Arasse, Daniel, «La meilleure façon de marcher. Introduction à une histoire de la marche» en VV. AA., Les figures de la marche, Réunion des musées nationaux, Paris, 2000 , p.40. 

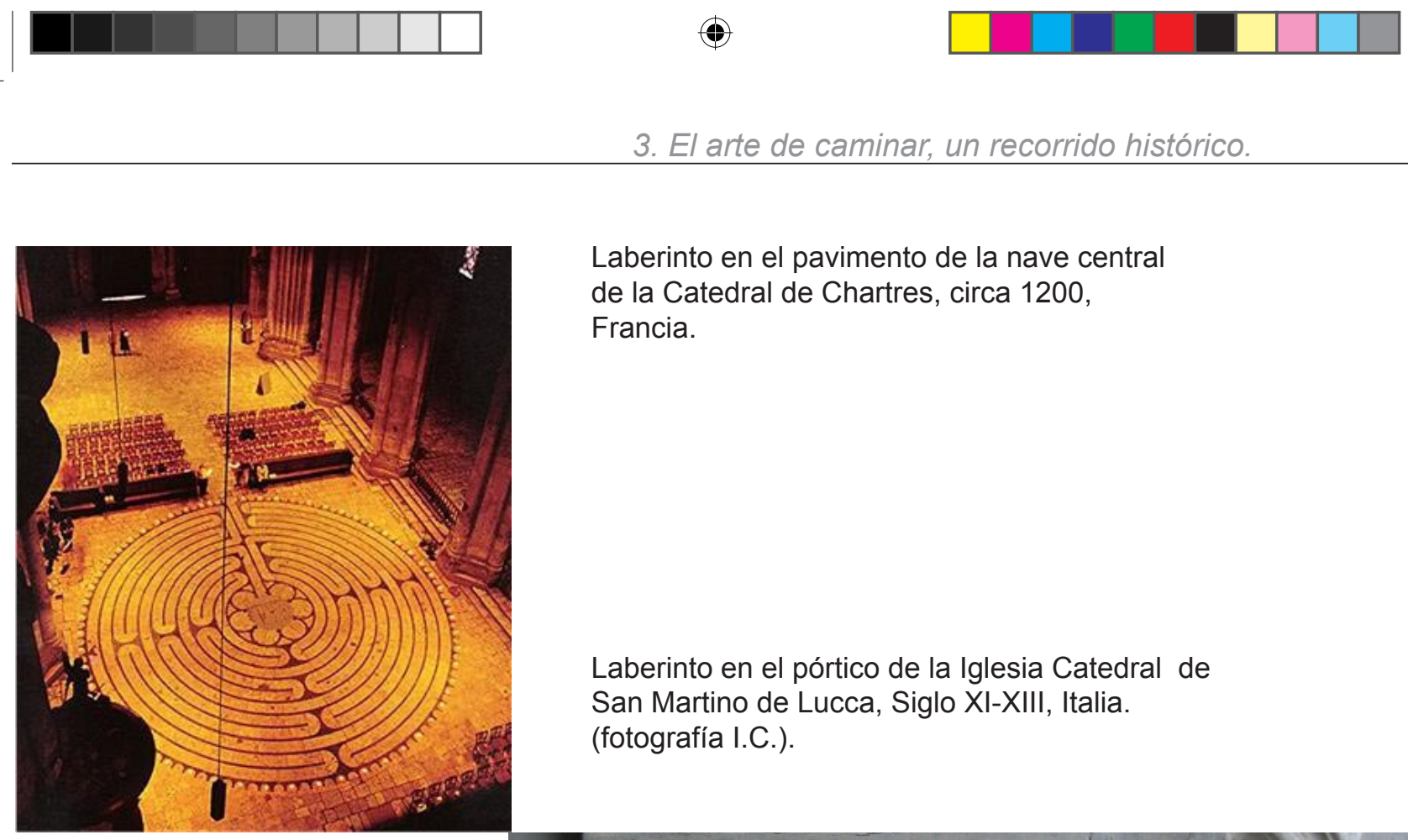

Laberinto en el pavimento de la nave central de la Catedral de Chartres, circa 1200,

Francia.

Laberinto en el pórtico de la Iglesia Catedral de San Martino de Lucca, Siglo XI-XIII, Italia.

(fotografía I.C.).

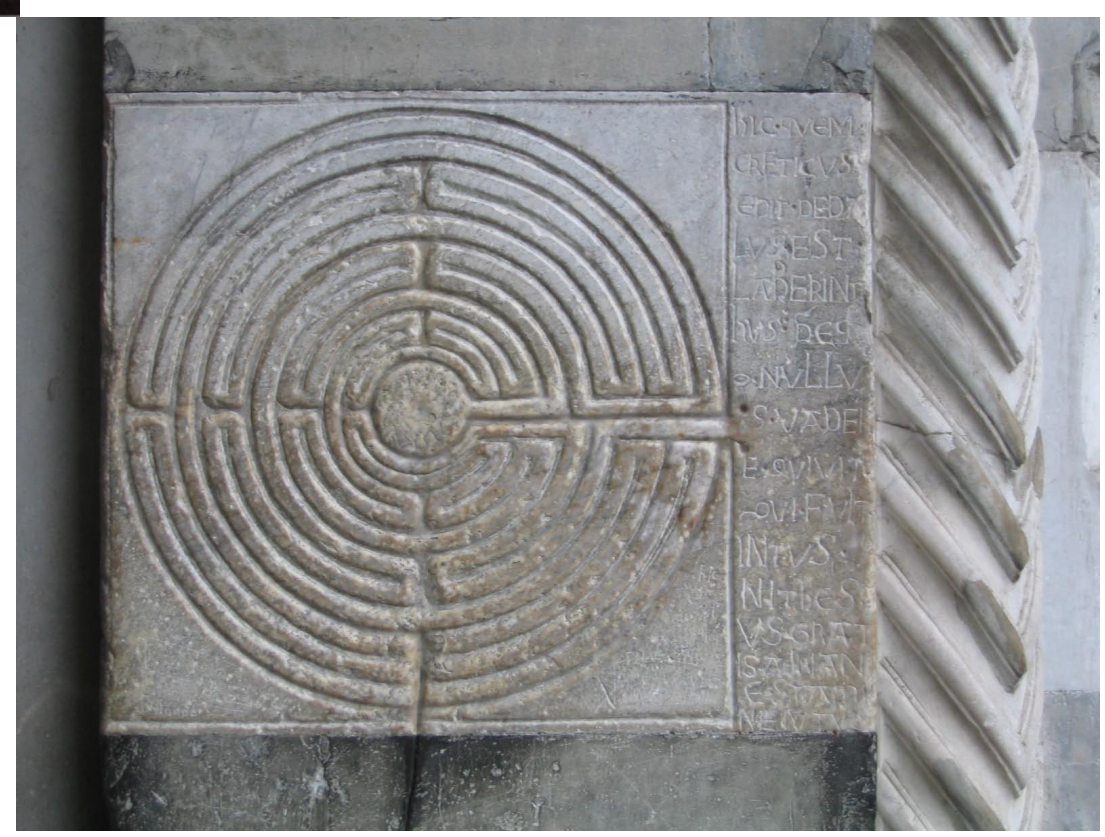

más célebres ejemplos y de los que más han influido en la aparición de muy diversos grupos de seguidores y creyentes en las cualidades mágicas y míticas de los laberintos. Además de su gran belleza e imponente escala, Chartres es un ejemplo especialmente interesante ya que en su nave central el creyente realizaba la "peregrinación" gracias al laberinto, rezando y cantando, (habitualmente de rodillas) mientras sigue sus cami- 


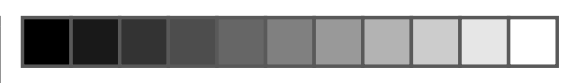

nos. En cuanto al de Lucca, no por ser de menor tamaño resulta menos enigmático o fascinante. Aunque se desconocen ritos concretos asociados a este ejemplo, resulta poco aventurado asociarlo a un viaje iniciático por hallarse precisamente en el pórtico, en el acceso a la catedral, punto de reunión de peregrinos y viajeros.

De hecho, diversas interpretaciones de estas realizaciones de la época, apuntan expresamente a la peregrinación a Jerusalén o a Compostela como referencia para entender estos laberintos en piedra. En algunos casos, incluso se realizaban danzas sobre el mismo (en el caso de los laberintos dibujados en naves o capillas) como expresión de celebración, sobre todo en ocasión de la Pascua, momento cumbre del calendario cristiano, como es bien sabido, por tratarse de la celebración del triunfo de Cristo sobre el pecado y la consecuente salvación de la humanidad. En este sentido, está documentada, por ejemplo, la "Danza de la Pelota" celebrada en la catedral de Auxerre (Francia), precisamente el domingo de Pascua. Una buena prueba de cómo, en el mundo medieval, los diferentes significados atribuidos a los laberintos siempre están, en última instancia, íntimamente relacionados con el eterno combate entre el bien y el mal.

A partir del siglo $\mathrm{XV}$, y producto de la revolución cultural que se produce en todos ámbitos, se abandona paulatinamente este modelo hegemónico hasta el momento y comienzan a conocer un gran éxito los laberintos deLaberinto de Villa Pisani, 155355 , Strà,Italia. 

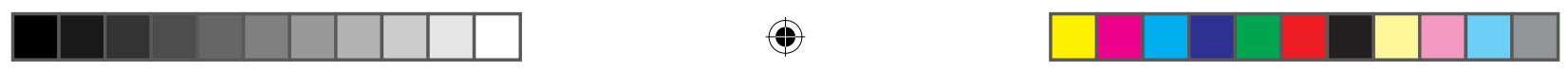

3. El arte de caminar, un recorrido histórico.

nominados "multidireccionales" o "multicursales". ${ }^{7}$ El rasgo definitorio de estos segundos es la posibilidad de elección en su interior. Se trata de laberintos potencialmente inextricables que dan entrada a la responsabilidad individual del visitante en su propio recorrido. Por tanto, el destino final es producto de las distintas elecciones llevadas a cabo por cada caminante en cada uno de los cruces y encrucijadas del conjunto.

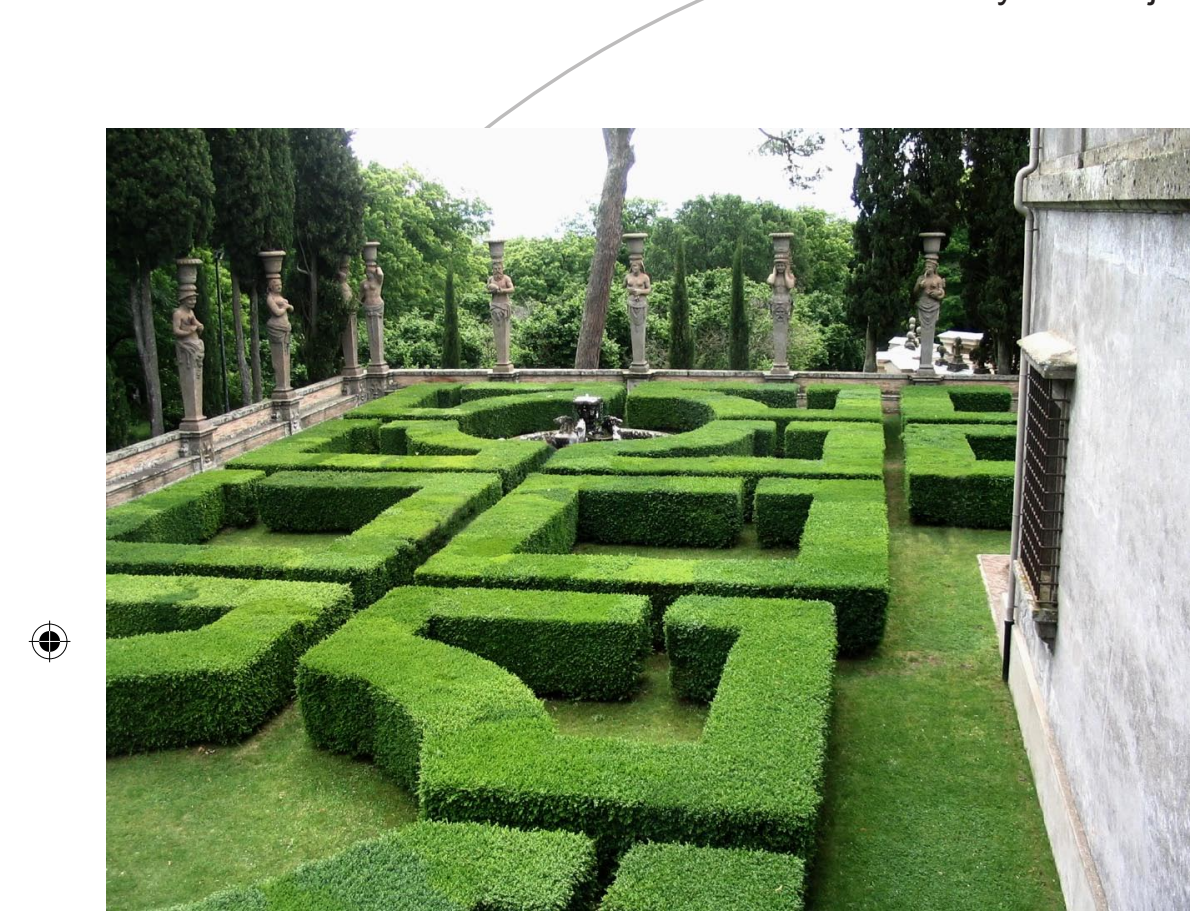

Laberinto de Villa Farnese en Caprarola, Italia.

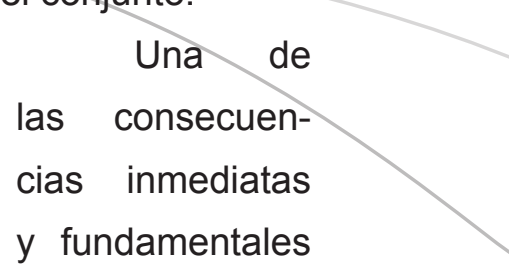

de la introducción de la capacidad de elección y en consecuencia de la posibilidad de tomar "caminos equivocados" que llevan a un punto sin salida, es la aparición de la noción de pérdida. La sustitución paulatina a partir del Rena-

cimiento de Dios como medida de todas las cosas y la colocación del Hombre como nueva referencia, fruto de una enorme confianza en sus posibilidades, nos lleva también, como consecuencia lógica, a la secularización del laberinto.

Es imbuidos en este nuevo contexto donde la posibilidad de sentir-

7 Esta diferenciación entre los dos tipos de laberinto queda más explícita en lengua inglesa, donde existe un vocablo distinto para referirse a cada uno de ellos. Así pues, los ingleses distinguen entre labyrinth, proveniente del mito griego y que conduce siempre al centro y maze, cuando se multiplican las posibilidades de elección y nos encontramos ante lo que nosotros denominaremos un laberinto multidireccional. 

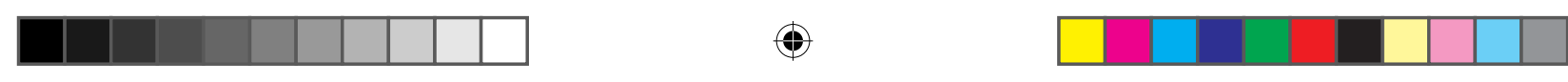

se físicamente perdidos se ha convertido en uno de los componentes fundamentales de los laberintos, ya en su gran mayoría multidireccionales. Este cambio de valores supuso en la práctica su "expulsión" de las iglesias europeas, hasta el momento el lugar donde los podíamos encontrar, produciéndose un traslado de los laberintos, desde el recinto sagrado al espacio profano que representaba el jardín. Estos nuevos laberintos introducen una noción de disfrute y deleite que era completamente ajena a los laberintos unidireccionales. Paralelamente, además del cambio del laberinto unidireccional al multidireccional, se produce también un paso, no menos significativo para el tema que nos ocupa, desde las dos dimensiones (ejemplos de Chartres y Lucca, que veíamos) al espacio tridimensional, produciéndose una eclosión de laberintos en los jardines de toda Europa, unida al auge del ars toparia. Los laberintos trazados en el pavimento, en el plano de tierra, por extrusión de sus líneas conquistan las tres dimensiones. Algunos de ellos, formados mediante setos recortados, se quedarán a una altura por debajo de la cintura, di-
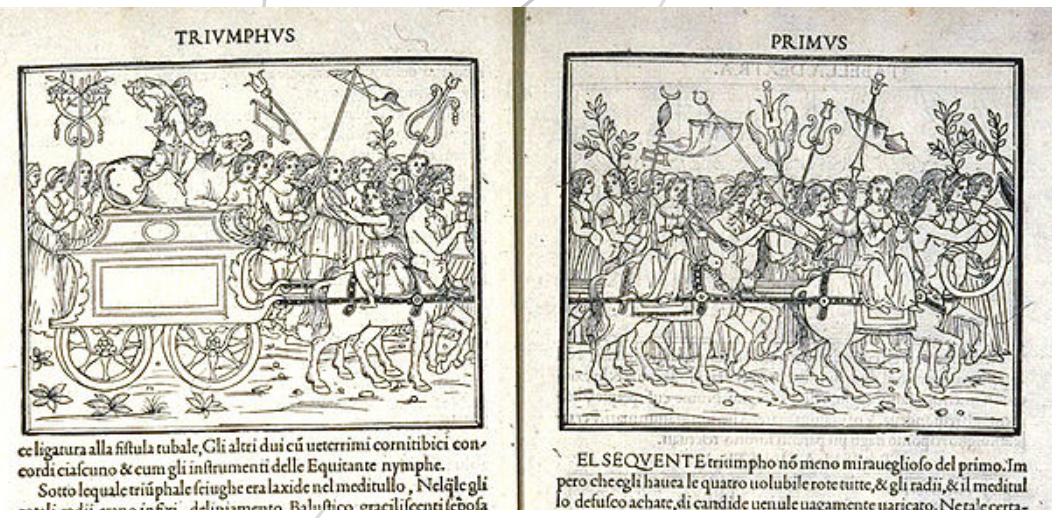

Hypnerotomachia Poliphili, 1499, Francesco Colonna

bujando virtuosas geometrías laberínticas que niegan la posibilidad de pérdida o extrañeza. Pero si damos un paso más allá, cuando el laberinto levanta sus muros vegetales hasta un altura superior a la vista y se imposibilita ver el conjunto si no es desde un punto de vista exterior al mismo y a mayor cota, el laberinto cobra otra dimensión dinámica basada fundamentalmente en empujar el visitante a su recorrido en aras de resolver la angustia producida por la omnipresente sensación de pérdida. Se 

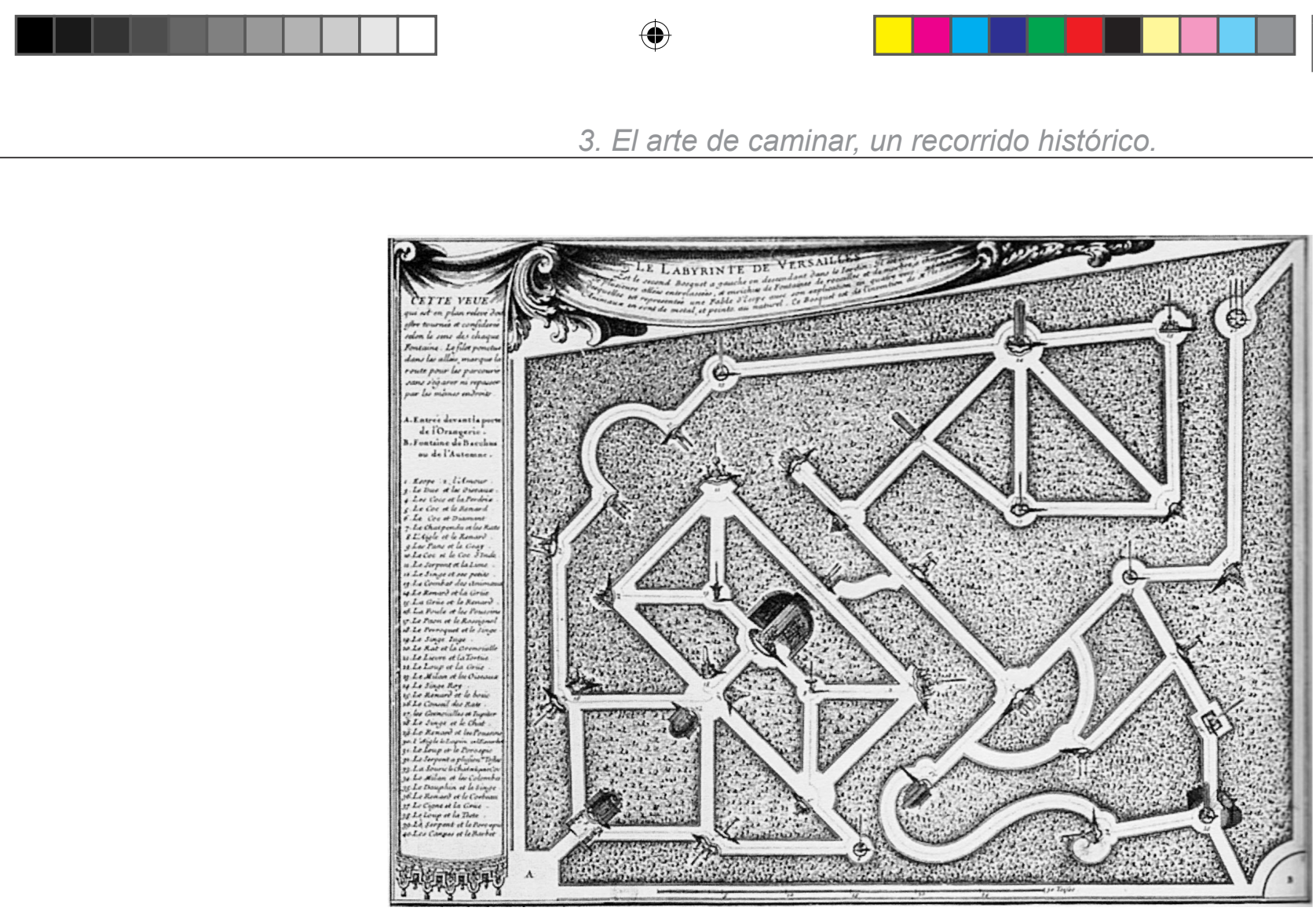

Plano del laberinto de Versalles (hoy desaparecido)

produce por tanto una modificación física del lugar así como de la actitud y el comportamiento del paseante.

Esta auténtica transformación del laberinto está muy influenciada por la aparición, a caballo entre el siglo XV y el siglo XVI, de una obra que tuvo una repercusión decisiva. Me refiero al texto editado en Venecia en 1499 y atribuido a Francesco Colonna, la Hypnerotomachia Poliphili, el cual se convirtió rápidamente en una importante herramienta del arte de los jardines en toda Europa. La obra de Colonna basa su argumento en un recorrido ${ }^{8}$, el viaje que emprende su protagonista Poliphilo en busca de su amada Polia. Este viaje es empleado por su autor a modo de "hilo de Ariadna" para recorrer entre otros sorprendentes y mágicos lugares un laberinto. Así se cumple, como nos recuerda Ramón Espelt: "un itinerario simbólico desde la naturaleza selvática hasta la comunión entre Natura-

8 De nuevo la importancia del viaje como marco narrativo en el que suceden los hechos más significativos. 

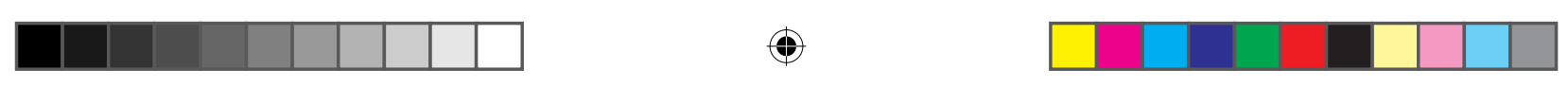

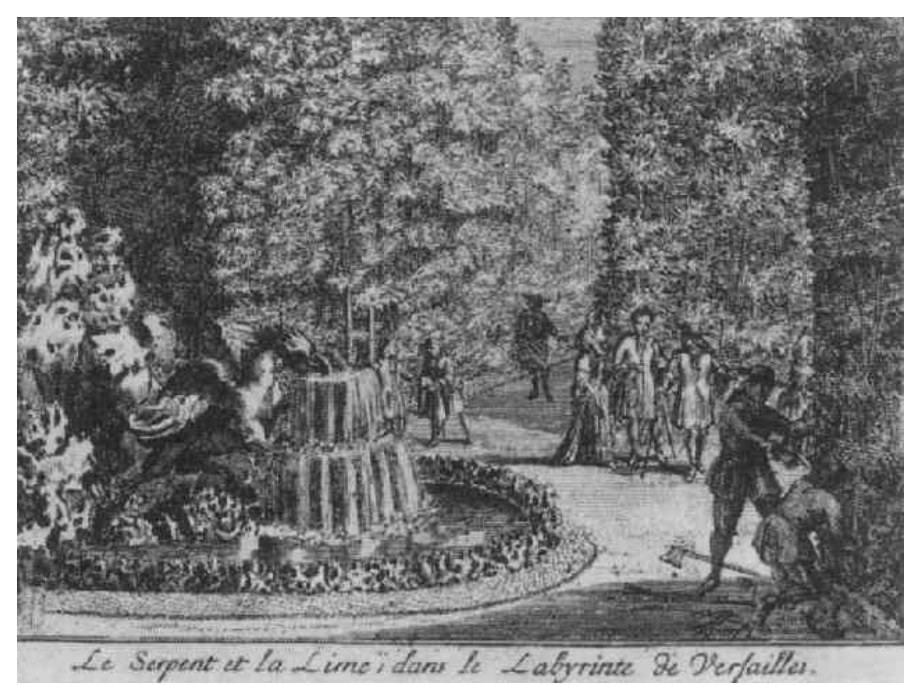

Charles Perrault, Laberinto de Versalles, 1679.

leza, Mito y Arte que representa la Isla de Venus."

Todo el recorrido de Poliphilo es una búsqueda constante a través de diversos peligros $y$ conflictos, teniendo siempre el miedo a la pérdida como una constante amenaza de fondo. Este jardín teórico descrito por Francesco Colonna alcanzó un éxito extraordinario llevándose a cabo muchas realizaciones similares por toda Europa, sobre todo en Italia. El itinerario por estos jardines se convierte, para quién desea estar atento, en un itinerario filosófico y vital, en una búsqueda constante del yo. Esta concepción filosófica y existencial del laberinto que se recorre en búsqueda del conocimiento, dio lugar a espacios intelectualizados que disponían tanto de una determinada secuencia en su recorrido, como de claves para el correcto desarrollo del mismo.

Uno de los más notables ejemplos realizados de laberinto con guión lo encontramos en los jardines de Versalles. La correcta interpretación simbólica fruto de un adecuado recorrido secuencial que ya veíamos en los jardines del palacio en su conjunto, estaba presente también en el interior del laberinto de Versalles, hoy desaparecido. Realizado en 1667, se trataba de un espacio acotado (al contrario de lo que sucedía, por sorprendente que pueda parecer, con el conjunto de los jardines) y cerrado por una reja. Estaba destinado en su origen a la correcta educación y formación del delfín, del heredero de la corona de Francia. En la entrada sendas esculturas del dios Amor y del dios Apolo nos recibían para

9 Espelt, Ramón, Laberints. Llocs, textos, imatges, films. Laertes, Barcelona, 2008, p. 113.

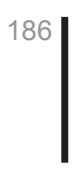



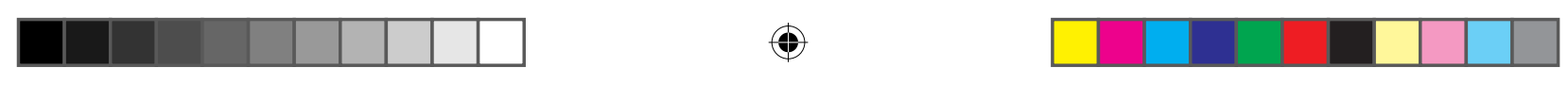

explicarnos la naturaleza de su interior. Contaba, según los parámetros del momento, con una serie de senderos entrelazados en cuyas encrucijadas se dispusieron un amplio número de estatuas (hasta algo más de 300 piezas). Estas estatuas embellecían el laberinto al tiempo que lo dotaban de significado transformándolo en un espacio con una gran carga simbólica. Además de estas imágenes, delante de cada una de las fuentes un poema de Isaac Benserade ayudaba a la mejor comprensión del verdadero significado de la escena, descubriendo aspectos y matices que antes pudieran quedar ocultos. Estas explicaciones sirven de ayuda para alcanzar la salida del laberinto que se convierte así en metáfora de la pasión. Perdernos en el interior del laberinto es reconocer la fragilidad del ser humano, su capacidad para perderse si se deja arrastrar por las pasiones humanas.

El escritor francés Charles Perrault, en su descripción de Versalles y en concreto del laberinto plantea un encuentro entre los dioses Amor y Apolo. El primero le advierte explícitamente al segundo en un momento determinado: "Pues sabéis que yo mismo soy un laberinto en el que resulta fácil extraviarse" $Y$ continúa "Igual que los diversos ornamentos de las fuentes servirán para encontrar la salida del laberinto a quienes se hayan extraviado, unas máximas contenidas en las fábulas servirán también a los amantes para salir de la infinidad de apuros en los que se encuentran cada día" 10

Versalles resulta una perfecta simbiosis entre un espacio para el divertimento ocioso de las clases en el poder y la intelectualización de un espacio convertido en libro de lectura obligada

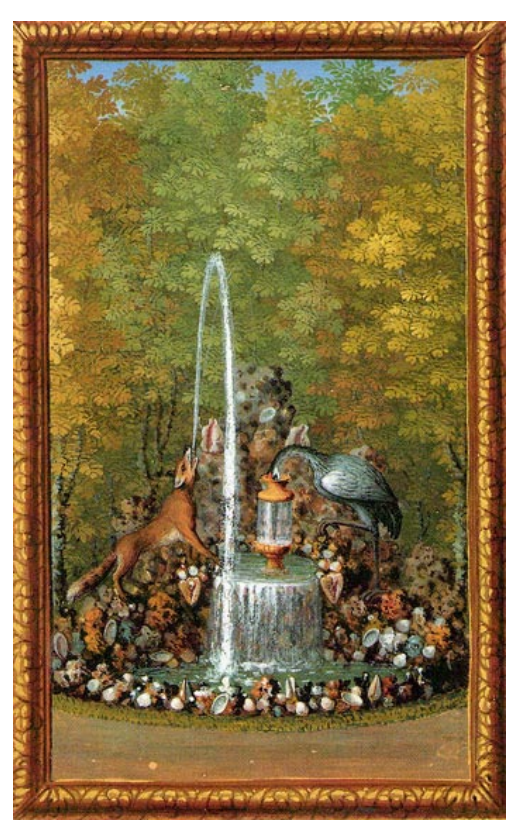

Jacques Bailly's, Le Labyrinthe de Versailles, circa 1675.

10 Perrault, Charles, "El laberinto de Versalles" en VV.AA, Manera de mostrar los jardines de Versalles, Abada editores, Madrid, 2004, p.98. 


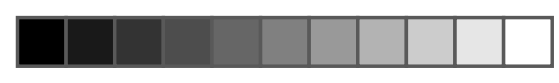

para el heredero del poder absoluto francés. Todo en el laberinto está dispuesto para propiciar el placer de extraviarse (léase en el laberinto, léase en las pasiones) y gracias a las claves esculpidas en vasos y narradas en estampas encontrar las claves para salir de él.

En España, uno de los mejores ejemplos de este tipo de laberinto que se conservan hoy en día es el de Horta en Barcelona. Este hermoso jardín comenzó a construirse en 1791 para Joan Antoni Desvalls i d'Ardena dentro del proyecto global de embellecimiento de los jardines de la finca de que disponía a las afueras de Barcelona. El laberinto, obra del arquitecto italiano Domenico Bagutti y del jardinero francés Delvalet junto con la partícipación del propio Joan Antoni Desvalls, (hombre culto que intervino en la concepción hidráulica del mismo) alcanzó pronto notoriedad. A la entrada, esta vez, es a Ariadna a quién encontramos, en un bajorrelieve en el cual vemos representado el instante en el que ésta entrega a Teseo el ovillo que le guiaría en su camino de regreso. A la famosa escena mitológica le acompaña la siguiente sentencia: "Entra, saldrás sin rodeo/ el laberinto es sencillo/ no es menester el ovillo/ que dio Ariadna a Teseo."

En esta ocasión, no alcanzamos el centro como recompensa a un arduo y trabajoso camino de avance hacia el conocimiento. Tampoco encontraremos a un horrible y despiadado monstruo contra quién deberemos batirnos a muerte. Quién nos espera en el centro del laberinto de Horta es Eros, el dios griego del amor. Se trata de un jardín con centro pero no unidireccional, aquí el centro

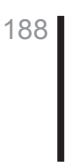

Estatua de Eros, Laberinto de Horta, 1791, Barcelona (fotografía I.C.)
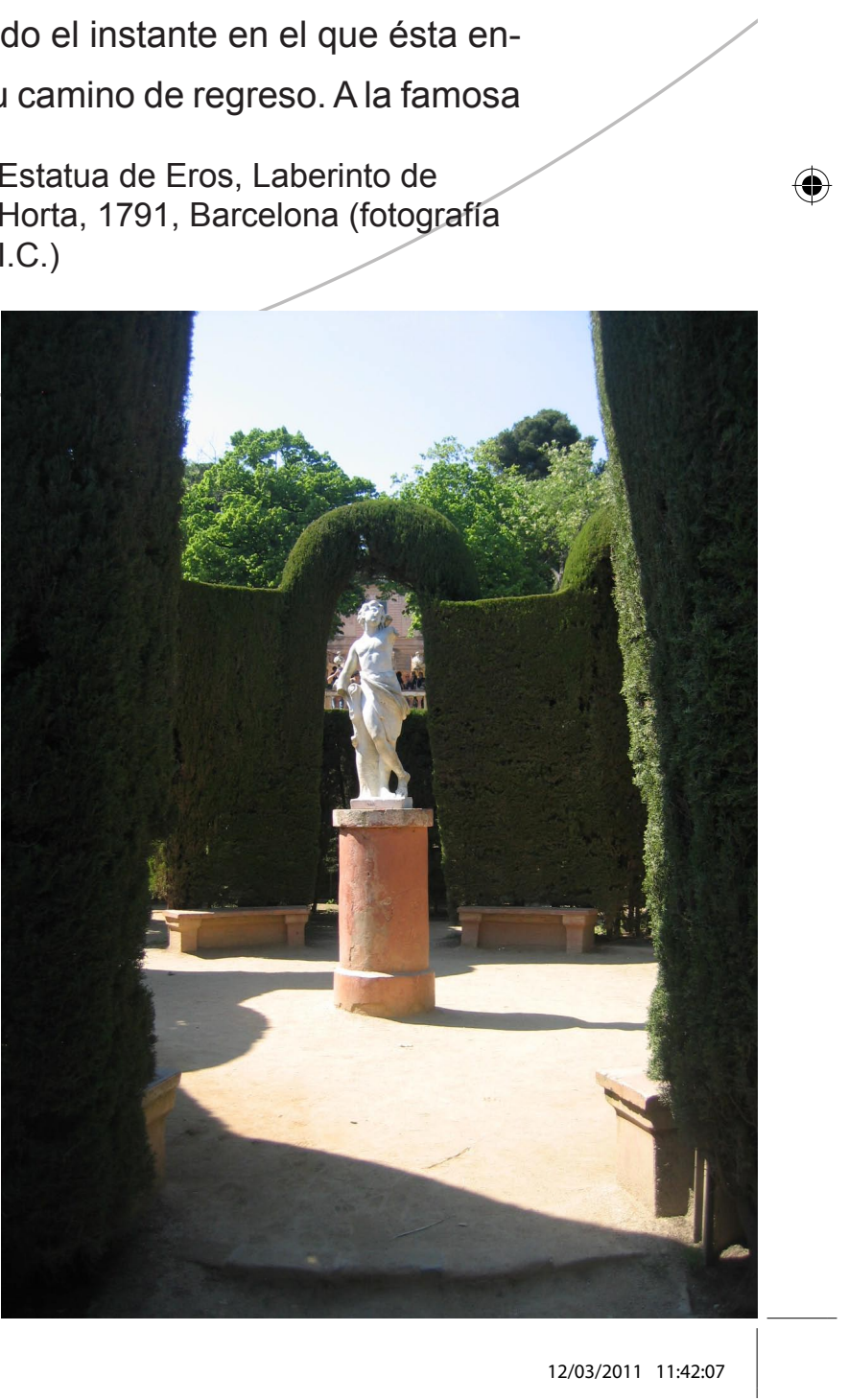

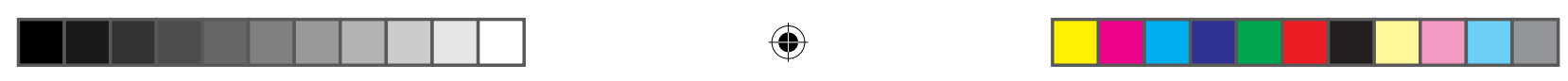

únicamente nos sirve de reclamo lúdico y galante, de premio ante nuestra osadía en adentrarnos hasta él y a nuestra destreza en alcanzarlo. La aparición de este centro es consecuencia lógica de las inquietudes de la época y de los significados atribuidos a estos jardines. A partir de aquí, aún debemos encontrar el camino de salida. Nuestro verdadero premio no es pues acceder a Eros sino, en realidad, salir airosos de nuestro encuentro con él, regresando al exterior del laberinto alcanzando la salida que se encuentra en el extremo superior del jardín.

Frente al fuerte y desasosegante dinamismo del interior del laberinto, que nos empuja a avanzar, a retroceder, a girar a izquierda y derecha en un movimiento que no hace sino acelerarse en la medida que más tardemos en alcanzar el centro o la salida, nos encontramos con una fuente de forma circular. $Y$ así con el círculo, figura geométrica estática y completa, se nos invita al reposo, al descanso y a la pausa. En definitiva, es una apuesta por re-

Laberinto de Horta, Barcelona (fotografía I.C.)

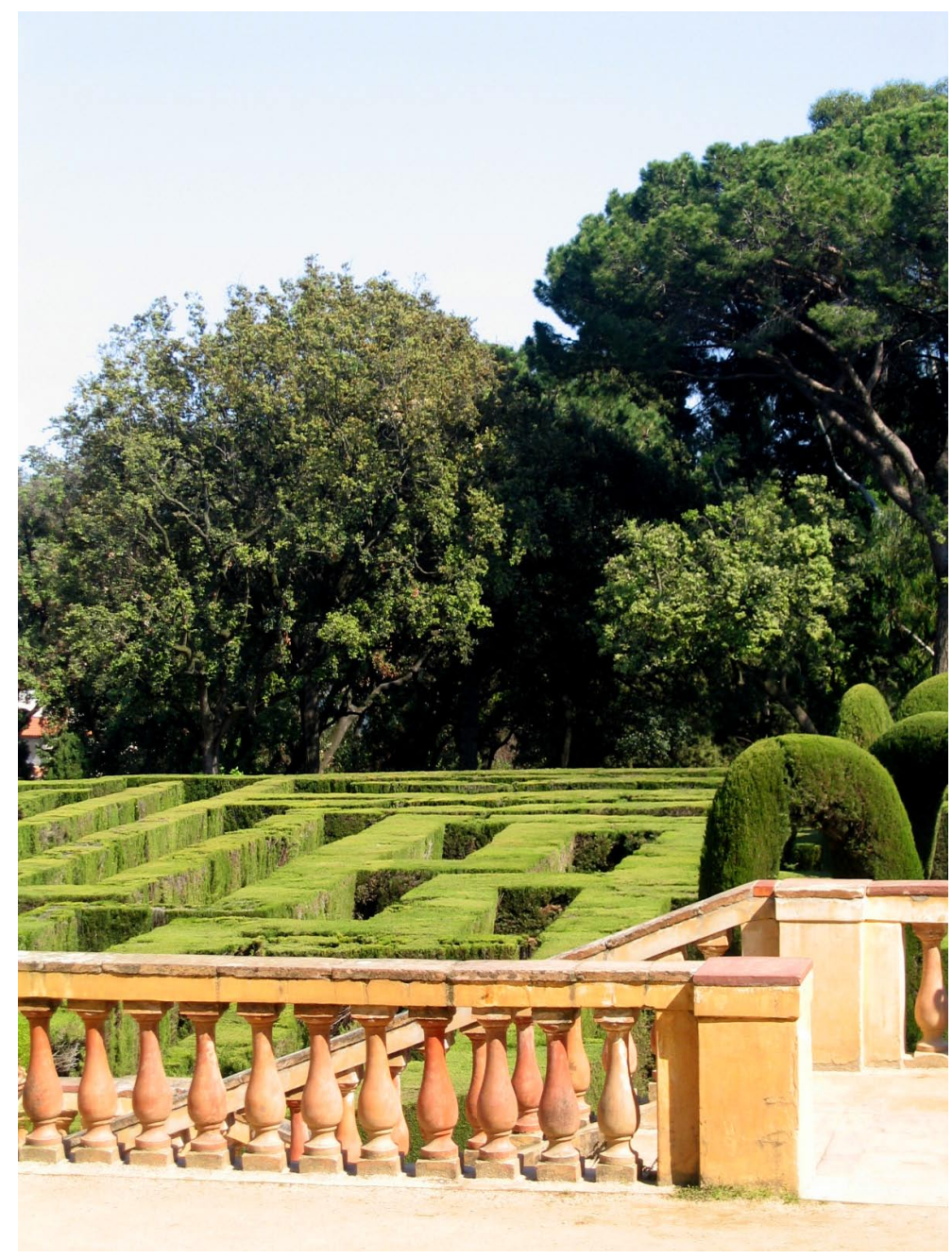



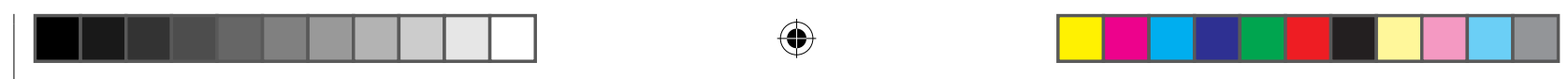

PAISAJES EN MOVIMIENTO

cobrar la paz y el sosiego perdidos entre los muros de ciprés del interior.

A partir de este punto, dos escaleras monumentales nos ayudan a continuar nuestro recorrido ascendente hacia la terraza superior, que tras la pausa se produce ya de otro modo y con otra predisposición. Aquí encontramos dos templetes circulares a izquierda y derecha con las esculturas de Dánae y de Ariadna respectivamente. El amor se ha transformado en desengaño y la sensación de triunfo que nos dejó alcanzar la salida del laberinto se desvanece. Es desde esta posición desde donde tenemos, por primera vez, una visión de conjunto y estática del laberinto que acabamos de abandonar. Se produce una suerte de intelectualización de la sensación de pérdida que acabamos de experimentar. Una vez abandonado el laberinto se ralentiza el dinamismo, se desdramatiza. El movimiento entre divertido y angustiado del visitante da paso a una nueva relación dinámica con el espacio cuando nos sabemos conocedores de las claves o (al menos) a salvo de las trampas del jardín. Aunque seamos conscientes de que este conocimiento no es sino un espejismo fruto de haber salido airosos del dédalo de calles encajonadas entre setos de

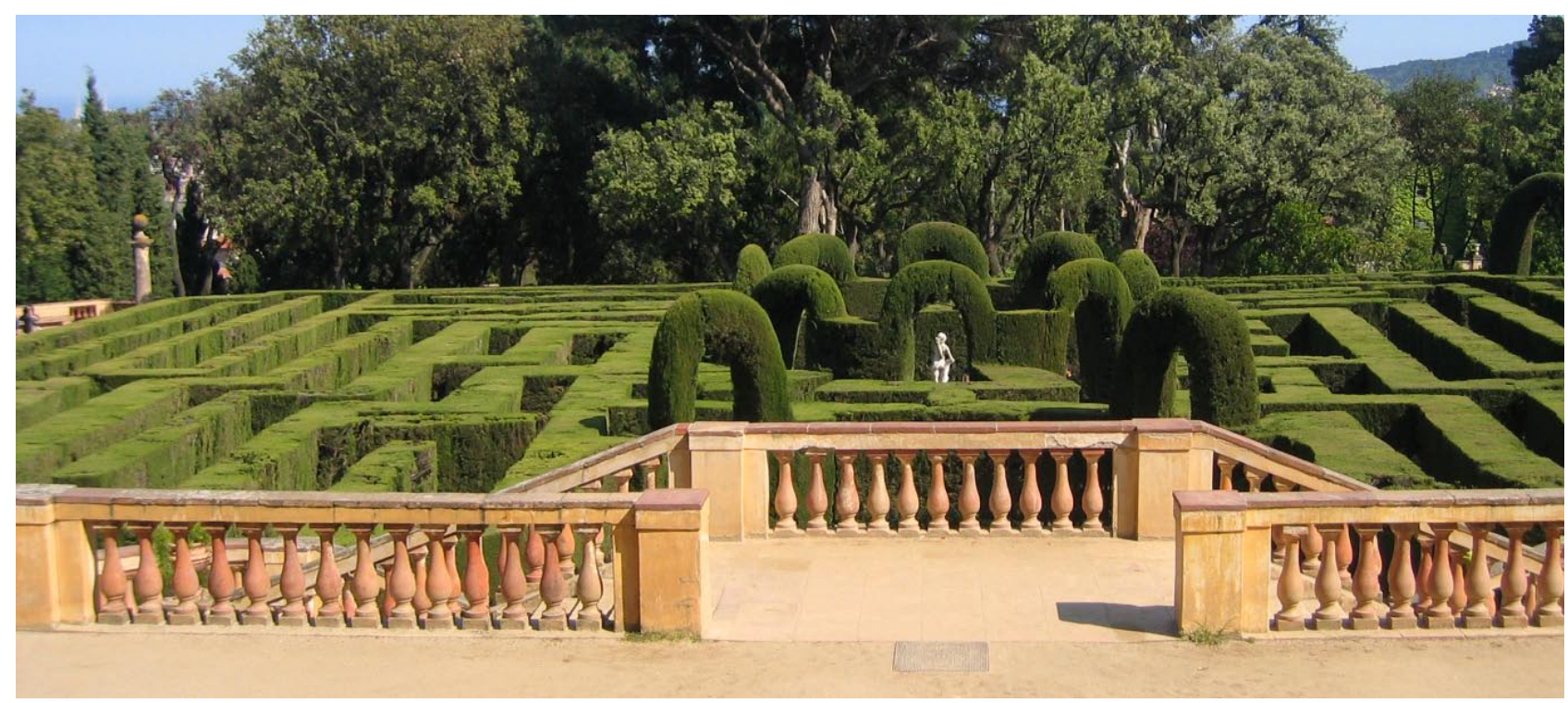

Laberinto de Horta, Barcelona. (fotografía I.C.).

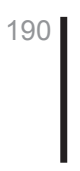



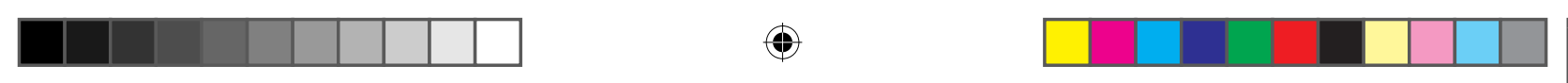

cipreses recortados que vemos a nuestros pies.

Dejando de lado los ejemplos concretos de laberintos construidos en diferentes jardines a lo largo de los siglos, pero atrapados ya por esos lugares fascinantes que son este tipo de construcciones volvemos a movernos en la delgada línea que separa el arte y la arquitectura para centrar ahora nuestra atención en unos espacios no construidos pero no por ello menos estimulantes. Me refiero a esos lugares laberínticos que son las cárceles de los grabados que creó Giovanni Battista Piranesi y que aún hoy en día siguen excitando nuestra imaginación.

G. B. Piranesi, nos ha dejado una obra que, sin necesidad de estar constituida por ejemplos construidos o edificados, ha tenido una colosal influencia posterior. Resulta más que pertinente, por lo tanto, que nos detengamos un instante en su obra si no queremos que esta visión del espacio dinámico quede incompleta. Hijo de cantero y arquitecto y grabador de profesión, a lo largo de la obra de Piranesi se siente esa sólida formación familiar y un consistente y bien labrado saber arquitectónico. Así, geometría y perspectiva bien armada resultan básicas en sus com-

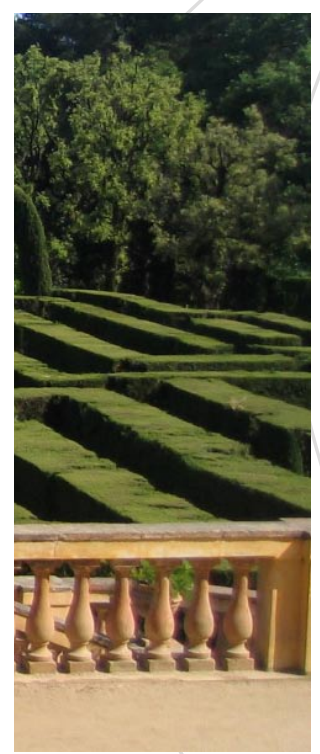
posiciones, reforzadas por la desnudez de los muros y la ausencia de decoración.

Como parte de este aprendizaje, Piranesi realizó a finales de 1740 su primer viaje a Roma desde su Venecia natal. El impacto que le produjo esta visita y la contemplación de la ciudad eterna por parte del joven creador supuso una experiencia determinante en el posterior desarrollo de su obra.

Así, hacia 1745 Piranesi presenta la primera edición de la serie de planchas titulada: "Invenzioni crapic(ciose) di Carceri all Acqua Forte datte in luce da Giovanni Buzard in Roma Mercant(e) al Corso." En esta serie el trabajo de Piranesi cambia de rumbo y el arquitecto pasará de las vistas, en mayor o menor medida, academicistas de Roma y su magnificencia a un mundo lleno de posibilidades expresivas donde la imaginación y la capacidad del artista le llevan a trazar sobre la plancha unos miste- 


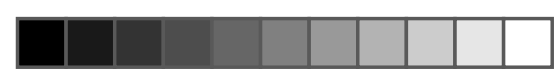

\section{$\oplus$}

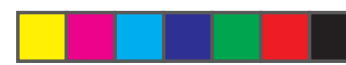

riosos espacios articulados mediante grandes estructuras arquitectónicas llenas de escaleras en zigzag, y de sugerentes y misteriosas entradas de luz contradictorias y desconcertantes. El espacio se vuelve laberíntico, dinámico y terriblemente evocador. Los grandes espacios de una escala grandiosa y monumental no estaban ausentes en sus series anteriores pero cobran una fuerza especial cuando Piranesi da el salto de "reportero" de las maravillas de la Roma eterna a creador de espacios producto de su locura imaginativa.

La gran atracción que aún hoy en día producen estos grabados se debe sin duda a la conexión de la noción de laberinto, y el espacio que le es propio, con una mirada y una perspectiva propias de finales del siglo XVIII. El efecto desconcertante, y angustioso por momentos, que logra Piranesi en sus grabados, ese sentimiento de laberinto y pérdida se produce gracias a la introducción, como decíamos, de diferentes fuentes de luz que potencian y acrecientan la sensación de extrañeza y desconcierto del espectador/visitante del laberinto. Como nos muestra el profesor Gómez Frechina, en los grabados de Piranesi encontramos: "Una continua sucesión de plataformas, rampas, escaleras, puentes, pasarelas y galerías sugieren un apremiante movimiento donde apenas hay espacio para los puntos de referencia, estabilidad y equilibrio."11

Aunque Piranesi continuó profundizando en los grandes hitos arquitectónicos de la ciudad de Roma, y llevó a cabo otras series de vistas imaginarias, ("Prima Parte" y "Los Grotteschi" concretamente) son en especial los laberintos pensados y grabados por el artista veneciano los espacios que han enriquecido significativamente su obra y han tenido una enorme influencia posterior, vehiculando una gran capacidad de ensoñación en arquitectos y creadores de generaciones posteriores de la cual podemos encontrar numerosos ejemplos.

Por citar tan sólo uno de ellos, cuando en 1986 Jean-Jacques Annaud adaptó para el cine la novela de Umberto Eco II nome della rosa (El

11 Gómez Frechina, Jose, "Giovanni Battista Piranesi i la seua obra” en VV. AA., Piranesi, Generalitat Valenciana, Valencia, 1996, p. 34. 

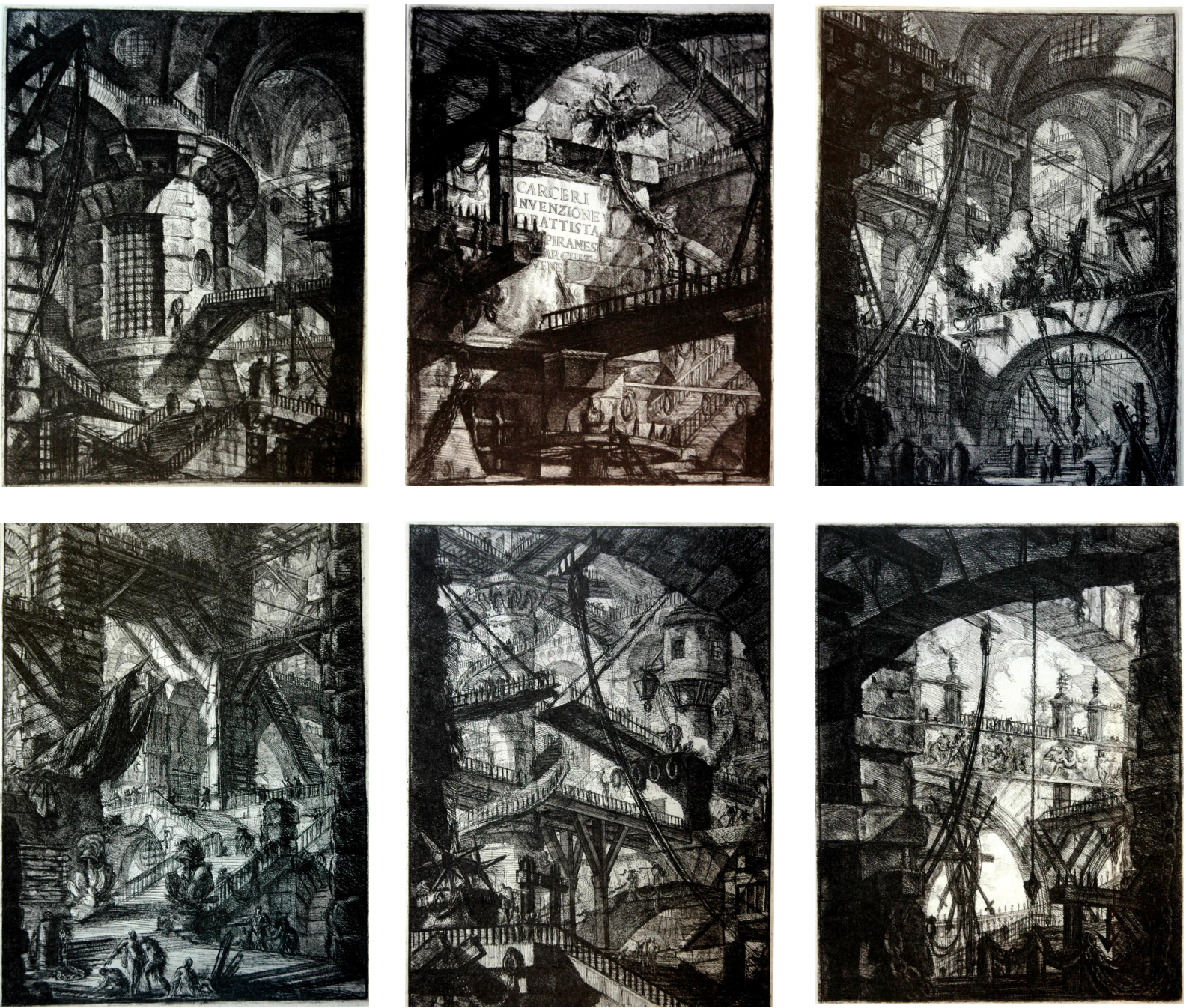

Giovanni Piranesi, Invenzioni crapic(ciose) di Carceri ,1745.

nombre de la rosa) será a Piranesi a quién acudirá para la recreación del laberinto de la biblioteca. Aunque ello no le impidió actuar con una gran libertad ya que el laberinto ideado y pensado por Umberto Eco no era, de hecho, un espacio tridimensional (espacialmente hablando) sino que se desarrollaba en planta inspirado tal vez por la planta del laberinto de Reims $^{12}$

12 Éste aparecía de hecho en la portada de la primera edición aunque fuese después sustituido por un magnífico grabado del laberinto de la Villa Pisani en ediciones posteriores. 


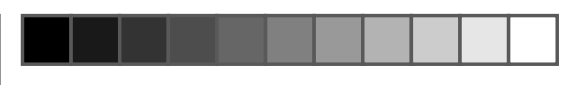

$\oplus$


Jean-Jacques Annaud, El nombre de la rosa,1986.

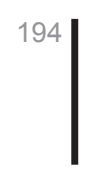



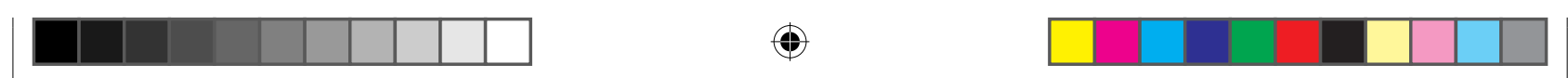

El espacio pensado por Eco, estaba imbuido de numerosas referencias clásicas. En el centro del laberinto se encuentra el libro prohibido cuyo conocimiento y difusión produciría el caos, (el "monstruo" en palabras de Jorge de Burgos, el bibliotecario ciego, encargado de su custodia). Igualmente Adso, el fiel ayudante de Guillermo de Baskerville, a su vez, logrará alcanzar la salida en su primera incursión en su interior, gracias al "hilo de Ariadna" que supone el tejido de su hábito, que el joven engancha y utiliza para dibujar el camino de salida gracias a su cultura clásica.

La imagen del laberinto que encontramos en El nombre de la rosa, ya no es la visión clásica o religiosa que veíamos antes. Tampoco se trata de un laberinto de amor, como aquellos asociados al ars toparia y los jardines del Renacimiento en adelante. El laberinto de la adaptación cinematográfica de la mencionada novela, construido entre el escritor italiano y el director de cine francés, es un laberinto con las claves propias ya del romanticismo. Se trata de un espacio piranesiano, lleno de magia e incertidumbre, de angustia y fascinación a partes iguales. Un espacio donde no es posible detenerse. Un lugar que bascula entre el ansia por el encuentro del segundo tomo de la Poética de Aristóteles, (libro dado por desaparecido para sus protagonistas) y la ansiedad por tal vez no ser capaces de encontrar la salida. Este ejemplo nos muestra de qué modo Piranesi ha fijado en el imaginario colectivo un laberinto tridimensional y arquitectónico de gran capacidad sugerente que ha excitado (y sigue haciéndolo) la creatividad de arquitectos y creadores de muy diversos campos.

Este giro producido durante el romanticismo en la concepción del laberinto es fundamental para poder entender la visión que se tiene del mismo ya en siglo XIX, donde encontramos a un pensador fundamental que conectará la figura simbólica y mítica del laberinto clásico con el espacio urbano y, por extensión, con la ciudad moderna: me refiero al filósofo alemán Walter Benjamin. Para Benjamin, la ciudad es la realización del antiguo sueño humano del laberinto. Aunque volveremos en el capítu- 


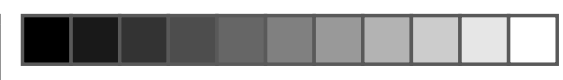

lo siguiente, de modo más amplio, a la figura del flâneur, y a su particular relación con la ciudad, la citación del laberinto como figura fundamental de la ciudad por parte de Benjamin resulta especialmente interesante si consideramos lo impensable de la fusión de ambas realidades hasta el momento.

De igual modo, el laberinto será reivindicado por el movimiento surrealista como "la patria del que duda", apropiándose de la maravillosa definición de Walter Benjamin. A partir de esta idea, es lógico que los surrealistas vean al Minotauro como su mejor aliado. Para este movimiento artístico, el ser mitad hombre y mitad toro, no es ya el monstruo a batir situado en el corazón del laberinto, sino la encarnación de lo irracional, de la animalidad/del ser humano. Ahora bien, en esta ocasión la animalidad del ser humano no es un aspecto prohibido que se deba controlar y combatir sino, por el contrario, una faceta positiva e interesante del individuo, digna de ser reivindicada frente a una sociedad totalitaria y reaccionaria que constriñe al ser humano y su libertad. La figura del Minotauro se convierte así en un símbolo de resistencia frente al racionalismo y sus excesos. No es, en consecuencia, por casualidad, que la revista aglutinadora del movimiento surrealista, surgida de la mano de André Masson y Georges Bataille, tome por título precisamente "Minotauro" (1933-1939)13 con la fuerte carga simbólica e ideológica que en su contexto sociocultural conllevaba la reivindicación del monstruo vencido por Teseo.

Como vemos, el laberinto se vuelve figura recurrente en el arte y el pensamiento de comienzos del siglo XX. Ahora bien, ya no se trata, evidentemente, de los laberintos que veíamos dibujados o elaborados con teselas en pavimentos de iglesias, ni tampoco están construidos con setos de boj para perdernos en ellos a la búsqueda de Eros. Se produce lo que podríamos considerar también como una actualización de la figura y una fusión muy interesante entre la experimentación del espacio urbano, es decir, del paisaje urbano, y la idea de laberinto. El mito se comple-

13 Con Masson, se produce también una confusión entre el laberinto y el cuerpo humano que abre interesantes e insospechados campos para el laberinto en tanto que figura mítica, pero que escapan al tema que aquí nos ocupa. 

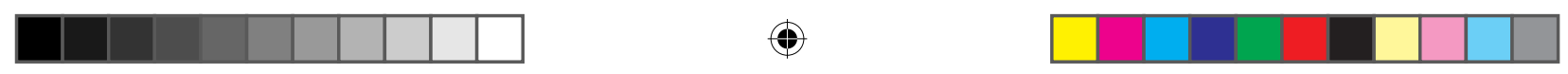

3. El arte de caminar, un recorrido histórico.

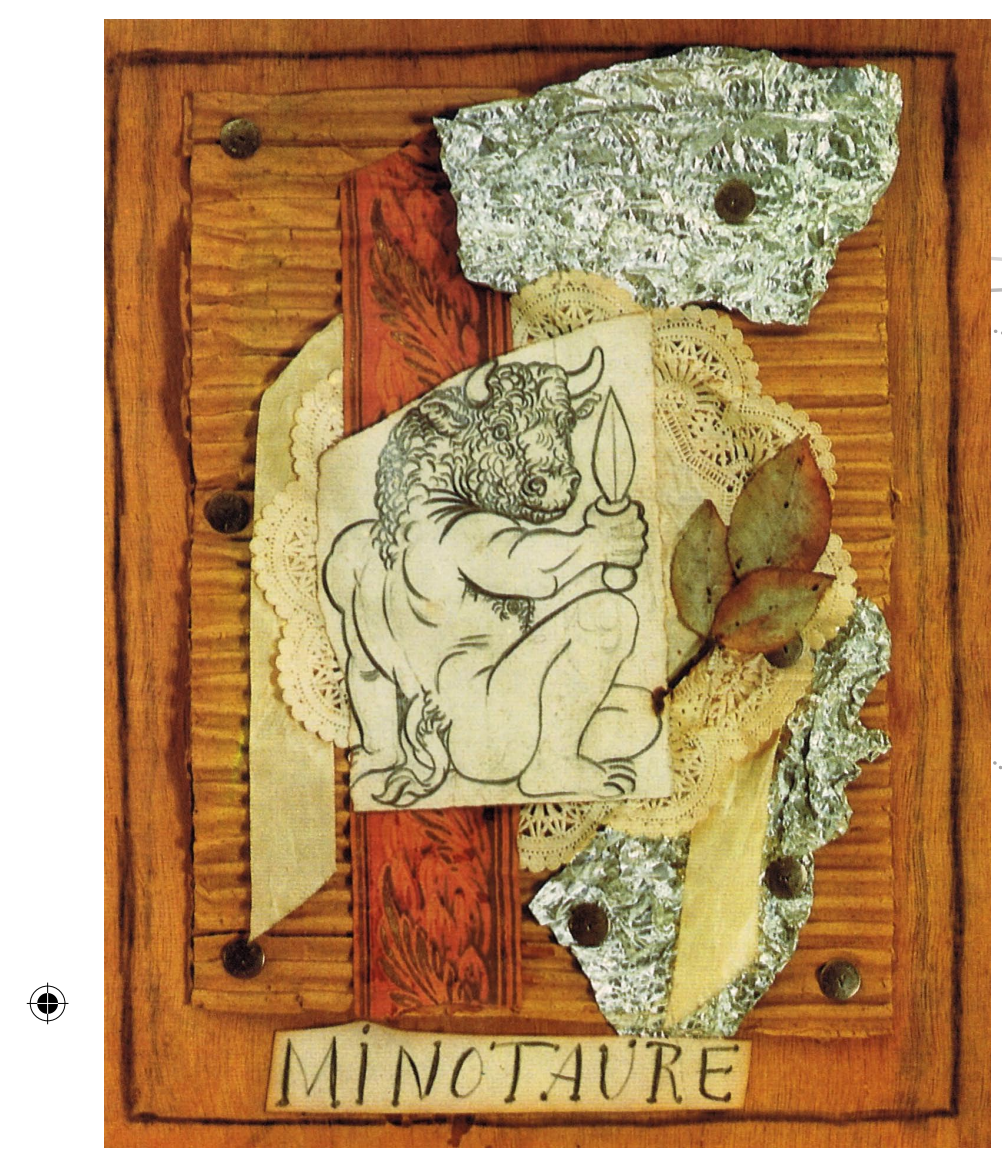

Pablo Picasso, Maqueta para la portada de la revista Minotauro, 1933.

jiza y se enriquecen sus lecturas. Gracias a una serie de artistas vinculados en mayor o menor medida con el movimiento surrealista, el laberinto pasa a ser identificado con la propia ciudad.

Aunque el testigo de las reflexiones llevadas a cabo por Friederich Nietzsche $^{14}$ o Georges Bataille, entre otros, en torno al laberinto lo recogerán con posterioridad los situacionistas colocando el concepto de deriva, íntimamente ligado al de laberinto, en el centro de sus preocupaciones, el situacionismo y sus paseos surrealistas por el laberinto urbano los trataremos más ampliamente en el próximo capítulo debido a lo esencial de la noción de movimiento en la vivencia y creación del espacio urbano.

Esta identificación entre laberinto y ciudad por parte de surrealistas y situacionistas, no supuso la muerte del laberinto fruto de su confinamiento en el espacio urbano agotando su capacidad expresiva. Bien al contrario, en la medida en que en años sucesivos, pasado ya el ecuador del siglo XX, el arte sale de las galerías y los museos para encontrarse

14 Nietzche dedicó un gran esfuerzo de pensamiento a la figura del laberinto y nos dejó otra de las grandes definiciones del laberinto, que, de nuevo, lo relaciona con la arquitectura y en este caso, el tipo: "Si quisiéramos ensayar una arquitectura modelada sobre el patrón de nuestra alma, el laberinto sería nuestro arquetipo", proclamó el filósofo alemán. 

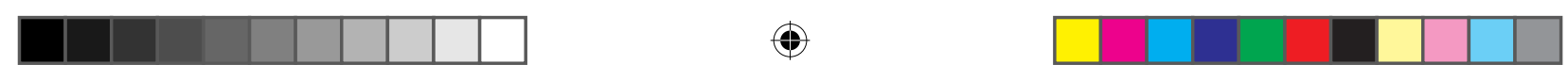

con la naturaleza, el laberinto volverá a tomar protagonismo continuando su viaje hasta nuestros días. Artistas como Walter de Maria, Richard Long, Nancy Holt o Robert Morris (vinculados en mayor o menor medida con el Earth Art o el Land Art ${ }^{15}$ ), trabajarán y experimentarán de nuevo con el espacio del laberinto, una figura que les permite un diálogo con la naturaleza propio de culturas primigenias, materializado

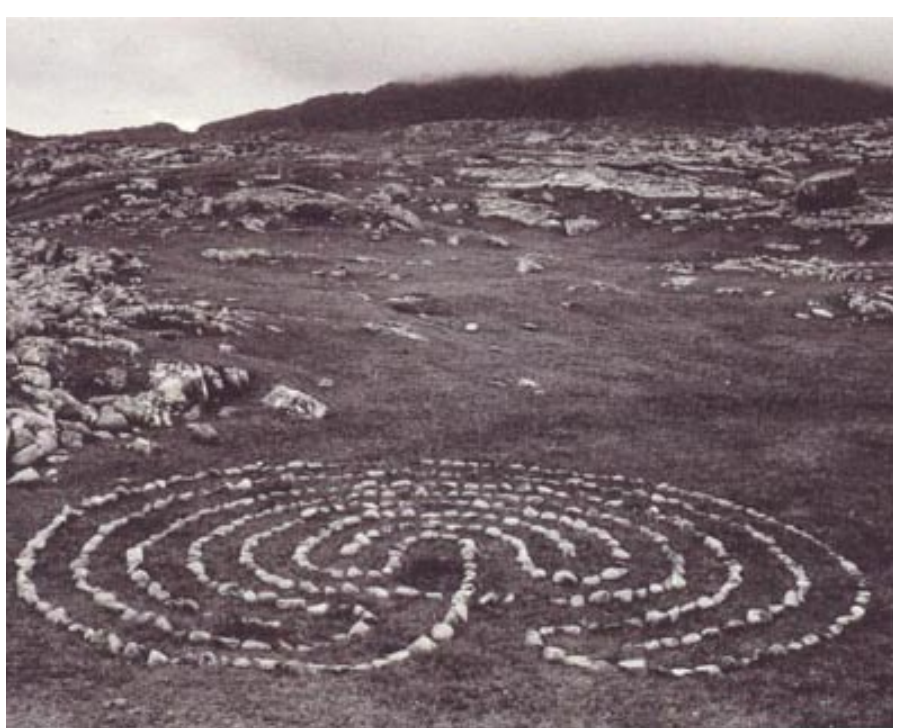

Richard Long, Connemara Sculpture, Ireland, 1971. también en la utilización de materiales autóctonos.

Para estos artistas, y sobre todo en el caso de Richard Long, existen unos tipos concretos de laberinto que cautivarán su atención especialmente y que excitarán su imaginación, se trata de los laberintos de hierba ingleses o turf maze, de fuerte implantación en Gran Bretaña, y los trojeborg, laberintos de piedra costeros escandinavos a los que están íntimamente ligados.

Uno de estos turf maze ingleses, tal vez el más conocido ( $y$ que con toda probabilidad visitara Richard Long a lo largo de sus paseos por la isla), es el de Alkborough, una pequeña localidad de North Lincolnshire (Inglaterra). Se trata de un hermoso laberinto unicursal elaborado con la fuerte y resistente hierba inglesa que consta de once niveles y que tiene aproximadamente unos 13,5 metros de diámetro.

Los trojeborg escandinavos, íntimamente ligados a estos últimos debido a los fuertes lazos económicos, culturales y sociales existentes

15 Para una aproximación a estas experiencias artísticas véase Bearsley, John, Earthworks and Beyond. Contemporary Art in Landscape, Abbeville, Nueva York, 1989. 

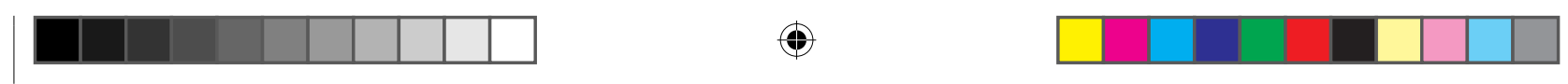

entre ambas orillas, se encuentran ampliamente extendidos en las costas escandinavas y de influencia, tanto en zonas de playa como próximos a importantes vías de comunicación e intercambio fluvial. Hablamos también de laberintos unicursales pero elaborados en este caso con piedras. El origen de estos laberintos está envuelto en un manto de misterio ya que la mayoría de topónimos hacen referencia a Troya o a Jerusalén lo que plantea un doble origen: romano por un lado, dada la identificación que los romanos hicieron de Troya con el laberinto cretense, y cristiano por otro, dada la vinculación del laberinto unicursal con la peregrinación a Jerusalén. Aunque en muchos casos el solapamiento entre ambos orígenes parece evidente.

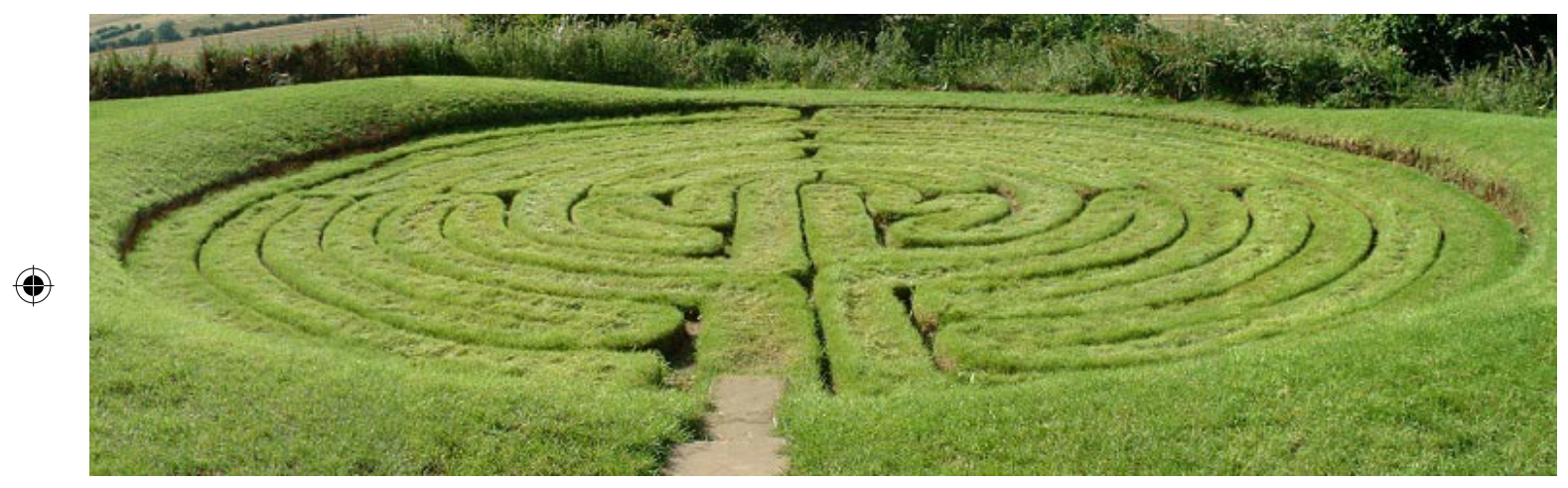

Turf maze de Alkborough, s/f., North Lincolnshire, Inglaterra.

Cuando Richard Long vuelve su mirada a estos laberintos escandinavos de piedras ${ }^{16}$ lo hace con el objeto de utilizarlos en su reflexión acerca del ser humano, de la escala temporal y la percepción por parte del artista de ambos aspectos. Para Long, el pasado es evocado en un instante específico y fugaz a través de la elaboración del laberinto, a partir de la manipulación pasajera de un material en un lugar sin edad específica. La utilización de la piedra, (por otra parte tan frecuente si no casi exclusiva en su obra) en su escultura Connemara Sculpture (1971) parece insistir en una idea de consciencia de la precariedad humana frente a la eternidad de este material, padre y guardián del mundo. El arte de

16 Véase al respecto: VV. AA. Piedras. Richard Long, Ministerio de Cultura, Madrid, 1986. 


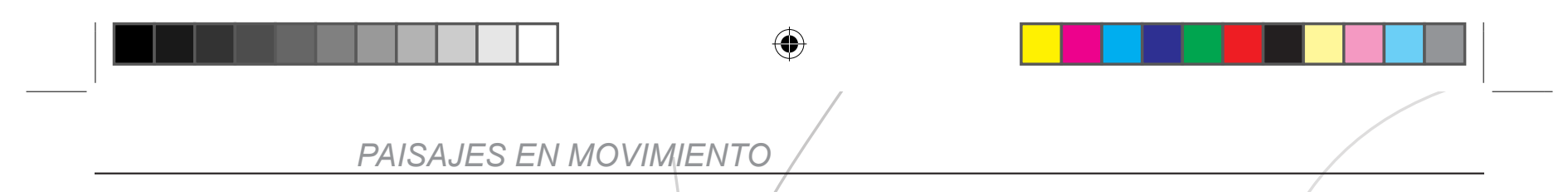

Richard Long aprovecha así el laberinto como espacio simbólico donde explotar el potencial de la conjunción naturaleza/cultura (paisaje por tanto, o Landscape art).

Tras este recorrido por la historia del laberinto, aproximándonos

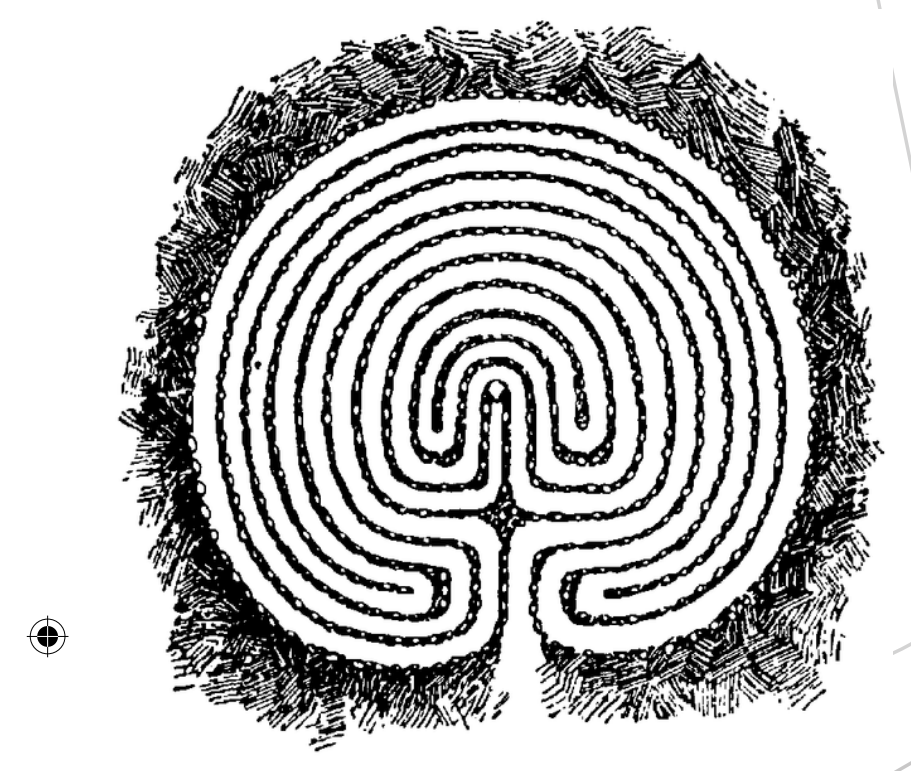

Diagrama del Trojeborg de Visby, s/f Dinamarca.

a algunos de sus episodios más significativos e interesantes para el tema que nos ocupa, quisiera concluir volviendo la mirada a un laberinto mucho más próximo a nosotros, de sensibilidad contemporánea, construido, y donde la idea de lugar dinámico y desasosegante alcanza cotas de gran dramatismo. Me estoy refiriendo al "Memorial del Holocausto del pueblo judío" construido por Peter Eisenman en el corazón de Berlín, junto a la puerta de Brandeburgo, entre 1998 y 2005.

El arquitecto norteamericano ha construido en la capital alemana un extraordinario laberinto partiendo de una retícula (aparentemente) homogénea de bloques de hormigón armado y calles rectilíneas entre ellos. Eisenman construye, mediante este sistema de llenos y vacíos, un espacio donde a través de pequeños cambios de volumen o escala en los diferentes bloques y ligeras pendientes ascendentes y descendentes en los caminos que recorren el conjunto creado por el arquitecto, la angustia y el miedo se apoderan del visitante, construyendo así un verdadero laberinto contemporáneo.

Entroncando con la idea de pérdida desarrollada por los situacionistas, Peter Eisenman cuestiona el racionalismo, tal y como hicieron los

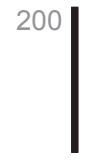



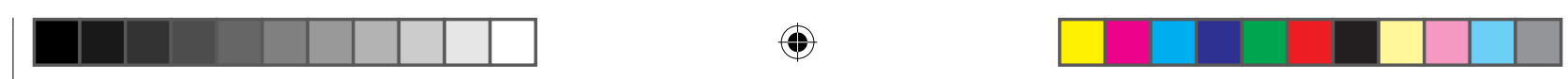

surrealistas, y construye una poderosa denuncia del horror que es capaz de producir el ser humano cuando, partiendo de una retícula de calles sensibleramente ortogonales y de volúmenes casi puros de hormigón (material conocido por su capacidad resistente y su durabilidad) al introducir sutiles distorsiones, genera un espacio que produce zozobra y ansiedad.

Aquí el monstruo no se encuentra en el centro ni tiene forma, el "monstruo" del Memorial Judío de Berlín está en la superficie tersa de sus bloques de hormigón, en sus caminos rectos. El monstruo es el ser humano, somos nosotros situados dentro de este dédalo de calles, de caminos inestables y perversos. El espacio urbano surgido del recorrido titubeante por la superficie informal creada por Peter Eisenman, se transforma en metáfora del capítulo más espantoso de la historia del siglo XX. La deriva por la ciudad se sitúa entre los bloques mudos y potentes del Memorial. Esta vez no queda tan claro que fuera Teseo quién venció definitivamente al Minotauro, o ¿acaso sucede al contrario? Y nos vienen entonces a la memoria las palabras con las que Jorge Luis Borges concluye su maravilloso cuento La casa de Asterión, dedicado al monstruo encerrado en el laberinto de Creta, a quién el escritor argentino trata con un enorme afecto:

"El sol de la mañana reverberó en la espada de bronce. Ya no quedaba ni un vestigio de sangre.

-¿Lo creerás, Ariadna?- Dijo Teseo-. El minotauro apenas se defendió."17

17 Borges, Jorge Luis, "La casa de Asterión" en Borges, Jorge Luis, El aleph, Alianza, Madrid, 2009, p.81. 


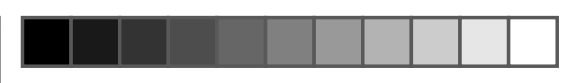

$\oplus$
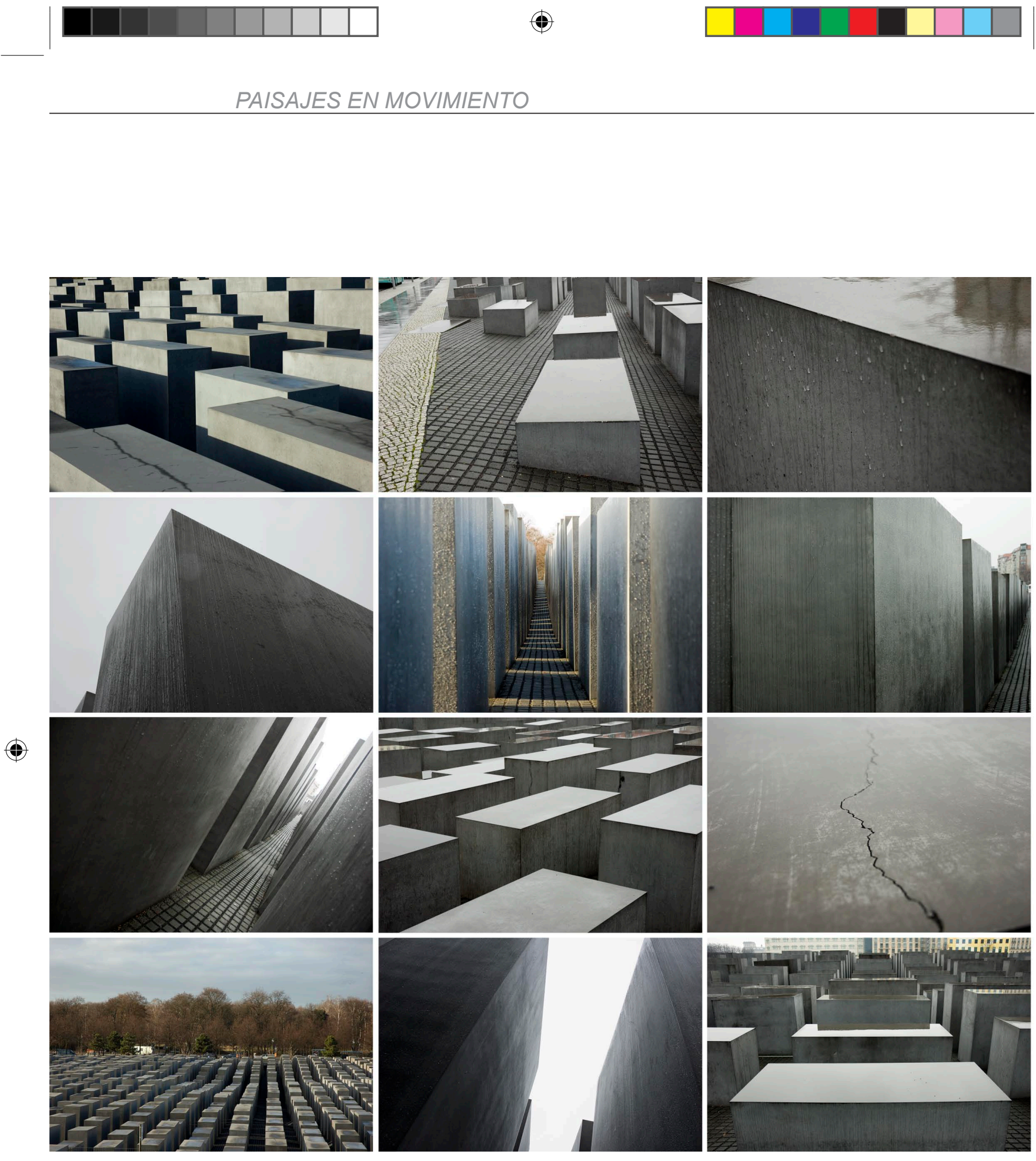

Peter Eisenman, Memorial Judío, Berlín, 1998-2005 (fotografías I.C.). 

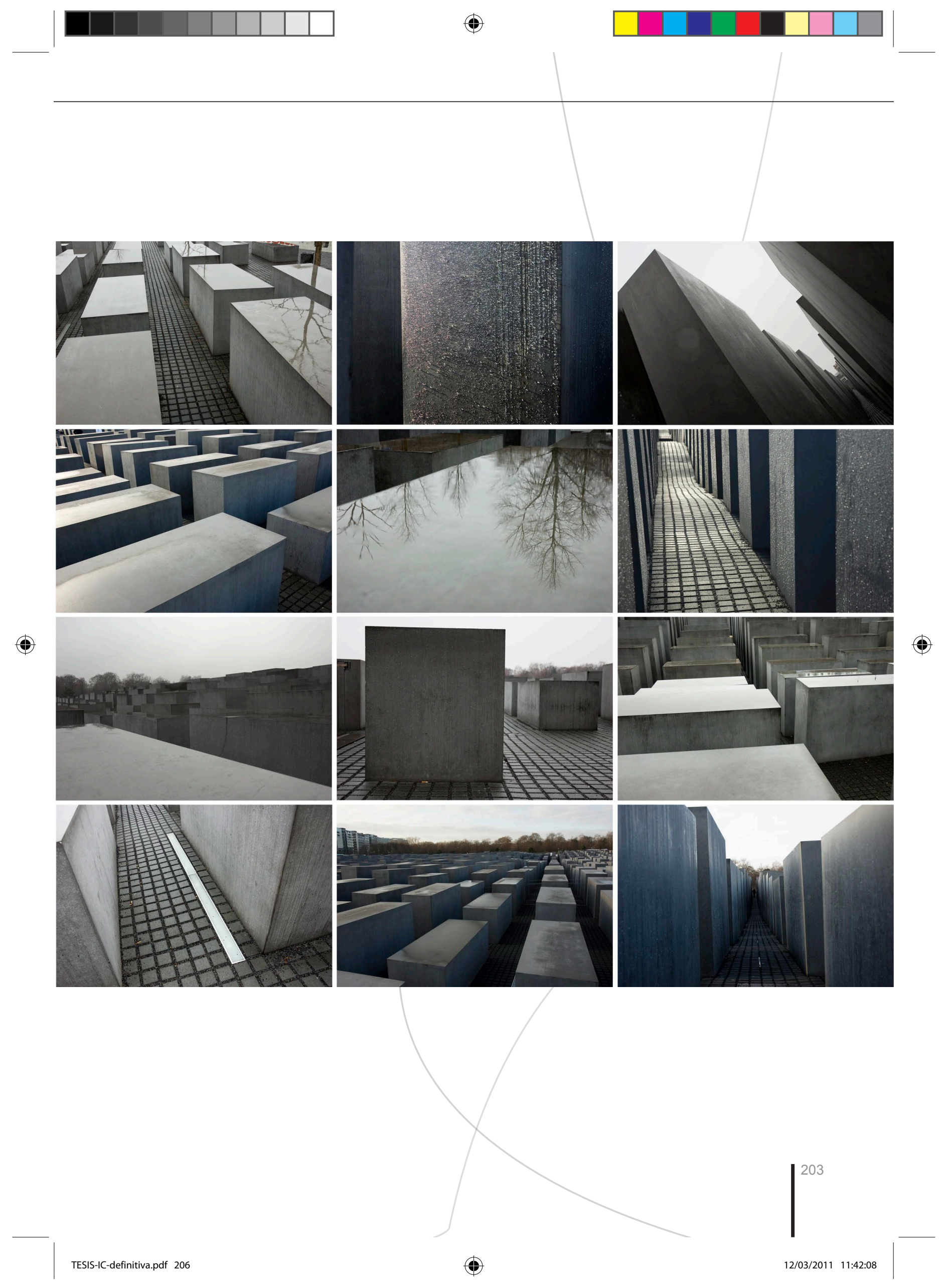


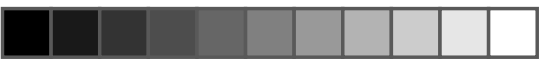

(†)
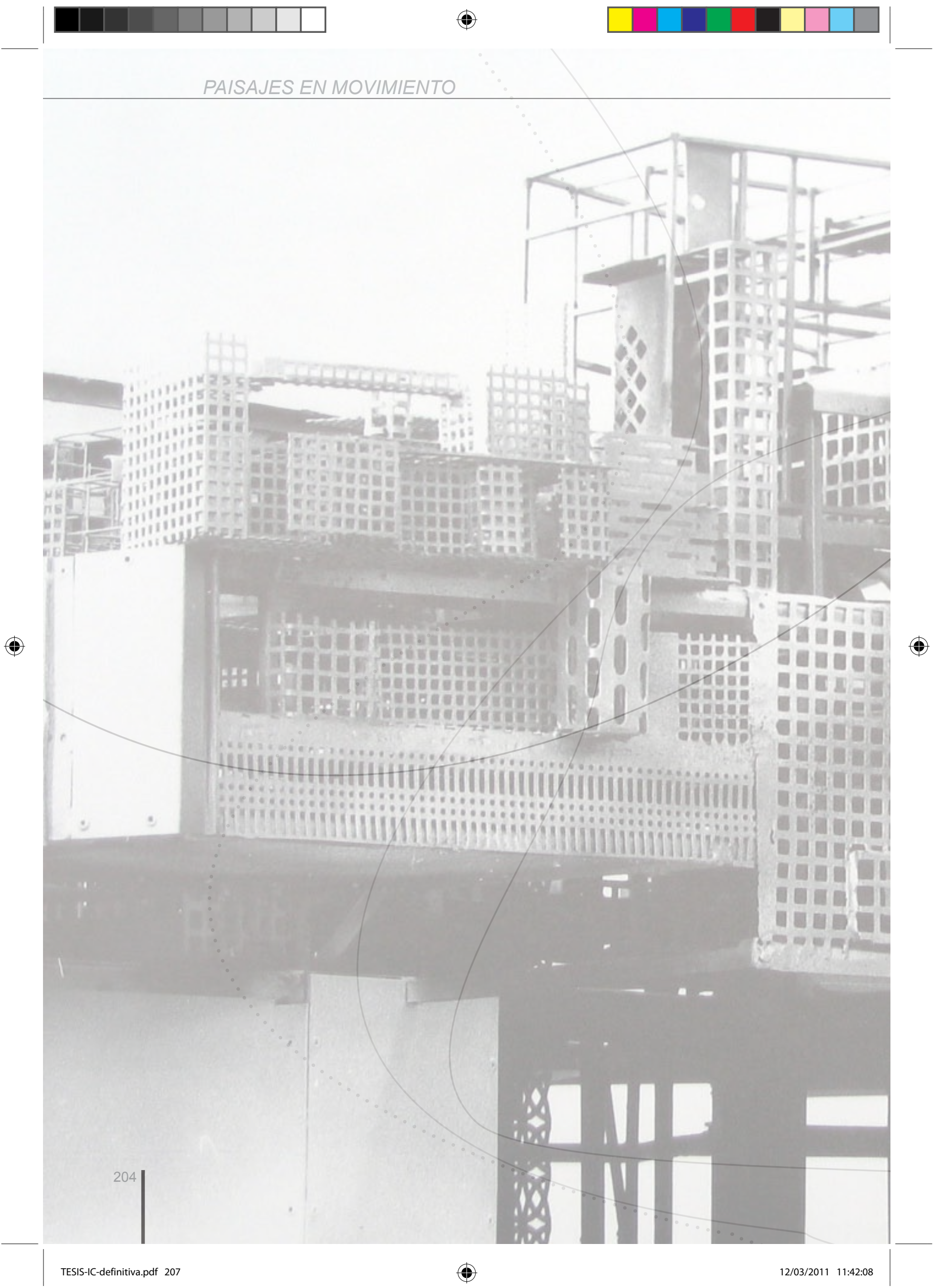


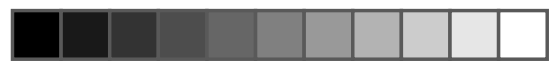

(1)

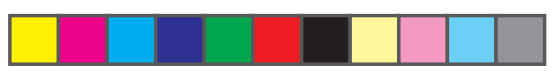

4. Experiencias entre el arte y el urbanismo en torno al movimiento.

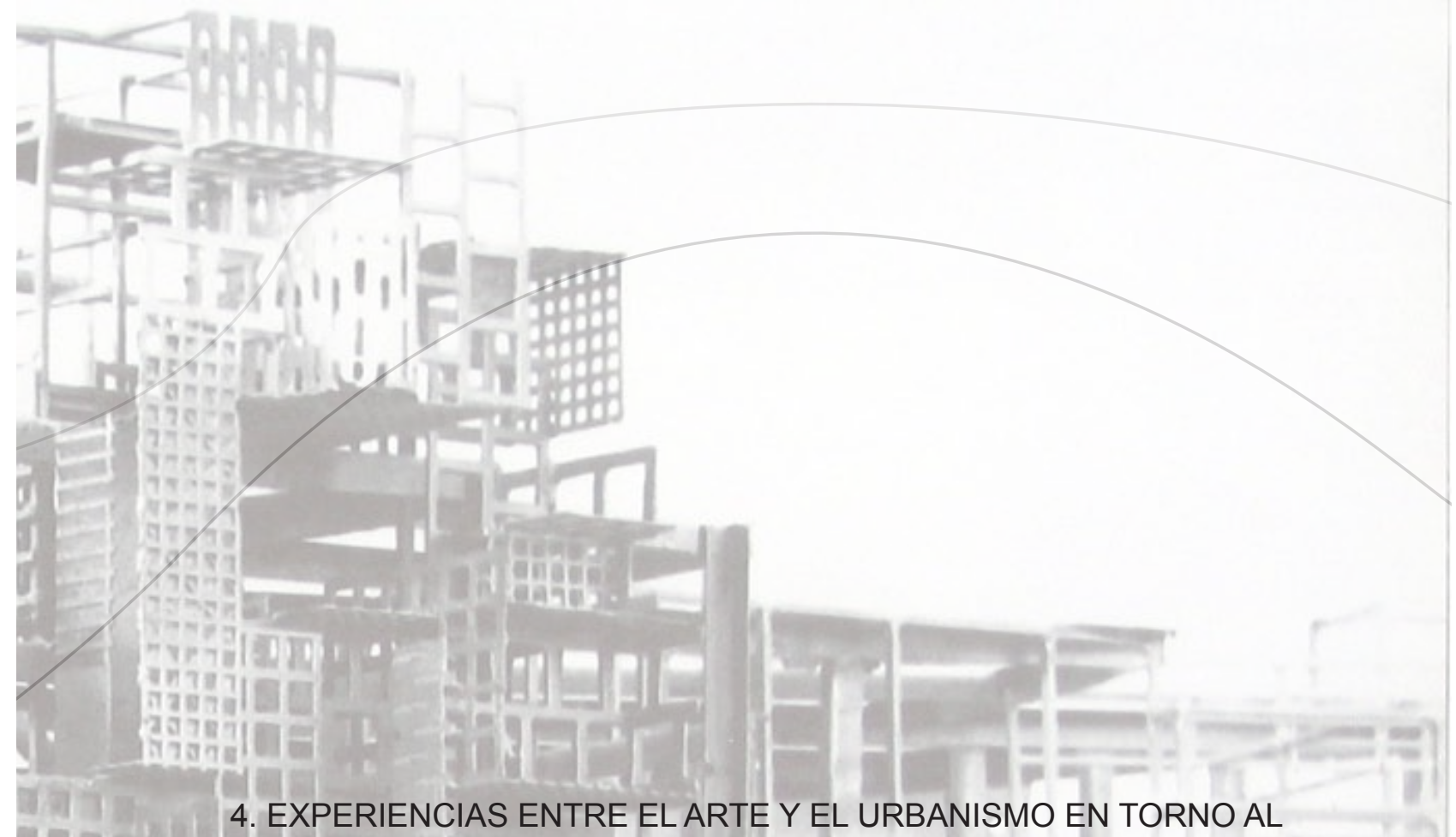

(4)

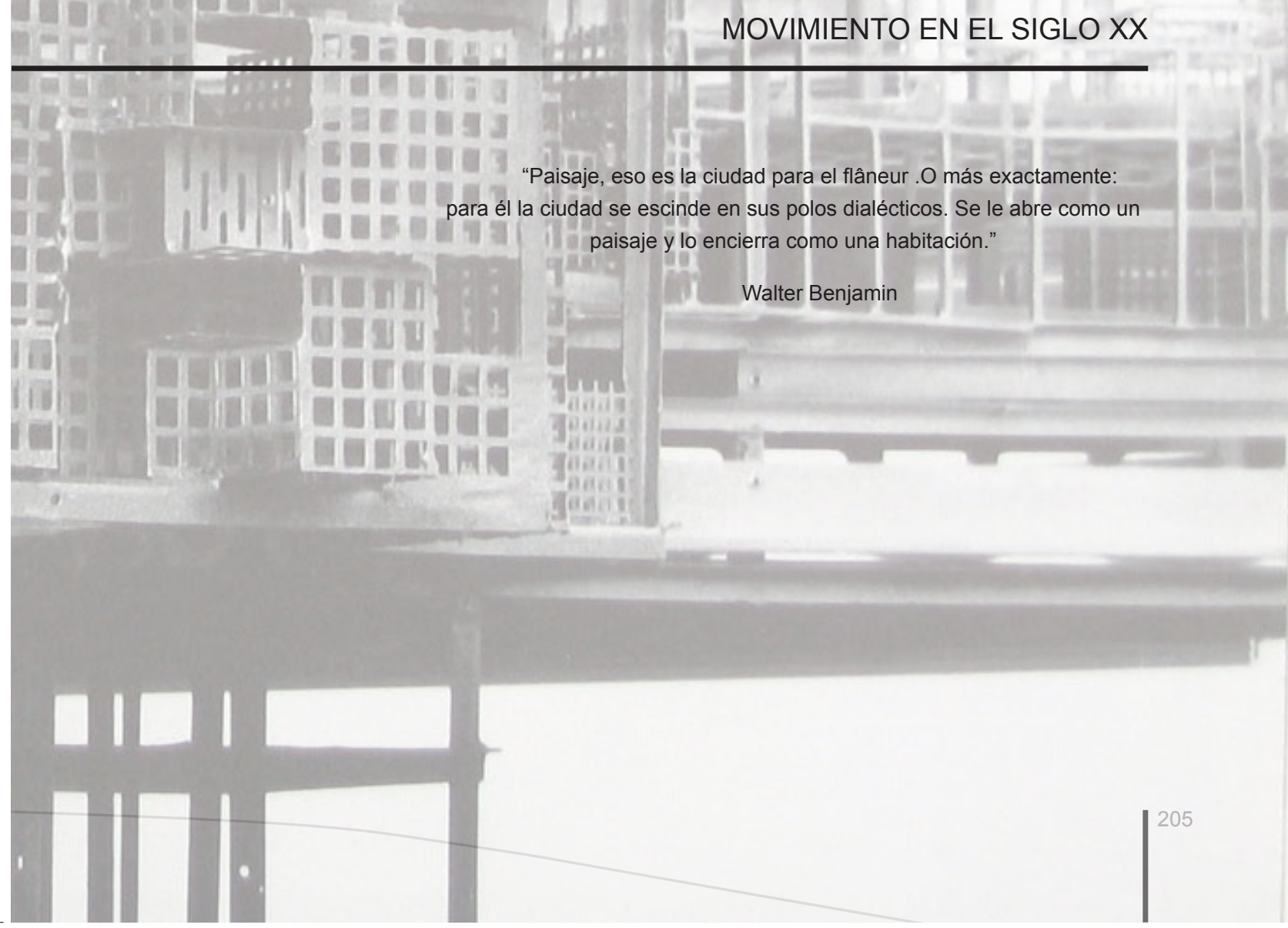




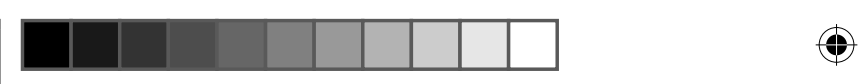

$\oplus$

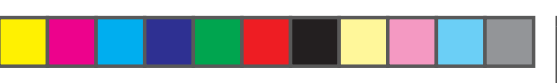

PAISAJES EN MOVIMIENTO
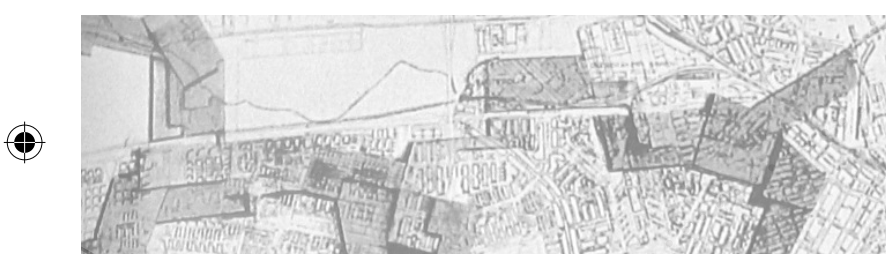

$\frac{19}{24}$.

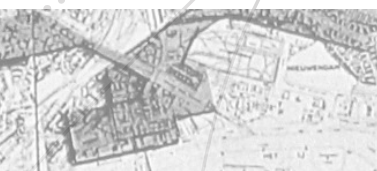

a
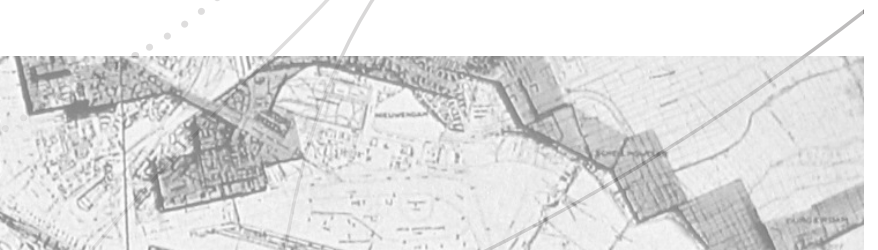

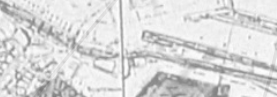
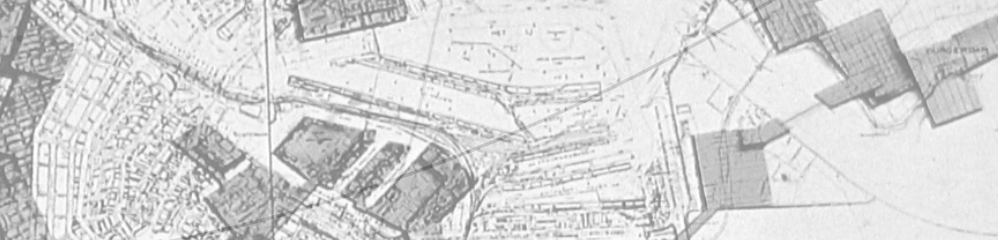

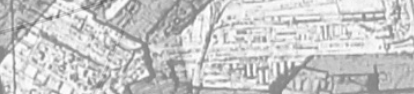

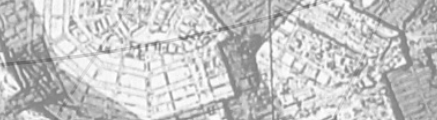

\&.
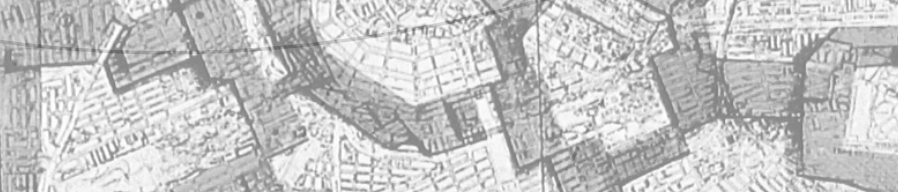

A)
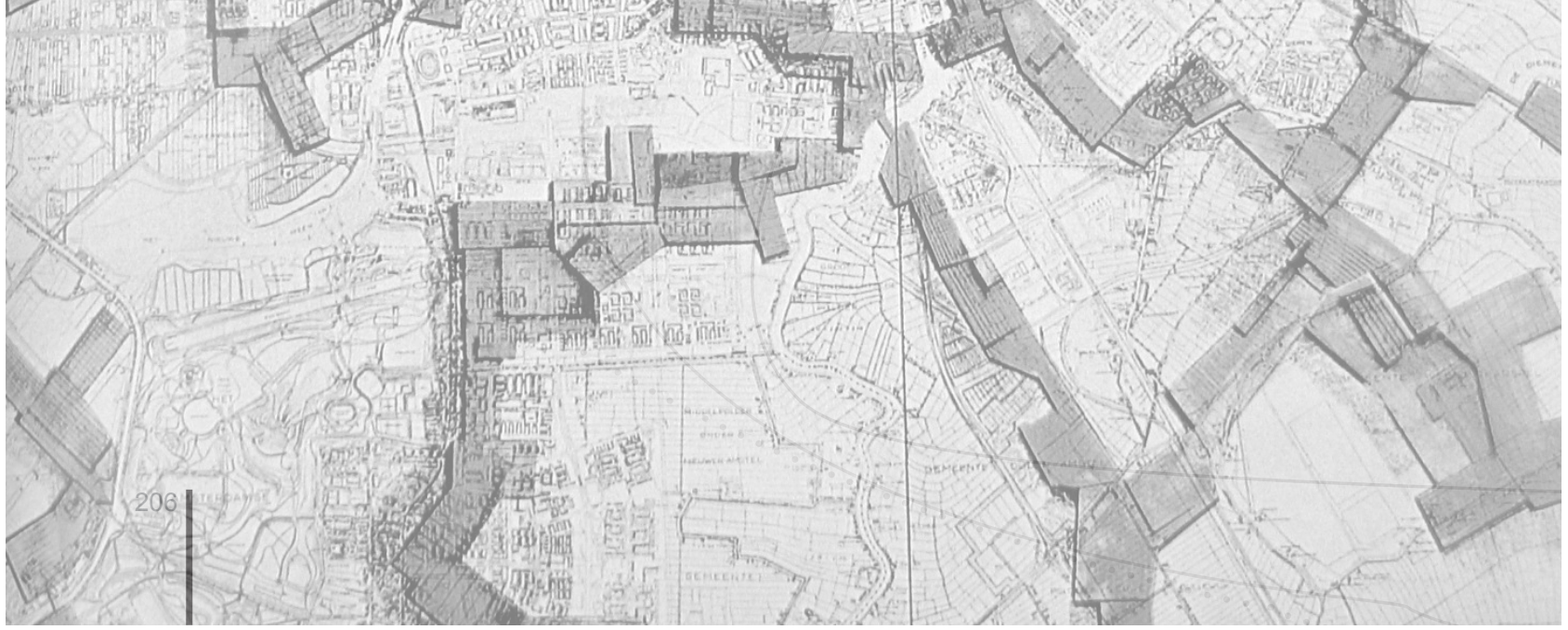

12/03/2011 11:42:08 

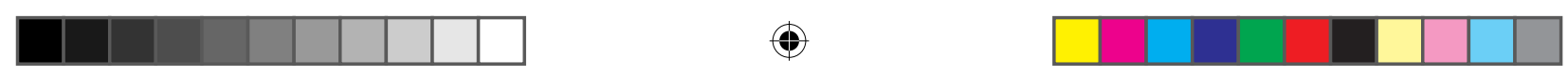

4.1 URBANISMO EN MOVIMIENTO: FLÂNEURS, SITUACIONISTAS Y CIUDADES

NÓMADAS

A finales del siglo XIX y principios del siglo $X X$ se produjo una crisis del urbanismo tradicional, organizado en torno a una idea central de espacio jeraquizado, permanente y estable que delimita claramente sus fronteras o límites, estableciendo un punto de vista único y fijo como el verdaderamente válido. El proceso de vinculación entre ciudad moderna y laberinto que vimos en el capítulo anterior formaba parte de un conjunto de planteamientos que han abogado desde entonces por unas organizaciones más fluidas y plurales, más ambiguas y móviles del hecho urbano.

Frente a los excesos del racionalismo, sus presupuestos objetivos y sus principios, Walter Benjamin hizo una novedosa lectura de la vida 

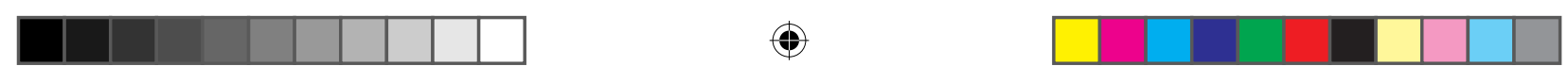

en la ciudad a partir de los textos del poeta francés Charles Baudelaire señalando el espacio urbano como un frenético "collage" de superficies cambiantes y de experiencias discontinuas y fragmentadas en las que el flâneur se siente como en su propia casa. La fascinación por el espacio intrínseco al laberinto llevó a Walter Benjamin, a defender, la necesidad personal de aprender el "arte de extraviarse" en el que la ceguera es una forma de orientación. Según el filósofo alemán, tenemos que callejear sin fin, y sin objetivo aparente, por el espacio urbano para perdernos en la multitud y vagar por el laberinto de la ciudad para ser capaces de "empezar a encontrar nuevos rumbos"1.

Se trata, en definitiva, de colocar el movimiento del individuo en cuanto generador de nuevos significados del espacio urbano, en el centro de nuestra atención y darle el merecido protagonismo que se merece, hasta el momento negado por interpretaciones más formales y académicas de la ciudad basadas en la lectura de las formas y los volúmenes construidos que forman el conjunto de nuestras ciudades como el único criterio válido de crítica y valoración.

A partir de este momento, y siguiendo estas sugerentes e innovadoras recomendaciones, han sido muchos los artistas y arquitectos que han apostado claramente por la fluctuación, la movilidad, el tránsito e, incluso, la desorientación como elementos consustánciales al deseo de resquebrajamiento de la ciudad ordenada y geométrica, de la estructura productiva y jerarquizada, que hegemoniza las ciudades contemporáneas. En este sentido, ya en los años treinta el escritor francés Georges Bataille abogaba por la estructura espacial del laberinto como la metáfora de un cuerpo sin jerarquía, sin cabeza pensante ni razón. Ante una ordenación del espacio clara y concisa, la idea del laberinto proponía despreocuparnos por encontrar la salida y disfrutar de tener la posibilidad de perderse, de no saber a ciencia cierta si salimos o entramos, de no conocer los límites ni las posibilidades de los diferentes recorridos. El objetivo, contra-

1 Benjamin, Walter, Poesía y capitalismo Iluminaciones II, Altea, Taurus, Alfaguara, SA, Madrid, 1988, p.37. 

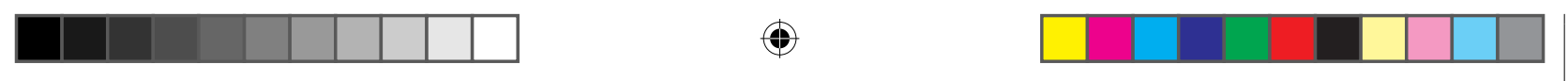

\section{Experiencias entre el arte y el urbanismo en torno al movimiento.}

riamente a lo que sucedía en los espacios laberínticos tradicionales que veíamos anteriormente, no era ya el de llegar a algún sitio (fuera la salida o el centro del mismo), sino la propia experiencia del trayecto, el impulso

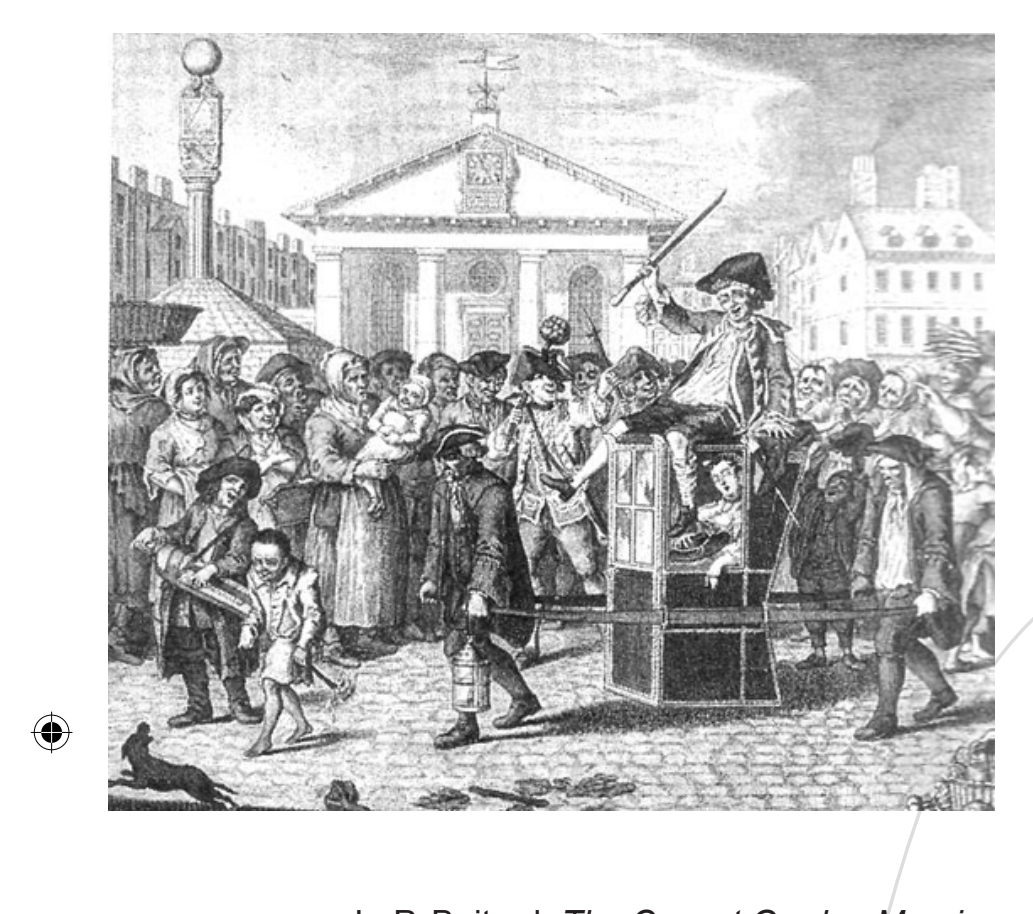

L. P. Boitard, The Covent Garden Morning Frolick, 1739. del recorrido y la travesía sin fines concretos. No se trata ya de alcanzar un objetivo final sino de disfrutar del desplazamiento, del recorrido. Este cambio fundamental de perspectiva supuso una revalorización del movimiento del visitante o del ciudadano que camina por su ciudad como generador de experiencias y, en consecuencia, de espacio urbano.

Para entender el enorme alcance de esta transformación, es interesante recordar de qué modo durante el Siglo XVIII, en las grandes ciudades europeas la diferenciación entre aquellos que caminan por la ciudad y aquellos que no lo hacian era un modo de distinción evidente entre las diferentes clases sociales. La élite pasará así por el espacio urbano sin entrar en contacto con él, ya que éste es asociado inevitablemente con los disturbios sociales y los conflictos que son inherentes a la ciudad en estos años. El espacio urbano es, en efecto, un lugar de cruce inevitable entre diferentes estratos de la sociedad y por tanto hay que buscar los mecanismos para evitar tanto las confrontaciones (a menudo violentas) como la identificación con las clases menos favorecidas. Así pues, caminar por la ciudad es entendido como signo de inferioridad social, un gesto indigno potenciado por la interpretación que se hace de 

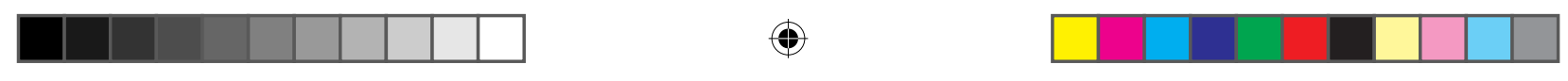

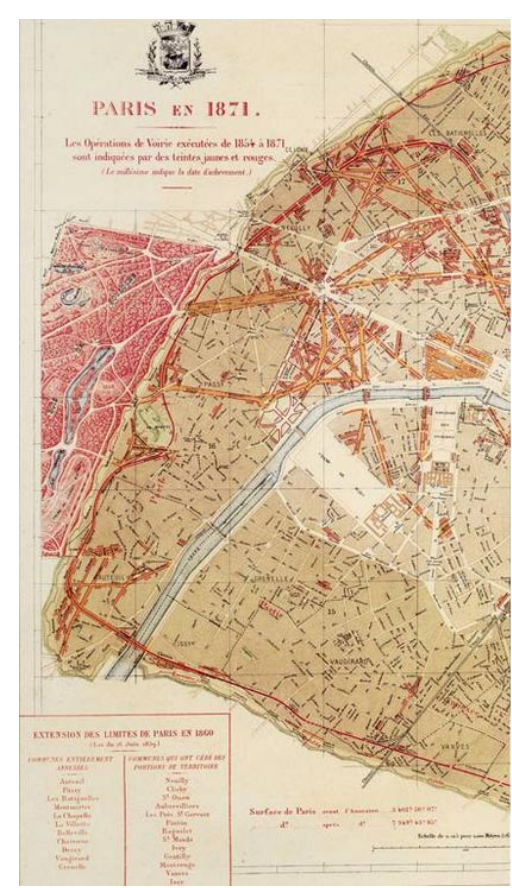

Plano de Paris con las reformas de Haussmann, 1871 (detalle).. la multitud en cuanto conjunto de maleantes, borrachos, pendencieros y prostitutas. ${ }^{2}$

De este modo, a caballo entre el siglo XIX y el siglo $X X$, frente a unos criterios urbanísticos claramente mayoritarios que favorecen las actitudes sedentarias y el control permanente, comienza a oponerse un proyecto de ciudad basado en lugares de tránsito, en territorios en permanente transformación, que contienen unas características nómadas que se apoyan en el deseo, el placer y el juego; unos aspectos que son verdaderamente improductivos, efímeros y cambiantes. Son ideas que apuestan por una ciudad nómada y hacen referencia al propio recorrido como un objetivo en sí mismo. Una ciudad en la que su forma deviene de los diferentes movimientos, de los espacios intermedios, de la mutación constante, del desplazamiento permanente y de la perpetua transformación. En estos proyectos el interés no se encuentra ni en el punto de partida ni, tampoco, en el de llegada (que de hecho ya no existe) ni, mucho menos, en posibles puntos de referencia estables. Se trata, como las propuestas que aquí se plantean, de unas experiencias del movimiento que apuestan por una arquitectura entendida, fundamentalmente, como percepción y construcción simbólica del espacio. Nos encontramos frente a una ciudad compuesta de múltiples paisajes dinámicos que necesitan del individuo para ser activados y puestos en funcionamiento.

Es en este contexto, donde surge una figura fundamental para entender el cambio de planteamiento y de criterio en la concreción del espacio urbano que se está produciendo; me refiero (tal y como he men-

2 Sobre este tema consúltese Arasse, Daniel, Op.cit., París, 2000. 
cionado anteriormente) a la aparición en París, y de la mano de Walter Benjamin, de la figura del flâneur.

Para entender la figura del flâneur hay que situarlo en su contexto, hay que colocarlo en el París de Haussmann, de los pasajes, esa "nueva invención del lujo industrial". Los famosos pasajes parisinos ${ }^{3}$ surgieron al calor de las reformas llevadas a cabo por el ingeniero y arquitecto Georges-Eugène Haussmann en la capital francesa bajo las órdenes del emperador Napoleón III (quién le nombraría barón complacido por las obras llevadas a cabo). Se trata de pasos a cubierto en el corazón de las masas de viviendas, revestidos de mármol y con techos de acero y cristal de donde reciben la luz, de manera que, tal y como se publicitaba en una guía ilustrada de París de 1852, "se suceden las tiendas más elegantes, de modo que un pasaje es una ciudad, un mundo en pequeño." Es en este mundo en miniatura donde, tal y como nos dice Walter Benjamin "el flâneur está como en su casa."

Los pasajes son entendidos como una fascinante realidad intermedia entre el exterior y el interior, entre la vivencia pública de la calle y la intimidad del hogar, de modo que son ambos y ninguno al mismo tiempo. El flâneur hace de la ciudad su hogar, de modo que "el bulevar es la vivienda del

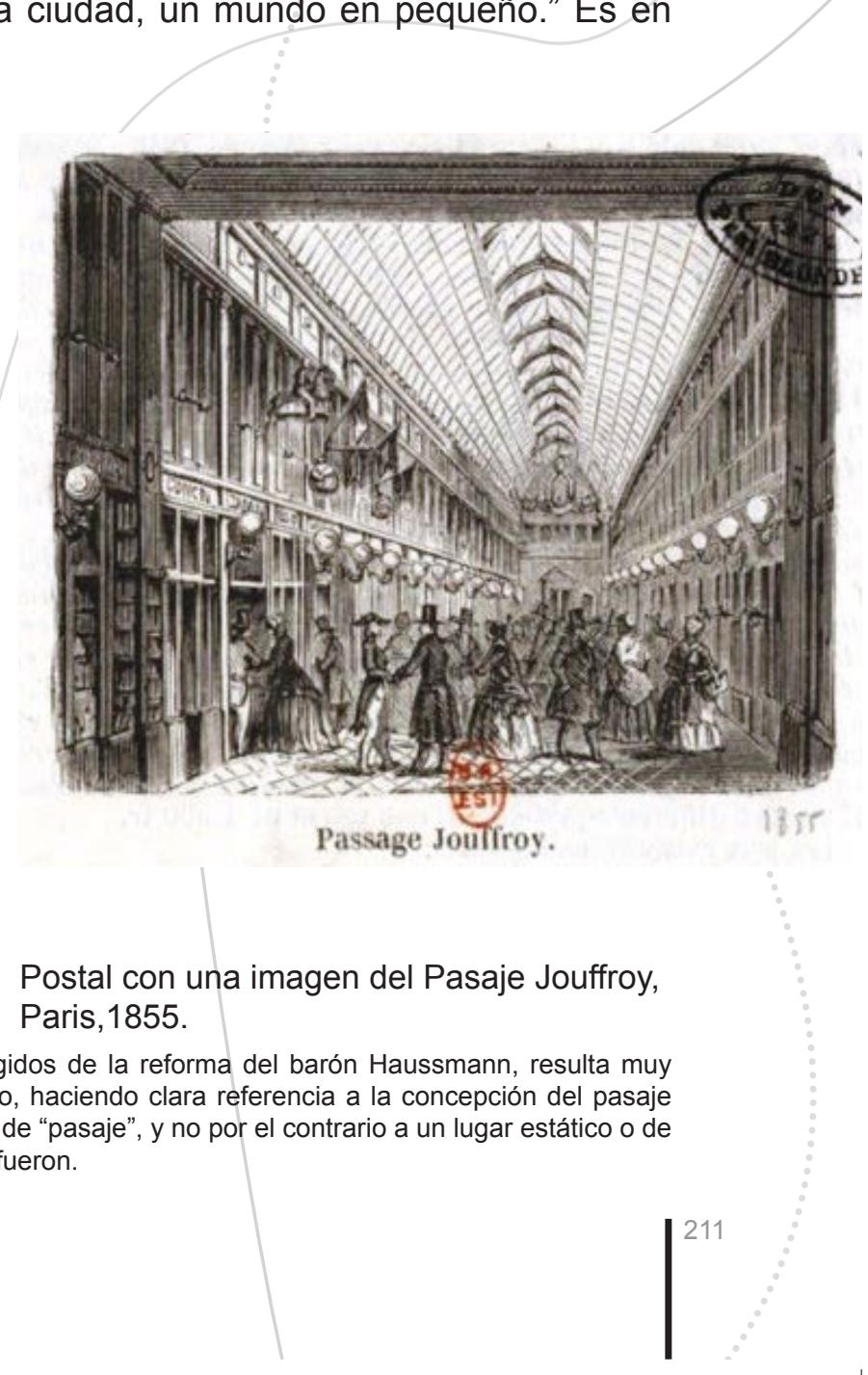




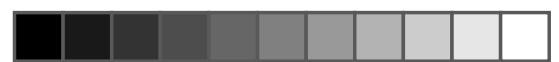

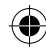
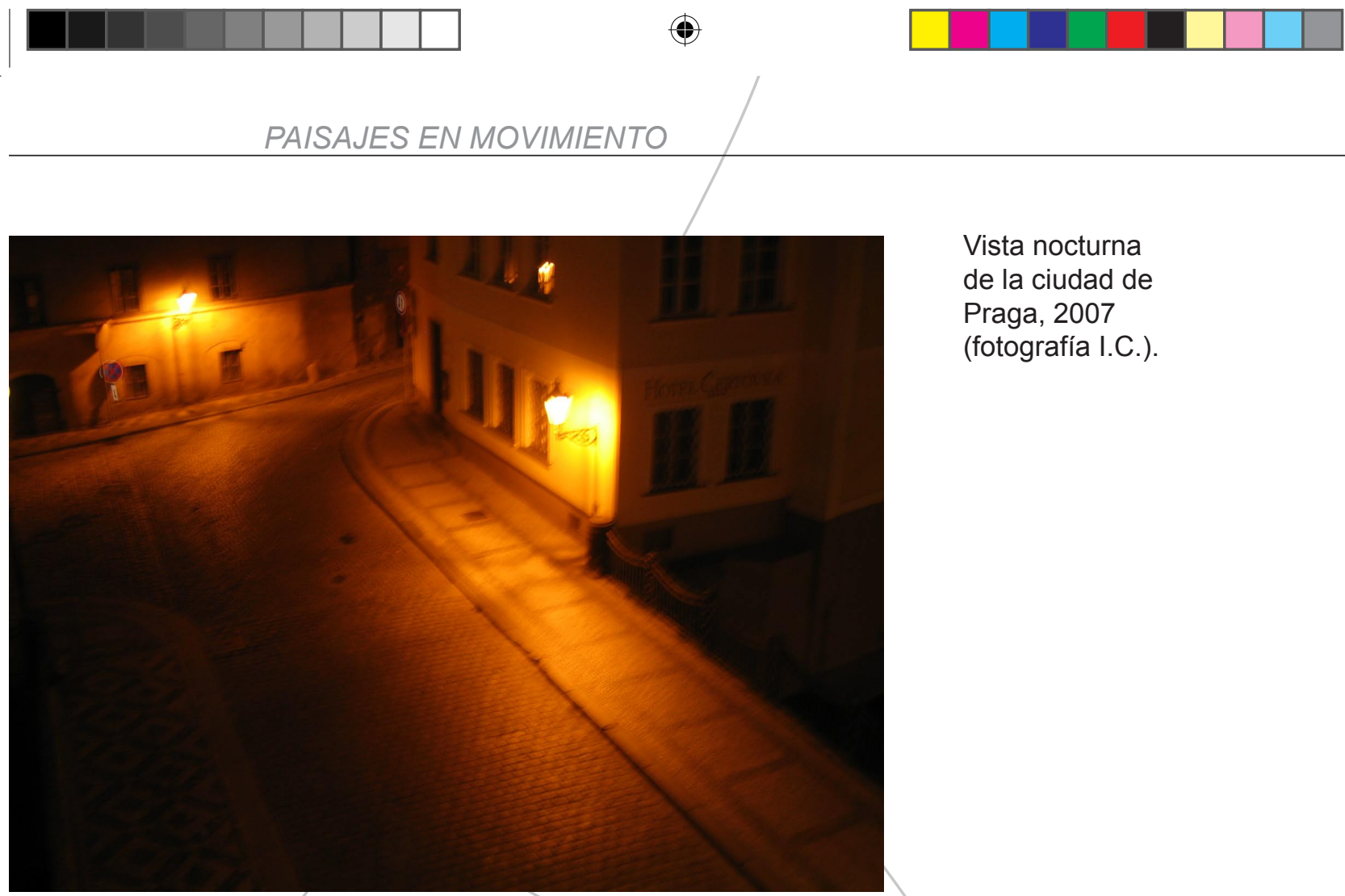

Vista nocturna

de la ciudad de

Praga, 2007

(fotografía I.C.).

flâneur, que está como en su casa entre fachadas, igual que el burgués

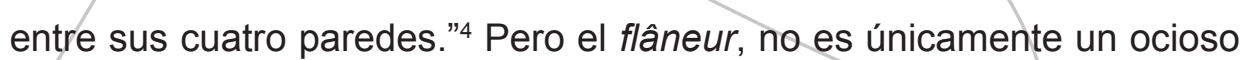
que pasa su tiempo caminado por la ciudad sin meta alguna, disfrutando de todo lo que la gran ciudad le ofrece, para el escritor Edgar Alan Poe éste tiene algo (o mucho) de asocial. Es un desconocido que busca la multitud para esconderse, ya que, tal y como lo interpreta Poe, en su propia sociedad no se siente seguro. Poe difumina la frontera entre el flâneur y el asocial, convirtiendo al primero en un abandonado en la multitud al modo de un héroe moderno que no tiene morada fija, o dicho más apropiadamente, que su casa son las calles.

Estamos, además, en el momento de la aparición en la gran ciudad de la luz de gas, lo que supuso una transformación radical del paisaje urbano. La luz de gas, que inicialmente se incorporó a los flamantes nuevos pasajes, comienza a estar presente también en las calles y plazas. La ciudad al anochecer se transforma por obra y gracia de la luz artificial en un lugar terriblemente sugerente para el paseante. Poe, por citar un nota-

4 Benjamin, Walter, Op.cit., Madrid, 1988, p.51.

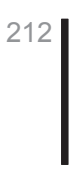



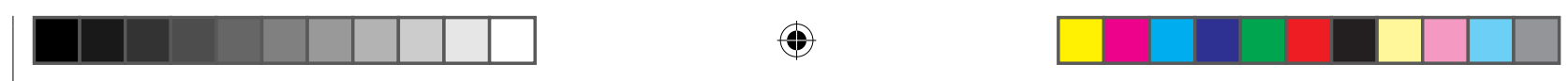

\section{Experiencias entre el arte y el urbanismo en torno al movimiento.}

ble ejemplo, dejará a la noche inundar sus narraciones. Para el autor norteamericano, la noche es el nuevo espacio de lo posible, deteniéndose en una ciudad completamente nueva que surge con diferente rostro a la luz de las farolas de gas que comienzan a inundar el paisaje urbano. Esta iluminación no hace sino apoyar y reforzar la identificación entre interior y exterior, entre la ciudad y la casa, resumiendo y ejemplificando el anhelo íntimo del flâneur. Pero no solamente Benjamin o Poe se interesan por la iluminación nocturna del espacio urbano, Alfred Delvau, Charles Dickens y otros autores también se manifiestan entusiasmados ante la idea de pasear por la ciudad bajo la nueva iluminación nocturna.

Como veíamos, la figura del flâneur, (no podía ser de otro modo), es consecuencia, y signo al mismo tiempo, de un contexto muy determinado. A principios del siglo XX, el movimiento en sí es uno de los motivos principales de preocupación y en consecuencia de investigación de las vanguardias artísticas. Un ejemplo fundamental de esta nueva actitud respecto al espacio urbano, lo podemos encontrar en las ideas y en las obras de los futuristas y, muy

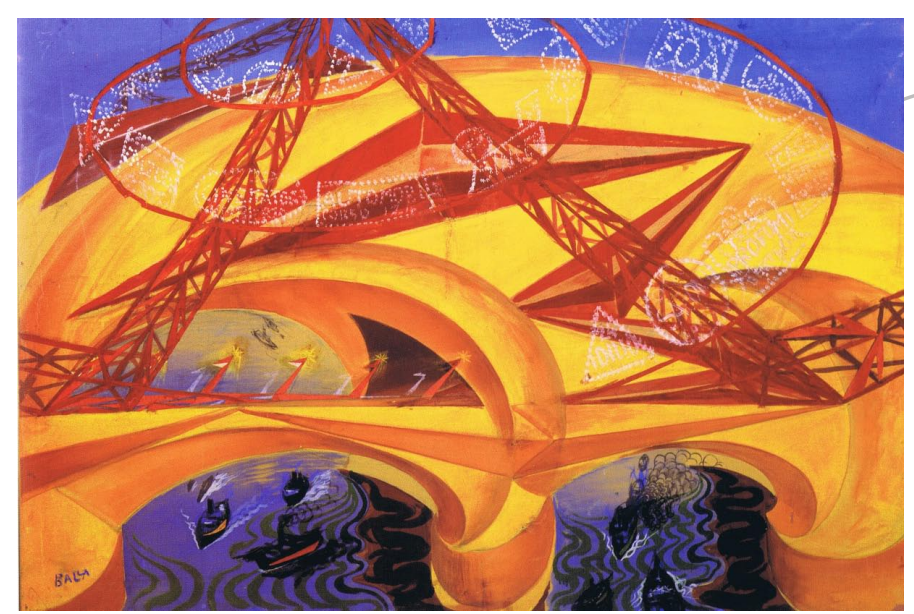

Giacomo Balla, Ponte de la Vellocità, 1913. especialmente, en su "Manifesto dell'architecttura futurista dinamica, stato d'animo, drammatica", publicado en Roma en el mes de febrero de 1920.5

La ciudad es entendida en estos años por las vanguardias artísticas como un espacio atravesado por incesantes flujos de personas y de mercancías, en definitiva de energía, sin que exista la

5 Para la lectura del manifiesto y de este modo poder comprender mejor la estrecha relación que establecieron los futuristas entre el arte, la ciudad y la velocidad, véase Celant, Germano (ed.), Arti et Architettura, 1900/1968, Skira, Milán, 2004. 


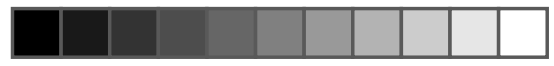

(†)
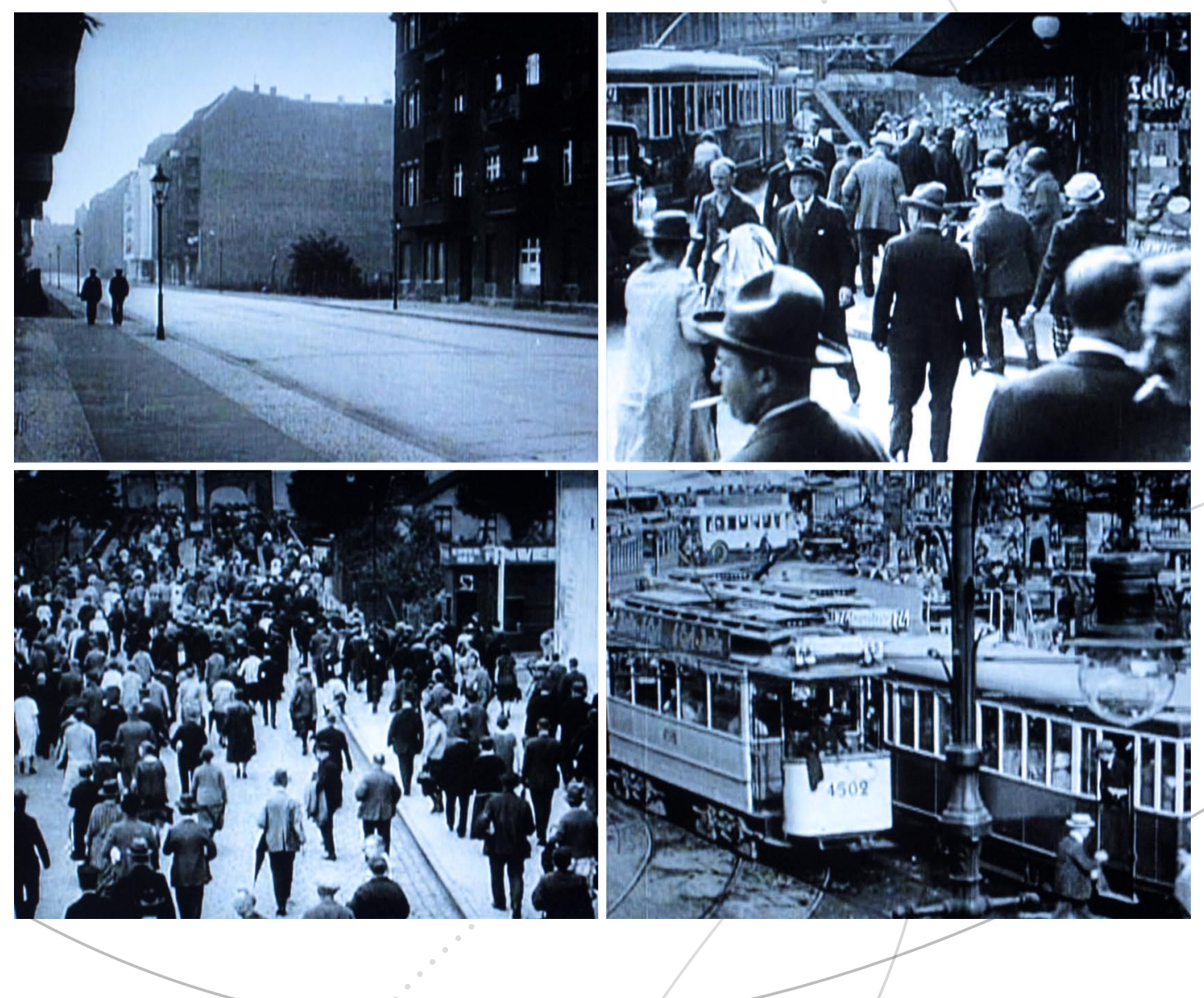

Berlín sinfonía de una ciudad, Walther Ruttmann, 1927.

posibilidad de generar una visión estática de la misma. Buena prueba de ello son las primeras películas europeas y norteamericanas en torno a la ciudad, de fuerte carácter experimental. Títulos como "Manhatta" (192021) de Charles Sheeler y Paul Strand, "Berlín sinfonía de una ciudad" (1927) de Walther Ruttmann o "El hombre con la cámara" (1929) de Dziga Vertov, despliegan todo el potencial de la ciudad de comienzos del siglo $X X .^{6}$

6 Sobre la importancia del cine de vanguardia en la configuración del imaginario colectivo sobre la ciudad, véase Barber, Stephen, Ciudades proyectadas. Cine y espacio urbano, Gustavo Gili, Barcelona, 2006.

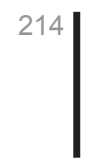




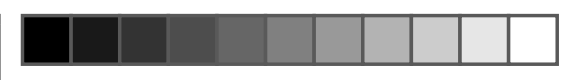

$\oplus$

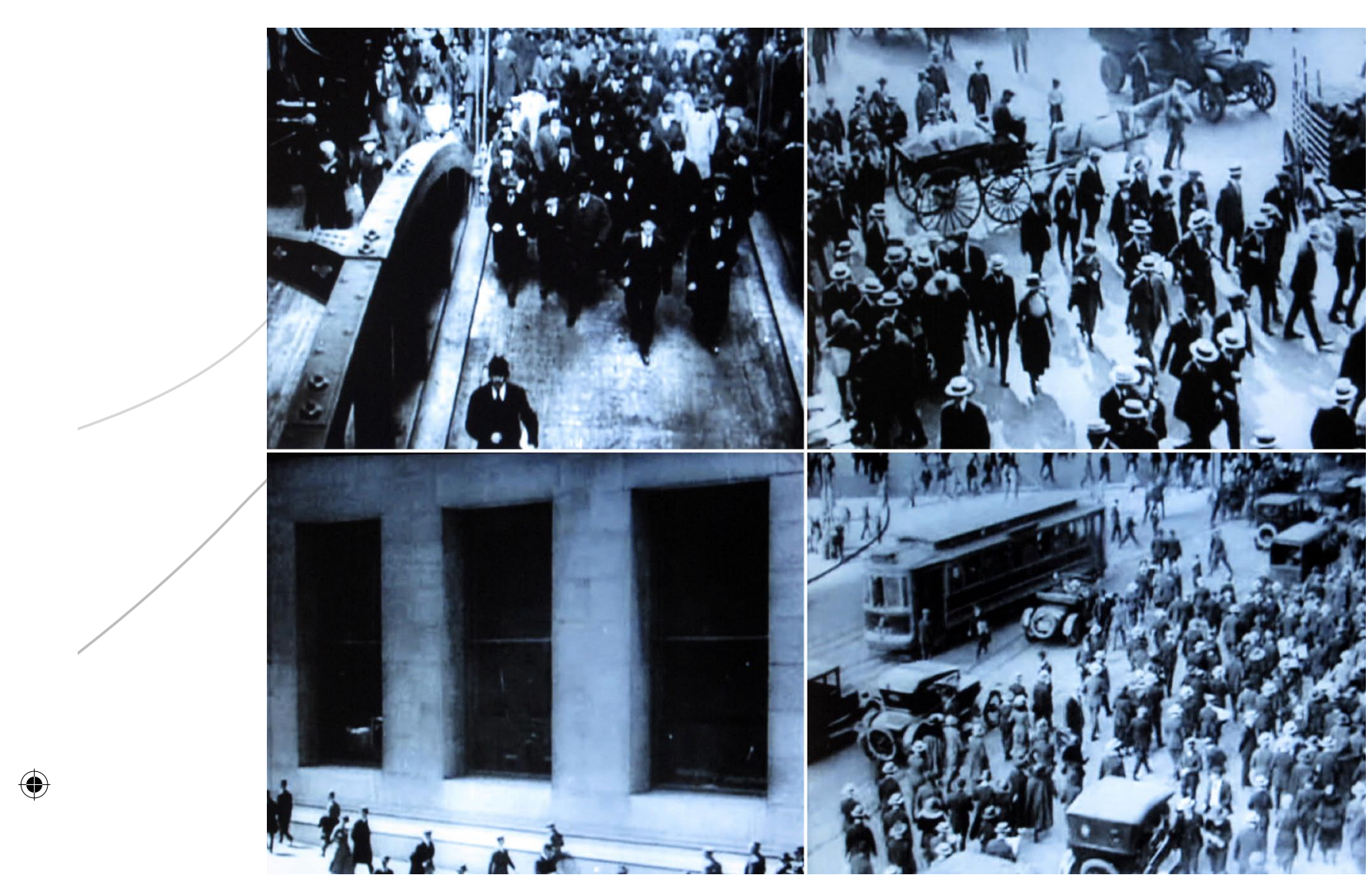

Manhatta, Charles Sheeler, 1920-21.

En este sentido, "Berlín sinfonía de una ciudad", por ejemplo, nos muestra un día cualquiera de primavera en la capital alemana. ${ }^{7}$ Desde que comienza la jornada laboral hasta la caída del sol, asistimos al trepidante ritmo de la vida en la gran ciudad, con una fascinación indisimulada por la velocidad a la que discurre. En la filmación (grabada en gran parte mediante cámara oculta, lo que la convierte en un documento de excepción), las imágenes se suceden sin descanso, acompañadas magistralmente por la música que impone un ritmo vertiginoso, cosmopolita y acelerado, donde las perspectivas y los encuadres inusuales no hacen sino

7 Sin lugar a dudas, en estos momentos, Berlín es una de las grandes capitales del mundo y en consecuencia, el retrato de la vida durante un día cualquiera en la capital alemana, se convierte en símbolo de la vida en la ciudad moderna, en paradigma de sus valores y de sus miserias. 

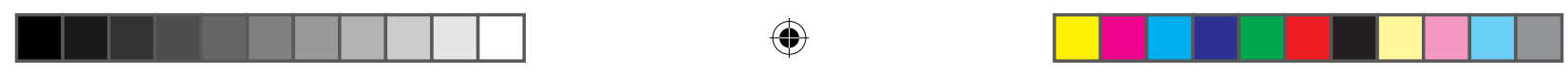

reforzar el carácter fuertemente dinámico de la ciudad. Los movimientos de sus habitantes se producen unos tras otros, acelerados, como si de una cadena de montaje se tratase, en un canto glorioso a la máquina, a la ciudad y, en definitiva, a la modernidad.

De todos modos, hasta el momento, todas estas experiencias artís-

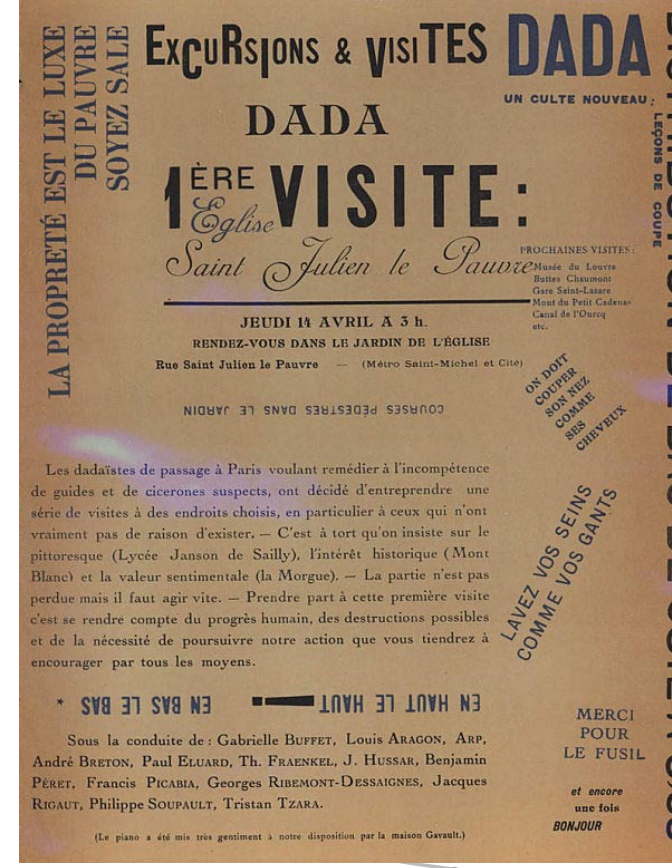

Invitación DADA para la primera visita a Sant Julien le Pauvre,1921. ticas se quedaron en la representación del movimiento, sin llegar a desarrollar una auténtica capacidad de intervención más directa y concreta en la organización y estructura de la ciudad. Conscientes de dicha limitación, el 14 de Abril de 1921, el grupo dadaísta de París propone iniciar una serie de incursiones urbanas por los lugares más banales de la capital del Sena, algunos de ellos olvidados por la propia ciudad. Artistas como Tristan Tzara, André Breton, Paul Eluard o Louis Aragon, fueron convocados junto a la pequeña iglesia de Saint Julien-le Pauvre, en el corazón del bario latino, con el fin de llevar a cabo una primera operación simbólica enfocada a poder desarrollar futuras intervenciones (más allá de cualquier visión estética u ornamental) en la ciudad, del mismo modo que hasta ese momento sólo estaba permitido a los arquitectos o urbanistas.

Este primer readymade urbano llevado a cabo por el movimiento Dada en París, marcará un punto de inflexión y un loable intento de traspasar dicha frontera, dando el salto infranqueable existente hasta el momento entre la representación del movimiento y su posible práctica en el espacio real, transformándolo en una acción estética. La incursión urbana 

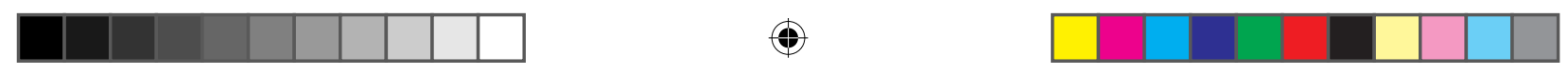

\section{Experiencias entre el arte y el urbanismo en torno al movimiento.}

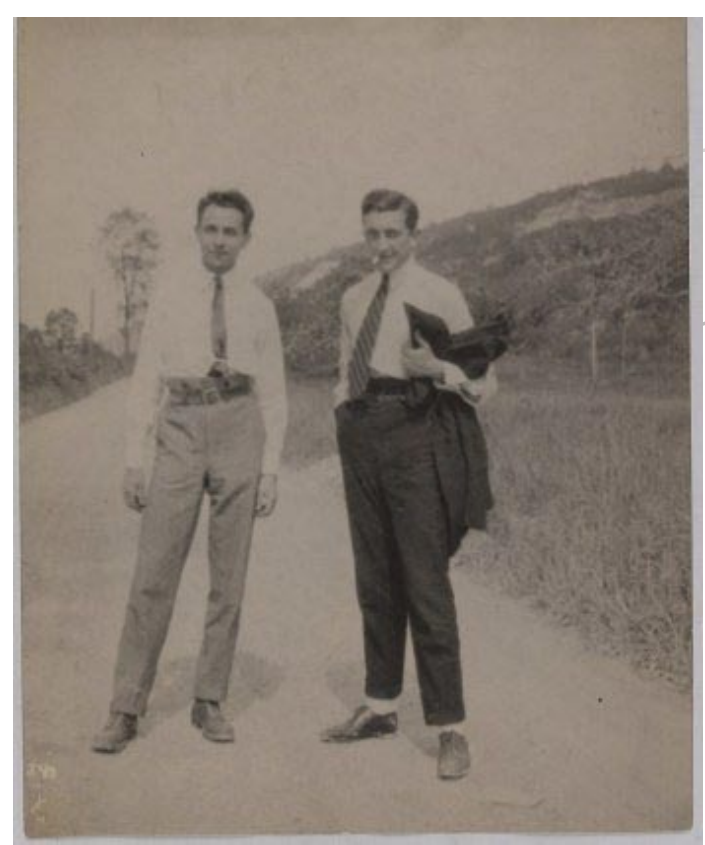

Louis Aragon y Max Morise en una de sus deambulaciones, 1921, Paris.

a Saint Julien-le Pauvre no tuvo continuación con otras experiencias similares en la ciudad. De hecho, aunque formaba parte de una serie de acciones que se llegaron a programar pero que finalmente no se realizaron, sirvió de germen a actuaciones y planteamientos posteriores. Supuso el antecedente necesario de la posterior deambulación llevada a cabo, tres años más tarde, por los surrealistas en el centro de Francia, concretamente en el mes de mayo de 1924.

En esta ocasión, André Breton, Louis Aragon, Roger Vitrac y Max Morise organizan una deambulación a cuatro por el centro de Francia, en un territorio ajeno a la ciudad, es decir, vacío desde el punto de vista de unos urbanitas convencidos como sus protagonistas. El itinerario, que se plantea con el fin de explorar, en palabras del propio Breton, "los límites entre la vida consciente y la vida soñada", comenzará en Blois, ciudad de partida elegida al azar, y les llevará después de varios días a pie hasta Romorantin. Se trataba de entrar en contacto con la parte más inconsciente del territorio mediante una deambulación basada en el abandono, el azar y la desorientación, con el propósito de indagar en los territorios no visibles y comprobar la sensación de lo "maravilloso cotidiano". El recorrido surrealista nos aproxima a estados anteriores de la civilización y de la relación del ser humano con el territorio, nos resitúa ante un individuo nómada que se descubre en una relación íntima con el mundo. Como bien señala Francesco Careri: "Este territorio empático penetra en la mente hasta sus estratos más profundos, evoca imágenes de otros mundos donde la realidad y la pesadilla conviven juntas, transporta al ser a un estado de in- 

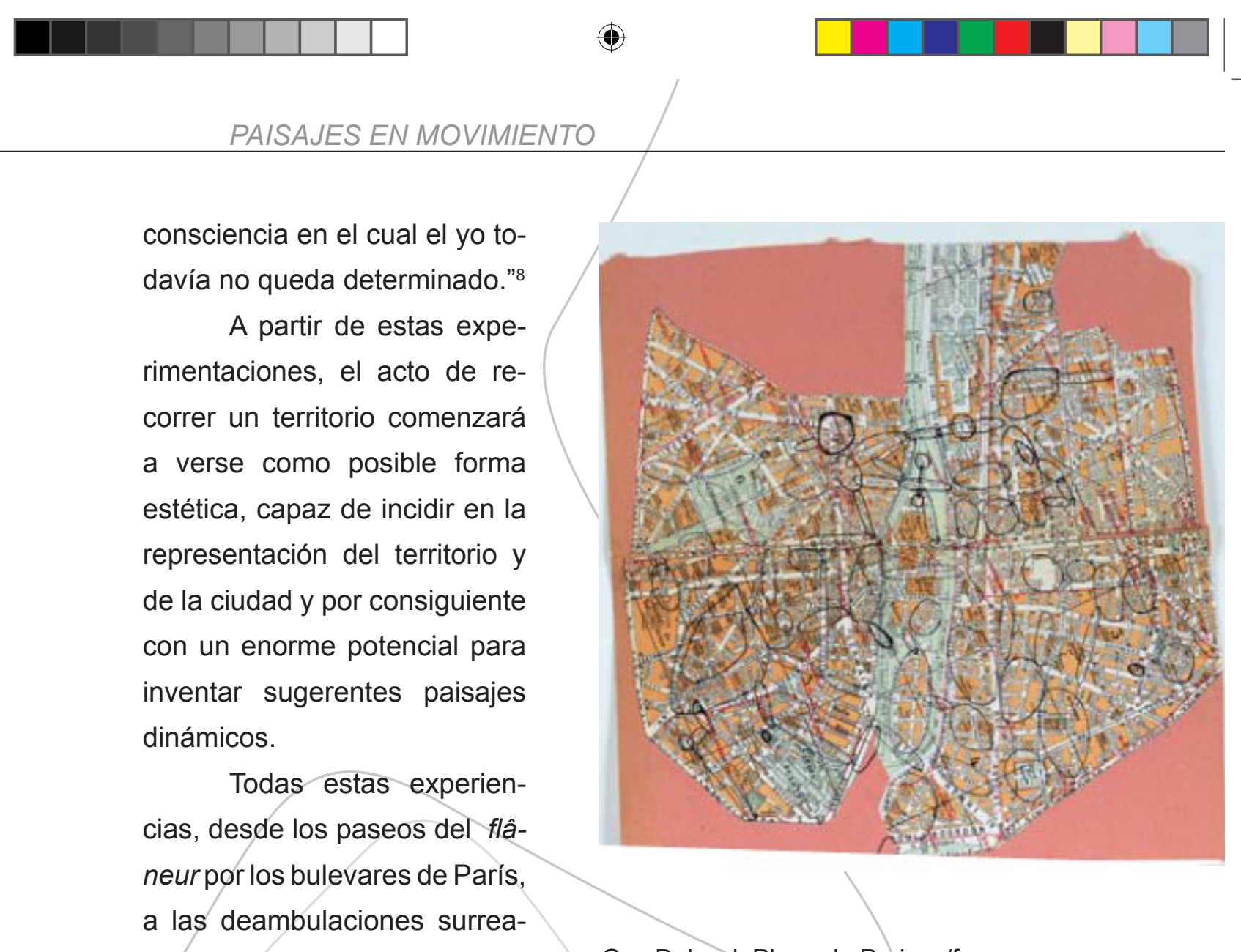

consciencia en el cual el yo todavía no queda determinado."

A partir de estas experimentaciones, el acto de recorrer un territorio comenzará a verse como posible forma estética, capaz de incidir en la representación del territorio y de la ciudad y por consiguiente con un enorme potencial para inventar sugerentes paisajes dinámicos.

Todas estas experiencias, desde los paseos del flâneur por los bulevares de París, a las deambulaciones surrealistas, pasando por las incursiones dadaístas y los textos ligados a todas ellas resultan

Guy Debord, Plano de Paris, s/f.

fundamentales para entender las posteriores propuestas de la Internacional Situacionista (1957-1972). Así pues, ya en los años cincuenta, para los situacionistas la posibilidad de perderse en la ciudad dejaba de lado el carácter más poético o anti-artístico del acto, para planteárselo como un medio de intervención estético-político con el cual ayudar a subvertir el orden y la estructura de la trama urbana. De este modo su propuesta de la deriva trata, fundamentalmente, de la materialización de un medio alternativo de habitar la ciudad, de un intento de desarrollar una acción gratuita y fugaz que no intenta dejar huellas físicas en el espacio urbano. Es la apuesta por una ciudad en constante movimiento, dinámica y mutante que se modifica constantemente y en la que se produce una desorienta-

8 Careri, Francesco, Walkscapes. El andar como práctica estética, Gustavo Gili, Barcelona, 2003, p. 83

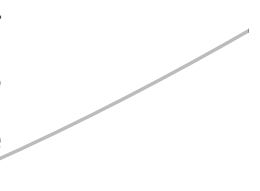




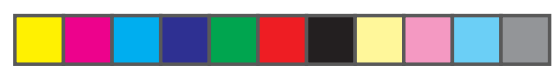

\section{Experiencias entre el arte y el urbanismo en torno al movimiento.}

ción completa. La Internacional Situacionista (muy influenciada por los escritos de Henri Lefebvre y sus críticas al funcionalismo urbanístico $)^{9}$, se plantea intervenir en el fenómeno urbano con el claro objetivo de conseguir una profunda transformación de la ciudad a través de una acción directa sobre las formas de su cotidianidad. Esta visión radical de las contradicciones que se generan en la ciudad contemporánea, como lugar de concreción y resistencia contra la alienación, va a tener su plasmación más importante en las obras de Guy Debord.

Debord escribió tres textos fundamentales para comprender sus planteamientos teóricos, para entender de qué modo pensaba que se podía transformar la realidad de la ciudad: Introducción a una crítica de la geografía urbana (1955), Teoría de la Deriva (1956) y su libro La sociedad del espectáculo (1967). En el primero de ellos el autor enuncia to que

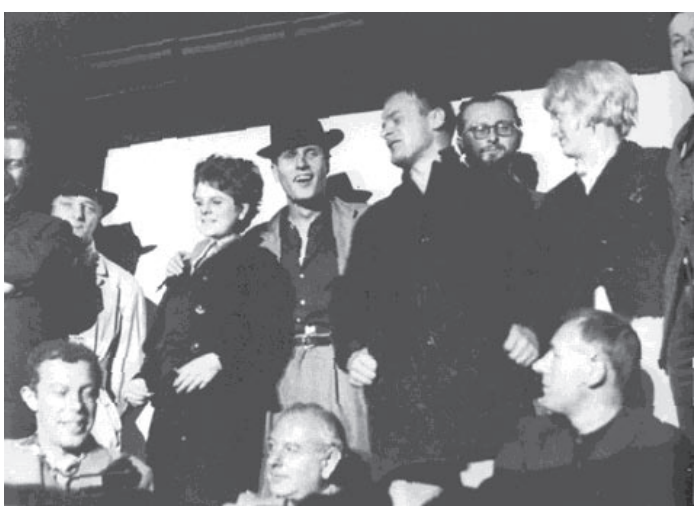
se puede entender como un principio

Los situacionistas en el Instituto de Arte Contemporáneo de Londres, 1960. trascendental para entender los planteamientos que guiaron sus actividades: "De todos los asuntos en los que participamos con mayor o menor interés, la búsqueda a tientas de una nueva manera de vivir es la única cuestión que sigue siendo apasionante. La estética y otras disciplinas se han mostrado claramente inservibles a este respecto y merecen el mayor desprecio. "10. En este texto, podemos encontrar gran parte de sus ideas básicas: la necesidad de revolucionar la vida cotidiana; el centrarse en los cambios micropolíticos más que en los "estructurales"; la defensa de

9 Lefebvre, Henri, La production de l'espace, Anthropos, París, 2000.

10 Debord, Guy, "Introducción a una crítica de la geografía urbana" en Andreotti, Libero y Costa, Xavier (eds). Teoría de la deriva y otros textos situacionistas sobre la ciudad, MACBA y ACTAR,

Barcelona, 1996, p.18. 

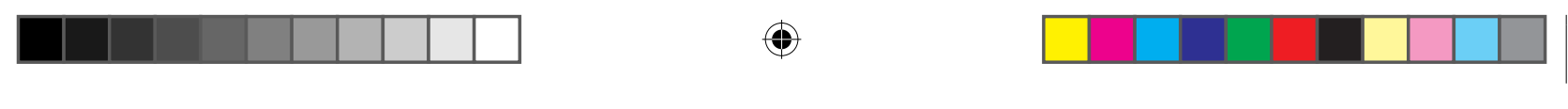

unos planteamientos transversales; la vinculación de las emociones, la felicidad y el juego; la búsqueda de nuevas formas de placer y el afloramiento de los deseos; la insubordinación contra los criterios habituales y las normas establecidas; la oposición a todo tipo de complacencia...

Para llevar a cabo estos objetivos, Guy Debord ideó la elaboración de unos mapas que superaran o al menos enriquecieran la cartografía tradicional. Se trata de sus conocidos mapas psicogeográficos, es decir, mapas que muestran "lo que manifiesta la acción directa del medio geográfico en la afectividad". Nuevas representaciones que nos permitan la creación de una cartografía renovada y alejada de cualquier convencionalismo, y que frente a los mapas tradicionales pensados para orientarnos in situ nos permitan, por ejemplo, vagar por la región alemana de Harz siguiendo las indicaciones de un mapa de Londres.

Guy Debord articuló su obra a partir de la elaboración de tres términos centrales que estructuran sus textos: la deriva, el détournement y el urbanismo unitario.

Para él, la deriva es un modo de comportamiento experimental ligado a las condiciones de la sociedad urbana, "una técnica de paso sin interrupción a través de ambientes variados. El concepto de deriva está indisolublemente ligado al reconocimiento de ciertos efectos de naturaleza psicogeográfica, y a la afirmación de un comportamiento lúdico-constructivo, en oposición a las nociones clásicas de viaje y paseo."11 Es una forma de investigación espacial y conceptual de la ciudad mediante el vagabundeo, una experiencia de abandono absoluto de cualquier actividad productiva y de consumo para dejarse llevar por el flujo de la ciudad. Una conducta centrada en los efectos del entorno urbano sobre los sentimientos y las emociones, "Tenemos que construir ambientes nuevos que sean simultáneamente, producto e instrumento de nuevas modalidades de comportamiento"12. El deseo de desestabilizar los códigos culturales oponiéndose a las categorías establecidas y multiplicando el sentimiento

11 Debord, Guy, "Teoría de la deriva” en Ibidem, p.22.

12 Ibidem, p.25. 


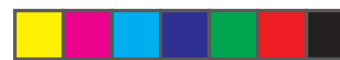

\section{Experiencias entre el arte y el urbanismo en torno al movimiento.}

de desarraigo. Provocar alteraciones en la vida cotidiana creando fisuras en la aparente homogeneidad de la ciudad para evidenciar las posibilidades que ofrece el movimiento. Una operación que acepta el azar pero que no se basa en él (como los surrealistas), pues éste puede llegar a ser, para Debord, limitado y conservador.

El segundo concepto se basa en el détournement (desviación) de los elementos estéticos prefabricados y su integración en una construcción artística superior. El détournement planteado por el autor francés consiste en la apropiación y reorganización de elementos ya existentes, lo que le vincula con el collage o el ensamblaje surrealista, la poesía de Lautremont o ciertas prácticas dadaístas. Es la acción creativa de saquear, sacar de contexto y darle un nuevo sentido (lúdico) a cualquier material cultural o vivencial. En este sentido, no puede haber pintura o música situacionista, sino un uso situacionista de estos medios.

El tercer término, que parece englobar en cierto sentido a todos los demás es el de urbanismo unitario. Es decir, el urbanismo entendido desde una lectura política del espacio urbano. Un espacio urbano que es considerado por Guy Debord como la representación física y palpable del conflicto social y cultural. Se trata pues, de un urbanismo interesado no ya en la ordenación de calles, plazas y equipamientos, sino en la construcción de atmósferas y "situaciones", momentos y estilos de vida radicalmente nuevos, que transformen las ciudades y por extensión a sus ciudadanos. Para los situacionistas la unidad básica del urbanismo ya no es la casa, sino el complejo arquitectónico producto de la combinación de todos los factores que conforman un ambiente. Para ello es necesario hacer posible una arquitectura que sea tanto un instrumento de conocimiento como un medio de intervención sistemático y lúdico en el espacio urbano.

La Internacional Situacionista proponía una ciudad basada en el juego y la espontaneidad, una ciudad nueva que apuesta por una arquitectura modificable y moldeable según el deseo de sus usuarios, (bien alejada por tanto de la ciudad onírica e inconsciente planteada por los 

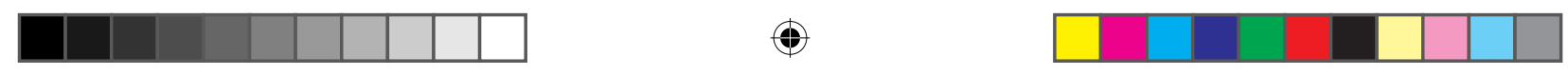

surrealistas) y donde los recorridos y el movimiento tiene un papel protagonista. En este sentido, entre algunas de las propuestas que los situacionistas proponían estaba, por ejemplo, crear pasarelas y escaleras a distintos niveles para comunicar los lugares más extraños; abrir las azoteas de las fincas y convertirlas en lugares de paseo y encuentros; crear laberintos que se transformen lumínica o espacialmente o situar farolas en las calles con interruptores para que los transeúntes puedan jugar y crear diferentes ambientes. Es decir, se trataba de posibilitar una ciudad que escapara al orden de los sistemas jerárquicos establecidos para ir "construyendo situaciones" que vayan mucho más allá de las reglas productivas y utilitarias, abogando por espacios de libertad y sistemas lúdicos de reapropiación de la ciudad.

Paralelamente a los textos, Guy Debord realizó, en 1957, dos mapas psicogeográficos de París que tenían en común su alejamiento de cualquier presentación unitaria y total de la ciudad, huyendo de los convencionalismos propios dela representación cartográfica. Lo que Debord nos presenta en estas dos guías etnográficas no es un callejero al uso de París, del tipo que utilizan miles de turistas cada año en su visita a la capital francesa, sino su visión de la vida cotidiana en la ciudad contemporánea. Y para ello, no duda en utilizar el término psicogeográfico: "La psicogeografía podría definirse como el estudio de las leyes exactas y los efectos específicos del entorno geográfico, ya sea organizado conscientemente o no, sobre las emociones y el comportamiento de los individuos"13. En estos mapas se muestran, pues, aquellos espacios de la ciudad que no aparecen en los planos que se utilizan habitualmente, lugares que quedan olvidados y marginados. Espacios despreciados por la ciudad, cuando no temidos, que forman parte del conjunto silenciado de una parte de la vida y de la historia de la misma.

En definitiva, el situacionismo persigue la elaboración, el levantamiento, de mapas que quieren hacer visibles los espacios que conforman las otras realidades ajenas a la oficial. En su Guide Psychogéographi-

13 Debord, Guy, "Introducción a una crítica de la geografía urbana” Op. cit., p.18. 

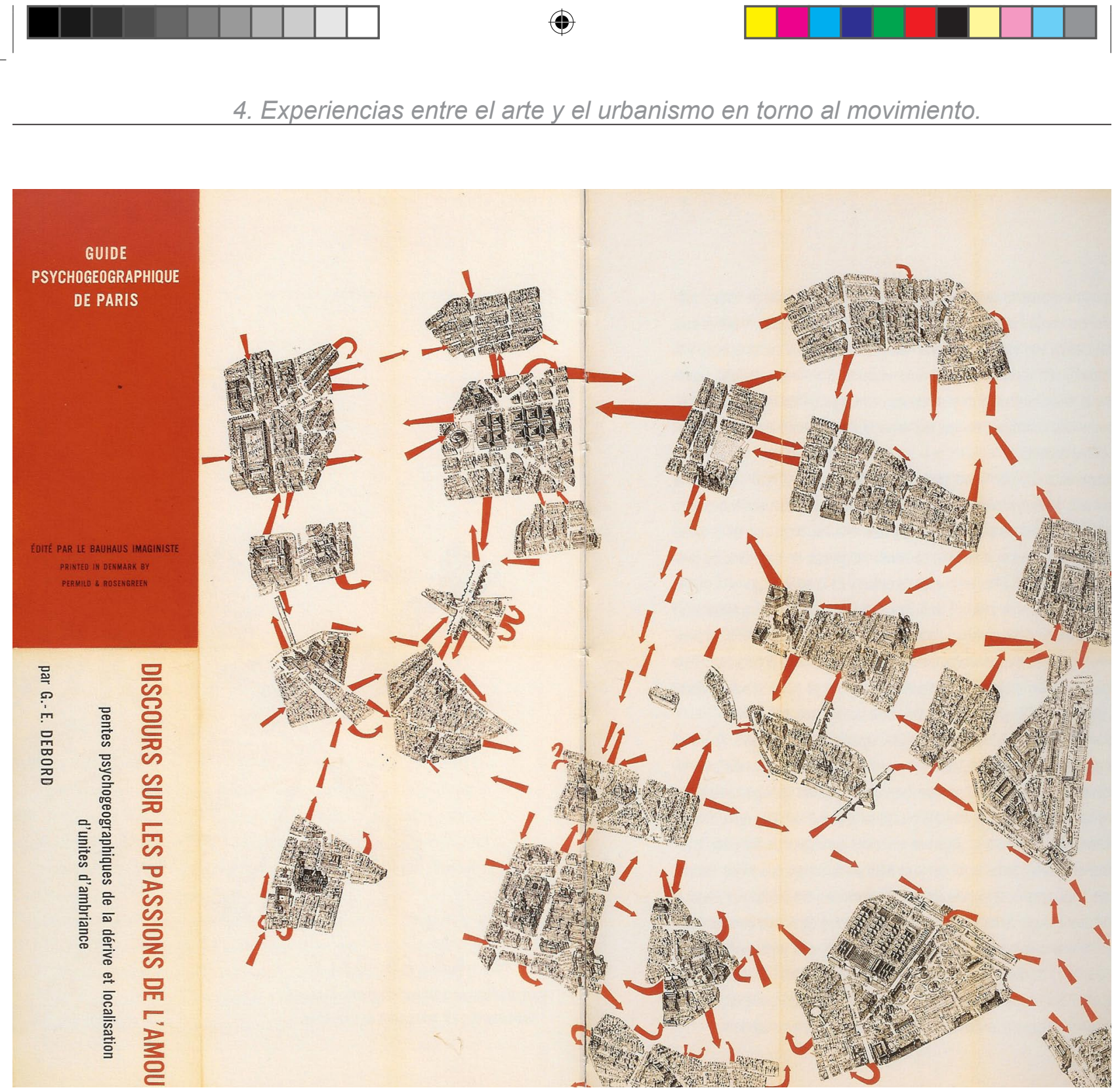

Guy Debord, Guide Psychogéographique de Paris, 1957.

que de Paris (1957), por ejemplo, los diversos fragmentos o islas que los componen, flotando sobre un fondo blanco, se vinculan entre sí mediante flechas rojas que incitan a las múltiples lecturas o recorridos deseables. 

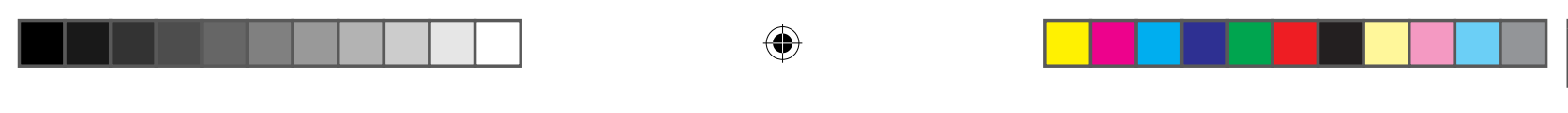

No existe una visión homogénea, racional ni completa de la estructura urbana, tan sólo un conjunto de posibilidades y caminos que tratan de desestabilizar la realidad hegemónica. Aconsejables caminos en los que dejarse llevar por la deriva en la que poder experimentar cada uno un proceso de construcción de la propia trama urbana-personal. Se trata de una cartografía más narrativa que objetiva, elaborada a partir de indicios de experiencias vividas 0 , tal vez, deseadas, que se ponen en relación las unas con las otras a partir de los diferentes recorridos que hemos realizado o que el plano nos invita a llevar a cabo. La guía no se puede entender desde un punto de vista estático, objetivo y exterior a la misma, necesitamos sumergirnos en ella para poder comprenderla y apreciarla y llegar a nuestras propias conclusiones. ${ }^{14}$

Así, la Guide Psychogéographique de Paris, está pensada a partir del antecedente de un mapa desplegable para los turistas pero en realidad lo que hace es, en lugar de ayudarnos a orientarnos, incitarnos a perdernos. Encontramos un París roto a pedazos, una ciudad que ha perdido cualquier unidad posible y de la cual tan sólo llegamos a reconocer diversos fragmentos del centro histórico fluctuando en un espacio vacío. Las flechas unen, mediante direcciones y flujos, unidades de ambientes homogéneos fijados en base a unos determinados relieves psicogeográficos. El tránsito por la ciudad debe comprender el examen de las diferentes experiencias subjetivas, es decir, los afectos, las pasiones y las pulsiones que se originan al frecuentar unas $u$ otras zonas de la urbe.

En otro mapa, The Naked City (1957), la ciudad ha quedado desnuda, la deriva ha expoliado sus elementos y estos fluctúan desorientados. Los barrios, descontextualizados, son continentes perdidos dentro de un espacio líquido, unos terrenos que vagan atrayéndose y rechazándose recíprocamente. Van a la deriva, sin dirección alguna, a merced de los diferentes vaivenes o corrientes. El mapa de París está divido en diecinueve partes diferentes conectadas entre sí por flechas direcciona-

14 Sobre la obra de Guy Debord y la importancia de las tesis situacionistas, véase Sadler, Simon, The Situacionist City, The MIT Press. Massachusetts, 1999. 

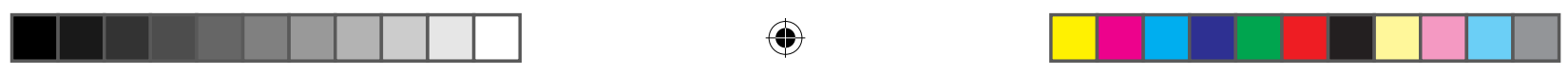

les que enfatizan aún más el carácter dinámico de la experiencia y en consecuencia del paisaje de la ciudad. Las flechas indican los posibles cambios de dirección que, espontáneamente, puede adaptar un sujeto teniendo en cuenta la conducta personal. Son fragmentos, trozos o partes aisladas rodeadas por el vacío, la unidad de la ciudad viene dada por la conexión de los deseos parciales. Realmente, lo que contemplamos, más que un mapa, es un paisaje psíquico construido mediante huecos entre los recuerdos y las experiencias gracias a nuestros recorridos múltiples por la ciudad.

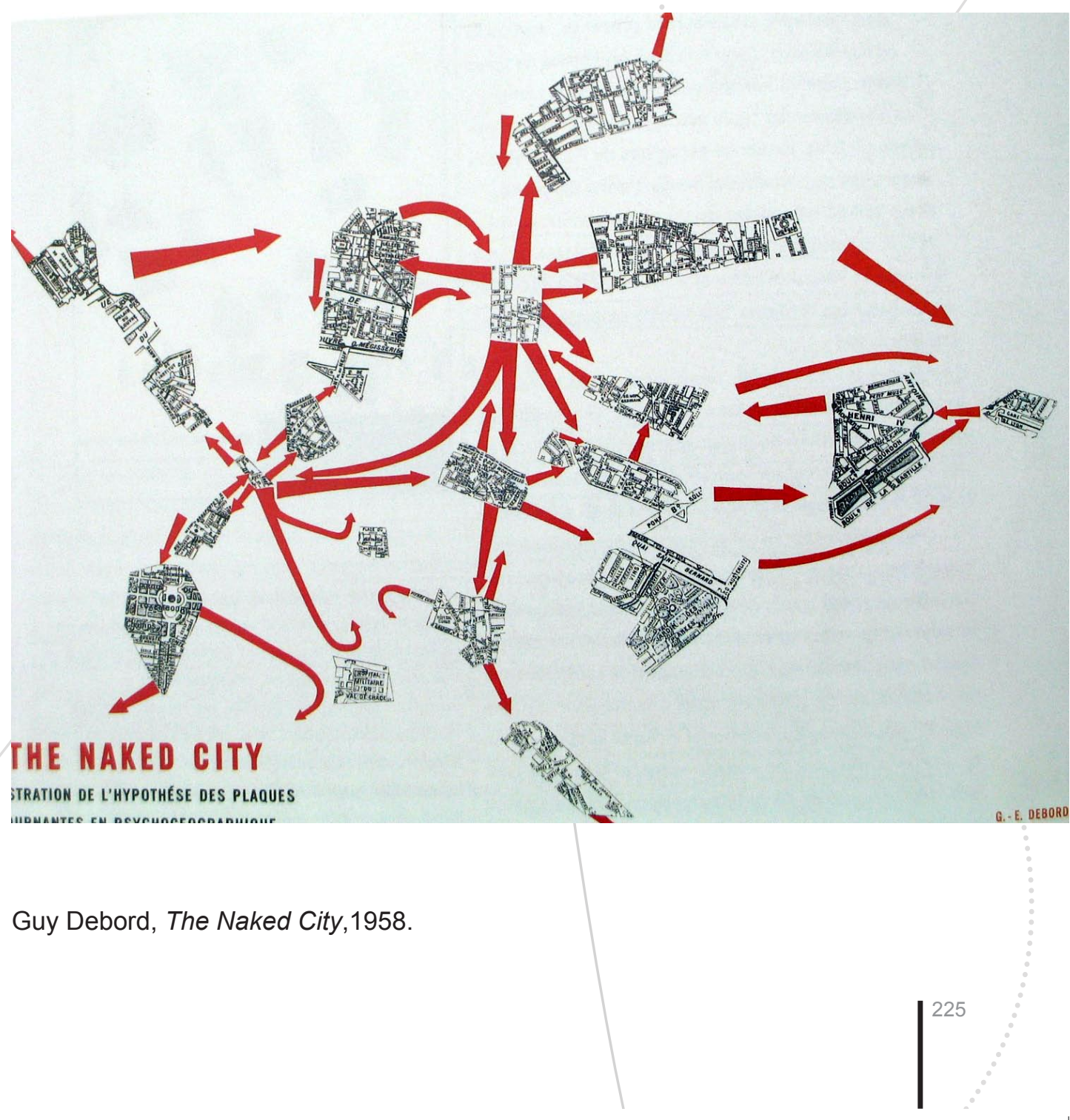



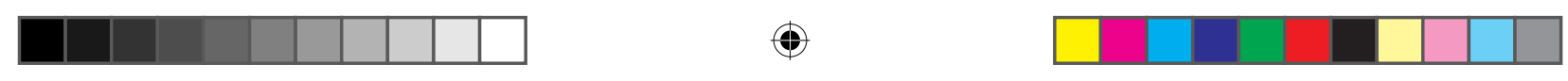

De entre los miembros de la Internacional Situacionista, destacó además de Guy Debord, la figura de Constant (1920-2005). De las aportaciones que éste realizó al movimiento, destacan dos por su especial importancia: una fue de carácter teórico y se refiere a la profundización de las tesis situacionistas en torno al tema del "urbanismo unitario" donde Constant propuso la creación del pedestal de una nueva civilización basada en el placer y en el juego que supondría una subversión del conjunto social y urbano; y otra de contenido más arquitectónico, al dotar con su propuesta de New Babylon una forma visual tridimensional a las ideas de la ciudad situacionista y de la Teoría de la Deriva.

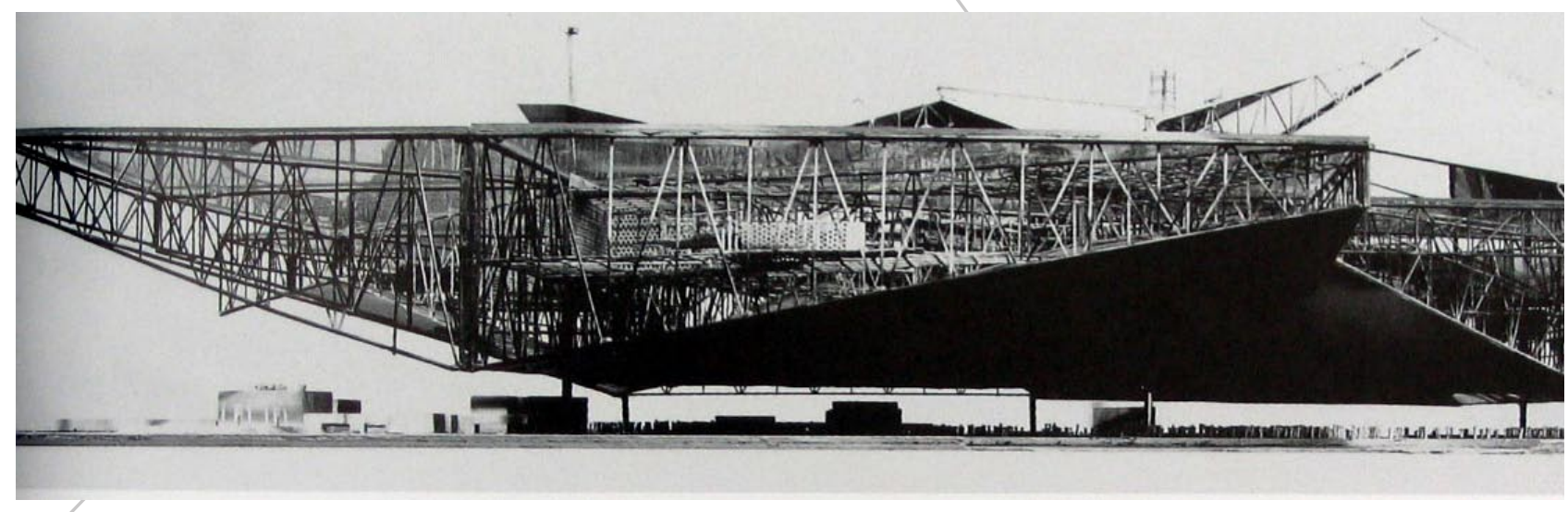

El proyecto de New Babylon arranca en la población de Alba, situada en el norte de Italia, en 1956 con motivo de la visita que realizó Constant para asistir al "Primer congreso de artistas libres". Todas las teorías de Constant respecto a la ciudad, como un teatro de operaciones estéticas complejas, adquieren una nueva significación cuando descubre (gracias al pintor Pinot Gallizio) la cultura nómada con motivo de su visita a un campamento gitano allí instalado. Aquí Constant queda fascinado al conocer de qué modo los nómadas transforman el territorio en un espacio de la memoria, entendiendo los vacíos como campos de significado surcados de signos que enriquecen y construyen et paisaje con múltiples

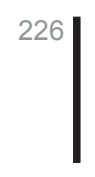



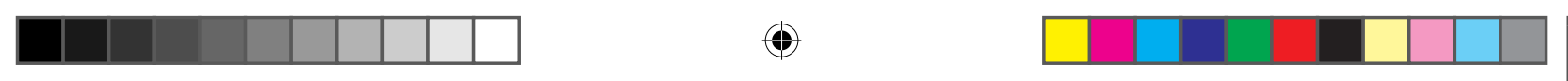

Constant,

Babylon, 1958-60.

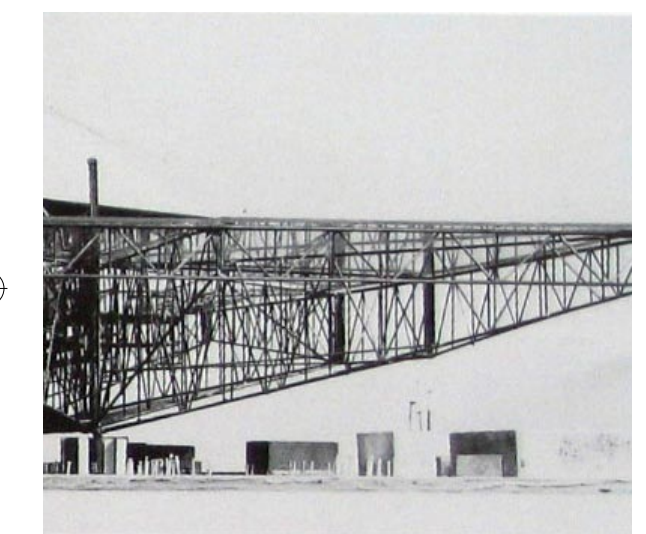

significados. Esta toma de conciencia del aspecto nómada del ser humano, como faceta aún presente hoy en día, incluso en nuestras sociedades sedentarias, junto al conocimiento que realiza de Guy Debord y de sus planteamientos urbanísticos (con el que le unirá un largo periodo de amistad personal e intelectual que no acabara ni cuando Constant abandone la Internacional Situacionista en el verano de 1960), le van a permitir esbozar un importante aparato conceptual que tiene como objetivo fundamental cuestionar los fundamentos de la sociedad occidental sedentaria y atacar el funcionalismo arquitectónico.

Con ese fin, va a imaginar una ciudad lúdica de carácter nómada 

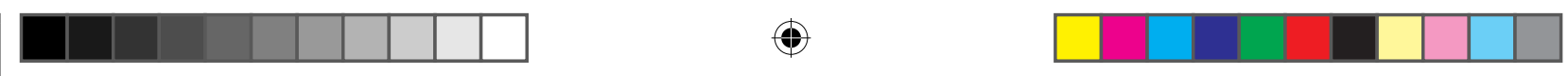

Constant, New Babylon Nord, 1958, (detalle).

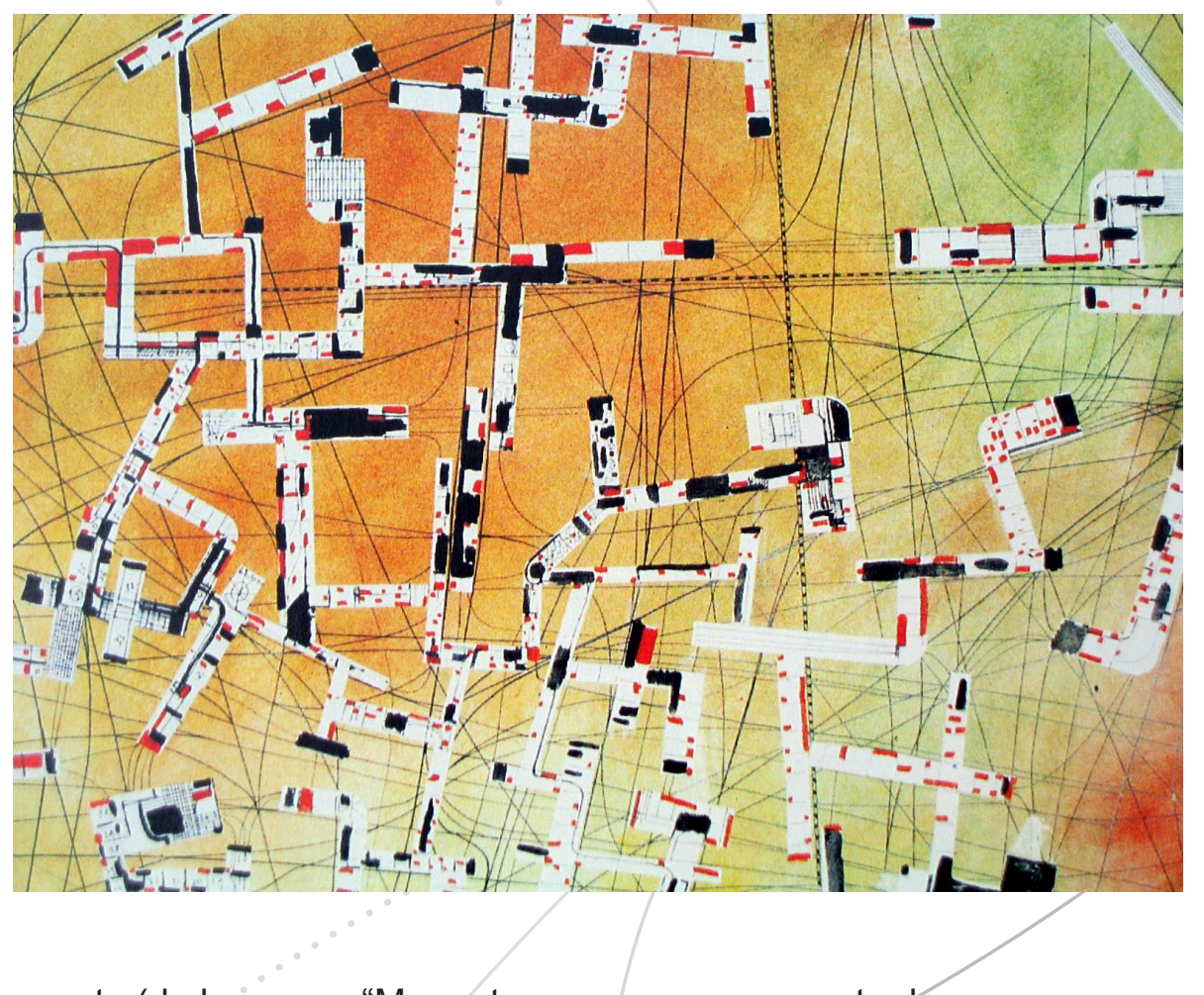

en una sociedad errante (de la que su "Maqueta para un campamento de gitanos" de 1958 fue un primer avance). Una ciudad en proceso permanente de construcción y reconstrucción, una ciudad mega-estructural y laberíntica construida en base a las líneas sinuosas de unos trayectos sin fin. El proyecto de Constant escenifica el anhelo por el paso de una ciudad sedentaria enraizada en el suelo, a una ciudad nómada suspendida en el aire, asociada con una sociedad más igualitaria y libre.

New Babylon es la plasmación arquitectónica de los deseos de una generación que soñaba con otras formas de vivir en el mundo e imaginaba otros espacios de libertad. Durante casi veinte años Constant realizó una serie interminable de maquetas, dibujos y croquis para dotar de estructura tangible a la forma en la que podría vivir y desarrollarse un espacio social en permanente revolución. Es una propuesta concebida como un proyecto revolucionario (con pretensiones de sobrepasar los fundamentos arquitectónicos) que, a través de la creatividad lúdica y colectiva del "urbanismo unitario", pretende cambiar el sistema artístico y cultural. 

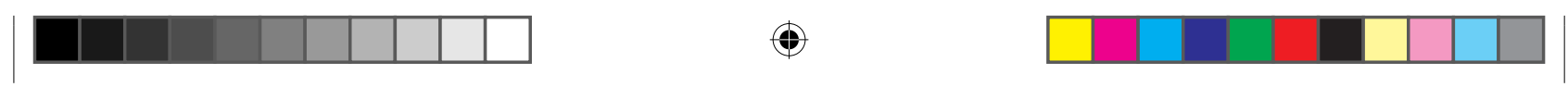

\section{Experiencias entre el arte y el urbanismo en torno al movimiento.}

Constant liga la práctica arquitectónica a la transformación social, apostando por una unidad integral entre comportamiento personal y entorno urbano. En en este contexto donde debe entenderse esta declaración: "Detesto a Le Corbusier por que era un funcionalista. Habitar, trabajar, circular y distraerse, todas esas funciones representan lo contrario de lo que yo deseo, eso era el Estado de los Trabajadores, la esclavitud, cuando yo pensaba en el Homo ludens, en el Estado de los Creadores". ${ }^{15}$

Por ello, New Babylon es la ciudad del homo ludens (que ya apuntara en su conocido libro el historiador holandés Johan Huizinga), pues la liberación del potencial lúdico del hombre está directamente relacionada con su propia liberación como ser social. Era el deseo de crear un nueConstant, Maqueta para New Babylon, 1958-60, (detalle).

vo espacio urbano en el cual sin sacrificar gran

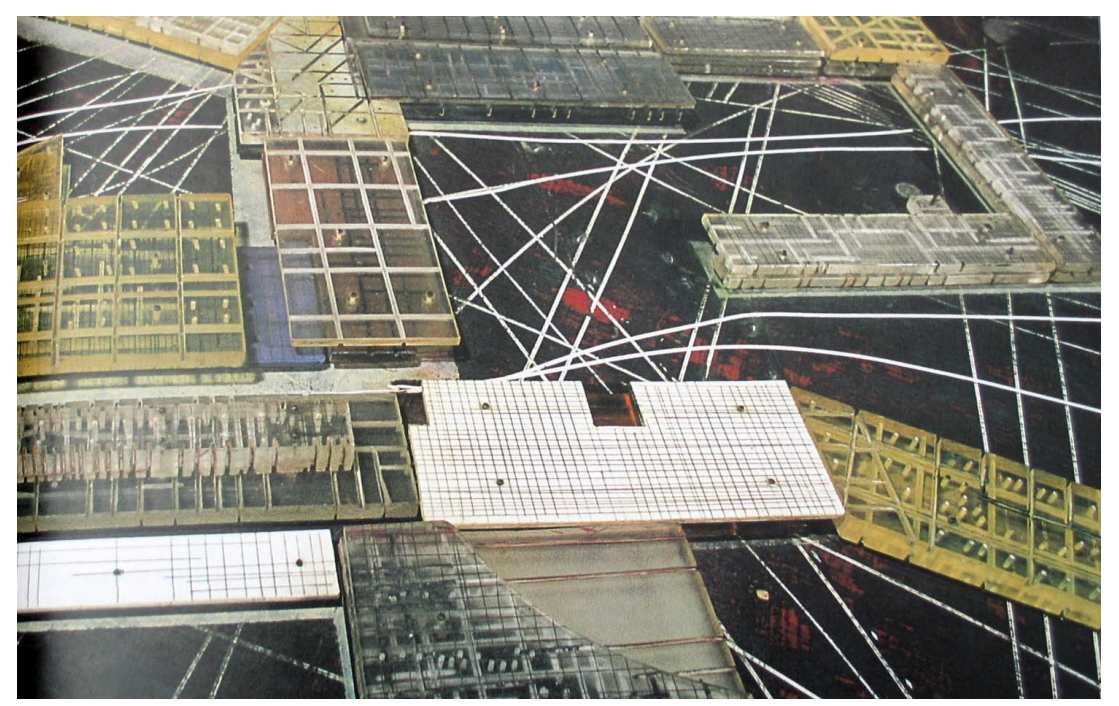
parte de la vida en su lucha por la existencia, cada uno pudiera construir su vida según sus propias aspiraciones y su propia libertad creativa.

Esa deseada libertad en el tiempo y en el espacio (despojado de toda carga productiva) debe llevar a una nueva forma de urbanismo basado en la movilidad y la fluctuación incesante de sus habitantes. Sin horarios ni domicilio fijo, el ser humano conocerá necesariamente 15 Careri, Francesco, « New Babylon. Le nomadisme et le dépassement de l'architecture » en VV.AA., Constant, une rétrospective, Musée Picasso Antibes, Antibes, 2001, p.65. 

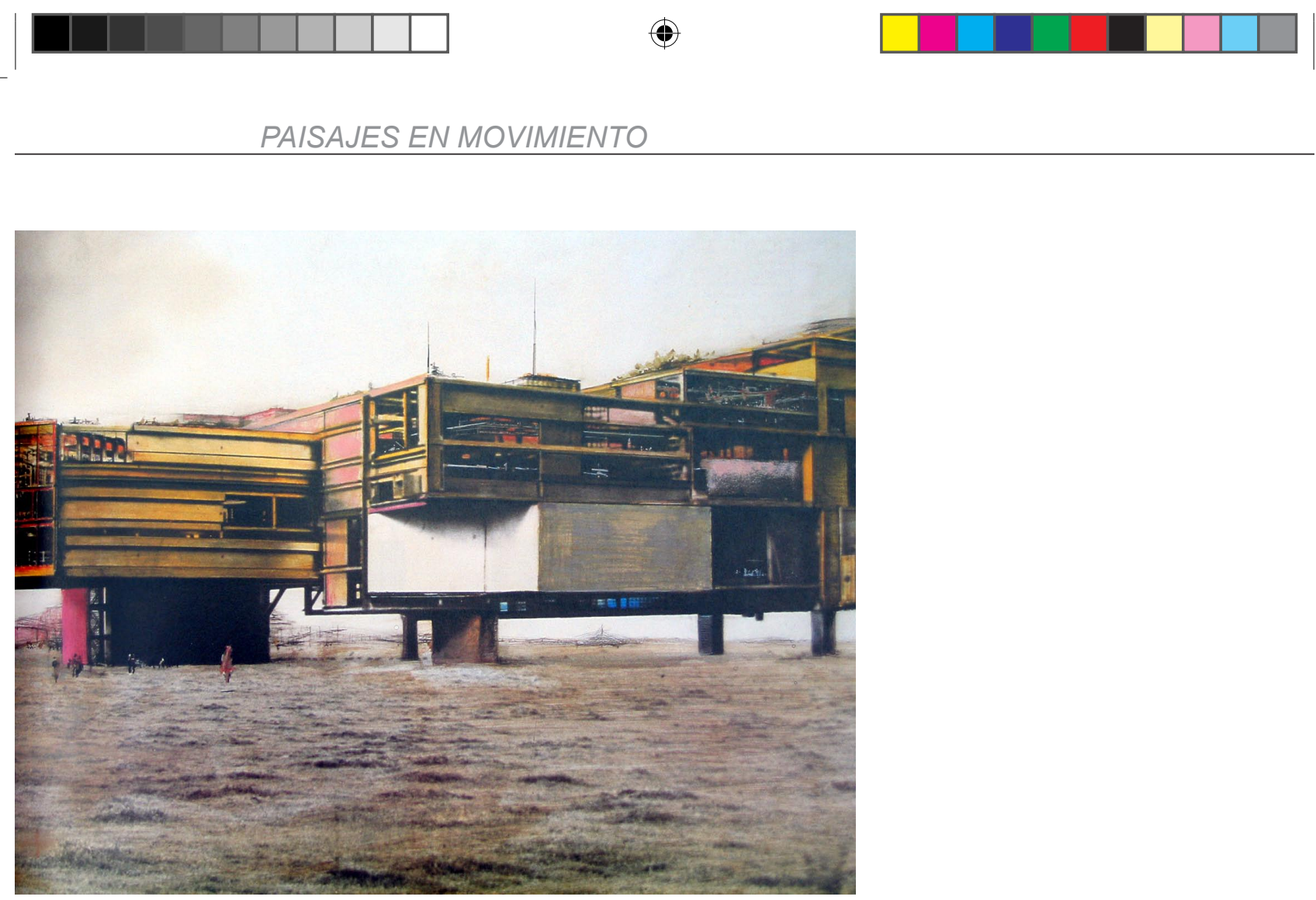

Constant, New Babylon, 1958-60, (detalle).

una vida nómada en un entorno artificial totalmente construido. Según el propio Constant, "New Babylon no se detiene en ninguna parte (porque la tierra es redonda); no conoce fronteras (porque ya no hay economías nacionales); ni colectividades (porque la humanidad es fluctuante). Cualquier lugar es accesible a cada uno y a todos. Todo el planeta se convierte en la casa de los habitantes de la tierra. Cada uno cambia de lugar cuando lo desea. La vida es un viaje sin fin a través de un mundo que se transforma con tanta rapidez que cada vez parece diferente."16

Con su propuesta Constant recompone la ciudad que Guy Debord había hecho saltar en pedazos conformando una nueva urbe que no conoce fronteras ni límites, de tal modo que cada habitante podrá transformarla como desee, cambiar el ambiente regulando el volumen, la intensidad luminosa, el ambiente olfativo, la temperatura... También queda abolida la diferencia entre espacio exterior e interior, no existen 16 Constant, "New Babylon. Una ciudad nómada" en Andreotti, Libero y Costa, Xavier (eds). Op. cit, p.158.

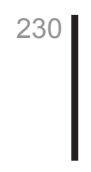



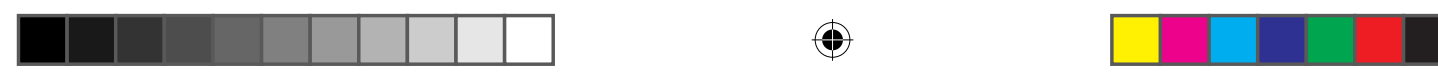

\section{Experiencias entre el arte y el urbanismo en torno al movimiento.}

volúmenes cerrados y se pueden crear nuevos accesos, añadir escaleras y rampas o colocar puentes. Constant entiende que todo elemento estático o inalterable debe ser evitado, y que el carácter variable de los elementos arquitectónicos es la condición de una relación fluida con los acontecimientos que suceden. Su concepción del urbanismo no está limitada a la construcción y sus funciones, sino también a todo uso que se pueda hacer o, incluso, imaginar. La ciudad está pensada como un espacio único en el que se fusionan como un solo objeto: la deriva, la ciudad y el recorrido nómada.

New Babylon consiste en un sistema de grandes corredores vacíos que se extienden por encima del territorio y permiten la migración incesante de la población multicultural de aquella nueva Babilonia. Constant propuso un conjunto de redes sobre las que las diferentes zonas se relacionan formando una masa compacta donde el sistema de los recorridos es indisociable del de las construcciones. Una cadena de sectores suspendidos donde la circulación de vehículos queda en el suelo y los espacios reservados a los peatones forman una malla lineal elevada donde la gente deambula en una deriva sin fin. Esos largos pasillos destinados a los vagabundos nómadas sustituyen a la ciudad consolidada, superponiéndose entre ellos como una telaraña informe y continua. Una ciudad hipertecnológica donde la ciencia estará sometida al control de la comunidad permitiendo dejar cantidad de tiempo libre a sus moradores. Es una extensa sucesión de megaestructuras, un compacto tejido urbano con una extensión geográfica indefinida, carente de centro y periferia. Un conjunto de enormes maquetas hechas de madera, formado por diferentes sectores, tales como el Amarillo o el Rojo (ambos de 1958), el Grupo de Sectores (1959), el Sector Constructivo (1960) o el Gran Sector Amarillo (1967), muy diversos fragmentos posibles que los habitantes de la ciudad pueden montar y desmontar como quieran. ${ }^{17}$

La propuesta de New Babylon se basa en una arquitectura la-

17 Para una visión más completa de la propuesta New Babylon de Constant, puede verse Wigley, Mark, Constant's New Babylon. The Hyper-Architecture of Desire, 010Publishers, Rotterdam, 1998. 

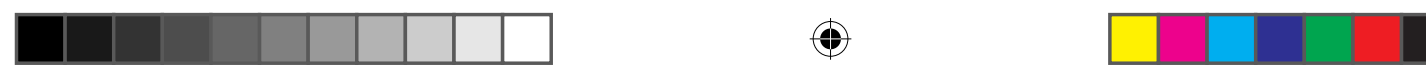

beríntica creada y constantemente transformada, no por una disciplina estética sino por la vida de la propia ciudad, por los recorridos que se producen en su seno. Es una urbe que camina por un mundo sin fronteras en una travesía errática y anti-arquitectónica. Para Constant el nomadismo no es tanto una reivindicación del viaje, como un elemento de rechazo del sistema capitalista, de la acumulación de bienes, de la propiedad privada y de toda frontera étnica o económica que pueda significar una limitación a las posibilidades creativas y a las formas de vida de las personas. Se trata de construir la sede de una nueva sociedad multiétnica en permanente transformación espacial, conceptual y perceptual.

Por estas razones, a New Babylon se le dota de una estructura laberíntica ya que se persigue conscientemente la desorientación. Pero un laberinto que no posea un centro al que llegar ni una salida que alcanzar sino un número infinito de centros posibles en torno a los cuales organizar las diferentes existencias. El laberinto posibilita no sólo la capacidad de perderse sino, y lo que es más importante todavía, el deseo de encontrar caminos desconocidos hasta ese preciso momento. Según Constant, un espacio social laberíntico, que continuamente se modifica, es el que mejor ayuda a la liberación del comportamiento personal, a dejar atrás actitudes o comportamientos conservadores. La plasmación de la ciudad como laberinto es una apuesta decidida por una concepción dinámica del espacio opuesta a cualquier perspectiva estática. Pero sobre todo, es la toma de partido por una estructura de la organización mental y un método de creación que desea unir espacio y vida en una decisiva declaración a favor de un comportamiento laberíntico. Es decir, un comportamiento basado en el trayecto, en las experiencias vividas, en la espontaneidad y en el gusto por lo desconocido.

"En la sociedad utilitarista (escribe Constant) se persigue por todos los medios la orientación óptima dentro del espacio, garantía de eficacia y de economía de tiempo, mientras que en New Babylon es más importante la desorientación, la cual permite la aventura, el juego, el cambio creador. El espacio de New Babylon tiene todas las características de un 

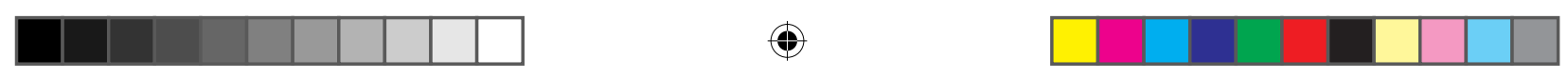

\section{Experiencias entre el arte y el urbanismo en torno al movimiento.}

espacio laberíntico dentro del cual los movimientos ya no sufren la coacción de las organizaciones espaciales o temporales. La forma laberíntica del espacio social "new babilónico" es expresión directa de la independencia social."18 La visión bastante utópica de Constant es consecuencia de una búsqueda permanente de la felicidad y el placer. Para él, todo en la sociedad (especialmente el urbanismo creado) debe estar al servicio

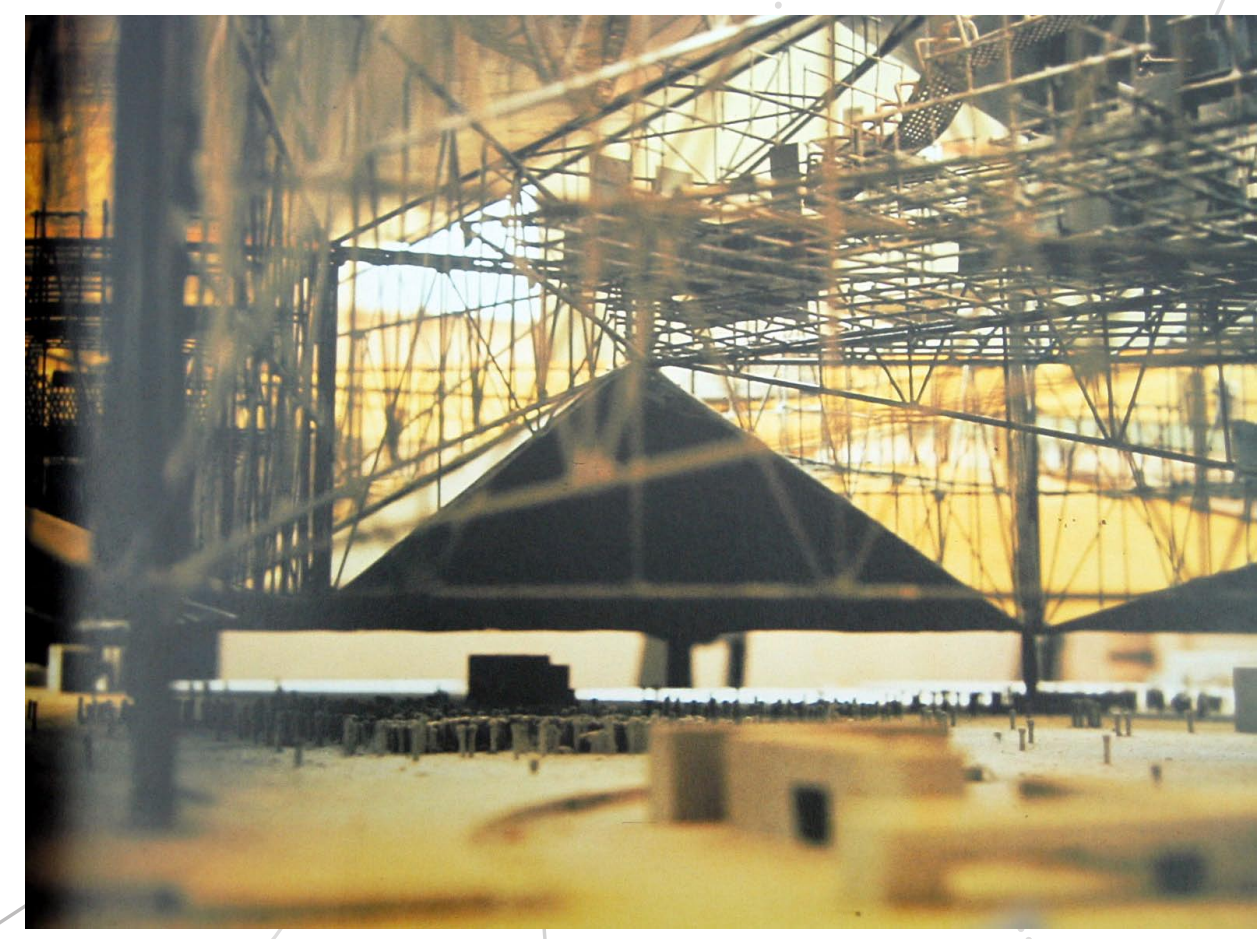

Constant, Maqueta para New Babylon, 1958-60, (detalle).

de esa visión lúdica de la existencia. ¿De qué pueden servir los grandes avances científicos o las innovaciones tecnológicas si no se aplican por conseguir más tiempo libre? Su propuesta es global, se refiere a un cambio cualitativo de las formas de producción, a crear situaciones nuevas

18 Constant, "New Babylon. Una ciudad nómada" en Andreotti, Libero y Costa, Xavier (eds). Op. cit, p.168. 

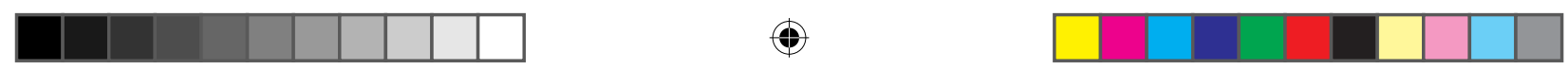

que permitan una vida más feliz y afecta a todo el tejido urbano, apostando por un urbanismo unitario que responda a un concepto dinámico de la existencia.

Sin embargo, no podemos dejar de advertir que a pesar del atractivo y el atrevimiento de muchos de sus planteamientos, también todas esas ideas poseen algunas contradicciones como, por ejemplo, unas grandes dosis de deslumbramiento por los avances técnicos. Una utópica (y moderna) visión del progreso que le llevan a pensar que a mayor desarrollo tecnológico mayor independencia social y mayor número de horas libres para el ocio y el placer (algo que ya se ha demostrado incorrecto). Asimismo, esa ansía por dar una idea unitaria y global a la construcción de una nueva ciudad (con el peligro de olvidar lo específico), vuelve a caer en algunos de los problemas que ya anunciara Debord cuando representaba una urbe fragmentada imposible e incapaz de organizar colectivamente todo el conjunto de realidades, historias y micropolíticas que confluyen en la misma.

A pesar de estas contradicciones, es innegable la importancia que estos planteamientos tuvieron en la reivindicación del carácter dinámico de nuestras ciudades. Las ideas desarrolladas por Guy Debord y por Constant supusieron una bocanada de optimismo que ha influenciado enormemente a generaciones posteriores y nos han ayudado a entender mejor la dimensión fluida, mutante y por qué no, nómada de nuestros espacios. 


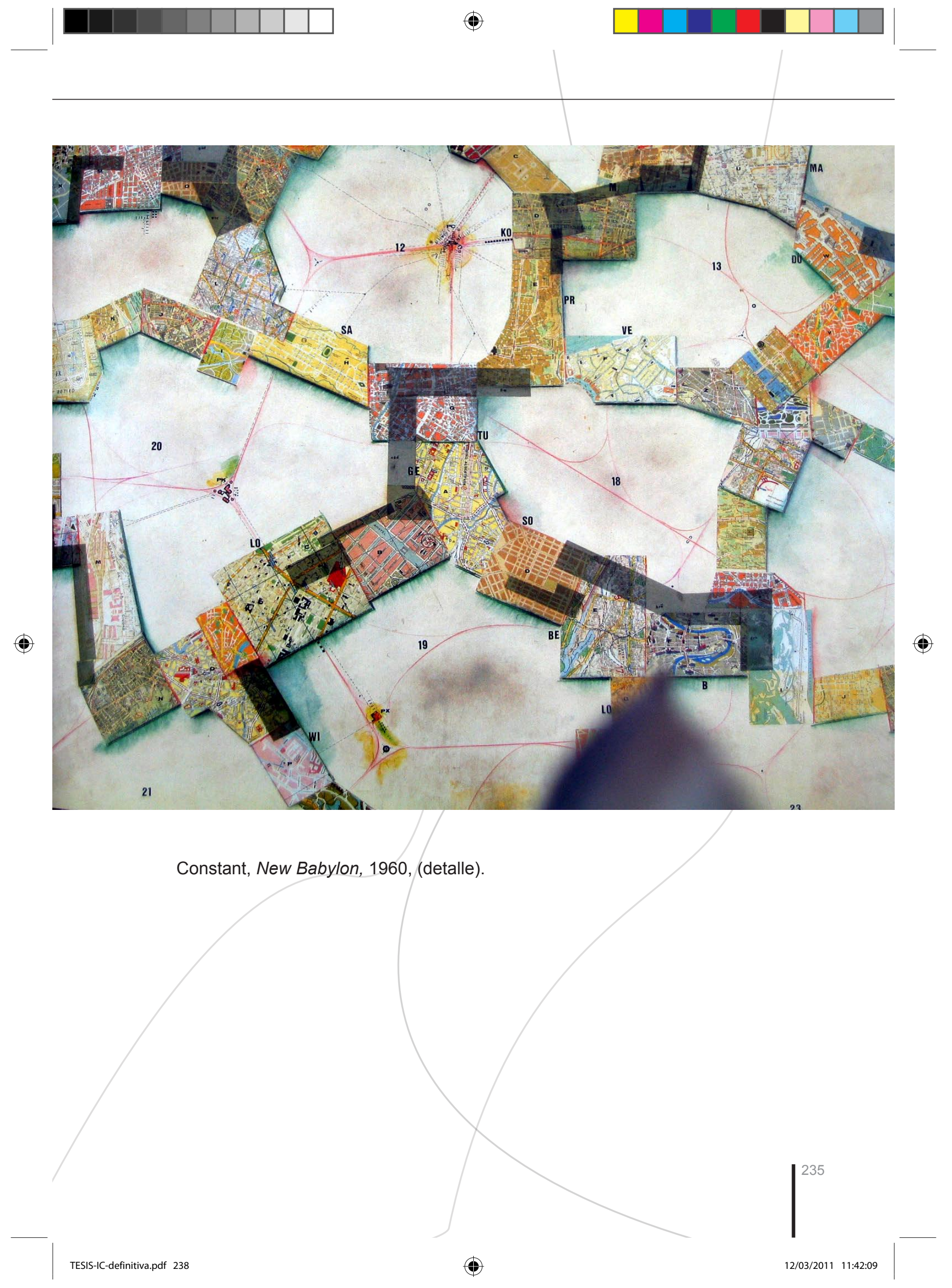




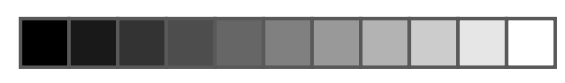

$\oplus$

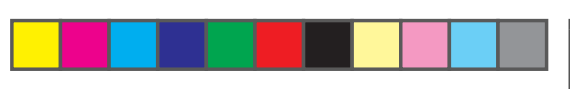

PAISAJES EN MOVIMIENTO

$\oplus$

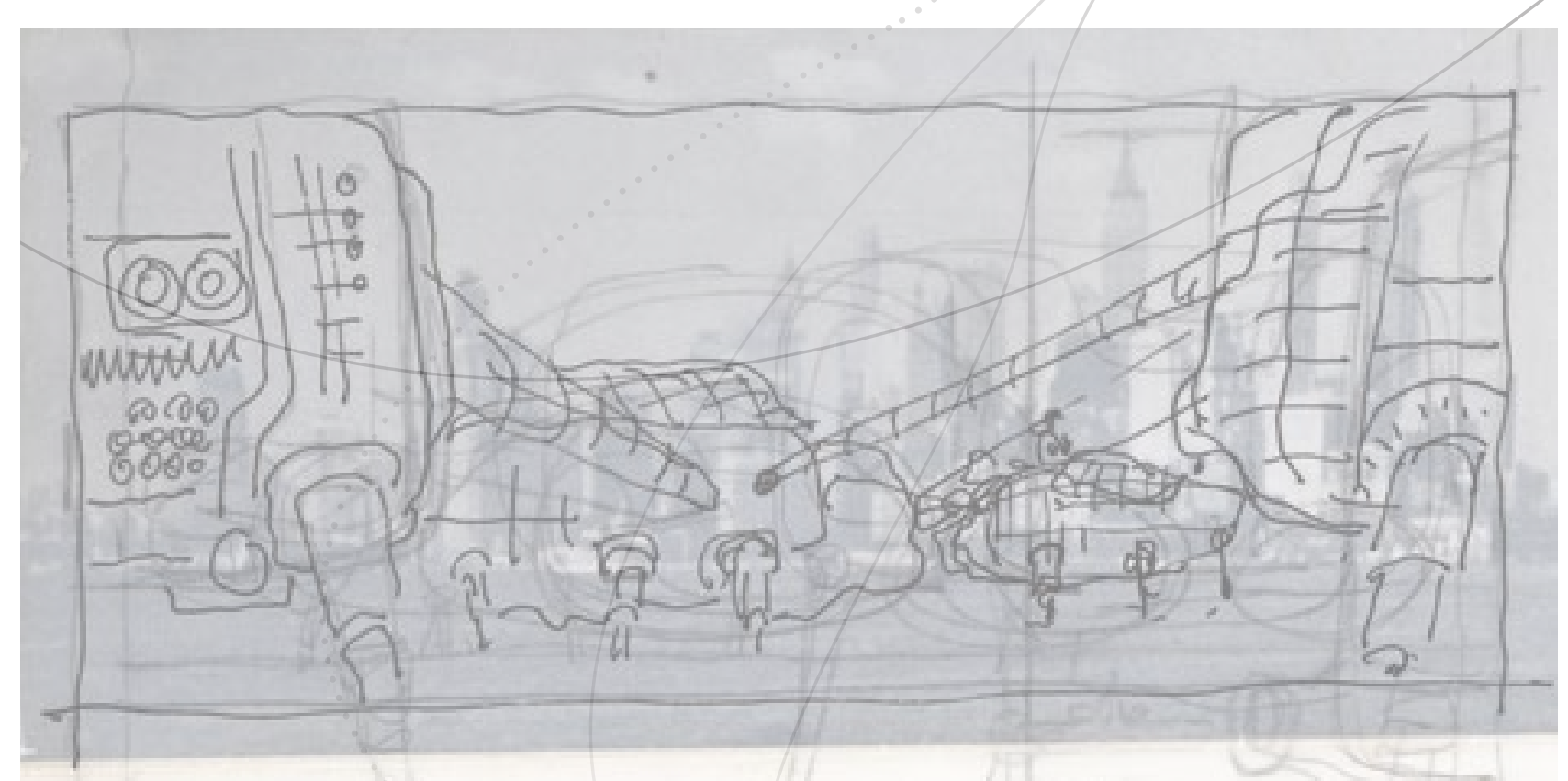

236 

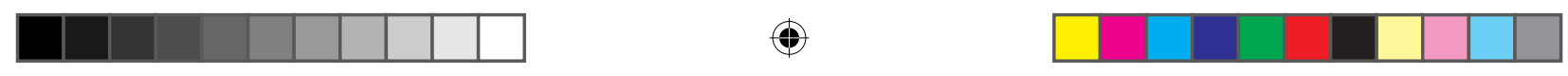

4.1 EL DINAMISMO DE LA “ARQUITECTURA RADICAL” DE LOS AÑOS SESENTA Y

SETENTA

Tras las experiencias que vimos en el epígrafe anterior, que pusieron en jaque estructuras tradicionales y modos estáticos de entender la ciudad, llegó la década de los sesenta. Con la llegada de la euforia económica y las elevadas tasas de consumo que ésta generó se creó un clima de optimismo social que propició simultáneamente una crítica radical de modas y costumbres, así como una apuesta, en gran medida utópica, por propuestas ciertamente impensables hasta ese momento. Veremos además de qué modo se puede observar en todos ellos la evidente influencia de Constant, ya que sin el proyecto de New Babylon hubiera sido muy difícil llegar a imaginar las ciudades nómadas y mutantes que grupos como Archigram propusieron durante esta década. 

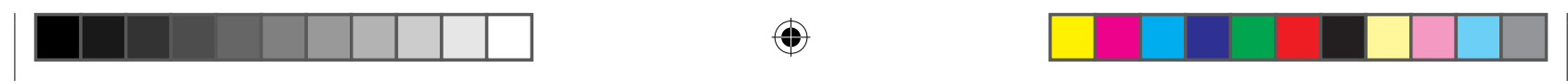

Producto sin duda de este nuevo contexto surgió en 1961, en Inglaterra, el colectivo de jóvenes arquitectos denominado Archigram (abreviatura de Architectural Telegram), formado por Dennis Crompton, David Green, Warren Chalk, Ron Herron, Michael Webb y Peter Cook, para el cual la ciudad era un ente obsoleto necesitado de una ruptura radical en cuanto a formas $y$

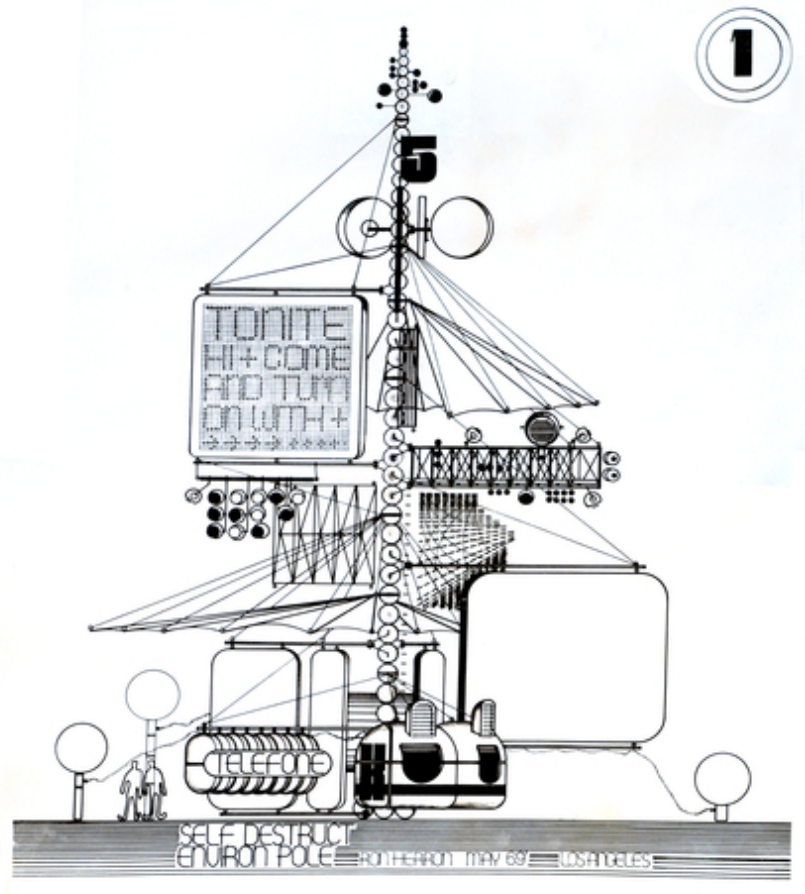

Peter Cook, Instant City, 1969. métodos. El grupo fundó una revista con el mismo nombre que sirvió de altavoz al afán transformador de la ciudad que vertebraba al colectivo. En ella, ofrecían una perspectiva lúdica y fantasmagórica de la ciencia-ficción, de las calculadoras electrónicas o de los ingenios espaciales, asociando la idea de producción de masas a los principios de indeterminación, juego y ligereza inherentes a los esquemas megaestructuralistas.

Enmarcado dentro de estos principios genéricos, la movilidad y el dinamismo ten-

drán un papel muy destacado. En los diez números que editaron de su revista (el último en 1970) detallaron minuciosa y temáticamente su visión del mundo, al tiempo que presentaban sus proyectos con una iconografía, unos colores o unos fotomontajes provenientes de la imagen publicitaria. Relación gráfica entre arquitectura, diseño y publicidad que ha llegado hasta nuestros días y en la cual la influencia de Archigram todavía se deja sentir en los proyectos más avanzados de la creación artística y 

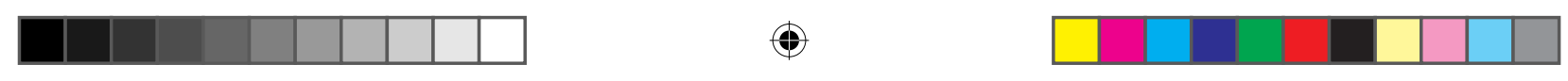

\section{Experiencias entre el arte y el urbanismo en torno al movimiento.}

arquitectónica contemporánea.

Para Archigram la sociedad de consumo de la post-guerra es, no sólo el telón de fondo sobre el cual desarrollan su trabajo, sino la fuente directa de ciertos conceptos que proponen para la estructuración de la ciudad. Con ellos arrancó un modo de entender la arquitectura y el urbanismo como disciplinas basadas en una sensibilidad de dominio de la imagen y de las redes de comunicación urbana. Trascendiendo los límites de cómo se entendía la disciplina hasta ese momento y creando interesantes puentes con otros aspectos del conocimiento

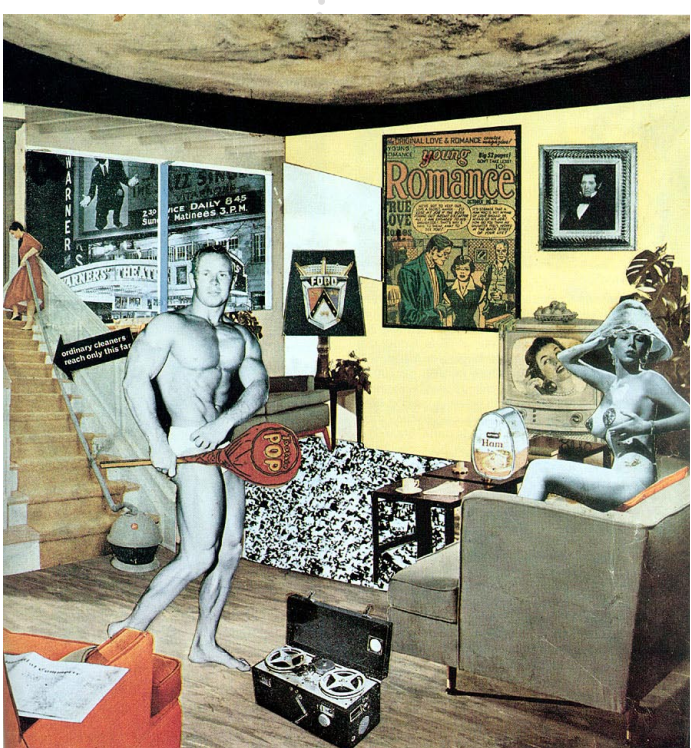

Richard Hamilton, Cartel de la exposición This is Tomorrow, Londres, 1956. recurrieron a la cibernética y a la informática, pero también a los datos de la economía y de la demografía, así como de la cultura pop (muy influenciados por la tarea de sus predecesores del Independent Group), para presentar, en forma de tebeos, configuraciones conectables y desconectables a redes técnicas complejas que generaban una megaestructura lista para ser enchufada. ${ }^{1} \mathrm{~A}$ las estructuras de grandes edificios, oponían macro-estructuras capaces de soportar en cualquier momento y situación todos los equipamientos y generar todo el entorno de una comunidad.

Hasta su disolución en 1974, Archigram basó sus planteamientos en una confianza plena en los avances tecnológicos. En este sentido, las palabras de Warren Chalk no pueden ser más esclarecedoras: "Perseguimos una idea, un nuevo estilo vernáculo, algo que pueda estar a la altura de las cápsulas espaciales, los computadores y los envases desechables

1 Sobre la relación de la cultura pop con la creación artística y arquitectónica de esos años, véase: Robbins, David (ed.), El Independent Group: La postguerra británica y la estética de la abundancia, Instituto Valenciano de Arte Moderno (IVAM), Valencia, 1990. 

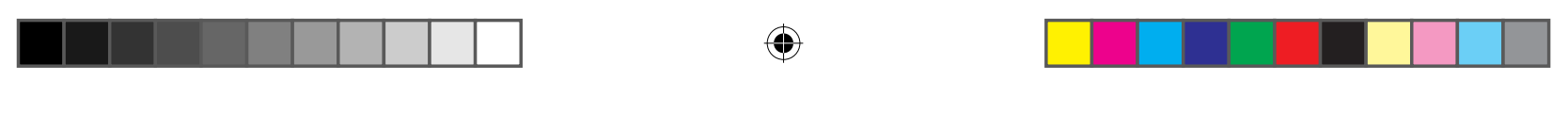

de una era electrónica y atómica" ${ }^{2}$. A los conceptos de prefabricación pesada, opusieron la producción masiva de artefactos que, más próximos a un automóvil o a un lavavajillas que a una casa, podrían ser utilizados, tirados, comprados a gusto del consumidor. Ello significaba la confianza en que el uso de esos objetos suponía un consumo fungible, autonomía técnica, movilidad y poder de decisión del usuario, lo cual posibilitaba una ciudad más personalizada, económica y libre.

Pero lo que aquí más nos interesa de los planteamientos de Archigram es la ruptura con lo que ellos consideraban arcaísmos mentales ligados al concepto tradicional de ciudad y que se plasmaba en su propuesta del "non-plan of a non-city" (no planeamiento de la no ciudad) basado en una fuerte idea de cambio constante y permanente de las estructuras urbanas y los paisajes asociados a ellas. Estas propuestas encerraban una crítica irónica y un deseo de ruptura radical con el urbanismo formulado hasta ese momento ya que frenaba los procesos innovadores y espontáneos y producía un estancamiento de la propia ciudad, la cual debía ser transformada mediante un proceso dinamizador mucho más interesante y enriquecedor. Archigram retomó de los situacionistas las nociones de "urbanismo unitario" y de "acontecimiento", para situar al individuo en el centro del proceso de concepción y evolución de la ciudad. En esta línea de pensamiento teórico (nunca consiguieron realizar ninguno de sus proyectos) se entiende que la ubicuidad, la movilidad, la reversibilidad, la instantaneidad, la precariedad o el indeterminismo sean algunos de sus conceptos operativos básicos. Conceptos todos ellos basados en procesos con un importante componente dinámico y donde la movilidad, en consecuencia, será determinante.

De toda la producción de Archigram, tal vez los proyectos más interesantes fueron aquellos que realizaron en los primeros años de la década de los sesenta, donde proponían ciudades alternativas visionarias que removían las jerarquías establecidas. Usaban los materiales más con-

2 Alison, Jane y otros (eds.), Future City. Experiment and Utopia in Architecture. Thames \& Hudson, Londres, 2007, p.21. 

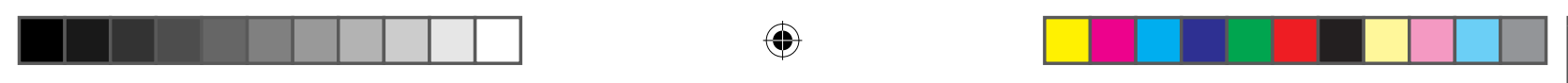

\section{Experiencias entre el arte y el urbanismo en torno al movimiento.}

temporáneos de la época (desde anuncios de la prensa diaria hasta imágenes de ciencia ficción) para desarrollar en sus collages unas propuestas efímeras, divertidas y cambiables, que ponían todo el acento en los planes urbanos integrales, ofreciendo una nueva concepción de la funcionalidad y elaborando una profunda crítica a la concepción americanizada del espacio urbano. Con sus universos mecánicos y delirantes donde la historia está congelada, Archigram formula
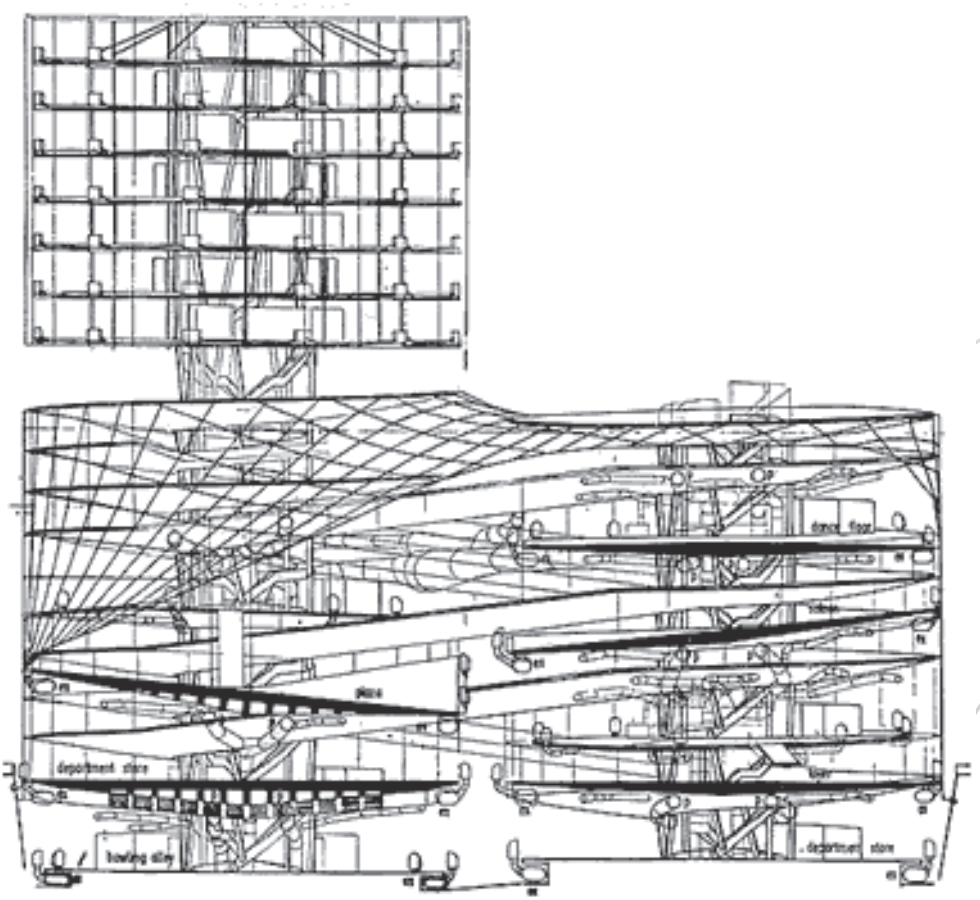

Mike Webb, Sin City, 1961-1963. comentarios irónicos

e implacables sobre

la sociedad de consumo y sus efectos, para instaurar un territorio metropolitano lúdico, prefabricado y evolutivo constituido de interconexiones, cables, estructuras hinchables, caravanas, contenedores, robots, cápsulas geodésicas... que como máquinas deseantes mutan permanentemente en tiempo real. ${ }^{3}$

Dado que los proyectos, por su propia naturaleza, nunca se construyeron, es decir, que eran consciente y premeditadamente irrealizables, éstos se han convertido en el mejor exponente de los planteamientos teóricos más interesantes e innovadores del grupo. Nos acercaremos a la obra de Archigram a través de los proyectos que, a mi modo de ver, son

3 Sobre esta cuestión puede consultarse: Cortés, José Miguel G. Espacios diferenciales. LAIMPRENTA CG, Valencia, 2007. 

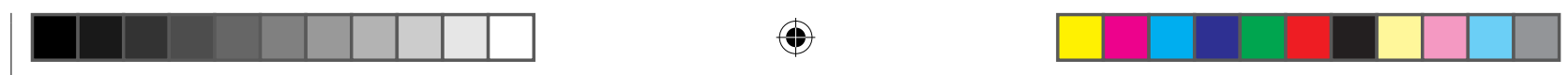

PAISAJES EN MOVIMIENTO

los más significativos para el tema que estamos tratando.

Sin Center, 1961-1963, de Mike Webb, por citar un primer ejemplo, es un centro de ocio en el corazón de Londres. Un gran edificio que reuniría salas de cine, boleras, bares, teatros, restaurantes..., es decir un lugar de concentración de miles de personas para las cuales las vías de circulación debían de permitir un flujo regular a través de diferentes artilugios. Webb concibió el edificio como una extensión de la calle en el interior del mismo, casi como una especie de galería del automóvil donde las rampas de acceso de los mismos tenían una fuerte presencia que llegaba a imponerse a las escaleras mecánicas para el acceso de los peatones.

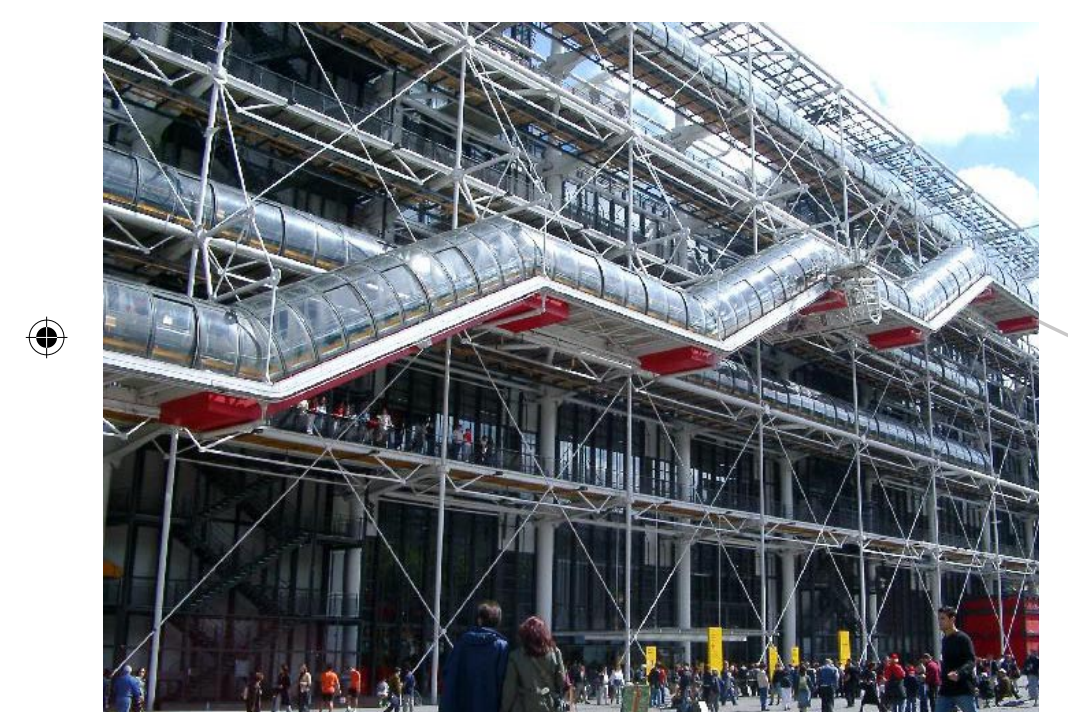

Richard Rogers y Renzo Piano, Centro Georges Pompidou, Paris, 1971.

Todo tenía una apariencia muy industrial, de este modo el techo era curvo y de cristal, cubierto de enormes anuncios publicitarios; el revestimiento de la fachada era de paneles de plástico transparente; los pisos estaban suspendidos por medio de cables... Todo estaba al servicio de poner en valor los elementos estructurales tales como la calefacción y la ventilación, la red de evacuación o los miles de cables. Estas ideas se concretarían años más tarde en la práctica en el Centro Georges Pompidou de París, cuya fachada está dinamizada por la presencia de las escaleras mecánicas que convierten a los usuarios del centro en elementos compositivos de la fachada, transformando un plano tradicionalmente inerte en una superficie vibrante, constantemente transformada por el incesante flujo de visitantes.

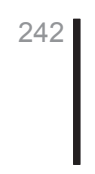




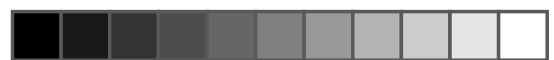

(†)

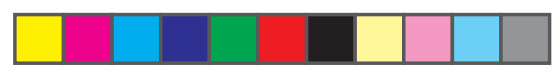

\section{Experiencias entre el arte y el urbanismo en torno al movimiento.}

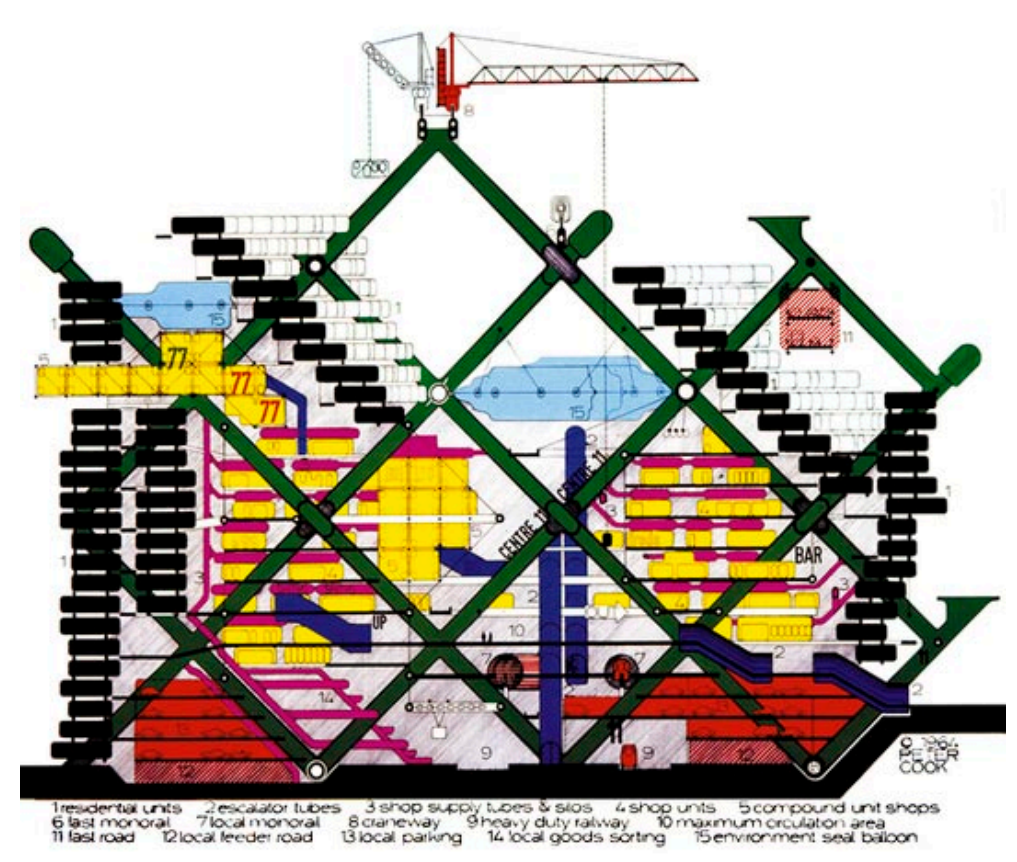

Peter Cook, Plug in

City, 1964.

Otro de los proyectos más interesantes es Plug-in-City, 1964, de Peter Cook. Fruto de la combinación de una serie de reflexiones llevadas a cabo por el grupo entre los años 1962 y 1964, es posiblemente la expresión más radical de una metropoli hipermecanizada y neofuturista, una megaestructura pensada como un "acontecimiento permanente" que llega a comprender una ciudad entera, una ciudad (difícilmente identificable) que se convierte en una estructura de redes a gran escala que contienen las vías de acceso y los servicios esenciales.

Plug-in-City partía de un modelo de ciudad lineal configurada mediante una alto y estrecho sistema de malla que comenzando cerca de Londres crecería en dirección a Liverpool y a partir de aquí atravesando el Canal de la Mancha pasaría junto a París para extenderse por toda Europa. A lo largo de la cima de la parrilla correría un importante monorraíl que transportaría además de pasajeros, grúas que desplazarían por turnos secciones de la parrilla de modo que la ciudad estaría constantemente construyéndose y reconstruyéndose a sí misma, cambiando de 

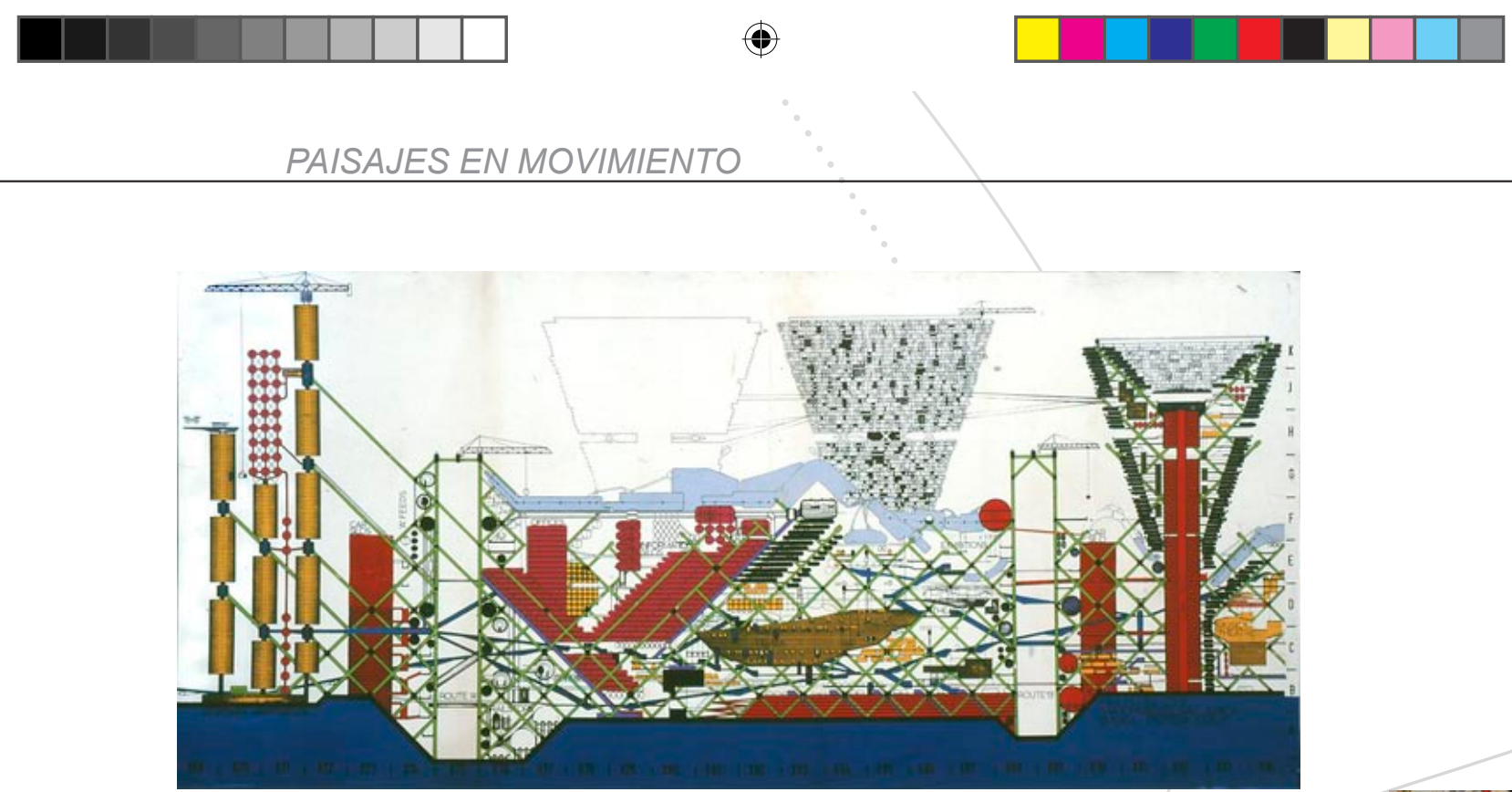

Peter Cook, Plug in City, 1964.

dirección o deshaciéndose en fragmentos con una supuesta muy buena inserción en el paisaje. ${ }^{4}$ Los espacios conformados por la malla son los lugares del sistema donde el ha-bitante de la ciudad podría conectarse o, más precisamente, donde las grúas del propio sistema conectan todo lo necesario para la configuración de una ciudad, desde el alojamiento hasta los equipamientos o incluso los paquetes de aparcamiento.

Así pues, Plug-in-city (plug significa enchufe o conexión) ensaya la aplicación de una estructura de malla a escala territorial, capaz de generar ciudad en cualquier entorno. Para ello, además de la grúa principal existen pequeñas vías para grúas secundarias así como gradas mecanizadas y elementos telescópicos. El interior de esta malla contiene a su vez instalaciones mecánicas y eléctricas diversas. Como vemos, la ciudad presta especial atención a los aspectos que posibilitan la circulación y la movilidad, tanto de personas como de componentes, facilitando una metrópolis mutante y dinámica apoyada a su vez en una alta diversificación de los edificios principales, ya que la idea fundamental del conjun-

$4 \quad$ En las referencias al proyecto de Plug-in-city, ya se nota un cierto respeto medioambiental pues se plantea que estos fragmentos de ciudad incluso son menos nocivos para el paisaje que la construcción de las modernas carreteras. 


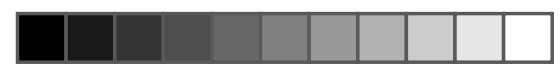

$\oplus$

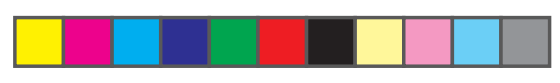

\section{Experiencias entre el arte y el urbanismo en torno al movimiento.}

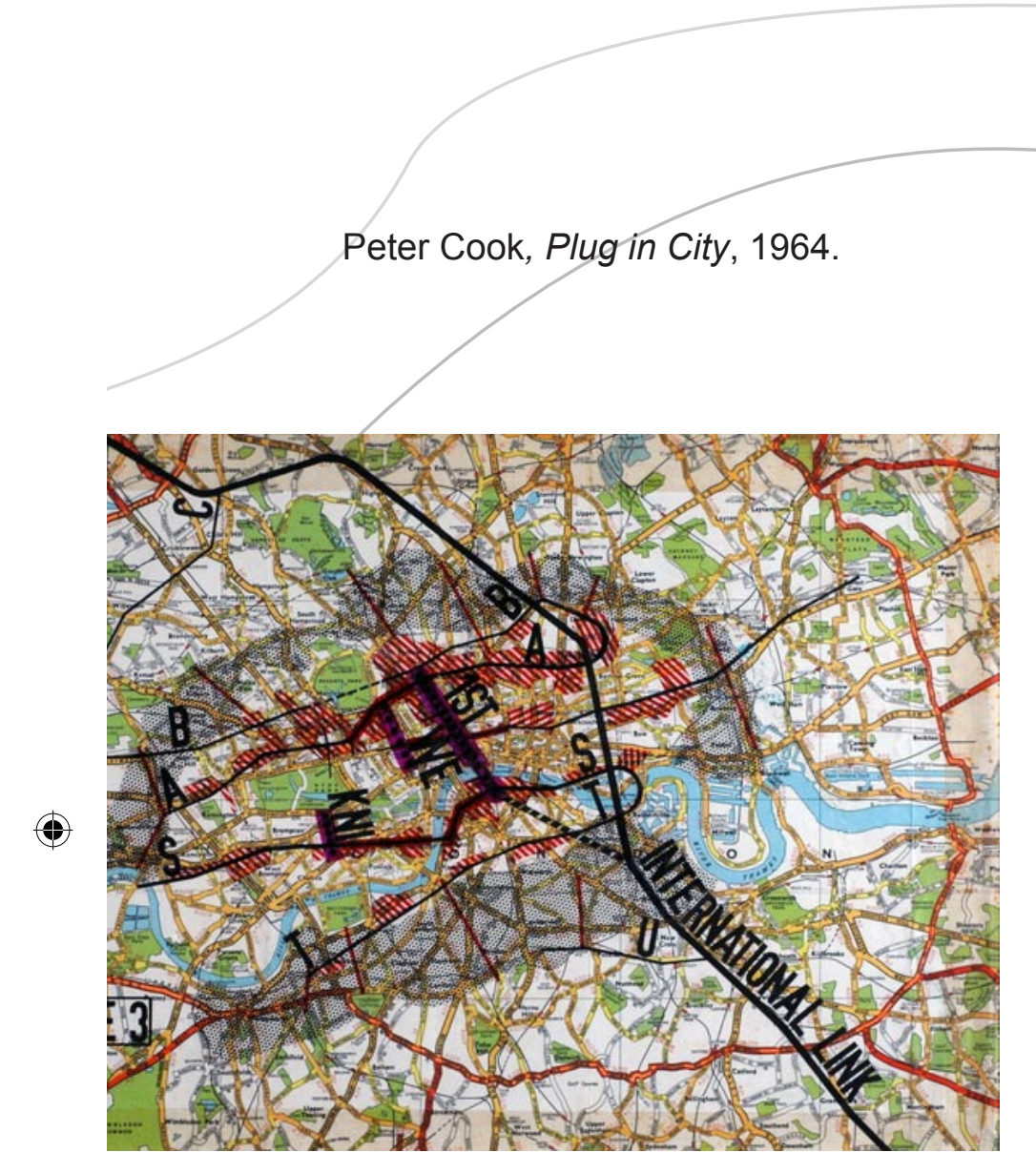

to es la máxima abertura de los límites que pueden encorsetar la estructura urbana. $^{5}$

Con un significativo título, ("La ciudad que camina") otro de los proyectos desarrollados por Archigram es Walking City, 1963-1964, de Ron Herron, donde nos encontramos con una ciudad que camina a través del mundo realizando un urbanismo indeterminado, a expensas del deseo cambiante de los individuos. Una ciudad situada en un futuro en el cual las fronteras habrán desaparecido en favor de un modo de vida nómada llevado a cabo por grupos diversos de gente a lo largo y ancho del planeta. Este proyecto, claramente inspirado por los avances tecnológicos de

5 Un importe estudio de este proyecto es "Design for Living: The Plug in City", Chapman, Priscilla en Schaik, Martin van \& Mácel, Otakar (eds.), Exit Utopia. Architectural Provocations, 1956-76, Prestel, Munich, 2005, pp.69 a 95. 
la época como el "overcraft" 6 así como por las plataformas de lanzamiento móviles y los cómics de ciencia-ficción imaginaba edificios itinerantes, nómadas, capaces de viajar por tierra y por mar. Como otros proyectos de Archigram, Walking City, anticipó el ritmo de vida frenético de una sociedad avanzada tecnológicamente aunque fue excesivamente optimista (o conscientemente irónico) en sus planteamientos.

Estas estructuras móviles están, de nuevo, concebidas para poder conectar diversas utilidades tecnológicas y redes de información en las diversas localizaciones en las que se vaya estableciendo temporalmente la ciudad, de modo que puedan satisfacer las necesidades de sus habitantes/usuarios. Gracias al carácter nómada de la ciudad se ponen en relación diversas culturas obligadas así a entenderse, creando redes de intercambio a nivel global destinadas a mejorar la vida de la gente y el entendimiento entre los pueblos, anticipando proyectos posteriores como Instant City.

Walking City, cuya formaderivó de una combinación de insecto y máquina en lo que supone una clara referencia a Le Corbusier y su "máquina para habitar", estaba configurada por construcciones inteligentes o robots en forma de plataformas vivientes gigantes con capacidad para deambular por el territorio en busca de recursos. Los pods (vainas) eran independientes e incluso parásitos debido a que podían conectarse a estaciones para intercambiar ocupantes o reabastecerse de recursos. Es, en definitiva, el proyecto de una urbe estructuralmente móvil que, según sus diferentes variaciones, camina por el desierto, atraviesa el océano sobre unos flotadores de aire y llega a la ciudad de Nueva York, en una visión apocalíptica del mundo después de una catástrofe nuclear. Un extraño "ser" que se desplaza con unas patas telescópicas en un errabundeo indeterminado y en el cual cada unidad transporta a los "trabajadoresviajeros", una población nómada a la búsqueda de trabajo en cualquier

6 El hovercraft es un vehículo aerodeslizador que se sustenta al lanzar un chorro de aire contra la superficie sobre la que se apoya, de modo que se genera un cojín de aire que le permite moverse sobre cualquier plano sensiblemente horizontal. El hecho singular que atrajo la atención de Archigram y le dio una enorme popularidad reside en su capacidad para deslizarse sobre diferentes superficies como agua, arena o hielo. 


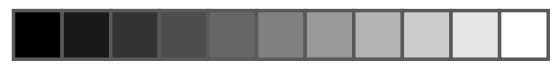

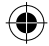

\section{Experiencias entre el arte y el urbanismo en torno al movimiento.}

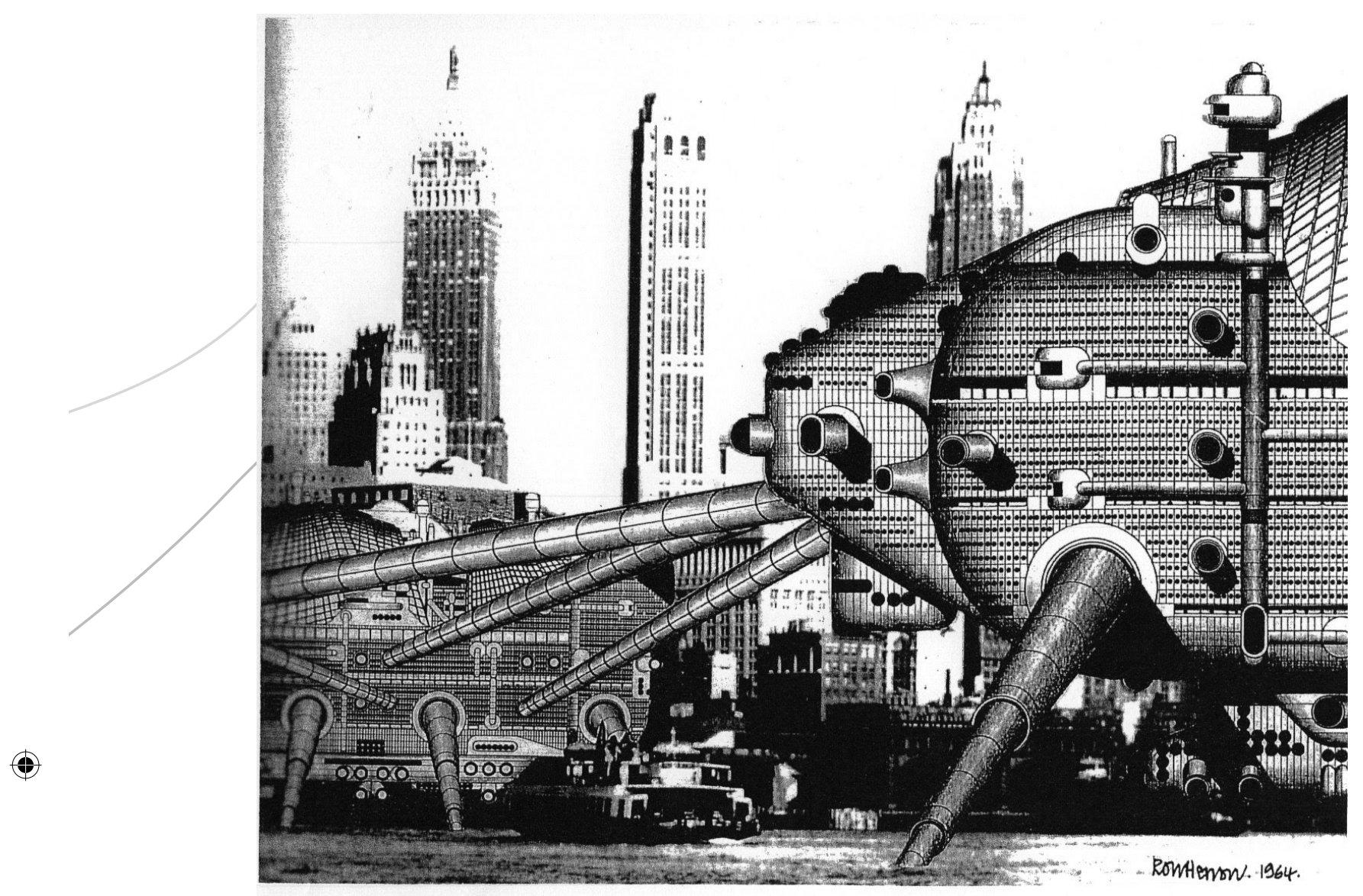

Walking City, Ron Herron, 1963-1964.

lugar del mundo. Esta monoestructura de características zoomórficas recuerda a un colosal coleóptero de escala prehistórica y, al mismo tiempo, a un fabuloso ingenio espacial robótico. Con esta propuesta Archigram desarrolla la noción de "híbrido" que es a la vez máquina, arquitectura, animal, circuito eléctrico, parte de una progresión matemática, elemento azaroso..., para cuestionar las relaciones del hábitat con el transporte y del individuo con la ciudad, para recrear la utopía de una ciudad nómada y viajera en un mundo en constante cambio. ${ }^{7}$

$7 \quad$ Sobre el proyecto Walking City, puede consultarse el catálogo Cortés, José Miguel G. (ed.) Contra la arquitectura. La necesidad de (re)pensar la ciudad, Espai d'Art Contemporani de Castelló, Castellón, 2000. 

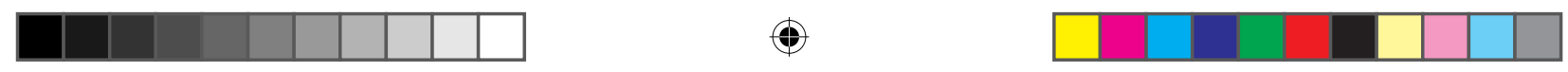

Por último el proyecto Instant City (1968), continuaba la investigación por parte de Archigram acerca de ciudades formadas a partir de estructuras itinerantes. Esta vez, Instant City, entraba en contacto con áreas periféricas de las grandes ciudades o con pequeñas localidades ajenas al ajetreo de las grandes metrópolis con el objetivo de satisfacer una determinada problemática detectada. El proyecto de "Ciudad instantánea" ponía la atención en el conflicto entre lo global y lo local, cuya expresión sería una doble reacción por parte de los habitantes de pequeñas ciudades frente a la metrópoli. Por un lado aparece un fuerte sentimiento de vulnerabilidad que lleva a un excesivo proteccionismo de lo propio y vernáculo y simultáneamente un incómodo complejo de inferioridad respecto a la metrópolis (las investigaciones del grupo se sitúan en Londres y su entorno natural) que lleva, fundamentalmente a los jóvenes, a un sentimiento de frustración y pérdida por la no vivencia de un mundo esplendoroso que ven pasar por la pantalla de la televisión.

Por todo ello, el proyecto propone una ciudad móvil y viajera lista para interactuar allí donde se dirige. Una ciudad que aportará ocio y cultura de modo temporal a esos centros que no disponen habitualmente de ellos. Por lo tanto, frente a una ciudad estática con carencias irresolubles, Instant City propone metrópolis viajeras. Los elementos que conforman
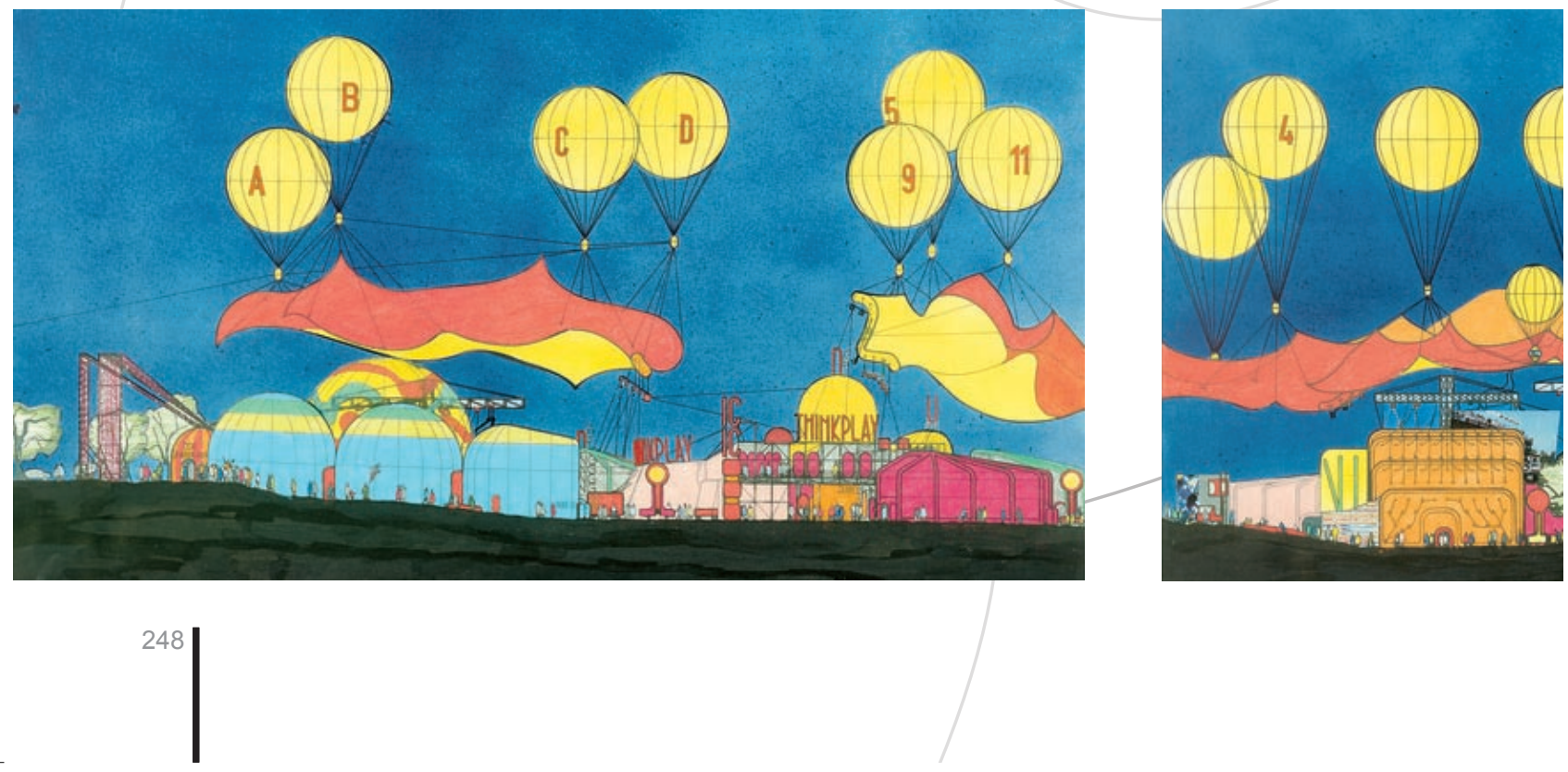

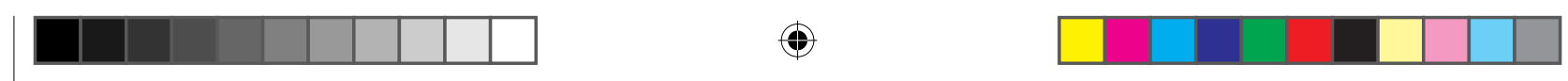

\section{Experiencias entre el arte y el urbanismo en torno al movimiento.}

formalmente esta ciudad instantánea son proyecciones de televisión, sistemas audiovisuales y de iluminación, estructuras neumáticas y ligeras y servicios de entretenimiento y educación. Este complejo organismo anticipaba además la disolución de la ciudad estática tradicional por una estructura fluida y cambiante situada en el intersticio entre el diseño de edificios y espacios públicos (el hardware) y el efecto de la información y la programación en el entorno y en el paisaje de nuestras ciudades y nuestros territorios (el software).

A pesar de que los proyectos que acabamos de ver son los más fascinantes desde el punto de vista del movimiento y la ciudad, también son interesantes otras propuestas como: Computer City, 1964, de Dennis Crompton donde la ciudad en tanto que proyecto arquitectónico se convierte en un dispositivo electrónico continuo que registra y controla tanto el crecimiento de la urbe como las necesidades de sus habitantes; o The Cushicle , 1966, de Mike Webb que es la versión más elaborada de un entorno libre de cualquier restricción, ya que lo lleva el individuo sobre la espalda y lo acondiciona a cada situación o estado de humor. Yendo más allá de la arquitectura y preocupándose por el entorno, poniendo el acento en la movilidad e inventando el nomadismo contemporáneo o despreocupándose de la permanencia de las diferentes partes constitutivas de la

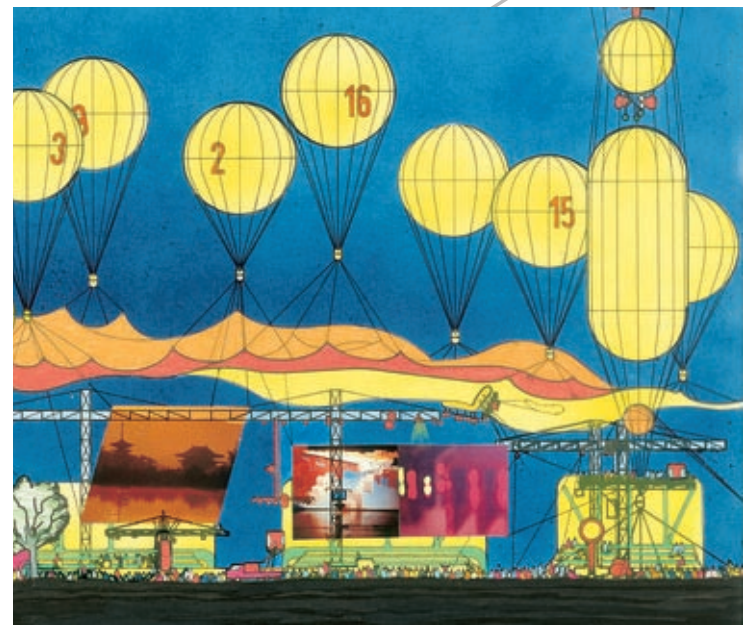

Instant City, Peter Cook, 1968. 

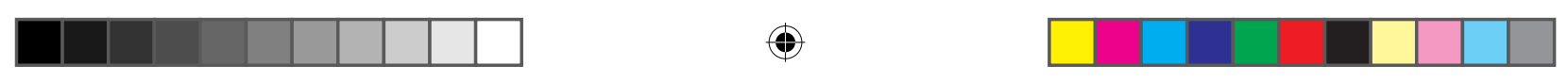

metrópoli, todas estas propuestas pretenden incidir sobre la necesidad de la constante metamorfosis de la ciudad que mostrará la variabilidad y la diversidad de los deseos individuales de sus habitantes.

A pesar de que la visión optimista de Archigram respecto a la nueva tecnología y de la capacidad de consumo en la sociedad capitalista hoy nos pueda resultar bastante inocente, sí que podemos asegurar que sus imágenes visionarias han tenido una enorme influencia y se han infiltrado en el inconsciente de muchos arquitectos contemporáneos. Obras como el ya citado Centro Georges Pompidou de París o el Lloyd's Bank de Londres de Richard Rogers o el Bank of Shanghai y Hong Kong de Norman Foster en la ex colonia británica, por citar tan solo algunas de las más emblemáticas, han abanderado la incorporación al lenguaje de la arquitectura de estructuras altamente tecnológicas ${ }^{8}$.

Asimismo, Archigram se anticipó a uno de los nudos gordianos de la práctica arquitectónica contem-

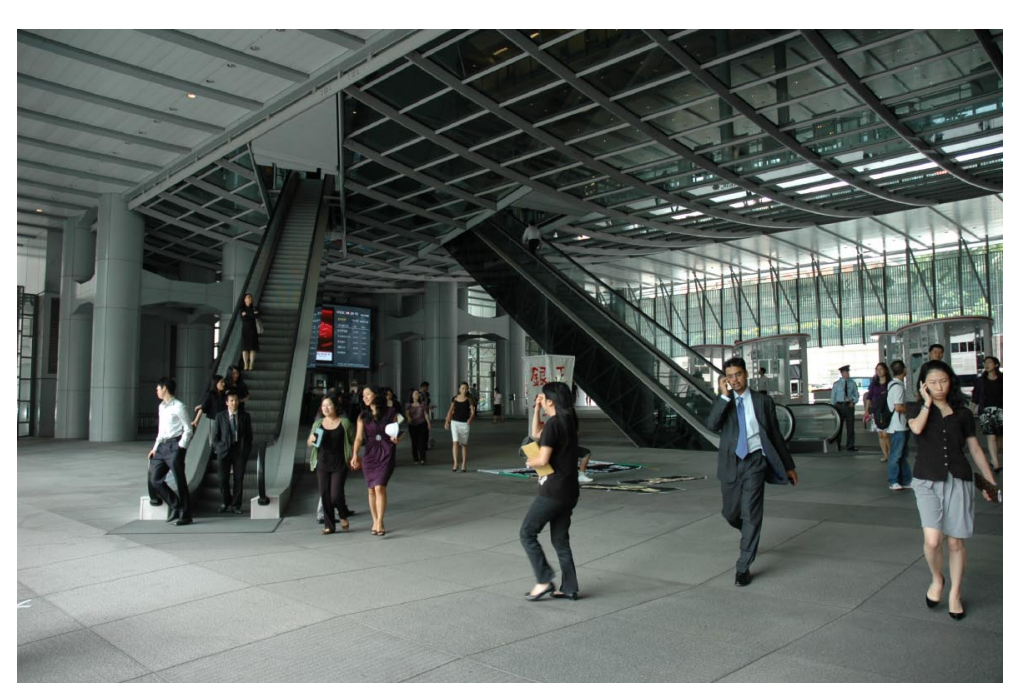

Noman Foster, HSBC, Hong Kong, 1968. (fotografía I.C.) poránea: el enorme impacto de la tecnologías digitales y la información global en la interacción del cuerpo y el espacio; la importancia capital de los ordenadores en la generación de la arquitectura del siglo XXI resulta hoy en día incuestionable. Paralelamente,

8 Estos edificios son los buques insignia de lo que algunas corrientes críticas denominaron arquitectura "high tech" cuyos máximos exponentes son Renzo Piano, Norman Foster y sobretodo Richard Rogers, quién debe sus influencias fundamentales a la arquitectura realizada durante estos años. 


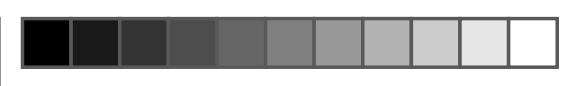

los collages de Archigram con su interacción de múltiples elementos de la cultura de su época y sus proposiciones urbanísticas han dejado una huella palpable en la obra de arquitectos holandeses como Rem Koolhaas o el grupo MVRDV. Estos son algunos ejemplos de la importancia

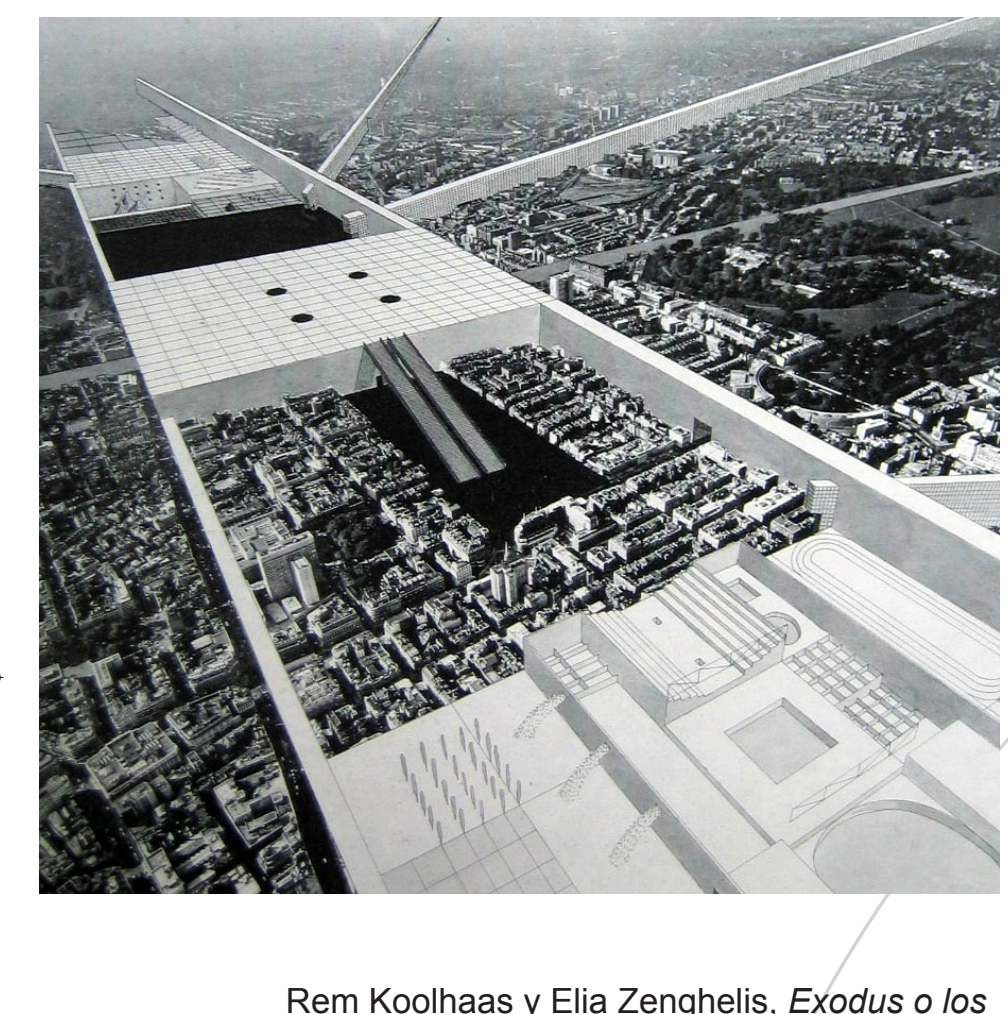

Rem Koolhaas y Elia Zenghelis, Exodus o los prisioneros voluntarios de la arquitectura,1972. que el trabajo de Archigram puede tener a la hora de reflexionar sobre el rol y la identidad de la arquitectura actual. Lástima que la movilidad de sus estructuras, la fascinación que sentimos al pensar en ciudades que caminan o en un espacio urbano que se genera y regenera a sí mismo en un movimiento sin fin, haya sido por motivos evidentes el aspecto que no ha tenido una plasmación tan clara en la arquitectura y el urbanismo posteriores.

La réplica italiana a Archigram vino de la mano de un conjunto de arquitectos formado por Paolo Deganello, Andrea Branzi, Máximo Morozzi y Gilbert Corretti que fundaron en 1966, en la ciudad de Florencia, el grupo Archizoom Associati9 que formó parte del núcleo del movimiento contestatario que se originó en ese país en la década de los años sesenta; un fenómeno cultural lleno de energía (y también de contradicciones)

9 La onomatopeya zoom, que junto con la abreviatura de la palabra arquitectura formaba el nombre del grupo hacía referencia a una fuerte voluntad por parte de sus miembros de introducción en la arquitectura de elementos propios del universo popular de ficción proveniente del cómic y del arte pop. 

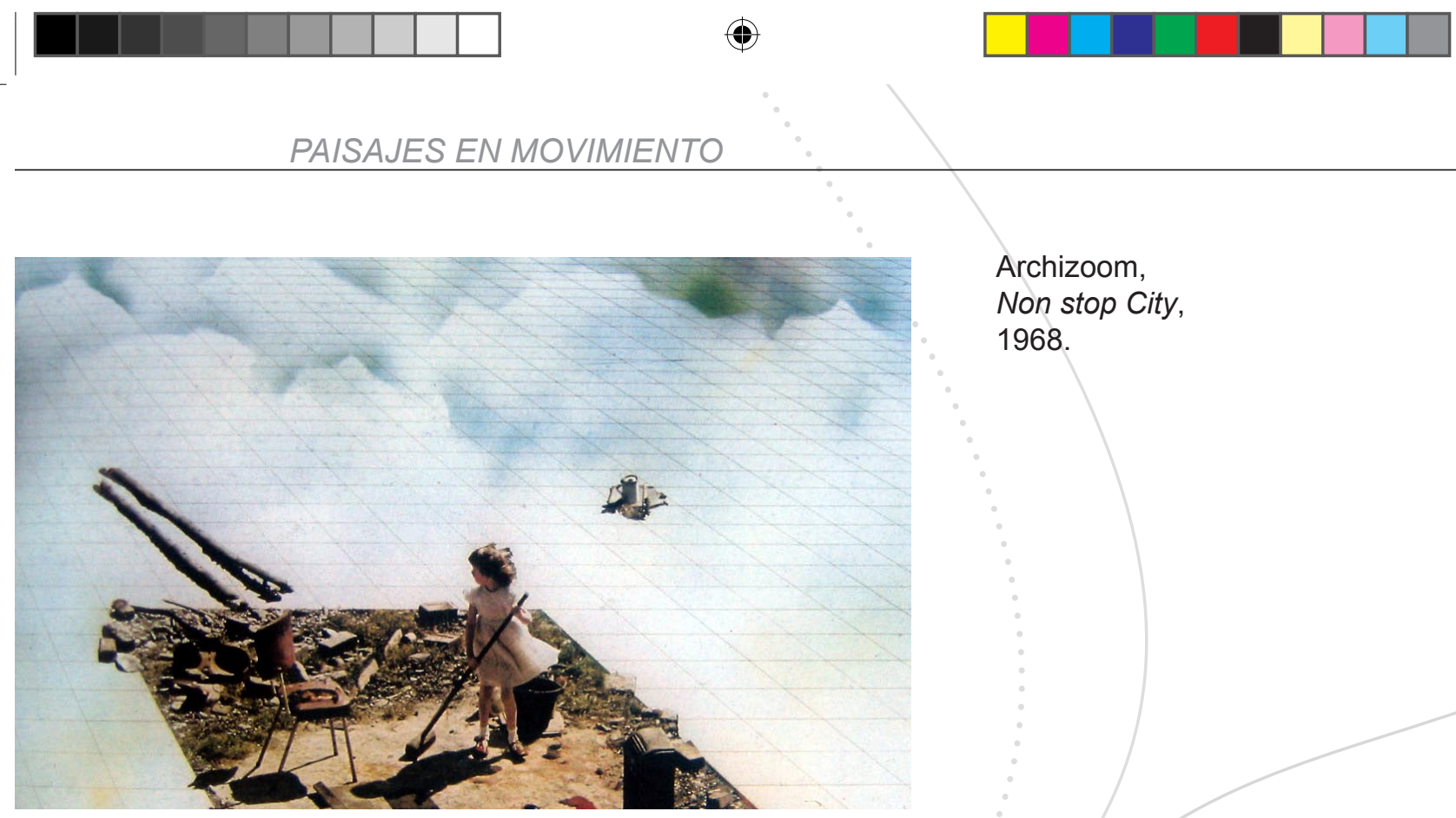

Archizoom,

Non stop City,

1968.

que proponía proyectos experimentales y utópicos basados en una profunda crítica radical a la sociedad de su época.

Así, en el manifiesto pu-blicado que marcaba el inicio de su trabajo y de lo que más tarde se ha conocido como la "arquitectura radical", proclamaban que, "La superarquitectura es la arquitectura de la superproducción, del superconsumo, de la sobreincitación al consumo, del supermercado, del superhombre, de la gasolina super. La superarquitectura acepta la lógica de la producción y del consumo, y ejerce una acción desmitificadora." ${ }^{10}$ Archizoom veía en el supermercado (especialmente en los "malls" comerciales norteamericanos) el lugar donde la lógica capitalista de la producción alcanzaba más claramente sus objetivos, es decir, la constitución de un espacio banal, homogéneo, neutral, completamente climatizado e iluminado artificialmente y que no ofrece en su interior ninguna calidad (es el reino del mero almacenaje). Según ellos, es una manera de concebir el espacio a construir que se ha hecho extensible a todos los países y en todas las líneas de producción, que está originando un urbanismo mundial y proponiendo una estructura formal en

10 Toraldo di Francia, Cristiano, "Superestudio \& Radicales" en VV.AA. Arquitectura Radical, Generalitat Valenciana, Valencia, 2001, p.210. 

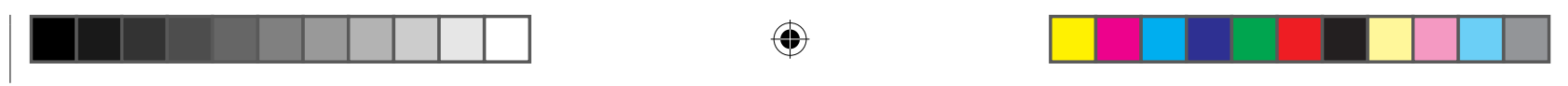

\section{Experiencias entre el arte y el urbanismo en torno al movimiento.}

la concepción de la ciudad. Unas características que van a estar muy presentes en su planteamiento de una ciudad contra-utópica extensible en todas las direcciones y en todos los territorios pues, para ellos, el espacio del supermercado escenifica un cierto urbanismo mundial del futuro.

La metrópoli, es, para este colectivo, el territorio en el cual se concretan las relaciones sociales, la metáfora que mejor ilustra la realidad y, por tanto, el lugar donde con radical claridad se deben proponer las modificaciones pertinentes para modificarla. La originalidad de su propuesta estriba en su rechazo a destruir la ciudad capitalista o moderna para reemplazarla por otra alternativa. Su planteamiento apuesta por ofrecer una visión crítica que intensifique y extrapole lo construido para hacer posibles intervenciones o modificaciones contundentes en el entorno cotidiano. Para Archizoom un lenguaje industrial-comercial, el consumo cultural masivo, la cultura popular, la influencia del pop art o el mundo de los cómics, junto a un humor de contenido muy crítico, son aspectos fundamentales a tener en cuenta a la hora de abordar los proyectos arquitectónicos. Como escribió Andrea Branzi. "La arquitectura radical se sitúa en el interior de un movimiento más amplio de liberación del hombre de las tendencias de la cultura contemporánea, liberación individual entendida como rechazo de todos los parámetros formales y morales que, actuando como estructuras inhibitorias, dificultan la realización completa del individuo." 11

Archizoom, cuyas realizaciones se prolongaron hasta 1973, compartía objetivos con el conjunto de arquitectos y movimientos europeos (se sentían especialmente próximos no sólo a grupos como Archigram, sino también arquitectos como los austriacos Hans Hollein, Max Peintner o Walter Pichler) que deseaban liberar al ser humano de las restricciones de la cultura burguesa, con la pretensión de abolir todos aquellos parámetros morales e ideológicos que crean las importantes constricciones sociales e imposibilitan al individuo el poder realizarse libremente. Asimismo, compartían con su grupo homólogo inglés un ácido humor y una

11 Branzi, Andrea, "La arquitectura soy yo" en Ibidem, p.18. 

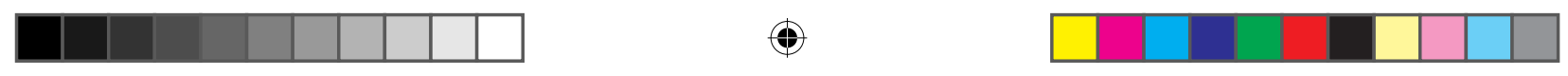

seria crítica a los dogArchizoom, Non stop City, 1968.

mas del Movimiento

Moderno. Andrea Branzi

(diseñador, arquitecto, líder de Archizoom y uno de los fundadores de la célebre Academia Domus) es uno de los más importantes teóricos del fenómeno radical italiano que se caracterizó por sus agudas críticas a todas las estructuras sociales. Las ideas que engloban a este conjunto de propuestas, que se han conocido con el nombre de "arquitectura radical", representan un

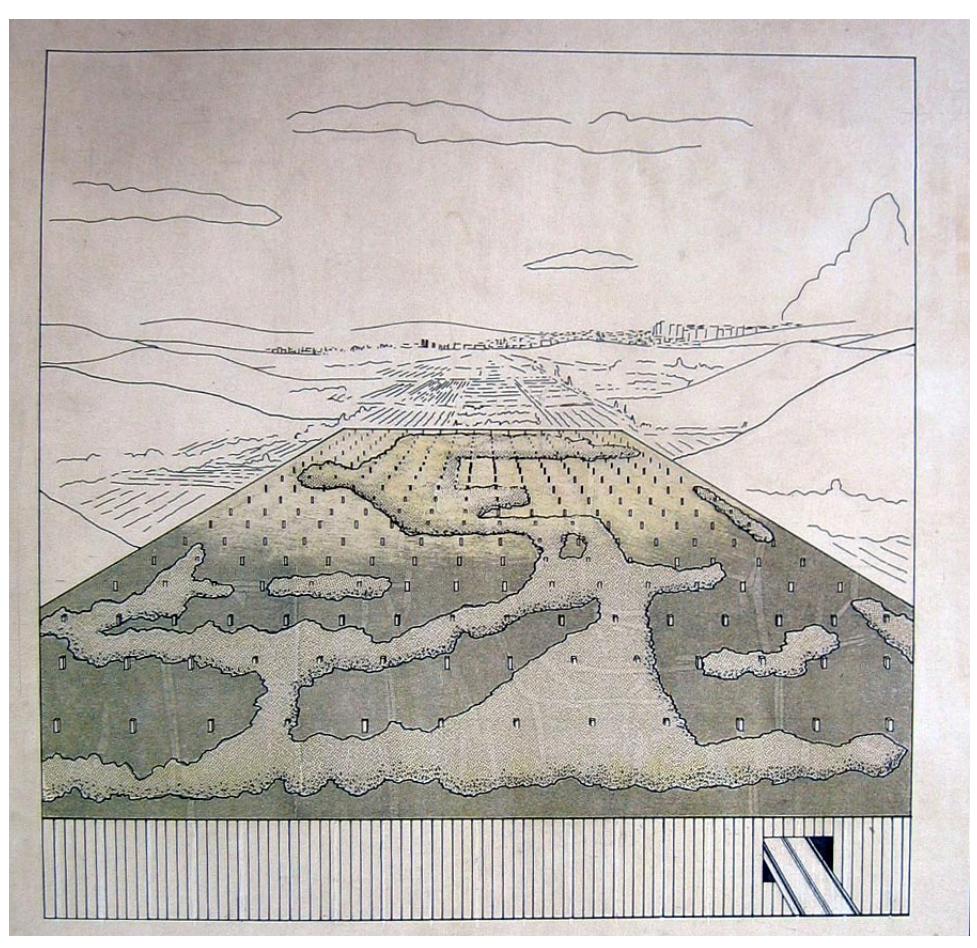
proceso continuo de crítica sobre la estructura de la sociedad que deja el uso de la disciplina en manos de reformadores contemporáneos.

Archizoom propone proyectos transgresores que no rechazan, en general, el campo específico de la arquitectura y, aunque a menudo se debilitan las conexiones con una operatividad estrictamente profesional, se registra un insólito rigor en las investigaciones teórica y simbólica. Sin embrago, y aunque resulta cierto que sus proyectos tienen más un carácter teórico que de construcción real de una metrópoli, Archizoom trata de radicalizar la tradición modernista subrayando su ideologización y ofreciendo una visión utópica que vaya mucho más allá de la planificación específica de una ciudad para adentrase en una crítica radical de las estructuras arquitectónicas que la sociedad promueve. De entre las 

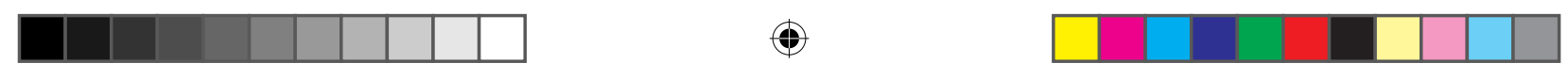

\section{Experiencias entre el arte y el urbanismo en torno al movimiento.}

intervenciones urbanas que Archizoom propuso, existen determinados proyectos que parecen un tanto cínicos en tanto que vienen a incidir en los males que tratan de denunciar, incluso viendo algunas de sus propuestas parece que estén planteando la desaparición de la ciudad. Sin embargo, lo que quieren sugerir es la eliminación de la ciudad como modelo jerárquico y social a través de la destrucción de las formas de poder acumuladas, y a favor de un nuevo estado igualitario en el que todas las personas sean libres de desarrollar su potencial.

De entre los distintos proyectos del grupo, el que nos interesa especialmente (y es definitiva su proyecto más complejo y sugerente) fue el proyecto de ciudad subterránea Non Stop City, 1969-1970, posiblemente su creación más ambiciosa. En éste, cobra una especial relevancia su estrategia realista de desmitificación de lo urbano. Para Archizoom la producción y el consumo (la fábrica y el mercado) son los elementos clave de una ideología utilitarista y de progreso en el que se concibe la realidad física y social como una relación totalmente continua y no diferenciada, la cual origina una transformación absoluta de la ciudad. Por ello es ne-

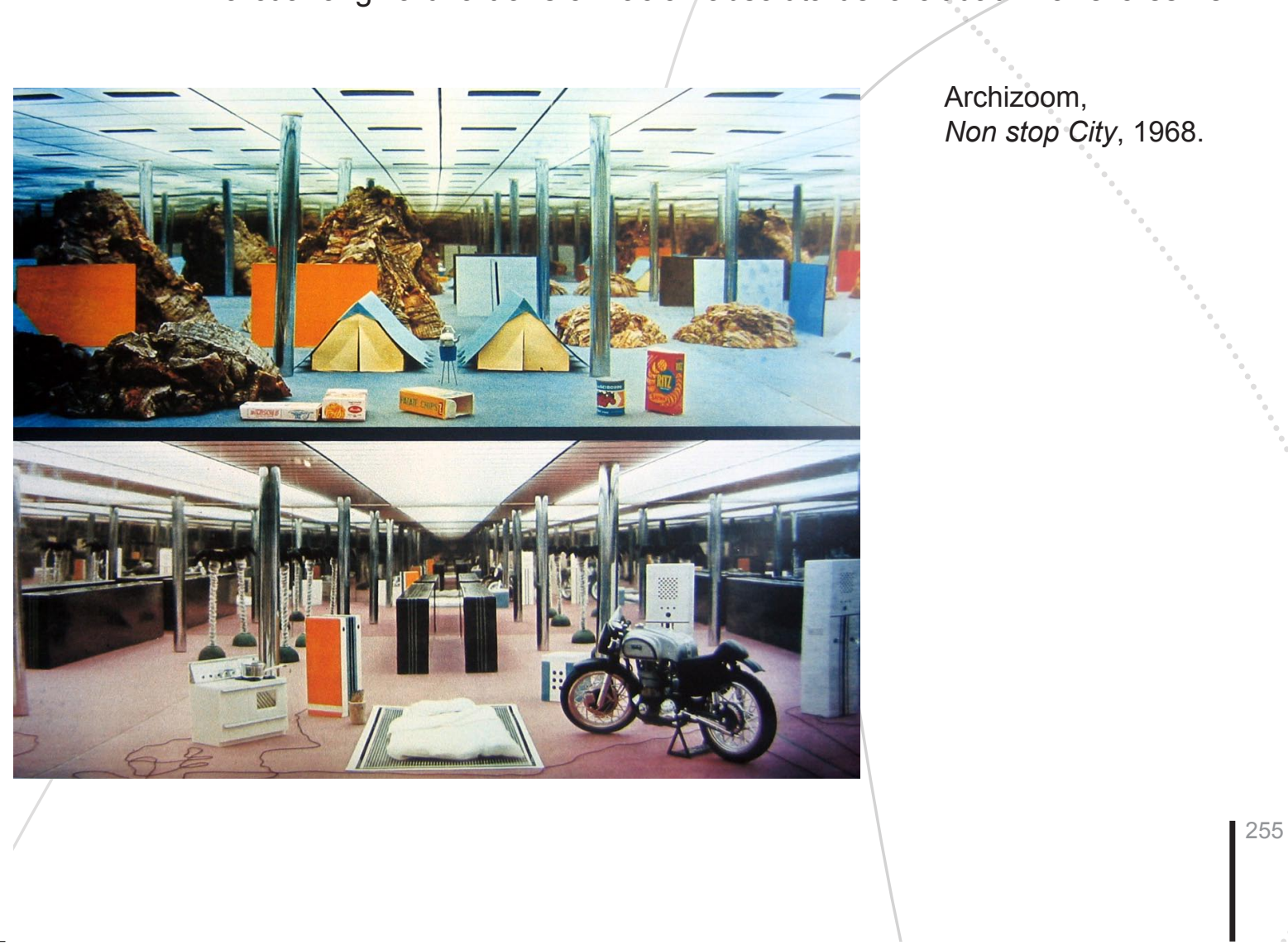



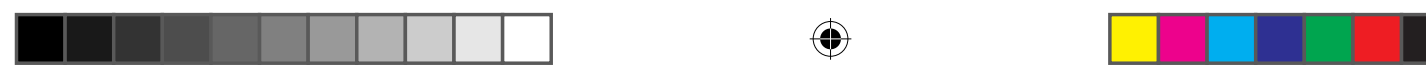

cesaria una crítica (aunque sea utópica), y también un planteamiento de comprensión de los fenómenos estructurales de la ciudad y de la sociedad en su conjunto. Un modelo de urbanismo global que pretende ser la representación simbólica del estado de degradación de la metrópoli moderna. A partir de los parámetros negativos de una vida (y una ciudad) nueva, plantean una Ciudad-Mundo artificial para un futuro artificial. Así, a una visión de un "no futuro" ofrecen un proyecto mental, "una ciudad sin cualidades". Con planos microclimatizados y "diagramas de vivienda homogéneos", Archizoom pretende vencer los límites de la tipología residencial actual y el concepto de arquitectura mayoritario creando una ciudad fluida que se extiende en un movimiento continuo y uniforme que no tiene límite ni fin.

De este modo, y considerando la arquitectura como una categoría intermedia de la organización urbana que es necesario sobrepasar se trata, según el propio Andrea Branzi, de radicalizar el componente industrial hasta extremos imposibles, crear barrios homogéneos y continuos, espacios internos bajo tierra que suprimirán definitivamente el problema (entre otros) de la iluminación natural de las habitaciones. Estructuras urbanas óptimas, potencialmente sin límites, donde las funciones humanas se desarrollan espontáneamente en una extensión libre, y conformadas uniformemente por un sistema de micro-climatización y una óptima circulación de información. El "natural y espontáneo" equilibrio de luz y aire es reemplazado: la casa se convierte en una parcela sin paredes, eso sí, muy bien equipada. Dentro de ella ya no existen jerarquías ni formas espaciales que condicionan la naturaleza. De este modo, se pretende que Non Stop City lleve a cabo una relación directa entre la metrópoli y los muebles o utensilios, la ciudad se convierte en una sucesión de armarios, camas, mesas, sillas...donde el mobiliario doméstico y el urbano coinciden completamente. Sería algo así como una serie interminable de inmensas superficies subterráneas cubiertas por campanas de cristal en las que se concentra la existencia, una existencia un tanto extraña y paradójica pues, ante la incapacidad de la ciudad para satisfacer las deman- 

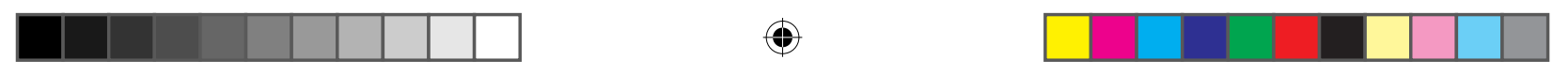

\section{Experiencias entre el arte y el urbanismo en torno al movimiento.}

das más perentorias de los seres que la habitan se plantea una ciudad sin fin, donde los movimientos de sus habitantes son más definitorios que su forma, ya que ésta se ha reducido hasta el extremo.

Se trata de una propuesta en la que la arquitectura es entendida como el instrumento para conseguir conocimiento y potenciar la acción mediante un modelo "arquitectónico" de urbanización total. Ello, puede dar lugar a una ciudad continua que sería la imagen límite de la historia

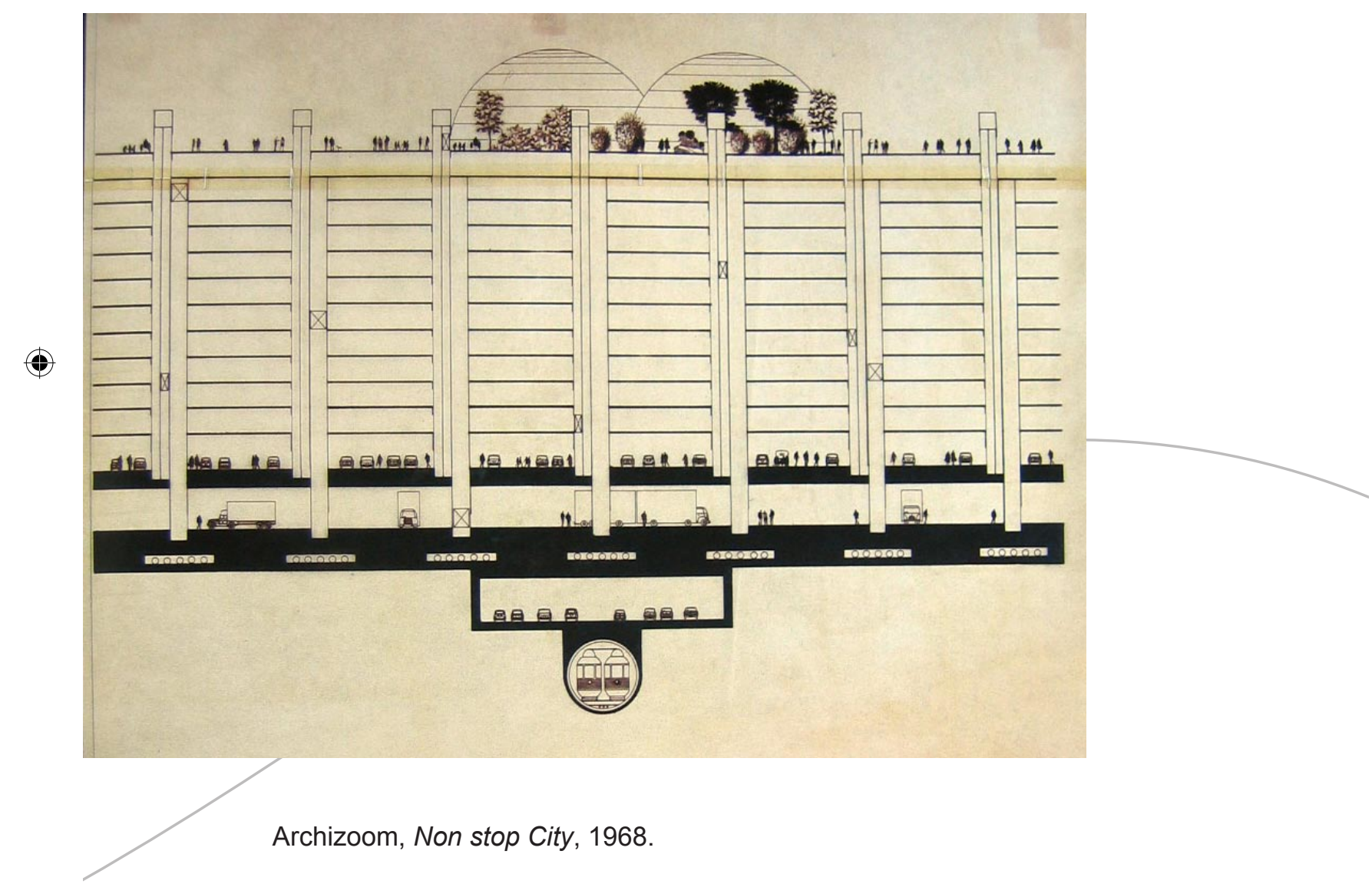

de la arquitectura, la cual halla su realización en una ciudad capaz de dar forma al mundo entero. Con estas propuestas radicales Archizoom pretende liberar a la ciudad de la última de sus restricciones: la arquitectura, y para ello propone unos "edificios" que no tienen fachada exterior ni compartimentación interior ni forma evidente, la arquitectura se diluye 

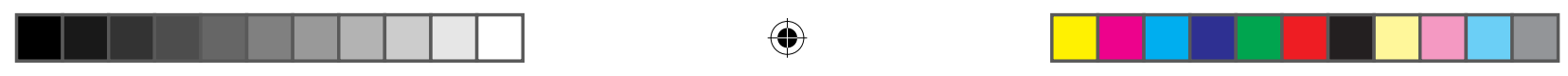

y confunde, parece que va a desaparecer. En definitiva, se trata de una concepción bastante pesimista, ya que no conduce a la construcción de ciudades más o menos ideales, sino que nos lleva a un profundo desarraigo de la arquitectura y a un planteamiento muy negativo de las posibilidades de la convivencia en las urbes modernas como lugares en las que las estructuras físicas y morales impiden al ser humano adquirir su propia libertad. El espacio de la Non Stop City, de la ciudad sin final (sin final ni en su forma ni en su movimiento), se vuelve continuo, homogéneo e ilimitado, con lo que toda la forma-

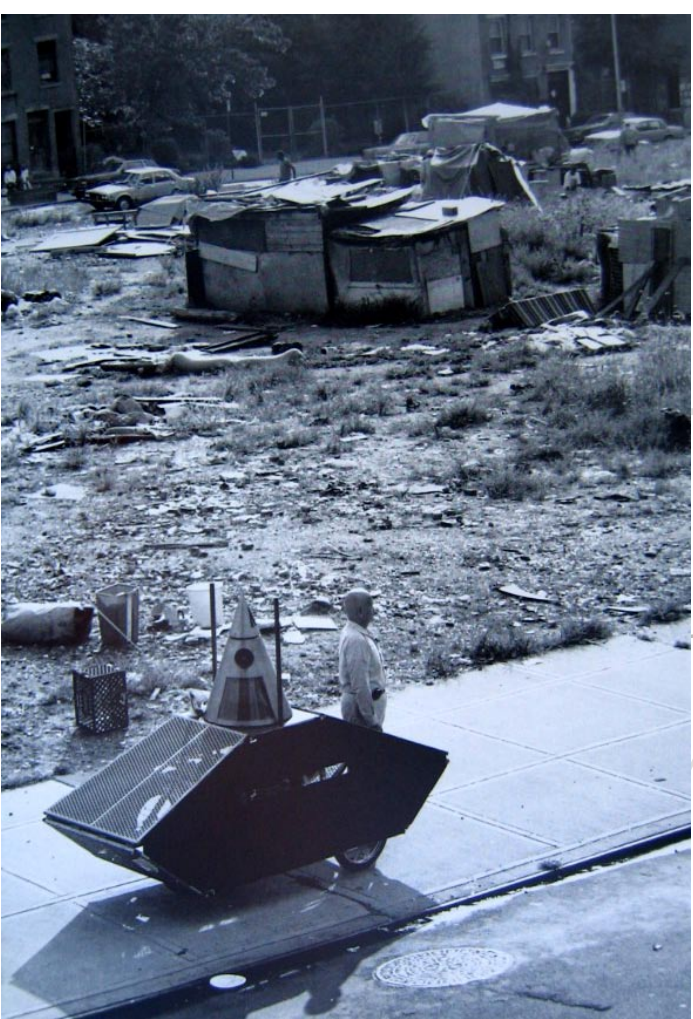

Krzysztof Wodiczko, Poliscar, 1990-91. lización y caracterización se deja en manos de sus habitantes. Son ellos quienes mediante sus movimientos, sus recorridos e intercambios la significan. Se trata de un espacio del movimiento puro, sin constricciones, constante $\mathrm{y}$ duradero en el tiempo y en el espacio. ${ }^{12}$

Por último quisiera finalizar este apartado citando el trabajo del arquitecto de origen polaco, pero afincado en Estados Unidos, Krzysztof Wodiczko. En los últimos años Wodiczko se ha interesado, fundamentalmente, por llevar a cabo una labor artística que fuera más allá de los muros del museo, que superara los límites impuestos al arte por parte de las instituciones culturales, para ampliar sus propuestas vinculándolas lo más estrechamente posible a las vivencias

12 Para entender más ampliamente esta propuesta, puede verse: Brayer, Marie-Ange y Migayrou, Frédéric, Archilab's Urban Experiments. Radical Architecture, Art and the City, Thames \& Hudson, Londres, 2005, pp.131 y ss. 

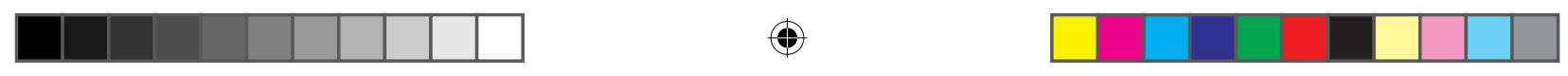

\section{Experiencias entre el arte y el urbanismo en torno al movimiento.}

de la ciudad y a las gentes que la habitan y la conforman. En contra de las visiones totalizadoras y homogeneizadoras de la cultura dominante Wodiczko muestra un arte crítico que tiene la pretensión de revelar las contradicciones de la sociedad mostrando sus limitaciones y miserias. Para ello se ha servido básicamente de unas enormes proyecciones públicas sobre diferentes fachadas de edificios institucionales o monumentos y de la creación de una serie de vehículos que se sitúan a medio camino entre lo que se entiende como una obra de arte y un objeto cotidiano de uso práctico. "Quisiera creer que mi trabajo de diseño o mis proyecciones públicas pueden entenderse como maneras de "intervenir" en la ciudad, con el fin de aportarle una dimensión crítica a la experiencia humana." ${ }^{13}$ Las obras de Wodiczko buscan revelar las contradicciones del entorno y los eventos que están ocurriendo en la actualidad, eventos y situaciones que tienen que ver con la política del espacio y la ideología de la arquitectura. Su trabajo tiene como propósito tratar de sacar a la luz las contradicciones y con-
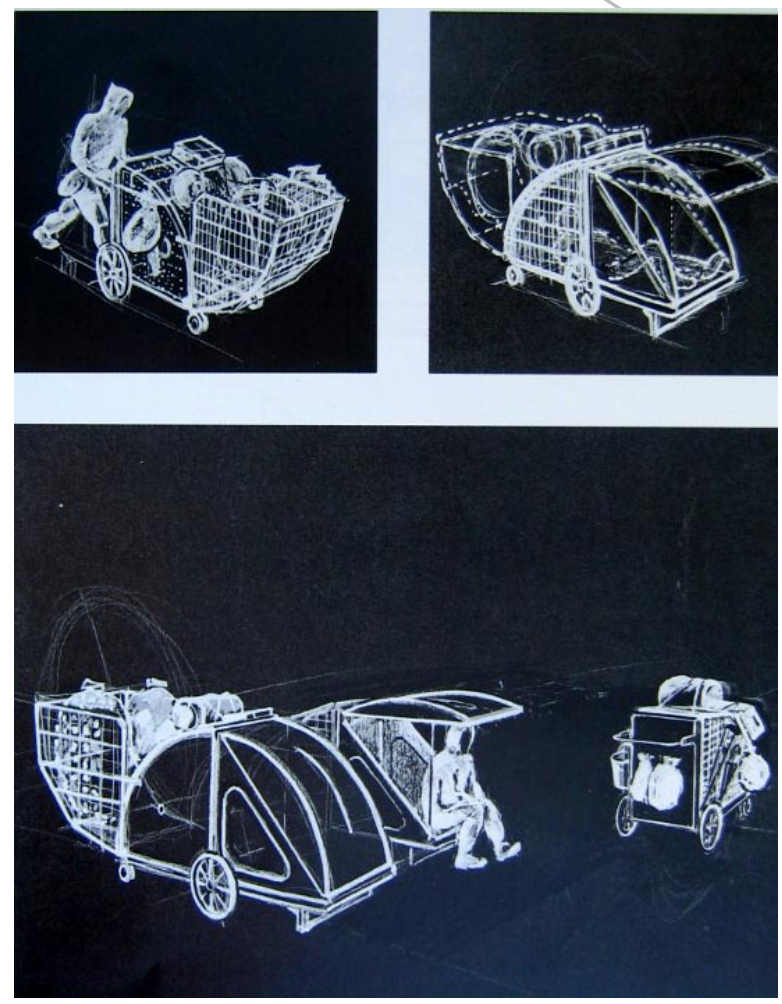

Krzysztof Wodiczko, Vehículo para la gente sin hogar, 1988. flictos que la arquitectura tradicional trata de ocultar.

En este sentido, Krzystof Wodiczko entiende que la arquitectura no es una mera correlación de edificios estables y estructuras permanen-

13 VV.AA. Krzystof Wodiczko, Fundació Antoni Tàpies, Barcelona, 1992, p.62. 

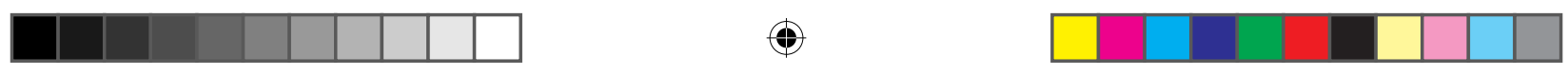

tes, sino un verdadero sistema social, una condición económica y, también, una experiencia psico-política. Según comenta el propio artista, "Lo que se ha definido como arquitectura es en realidad un implacable sistema inmobiliario, encarnado por un continuo acontecimiento a aterradora escala-masiva, cuyas operaciones centrales y más inquietantemente públicas son el terror económico, el desahucio físico y el éxodo de los grupos más pobres de la ciudad del interior de los edificios hacia fuera." ${ }^{14}$ Lo que se trata por tanto, es de ser conscientes del contacto con las estructuras arquitectónicas, de que nuestra mirada no sea pasiva ni estática con el fin de evitar que absorbamos, sin darnos cuenta, su orden de prioridades políticas e

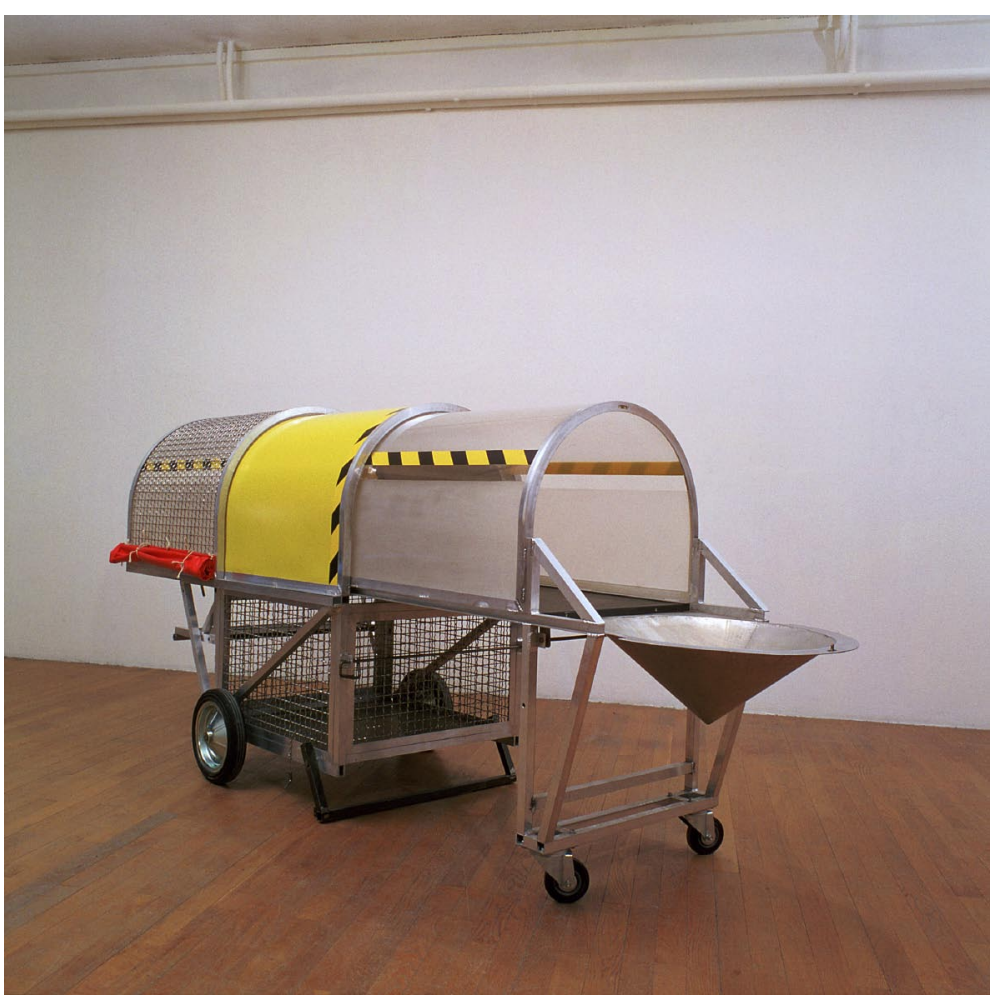

Krzysztof Wodiczko, Vehículo para la gente sin hogar, 1988 (abierto). ideológicas. Por el contrario, es cuestión de generar un efecto social dinámico y concentrarnos de manera crítica en los cuerpos arquitectónicos.

Para ello, el artista polaco, frente a sectores más inmovilistas y acomodados (y por tanto más estáticos y sedentarios) fija su atención en aquellos sectores permanentemente nómadas de la sociedad, en aquellas minorías cuya mera presencia crea situaciones problemáticas o de

14 Ibidem, p.51. 

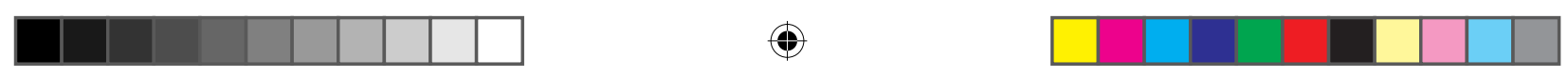

\section{Experiencias entre el arte y el urbanismo en torno al movimiento.}

conflicto, para poder descubrir el poder oculto que organiza la existencia cotidiana en las urbes contemporáneas, poder que ignora a muchos sectores que las habitan. Simultáneamente, a Wodiczko esta experiencia le sirve para analizar y reflexionar acerca del carácter nómada del ser

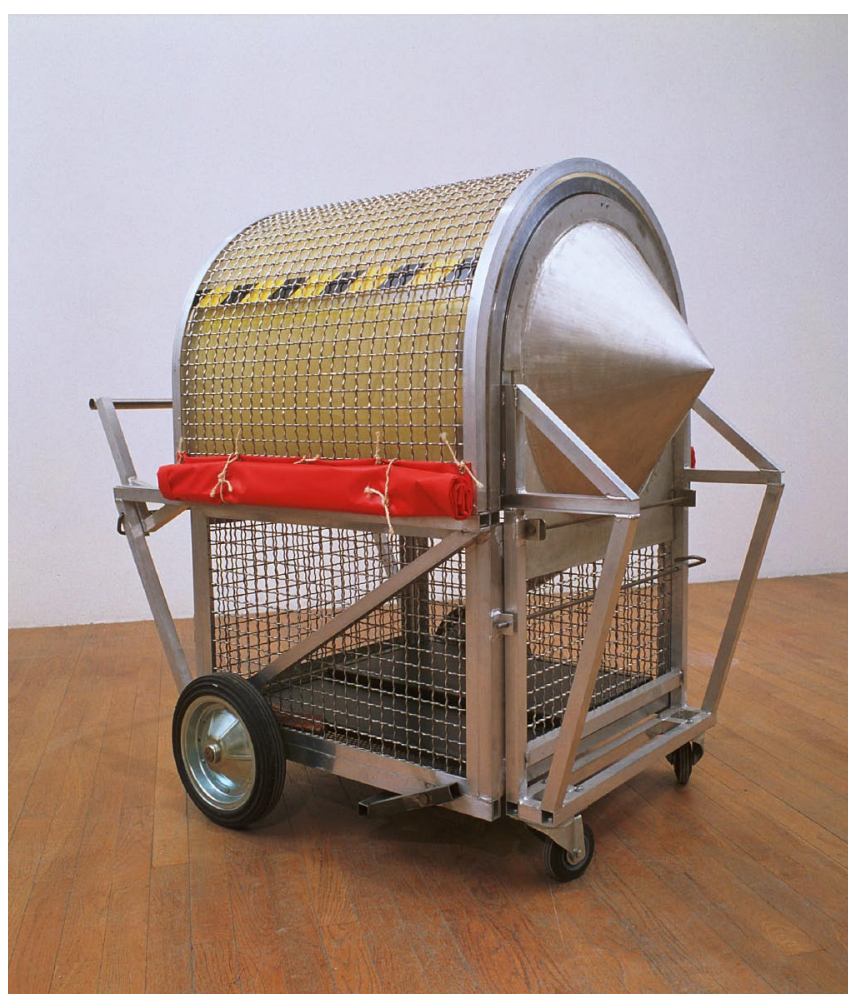

Krzysztof Wodiczko, Vehículo para la gente sin hogar, 1988 (cerrado).

humano y de sus huellas en las urbes contemporáneas, sobre de qué modo aún existen sectores en nuestras ciudades, cada vez más consolidadas, con una vivencia diferenciada de la ciudad surgida precisamente de su nomadismo.

Según Wodiczcko, hay aspectos de los que en la ciudad no se quiere hablar, situaciones sobre las que se pretende crear silencios significativos; por esta razón, su trabajo trata de las estrategias para poder utilizar la palabra a través del espacio público. El arte utilizado como voz y mensaje de aquellos que no poseen voz o se la han arrebatado, la actividad artística como elemento para ganar el espacio público de la ciudad como lugar de comunicación. Pero, eso sí, alejándose de esas prácticas de intervención en el espacio ciudadano que no son más que una legitimación pública del status quo o una mera decoración urbana. Así y frente a la canalización o el control de las experiencias urbanas, Wodiczko busca crear un compromiso mediante las interrupciones, infiltraciones y apropiaciones estético-críticas que 


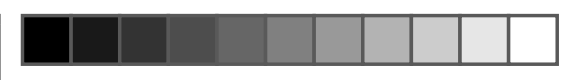

$\oplus$

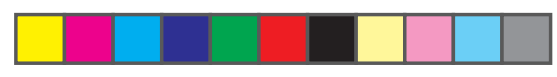

cuestionen las operaciones simbólicas, psico-políticas y económicas de la ciudad.

Fruto de este interés en dar voz a sectores desfavorecidos y ninguneados de la sociedad y de la reflexión paralela acerca del nomadismo en la ciudad contemporánea surgen dos de sus trabajos más interesantes, llamados significativamente "vehículos": el Vehículo de los sin hogar (1988) y el Poliscar (1990-91). En realidad, los proyectos de ambos vehículos no constituyen una ruptura respecto a sus anteriores proyecciones sobre edificios, sino que son una extensión de las estrategias representacionales empleadas en las mismas, pero adaptándolas para tratar de

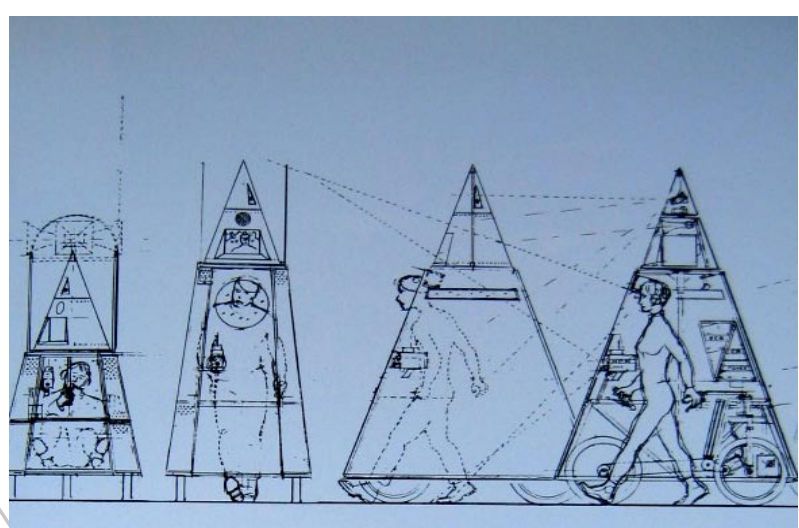
confrontar el espacio urbano en su globalidad; lo cual supone un paso adelante en su desvinculación de la ciudad construida y sedentaria a favor de una urbe nómada y cambiante.

La primera de estas obras es producto del grave problema que representa la falta de alojamiento para miles de personas en la ciudad contemporánea. Se trata de un vehículo diseñado en función de las necesidades y de las limitaciones específicas que plantea la existencia urbana nómada de los que podríamos denominar refugiados o víctimas de las transformaciones de las grandes ciudades. Según Wodiczko, "Adornados con el rechazo de la "arquitectura" de la ciudad, los sin hogar se convierten en los "edificios" nómadas, los "monumentos" móviles de la ciudad. Pero, anclados en las posiciones económicas y sociales más bajas y ata-

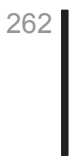


dos a su entorno físico, los sin hogar consiguen una estabilidad simbólica, mientras que los edificios y monumentos oficiales de la ciudad pierden su carácter estable, pues están continuamente sometidos al cambio inmobiliario." 15 Para la mayoría de la población las personas sin hogar no son considerados ciudadanos, no se les quiere ver, son percibidas como objetos sin identidad y a los que se les debe evitar reconocer; son como barreras inmóviles que impiden el paso de los "verdaderos" ciudadanos que si pagan impuestos. Sin embargo, su constante deambular por las calles de la ciudad les otorga una cierta identidad como actores de primer orden en el casco urbano. Son móviles, pero resulta casi imposible esquivarlos; son cada vez más numerosos y reclaman un espacio en la ciudad. Para ellos Wodiczko planeó construir un vehículo pragmático y simbólico que pudiera ayudar a hacerles la vida más fácil y estimular a cambiar la forma en que la gente los percibe. Es decir, enfrentar súbitamente a la población con un nuevo tipo de arquitectura móvil que al hacerse visible de un modo ostentoso invitara a pensar sobre el problema de la falta masiva de casas donde vivir.

Wodiczko propone un vehículo que es al tiempo arquitectura y escultura pero que no es ninguna de las dos; es algo eminentemente práctico y útil pero al mismo tiempo produce una imagen con fuertes asociaciones. Es un objeto y una idea, un acontecimiento, una experiencia urbana y un experimento social, y todo ese conjunto de posibilidades es lo que le aporta su mayor riqueza. Para el artista polaco, "El proyecto del vehículo para los sin hogar viene a ser la resistencia de la arquitectura desahuciada contra la arquitectura desahuciadora. Pretende traspasar literalmente las fronteras que separan a unas comunidades urbanas económicamente segregadas. Al penetrar en el espacio, establece también un provocador medio de comunicación entre los sin hogar y quien si tiene vivienda." ${ }^{16}$ Yo quisiera añadir que, además, pretende ser un vehículo de intercambio entre la ciudad sedentaria y la ciudad nómada.

15 Ibidem, p.54.

16 Ibidem, p.48. 

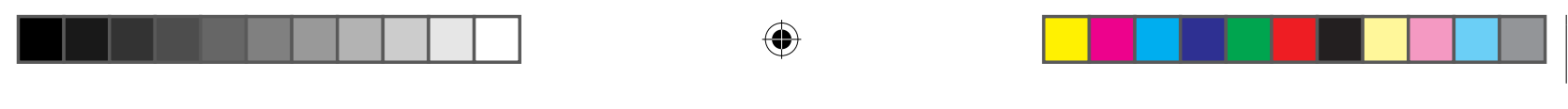

En este sentido, más que un producto que va a mejorar la condición de las personas sin hogar (Wodiczko se niega a fabricarlo en serie), lo que trata de ser es un elemento simbólico que muestre las contradicciones y las paradojas de la sociedad contemporánea, especialmente en el tema de la especulación inmobiliaria y la marginación de determinados sectores sociales desfavorecidos, es decir, busca el reconocimiento de la pobreza en el corazón de la pretendida sociedad del bienestar. De todos modos, sí que se le dio importancia también como plataforma de supervivencia para los indigentes y por ello para su diseño contó no sólo con la colaboración de profesionales, sino también con verdaderos indigentes que fueron sugiriendo aspectos y proponiendo diferentes mejoras en el prototipo.

Se trataba de crear un vehículo funcional, económico e ingenioso que cubriera las necesidades cotidianas de estas personas (como dormir o lavarse), siempre considerando a estos como sujetos móviles, sin posición fija en la ciudad. Un vehículo que mejorando otras alternativas usadas mayoritariamente (carritos de supermercado) permitiera a los sin hogar, los nuevos nómadas, desplazarse de aquí para allá en la ciudad, transportando sus escasos y por lo tanto valiosos enseres y teniendo una mínima estructura para residir temporalmente en parques y jardines. Todo ello, para dotar a los "no ciudadanos", a los que no poseen ningún derecho, el derecho a una pequeña propiedad y a una cierta privacidad. Asimismo, con este vehículo, Wodiczko consigue además de dotar de presencia y visibilidad a las personas sin hogar otorgarles una cierta autonomía al hacer posible unos desplazamientos más cómodos y confortables. De este modo, los sin hogar se convierten en estructuras permanentes expuestas en el exterior, en formas arquitectónicas simbólicas con un componente dinámico fundamental, en habitantes nómadas transformados en referentes políticos en un marco de ciudad sedentaria.

El otro vehículo que ideó el arquitecto fue el Poliscar, una versión más sofisticada del anterior y que tiene como objetivo central la movilidad y la comunicación de los sectores más desprotegidos social y cultural- 


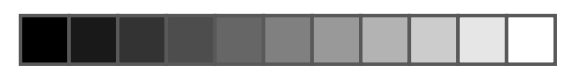

$\oplus$

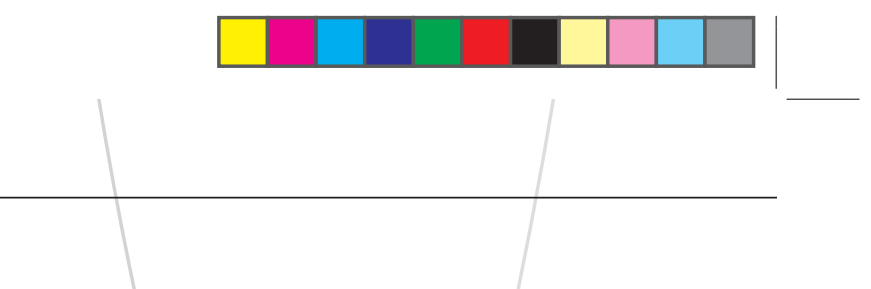

mente. Se trata de un instrumento de maniobra, de desplazamiento, de aparición y desaparición, que tiene como propósito fundamental el sobrevivir en un ambiente realmente hostil. Quizás, por esta idea de supervivencia que ambos vehículos comparten, poseen una cierta forma agresiva (la vida en las calles de las ciudades es cada vez más dura), un determinado parecido con algún arma (el primero con un misil y este segundo con un tanque) y una complexión sólida, corpulenta y cerrada un tanto arcaica o también cómica. Según el propio Wodiczko dice, "Creo que quizás el vehículo de comunicación (el Poliscar) podría entenderse iconográficamente como algo grotesco, pero es simplemen-

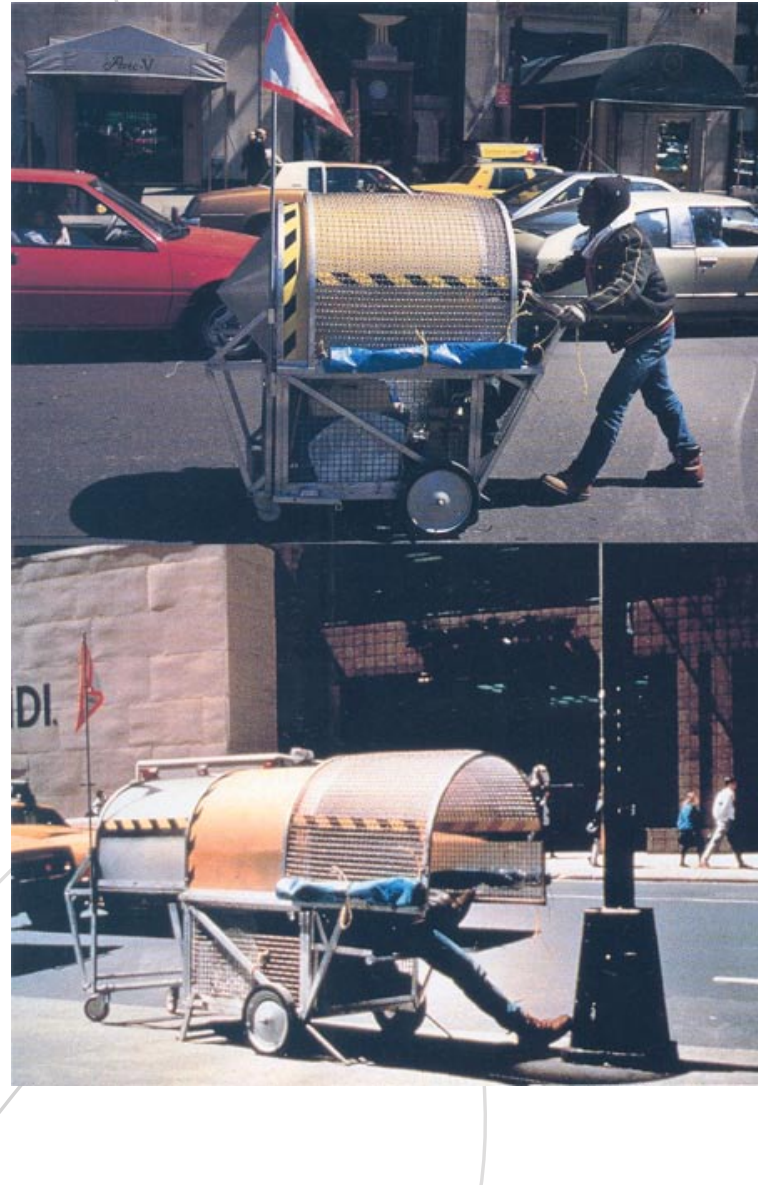

Krzysztof Wodiczko, Vehículo para la gente sin hogar, 1988. te una respuesta a la imagen de la ciudad contemporánea, que la policía uniformada y los ejércitos de agentes inmobiliarios han convertido en zona militarizada."17

Posiblemente, tanto un vehículo como el otro son dos propuestas para los sin hogar que pueden ser utilizadas como hábitat (ya que no poseen arquitectura alguna), y al mismo tiempo como medio de comunicación y relación. Krzystof Wodiczko concibió con todo detalle unos vehículos que podrían ayudar a devolverles a muchos habitantes de las ciudades, las posibilidades que, generalmente, les son negadas. Devolverles la palabra (y por tanto el derecho a la existencia) a través de unos

17 Ibidem, p.65. 

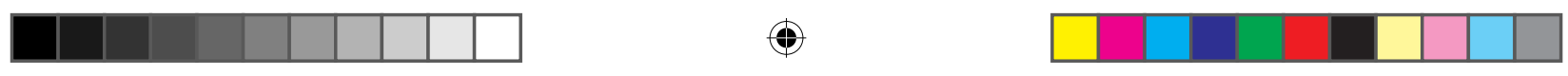

modelos de vehículos que les puede permitir organizarse y adquirir presencia física en el espacio público urbano. Convertirles en sujetos nómadas de pleno derecho en una ciudad dinámica pensada desde y para el movimiento de estos habitantes negados y olvidados, un nuevo espacio visible e insertado en el corazón de una ciudad tradicionalmente estática y asentada.

Siguiendo el rastro del espacio urbano nómada dentro de la ciudad tradicional y dentro de estos mismos planteamientos cuestionadores de la forma estática habitualmente asociada a ella desde el urbanismo y la arquitectura más conservadores (aunque sin la enorme carga política y social de los vehículos de Wodiczko), el arquitecto japonés Toyo Ito ideó en 1985 su Vivienda para una mujer nómada en Tokyo.
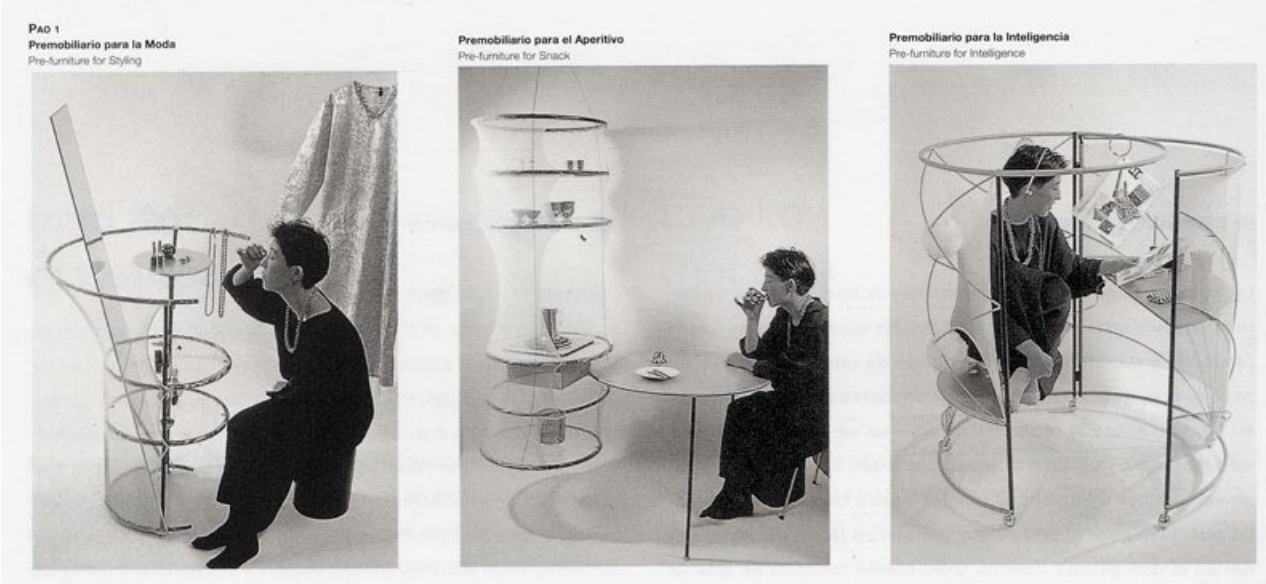

Toyo Ito, Vivienda para una mujer nómada enTokyo, 1985. 

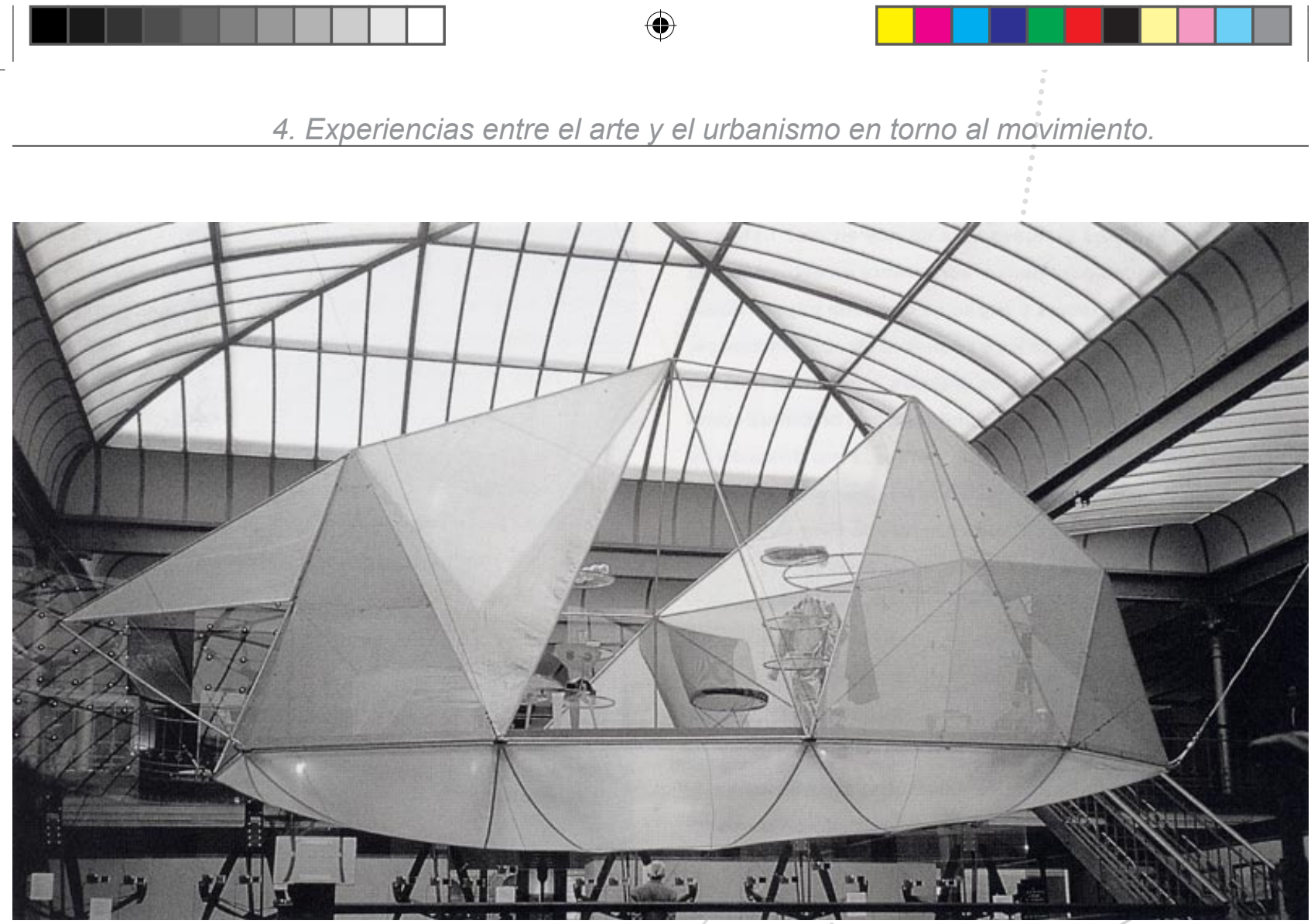

Se trata de una vivienda pensada para una muchacha joven que vive sola y que disfruta plenamente vagando por la inmensa ciudad de Tokyo de modo que toda la ciudad es su vivienda. Tanto la casa (o pao), la ropa de la muchacha, como los tres muebles que junto a la cama, situada en el centro la conforman (el mueble inteligente, el mueble para el coqueteo y el mueble para la comida ligera) está realizados con una fina película textil traslúcida. La casa es por tanto desmontable y transportable, pudiéndose levantar en cualquier rincón de la ciudad, convirtiéndose. así en el refugio de una habitante nómada que entiende que su casa es la ciudad entera; planteando de este modo una relación nueva con la gran metrópoli, una relación fluida, cambiante y nómada, más apropiada (según el arquitecto japonés) para la vida en las grandes metrópolis del siglo XXI. ${ }^{18}$

18 Ito, Toyo, Escritos, Colegio Oficial de Aparejadores y Arquitectos técnicos de Murcia, Valencia, 2000, p.61-65. 


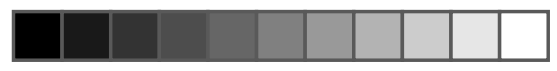

$\oplus$

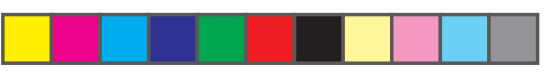

PAISAJES EN MOVIMIENTO

$\oplus$

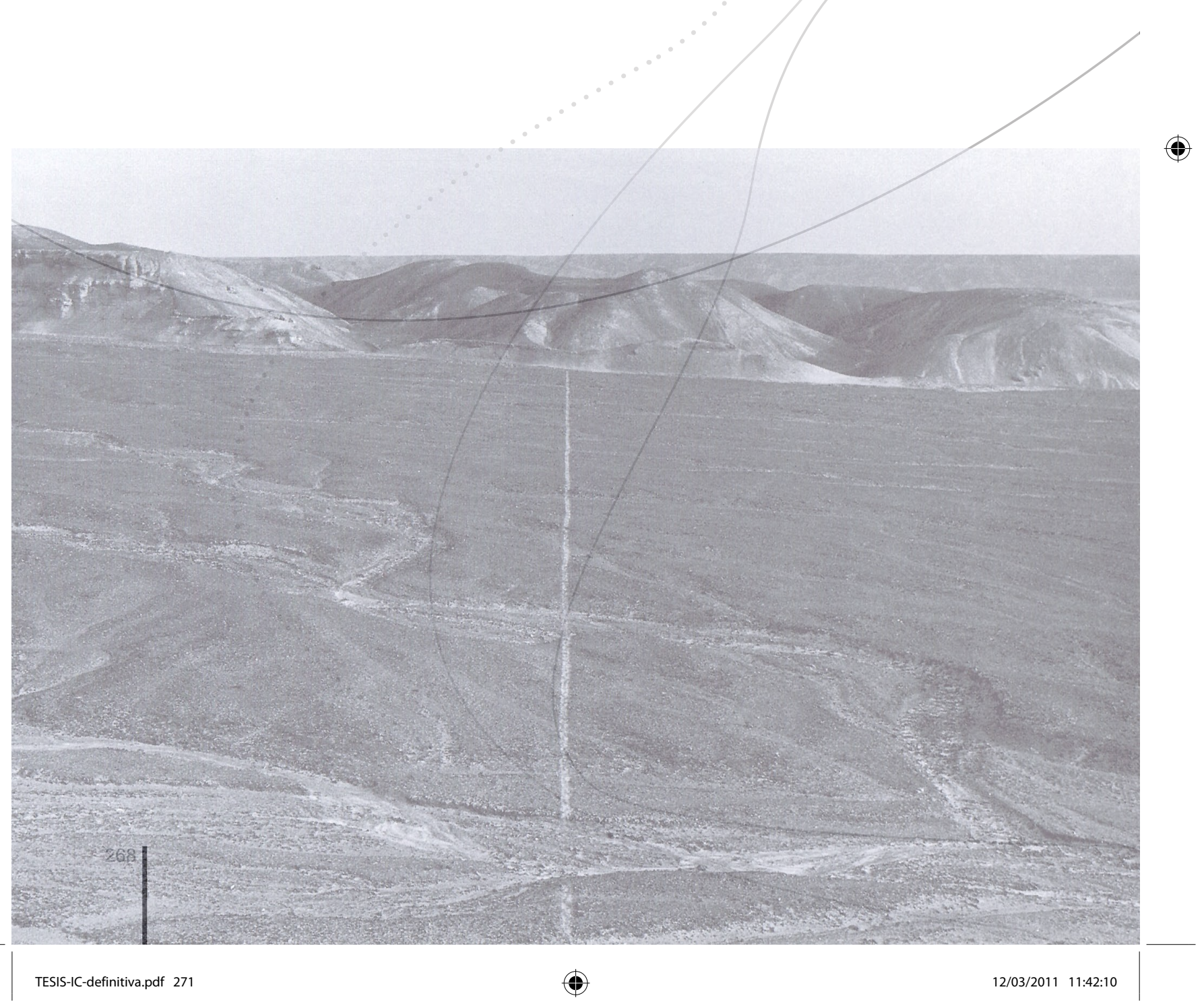



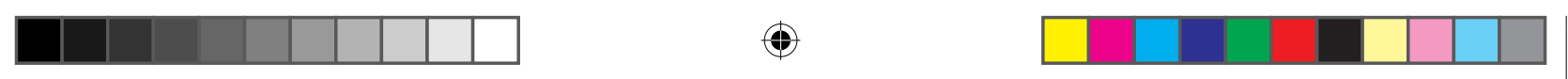

4.3 EL TERRITORIO COMO PAISAJE URBANO

Mientras determinados "visionarios" del mundo de la arquitectura estaban en plena ebullición imaginando ciudades que caminan, estructuras nómadas que colonizan el territorio o pequeños vehículos que dan presencia pública a los desheredados de las grandes ciudades del siglo $\mathrm{XX}$; paralelamente, una relación muy estrecha con el territorio y el paisaje, mucho más silenciosa y reposada, basada en su recorrido, se reivindicaba con fuerza por diferentes artistas y arquitectos. Esa intensa relación servía de marco y referente a otras experiencias artísticas cuyo campo de acción era el paisaje y las relaciones dinámicas establecidas por el artista o el espectador con el territorio.

En Occidente, el potencial que imprimía el movimiento y el cami- 


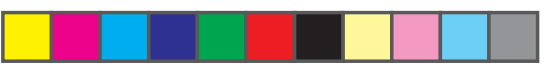

nar en la vida cotidiana se conformaba como objeto de estudio filosófico desde finales del siglo XVIII. El gran filósofo alemán Immanuel Kant, por ejemplo, convirtió en costumbre metódica el paseo a las siete de la tarde por su ciudad natal de Köninsberg ${ }^{1}$, mientras que en Francia, los paseos de Jean Jacques Rousseau también adquirieron especial notoriedad debido, sobre todo, a que fueron estos paseos los que le sirvieron de inspiración para sus conocidas "ensoñaciones."

Estos paseos vienen a situar al individuo en el seno de la naturaleza, pero ya de modo consciente, apareciendo con ellos una nueva sensibilidad en la relación del ser humano con su entorno. Esta presencia, esta "vuelta a la naturaleza",

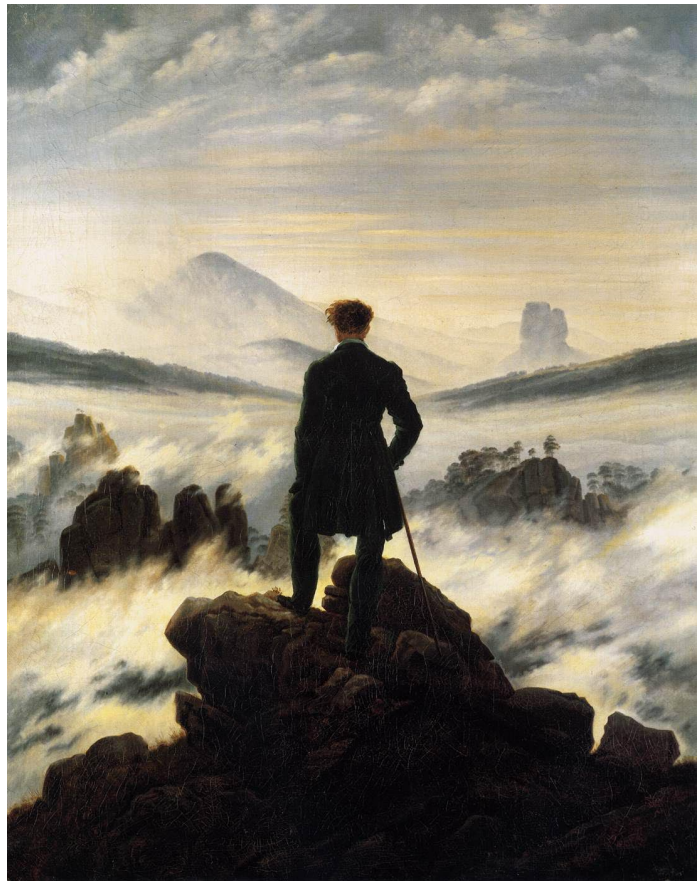

Caspar David Friedrich, El caminante sobre el mar de nubes, 1817-18. será uno de los componentes esenciales del romanticismo y por lo tanto del paisaje romántico. Paralelamente, tras décadas de convulsiones sociales y políticas ${ }^{3}$ el romanticismo propuso la recuperación de valores como la imaginación, la intuición o la emoción, pero por encima de todo, la individualidad del ser humano, es decir, el valor de individuo como ser único e irrepetible. El único valor constante en las exaltadas discusiones y debates de la época, siempre vivos y controvertidos, era la fe en la trascendencia de la individualidad. El interés

1 Tal era la puntualidad de Kant en sus paseos vespertinos que se cuenta que los ciudadanos de la ciudad aprovechaban que éste pasaba por delante de sus casas para ajustar los relojes y ponerlos en hora. Además, Königsberg, populosa y rica ciudad de lo que en su día fue la Prusia Oriental, está situada en las orillas y en las islas del río Pregel, que en el siglo XVIII estaba atravesado por siete puentes, y ha pasado a la historia de las matemáticas por la disposición de sus puentes que dio lugar a un juego, precisamente en la época de Kant, que atrajo la atención de los más famosos matemáticos del momento. Estaba basado en un recorrido urbano, y consistía en descifrar si era posible planificar un paseo de tal modo que se cruzaran todos los puentes de la ciudad sin pasar por ninguno más de una vez, cosa que nunca logró el consenso.

2 Rousseau, Jean-Jacques, Ensoñaciones del paseante solitario, Alianza, Madrid, 1979.

3 Fundamentalmente, los tumultuosos últimos años de la llustración y la Revolución Francesa 


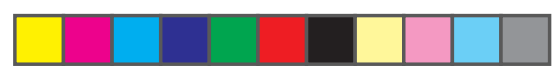

\section{Experiencias entre el arte y el urbanismo en torno al movimiento.}

se centraba en la sensibilidad personal del artista. Como nos plantea el historiador Hugh Honour: "De esta manera la validez de una obra de arte pasa a residir en ella misma, pues adquiere coherencia interna en la medida en que es reflejo de la experiencia vital, personal, del artista." ${ }^{4} \mathrm{El}$ ser humano, en cuanto individuo, busca su "lugar en el mundo", en un orden natural que no logra entender. Este desconocimiento le causa zozobra y desconfianza y lo lanza a una búsqueda de conocimiento, con el ánimo de comprender el mundo que le rodea y de este modo dotar de sentido a su existencia. El paisaje se le ofrece entonces, como un modo excepcional de ver el mundo con este estado de ánimo.

En esa búsqueda del sentido del mundo y de la posición que el ser humano ocupa en él, el recorrido por su entorno y su máxima expresión, el viaje, cobran un enorme protagonismo ya que solamente se puede acceder a dicho conocimiento gracias a la experiencia directa. Viaje, camino y paisaje aparecen en esos momentos como términos si no indisolubles si complementarios; unidos todos a través de la experiencia del observador, de modo que se pone en crisis el paisaje como objeto en sí mismo (dependiente del canon o las convenciones del género), pasando a ser conformado desde y para el espectador. El viaje pasa a ser

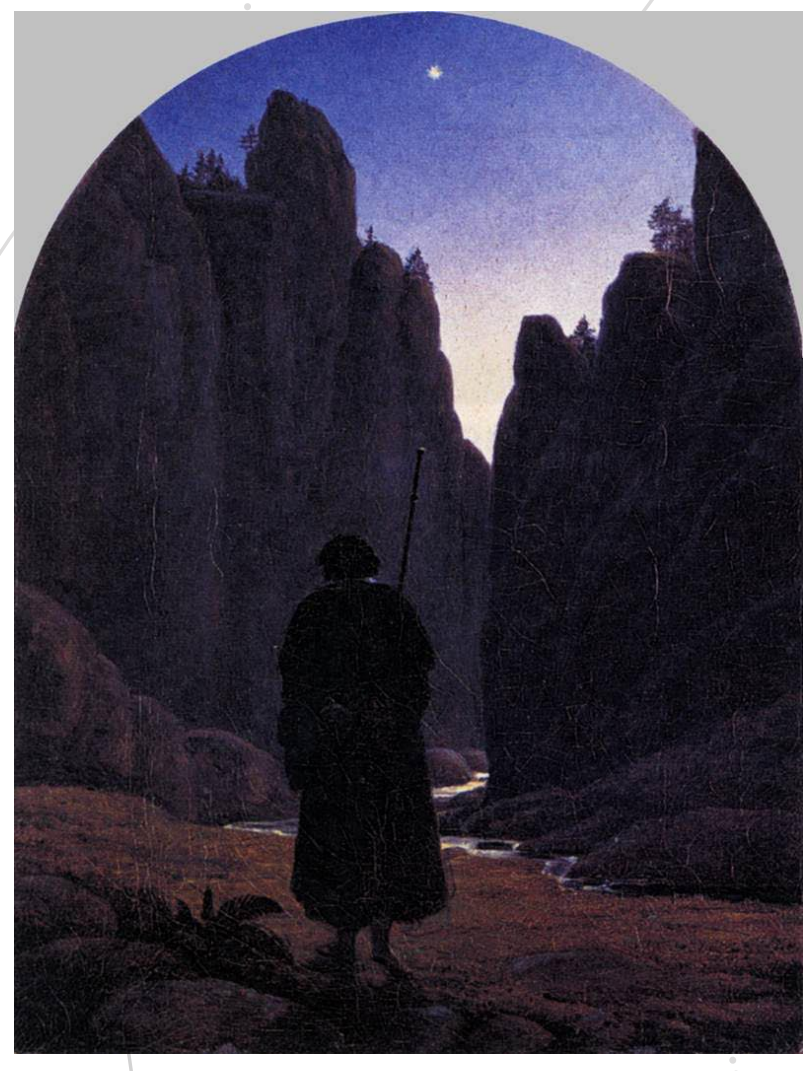

Caspar David Friedrich, Peregrino en un valle rocoso, circa 1820.

4 Honour, Hugh, El Romanticismo, Alianza Forma, Madrid, 1992, p.25. 


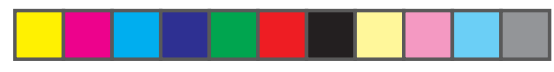

entendido como una profunda experiencia intelectual, estética y moral. La valoración del viajero, (en nuestro caso el caminante) y no ya tan sólo del camino, ensancha enormemente las posibilidades paisajísticas, dando cabida a las emociones, sensaciones y sentimientos del sujeto. Este es, tal vez, el nudo gordiano del término mismo de paisaje que, como veíamos, apela al individuo o la colectividad para llegar a significarse frente a un territorio físico concreto recreando paisajes.

Los conceptos de paseo y de viaje de tradición romántica continuarán estando vivos a comienzos del siglo XX. Así, en Inglaterra el escritor y poeta Edward Thomas dedicará largas horas a caminar por la campiña evidenciando el tan arraigado amor inglés por el territorio; igualmente El paseo es el título de una pequeña joya de la literatura de comienzos del siglo XX escrita por Robert Walser. El escritor suizo comienza su novela corta contraponiendo el estado de ánimo frente al paseo, frente al recorrido de un mundo exterior por descubrir, a la estaticidad y el inmovilismo plasmado en la hermosa imagen del escritor enfrentado al papel en blanco haciendo hincapié en lo interesante del caminar: "Es divinamente hermoso y bueno, sencillo y antiquísimo ir a pie. Suponiendo que zapatos y botas estén en condiciones"5

A medida que avanzó el siglo XX aparecieron múltiples propuestas en el mundo del arte, muchas de ellas de carácter transgresor respecto a lo que eran los cánones artísticos del momento, que plantearon el paisaje como fruto mismo del recorrido, criticando y poniendo en crisis la idea del mismo como una mera instantánea. Con este planteamiento, se desea entender el paisaje como experiencia, frente a unas ideas que lo consideraban un simple objeto. Algunas de estas experiencias artísticas se aglutinaron en torno a lo que se ha denominado Land Art, aunque conviene aclarar que el término es muy confuso y aglutina a artistas con muy diversas (incluso en ocasiones contrapuestas) inquietudes. ${ }^{6}$

5 Walser, Robert, El paseo, Ediciones Siruela, Madrid, 1996, p23.

6 El término, difícilmente traducible por "arte de la tierra", fue acuñado por vez primera por Walter de Maria para nombrar sus intervenciones en el paisaje realizadas en la década de los años sesenta y conoció rápidamente un enorme éxito. Sobre la aparición e importancia del Land Art véase Guasch, Anna Maria, El arte último del siglo XX, Alianza, Madrid, 2000, pp.51 a 80. 

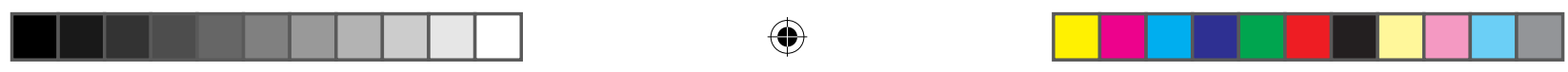

\section{Experiencias entre el arte y el urbanismo en torno al movimiento.}

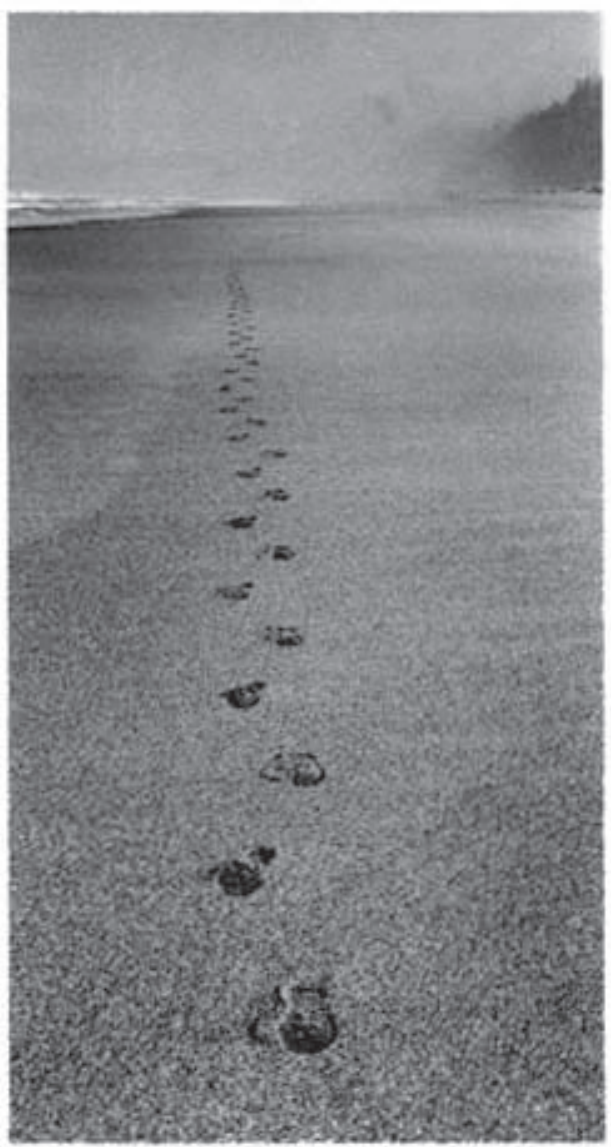

YUROK

A KOUG DAY COASTAL WALK

OEL NORTE AND HUMBOLDT COUNTIES CALIFOANIA SPAING 1980

Hamish Fulton, $A$ four day coastal walk,1980.
Uno de los artistas fundamentales que se han asociado con el Land Art es Richard Long. La obra de este artista inglés, entronca decididamente con la tradición de recorrido que tanto interesó, como veíamos, a artistas y pensadores románticos, sobre todo en el ámbito anglosajón y alemán. Los recorridos llevados a cabo por Long, sus paseos pragmáticos y respetúosos, amantes de los pliegues y recovecos de la superficie del planeta, de los lugares olvidados y casi inaccesibles, en una exploración en muchas ocasiones solitaria del mundo, entronca directamente con los planteamientos románticos en cuanto al respeto a la naturaleza, el concepto del ser humano y la posición de éste en aqueIla. Asimismo, su obra es sin ninguna duda fruto, también, del enorme apego popular que los ingleses sienten por las caminatas en su bien amada campiña.

La aparente sencillez de la obra de Richard Long encierra un conjunto de múltiples capas llenas de sutiles sugerencias, muy ricas en asociaciones y matices. El uso de materiales desnudos, sin tratar, y de técnicas que no dan lugar a la manufactura, remiten al pasado nómada del ser humano, a culturas arcaicas y primigenias. Sin ir más lejos, la técnica más querida por Long es el

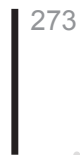

TESIS-IC-definitiva.pdf 276 

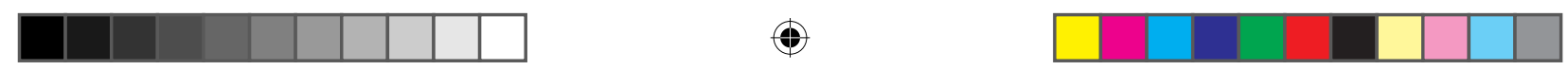

propio paseo por campos y montañas. Las esculturas que a menudo encontramos en galerías y museos del artista inglés son fruto de esos paseos que son los que las dotan de significado e interés. Las rutas de estos paseos están determinadas por formas geométricas, en ocasión semejantes a las de las propias esculturas.

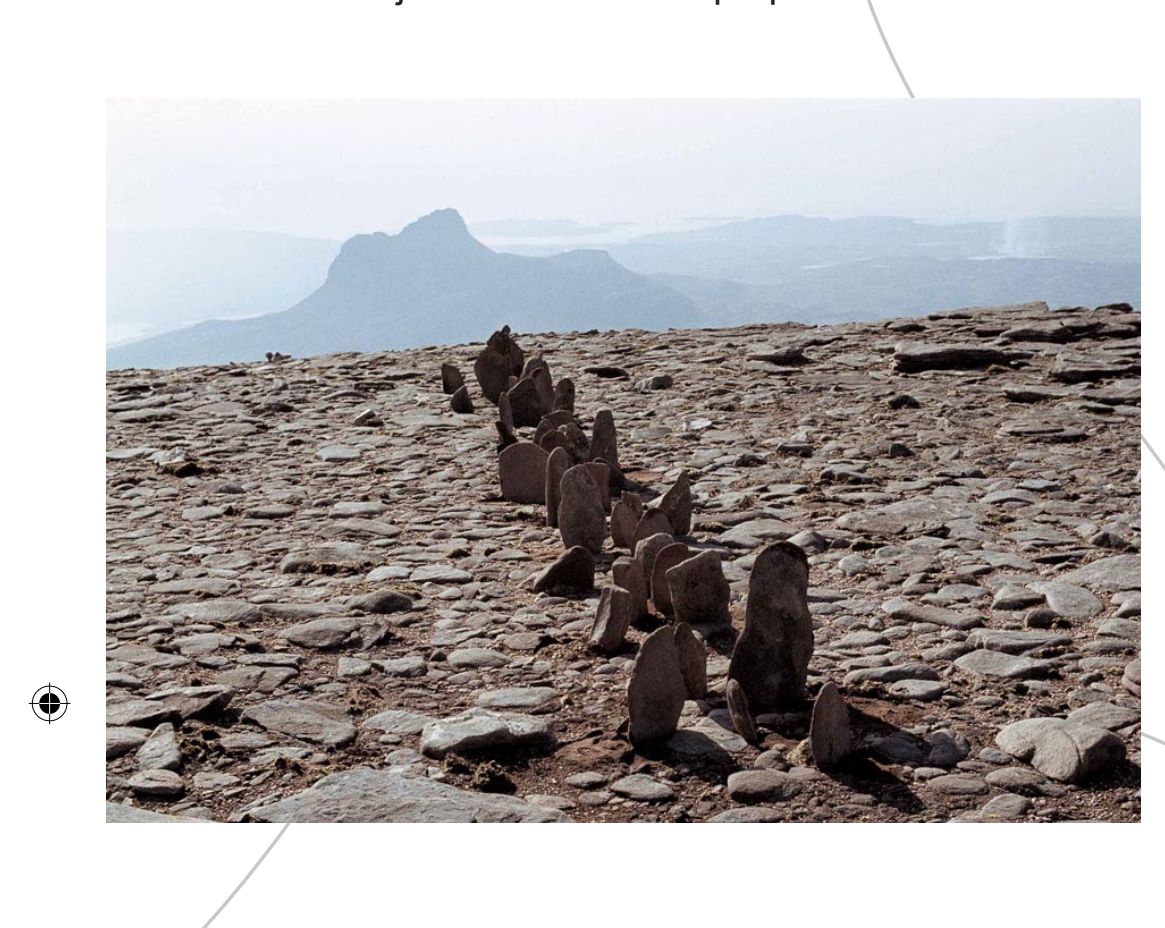

Richard Long, A Line in Scotland, 1981.

ParaLong, los caminos 0 senderos trazados en el territorio para caminar y llegar mediante ellos desde un lugar a otro, pueden convertirse en una barrera $y$, al mismo tiempo, en una protección para la experiencia de la naturaleza. Desde el momento en que el caminante está obligado a caminar por ellos, éstos le evitan los rasgos más incómodos y desagradables o duros del propio paisaje. Las formas geométricas (con frecuencia círculos o cuadrados) que Long dibuja en un mapa antes de salir, para posteriormente recorrerlas en la mayor medida posible, niegan el carácter útil y funcional, el rol protector otorgado tradicionalmente a los caminos. Imponiendo la voluntad del artista (del individuo creador) sobre un mapa, el artista se coloca a sí mismo en una relación con el paisaje más directa y profunda que aquella vivenciada por el excursionista experimentado que recorre los senderos o caminos preestablecidos.

En definitiva, ahora que el artista se propone atravesar o sortear 

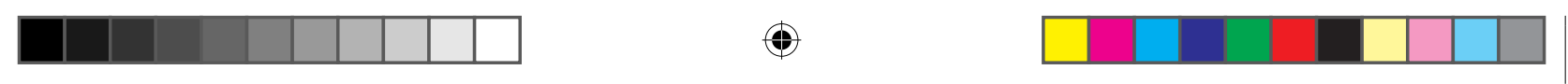

\section{Experiencias entre el arte y el urbanismo en torno al movimiento.}

accidentes tales como acusadas pendientes, fuertes corrientes de agua o pasos escarpados, según su previa voluntad, la imposición abstracta en el mapa se transforma en una imposición a sí mismo, en lo que supone una experiencia del paisaje de una enorme potencialidad y magnitud. Es muy interesante destacar que cuando el artista abandona el lugar, el paisaje no ha sido transformado en modo alguno al contrario de lo que sucedía con otros artistas incluidos en el Land Art. ${ }^{7}$ Cuando finaliza sus walking sculptures ("esculturas caminantes", podríamos traducir) es él quien ha sufrido las consecuencias de las líneas que ha trazado previamente en el mapa. La verdadera transformación la ha sufrido el propio artista y, posteriormente, se ha producido también en el espectador de la obra que accede a ella, a través de la grabación del paseo, a través de la memoria. Sin sus fotografías, sin sus imágenes, no podríamos conocer su existencia, ni sentirnos cercanos a la experiencia que supone el caminar por la naturaleza.

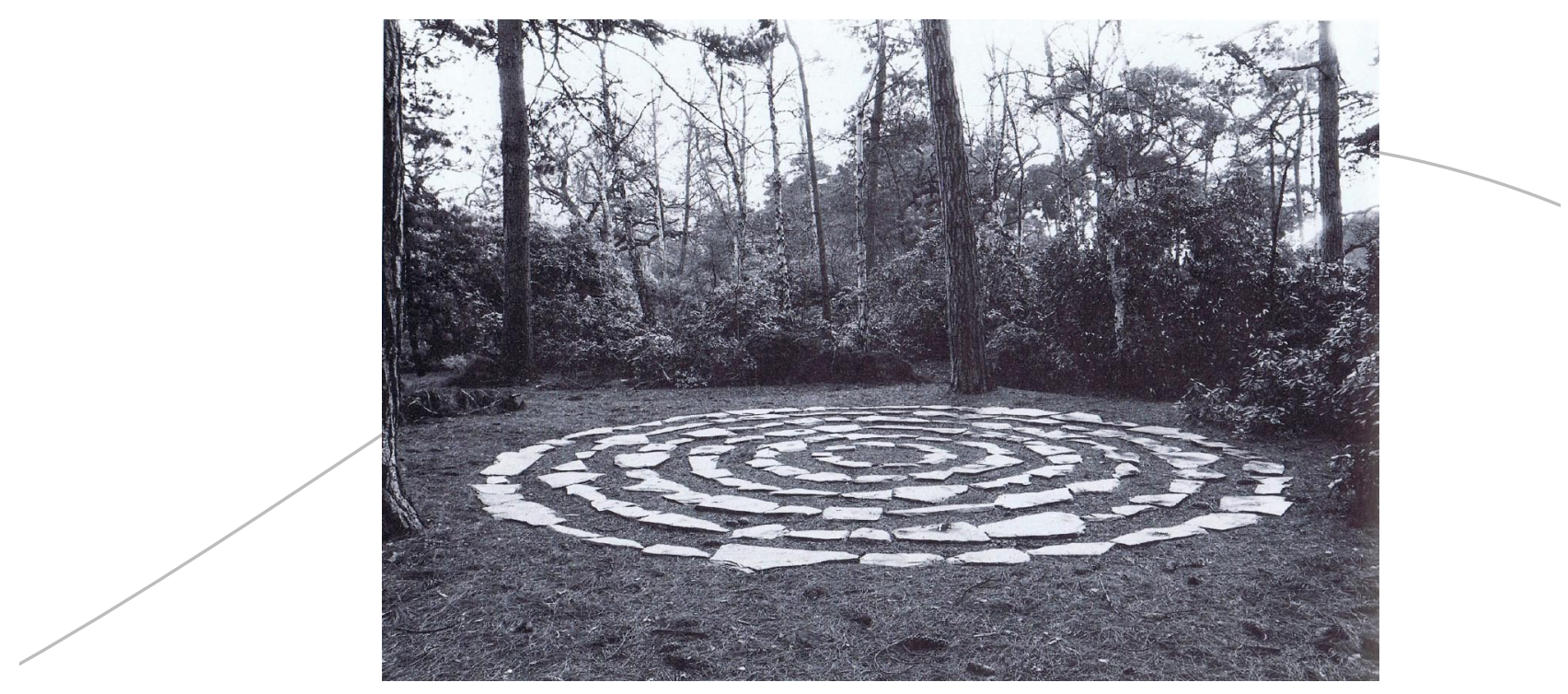

Richard Long, Six Stone Circles, 1981.

$7 \quad$ Las esculturas de Richard Long están, en este sentido, muy distantes de las obras de artistas como Michael Heizer, (por ejemplo sus Túmulos efigies, Buffalo Rocks State Park, Illinois, 19831985) o Charles Ross (Eje estelar, Nuevo México, Albunquerque, 1974). 

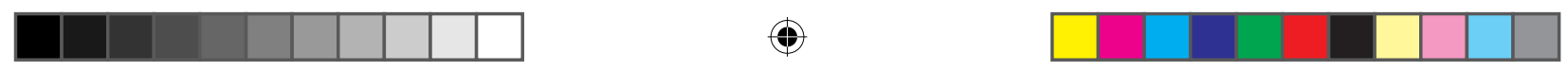

Richard Long, A line made by walking, 1967.

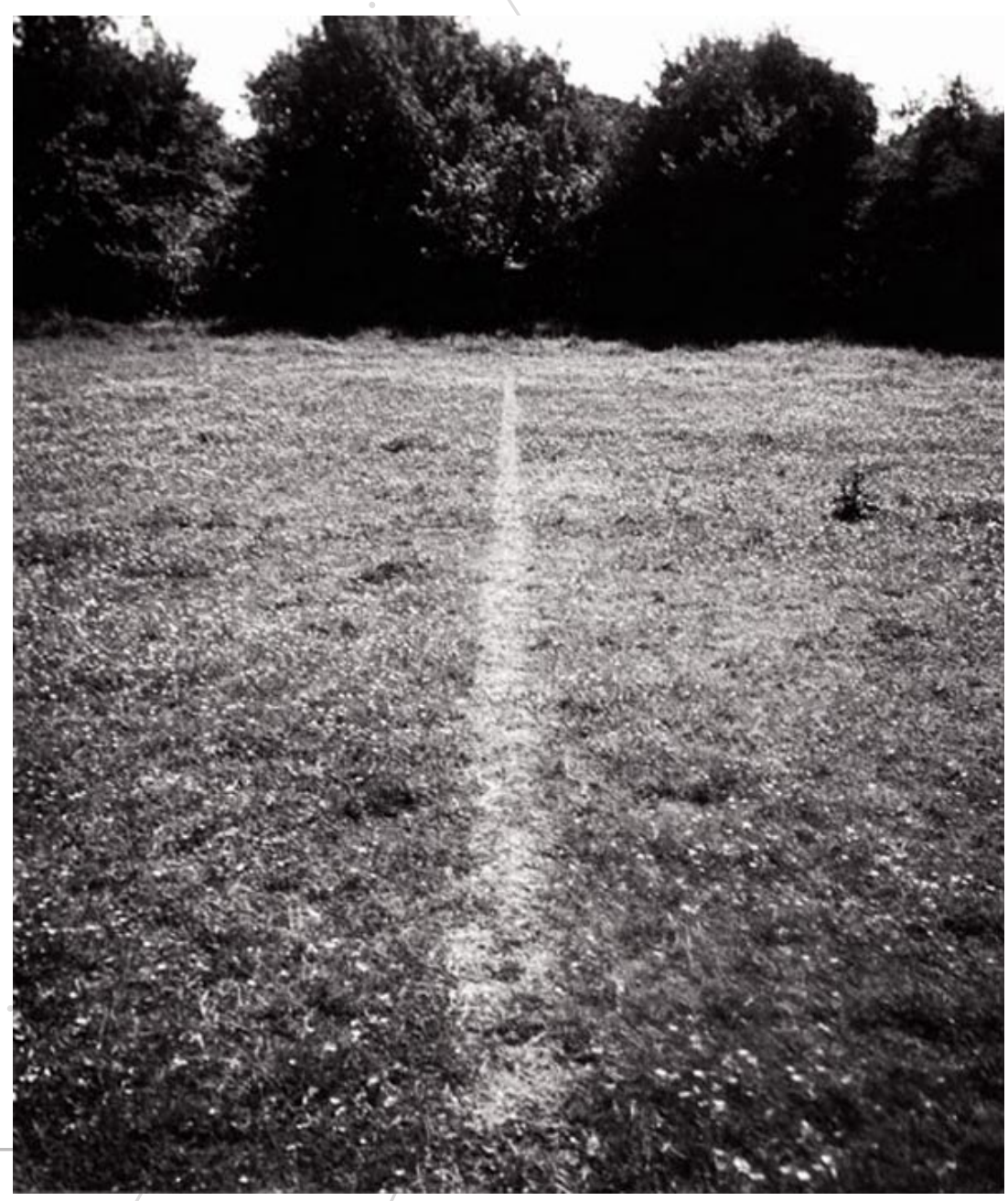

Las fotos de estos trazos que crea Richard Long, o mejor dicho, de la pieza ejecutada en el lugar concreto donde el artista ha detenido su marcha (como en el caso de su conocida pieza A Line Made by Walking que veremos más adelante), tan solo encontramos las huellas en los planos cartográficos o la lista de nombres descriptivos del recorrido, collages..., en definitiva, la memoria y los testigos de la marcha realizada por el propio Richard Long. Este respeto por la naturaleza que siente el artista es producto de un acusado sentimiento de humildad, donde la paciencia y la minuciosidad en el trabajo son expresión de una devoción por 

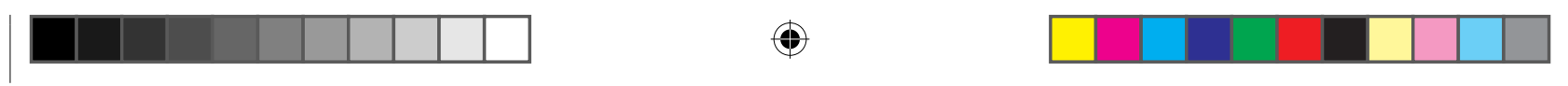

\section{Experiencias entre el arte y el urbanismo en torno al movimiento.}

el territorio que entronca con las culturas primitivas. Cuando Long emplea una hora caminando en círculos concéntricos en un paisaje determinado, no se trata de un capricho conceptual, sino de prestar la debida atención e interés al hecho físico y concreto de caminar en un territorio real, transformando la actividad de caminar en un ritual cultural, social y, también, paisajístico.

Con sus actitudes y prácticas escultóricas el artista inglés busca explicar las cosas por analogía entre el hombre y el paisaje, pero no vuelve por ello la mirada al romanticismo sino a un tiempo muy anterior. Quiere recuperar una relación con la naturaleza previa a la aparición de la escritura, que lo vincula con un diálogo establecido por el ser humano cuando aún era nómada y existía una profunda simbiosis entre el hombre y el paisaje.

Una pieza muy esclarecedora de cuáles son las preocupaciones y el modo de trabajar de Long es A line made by Walking, 1967. La obra nos muestra una línea hecha en el campo hollando la hierba a base de repetir el movimiento de su recorrido un número indefinido de veces. De hecho, la visibilidad de la línea es deudora de la repetición del movimiento, convirtiendo esta insistencia en pasear por el mismo lugar en el testigo de la marcha. Si el artista hubiera realizado el recorrido una única vez, la huella, demasiado débil, demasiado ligera, habría desaparecido al finalizar el paseo. Lo que queda, lo que permanece, es el testimonio fotográfico, si él no reconoceríamos su realización.

La línea trazada así, al caminar repetidamente por la hierba, funciona desde un doble punto de vista perspectivo y formal. Al observar la imagen de la línea (en realidad lo único que nos llega en cuanto espectadores de la obra), la perspectiva elegida por el artista afirma las dos dimensiones de la fotografía. El punto de vista seleccionado es del propio Long al finalizar el recorrido, lo que no hace necesario un gran esfuerzo por nuestra parte para recrear el camino en nuestra imaginación, compartiendo así su experiencia. El artista está presente aunque ya no esté 

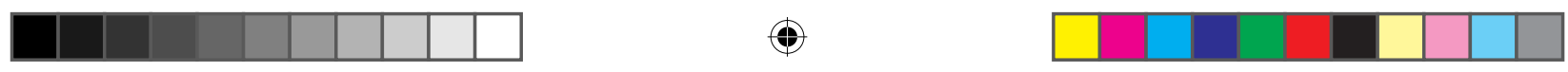

ahí físicamente, ni realizando el movimiento ni tan siquiera dentro del encuadre de la imagen. En palabras de Francesco Careri: "La imagen de la hierba hollada contiene en sí misma una ausencia: la ausencia de la acción, la ausencia del cuerpo, la ausencia del objeto."9 Lo que inicialmente se presenta como una declaración de principios por parte del artista, se revela en una cuidada y narrativa composición que envuelve y apela al espectador directamente. Como nos señala el profesor Graham Beal: "El acto de Long viene a simbolizar todos los senderos que han sido realizados por el hombre a lo largo de la historia y las fotografías de sus esculturas se convierten en una metáfora de la trascendencia de la vida humana en la superficie del tiempo geológico, todo ello a partir de una simple fotografía de una actividad sencilla." ${ }^{10}$

Muchos de sus recorridos Richard Long los llevó a cabo con el también artista británico Hamish Fulton. Una experiencia vital y artística conjunta que originó un buen número de obras escultóricas, las cuales tuvieron una interesante y diferente significación con la incorpora-
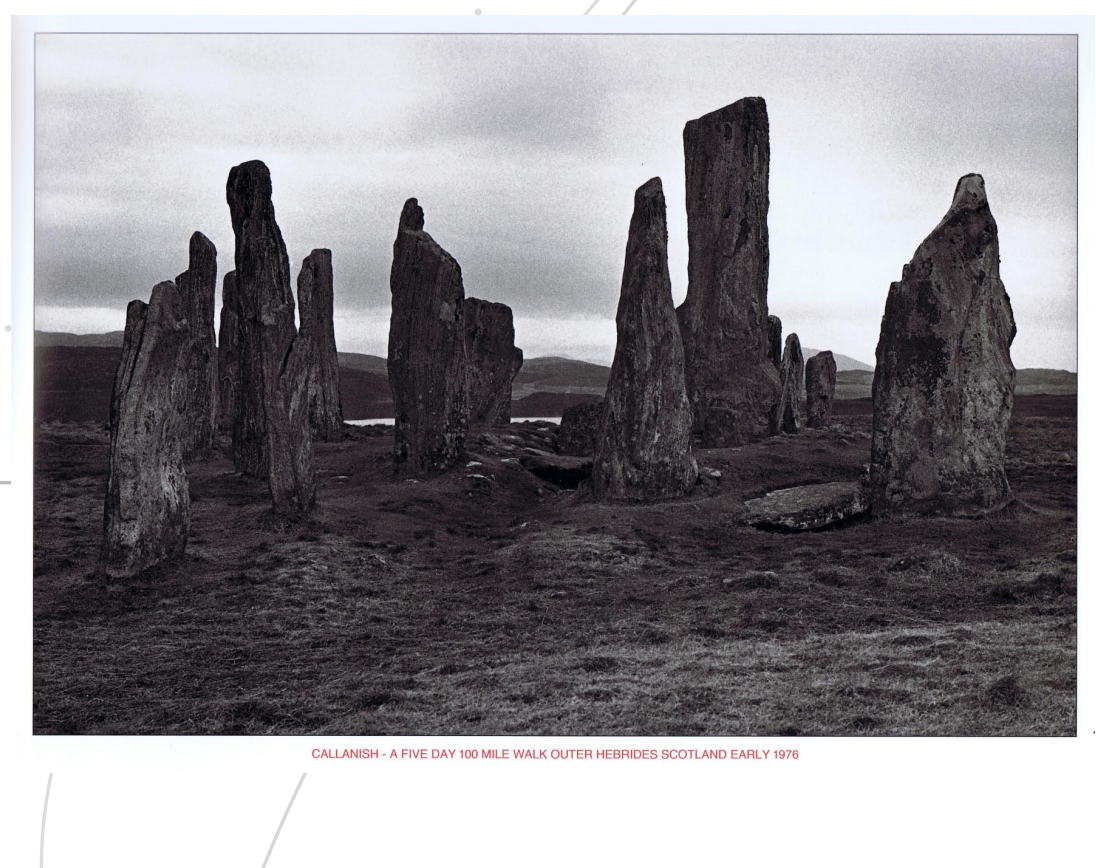

Hamish Fulton, ,Callanish-una marcha de cinco días y cien millas islas Hébridas Escocia principio de 1976, 1976.

9 Careri, Francesco, Walkscapes. El andar como práctica estética, Gustavo Gili, Barcelona, 2003, p.146.

10 Beal, Graham, "Richard Long: the simplicity of walking, the simplicity of stones", Neff, Terry, (ed.). A quiet revolution. British Sculpture since 1965, Thames and Hudson, Londres, 1987, p.112. 

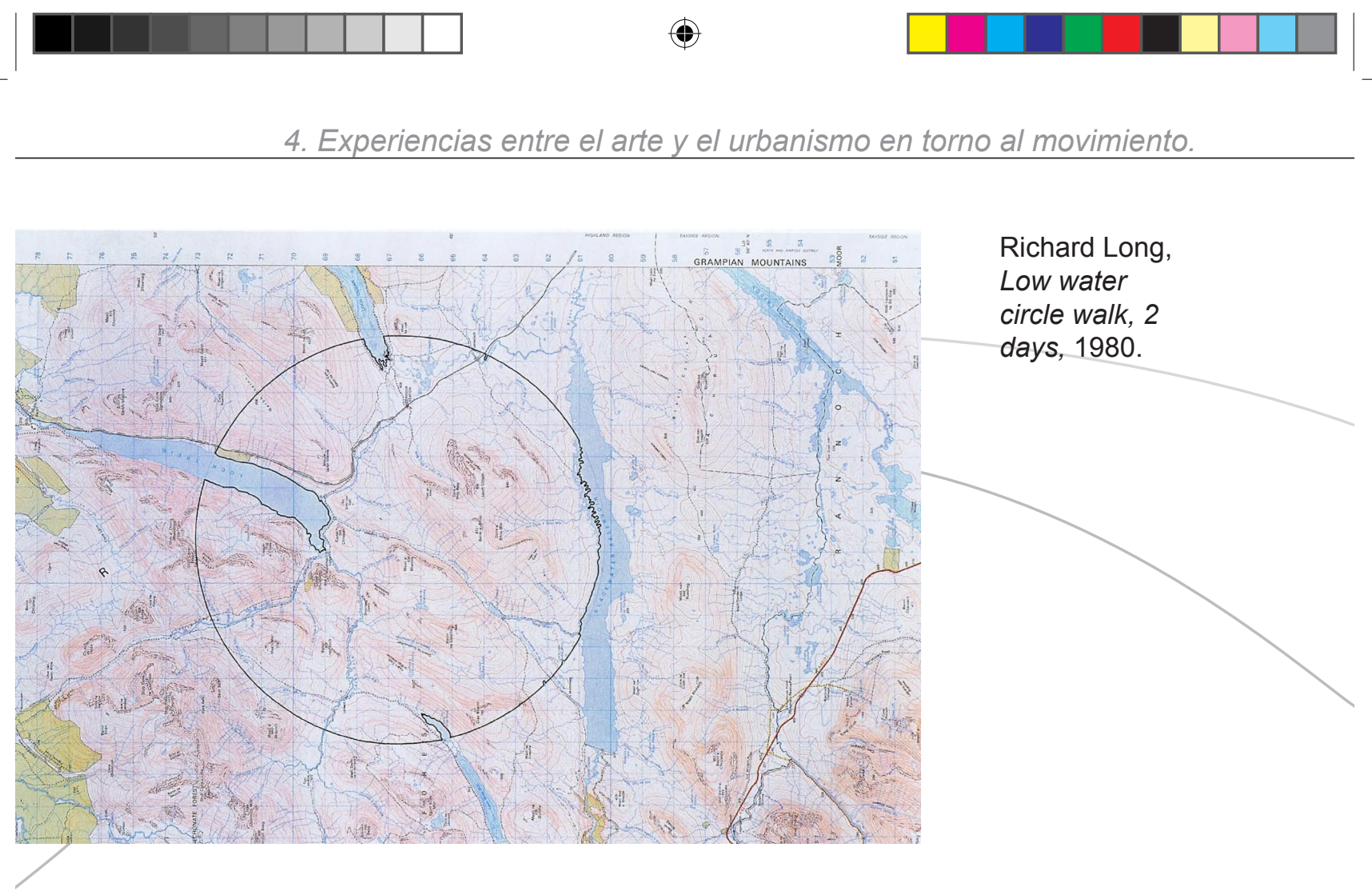

ción de diversas palabras y textos poéticos acompañando las fotografías. Textos que incluso, en diversas ocasiones, y gracias a su poder evocativo se llegan a independizar de las imágenes. Las esculturas de Hamish Fulton, heredero de la obra literaria de poetas ingleses en la senda de Edward Thomas, pueden llegar a transmitir la sensación de estar en un bosque situado en Canadá o en Japón; en este sentido, los títulos de sus obras tienen una gran importancia para apreciar el tema y contribuir a nuestra imaginación y participación. La evocación de estos paisajes en la obra de Fulton nos ayuda a cuestionarnos la relación del hombre con su entorno y el poder que la cultura ha tenido para separar al ser humano de la naturaleza de la cual formaba parte. ${ }^{11}$ Las fuertes evocaciones pausadas que hace Fulton del paisaje son una tentativa de realizar una forma de integración entre los dos; así, los títulos se convierten en frases que marcan el inicio y el final de los recorridos que han hecho, estableciendo una fuerte relación entre las fotografías y las descripciones escritas que viene a subrayar la diferencia significativa existente entre los dos tipos de representación/descripción. ${ }^{12}$

11 Por ejemplo, otras culturas, como la de los indios nativos norteamericanos no lograron entender nunca el término "salvaje", aplicado por los colonos a animales o lugares.

12 Véase el catálogo Hamish Fulton, Instituto Valenciano de Arte Moderno (IVAM), Valencia 279 1992. 

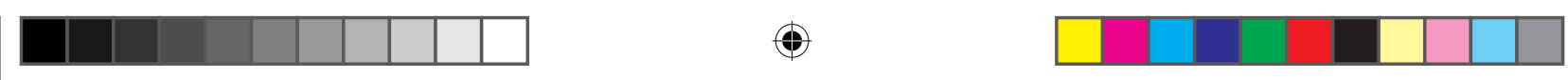

Otra figura fundamental para entender el arte contemporáneo y su vinculación con el entorno, que desarrollará su actividad durante estos años, fue el artista norteamericano Robert Smithson, quién debido a sus preocupaciones en torno al arte vinculado a la naturaleza, el paisaje y el movimiento también ha sido asociado en la historiografía artística con el Land Art. De todos modos, gran parte de sus intereses, su forma de intervención o la escala de sus realizaciones lo alejan considerablemente de los intereses y las preocupaciones de Richard Long o Hamish Fulton. Se trata de un artista (extremadamente influyente en los Estados Unidos en la década de los sesenta), que rompe con la tradición de las vanguardias, reintegrando las nociones de tiempo y espacio en su quehacer artístico.

Smithson se replanteara la relación lugar-escultura hasta conseguir hacer det hecho escultórico un sitio, un lugar, cuya ocupación comporta, también, una dimensión temporal evidente. Además, con sus obras nos obliga a abandonar las galerías de arte y los museos para acudir a los espacios exteriores en contacto directo con la naturaleza, de modo que seamos capaces de establecer un diálogo construido mediante la presencia y la ausencia, o basado en la relación entre la concepción y la percepción del arte. Sus propuestas se van a caracterizar por remitirnos
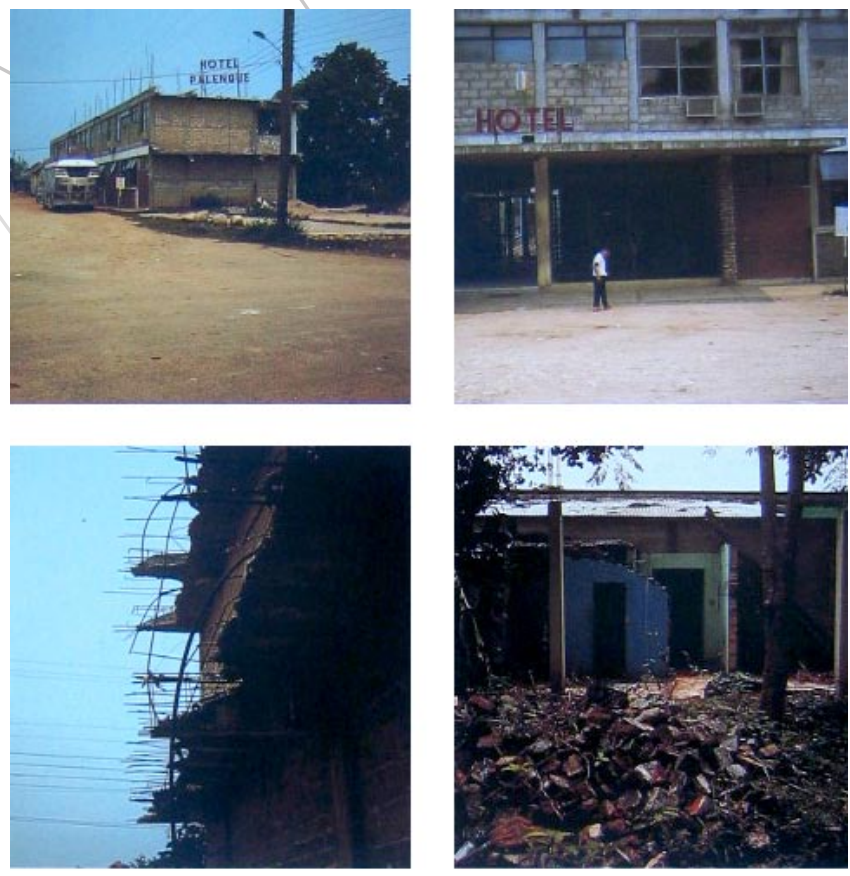
constantemente a una visión en-

Robert Smithson ,Hotel Palenque, Yucatán, México, 1969-72.

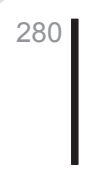

TESIS-IC-definitiva.pdf 283

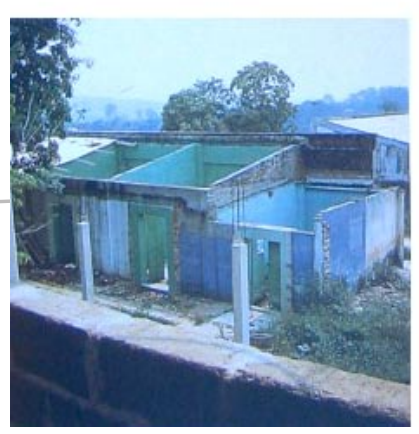

$\oplus$

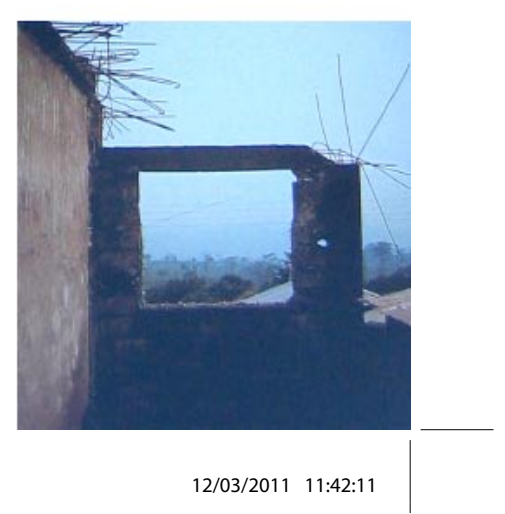



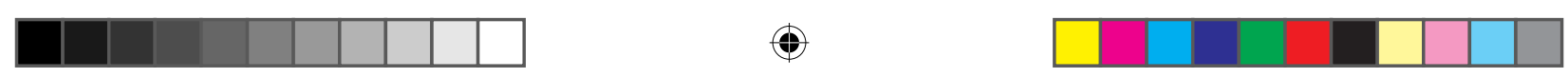

\section{Experiencias entre el arte y el urbanismo en torno al movimiento.}

trópica que tiene en cuenta simultáneamente a "uno" y al "otro", de ahí su predilección por los reflejos (cristal, espejos, agua) y su fascinación por medios como la fotografía y el cine. La mayoría de sus obras se fundan sobre una noción de ida y vuelta continua que coloca en primer plano el sentido de movimiento y la pérdida de toda referencia estable (tanto en el tiempo como en el espacio), moviéndose constantemente entre el objeto y el lugar, entre lo próximo y lo lejano. Robert Smithson pone en pie una verdadera estrategia de la confusión (en el sentido del espacio laberíntico que vimos anteriormente) y de desorden, para que las diferencias entre lo racional y lo irracional tiendan a confundirse, situando al ser humano en un plano distinto de en el que se mueve cotidianamente.

El trabajo de Robert Smithson parte de una sólida idea de movimiento fluctuante que se desplaza alternativamente hacia la periferia para volver posteriormente al centro, en una serie de oposiciones que parecían claramente antagónicas pero que él consigue convertirlas en relacionales y recurrentes, tales como: la naturaleza y la cultura, la ciencia y la ficción, la civilización y el desierto, lo vernáculo y lo geológico, el fragmento y el conjunto, el museo y la mina, la estructura y la desintegración, el lugar y la dislocación, la forma y la descomposición, el Site y el Nonsite. Pues a Robert Smithson, lo que le interesaba realmente (tal y como muestra el conjunto de sus películas, collages, dibujos, textos, fotografías...) no era tanto llegar a ningún destino concreto ni fijado de antemano como el hecho en sí mismo del viajar, el tránsito de un lugar a otro. Para él nada posee un carácter estático, nada puede ser fijado ni siquiera nombrándolo. Su obra pretende trasmitir la idea de que el tiempo y el lugar son proyecciones mentales, parte del viaje cambiante de los desplazamientos.

Así, en su texto "Una sedimentación de la mente: proyectos de tierra" escribe, "La mente de uno y la tierra están en un estado de erosión constante; los ríos mentales desgastan riberas abstractas; las ondas cerebrales socavan acantilados de pensamientos; las ideas se descomponen en piedras de desconocimiento; y las cristalizaciones conceptuales se 

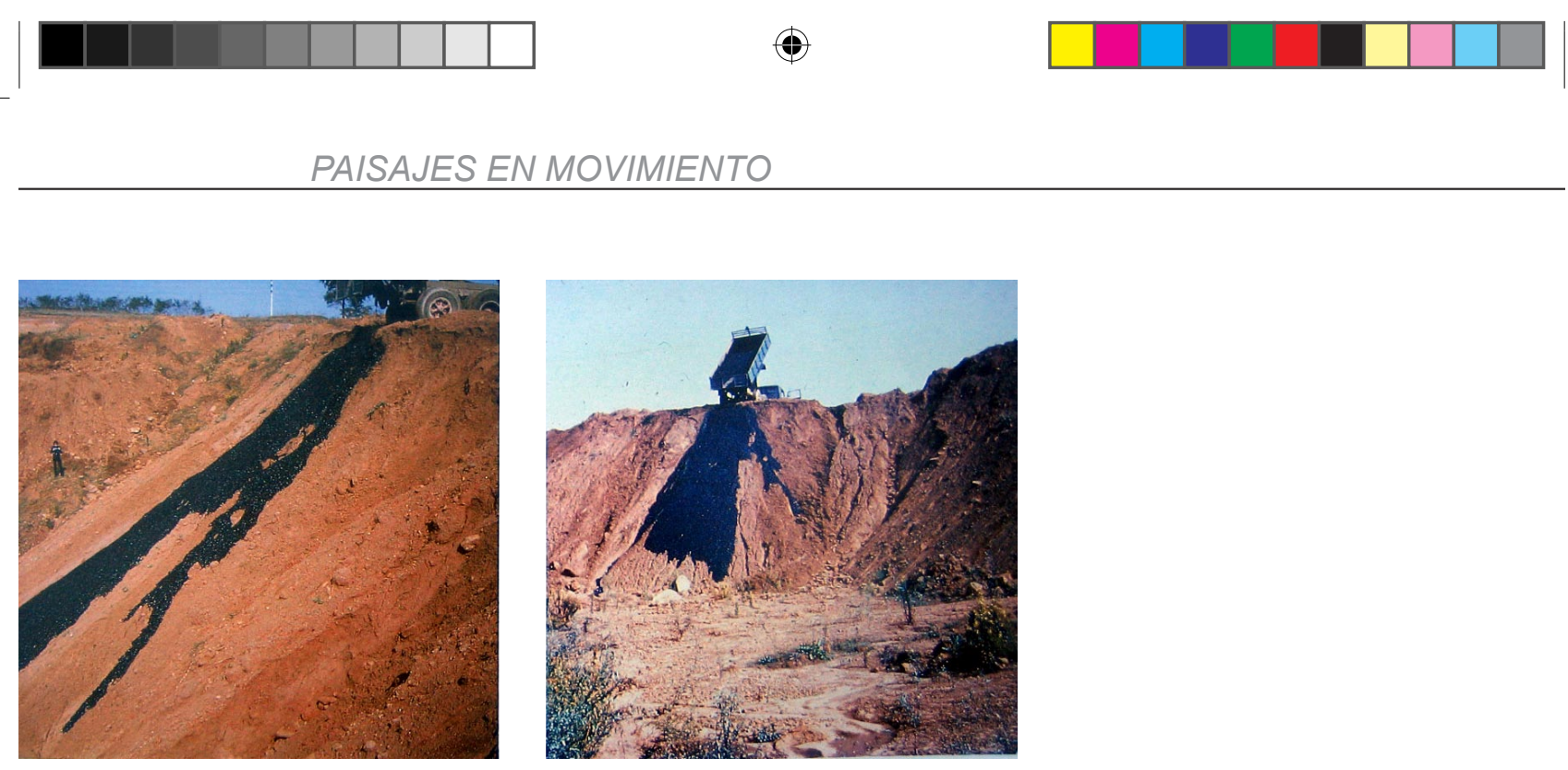

Robert Smithson ,Derramamiento de asfalto, Roma, 1969.

separan formando depósitos de razón arenosa. En este sistema geológico se producen vastas facultades de movimiento, y se mueven del modo más físico. Este movimiento parece estático, pero aplasta el paisaje de la lógica bajo ensueños glaciales."13 Smithson aplica con frecuencia la analogía de las ciencias naturales (especialmente, de la geología) al pensamiento. En sus obras se puede apreciar la influencia no sólo de escritores y filósofos como J. G. Ballard, R. Barthes, S. Beckett o J. L. Borges, sino también su inspiración en la historia natural, la arqueología, la física o la ciencia ficción. Todo lo cual le sirve para actuar como un científico de la disolución y la corrosión. Relaciona el cuerpo con el paisaje vinculando las avalanchas, las descomposiciones y los derrumbes del entorno físico con el sedimento cerebral y los fluidos corporales, para hacerlos confluir en una "geología abstracta" que puede llegar a concretarse a través de las regiones del arte.

La serie de obras realizadas entre 1968 y 1970, por ejemplo, las podemos contemplar desde este punto de vista, como una serie de acciones que nos hablan de la dispersión, el deslizamiento y el flujo de los diversos materiales. Obras donde contrasta la liquidez de esas materias con la solidez de la estructura. Así, vemos corrimientos de tierras que

13 VV. AA. Robert Smithson. El paisaje entrópico. Instituto Valenciano de Arte Moderno (IVAM), Valencia, 1993, p.125. 

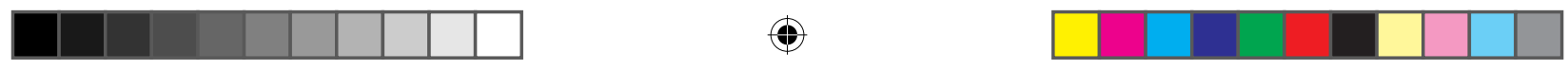

\section{Experiencias entre el arte y el urbanismo en torno al movimiento.}

engullían casas y mostraban la importancia de la estructura ante el avance de la naturaleza (Leñera parcialmente enterrada, 1970); o edificios convertidos en ruinas de nuestro tiempo gracias a que han sido invadidos por la vegetación (Hotel Palenque, 1969). Se trataba de superar los perímetros, salvar los límites y desbordar las fronteras, empujando cada posición hasta el punto de ruptura. Una ruptura que podía ser por derrumbamiento o por desparramamiento, como la serie de obras realizadas con
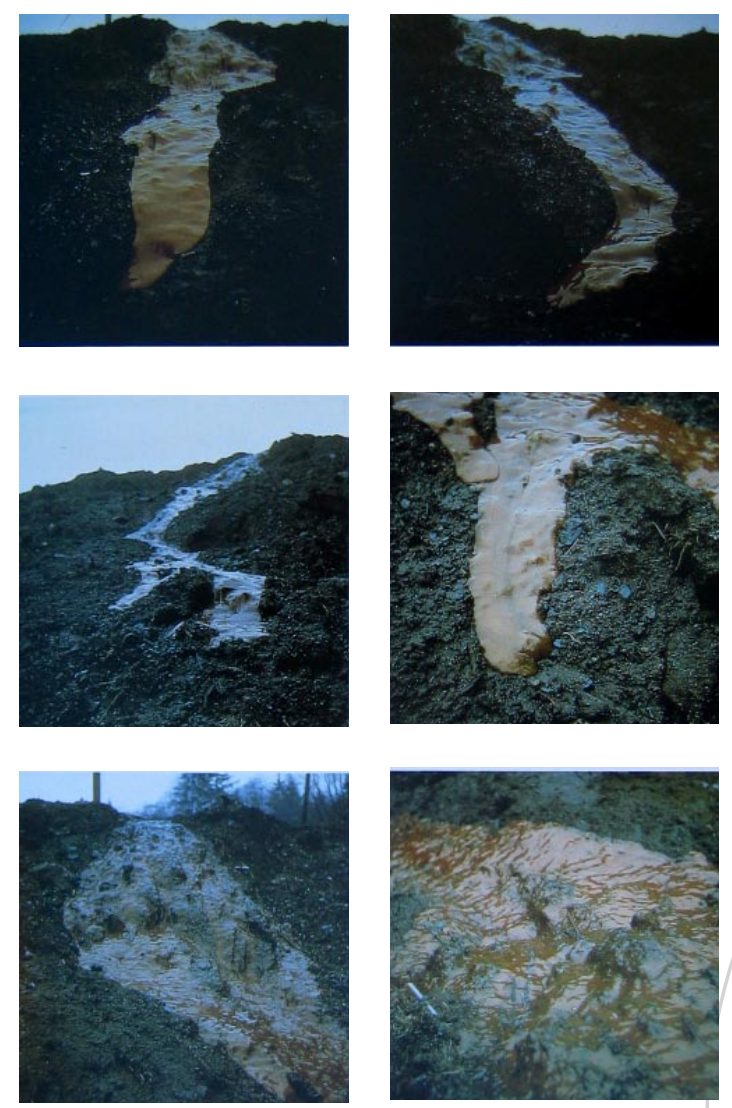

Robert Smithson, Vertido de cola, 1969.

14 Véase Ibídem, pp.135 a 165. diferentes materiales como el cemento, el barro, el alquitrán... Todos, materiales altamente viscosos que fluyen lenta y sensualmente por superficies o laderas, materiales que se moldean con el suelo y que erosionan la tierra hasta parecer lubrificadores en una entropía de carácter fluvial (Derramamiento de asfalto, Roma o Vertido de cola, ambos de 1969)..$^{14}$

El interés que Robert Smithson mostró por la naturaleza produjo que su obra tuviera una gran vinculación con ella a lo largo de su corta carrera. Una buena muestra de ello fue el gran número de excursiones que realizó a partir de la década de los años sesenta, bien de un solo día a áreas periféricas suburbanas o viajes más largos a zonas realmente marginales y emplazamientos recónditos. Sin embargo, aquí lo que me interesa destacar son aquellas experiencias que tienen una amplia y clara vinculación con su entorno, aquellas

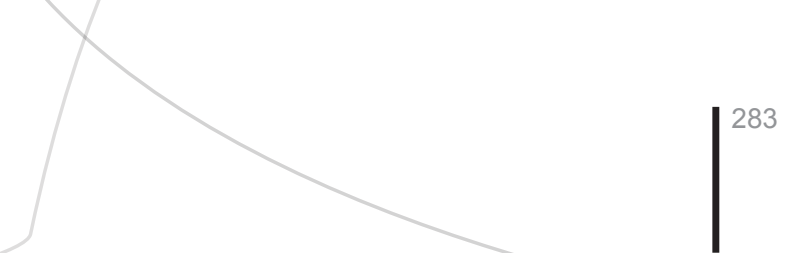



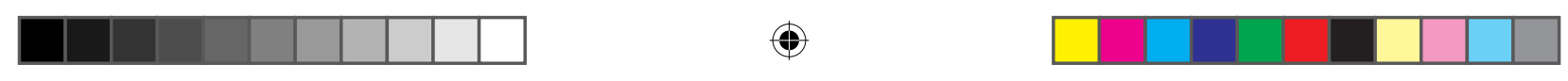

obras cuya escala de la realidad tienen la pretensión de integrarse con la naturaleza. Me refiero a las obras que al estar situadas en la periferia de la ciudad, en esa tierra de nadie, se vinculan con la naturaleza y la ciudad al mismo tiempo y son interesantes precisamente por este carácter de obra en el límite, porque no les dejan ser ni una cosa ni otra. Son intervenciones situadas en esos lugares tan ricos en matices y posibilidades que son los bordes de las ciudades, me estoy refiriendo a los Nonsites. En 1968 Smithson metió fragmentos de roca recogida

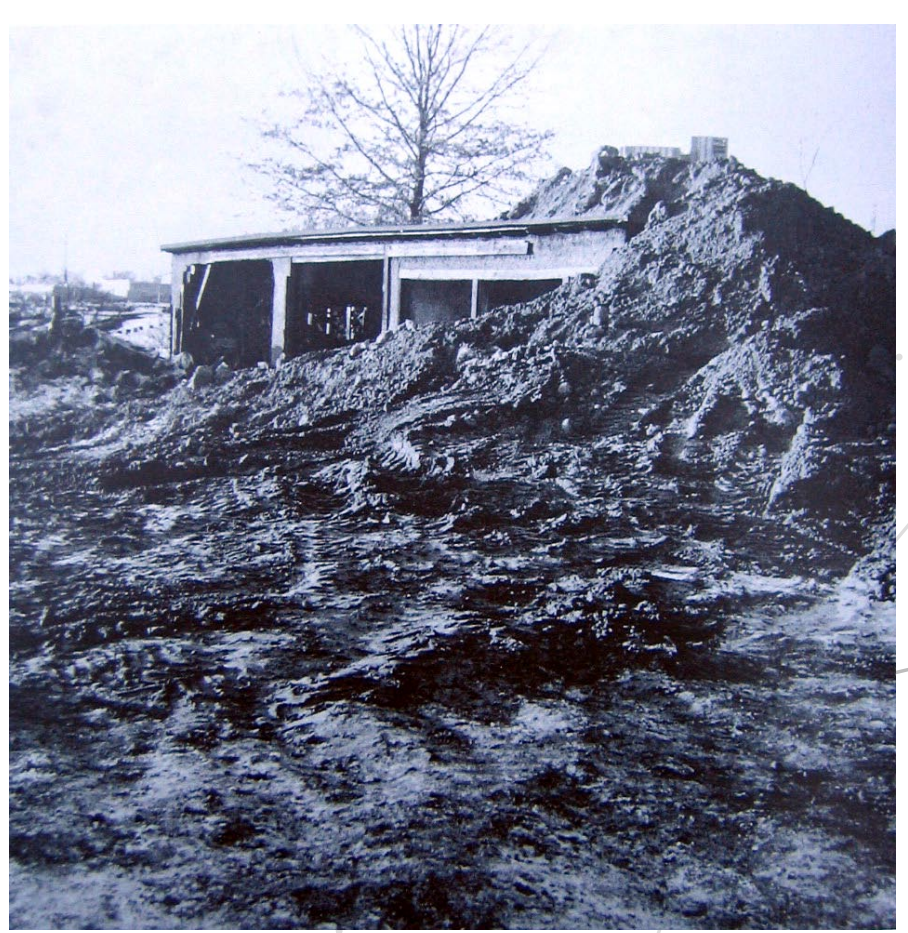

Robert Smithson, Leñera parcialmente enterrada, Kent State University, Ohio, 1970. cerca de Nueva Jersey en bolsas y los trasladó a Manhattan para exponerlos en diversas galerías de arte. Allí los montó en contenedores, en cubos de aspecto industrial, rodeados de mapas y fotografías del proceso de recogida y traslado desde el emplazamiento geológico, lo cual le daba un cierto aspecto de exposición mineralógica de Museo de Historia Natural. ${ }^{15}$

$$
\text { En este proceso }
$$

el artista norteamericano había retirado diferentes rocas del lugar donde se encontraban dejando un vacío donde antes había "algo", creando así un Nonsite. El Nonsite constituye el trasplante de un Site a un contexto artístico pero que remite constantemente al Site de origen. La intervención de Smithson había introducido un vacío en el

15 Véase Hobbs, Robert, Robert Smithson: Sculpture, Cornell University, Londres, 1981. 

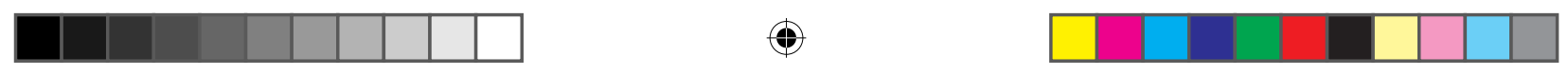

\section{Experiencias entre el arte y el urbanismo en torno al movimiento.}

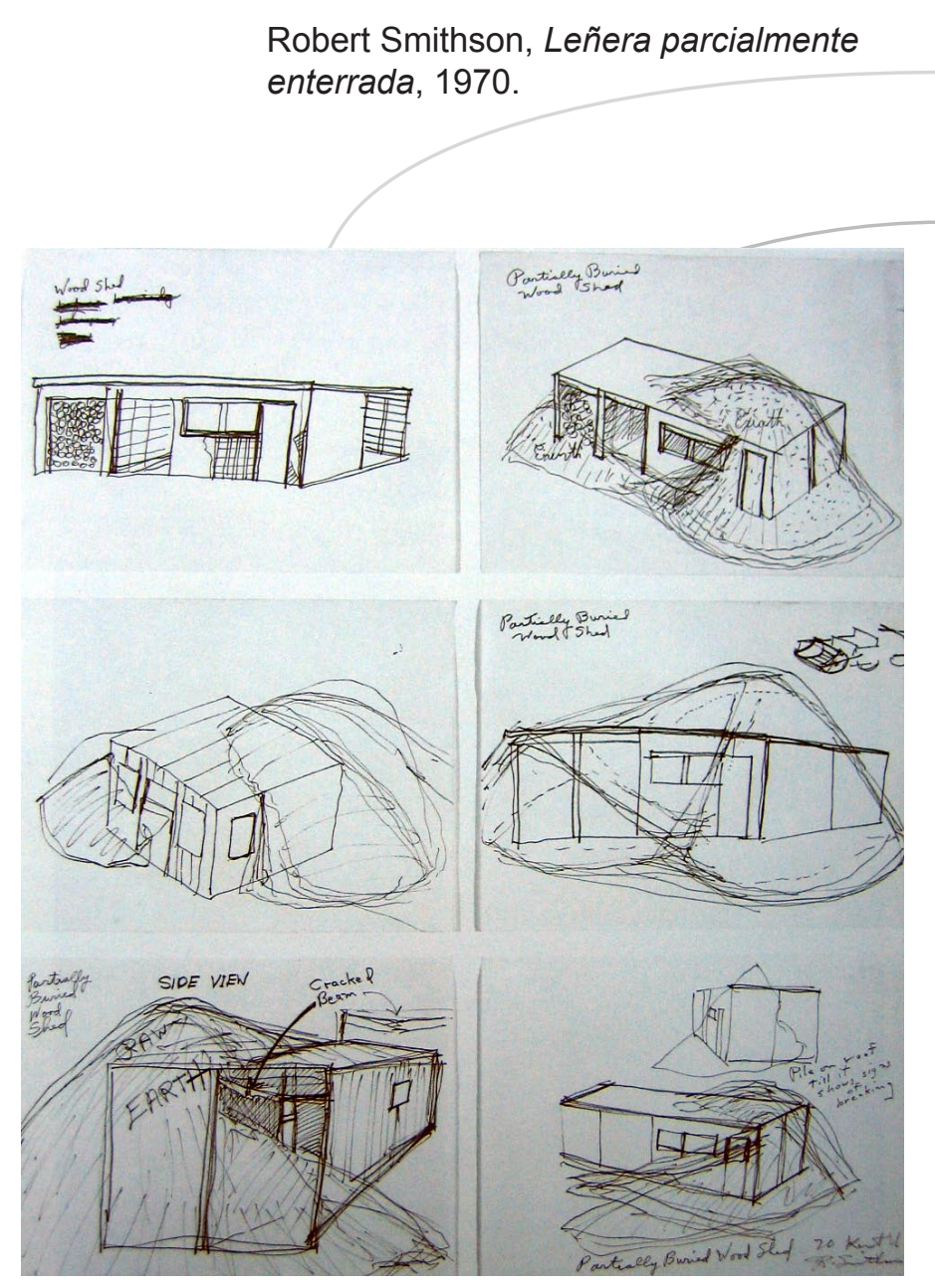

paisaje y había roto su continuidad, su trabajo poseía un carácter relacional en el sentido que entablaba una dialéctica entre la obra y el mundo exterior. Los fragmentos de naturaleza (yeso, pizarra, mineral de hierro, sílice...) separados/arrancados del lugar y del tiempo geológico creaban, al ser literalmente "objetos desplazados" carentes de emplazamiento, una situación compleja. Como escribe Smithson, "El ámbito de convergencia entre el Site y el Nonsite consiste en una pista de riesgos, un camino doble compuesto de señales, fotografías y mapas que pertenecen a ambos lados de la dialéctica a la vez. Ambos lados están presentes y ausentes a la vez. ¿Es el Site un reflejo del Nonsite (espejo), o es el contrario? Las reglas de esta red de señales se descubren conforme se recorren caminos inciertos tanto mentales como físicos." ${ }^{16}$ Por ello, aunque estén constituidos por materiales tangibles, los Nonsite son esencialmente obras conceptuales pues, informan sobre el lugar y el viaje del artista hacia ese lugar.

16 Smithson, Robert en Ibídem, p.121. 

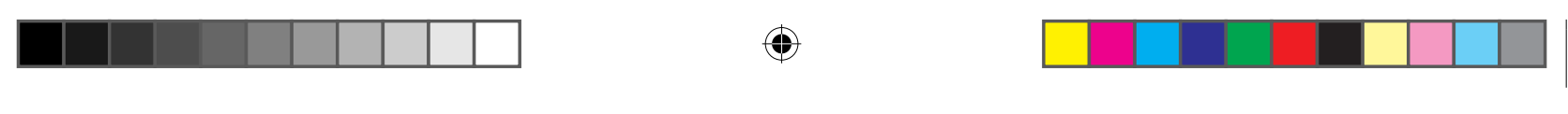

De nuevo son los viajes, especialmente los que realizó a través de los espacios vacíos de la periferia urbana contemporánea lo que más nos interesan aquí de los trabajos de Robert Smithson. En 1967 realizó "Un recorrido por los monumentos de Passaic, Nueva Jersey" que sería publicado en forma de ensayo fotográfico en la revista Artforum el mes de diciembre de ese mismo año. Son un conjunto de fotos en blanco y negro y un texto, que son el resultado de sus vagabundeos por los espacios vacíos de la periferia de su ciudad natal, de su exploración de unas zonas marginales y desconocidas. Una odisea urbana hacia las partes más degradas del entorno físico, un viaje a la "ciudad inferior" de la que nadie se acuerda y no sale en las guías turísticas. Passaic parece un lugar de paso más que una ciudad, una zona sobre la que uno lanza una mirada rápida y superficial pero en la que no se detiene porque parece que estés en "ninguna parte".Por ello, es importante que Smithson viaje hasta allí y examine cuidadosamente la ciudad a pie viviéndola en tiempo real.

El espacio recorrido por Robert Smithson se presenta como una experiencia relacional con una periferia carente de representación, una forma de conocer las ruinas de la cultura industrial y de progreso para mostrarnos la realidad del paisaje suburbano. Lo que recoge no son instantáneas de los monumentos dedicados a los héroes de la ciudad o a los hechos importantes de su historia, sus imágenes nada tienen que ver con la parte mítica de la existencia ciudadana ni con la idea de la "ruina romántica". Al contrario, son una inversión de la sensibilidad romántica, son lo tributos de los suburbios, la memoria de la incuria (de hecho ninguno de ello son lugares elegidos por los vecinos para pasear o emplear su tiempo libre); es la parte más oscura y negativa de la ciudad de la que Smithson nos quiere hablar. Como nos dice Francesco Careri: "Robert Smithson compendió que con el Earthart se abrían nuevos espacios que podían experimentarse física y conceptualmente, y que los artistas podían transformar la mirada del público sobre estos territorios, reproponerlos bajo una óptica nueva, descubrir sus valores estéticos."17

17 Careri, Francesco, Op. cit, p.146. 


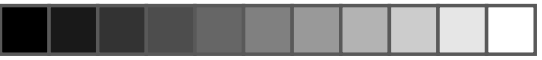

(†)
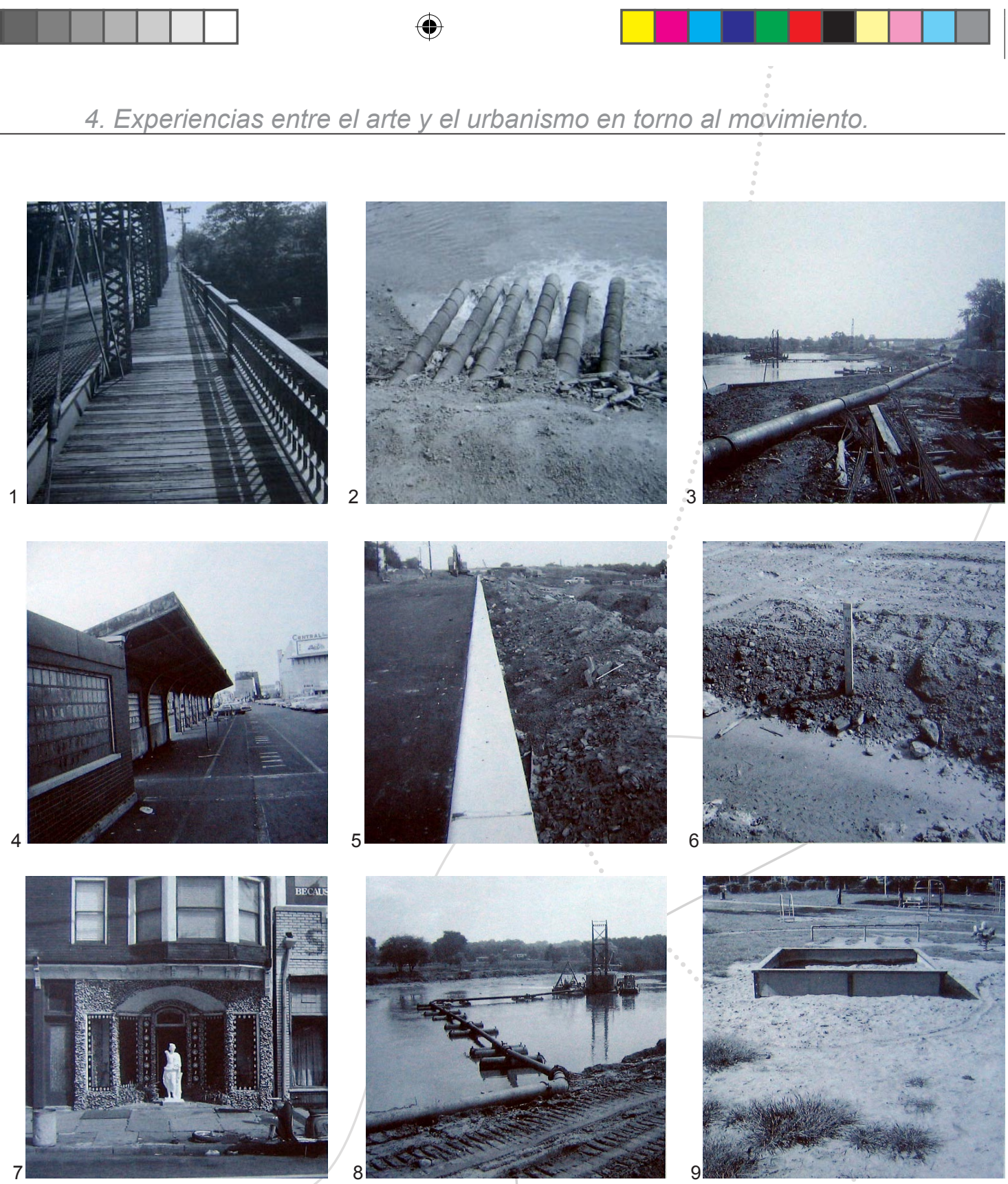

Robert Smithson, Los Monumentos de Passaic, 1967.

1 El Monumento del Puente mostrando las pasarelas de madera

2 El Monumento de la Fuente-Vista de pájaro

3 El Monumento de las Grandes Tuberías

4 Sin título

5 Sin título

6 Sin título

7 Sin título

8 Monumento con pontones: La plataforma de Bombeo

9 El Monumento de la Caja de Arena (llamado también El Desierto) 

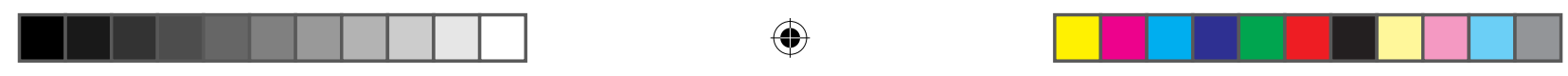

Sus imágenes nos muestran los límites de la ciudad y la no-ciudad, esos "terrain vague", esa línea geológica que la divide en dos áreas adyacentes pero hostiles: la naturaleza y la cultura, la creación y la destrucción, la civilización y el desierto. Es la ciudad inconclusa compuesta por los antimonumentos y el antipaisaje formado por las plataformas de bombeo y las viejas tuberías industriales, los aparcamientos vacíos y las paredes llenas de grafitis. Para Smithson, Passaic se convierte en un emblema de la periferia del mundo occidental, en el lugar de los desechos y de la producción de un paisaje nuevo compuesto de rechazos y de trastornos. "Resultaba difícil distinguir la carretera nueva de la vieja, se confundían ambas en un caos unitario. Puesto que era sábado -escribe-, muchas máquinas no estaban en funcionamiento, y esto les hacía aparecer como criaturas prehistóricas atrapadas en el barro o, aún mejor, máquinas extinguidas-dinosaurios mecánicos desprovistos de piel." ${ }^{18} \mathrm{EI}$ suyo no es tan sólo un viaje espacial a la periferia urbana (los despojos de la ciudad, las canteras abandonadas, las fábricas caídas, los lugares vacíos...), es también una metáfora de la periferia de la mente, de los despojos del pensamiento y de la cultura. Como el propio artista plantea: "Passaic parece estar lleno de "agujeros" en comparación con la ciudad de Nueva York, que parece estrictamente empaquetada y sólida. Esos agujeros son, en cierto sentido, los vacíos monumentales que definen, sin pretenderlo, los vestigios de la memoria de un juego de futuros abandonado". ${ }^{19}$

Dentro de este interés por la noción de vagar, podemos comprobar de qué modo la espiral se convirtió en motivo recurrente de sus idas y venidas. En 1970, gracias a la Spiral Jetty (Muelle en espiral) la figura que tanto le interesó tomó escala monumental, produciendo una obra fascinante que ha seducido a múltiples artistas y arquitec-

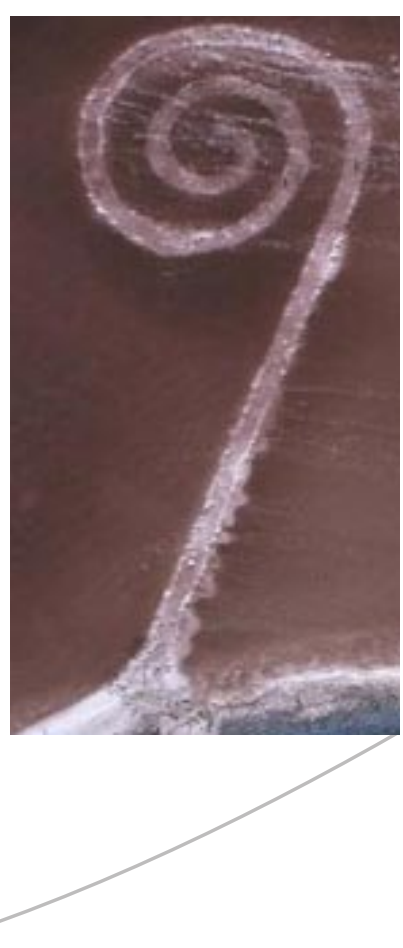

18 Smithson, Robert. Un recorrido por los monumentos de Passaic, Nueva Jersey, Gustavo Gili, Barcelona, 2006, p. 14 y 15.

19 Ibídem, p.20 y 21. 

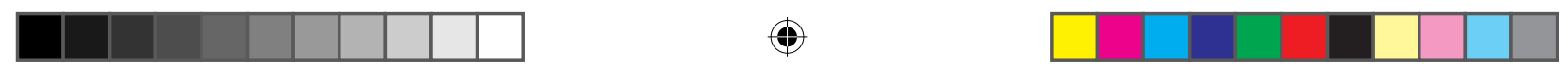

\section{Experiencias entre el arte y el urbanismo en torno al movimiento.}

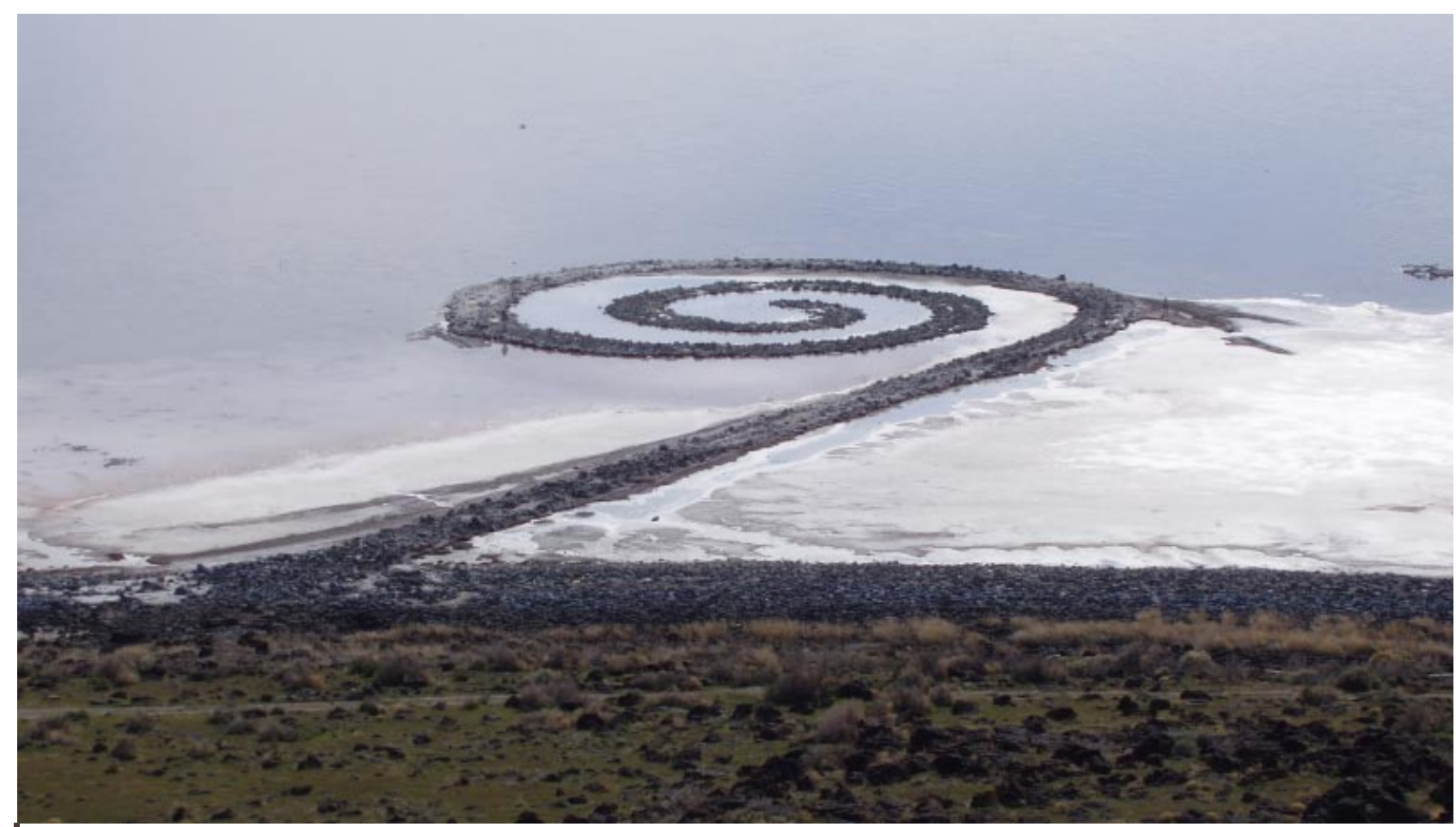

Robert Smithson, Spiral Jetty, Great Salt Lake, Utah, 1970.

tos posteriores. La espiral se convierte aquí en una forma sensiblemente prehistórica de cristales, lodo y rocas depositados por enormes volquetes en el Great Salt Lake de Utah, donde, debido al color de las aguas, se produce simultáneamente una fuerte analogía con la sangre. En este simbólico lago de Utah ${ }^{20}$ construyó el artista norteamericano su espiral como una forma asimétrica sugerente de los cristales de sal con forma de espiral que se incrustaban en las orillas del lago cada verano.

La espiral adquiere todo su componente simbólico. Esta es, como nos recuerda el profesor J.E. Cirlot's en la entrada "Espiral" de su fundamental Diccionario de símbolos: "Una forma esquemática de la evolución del universo. Es también una forma clásica que simboliza la órbita de la luna, un símbolo del crecimiento, relacionado con la Proporción Aurea 20 El lago se encuentra próximo al Golden Spike Monument, un obsoleto monumento que conmemoraba la conjunción entre las vías del primer ferrocarril transcontinental; paralelamente, también es conocido como el "America's Dead Sea" (El mar muerto de América). 

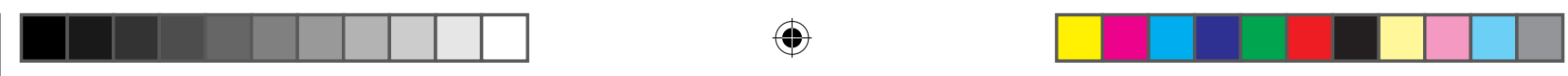

surgida del concepto de rotación de la Tierra"21. Todos estos conceptos, vienen reforzados por la otra parte de la pieza, indisociable de la construcción física de la espiral: la película que el artista filmó acerca de la espiral. Aquí se nos muestran, apoyadas por los textos elegidos por Smithson para ser leídos mientras está filmando, las fuerzas centrífugas y centrípetas de la Jetty asociadas a la espiral. "Hay veces en las que el gran exterior se encoge fenomenológicamente a las escala de una prisión $y$ hay veces en las que el interior se expande hasta la escala del universo.", nos decía el artista en sus escritos a propósito de la Spiral Jetty. ${ }^{22}$ El movimiento en toda la obra de Robert Smithson es tan profundo y está compuesto de tal número de capas e implicaciones que el propio artista comentó también en dichos textos en relación a la Spiral

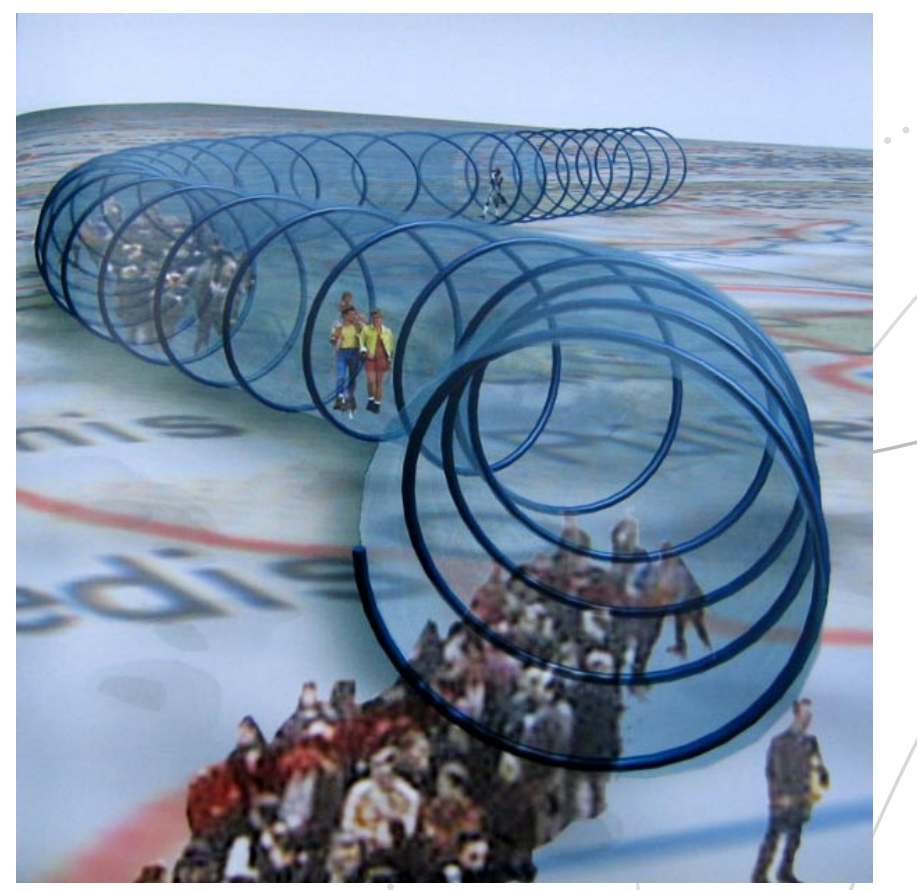

Stalker, Transborderline, 1999. Jetty: "Era como si la tierra firme oscilara en ondas y pulsaciones, y el lago permaneciera quieto como una piedra." 23

Otro grupo con inquietudes muy similares (y de hecho deudores de Robert Smithson, a quién homenajearon en alguna de sus intervenciones), fue Stalker. Un colectivo (de entre siete y quince personas en función de los proyectos específicos) formado por jóvenes artistas, arquitectos

21 Cirlot, Juan Eduardo, Diccionario de símbolos, Siruela, Madrid, 2006, p.86.

22 Textos recopilados por Nancy Holt en su obra: Holt, Nancy, The writings of Robert Smithson, New York University Press, Nueva York, 1979, p.109.

23 Ibídem, p.111. 

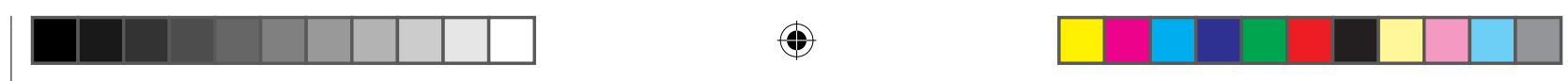

\section{Experiencias entre el arte y el urbanismo en torno al movimiento.}

y antropólogos, creado en Roma en 1995, que deben mucho a las investigaciones urbanas que los situacionistas llevaron a cabo en París en la década de los años cincuenta. Es un grupo de una composición bastante informal donde Francesco Careri y Lorenzo Romito son los dos teóricos más destacados. Sus trabajos de investigación y sus acciones están centrados en el deseo de escrutar el inconsciente de la ciudad y en analizar los procesos de transformación de las zonas urbanas situadas en los límites de la ciudad. En el año 1966 redactaron un manifiesto, denominado Stalker. A través de los territorios actuales, que es fundamental para poder entender sus presupuestos básicos. ${ }^{24}$

A Stalker, lo que realmente les interesa es explorar las transformaciones urbanas ocurridas en esos espacios de nadie, en los límites entre el campo y la ciudad, en esos vacíos o intersticios que se abren entre la periferia y el centro. Les preocupa, muy especialmente, (al igual que a Robert Smithson), las partes más ocultas de la ciudad, las que se encuentran más allá de los grandes ejes de comunicación y que generalmente ni visitamos ni sabemos nada de ellas. Para ellos el andar es una práctica que ha posibilitado siempre la creación de arquitectura y paisaje, "Hemos elegido la caminata como una forma de arte que permite subrayar un lugar trazando físicamente una línea, como una pre-arquitectura que se insinúa en la nueva naturaleza". ${ }^{25}$ Por esa razón, tratan de inventar el espacio a medida que se desplazan por él, intentan producir y construir la ciudad a través de los paseos y las marchas. Con sus caminatas desean atravesar esos lugares oscuros y desconocidos de la ciudad que casi no tienen nombre, que no se conocen o no se quieren ver para con sus recorridos dotarles de significado. ${ }^{26}$ En este sentido, es interesante recordar la obra que realizaron en 1996 titulada "Run Down. Homenaje a Robert Smithson", en la que Stalker vuelve a los escenarios (al límite entre ciudad y zona industrial desvencijada) donde el artista norteamericano

24 Consúltese su página Web http://www.osservatorionomade.net

25 Citado en Cortés, Jose Miguel G., Op. cit., 2007, p.162.

26 Las referencias a la visita realizada por el grupo Dada el 14 de abril de 1921 a Saint-Julien-le-

Pauvre en París son también inevitables. 

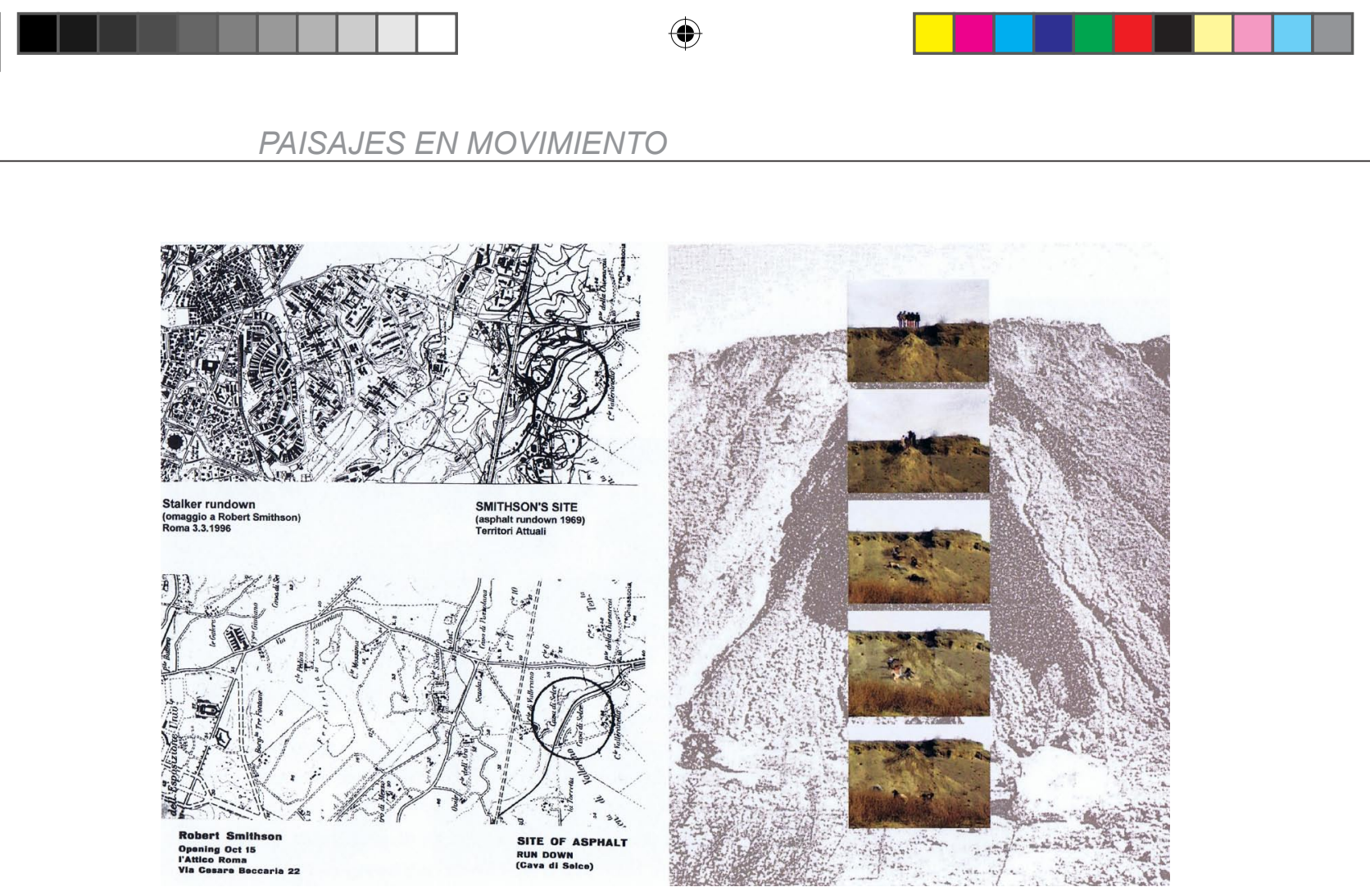

Stalker, Run Down. Homenaje a Robert Smithson, 1996.

llevó a cabo su famosa obra "Monumentos de Passaic" que acabamos de ver. Al igual que los espacios de la ciudad tienen y necesitan de su historia y de sus raíces, también Stalker se reconoce en prácticas artísticas anteriores.

Para este colectivo italiano la constante transformación de la ciudad contemporánea está originando unas nuevas geografías compuestas de territorios mutantes, inexplorados, olvidados y algunos, incluso, vírgenes que denominan "Territorios actuales", los cuales según ellos mismos, "constituyen el negativo de la ciudad construida, las áreas intersticiales y marginales, espacios abandonados o en proceso de transformación. Se trata de lugares de la memoria reprimida, del devenir inconsciente de los sistemas urbanos, el lado oscuro de la ciudad. Espacios de confrontación y contaminación entre lo orgánico y lo inorgánico, entre naturaleza y artificio." 27 Stalker lleva a cabo obras colectivas que adquieren la forma de experiencias, de momentos vividos que tratan de intensificar

27 Cortes, Jose Miguel G., Ibid., p. 159. 

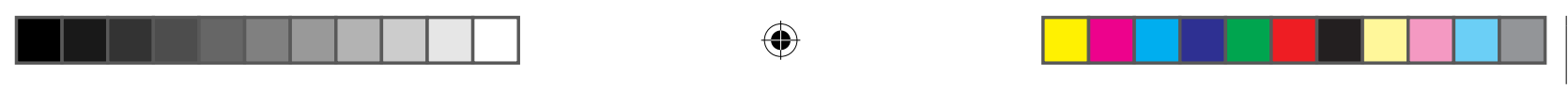

\section{Experiencias entre el arte y el urbanismo en torno al movimiento.}

la percepción inagotable de los espacios. Es un trabajo que mediante la marcha, el análisis y la medida pretende el conocimiento de los diferentes territorios que parecen estar ausentes de identidad pero disponibles para ser recorridos.

Para Stalker, gracias a la experiencia de caminar por el espacio urbano se manifiestan los factores interiores de la ciudad y se revelan las diferentes zonas que la componen, identificándolas mediante una múltiple actividad que les permite afrontar las diversas contradicciones que se plantean en las urbes contemporáneas: por un lado, lo referido a la protección de lo abandonado; por otro, la intervención dentro de las condiciones mutantes e inestables en las que se encuentran; y por último, la representación a través, fundamentalmente, del cultivo de la percepción sensorial. Su tarea consiste en crear muy diferentes mapas de esos espacios atravesados y reconocidos, de levantar estudios de cómo se encuentran esos lugares, de realizar unas líneas topográficas de una geografía ambigua y desconocida a través de la cual se pueden ir entendiendo las posibles transformaciones del territorio urbano y comprendiendo la forma y el modo de su evolución (cronológica e histórica) que le ha dotado de su peculiar singularidad. Evidentemente, los territorios que ocupan sus paseos son aquellos que no acaban de tener función alguna y que se no están recogidos en ninguna guía ni ningún mapa. ${ }^{28}$

Otro de los objetivos fundamentales del grupo italiano es conseguir ser capaces de situarse en los diferentes espacios sin mediación alguna, sin elementos que empañen el contacto íntimo y directo, para poder introducirse en sus dinámicas. Y para ello es necesario, según sus propias palabras, "Una búsqueda nómada enfocada hacia el conocimiento mediante la travesía, sin necesidad de regular, ratificar o definir el objeto de conocimiento, sin poner obstáculos a su devenir. Atravesar equivale, para nosotros, a un acto de creación; supone la creación de un sistema de relaciones dentro de la yuxtaposición caótica del tiempo y el espacio."29

28 Consúltese Tortosa, Guy, Stalker à travers les territoires actuels, Jean Michel Place éditeur, París, 2000.

29 Ibídem, p.47. 


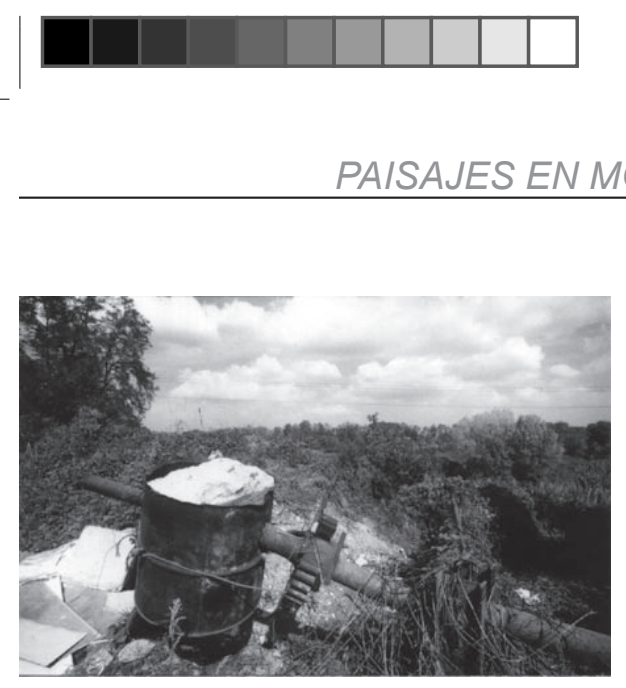

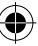
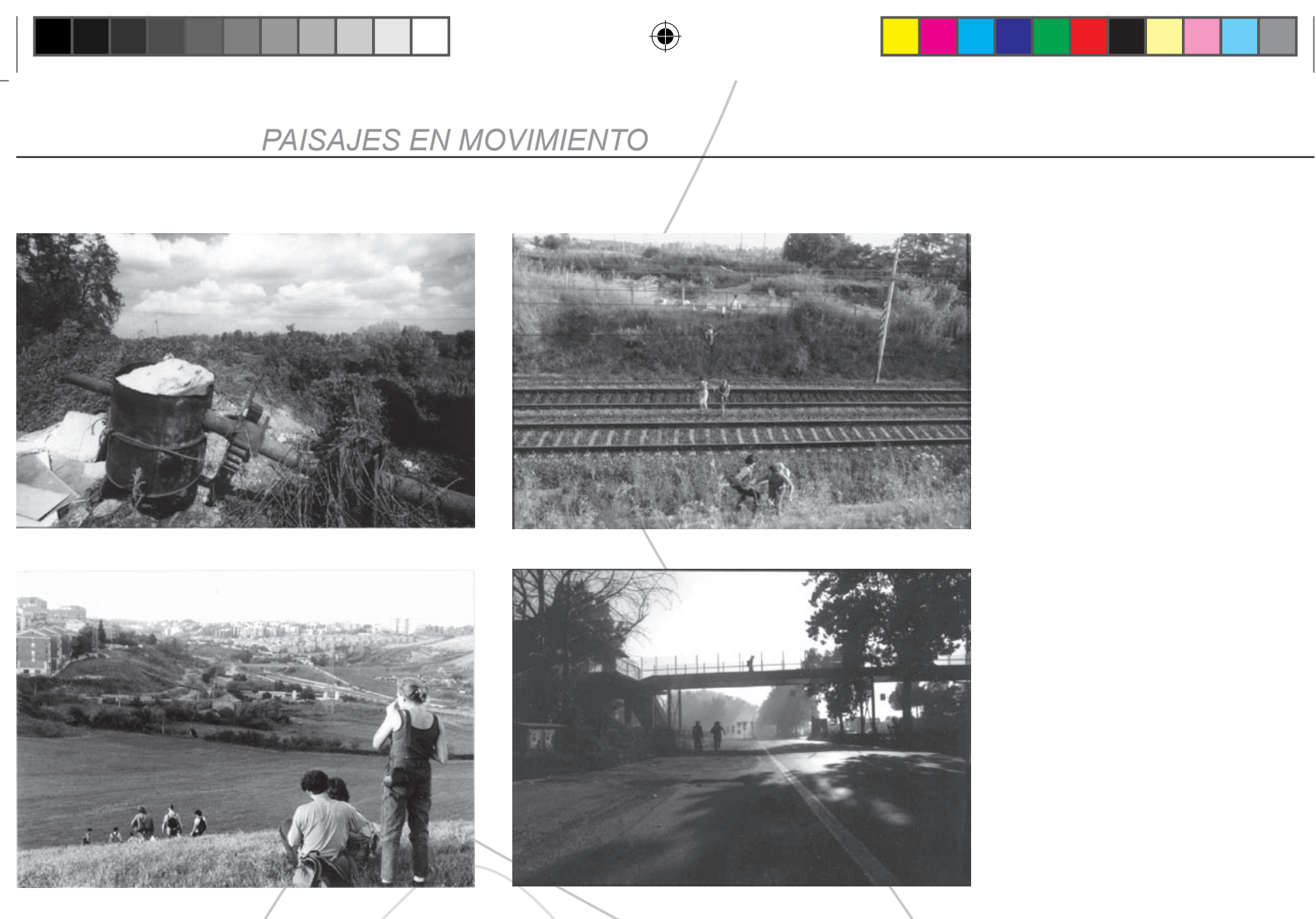

(†)
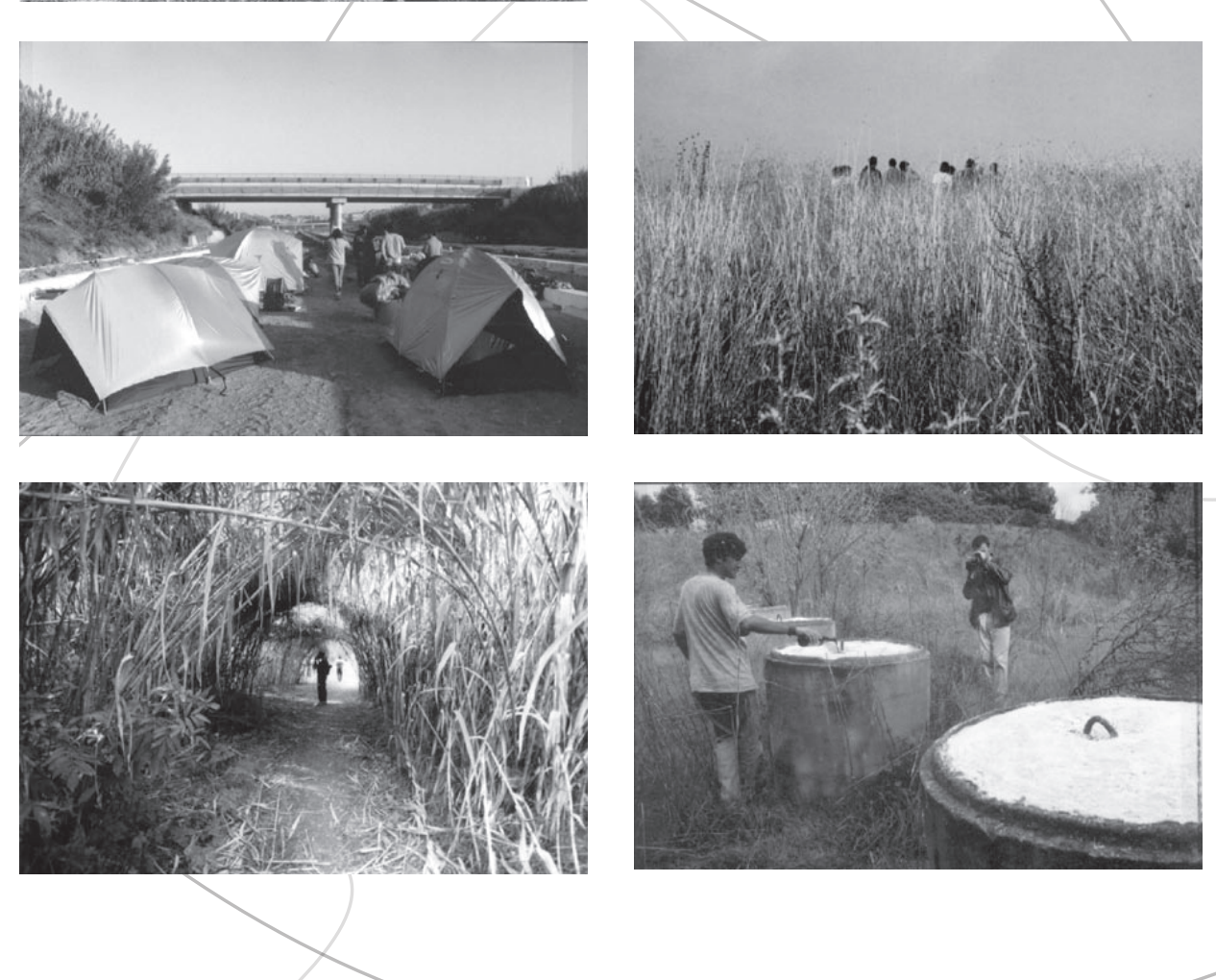

Imágenes de las caminatas/recorridos llevadas a cabo por el grupo Stalker entre 1995 y 2002.

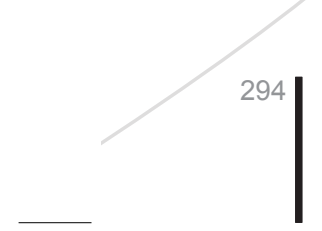



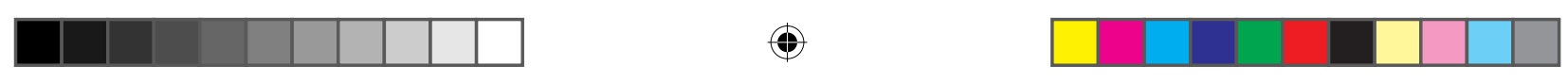

\section{Experiencias entre el arte y el urbanismo en torno al movimiento.}

Se trata, en definitiva, de la elaboración de una topología fluida que se constituye mediante el propio devenir, una cartografía del territorio guiada por la experiencia del propio recorrido y la interacción con sus protagonistas ocasionales. Para Stalker el conocimiento de la existencia de estos territorios no se puede producir si no es en estos términos, si no se ponen las bases que permitan la posibilidad del descubrimiento fortuito o del encuentro inesperado, de la intensificación de la capacidad de intervención como la única forma posible capaz de cartografiar los nuevos espacios.

La deambulación espacial, el recorrido, es para ellos como un campo cognitivo que requiere una permanente actualización. En este sentido, tiene interés recordar la estructura creada con el nombre de "Transborderline", 1999, que pretende ser un conducto para el intercambio de las culturas y la libre circulación de las personas entre las fronteras (cruzarlas y superarlas sin realmente cambiarlas) de diversos países. Es el prototipo de un nuevo espacio público nacido fuera de los límites fronterizos y creados para enfrentarse cara a cara con otros mundos, con aquellos que son diferentes. Construyen con este fin una espiral tridimensional que posibilite la aparición de un tránsito libre y nómada donde muchos caminos se crucen y se confundan. Un espacio sinuoso donde el significado y los valores simbólicos de las fronteras son puestos en cuestión, así como también es puesto en duda el mito de su impenetrabilidad.

En su trabajo, la práctica del recorrido se ha consolidado como un sentido modo de expresión y un útil instrumento de conocimiento de las transformaciones del paisaje de la ciudad. En esa dirección son muy interesantes las obras denominadas "Transurbancias", que fueron realizadas partir de 1995 en diversas ciudades europeas (Roma, Milán, París o Berlín) y que se plantean una lectura de la ciudad desde el punto de vista del errabundeo. Para Stalker, "La transurbancia vuelve a otorgar al ciudadano el título de viajero, permitiéndole explorar unos recorridos inéditos, llenos de contradicciones estridentes, de dramas que a veces componen unas armonías inéditas. Se trata de volver a encontrar en el territorio metropolitano un sentido que surja de la experiencia de lo real y de sus 

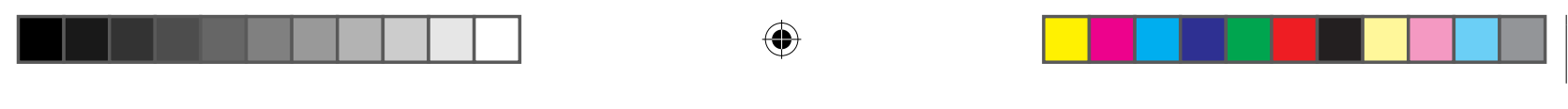

contradicciones, a través de una mirada libre de opiniones, una mirada que no busque justificaciones históricas o funcionales tranquilizadoras y al mismo tiempo frustrantes, que no reduzca su propio horizonte a las secciones de las guías turísticas, sino que descubra el potencial de los acontecimientos urbanos en su inimaginable complejidad."30 Para StaIker, es cuestión de recuperar la dimensión del viaje y del descubrimiento no en lugares lejanos sino en el seno de la propia ciudad, de mirar la urbe contemporánea como un collage de múltiples lugares inexplorados y caóticos que ni sospechábamos que podían existir ni habitar la ciudad. El viajero romántico que salió al encuentro de la naturaleza, es reinterpretado y se busca a sí mismo, esta vez, en la propia ciudad contemporánea.

Algo de todo esto es lo que podemos encontrar en la obra "Planisferio Roma" (1996), un mapa realizado como consecuencia de una caminata circular de sesenta kilómetros durante cinco días en un perímetro alrededor de la capital italiana. Sobre este planisferio están indicados en diferentes colores distintas situaciones: con el color blanco se señalan los recorridos seguidos por el grupo; con el color azul los espacios mutantes; y con el color amarillento la ciudad formateada. Como consecuencia de todo ello encontramos una constelación de islotes que parecen flotar en un mar repleto de líneas en una clara referencia a las "Guías psicogeográficas" de Guy Debord. Como en ellas, el plano que aquí encontramos no corresponde a la realidad física de la zona geográfica que pretendidamente se desea representar. En ambos ejemplos, se trata de una manera de reconstruir la topografía inconsciente (y sin embargo activa) de una ciudad determinada, de una ciudad que pretendíamos conocida pero ahora es redescubierta y asimilada a un territorio descentrado con múltiples orientaciones y direcciones. El mapa que Stalker ha creado está elaborado mediante un conjunto de muy diversas referencias y experiencias y que nada tiene que ver con la reproducción fiel de un terreno que pudiese hacer un geógrafo. Esto es otra cosa, un viaje físico y psíquico a través de una cartografía urbana abierta en todas las direcciones y

30 Texto recogido de su página web ya citada. 

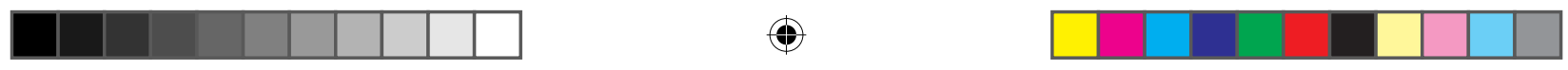

en todos los sentidos. Un plano desmontable y susceptible de cualquier cambio o modificación, un collage concebido como una obra de arte y vivido como una acción política.

Su trabajo es la plasmación sobre un papel de caminatas colectivas realizadas en lugares escogidos que pretenden revelar la ciudad nómada que permanece agazapada en el interior de lo que se denomina la ciudad "real", señalando la existencia de un sistema territorial difuso y de atribuirle un valor simbólico mediante el arte. Caminatas que se basan tanto en elementos de ficción propios como en las deambulaciones que ya estaban presentes en las famosas derivas de la Internacional Situacionista.

Stalker, Planisferio Roma, 1996.
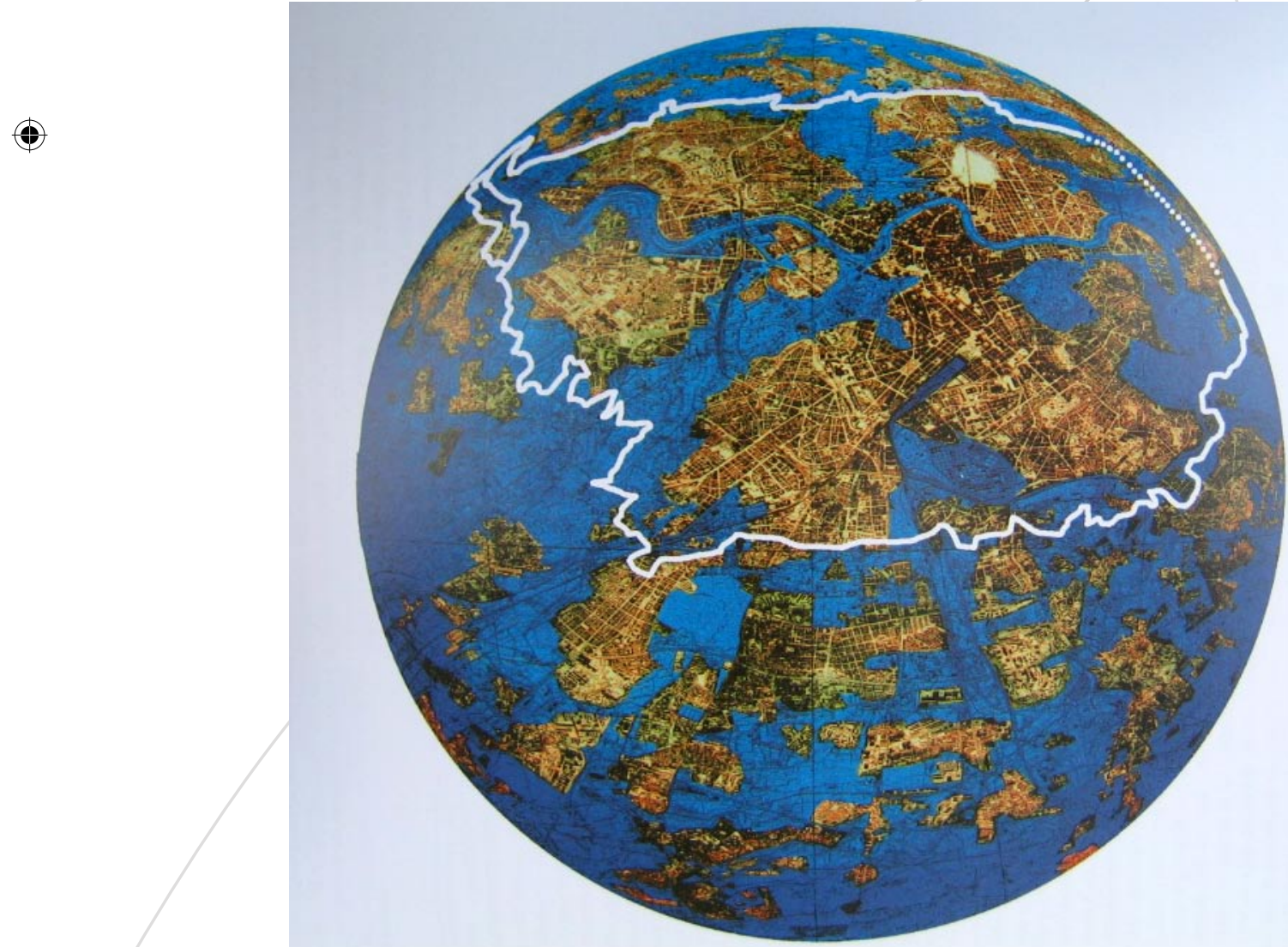


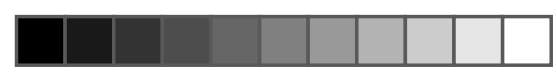

$\oplus$
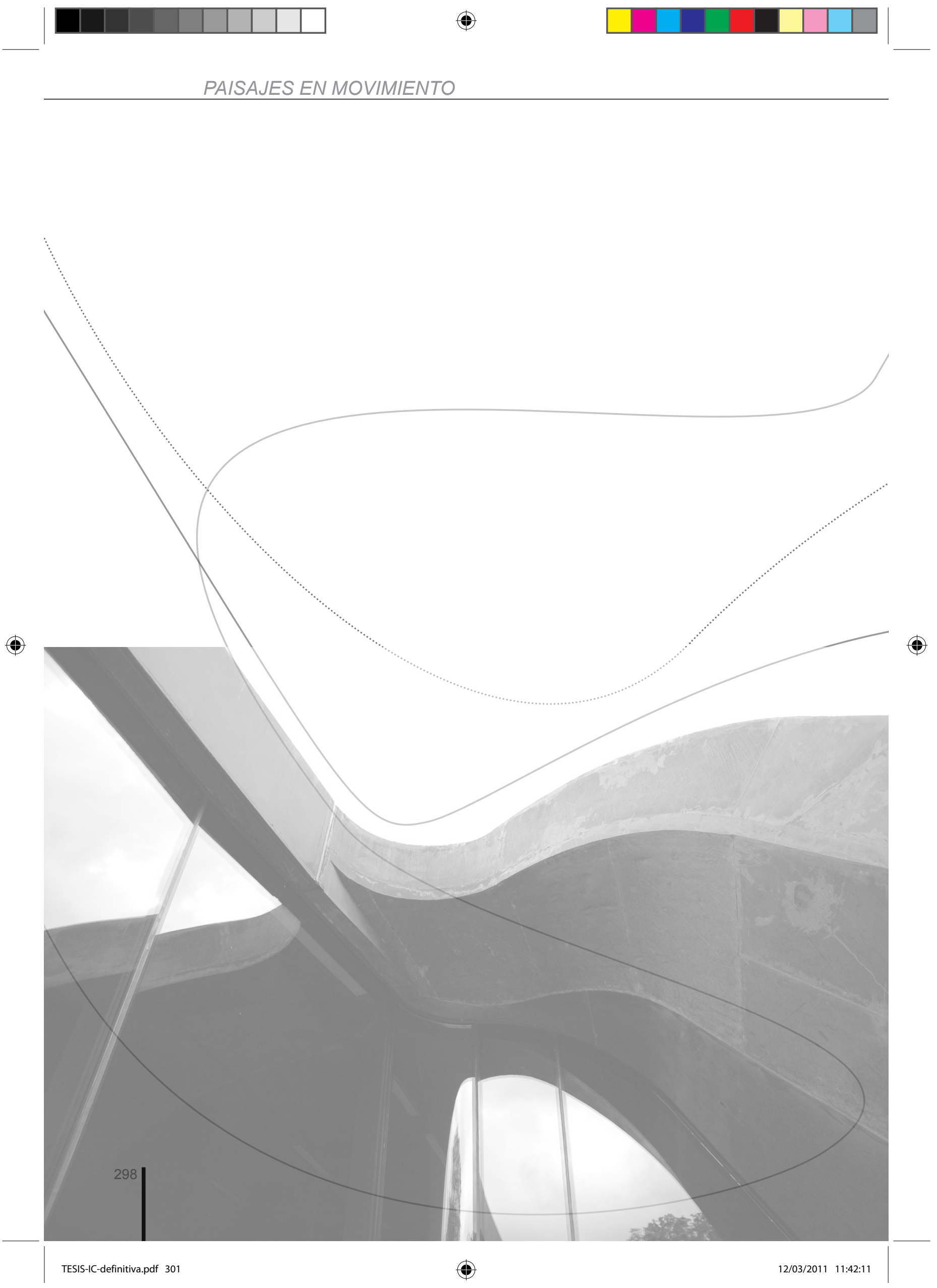

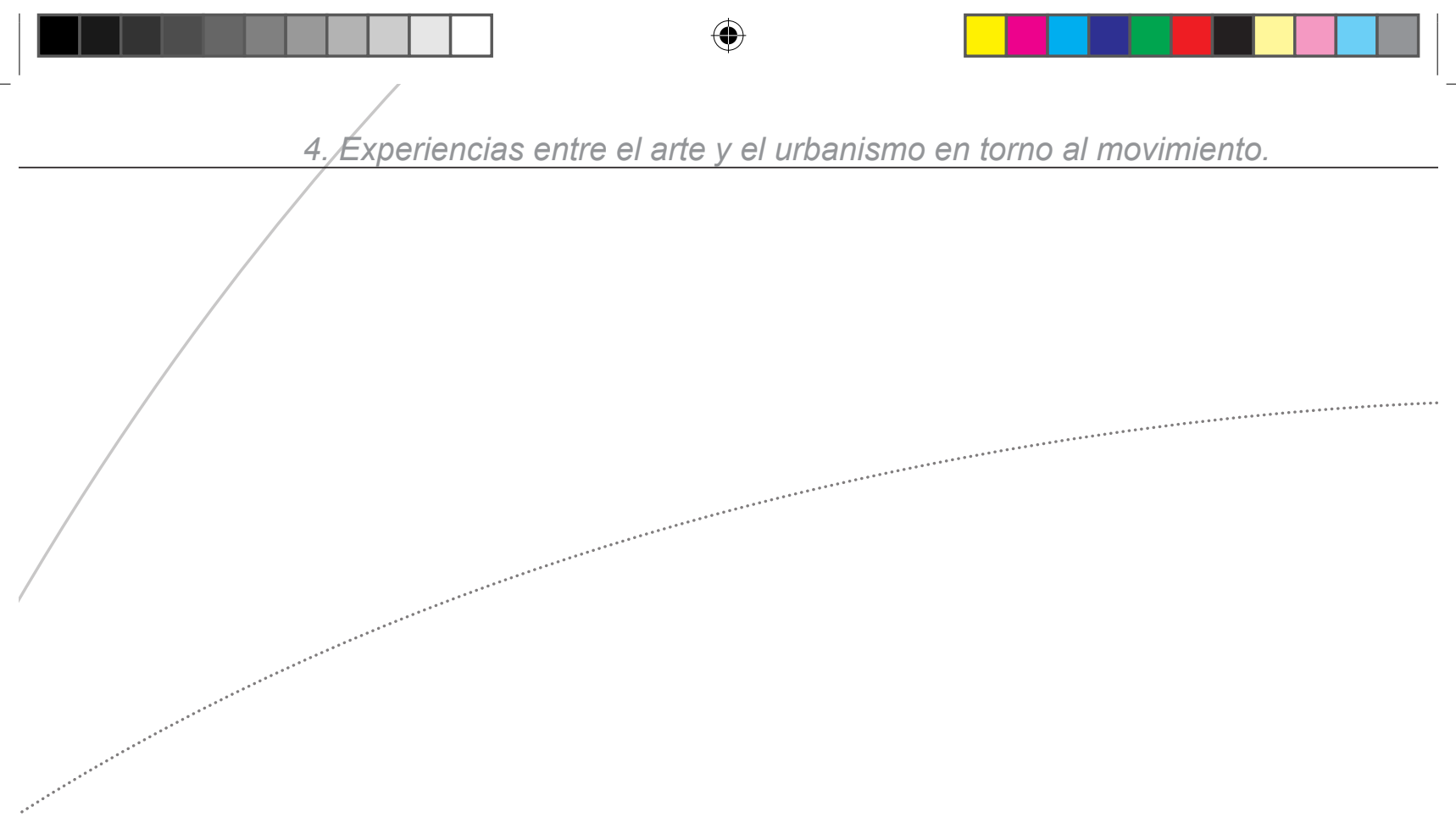

Tras la mirada que acabamos de dedicar a las experiencias realizadas en el mundo anglosajón y que contaban con un carácter más intrínsecamente artístico, quisiera que volviéramos ahora, que cruzáramos de nuevo, al mundo de la arquitectura para comprobar que fue de los planteamientos desarrollados por grupos como Archigram o Archizoom cuya obra analizamos en anteriores apartados. Al interrogarnos sobre el devenir de aquellas experiencias radicales que vinculaban arquitectura, ciudad y movimiento de un modo desprejuiciado, tenemos que acercarnos de nuevo a Londres y a una de las figuras fundamentales surgidas de la Architectural Association a finales de la década de los setenta. Me estoy refiriendo a la arquitecta anglo-iraquí Zaha Hadid, cuya obra está 

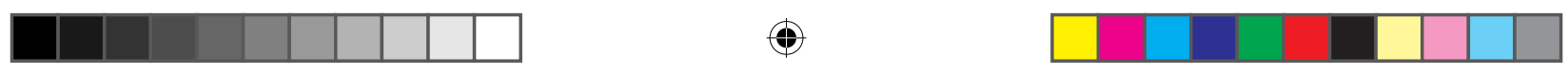

muy influenciada por todos aquellos movimientos vanguardistas de mediados del siglo pasado, y que posee una componente dinámica y fluida determinante. $^{1}$

Desde el inicio de su carrera, Zaha Hadid ha estado experimentando con los límites del diseño arquitectónico. Sus proyectos han sido múltiples y variados, pues ha construido edificios, ha realizado proyectos de mobiliario y de es-

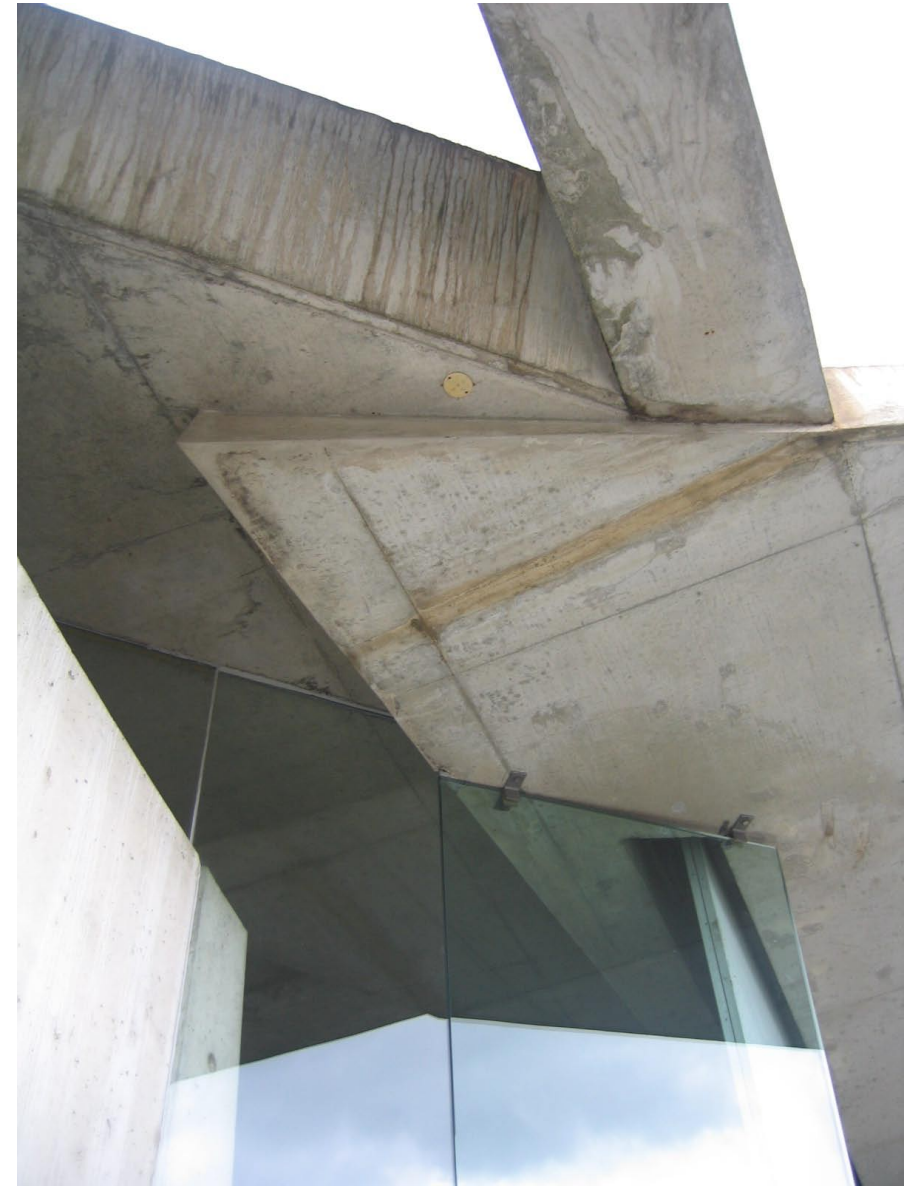

Zaha Hadid, Estación de Bomberos de Vitra, 1991-93, (fotografía I.C.).

1 Aeste respecto podemos conocer la opinión tan favorable del propio Peter Cook (pieza fundamental del grupo Archigram) en su texto "The Emergence of Zaha Hadid" en VV.AA. Zaha Hadid. Complete Works, Thames \& Hudson, Londres, 2004, p.8. tructuras temporales, ha creado instalaciones y ha planteado montajes de exposiciones donde la estaticidad parece completamente desterrada. Al comienzo de su carrera, en la época de estudiante en Londres y los primeros años de actividad profesional, uno de los elementos más personales de sus obra fueron los dibujos y pinturas en los cuales ella no renunciaba a fugas imposibles y puntos de vista de acelerado dinamismo, considerándolos como un importante medio para la experimentación e investigación (plástica y espacial) en el proceso de creación. Con ellos, Hadid saca a la

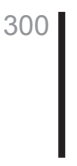



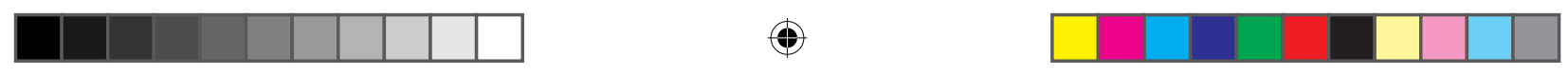

\section{Experiencias entre el arte y el urbanismo en torno al movimiento.}

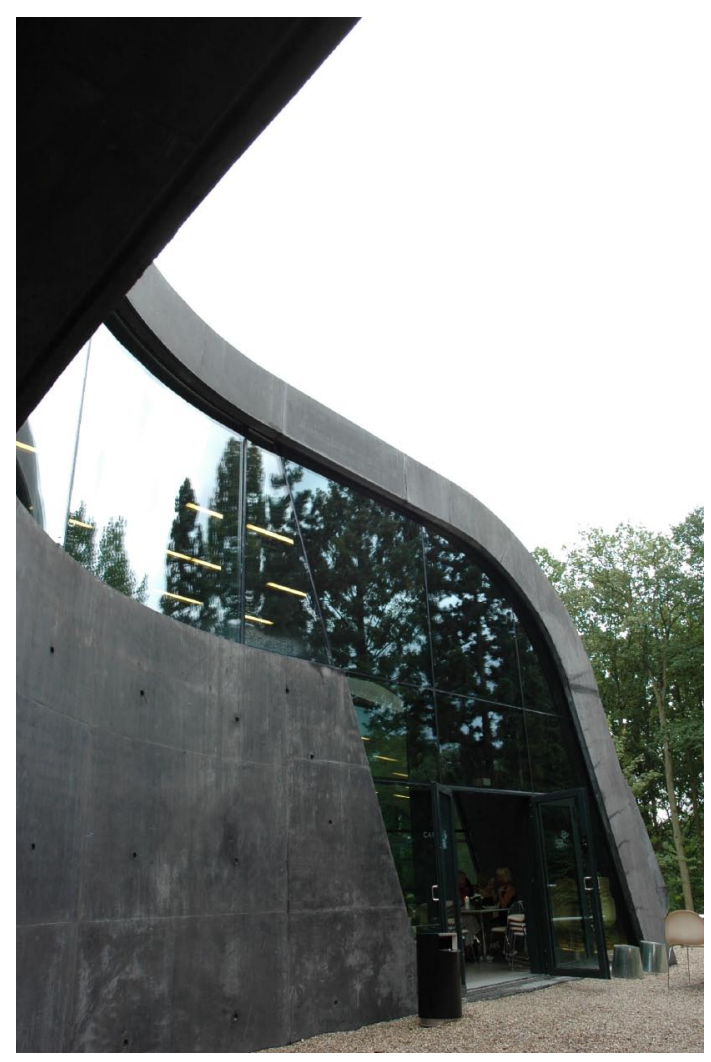

Zaha Hadid, Museo

Ordrupgaard en Copenhague, 2001-05 (fotografía I.C.). luz los espacios inconscientes u ocultos, encuentra aquello que late en las diferentes construcciones y audazmente explora los ritmos de la vida cotidiana para concretarlos en proyectos que concibe como si fueran la plasmación grafica de la explosión de la materia en el espacio. Sus ideas son como una ráfaga inicial donde las detonaciones y erupciones desparraman y diseminan diferentes elementos, líneas, superficies, formas, paisajes, contexto urbano y porciones de color en un vacío desconocido, evocando inestabilidad y movimiento perpetuo.

Fueron precisamente esta inestabilidad y este movimiento los que supusieron un freno inicialmente en la oportunidad de la arquitecta iraquí para construir sus proyectos, para trasladar directamente el dinamismo y la fluidez de su caligrafía pictórica (los dibujos y bocetos) hacia los sistemas constructivos y no tanto por su capacidad, como se ha demostrado, sino por la falta de confianza de promotores y políticos en una obra que agitaba los cimientos demasiado estancos del quehacer arquitectónico. El nivel de experimentación, en los dibujos y pinturas de sus comienzos, llegó a un punto donde la distinción entre forma y contenido se disipaba de modo que no se podían distinguir, o se confundían, cuáles eran los trazos gráficos que pertenecían a cada aspecto. ${ }^{2}$ Hadid ha sido capaz, posteriormente, de llevar las proyecciones isométricas y las perspectivas hacia distorsiones literales del espacio, desde unas axo-

2 La fascinación que la arquitecta siente por los arquitectos constructivistas rusos es determinante y su influencia se hace patente en estos dibujos de sus primeros años como por ejemplo las plantas para el proyecto del Club Peak en Hong Kong (1982/1983). 

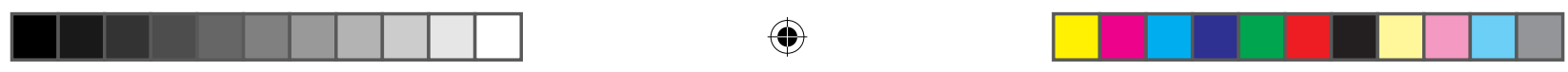

nometrías explosionadas hasta la eclosión del espacio en fragmentos.

Un buen ejemplo de ello es una de sus primeras obras: la Estación de Bomberos de Vitra (1991/1993). Aquí, como la propia arquitecta nos explica: "en lugar de diseñar el edificio como un objeto aislado, se desarrolló como un límite de la zona paisajística; es decir, definiendo el espacio en lugar de ocuparlo." 3 Eso se aprecia cuando observamos que toda la obra está concebida desde y para el movimiento. En primer lugar exteriormente, a partir del recorrido lineal exterior que conecta los espacios de la fábrica y posiciona la obra revelándose la obra desde una perspectiva siempre fugada. En segundo lugar, en cuanto al espacio propiamente de la obra, donde tanto los recorridos en el asfalto de los grandes camiones rojos como los movimientos coreográficos de los bomberos que aparecen señalados en el suelo, a modo de pequeñas anotaciones, buscan tensar el espacio de manera que la necesidad de permanecer alerta y la posibilidad de entrar en acción en cualquier momento vertebran todo el proyecto. Los espacios así conseguidos, son la resultante de perforaciones, inclinaciones, quiebros

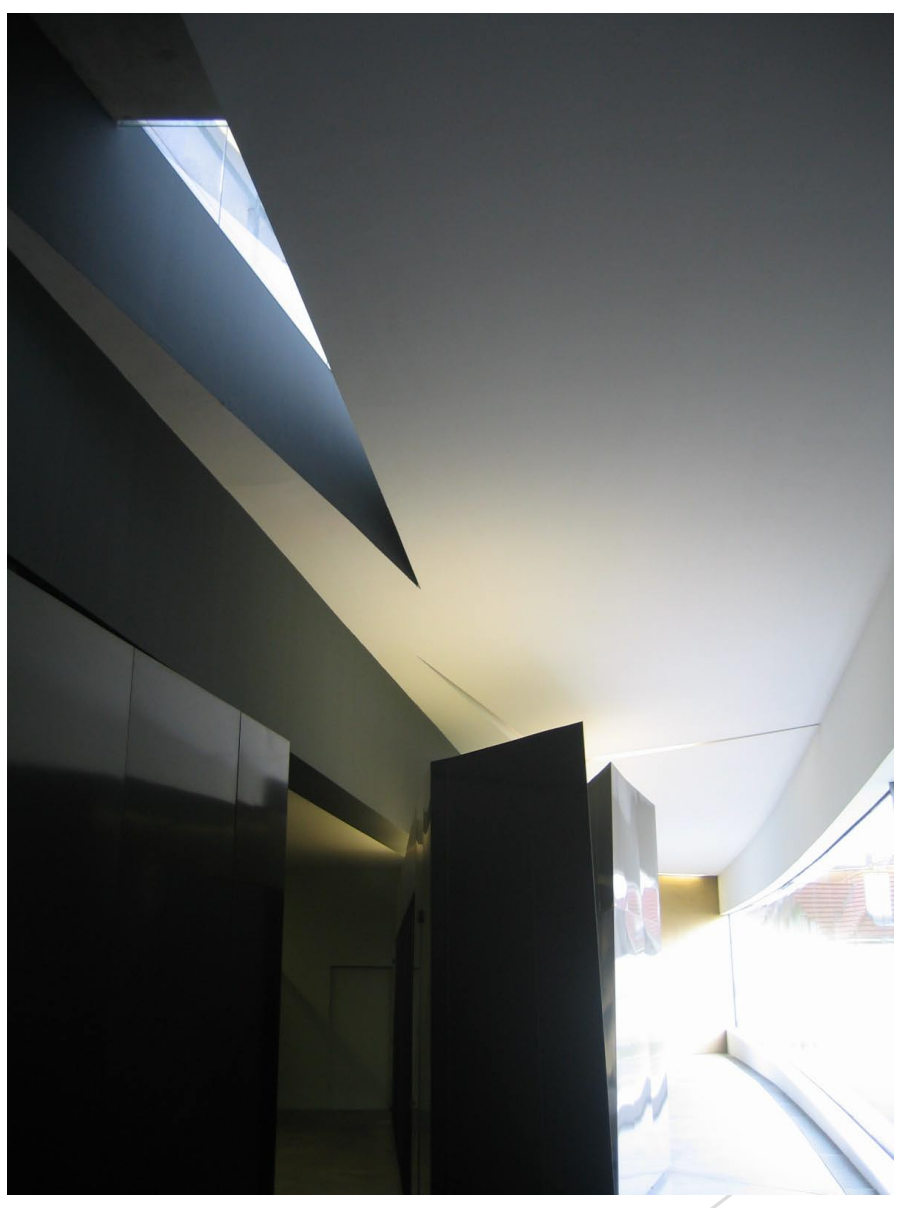

Zaha Hadid, Estación de Bomberos de Vitra, 1991-93, (fotografía I.C.).

3 Declaraciones recogidas en VV.AA. Zaha Hadid 1983-2004, El Croquis, Madrid, 2004, p.140. 

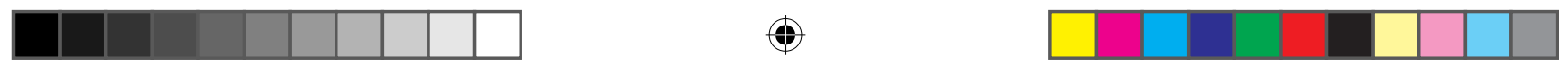

\section{Experiencias entre el arte y el urbanismo en torno al movimiento.}

Zaha Hadid, Estación de Bomberos de Vitra, 1991-93, (fotografía I.C.).

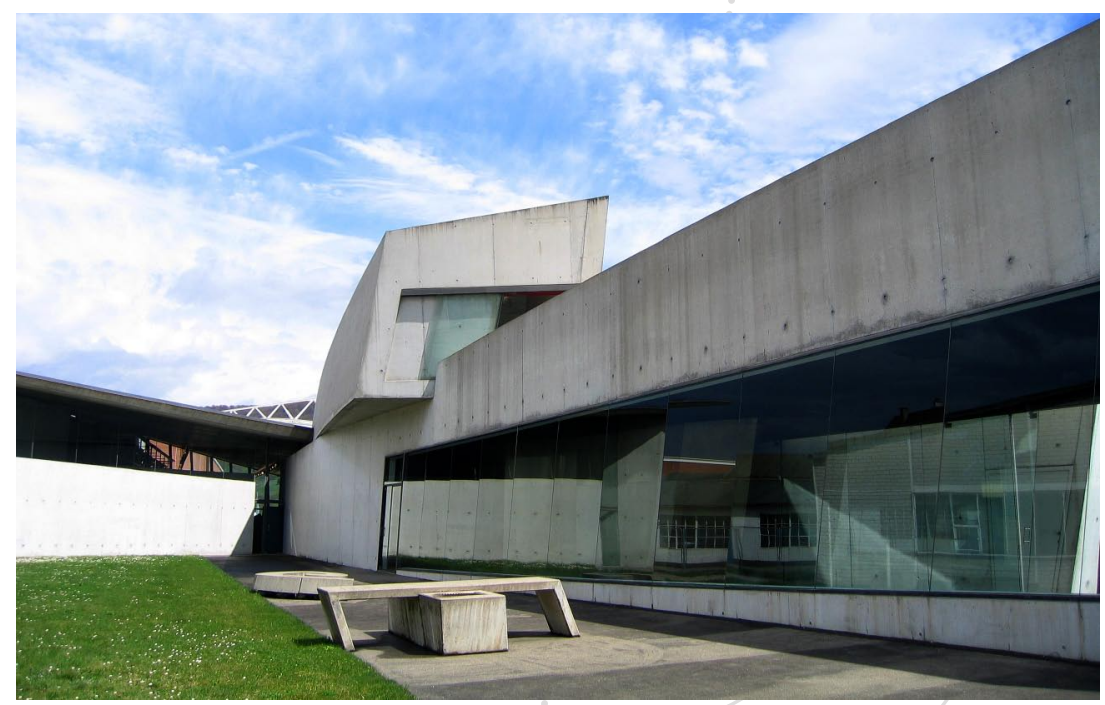

y giros de acuerdo a diferentes requerimientos funcionales y plásticos. Los muros parecen deslizarse unos sobre otros, e incluso las puertas correderas, debido fundamentalmente a su escala y movimiento, inciden en este aspecto formando verdaderos muros móviles. Tal y como nos señala su propia autora, "El edifico entero es movimiento congelado"4.

Podemos decir que una parte importante de la contribución de Hadid a la cultura espacial actual se refiere, muy especialmente, a las invenciones tipológicas y a la sugerencia de nuevos métodos de orientación, navegación y hábitat en la ciudad contemporánea.

La obra de Zaha Hadid surge de poner especial énfasis en una concepción de la construcción de los espacios donde las partes ya no se corresponden exactamente con el todo, como sucede en la planificación arquitectónica más tradicional, en la cual nada puede ser anulado o añadido sin perturbar o transformar el conjunto. Su intención, por el contrario, es crear espacios sin fin (abiertos, adaptativos, ligeros, flotantes y flexibles) con la posibilidad de aumentarlos fluidamente según las necesidades de cada momento. Como ella misma gusta de manifestar, la ciudad fluye hacia dentro y el proyecto fluye hacia fuera. Así y para dar respuesta

4 Ibídem, p.140. 


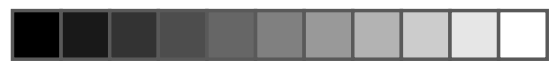

(†)
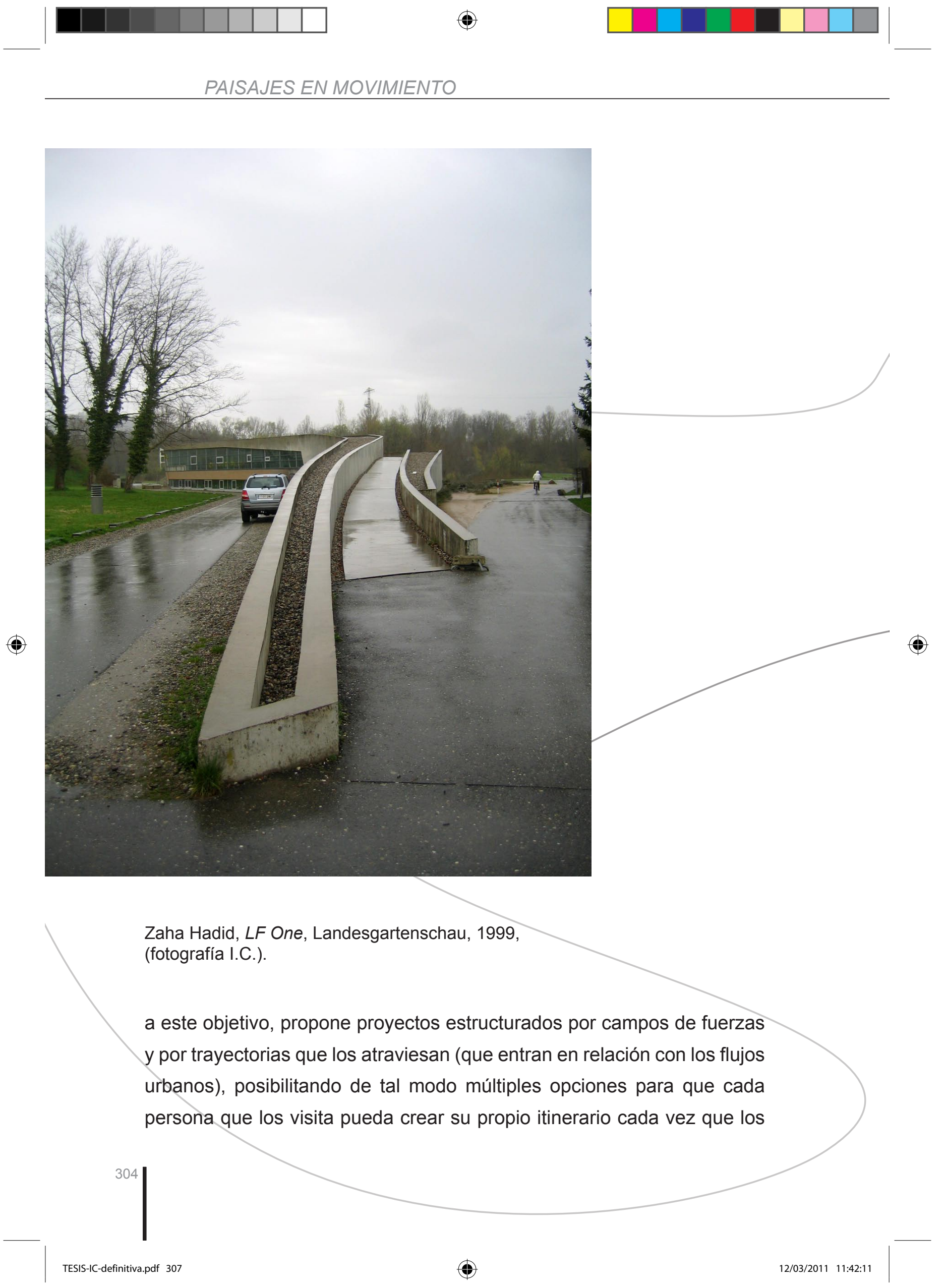

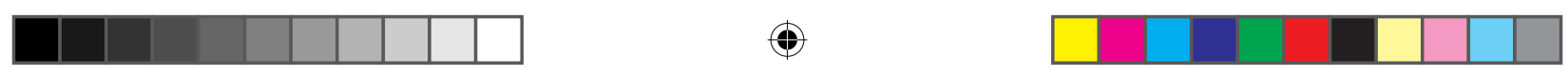

4. Experiencias entre el arte y el urbanismo en torno al movimiento.

recorre. Se trata de una idea de progresión espacial en contraposición a la de recorrido lineal, un diagrama de red abierto que permite una amplia multiplicidad de trayectos serpenteantes (dentro y fuera, arriba y abajo...) para llegar a obtener organizaciones ambiguas que se interceptan visualmente al tiempo que mantienen una articulación de lo heterogéneo y hacen posible promover acontecimientos espaciales poco frecuentes.

A este respecto, es muy significativo uno de sus primeros proyectos, el LF One en Landesgartenschau (1999). Este centro polifuncional (en principio destinado a celebraciones y exposiciones) surge, a partir de la atenta lectura del entorno, del entrelazamiento de tres de los caminos de la red que lo rodean y que generan los espacios del edificio, tanto exteriores como interiores. El primero de ellos se eleva formando un recorrido de fuerte componente paisajística, el segundo queda agazapado en un lateral y el tercero describe una atractiva curva que atraviesa diagonalmente el edificio. Los cuatro espacios interiores, longitudinales y parcialmente entrelazados, quedan definidos a partir de esta geometría delicada y dinámica. Este "haz de espacios", como lo define la propia arquitecta, formaba parte de una investigación cuyo objetivo era obtener nuevas espacialidades fluidas a partir del análisis de formaciones propias del paisaje natural. "Las características generales más importantes que nosotros buscamos en los espacios paisajísticos -al contrario de lo que ocurre con los espacios urbanos y arquitectónicos tradicionales- son la abundancia de definiciones territoriales y la sutileza de éstas, así como la fluidez de las transiciones entre los espacios." ${ }^{5}$

En esta obra podemos encontrar aspectos fundamentales de su personal concepción arquitectónica que reaparecerán posteriormente en proyectos más recientes y ambiciosos, como el Centro de Arte Contemporáneo de Roma (MAXXI) recientemente inaugurado que comentaremos más adelante. Estos últimos proyectos, Hadid, insiste en orientarlos horizontalmente e incluir el suelo (y su manipulación) como un material constructivo más, cara a establecer una nueva situación urbana. Es la

5 Ibídem, p.290. 

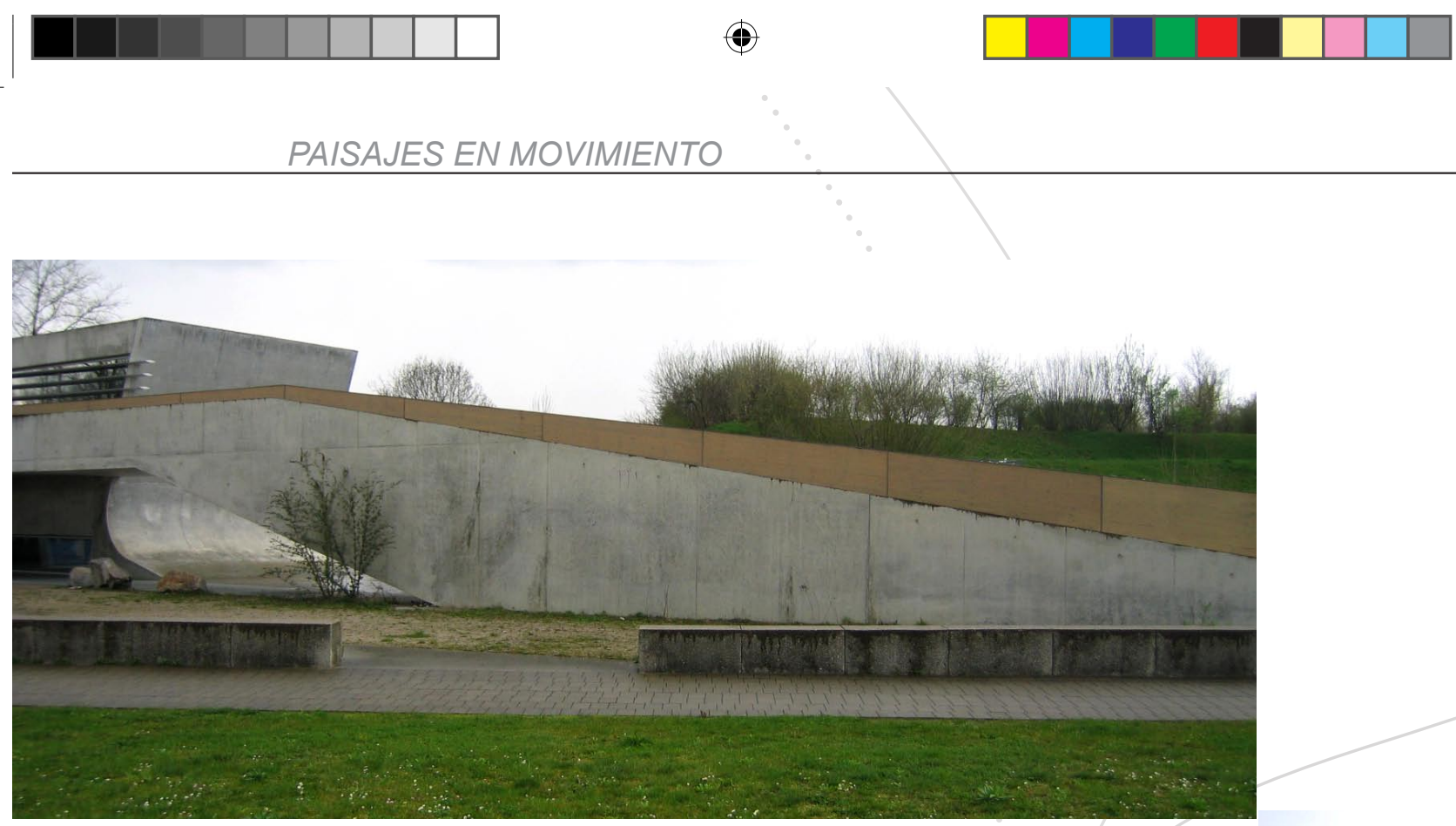

Zaha Hadid, LF One, Landesgartenschau, 1999, (fotografías I.C.).

idea de que el campo de fuerzas, que ella menciona constantemente, se exprese y cree una fuerte tensión en las estructuras que las encorsetan y pretendentraspasar. Mediante una relación fluida, la arquitecta iraquí, desea vincular muy estrechamente planteamientos del urbanismo y del paisaje hacia el interior de sus edificios. Para ella ya no existe una topografía natural sino que se inventa un nuevo paisaje en el que el espacio ya no está fijado a una sola zona, sino que se extiende al mundo subterráneo o al nivel de la calle, aunque también puede subir más. Así, su arquitectura se extiende en todas las direcciones espaciales (y se articula el vacío) en lugar de quedar bloqueada en un único plano. De este modo, sus proyectos se amplían bajo tierra cuando el/suelo se parte y se levanta, con lo cual se puede ocupar el espacio subterráneo como si fuera otro suelo. Según explica ella misma, "Es la multiplicidad de los suelos para crear muchos espacios cívicos e intensificar la actividad ciudadana. Articular el suelo como una topografía estratificada, alabeando y multiplicando su superficie"6. Como se puede apreciar es una contundente violación de la lógica espacial con el propósito de matizar su organización y su articula6 Ibidem, p.57.

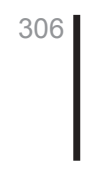



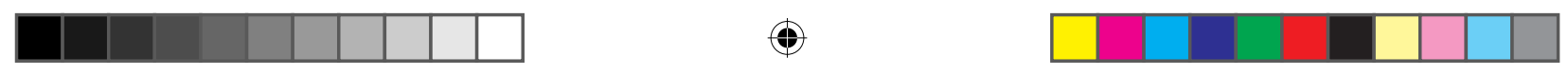

\section{Experiencias entre el arte y el urbanismo en torno al movimiento.}

ción ampliándola y enriqueciéndola.

De esta manera, Zaha Hadid consigue dotar a sus propuestas de una gran flexibilidad, de una destacada fluidez y de una importante sensación de transparencia, pese a que muchos de sus edificios están construidos con hormigón armado. Dibuja sus edificios como volúmenes ligeros que parecen casi flotar, sugiriendo que la manipulación que lleva a cabo de la geometría y de la estructura puede liberar al espacio de sus fronteras. Con lo cual les dota de esa sensación de transparencia, al tiempo que abre posibilidades para la interpretación de un nuevo espacio que se

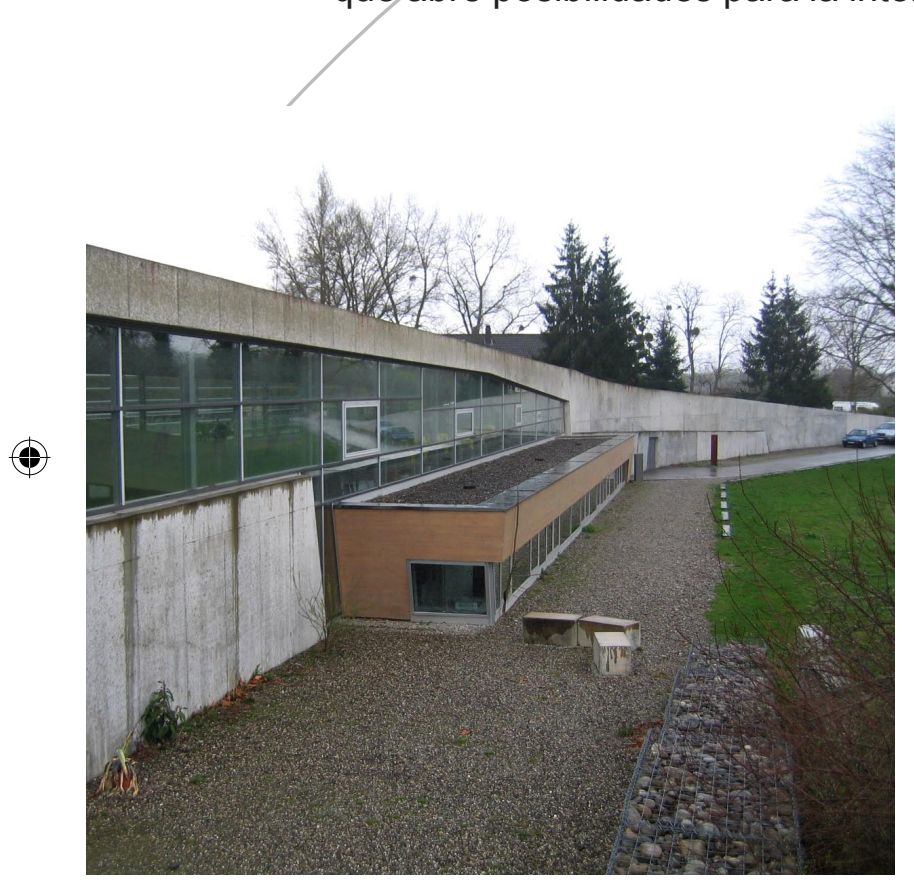
presenta a la vez, denso y abierto, definido e indefinido, real y virtual. Según le gusta explicar, "Se trata de ofrecer un espacio que, de manera variada, proporcione a la gente un placer, un goce, un descanso y un bienestar similares a los que podrían disfrutar en el paisaje (...) Lo verdaderamente primordial consiste en añadir algo a nuestras vidas. Esto supone reinventar permanentemente las formas de nuestro marco vital, cuestionar la visión que tenemos de él y cómo lo habitamos"7. Por esta razón, varios de sus proyectos intentan conseguir nuevas espacialidades fluidas a través del estudio de formaciones del paisaje natural. Hadid busca la abundancia de definiciones territoriales y la sutileza de diferentes ámbitos que se penetran entre sí, donde las distinciones son vagas y latentes, llegando a pensarse que carecen de orden y definición; y sin embargo, contienen unas analogías potenciales que favorecen la invención de intervenciones complejas, múltiples y transitorias.

7 VV.AA. Zaha Hadid. Architektur, Hatje Cantz Verlag, Ostfidern-Ruit, 2003, p.38. 


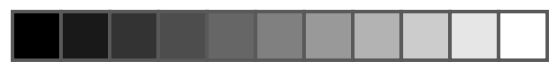

$\oplus$

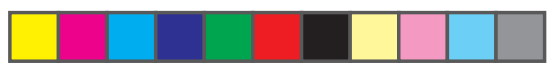

Su escenografía para la ópera contemporánea Begehren (Deseo), en Graz en el 2003, por ejemplo, es la evocación de un paisaje surreal en constante transformación. La estructura escénica evoca un paisaje translúcido y etéreo que está conformado por diferentes capas de distintos materiales que provocan un espacio híbrido, en el que el público experimenta un panorama de transformaciones multidimensional y una experiencia plurisensorial de metamorfosis. O, sirva como ejemplo también, su diseño para el pabellón egipcio en la Exposición Universal de Shanghái 2010, donde Zaha Hadid nos propone un caja neutra, una boîte à miracles que esconde en su interior una escenografía onírica y fluida donde el movimiento de los visitantes hace reverberar las cintas de moebius que se entrelazan y confunden organizando el espacio inundado de objetos y de personas en constante desplazamiento para disfrutar de las diferentes atracciones del pabellón. El movimiento continuo parece

Zaha Hadid, Pabellón de Egipto en Exposición Universal Shanghai, 2010, (fotografías I.C.).

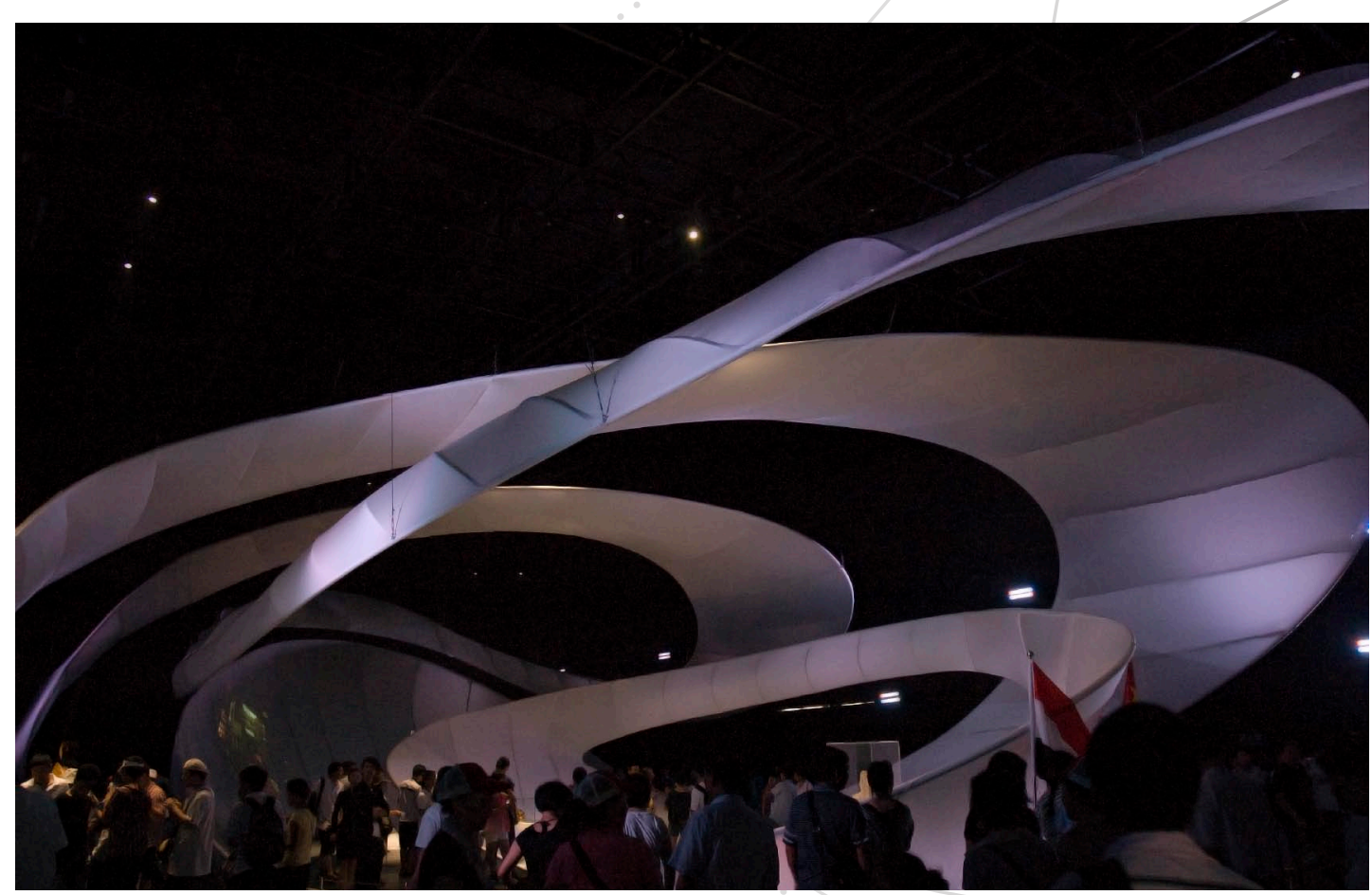



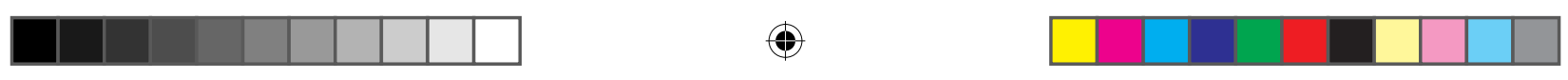

\section{Experiencias entre el arte y el urbanismo en torno al movimiento.}

haber reemplazado a la forma como elemento dominante de su arquitectura, consiguiendo hacer de su obra una experiencia mucho más abierta, lírica y experimental con espacios más visuales dinámicos y versátiles.

Así, en vez de compartimentos preconcebidos y exclusivos, Hadid desarrolla elementos extraños y ambiguos que ocasionan una complejidad espacial que al mismo tiempo te captura y te libera. Es una transformación morfológica de los edificios en el que la estructura se conforma

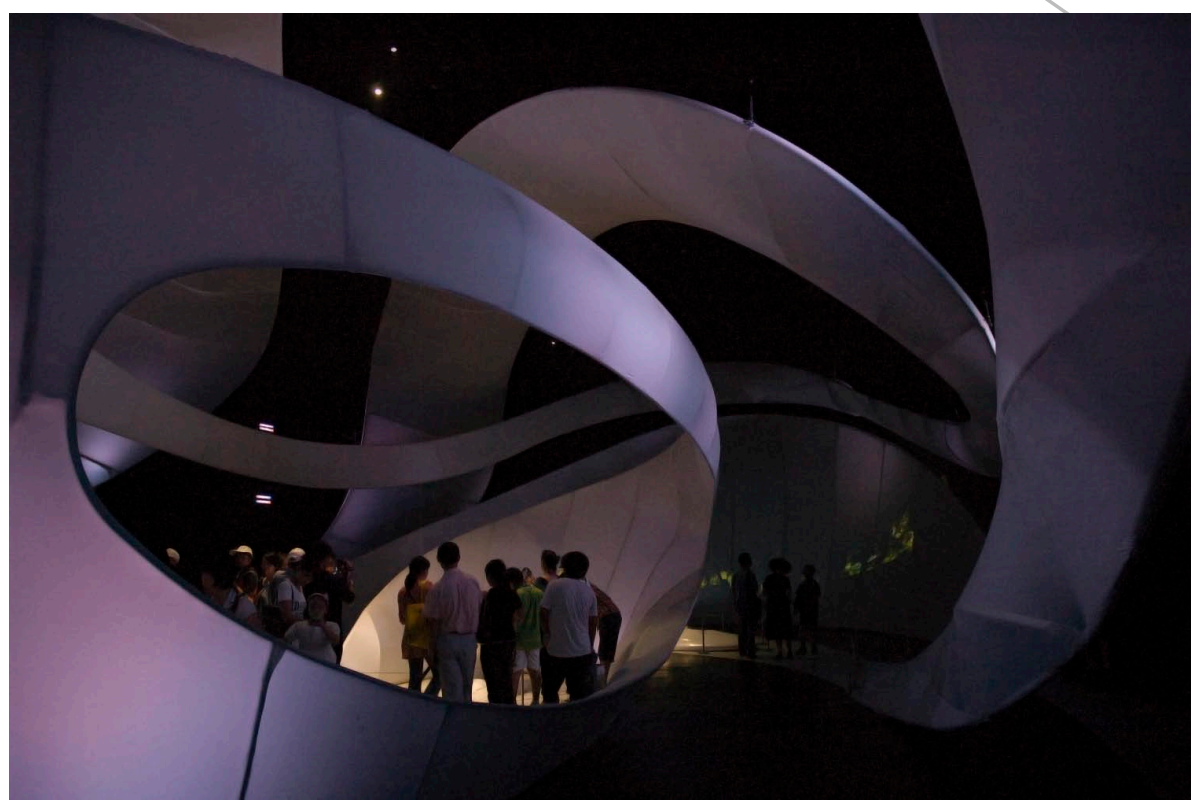

como "un espacio que respira" gracias a la transición constante entre comprensión y liberación. Una transición que posibilita un proceso dinámico que activa la construcción permitiendo ángulos de más de $90^{\circ}$, líneas que se replantean su regularidad a la hora de atravesar el espacio, y planos que aparecen conformados de sutiles curvaturas e intersecciones. Zaha Hadid está muy interesada en posibilitar espacios de acontecimientos en permanente cambio, como es el proyecto para el Chanel Mobile Art, un pabellón de exposiciones temporales de arte contemporáneo de la firma multinacional, que esta vez no surge ligado siquiera a un contexto concreto sino que está creado para ser montado y desmontado en 

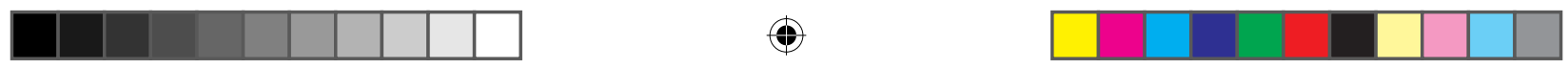

diferentes localizaciones. Esta sala (pensada inicialmente para Tokio, Paris, Hong Kong y Nueva York) está ideada como una formación paisajística blanda, como un paisaje de formas suaves.

Como vemos sus proyectos siempre han tenido una fuerte componente líquida (ligada al paisaje) con volúmenes cayéndose, elevándose o desparramándose (al modo de las obras de Robert Smithson) ${ }^{8}$, desafiando las convenciones arquitectónicas rígidas y proponiendo nuevas potencialidades basadas en la elasticidad, la flexibilidad y la ductilidad. Una buena muestra de ello es su proyecto de ampliación para el Museo Ordrupgaard en Copenhague. EI

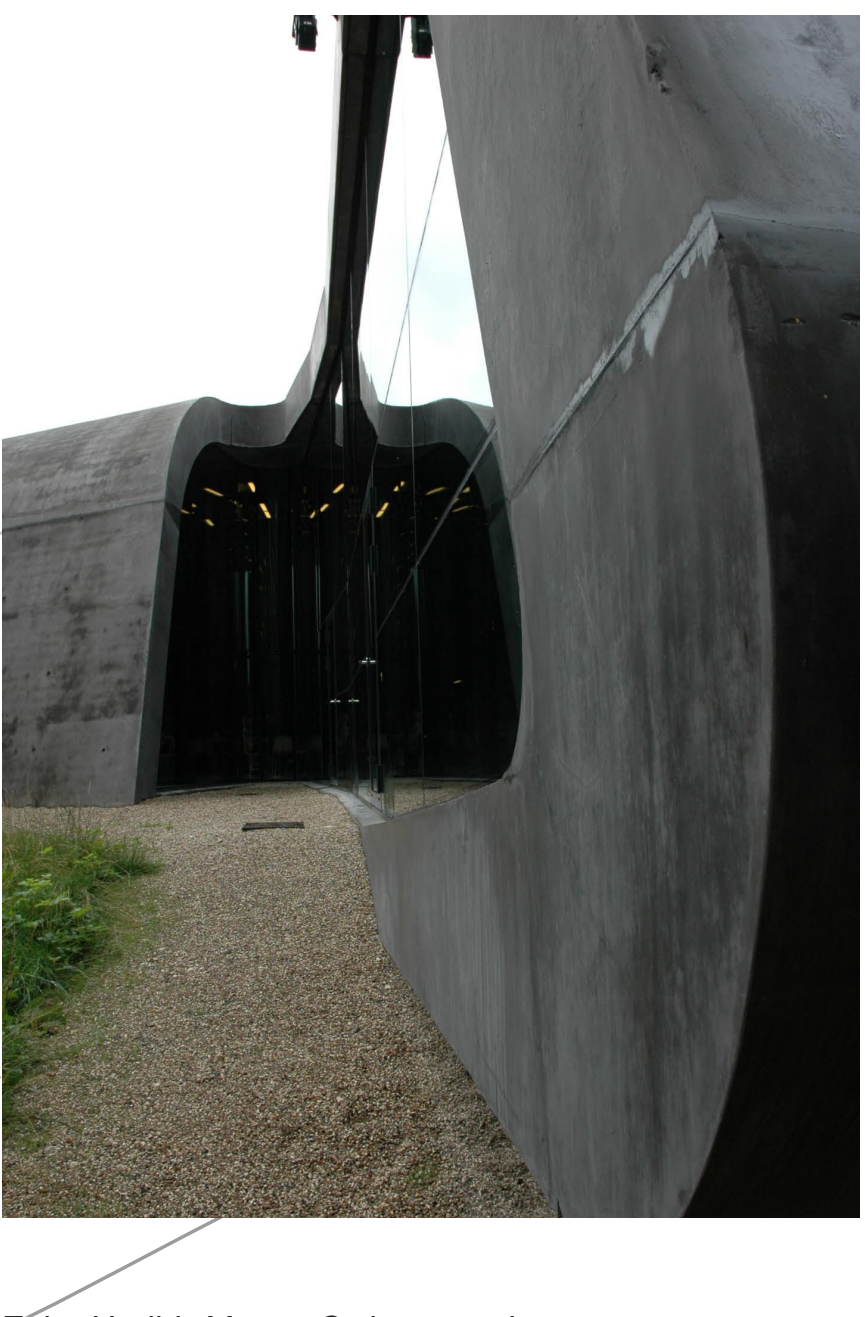

Zaha Hadid, Museo Ordrupgaard en Copenhague, 2001-05 (fotografía I.C.). nuevo edificio surge como una formación paisajística blanda, como un paisaje de formas suaves a pesar de la contundencia estática del hormigón armado negro con el que construye el volumen, creando así una forma geológica de múltiples resonancias. El dinamismo y la fluidez del conjunto sugieren un énfasis en el movimiento a través de y alrededor del edificio.

El lenguaje arquitectónico de Zaha Hadid insiste en la comple-

8 Como por ejemplo en su conocida obra Asphalt Rundown, Rome (Derramamiento de asfalto, Roma), 1969, que vimos en el capítulo anterior.

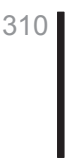



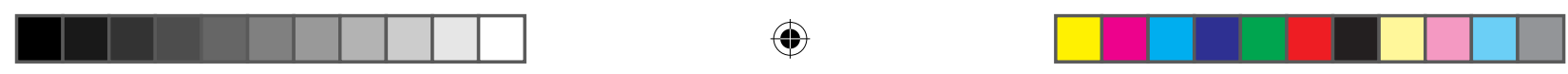

\section{Experiencias entre el arte y el urbanismo en torno al movimiento.}

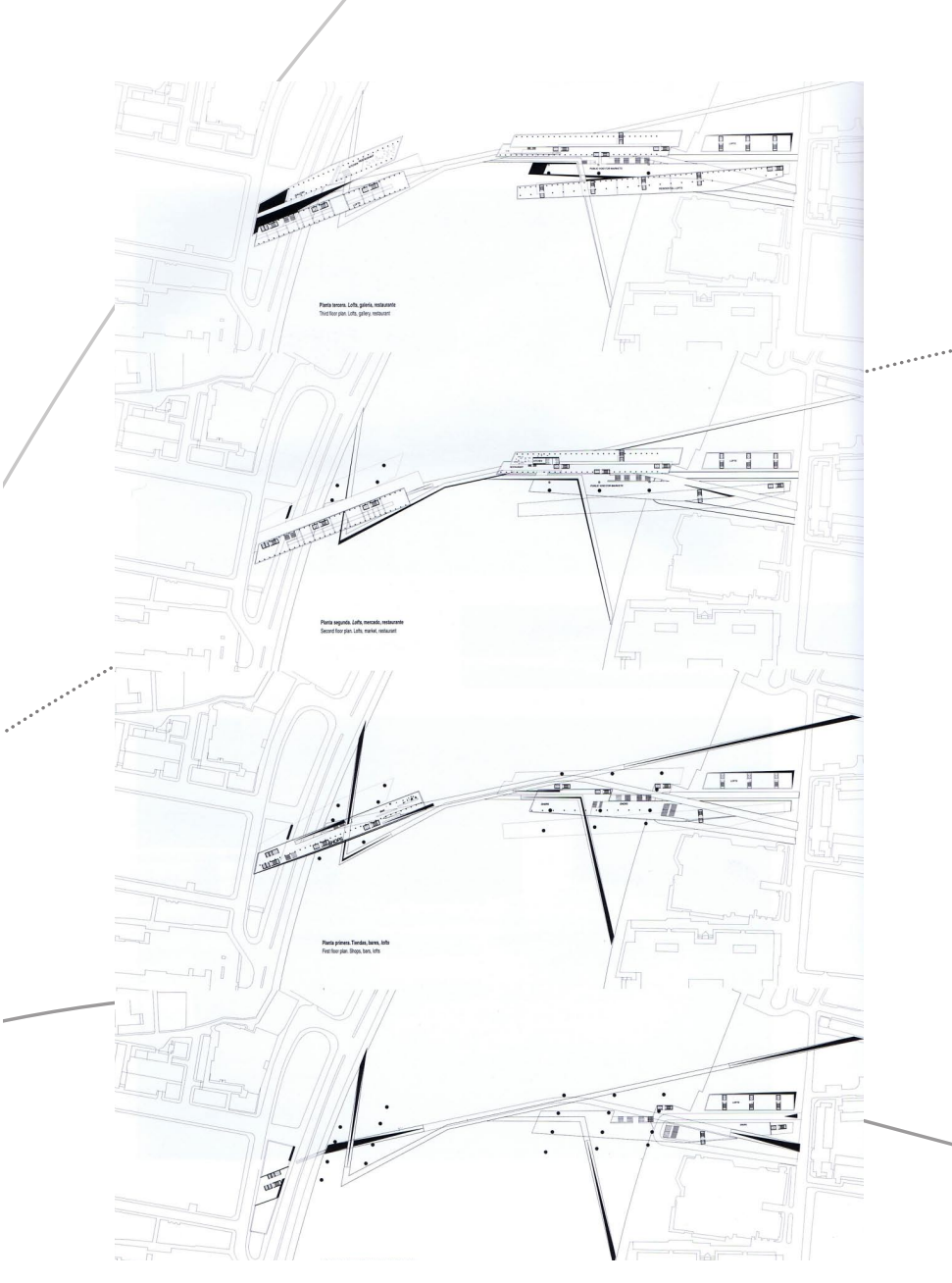

Zaha Hadid, Puente sobre el Támesis 1996.

jidad de curvas y planos, sin fisuras, y en una transición fluida entre elementos dispares. Con esta conformación del espacio se alienta a los usuarios y/o visitantes a reinventarse a sí mismos en términos vinculados a las actitudes, posturas, estilos o movimientos. Es por este motivo que a la arquitecta anglo-iraquí siempre le han interesado los puentes, pero no de un modo convencional, sino como lugares de enorme potencialidad donde transformar dichas actitudes. Sus puentes son lugares del tránsito pero también de la permanencia, del mismo modo que el resto de sus arquitecturas son lugares del estar pero también del pasar. Su proyecto para un puente habitable sobre el Támesis en Londres (1996), funde diversas tipologías en un rascacielos horizontal que se fragmenta haciendo interrelacionarse diversas partes de la ciudad.

Aunque no lo construyó, la experiencia del puente sobre el Támesis está presente en la obra más significativa de la arquitecta en España: el puente sobre el Ebro que construyó en Zaragoza con motivo de la Exposición Universal de 2008. Aquí, de todos modos, no es el paisaje urbano el que toma las riendas sino un entorno mucho más natural, de modo que el puente se transforma en topografía en lugar de en edifica- 

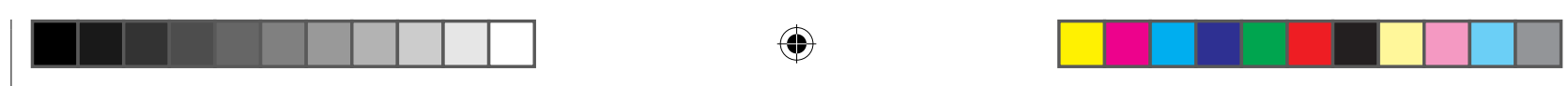

ción fragmentada. En Zaragoza, las referencias orgánicas son fundamentales, transformando el puente en un paisaje. Un paisaje, en el que nos introducimos bien para llegar de un extremo al otro o bien para detenernos en sus sugerentes espacios interiores donde las rampas, las luces y las sombras producidas por los huecos y las líneas de luz dirigen el movimiento, acelerándolo y ralentizándolo a conveniencia, conectando los distintos espacios. El pabellón está compuesto por cuatro volúmenes longitudinales, (denominados vainas (pods) en el proyecto), que surgen a partir de la extrusión de una sección estructural y espacial en forma de diamante a lo largo de varias directrices curvas, produciendo una sorprenderte y compleja estructura espacial cuya imagen nos remite al mundo de la biología. El cruce de los diferentes volúmenes filiformes, multiplica las posibilidades de vivencia del pabellón, generando con sus desplazamientos un espacio dinámico y fluido de intercambio y conexión.

Con similares inquietudes y contemporáneos a Zaha Hadid surge el grupo de arquitectos NOX, fun-dado en Rotterdam en 1990 y dirigido por el arquitecto Lars Spuybroek. Este colectivo holandés, más que un estudio de arquitectura convencional, es una amalgama de profesionales y medios múltiples interviniendo heterodoxamente en la realidad circundante. Con una profunda vocación multimedia llevan a cabo una práctica en la que relacionan amplia e íntimamente la arquitectura con los mass media, la vídeo-creación y las instalaciones, los textos y las revistas. Según manifestó el propio Lars Spuybroek, "Estamos experimentando una extrema liquidación del mundo, de nuestro lenguaje, de nuestro género, de nuestros cuerpos... (hemos entrado) en una situación donde todo está mediatizado, donde toda materia y espacio están fusionados con su representación en los medios de comunicación, cualquier forma está combinada con información." Para él todo se encuentra en estado de apertura y no de fijación, sus investigaciones y proyectos desean buscar la fusión del cuerpo con el medio ambiente y la tecnología en un continuum en constante mutación.

9 Spuybroek, Lars, NOX, Machining Architecture, Thames \& Hudson, Londres, 2004, p.26. 


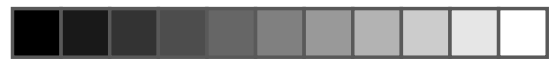

$\oplus$

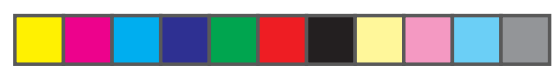

4. Experiencias entre el arte y el urbanismo en torno al movimiento.

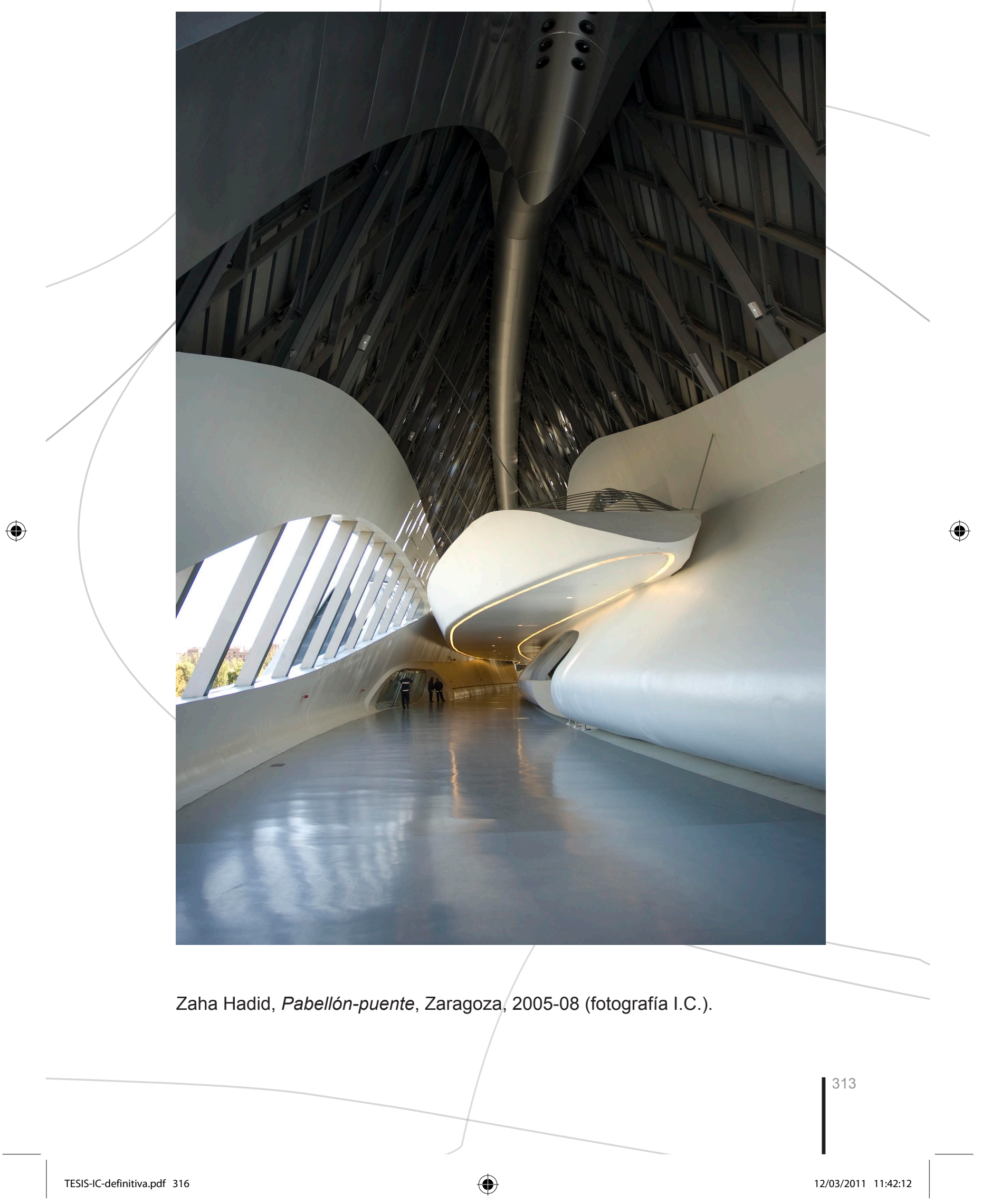



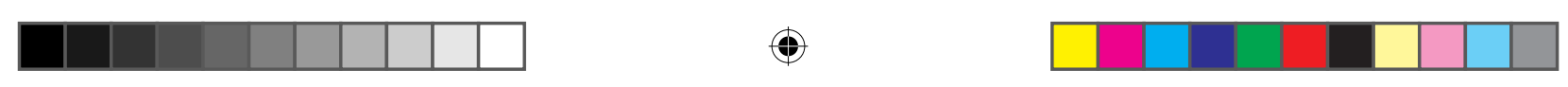

NOX, Pabellón de agua dulce, Neelteje Jans, 1993-97.

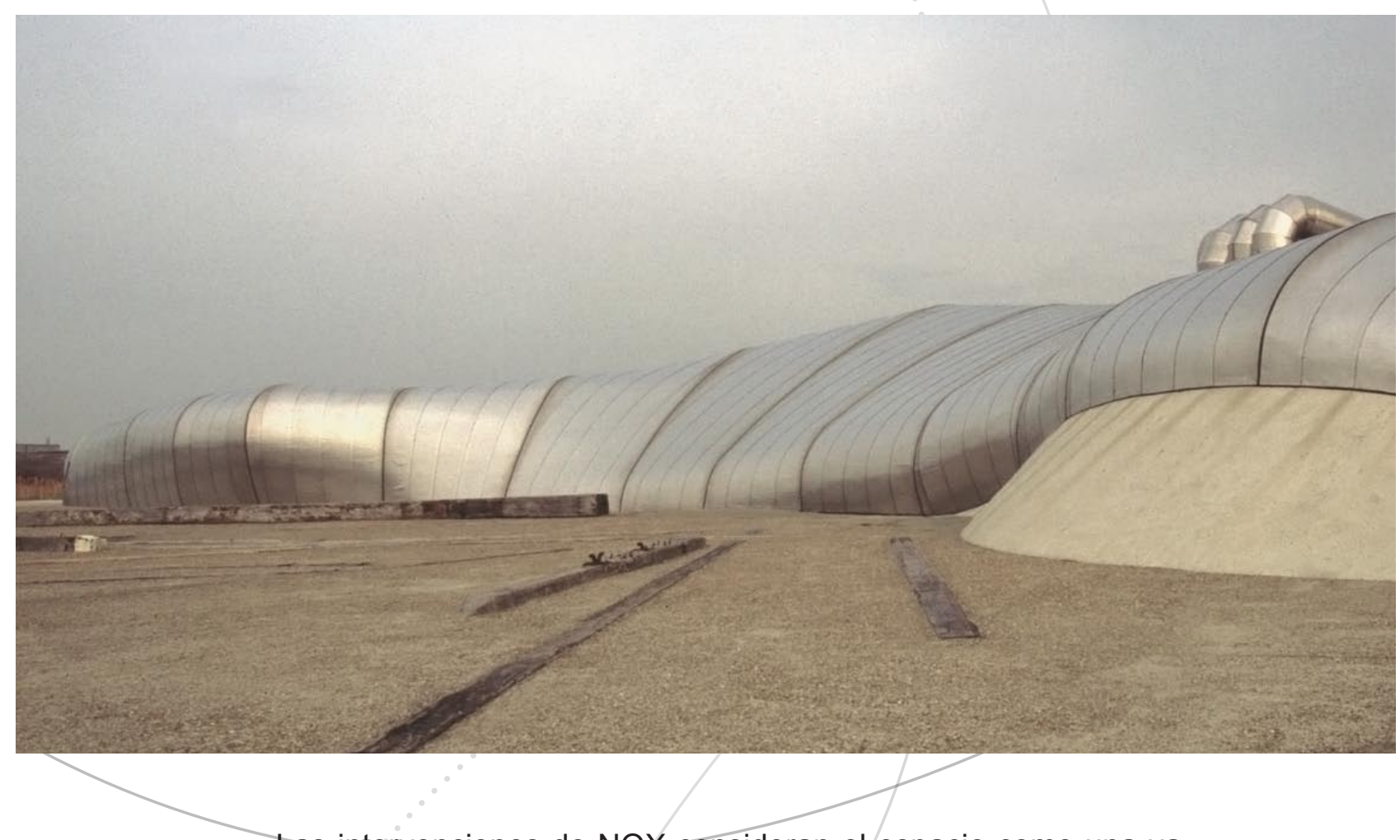

Las intervenciones de NOX consideran el/espacio como una variable más de los comportamientos humanos y no su contenedor y, ni mucho menos su inductor. Existe en ellos una voluntad de ir disolviendo el espacio real e ir pensando en un futuro donde la forma arquitectónica sea el resultado de diferentes vectores que partirán de los deseos y necesidades del cuerpo humano. De este modo los edificios se concebirán a modo de vestimentas ampliadas y sus formas extrañas y convulsionadas nos hablarán de la complejidad de nuestros pensamientos y sensaciones, se adaptarán a nuestros humores, a nuestros miedos y a nuestra sensualidad. Hablamos de una especie de "geometría motor" en la que el movimiento del cuerpo humano se relaciona directamente con la geometría transformativa del edificio. Es decir, se trataría de una conti- 

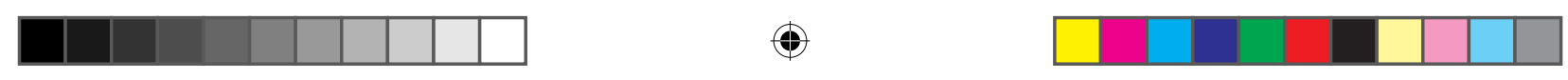

\section{Experiencias entre el arte y el urbanismo en torno al movimiento.}

nua mutación donde todo es móvil, un movimiento en espiral que afecta tanto a la estructura como a la circulación o a la forma y es concebido como un campo de abertura e indeterminación. Para

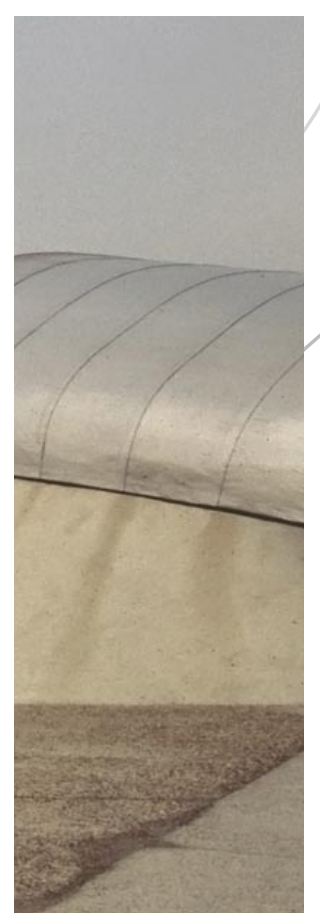
NOX el movimiento posee un carácter estructural no formal, es una compleja coreografía realizada y trazada por partículas digitales que permiten crear efectos inesperados, demostrando que los movimientos abstractos de la topología arquitectónica intensifican las sensaciones del cuerpo creando una mayor tensión psíquica y física.

Entienden la arquitectura como un medio fundamental para conectar los comportamientos y la acción, al mismo tiempo que le otorgan la capacidad de acelerar los ritmos y los ciclos corporales de tal forma que pueda abordar la plasticidad y la flexibilidad del cuerpo humano para integrarlo en un entorno tecnológicamente avanzado. En ese sentido, escriben: "Imaginen una tecnología que está dirigida hacia a aceleración del cuerpo más que a pretender calmarlo. Imaginen que la arquitectura está deglutida por la tecnología lo cual posibilita que sea completamente capaz de absorber e intensificar los ritmos corporales. Ello significa que los movimientos del cuerpo pueden afectar a la forma. Y, a la inversa, quiere decir que la forma rítmicamente podrá a su vez activar el cuerpo." 10 Se trata, por tanto, de una arquitectura flexible para un uso flexible, en la que la elasticidad de los materiales y de las formas sirve para crear unos proyectos moldeables, imprecisos y dúctiles. Diseñar espacios para facilitar funciones específicas pero también para estimular otras nuevas donde los estados determinados de los objetos son todavía legibles y usables como funciones pero también, donde estados menos determinados se pueden ir materializando para conseguir favorecer nuevos comportamientos. Un programa de elaboración de la arquitectura entendido como la exploración de la interconexión entre acción, percepción y construcción; una arquitectura que construye edificios con el propósito

10 Ibídem, p.52. 

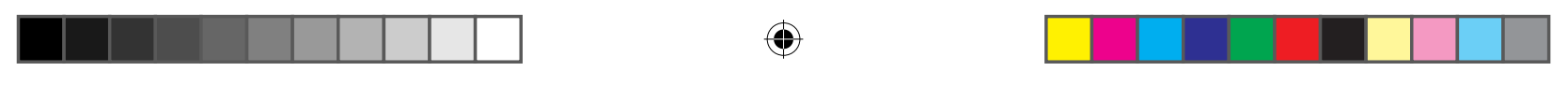

de reconstruir una experiencia, mucho más que el simple levantamiento de una estructura tectónica. ${ }^{11}$

A NOX le interesa la creación de lo que definen como "lo líquido" en la arquitectura pero, no sólo para capturar la geometría de lo fluido y de la turbulencia, sino también para disolver todo aquello que pueda ser entendido como sólido o estático. Persiguen una unión sin costuras de cuerpo y espacio, objeto y velocidad, piel y entorno que se traduce en una práctica que intenta fusionar el plano y el volumen, el suelo y la pantalla, la superficie y la estructura. En este sentido rechazan las experiencias mecanicistas convencionales del cuerpo en favor de un entorno más plástico y visceral en el que la acción humana (espacial, perceptiva y visual) adquiera un relevante protagonismo. De este modo, la blanda y líquida arquitectura que el colectivo NOX desea crear está directamente relacionada con la movilidad del cuerpo, con sus velocidades y sus movimientos, sugiriendo unos espacios de los que nunca podremos estar absolutamente seguros. Mediante una ingeniera genética de carácter digital cruzan las fronteras del cuerpo biológico dotándole de vida electrónica, generando formas líquidas en las que la acción humana y la arquitectura se encuentran sintetizadas.

Se trata por tanto del deseo de recolocar el cuerpo en la arquitectura y motorizar la realidad para así poder transformar, radicalmente, la experiencia de cómo vivimos y habitamos el espacio. A través de la fusión de arquitectura y tecnología NOX espera que los edificios se conviertan en estructuras blandas capaces de actuar y de reaccionar al comportamiento, la actividad y los deseos humanos e incluso, que esta ductilidad arquitectónica permita construir sistemas que literalmente se puedan llegar a mover con las personas para conseguir que los acontecimientos sean intercambios mutuos entre el cuerpo y su entorno más próximo. Así, desafiando los elementos perceptivos tradicionales, estas propuestas arquitectónicas introducen otros modos de conocimiento que les permiten

11 Aeste respecto puede consultarse Zellner, Peter, Hybrid Space: New Forms in Digital Architercture, Thames \& Hudson, Londres, 1999. 

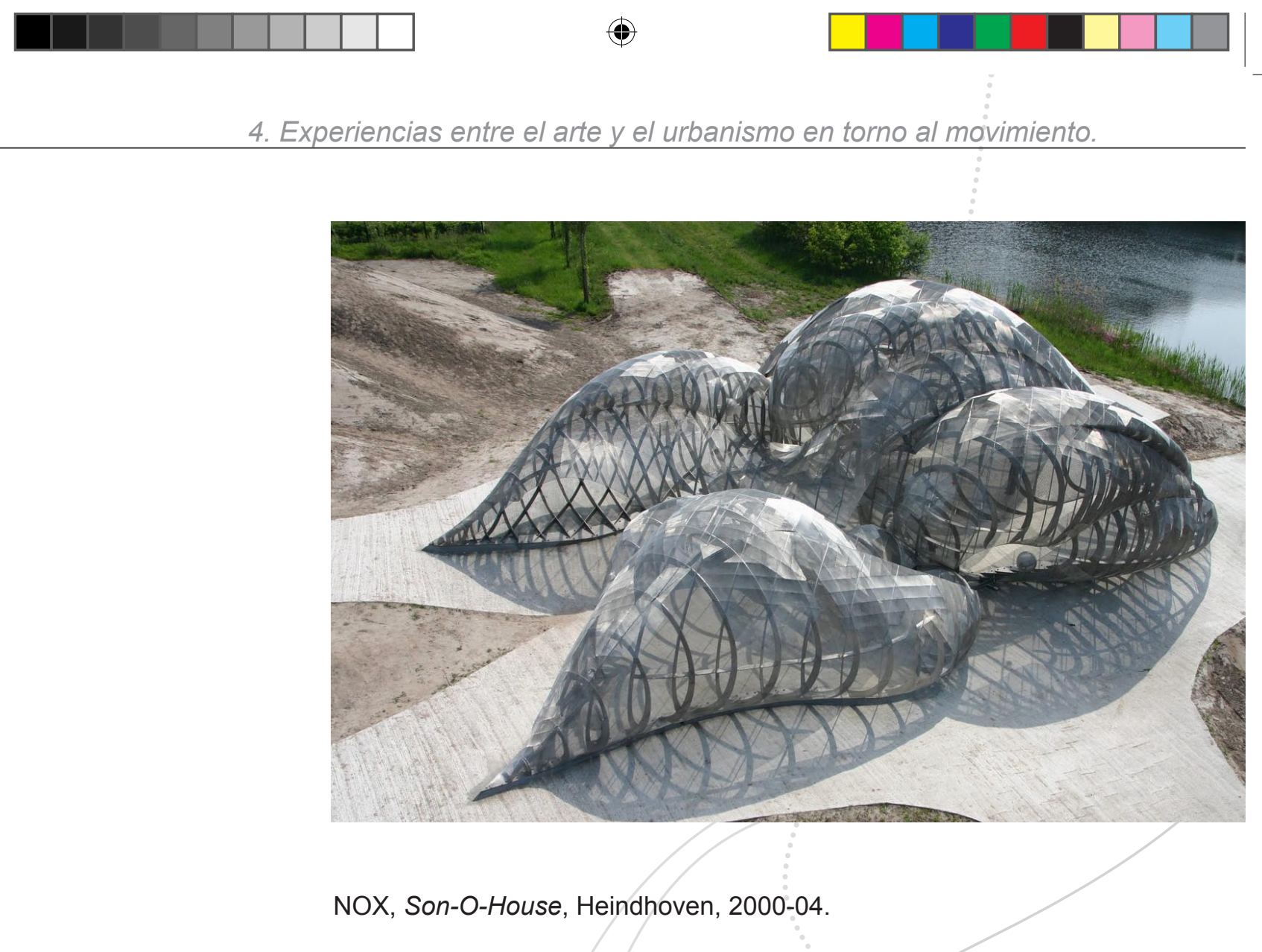

explorar nuevas funciones y diferentes programas constructivos.

Si nos acercamos a su obra para comprobar de qué modo se plasman estas inquietudes, el proyecto tal vez más interesante sea la SonO-House, la casa donde "los sonidos viven" (2000-04) situada en Eindhoven, Holanda. Es una obra situada en un barrio comercial de la citada ciudad y abierta veinticuatro horas al día, que actúa como una pieza de arquitectura y como un conjunto de sonidos en permanente transformación. El proyecto se basa en la interpretación de movimientos corporales en distintas escalas, captadas por alrededor de más de veinte sensores infrarrojos y utilizados para rizar, mezclar y distorsionar las superficies de un complejo juego de espacios. La estructura del edificio permite a las personas que lo visitan escuchar los múltiples sonidos y participar además en la composición de los mismos. Este relación interactiva ha sido desarrollada por el artista Edwin van der Heide con la pretensión de que las conductas humanas activen diferentes algoritmos (una cámara graba 


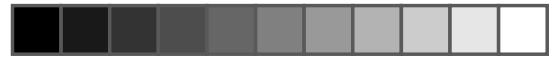

$\oplus$

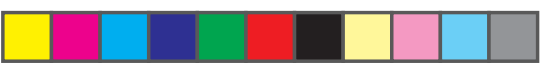

PAISAJES EN MOVIMIENTO

los movimientos corporales y un ordenador los analiza) cambiando la posición y los efectos espaciales del sonido. El pabellón posee una forma orgánica que se asemeja bastante a un gran animal abandonado en un paisaje extra-urbano. La estructura del mismo está completamente definida por ordenador y realizada en láminas de acero inoxidable en forma de complejo y extraño mosaico que se transforma completamente a medida que se modifican las condiciones de la luz que recibe.

Hay, de todos modos, en la producción de NOX, otra obra que quisiera destacar (con grandes vinculaciones con el puente de Zaragoza de Zaha Hadid que anteriormente mencionábamos), se trata del PabeYlón de agua dulce (1993-97) que NOX construyó en la isla artificial de Neelteje Jans en el sudoeste de Rótterdam en Holanda, con motivo de una exposición dedicada a mostrar el ciclo completo del agua y en la que NOX proyectó la parte que muestra el agua dulce y el grupo Kas Oosterhuis la del agua salada. Es un edificio de unos sesenta y cinco metros de largo que recuerda una ola alargada o una turbulenta callejuela en el que se combina la dureza y la debilidad de la carne humana, del cemento
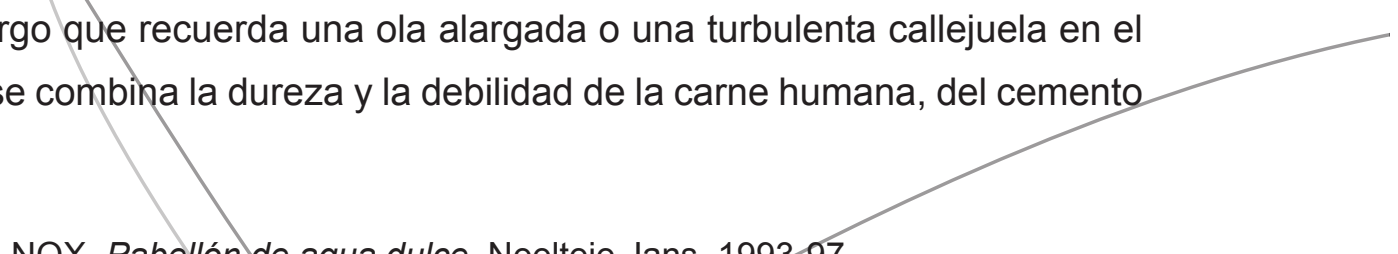

NOX, Pabellón de agua dulce, Neelteje Jans, 1993-97.

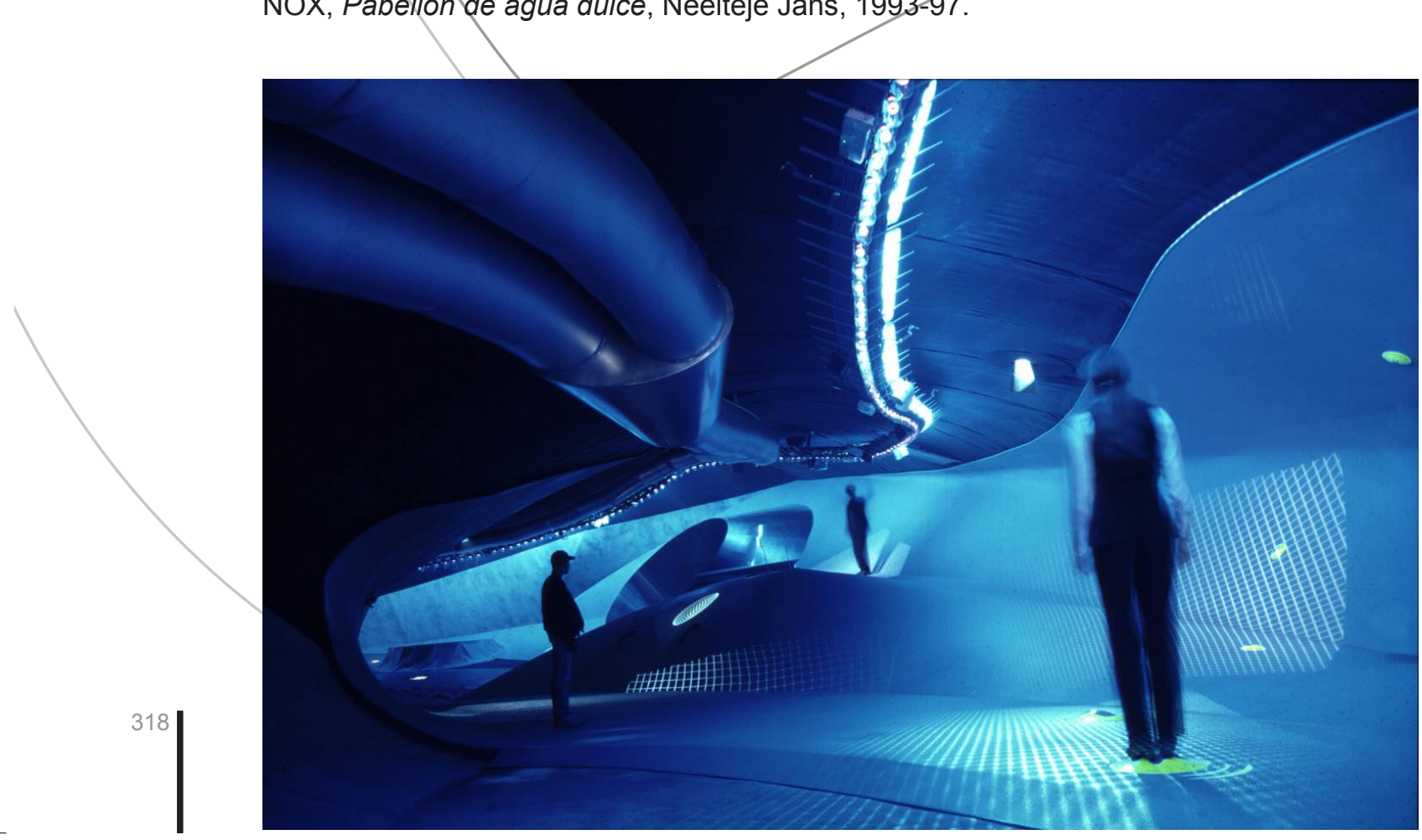



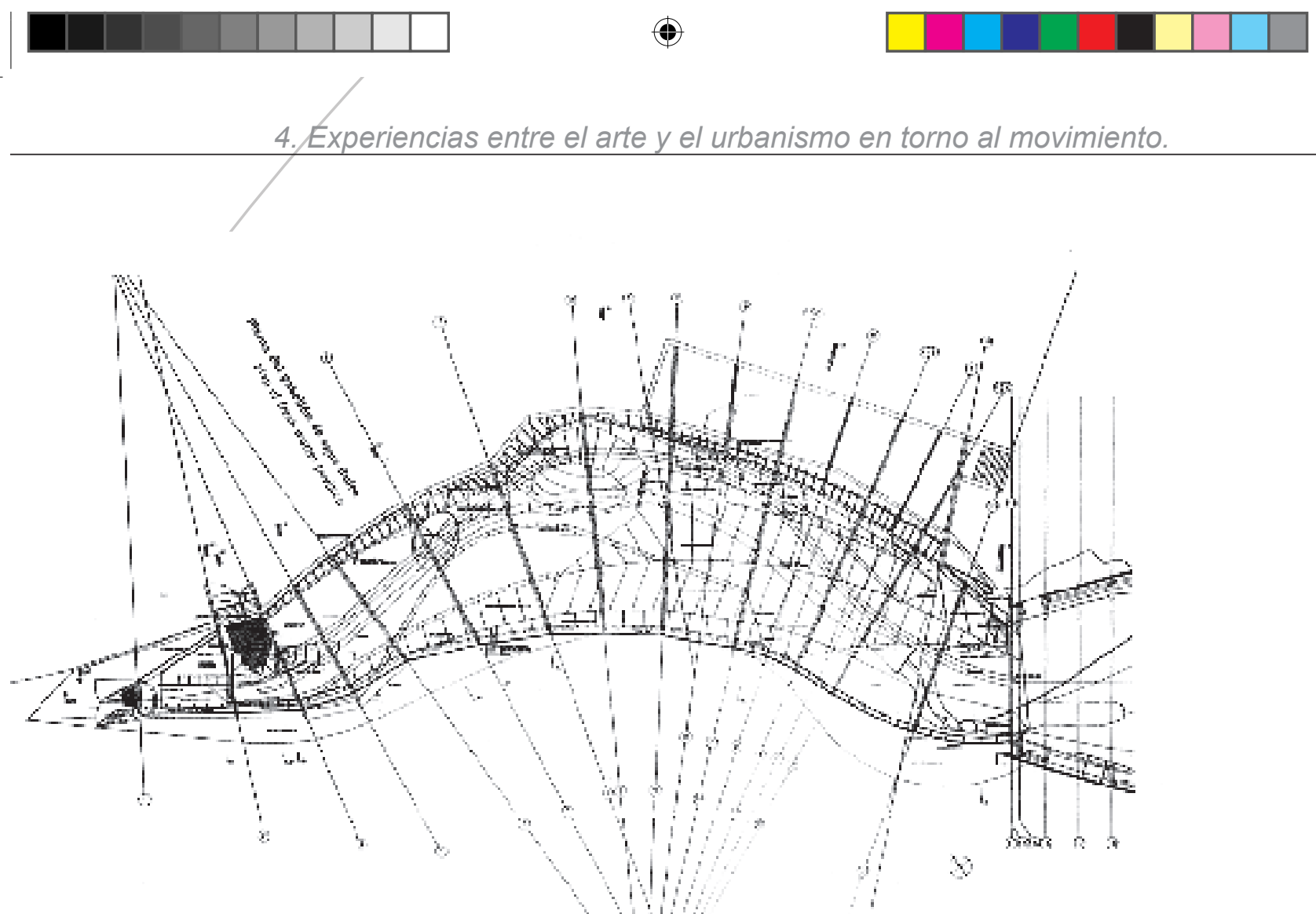

NOX, Pabellón de agua dulce, Neelteje Jans, 1993-97, Planta.

y del acero inoxidable, junto a múltiples medios electrónicos interactivos o el agua, y todo ello en una completa fusión del cuerpo, la tecnología y el entorno. Basado en una meta-estable agrupación de elementos arquitectónicos e informativos, la forma del edificio está compuesta por la deformación fluida de catorce elipsis espaciales. La entrada es un largo tubo creado por estas elipsis pero, el conjunto del edifico se forma y se deforma constantemente gracias a las influencias del propio terreno en el que está instalado, a la dirección del viento, a las dunas de arena y también, muy especialmente, debido a los flujos de los visitantes, que actúan como el paso de las olas a medida que recorren el edificio. Todos estos flujos transforman permanentemente el conjunto del edificio. ${ }^{12}$

Pero esta situación de inestabilidad y movilidad constante se da de un modo especial en el interior del edificio. La deformación externa de los objetos se refleja en el interior, el cual registra los movimientos de los

12 Sobre algunos proyectos de NOX y su vinculación con otros colectivos similares, puede consultarse Brayer, Marie-Ange y Simonot, Beatrice (eds.), Archilab's Earth Buildings:Radical Experiments in Land Architectures, Thames \& Hudson, Londres, 2003. 

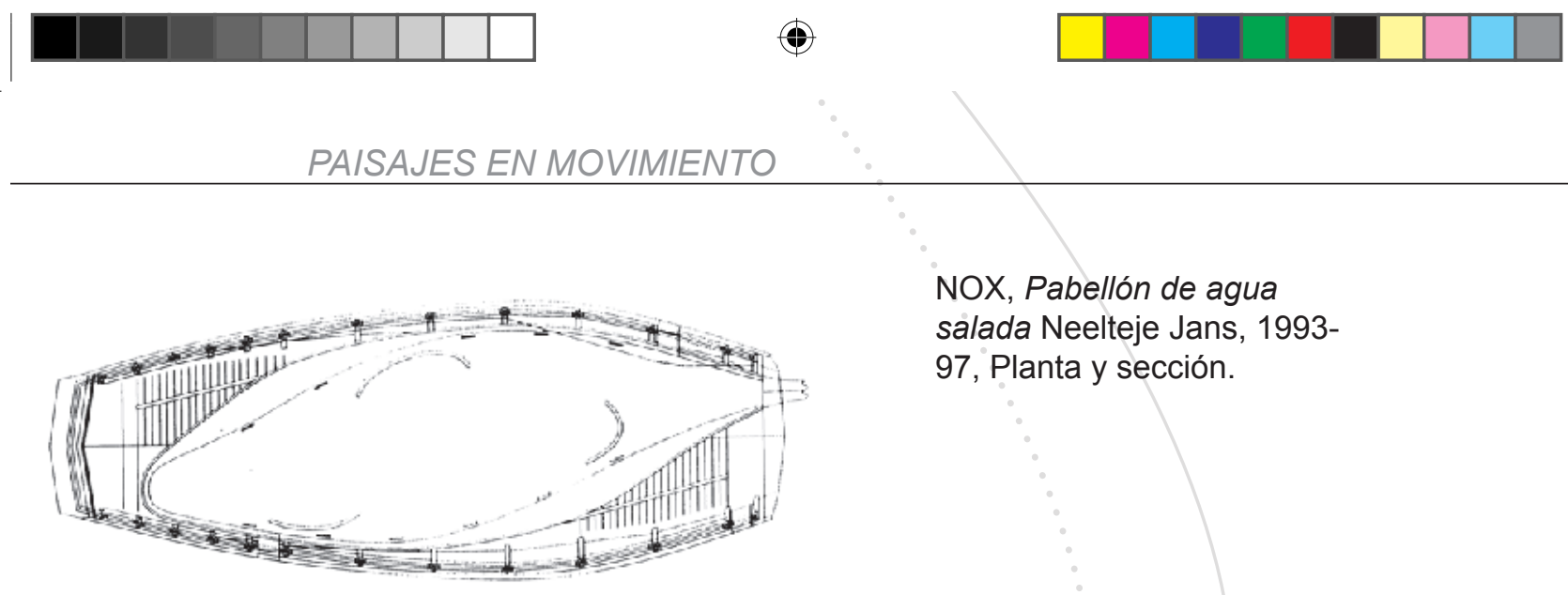

NOX, Pabellón de agua

salada Neelteje Jans, 1993-

97, Planta y sección.

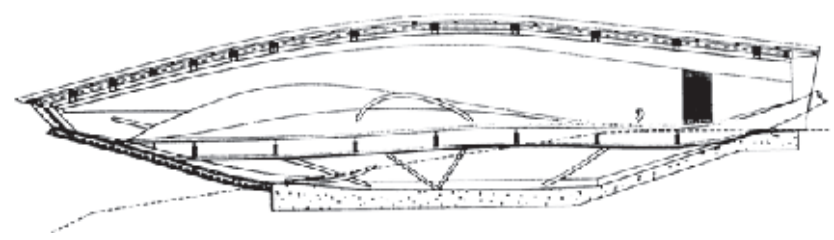

diecisiete sensores que responden interactivamente con el espectador. Se trata de una arquitectura líquida en la que no se percibe la distinción entre los suelos, los muros y lostechos, que tampoco posee ángulos rectos ni superficies planas y en la que por tanto se subraya la sensación de inestabilidad, fluidez y ductilidad. Según explica Lars Spuybroek, "El pabellón del agua es un edificio especial por muchas razones: es el primero en el que toda su estructura topológica es curva, no sólo el techo y las paredes, sino también los suelos; ninguna sección es horizontal. Es el primer edificio completamente interactivo en el cual los visitantes pueden modificar la luz y el sonido de su interior a través de un amplio número de sensores." ${ }^{13}$ Sin suelos horizontales y sin una relación externa con el horizonte caminar dentro del pabellón se convierte en una experiencia semejante a la sensación de estar cayéndose constantemente.

El edificio, paralelamente, no se limita a recoger una exposición más o menos atrevida, sino a organizar un programa en el que se suceden un conjunto constante de acontecimientos relacionados con el tema que la vertebra. Así se crean una serie de situaciones con el hielo, la

13 Spuybroek, Lars, Op. Cit., 2004, p.93. 

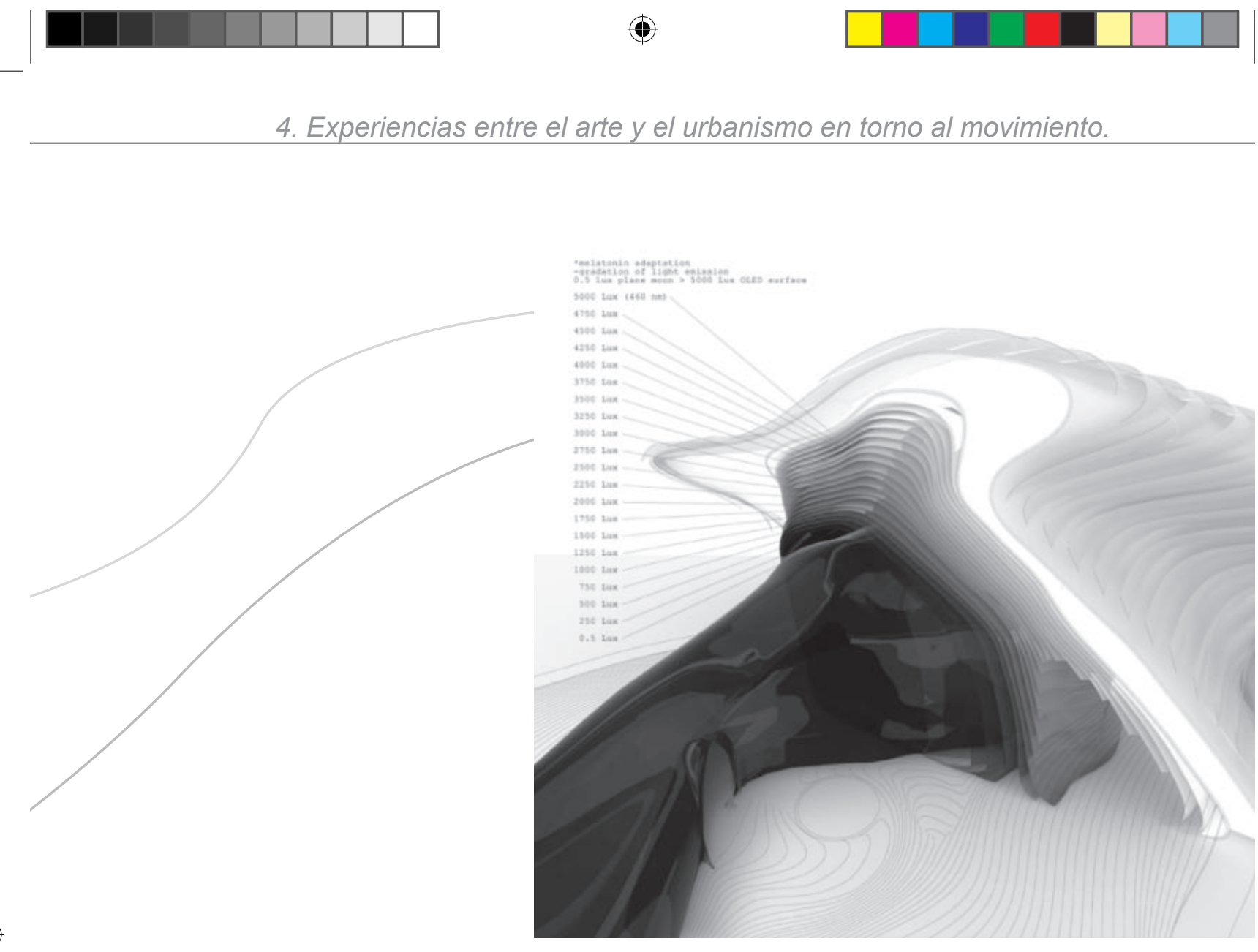

R\&Sie, The Building Which Never Dies, Austria + France, Les Andelys, 2009.

bruma, la niebla, la lluvia, las olas, las ondas, las gotas..., con los que las imágenes y los sonidos que emergen en la sala dependen de las actividades de los espectadores pero, al mismo tiempo, las actitudes de los visitantes dependen de las imágenes que se generan constantemente, creándose una relación recíproca e interactiva en los dos sentidos. Es un proyecto en el que se funde la visión y la acción de los espectadores, el continente y el contenido, con el propósito de alcanzar una percepción mucho más fluida y una arquitectura en permanente transformación.

Estamos viendo de qué modo la arquitectura de finales del siglo XX y comienzos del XXI (o al menos una parte de ella), está abandonando el ángulo recto y las categorías estancas más tradicionales para hablarnos de pliegues, de vainas o de espacio vinculados a las actitudes de sus visitantes y del paisaje que la rodea, transformándose ella misma en un 

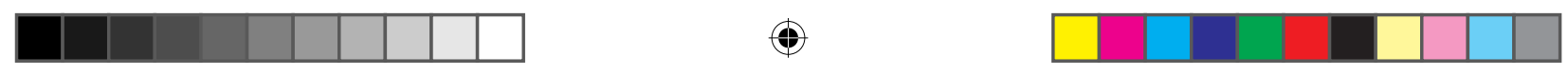

paisaje a recorrer y experimentar. Otras investigaciones al respecto llevadas a cabo desde este mismo planteamiento y ciertamente interesantes, según mi punto de vista, son las llevadas cabo desde la Agencia R \& Sie, formada por los arquitectos François Roche y Stéphanie Lavaux. Estos arquitectos franceses, trabajan juntos desde 1993 en la búsqueda del desarrollo de una experiencia crítica en el interior de la arquitectura que haga posible una mutación de sus parámetros contextuales y permita abolir polaridades como objeto-sujeto, objeto-territorio... Interesados en una actitud cuestionadora de la arquitectura moderna se sitúan entre los modos relacionales y la hibridación donde el localismo es el soporte de una mutación producida

R\&Sie, Ecosophical apparatus and skizoïd machines, Pabellón Internacional, Venecia, 2008, (maqueta). en la corporeidad del territorio. Para Roche, la arquitectura es una de las partes más visibles

de la sofisticación política, social y estética de una sociedad determinada. Y por ello, es necesario poner en pie una estrategia capaz de crear proyectos experimentales que pasen por la reformulación, entre otras cuestiones, del estatuto de autoría y de la posición del arquitecto en la sociedad contemporánea, para entenderlo más como un intercesor de las pulsiones colectivas, de los modos relacionales y de su transformación, 

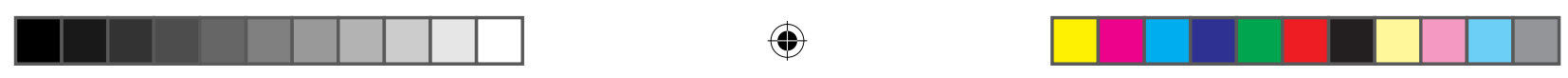

\section{Experiencias entre el arte y el urbanismo en torno al movimiento.}

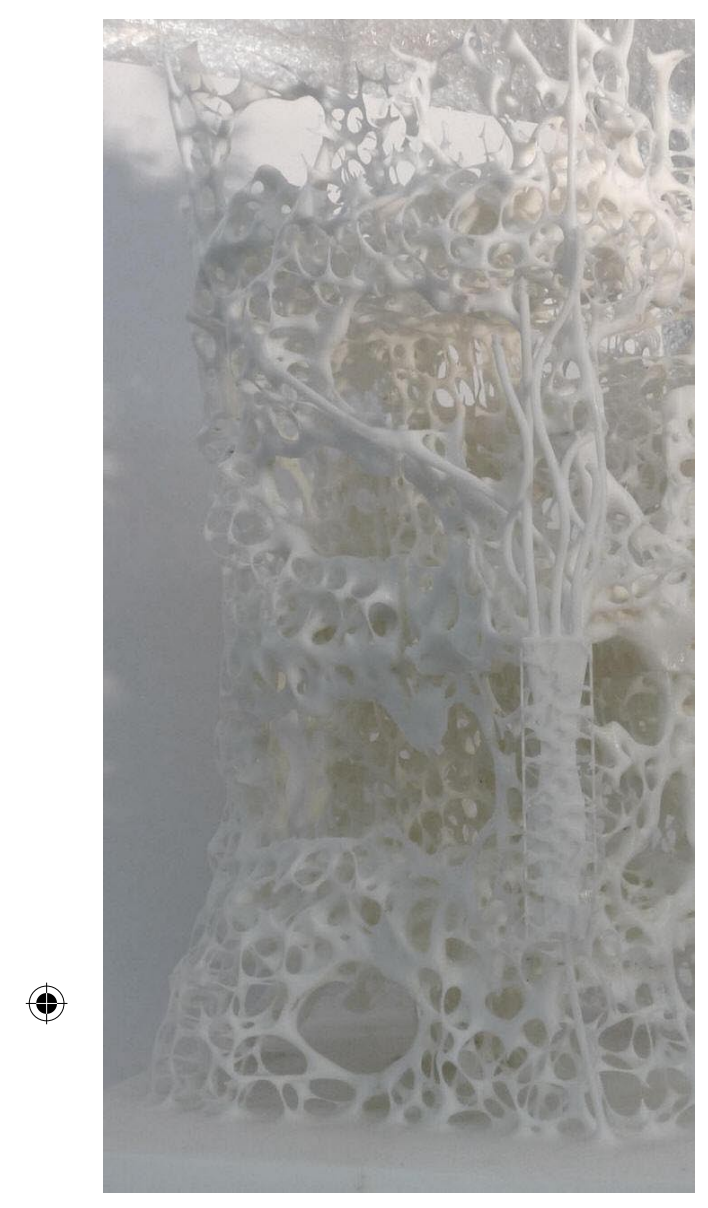

R\&Sie, Ecosophical apparatus and skizoïd machines, Pabellón Internacional, Venecia, 2008, (maqueta).

que como un guía espiritual o un creador chamánico. ${ }^{14}$

El objetivo es potenciar un sentido de la innovación en la arquitectura que sea capaz de adquirir riesgos teniendo en cuenta el carácter ambiguo, palpitante y vibratorio del momento actual; capaz de hacer visible esta época, a la vez desencantada, voluptuosa, profundamente inquieta y violenta. Es precisamente el disfuncionamiento de la ciudad de principios del siglo XXI, lo que permite imaginar otra articulación de la arquitectura y la creación de nuevas formas y relaciones. Las propuestas de $\mathrm{R}$ \& Sie participan de su entorno a través de un doble movimiento de mimesis (como método de invención) y de reciclaje, de extracción y de transformación. Sus creaciones se desarrollan en el interior de una experiencia crítica que trastoca los parámetros ambientales para convertirse en un cuerpo mutante afectado por la multiplicidad de los "otros", tales como: el clima, la territorialidad, los flujos, la proximidad, las relaciones o los materiales vernáculos, así como el contexto histórico y humano del lugar en toda su complejidad. Tratan de insistir en el devenir social como el elemento fundamental del escenario a escribir y luego a construir. Para ellos, más allá de la forma o la función, la arquitectura se debe definir por un juego de relaciones más o menos complementarias o contradictorias.

Según ellos mismos escriben, "Hablar de espacio, en tanto que tal, revela la tradición moderna que ha considerado poder imponer la

14 Véase al respecto VV. AA., R. \& Sie...Architects. Spoiled Climate, Arte Prima, Paris, 2004. 

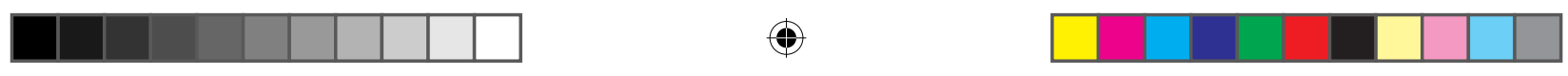

idea según la cual la arquitectura se constituye gracias a la fisicidad de los pilares y los muros. ¡Pero la arquitectura no está hecha de eso! (...) ¿Qué es el espacio? Conviene cuestionarse correctamente la noción de espacio. Pues el espacio no es la primera materia sino la resultante. Esta compuesta tanto de flujos corporales como de modos relacionales, de los ruidos de la vecindad como de la polución del aire. El espacio está constituido de feromonas, de química, de percepciones fenomenológicas. Realmente, es una falacia reducir el espacio a su simple fisicidad. Es muy importante elaborar escenarios que no sean cerrados, que sean incluso contradictorios." 15

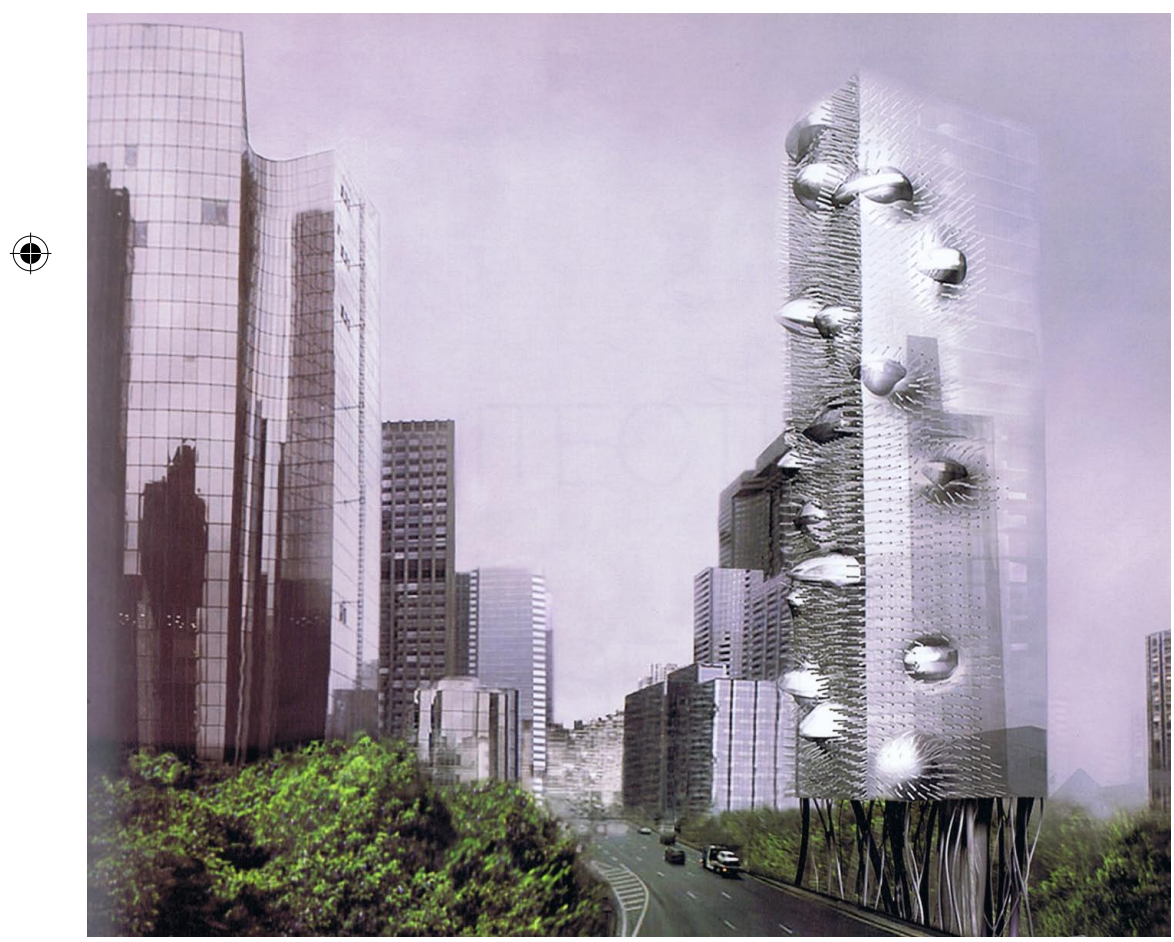

R\&Sie, (Un) Plug Building, Paris, 2000.

15 Roche, François, Corrupted Bodies, Damdi Publishing, Londres, 2004, p.33. 


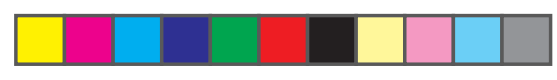

\section{Experiencias entre el arte y el urbanismo en torno al movimiento.}

Así, partiendo de teorías matemáticas vinculadas con el Caos y gracias a la aparición de un renovado interés en el mundo de la arquitectura por los fractales, R \& Sie proponen reconsiderar las distorsiones, las compresiones o los pliegues, mediante modos operacionales que tienen como base los ordenadores y que combinan lo virtual y lo imaginario para recomponer la realidad, tratando de reelaborar las formas arquitectónicas. Una arquitectura inestable y unas formas, interesadas más en revelar las contradicciones y los fantasmas de una sociedad, en plasmar las paradojas y las contradicciones de las ciudades, que en proponer formas más o menos estables o ideales. "Nuestros instrumentos de codificación y de transformación de los territorios tratan, no de una proyección ideal, sino sobre un estado del lugar, un biotopo mutante y tangible, salido del error generalizado de los pensamientos urbanos y de su impostura. De esta ambigüedad surgen nuestros escenarios frágiles y únicos." ${ }^{16}$ La agencia $\mathrm{R} \&$ Sie utiliza las nuevas tecnologías para renovar los códigos y las formas de la arquitectura contemporánea y provocar procesos de mutación y de hibridación, donde lo imaginario y lo virtual se conjugan para recomponer lo real mediante la integración de lo inestable, lo temporal y lo efímero. Es decir, entendien-

16 Ibídem, p.47.

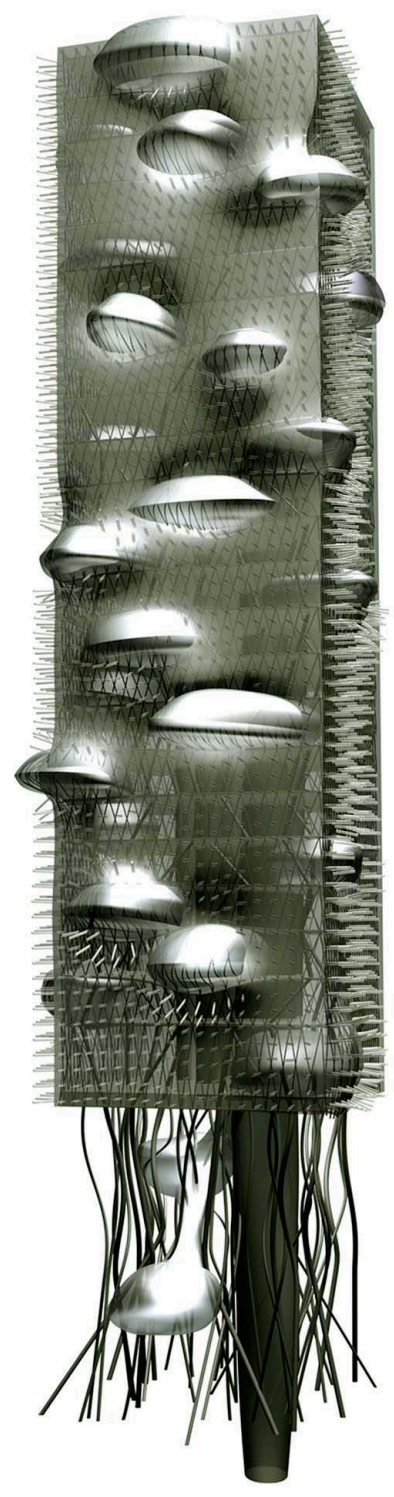

R\&Sie, (Un) Plug Building, Paris, 2000. 

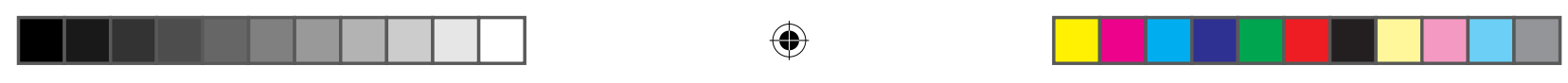

do la arquitectura como una materia evolutiva y mutable que dialoga con lo entrópico y lo orgánico.

Para estos arquitectos franceses, el concepto de integridad y unidad definida y defendida por la modernidad ha explosionado de tal modo, que una de las características centrales de nuestra época son los profundos problemas de transformación y de hibridación que están sufriendo las diferentes esferas sociales e identitarias (desde el campo sexual al científico y desde el artístico al sanitario). Ello no significa que el cuerpo (personal o social) haya sido negado, sino que se ha hipertrofiado de tal modo que la piel ha dejado de ser frontera de nada, ha desistido de ser un elemento que cubre y protege el cuerpo, para convertirse en una superficie reactiva al entorno más próximo. Una piel transformada, metamorfoseada y manipulada hasta ser asimilada a la distorsión de la realidad que la circunda. Por estas razones, y reaccionando al ritmo de la naturaleza para descubrir cómo los múltiples estratos de un territorio necesitan de un replanteamiento constante o de unas transformaciones urbanas morfológicas, R \& Sie presentan unos proyectos que son pensados como organismos vivos cuyo desarrollo se basaría en las características de especies vegetales o animales, dando pie a formas híbridas en las que se trastocan tanto las relaciones como la naturaleza de la arquitectura.

Se trata de plantear una arquitectura que se encuentra en proceso de realización constante, que integra lo inacabado y la autodeterminación como un parámetro constitutivo de su realidad. Unos edificios que no permanecen impermeables a las transformaciones de la sociedad, sino que se mantienen ligados a la disolución, a la fragmentación de los mecanismos informacionales y productivos de la misma. De este modo, R \& Sie proponen una narrativa topográfica a través de la arquitectura que busca un diálogo constante entre el lugar y sus mutaciones.

Estas ideas acerca de la distorsión, la clonación, el trasplante o la hibridación arquitectónica se ven reflejadas con claridad en su proyecto de (Un) Plug Building para el barrio de La Défense de París, 2001, un edificio de veintitrés pisos de oficinas para la compañía EDF. Así, vemos como 

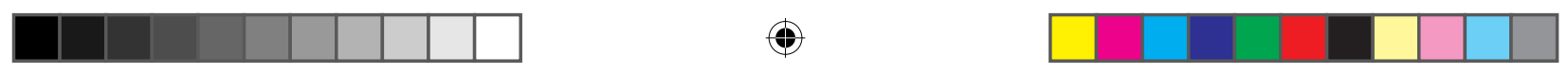

\section{Experiencias entre el arte y el urbanismo en torno al movimiento.}
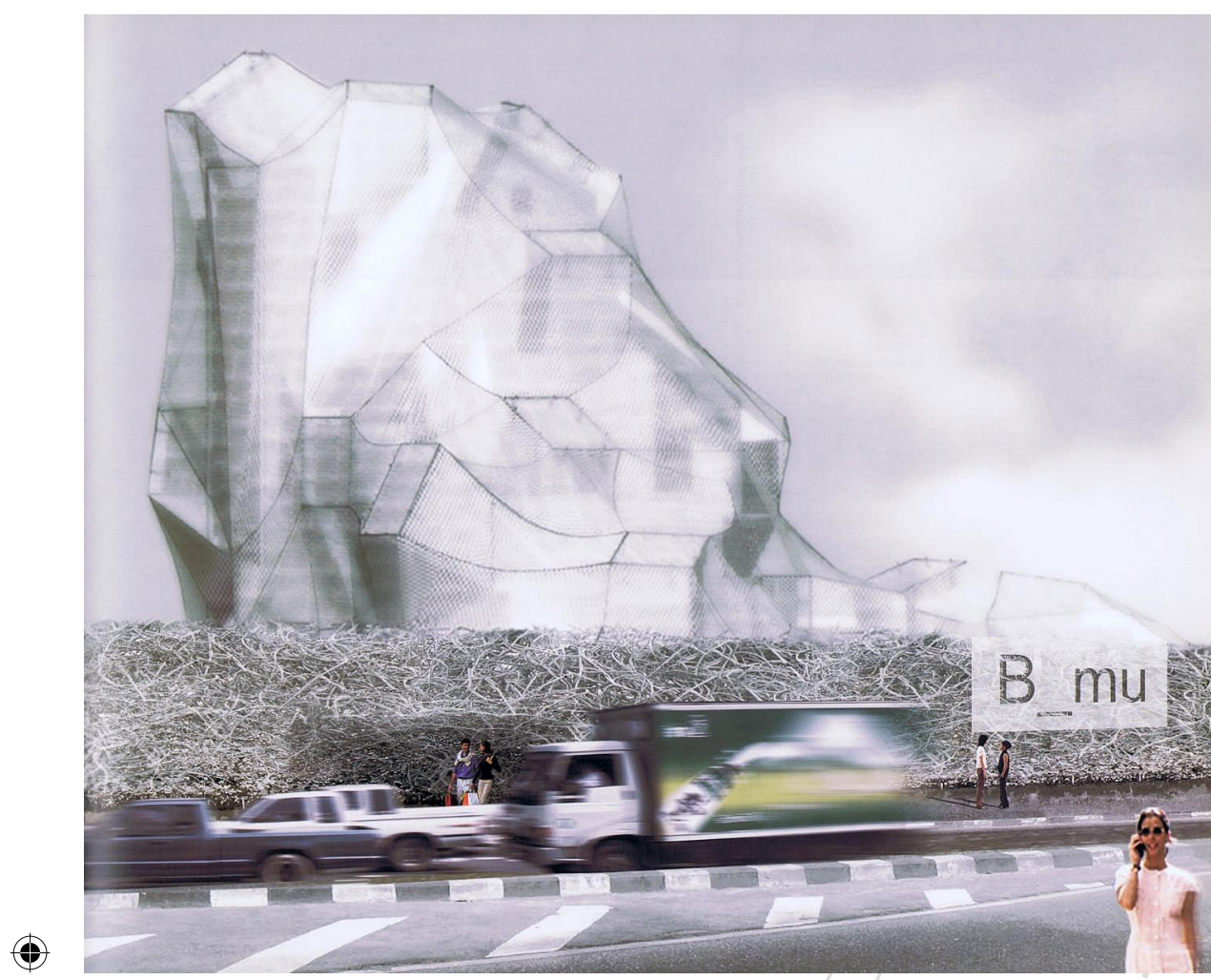

R\&Sie, Dustyrelief (Alivio polvoriento), Bangkok, 2002.

se deforma una estructura genérica de oficinas para convertirla en una fachada productiva de electricidad gracias al uso de energías renovables, solares y eólicas. La fachada se convierte en una membrana viva reactiva al sol y cubierta de células fotovoltaicas (captadoras de la energía térmica y eléctrica) que producen la mayor parte de energía que el edificio necesita. La torre se ha alejado de una visión más abstracta y se ha llenado de pelos y protuberancias que han mutado la usual piel de vidrio, moderna y frígida, en una superficie blanda y peluda de evidentes connotaciones organicistas. R \& Sie desean infiltrarse en el territorio donde se ubica el edificio, huyen de cualquier irrupción intempestiva en el contexto urbano $y$, para ello, buscan generar transformaciones que posibiliten una relación lo más plural y fluida posible entre el mundo natural y la proyección arqui- 

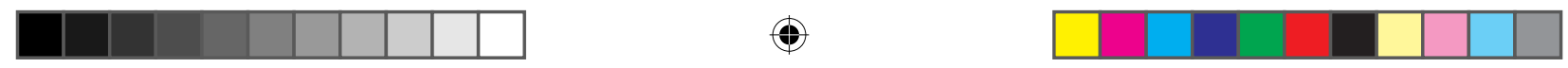
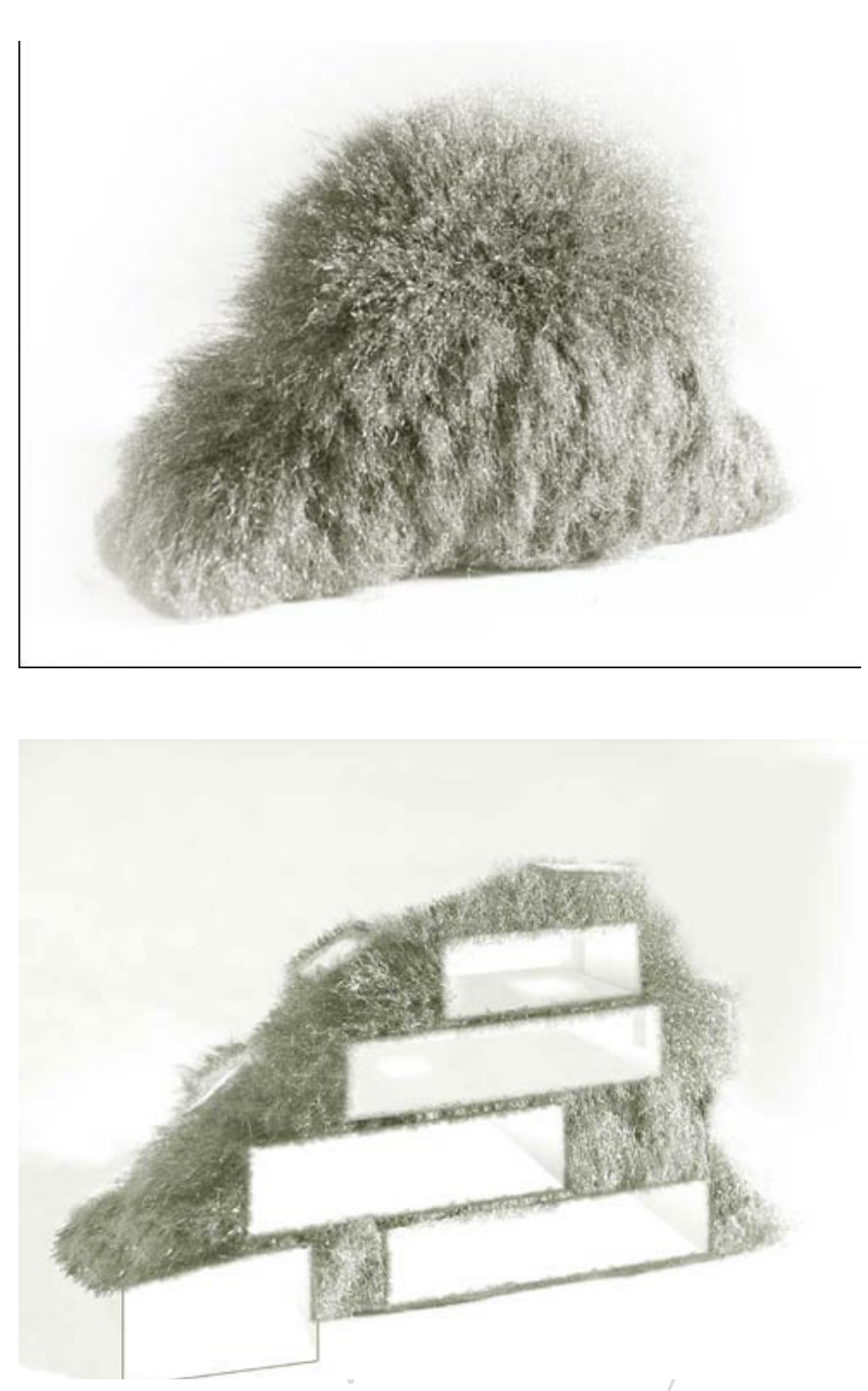

R\&Sie, Dustyrelief (Alivio polvoriento), Bangkok, 2002. tectónica. ${ }^{17}$

Con esta propuesta lo que pretenden es reactivar la noción de localismo, o de "hiperlocalización" como ellos lo denominan, en el sentido más palpitante y contradictorio del término. Es decir, no desean huir ni embellecer las problemáticas donde se sitúa un edificio concreto, sino que se trata de un intento de visualizar y hacer palpables las condiciones reales de existencia de los mismos. Es el deseo de exacerbar, de Hevar incluso al límite esta realidad e intervenir en ella. Lo cual tiende a crear situaciones paradójicas y altamente contradictorias al utilizar y subrayar en sus propuestas determinados factores o problemáticas que están en el entorno pero que todo el mundo que allí vive quisiera ver desaparecer o, al menos, aligerar. Ejemplar de esta actitud y de estos planteamientos es el proyecto para la creación de un museo de arte contemporáneo en Bangkok cuyo nombre es Dustyrelief (Alivio polvoriento), (2002). En

17 Sobre diferentes proyectos suyos, consúltese, VV. AA., $R$ \& Sie. I've Heard About..., Musée d'Art Moderne de la Ville de Paris, 2005. 

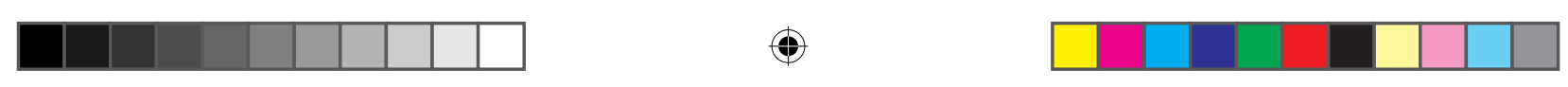

\section{Experiencias entre el arte y el urbanismo en torno al movimiento.}

la capital tailandesa, $R \&$ Sie intentan crear una arquitectura que, según ellos, tienda a aspirar un lugar pero nunca a dominarlo. Por ello, parten de lo que entienden son las dos particularidades fundamentales de la ciudad: ser una de las urbes más contaminadas del planeta y no poseer ninguna planificación urbanística. Su idea era, por tanto, integrar esos dos fenómenos para crear un proyecto que incorporara la pérdida del control y la polución como los productores básicos de la forma arquitectónica. Por ello, el museo propone esa forma irregular y gris (como un enorme montículo creado por el polvo urbano acumulado), donde los residuos carbónicos que flotan por el aire se convierten en la piel del edificio. Mediante un sistema electroestático sobre las fachadas del museo, el edificio se comporta como un filtro urbano moldeable, blando y polvoriento, como una membrana aislante entre dos mundos bien distintos: un exterior caótico y sofocante, y un interior climatizado, ordenado y aséptico. Como manifiesta François Roche, "la forma nunca está dada a priori sino que es el resultado de las condiciones existentes; el polvo de Bangkok reconstruye y contamina la arquitectura del museo, de igual modo que reconstruyen constantemente el paisaje"18. Naturalmente, esta propuesta de R \& Sie

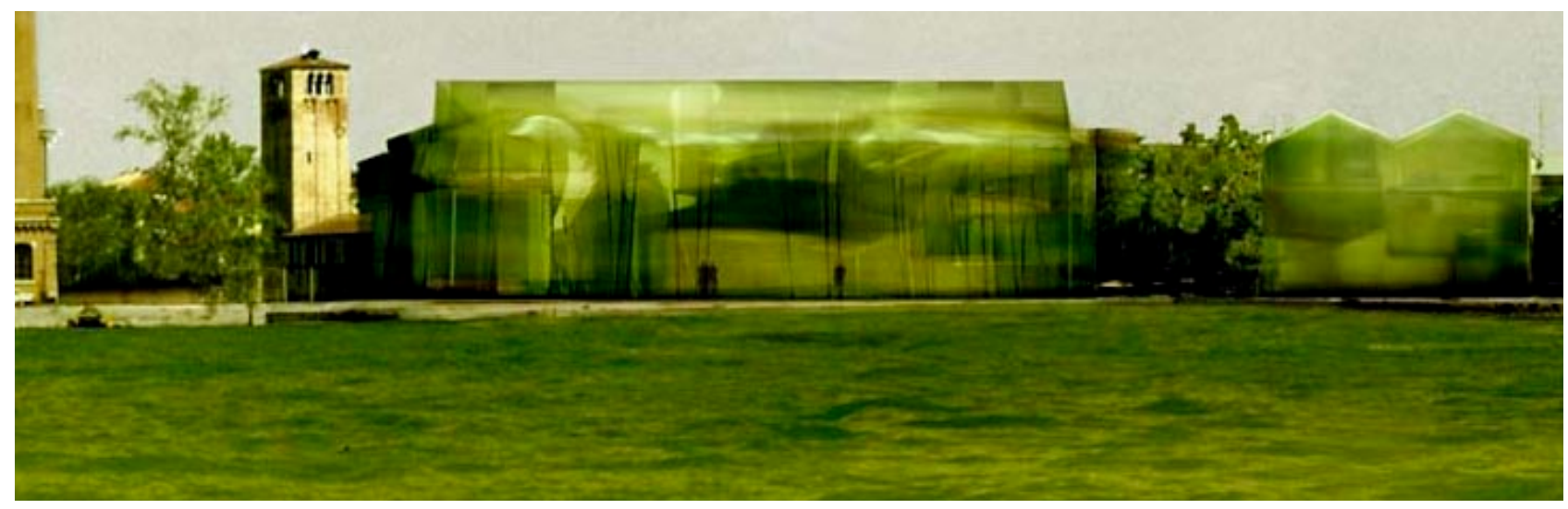

R\&Sie, Aspiration, Venecia, 1998.

18 VV. AA., Op. Cit, 2004, p.56. 

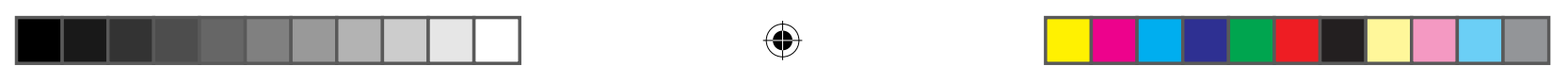

tiene un fuerte carácter irónico a medio camino entre una crítica radical a los postulados de una arquitectura moderna que trataría de maquillar la ciudad e idealizar el papel del arquitecto y una actitud cínica producto de un profundo desengaño social y político.

Por último, en su proyecto Aspiration para la ampliación de la Escuela de Arquitectura de Venecia, (1998), François Roche y Stéphanie Lavaux parten de los movimientos de la laguna para formalizar su propuesta. Como es bien sabido, en Venecia el agua es un elemento central de su existencia, aquello que le da su especificidad, casi su razón de ser, al tiempo, que anuncia su muerte. La personalidad de la ciudad italiana se identifica con la laguna, con los flujos producto de las mareas y el encuentro entre las corrientes fluviales y el mar, en definitiva, con los movimientos del agua. $Y$ es eso precisamente lo que plantean, un edificio que es movimiento de agua. R \& Sie utilizan el cálculo matricial para aspirar el liquido e intervenir en el edificio. Y esto, con la pretensión de evidenciar procesos de sedimentación y de transformación. El movimiento cíclico del agua se trabaja aquí, no como material de proyecto, sino como proyecto en sí mismo, en un ejercicio que no busca soluciones constructivas concretas y tangibles (que solucionen por ejemplo problemas derivados de filtraciones o humedades) sino que aspira a abrir caminos y vías de experimentación y de reflexión para una arquitectura más permeable al paisaje que la rodea y a los procesos que la generan. Arquitectura, ciudad y paisaje se funden en Aspiration, un proyecto de una gran carga poética y un rotundo dramatismo. 


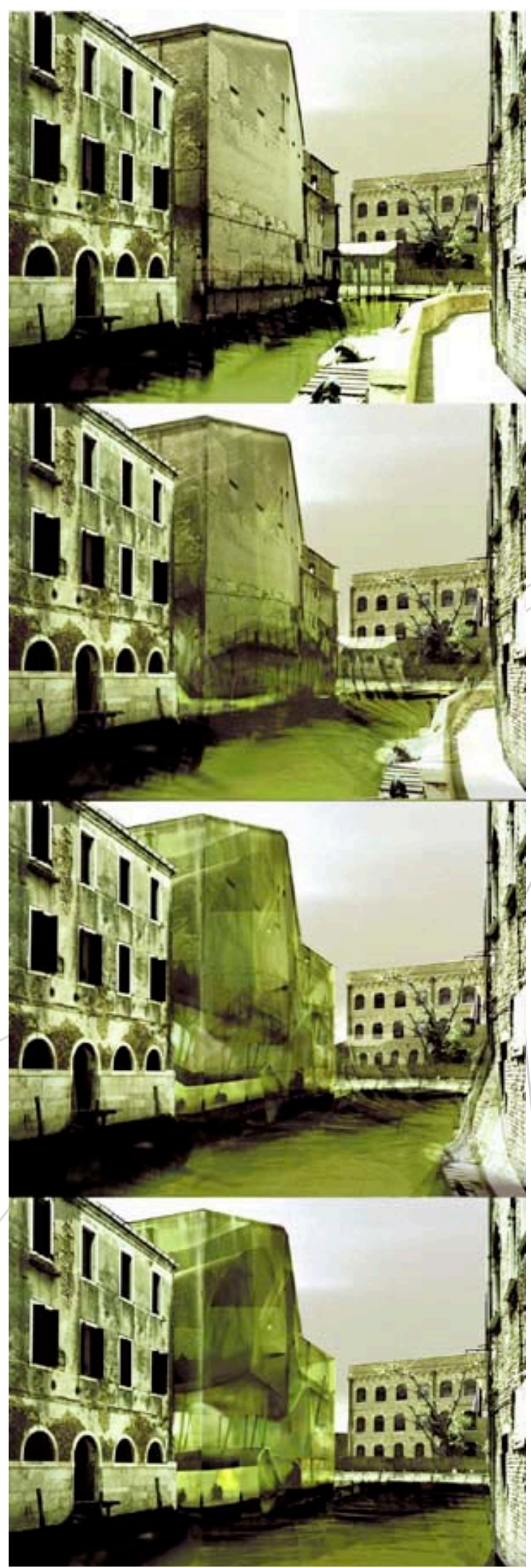

TESIS-IC-definitiva.pdf 334
R\&Sie, Aspiration,

Venecia, 1998. 

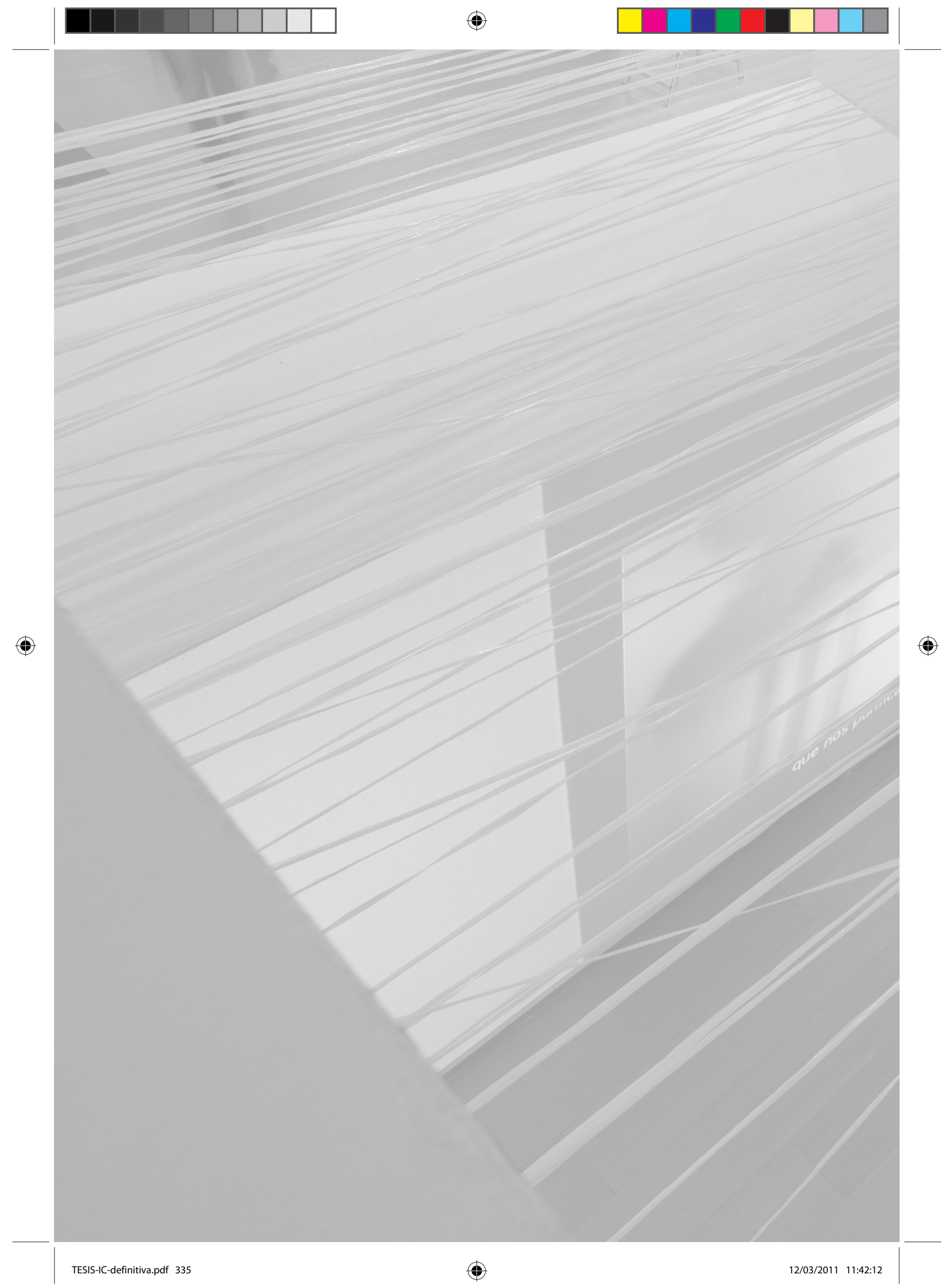


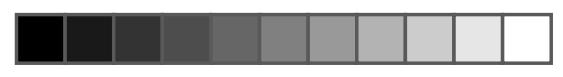

(
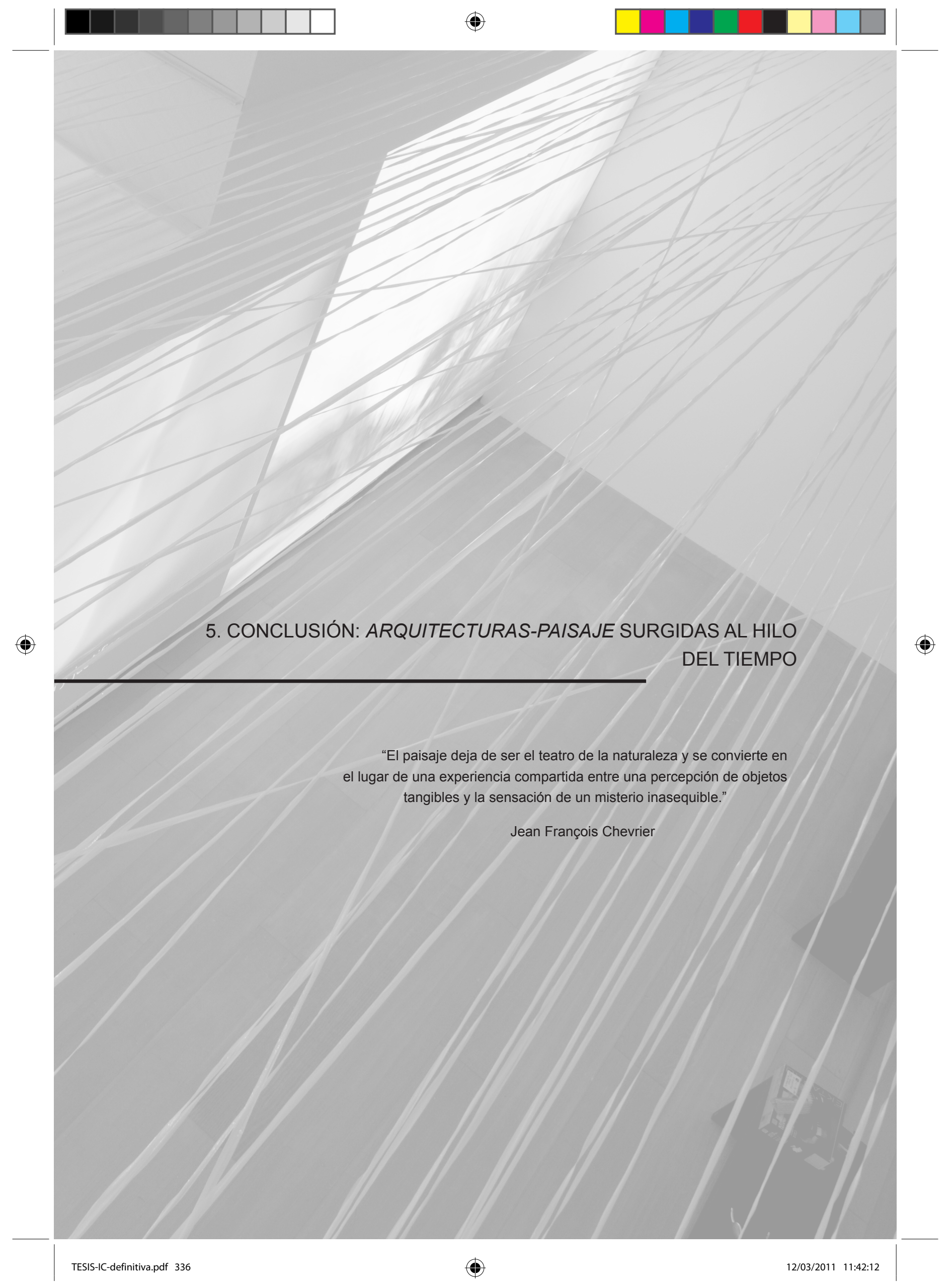


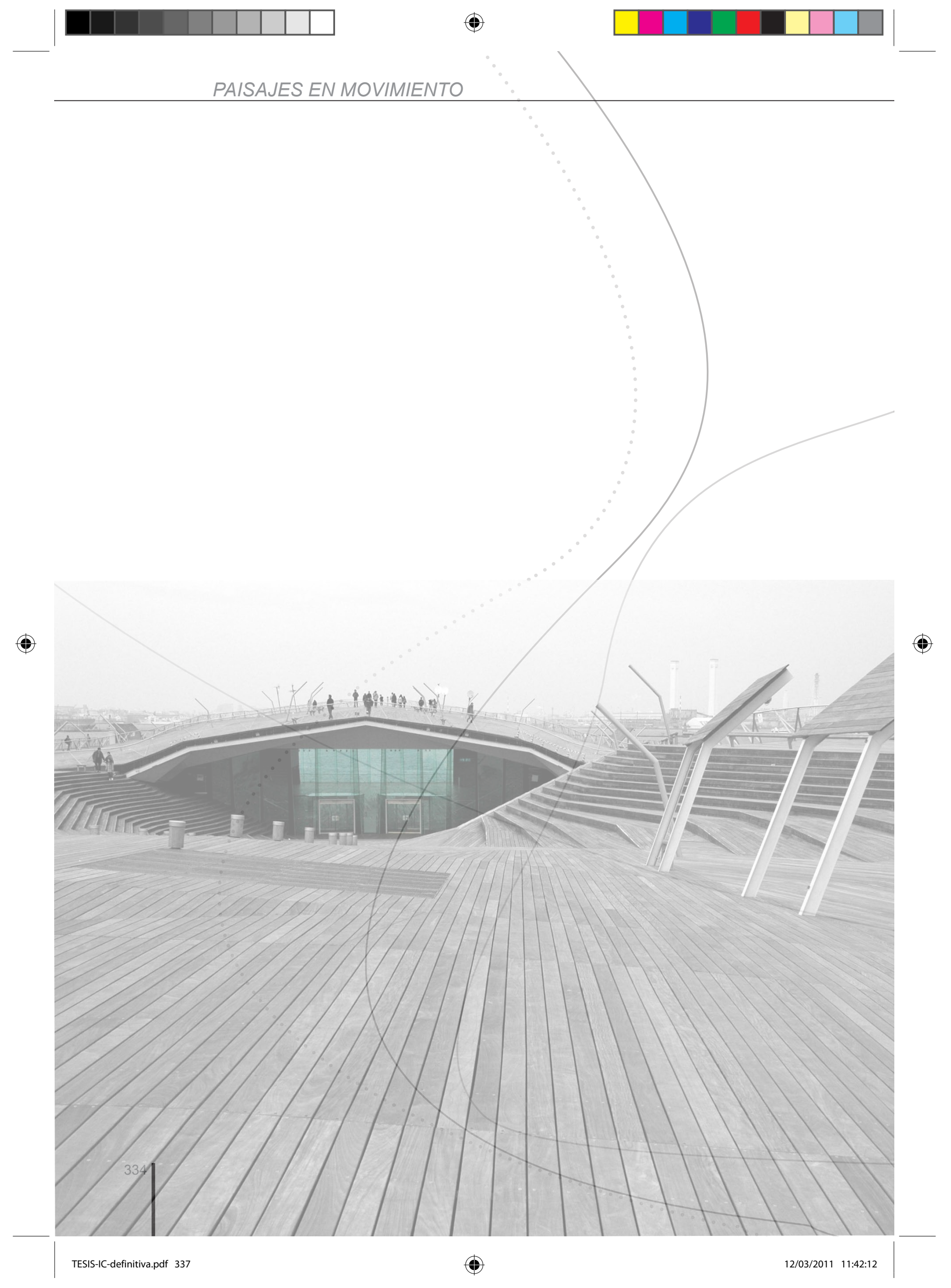


Hemos ido analizando durante toda esta tesis las fecundas experiencias que han surgido de incorporar conscientemente la noción de movimiento a la arquitectura y el paisaje a través de diferentes momentos históricos y distintos contextos culturales. Lo hemos llevado a cabo con el ánimo de reconocer y destacar, de ejemplificar, de qué modo la arquitectura y el urbanismo se han enriquecido teniendo en cuenta el factor dinámico y perceptual de los mismos. El concepto de paisaje ha jugado para ello un papel determinante, ya que ha sido en este campo donde arquitectura, ciudad y movimiento se han reconocido mutuamente, interactuando y creando muy interesantes capítulos espaciales y simbólicos. 

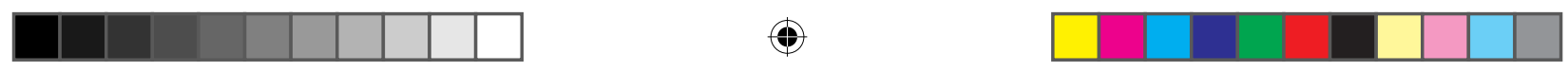

Con este propósito, hemos ido desenlazando el ovillo de Dédalo, el hilo de Ariadna, para seguir el rastro de complejas y bien distintas experiencias que nos han traído hasta nuestros días y que son determinantes para comprender algunos de los aspectos más interesantes, a mi entender, de la práctica de la arquitectura y de la planificación urbanística actual y en consecuencia para la comprensión de nuestras ciudades. Hemos comprobado de qué manera, desde que el ser humano se enfrentó como nómada a un mundo ajeno y hostil, el movimiento (como motor de creación) ha enriquecido y completado muy diversas experiencias artísticas y arquitectónicas. Somos seres dinámicos y nuestros espacios lo son, o al menos deberían serlo, en la misma medida, aunque a menudo

Nómadas, Mongolia, 2005 (fotografía I.C.).

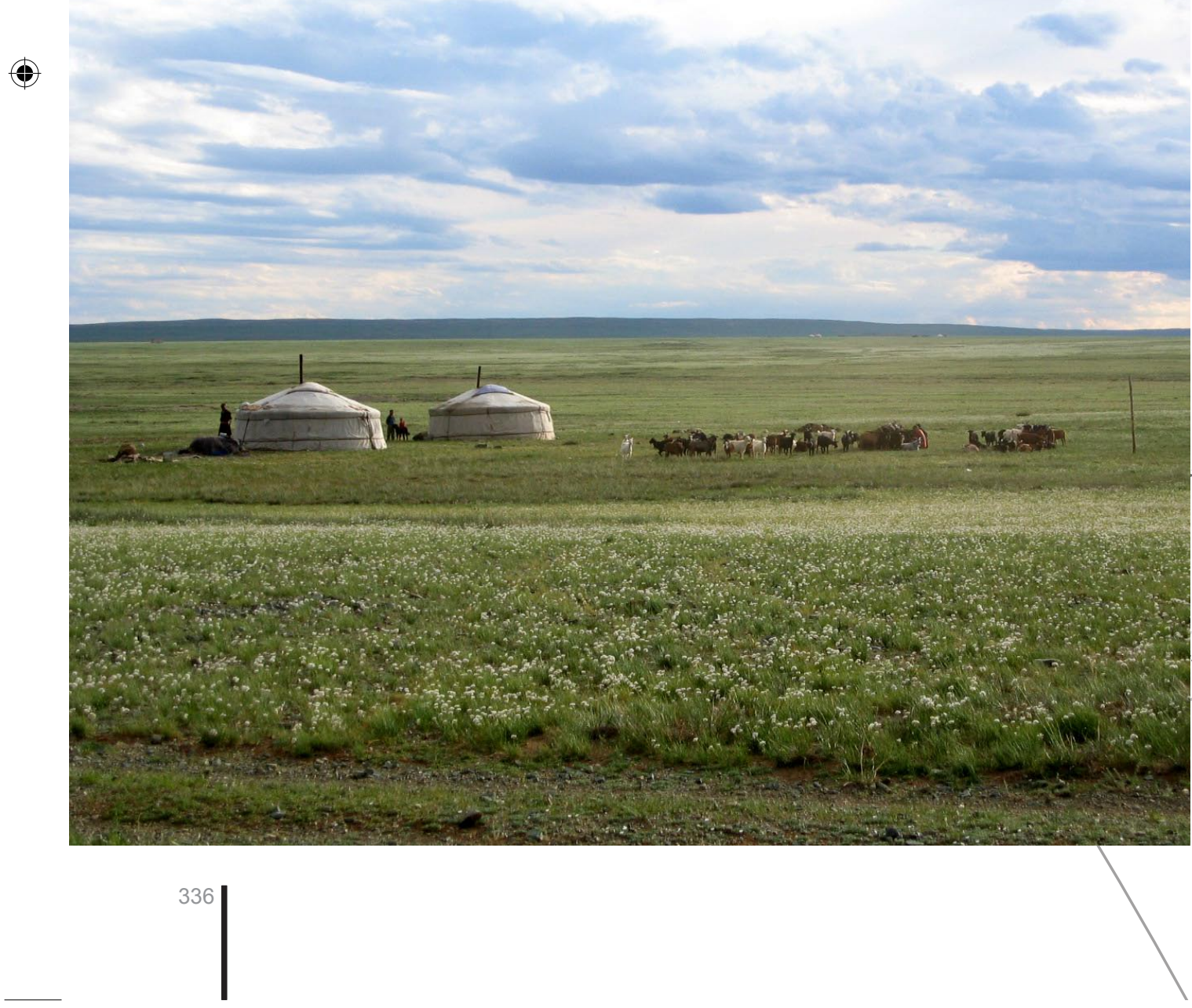



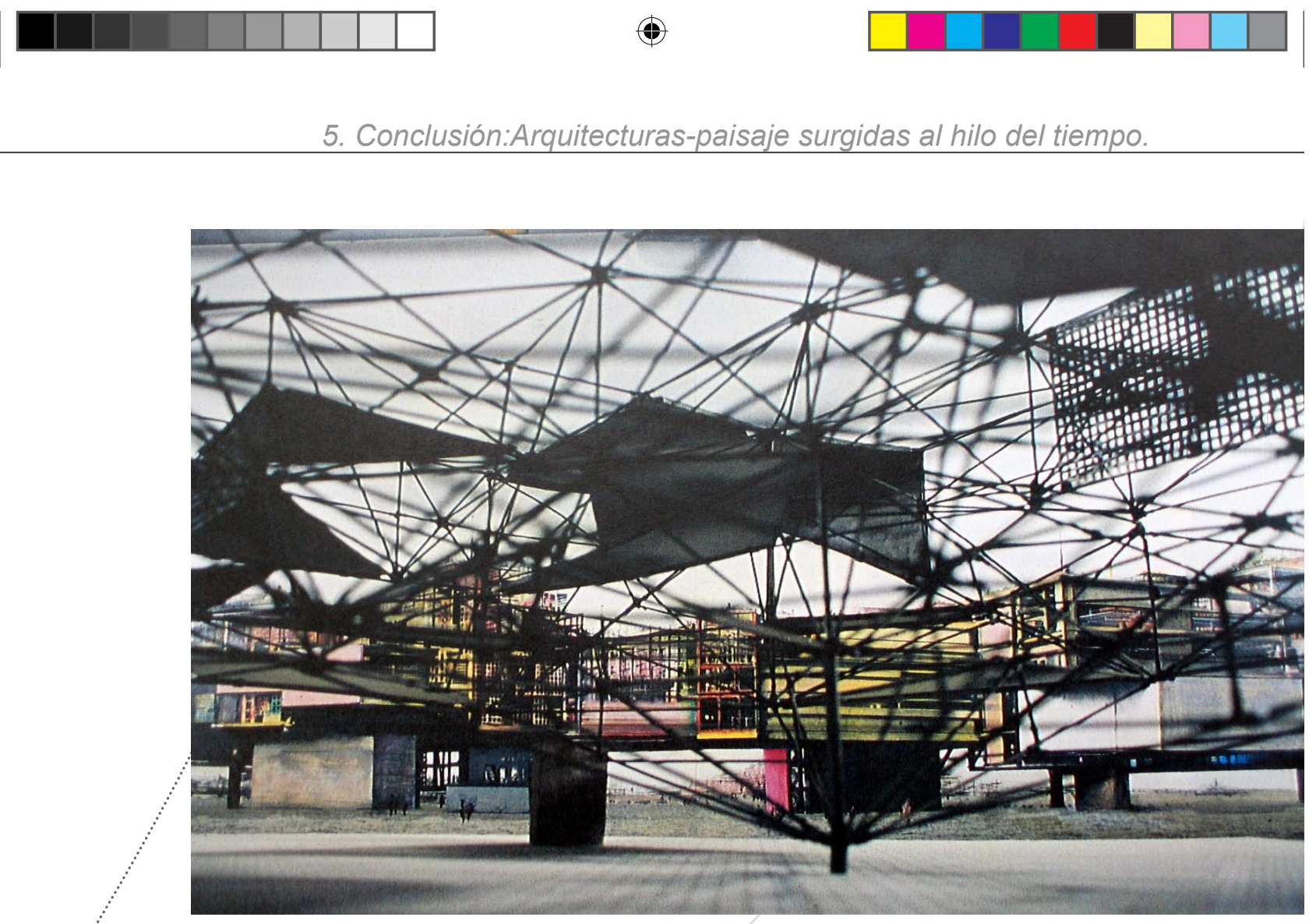

Constant, Maqueta para New Babylon, 1958-60, (detalle).

nos cueste experimentarlo y reconocerlo. Otros planteamientos que niegan esta componente dinámica eseneial de nuestras ciudades y nuestros edificios son, a mi entender, fruto de propuestas técnicas y conceptuales en gran mediad estáticos y a menudo inmovilistas. A lo largo de los capítulos precedentes, hemos podido comprobar la fascinación que el homo viator, el nómada, o el flâneur, han causado en la imaginación de artistas, arquitectos y urbanistas. Desde rituales de fuerte componente religiosa a ciudades nómadas o estructuras flotantes portadoras de cultura, el movimiento, como hemos visto, siempre ha estado presente en los espacios que hemos ido creando colectivamente, enriqueciendo nuestra experiencia y ampliando nuestras fronteras y en definitiva nuestra mirada.

Es esta mirada, recordemos, la que, tal y como he intentado dejar constancia en estas páginas, ha transformado nuestro territorio y nuestras ciudades en paisajes, en paisajes eso sí no estáticos o fijos a modo 

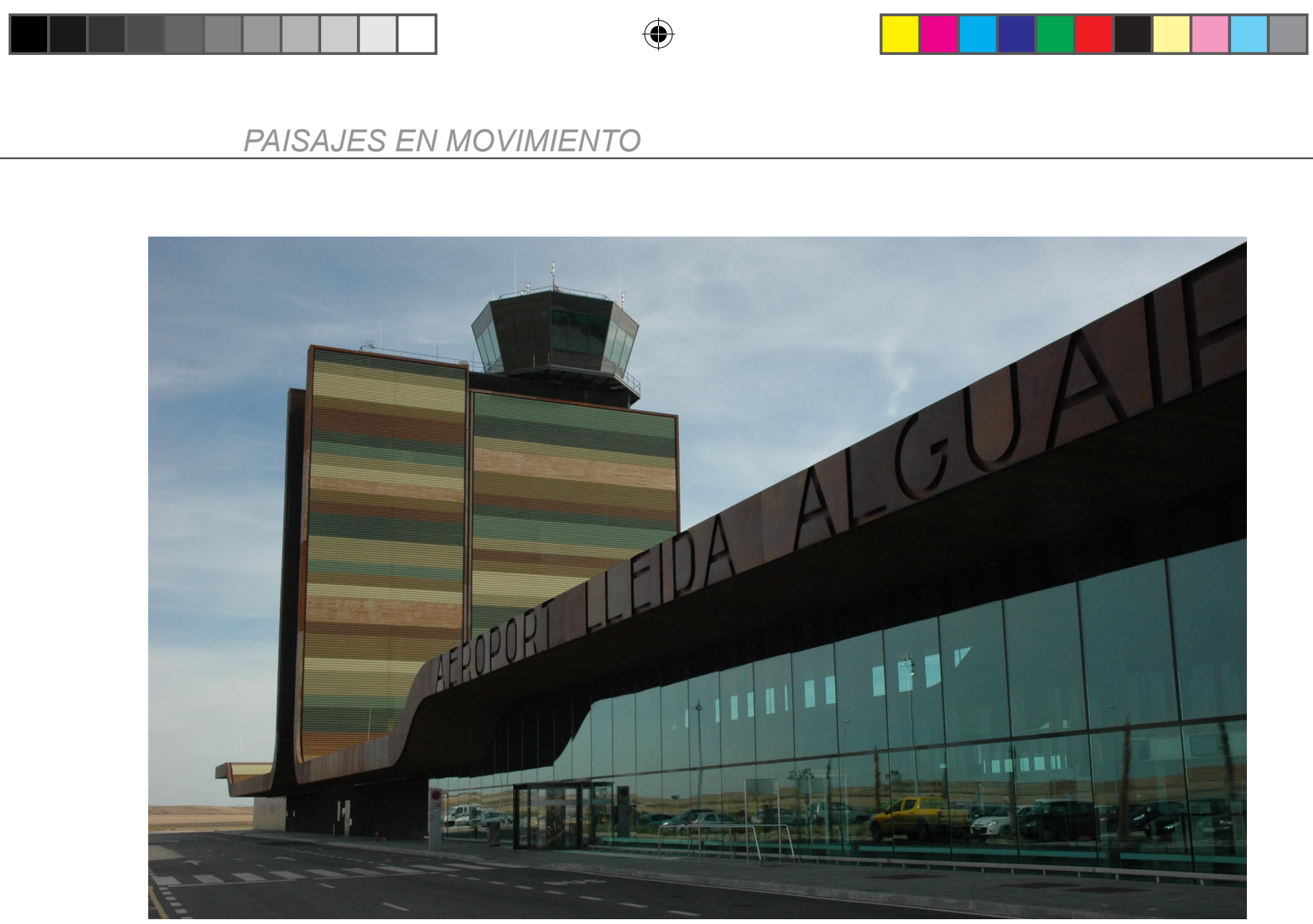

B720 Fermín Vázquez Arquitectos, Aeropuerto de LLeida, 2010, (fotografía I.C),

de cuadros sino, por el contrario, en constante mutación y cambio. Es precisamente esa reivindicación del movimiento la que nos ha traído, la que nos ha conducido hasta estas últimas páginas desde la introducción, hace ya algunos capítulos. Así hemos llegado hasta la contemporaneidad para interrogarnos, a modo de conclusión, acerca de lo que queda de ese movimiento histórico, de ese dinamismo enriquecedor de nuestras ciudades y arquitecturas a finales del siglo XX y comienzos del siglo XXI.

Situando el punto de vista en nuestro contexto cultural actual, (fundamentalmente el arquitectónico y urbanístico), una de las primeras características que podemos apreciar, y que resulta profundamente reveladora de la situación en la que nos encontramos, es el hecho de que la tradicional y excluyente distinción entre categorías herméticas como natural o artificial, territorio y ciudad o arquitectura y paisaje resulta más ineficaz que nunca a comienzos del siglo XXI. Algunas de las más excitantes experiencias culturales del cambio de siglo han surgido a partir del 


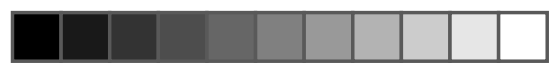

(†)

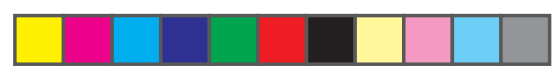

5. Conclusión:Arquitecturas-paisaje surgidas al hilo dél tiempo.

reconocimiento de la necesidad de superar dichos corsés y la puesta en escena de los diferentes actores en escenarios nuevos de encuentro, no ya de confrontación, entre distintos ámbitos. Han surgido, en la ciudad contemporánea, situaciones/piezas apoyadas en un discurso enriquecido mediante la contaminación entre campos históricamente excluyentes entre sí. Hoy en día, a mi modo de ver (y esta es el núcleo de la tesis que vertebra toda la investigación), un edificio puede ser paisaje y puede ser ciudad al mismo tiempo, de un modo si no nuevo, más sugerente y radical que nunca.

Actualmente, un número nada desdeñable de proyectos, y desde mi punto de vista los que resultan más interesantes, surgen desde una
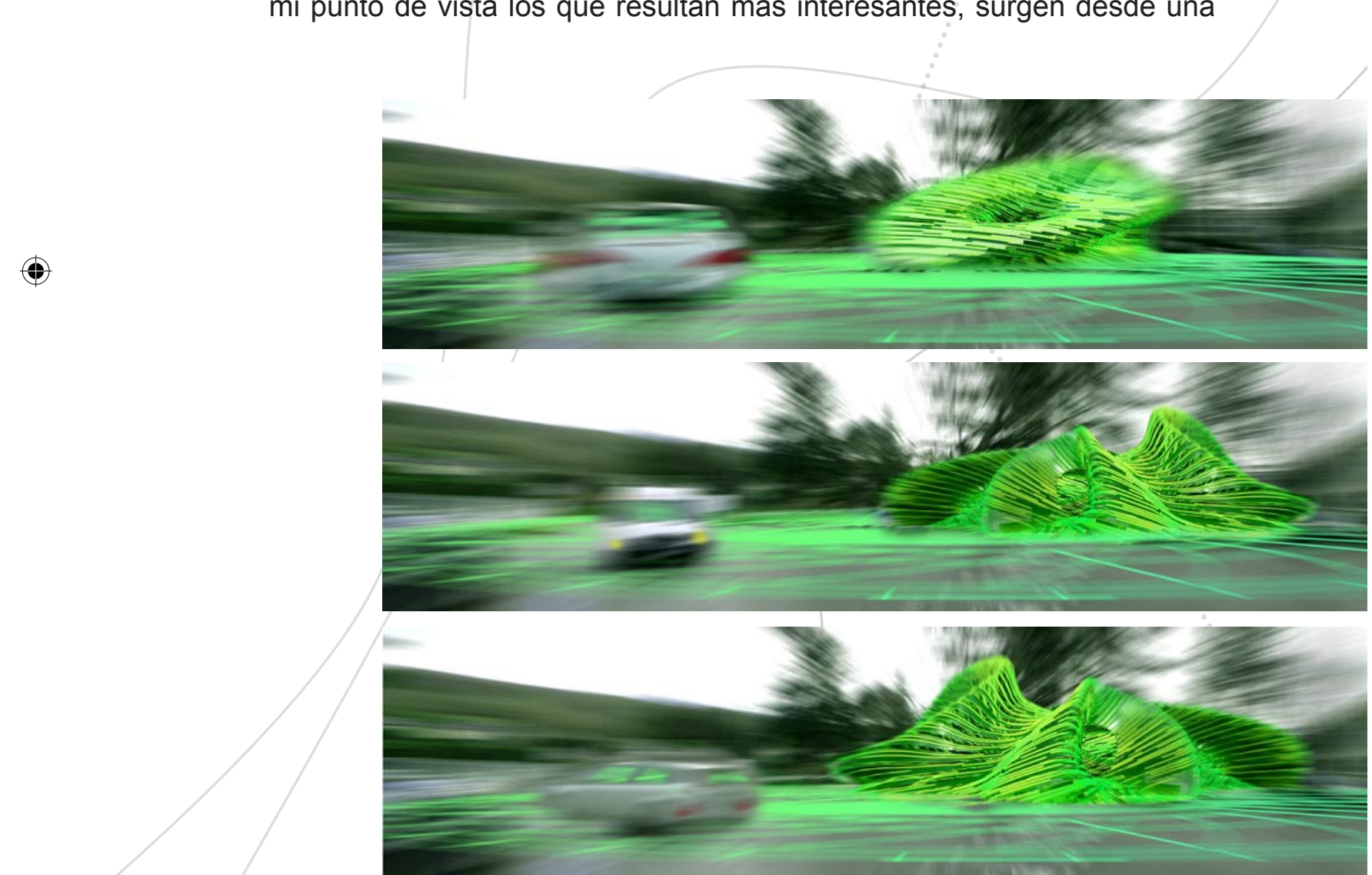

R\&Sie, The Building Which Never Dies, 2009. 

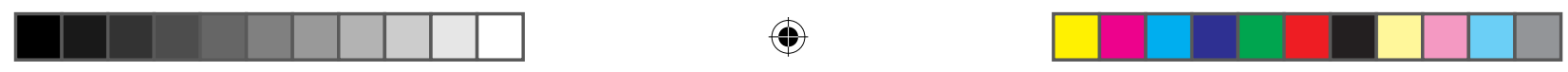

concepción de la arquitectura, no como elemento impuesto o superpuesto al lugar, sino como el propio corazón de la experiencia del lugar. Se proyectos que se plantean a partir de la "deformación" de la arquitectura para adaptarse al contexto, o incluso, en algunos de los casos más arriesgados, desde la transformación del propio contexto para adaptarse a la nueva arquitectura. Proyectos que se generan desde una modificación de la situación concreta física y real, es decir, de lo que se conoce convencionalmente como el "emplazamiento" de la intervención, mediante una mutación de parámetros; rechazando así la noción de arquitectura como incorporación, como objeto "añadido a" y empujándola en consecuencia al territorio más ambivalente y aglutinador del paisaje y la ciudad.

FOA (Foreign Office Architects), Terminal Marítima de Yokohama, 1996/2002 (fotografías I.C.).

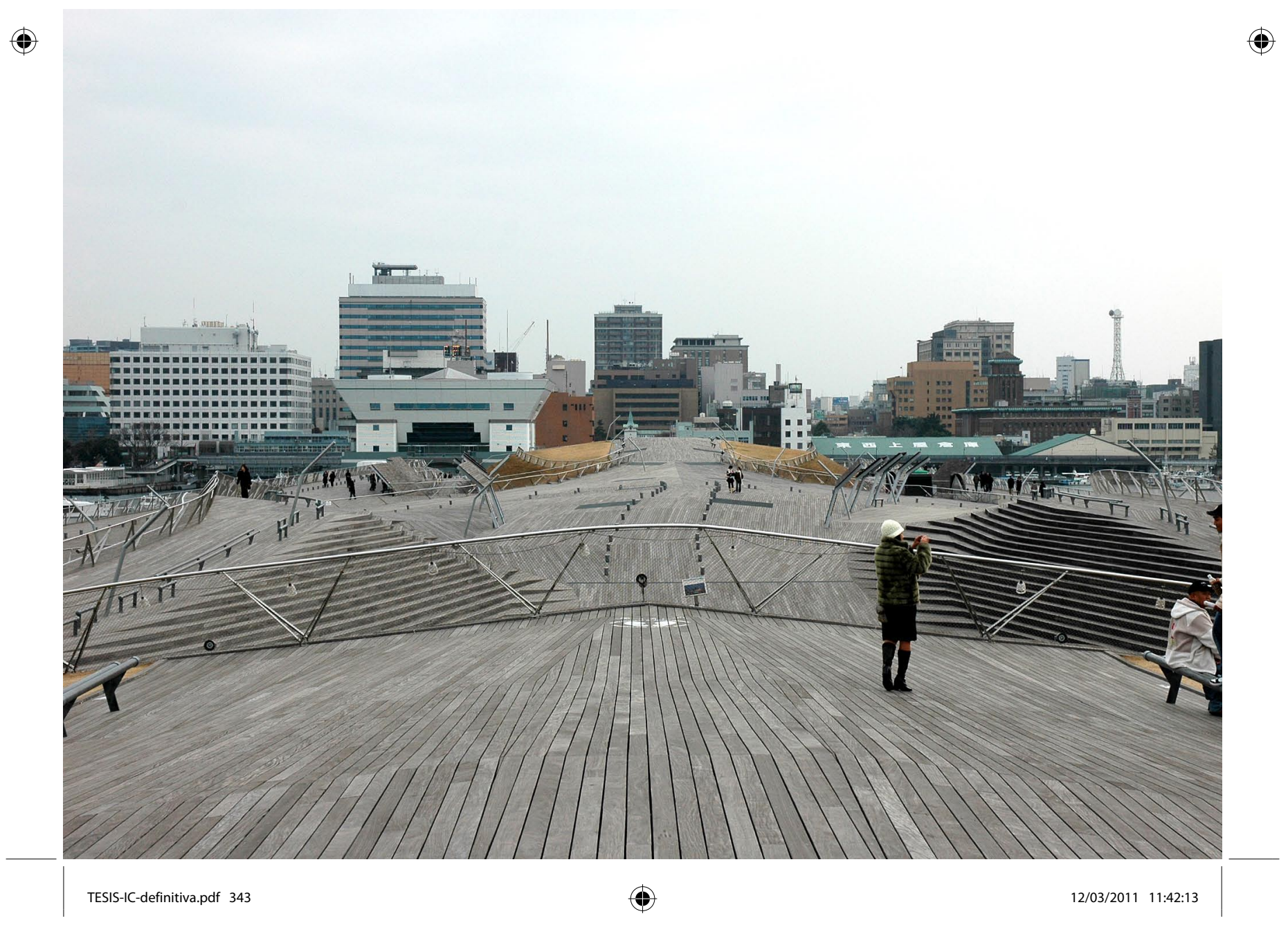



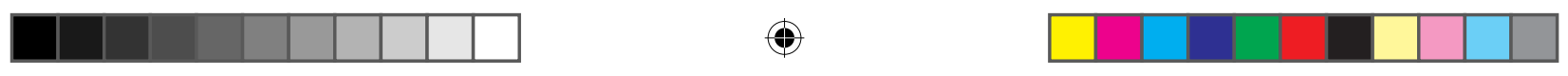

5. Conclusión:Arquitecturas-paisaje surgidas al hilo del tiempo.

Una de las manifestaciones más explícitas y reiterativas de este planteamiento es la manipulación del tradicional plano del suelo a la búsqueda de un paisaje artificial, nuevo y rico en matices y significados, produciendo en ocasiones el solapamiento de distintas situaciones y la superposición de capas de distinta índole; incorporando de este modo conceptos y herramientas tradicionalmente asociados al paisaje y al urbanismo en la configuración de los espacios intrínsecos de la arquitectura en tanto que disciplina autónoma. En este sentido resulta verdaderamente paradigmático el proyecto llevado a cabo por FOA (Foreign Office Architects) para la Terminal Marítima de Yokohama (1996/2002) en Japón.
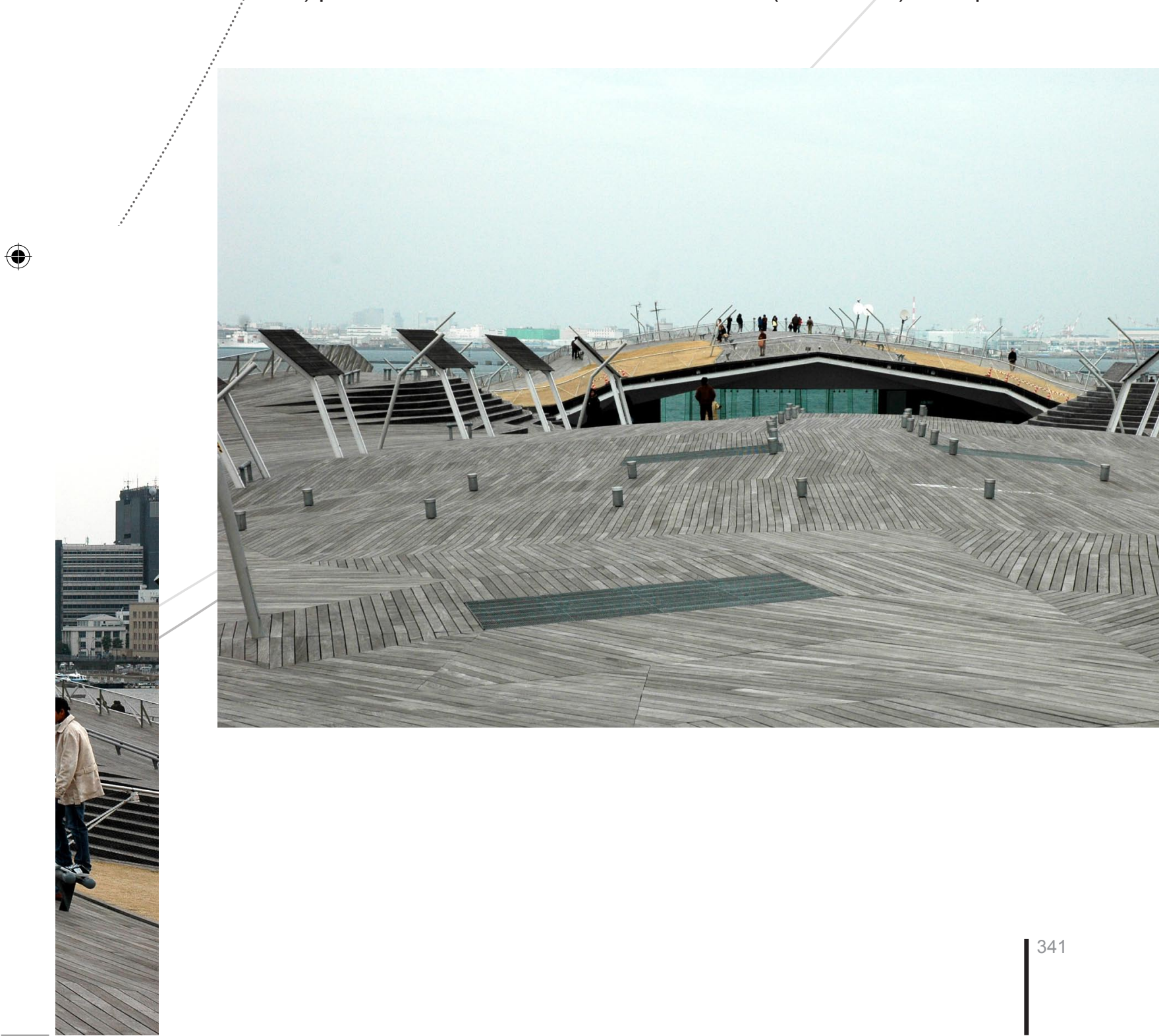


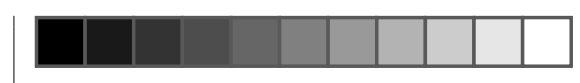

Podemos observar cómo esta terminal se genera a partir de un enorme plano del suelo que se pliega para constituir un verdadero paisaje de relación entre los viajeros que llegan o parten desde la terminal (y a partir de ellos, el mundo) y la ciudad de Yokohama. Este proyecto no puede ser entendido si se aborda desde criterios estrictamente arquitectónicos ya que el estudio dirigido por Alejandro Zaera transforma en la ciudad japonesa una estación de pasajeros en un paisaje de enorme capacidad sugerente, incorporando conceptos propios de esta disciplina, tales como la continuidad, la intensidad de flujos, las conexiones, la climatología o la relaciones de lejanía o proximidad. Como el propio Zaera nos explicaba en la revista El Croquis 115/116: "El suelo de la ciudad se conecta sin solución de continuidad al nivel de embarque, y desde allí se bifurca para crear toda una variedad de acontecimientos urbanos. Como consecuencia el edificio deviene en prolongación de la ciudad."1

La propuesta de Alejandro Zaera para Yokohama es, además,

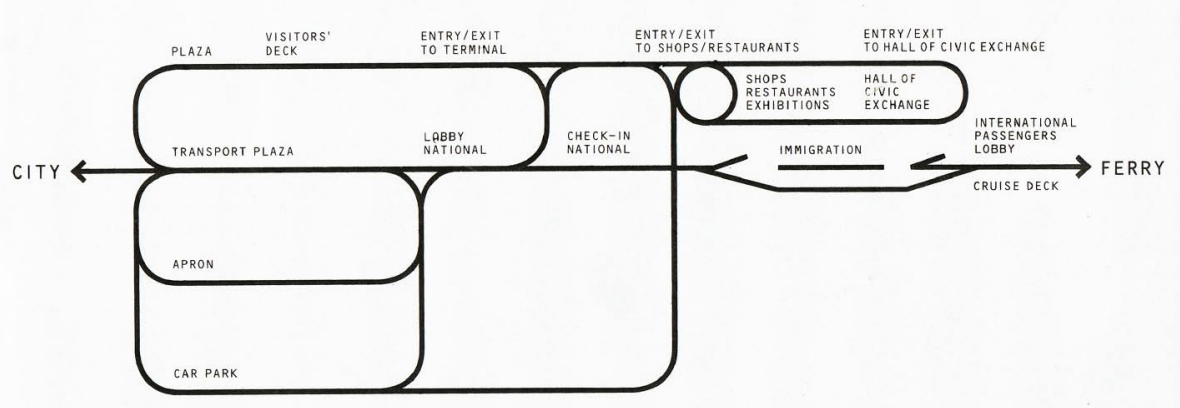

FOA (Foreign Office Architects), Terminal Maritima de Yokohama, 1996/2002, Esquema de relaciones.

especialmente interesante porque nos permite aproximarnos a otra de las características fundamentales de estos espacios urbanos dinámicos entre el arte y la arquitectura: las relaciones que se establecen en distintos ámbitos y escalas. En Yokohama, este sistema de relaciones se

1 Para conocer la explicación del propio Alejandro Zaera sobre este proyecto véase la revista El Croquis 115/116, Madrid, 2003.

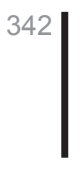



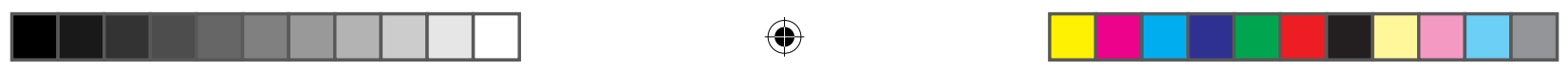

5. Conclusión:Arquitecturas-paisaje surgidas al hilo del tiempo.

ha organizado como una serie de bucles en los cuales se han eliminado los límites entre lo dinámico y lo estático facilitando así una multiplicidad de recorridos, de caminos alternativos que intensifican la experiencia de transitarlo. Quisiera aprovechar el ejemplo de Yokohama para hacer notar de qué modo la noción de relación, uno de los pilares fundamentales en cualquier proyecto de paisaje, es en efecto, el detonante principal en muchos otros proyectos similares al que nos ocupa.

Si nos acercamos al recientemente inaugurado Centro de Arte Contemporáneo de Roma (MAXXI), obra de la arquitecta Zaha Hadid, (a cuya obra ya nos aproximamos en el capítulo anterior), por ejemplo, veremos que estamos, de nuevo, ante un edificio lineal, direccional, una masa surgida a partir de vectores de circulación. Es como una segunda piel para el lugar donde se encuentra ubicado, debido a que los diferentes elementos arquitectónicos están geométricamente alineados con las redes circundantes, esta vez no derivadas del paisaje natural como en proyectos anteriores de la arquitecta anglo-iraquí, sino del paisaje urbano. Esto

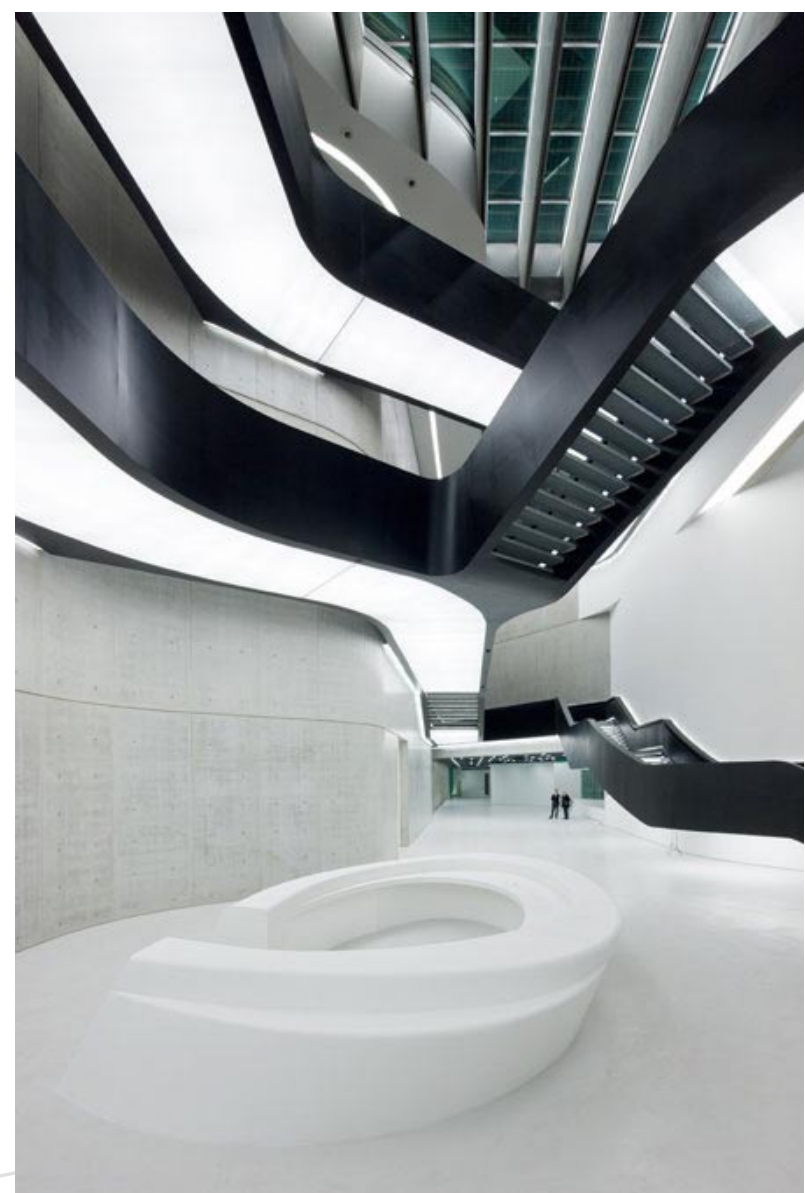

Zaha Hadid, Centro de Arte Contemporáneo de Roma (MAXXI), 1998-2009. convierte al MAXXI más que en un edificio en, como dice la pro- 

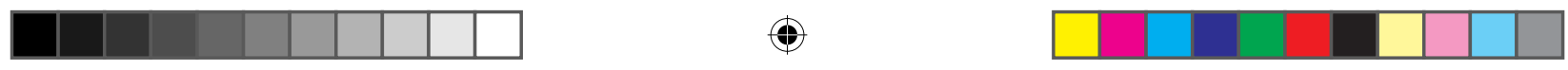

pia Zaha Hadid, "una condensación de las distintas orientaciones de los entornos que lo rodean. Podría decirse que el proyecto descubre recorridos urbanos que permanecen latentes dentro del contexto circundante"2.

Se trata de arquitecturas, a diferencia de lo que pueda parecer de un modo superficial, eminentemente contextuales. De este modo, entrelazando y confundiendo las circulaciones de los edificios con las del espacio público la arquitectura expande su dimensión pública y se generan nuevos espacios más ricos en matices y de significados ambivalentes. La forma viene fuertemente determinada, en estos casos, por el entorno y por el programa, con lo cual solamente puede explicarse por las cualidades específicas de ese lugar, o de un modo más preciso, por las relaciones establecidas entre arquitectura y ciudad. Se produce una confusión entre el paisaje urbano y el espacio interior

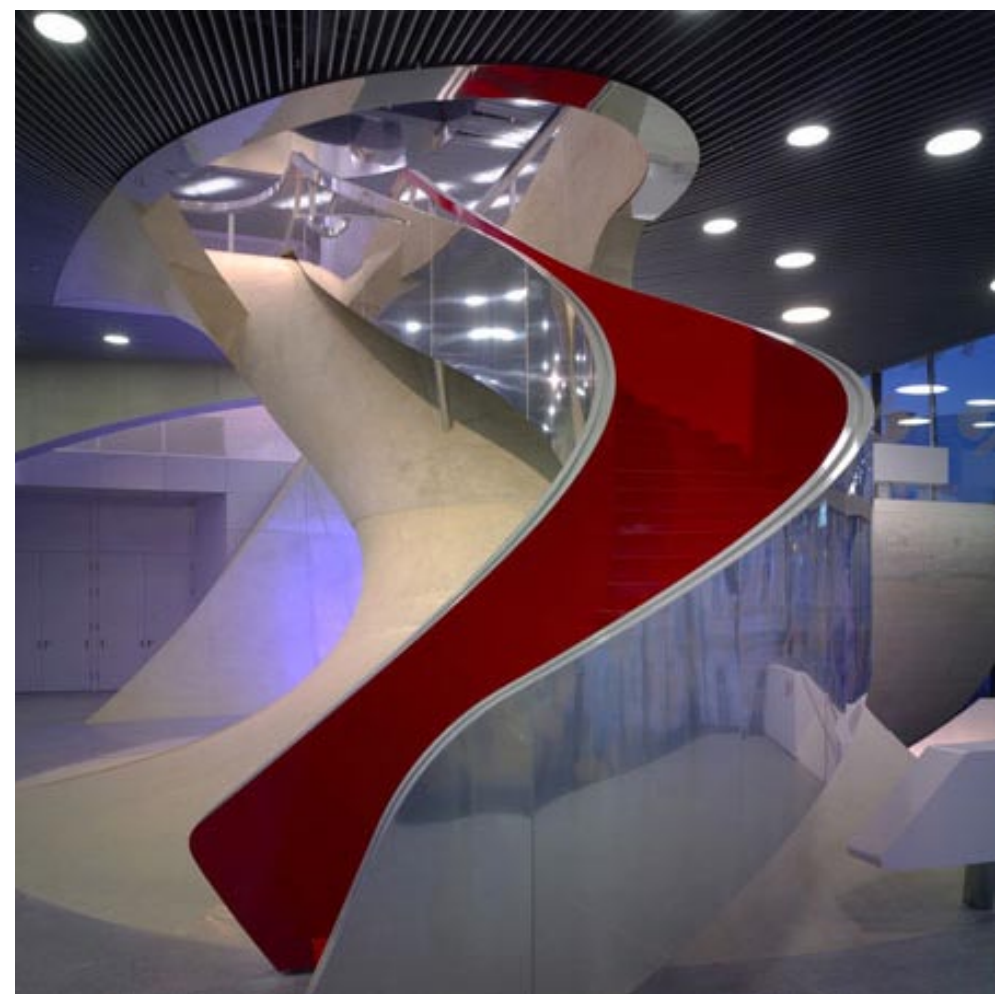

UN Studio, Auditorio, Graz, 1998-2008.

del edificio, apareciendo un nuevo paisaje que no es ni el primero ni el segundo, sino una compleja entidad formada a partir de la fusión de am-

2 VV.AA. Zaha Hadid. The Complete Buildings and Projects, Thames \& Hudson, Londres, 1998, p.45. 

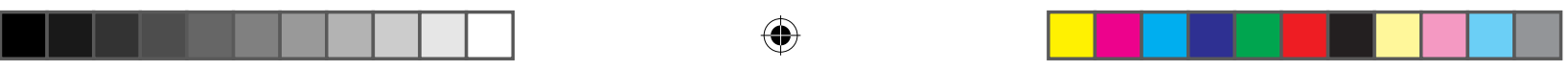

5. Conclusión:Arquitecturas-paisaje surgidas al hilo dèl tiempo.

bos. Ya no podemos hablar del "interior" o del "exterior" con la rotundidad a la que estamos acostumbrados habitualmente, sino que es el propio movimiento del visitante/usuario el que pone en funcionamiento una serie de mecanismos perceptivos y simbólicos que generan lo que estamos denominando un paisaje en movimiento; mecanismos que generan una realidad que trasciende las tradicionales dicotomías dentro/fuera o paisaje/arquitectura.

Podríamos decir que estos dos

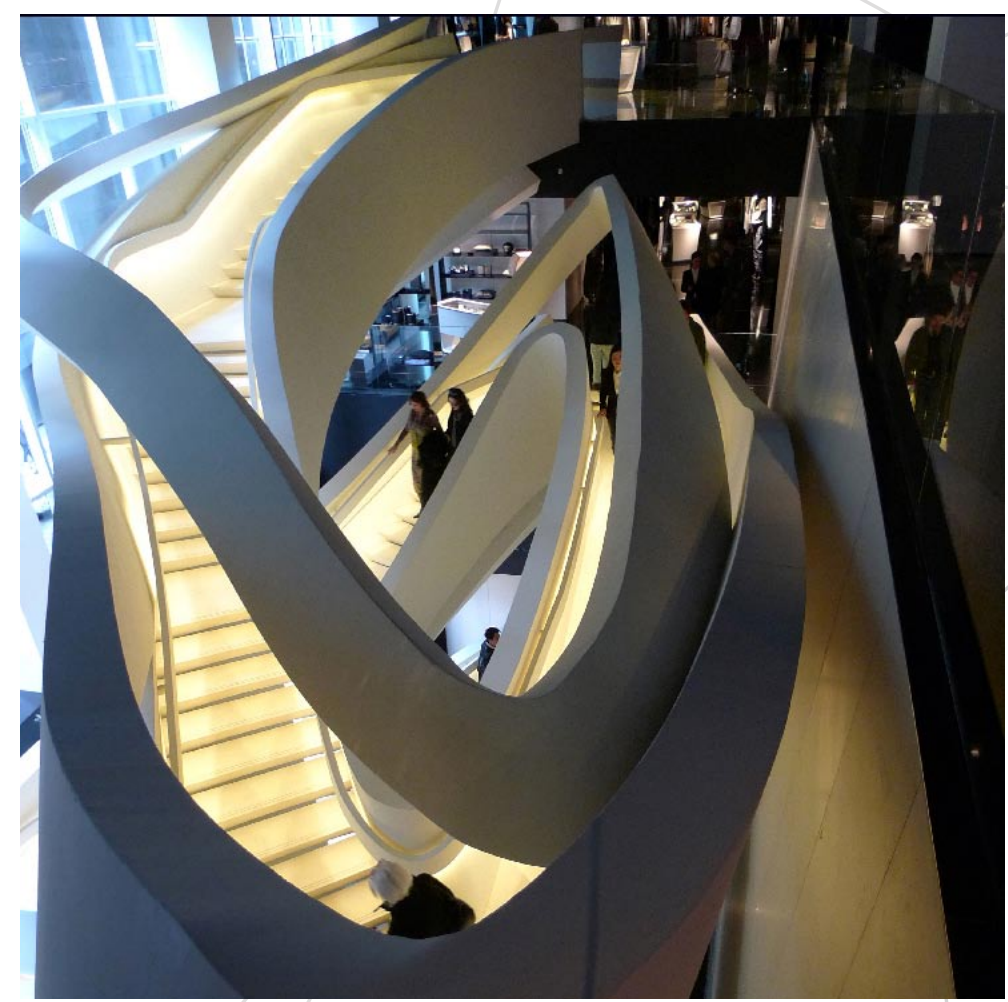

Maximiliano Fuskas, Armani, 5th Avenue, Nueva York, 2008. ejemplos mencionados son un episodio contemporáneo de lo que entendemos ha sido un largo camino recorrido, iniciado tal vez, en 1446, cuando Leon Battista Alberti incorporó bancos en su fachada para el Palazzo Rucellai en Florencia, comenzando así tímidamente a difuminar las fronteras entre la arquitectura y el espacio urbano en Occidente, intensificando de este modo el potencial interactivo entre la arquitectura y el espacio urbano. Son propuestas dirigidas a que la ciudad se transforme en un paisaje para sus habitantes, donde las fronteras otrora claramente definidas, entre las diferentes categorías se vuelven más permeables 

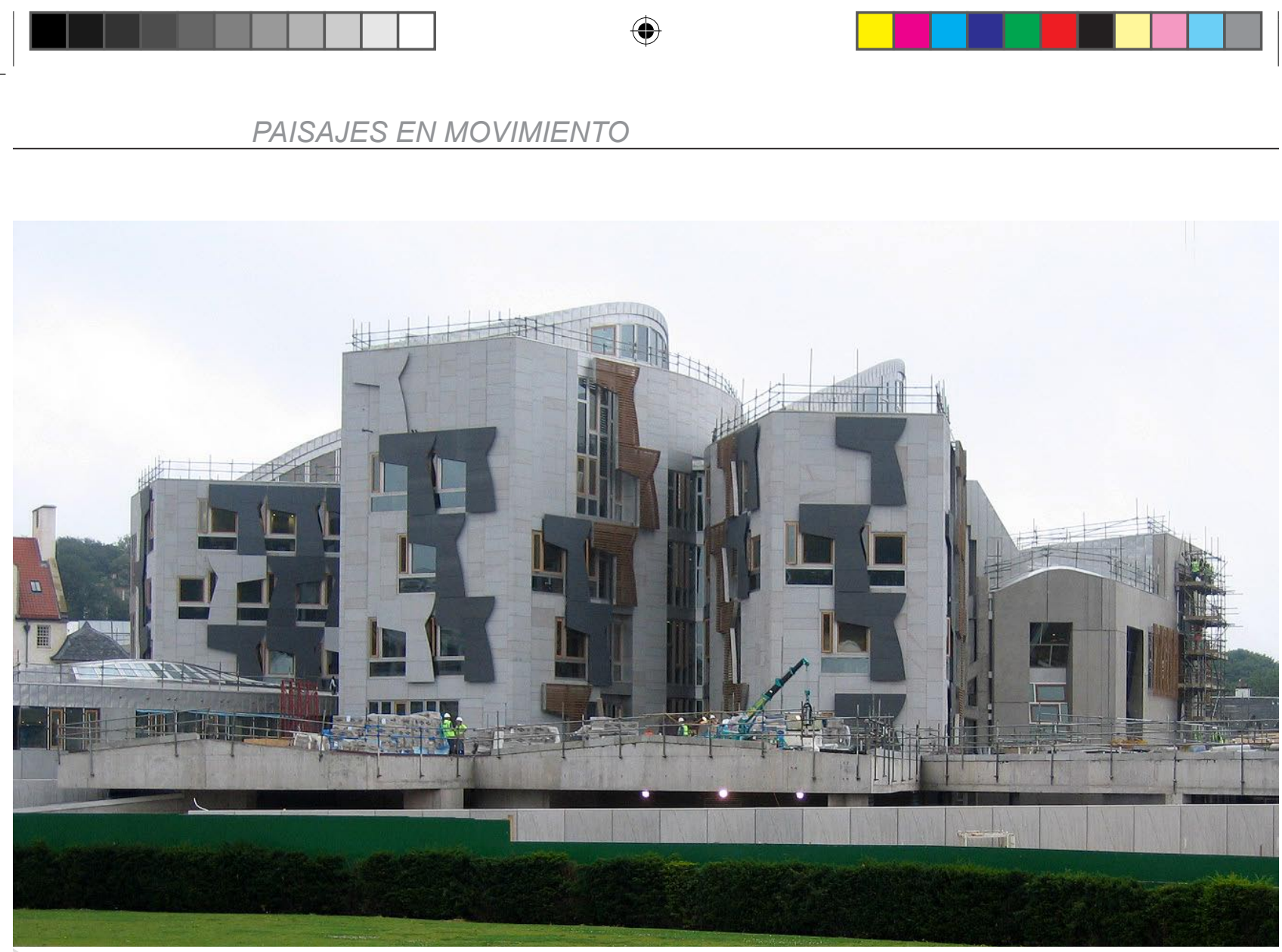

Enric Miralles, Parlamento de Escocia, Edimburgo, 1999-2004, (fotografía I.C.).

hasta prácticamente desaparecer en incontables ocasiones. Estos límites como vemos, se diluyen, creando entidades de enorme interés y que portan en su seno una profunda carga liberadora y un potencial cultural de enorme valía e interés.

A menudo, estos proyectos buscan, premeditadamente también, la fragmentación de la planta con el objetivo de facilitar y potenciar esas transformaciones, permitiendo de este modo entradas y salidas que dinamizan los flujos que vinculan la ciudad y la arquitectura mediante ự movimiento constante de usuarios e información. En estos ejemplos de arquitecturas de enorme complejidad, el visitante se enfrenta a espacios que nos remiten con claridad a la noción de laberinto que vimos anteriormente. Así pues, al usuario/habitante tan solo se le muestran visiones fugaces de los espacios que tiene que atravesar, obligándole de este

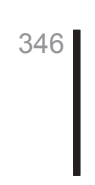



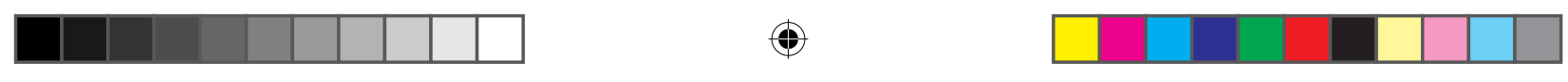

5. Conclusión:Arquitecturas-paisaje surgidas al hilo del tiempo.

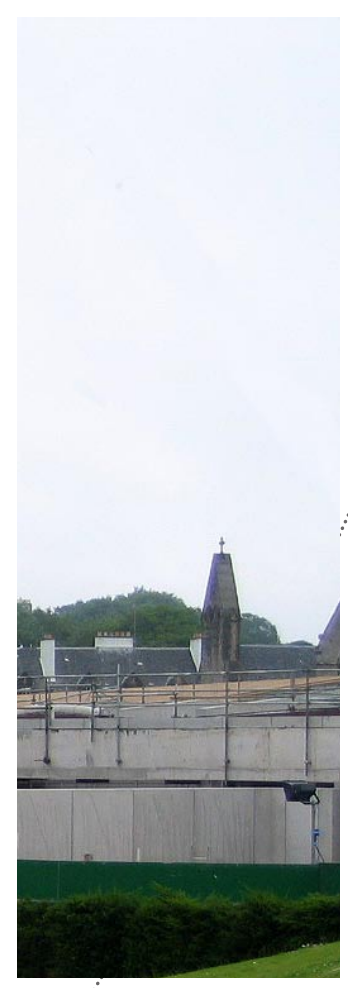

modo a un ejercicio espacial de recomposición de coordenadas y de interrogación y búsqueda personal. Persiguiendo esta meta, muchos de estos proyectos se articulan intentando romper barreras, eliminar obstáculos y limar aristas entre edificio y espacio urbano.

La arquitectura y el urbanismo de los "paisajes en movimiento" invocan la experiencia temporal como algo necesario para activarse y su dimensión, consecuentemente, no puede ser aprehendida sin la propia experiencia personal. De aquí la importancia que animaciones y videos han adquirido en los últimos años para comprender y controlar dichas obras de arquitectura. El gran auge de dichas animaciones asistidas por ordenador y renders, no es sino un síntoma de la necesidad de encontrar herramientas que nos permitan conocer y mostrar una arquitectura cada vez más dinámica, basada en relaciones y recorridos, para la cual alzados, plantas y secciones resultan claramente insuficientes. La forma es, en muchos casos, el campo donde se manifiestan vectores y distorsiones difícilmente representables a día de hoy. Estas inquietudes proyectuales darán lugar en numerosas ocasiones a geometrías alternativas que permiten la posibilidad de trabajarcon superficies de curvatura variable, lo que permite acercarnos a formas y objetos que no pueden ser desplazados sin que sus propiedades se vean alteradas ni su propia forma modificada.

Así, la formalización de estas arquitecturas surgidas desde el contexto, planteadas no en tanto que "arquitecturas-objeto" sino desde el reconocimiento del entorno, se produce desde una fuerte vocación relacional que busca sintetizar las tensiones y posibilidades del lugar, revalorizar su energía. Todo ello con el propósito de enmarcarlas y relacionarlas con los condicionantes de un entorno global más ambivalente, en el que éstas se inscriben, no renunciando al objeto y la figuración aunque planteándolos desde una nueva óptica, desde una perspectiva más abierta. Estas propuestas reconocen, desde un principio, su capacidad para potenciar 

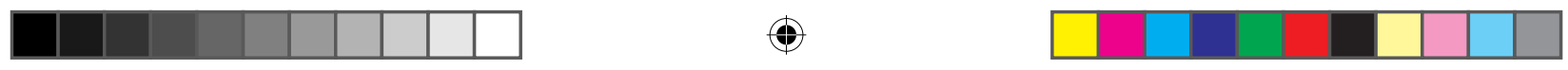

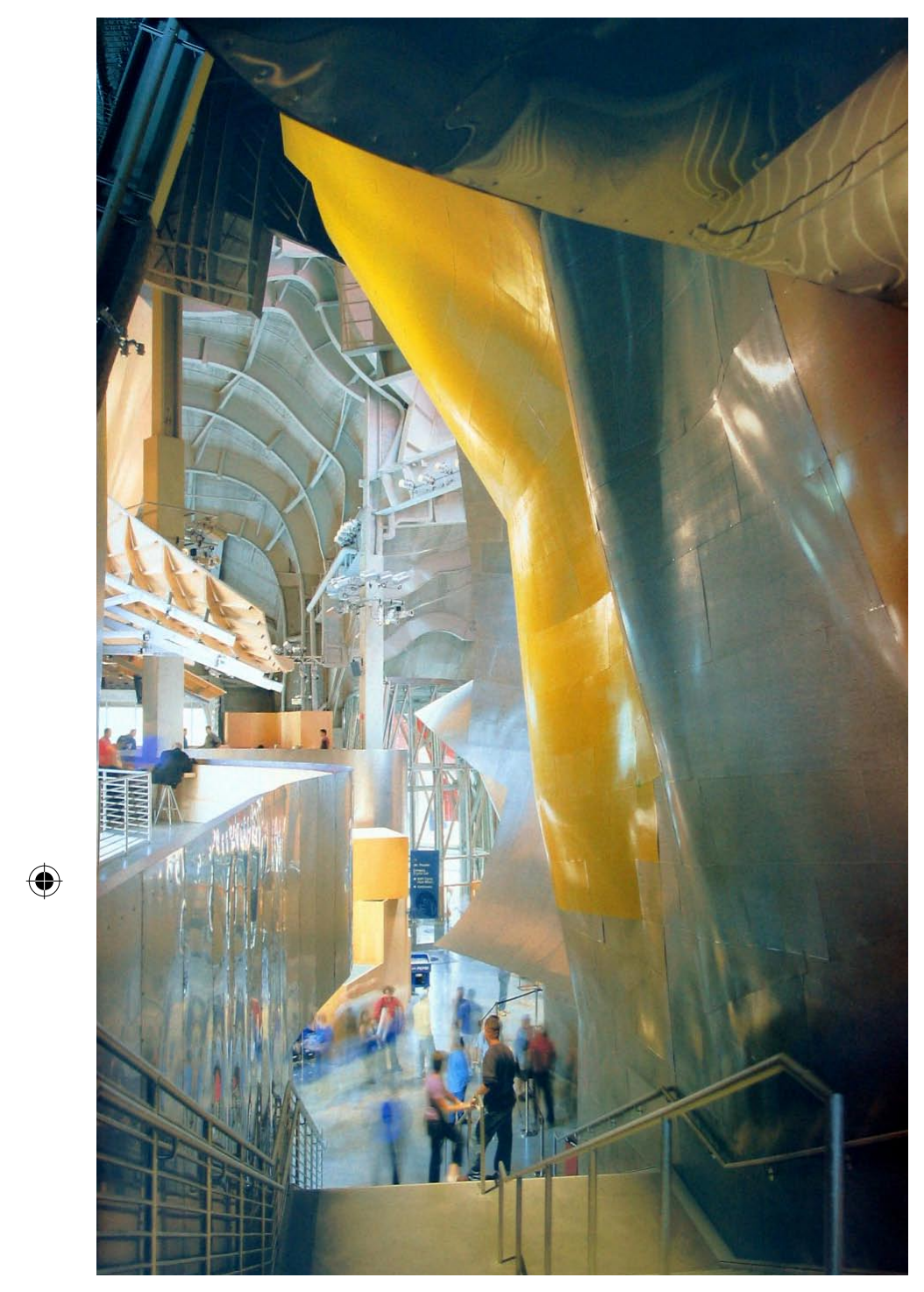

Frank Gehry, Walt Disney Concert Hall, Los Angeles, 2003. el lugar en el sentido de entrar en resonancia e interacción con él. Por lo tanto, no se trata ya de proyectos, de objetos, que busquen completar y terminar algo que se presupone inacabado, sino de dialogar con el entorno trascendiéndolo y creando relaciones transversales que multipliquen las posibilidades del propio lugar en un permanente intercambio bidireccional de información y de energía que da lugar a sistemas mucho más complejos, dinámicos y abiertos.

Este nuevo enfoque fluido, no afecta tan solo a la relación de la arquitectura con su entorno, sino que se ha producido simultáneamente otro cambio determinante: ahora es el propio proyecto el que se reconoce en constante desarrollo. De este modo, la arquitectura pasa a ser un paisaje vivo formado por múltiples (y en ocasiones contradictorias) capas. La arquitectura se presenta a sí misma como "proceso" en lugar de como "objeto" terminado. Este interés por el cambio, por el desarrollo 

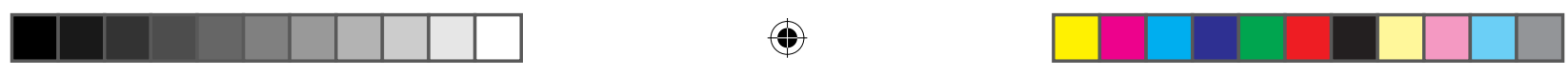

5. Conclusión:Arquitecturas-paisaje surgidas al hilo del tiempo.

en el tiempo y por el movimiento subyacente e inherente a la arquitectura (paisaje), es el que ha desviado la atención desde la definición de la forma conclusa y terminada hacia la consolidación de procesos dinámicos generadores de arquitectura y espacio urbano. Así, la estabilidad formal ha dado paso al ecologismo y la atención por el lenguaje ha virado hacia un vitalismo arquitectónico que transforma permanentemente la forma; una forma siempre en desarrollo y mutación, inmersa en un desarrollo de ida y vuelta entre lo sensible y lo racional.

Es en este nuevo contexto donde el ángulo recto, omnipresente hasta la fecha, ha capitulado cediendo el protagonismo a una arquitec-

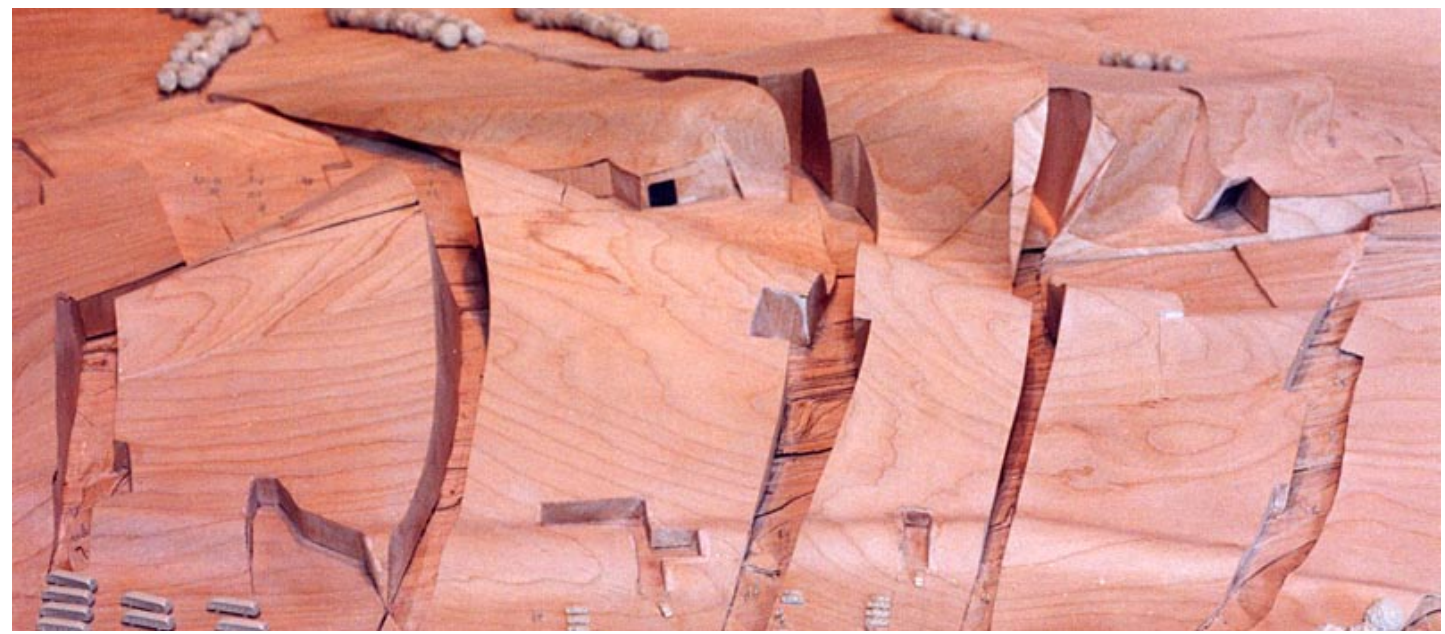

Peter Eisenman, Ciudad de la Cultura, Santiago de Compostela, 1999-2011.

tura mucha más abierta, fluida, suave y adaptativa. Ahora, las formas se constituyen, fundamentalmente, de cambios y variaciones, interpretando informaciones cada vez más abundantes y complejas, que las configuran y que transforman el entorno. Es por ello que ha surgido, hace ya algunos años, un renovado interés por un espacio hecho de curvaturas, dobleces y pliegues que evidencian el interés por lo orgánico, lo animado 


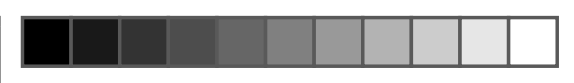

$\oplus$

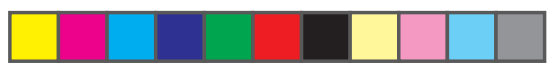

y lo dinámico y que demuestran la importancia otorgada a la continuidad, a la superposición de estratos y capas (de nuevo conceptos ligados al paisaje) con el fin último de diluir los límites de la propia arquitectura. Este fenómeno ha facilitado la aparición de múltiples campos de fuerza y trayectorias transformadoras de la realidad circundante.

Un ejemplo paradigmático de este renovado interés por lo orgánico y por una fusión de la arquitectura con la naturaleza es el Centro Paul Klee en Berna (Suiza), 1999-2005, de Renzo Piano. Aquí, partiendo de una cualidad del paisaje como es la identidad entre estructura y espacio, el arquitecto italiano ha creado un paisaje habitable donde la articulación entre el entorno, lo tectónico y lo tecnológico ha dado lugar a una nueva naturaleza artificial con claras referencias a accidentes geológicos o movimientos naturales. Con este propósito no ha dudado de apropiarse de procesos propios del crecimiento orgánico, unos procesos vitales
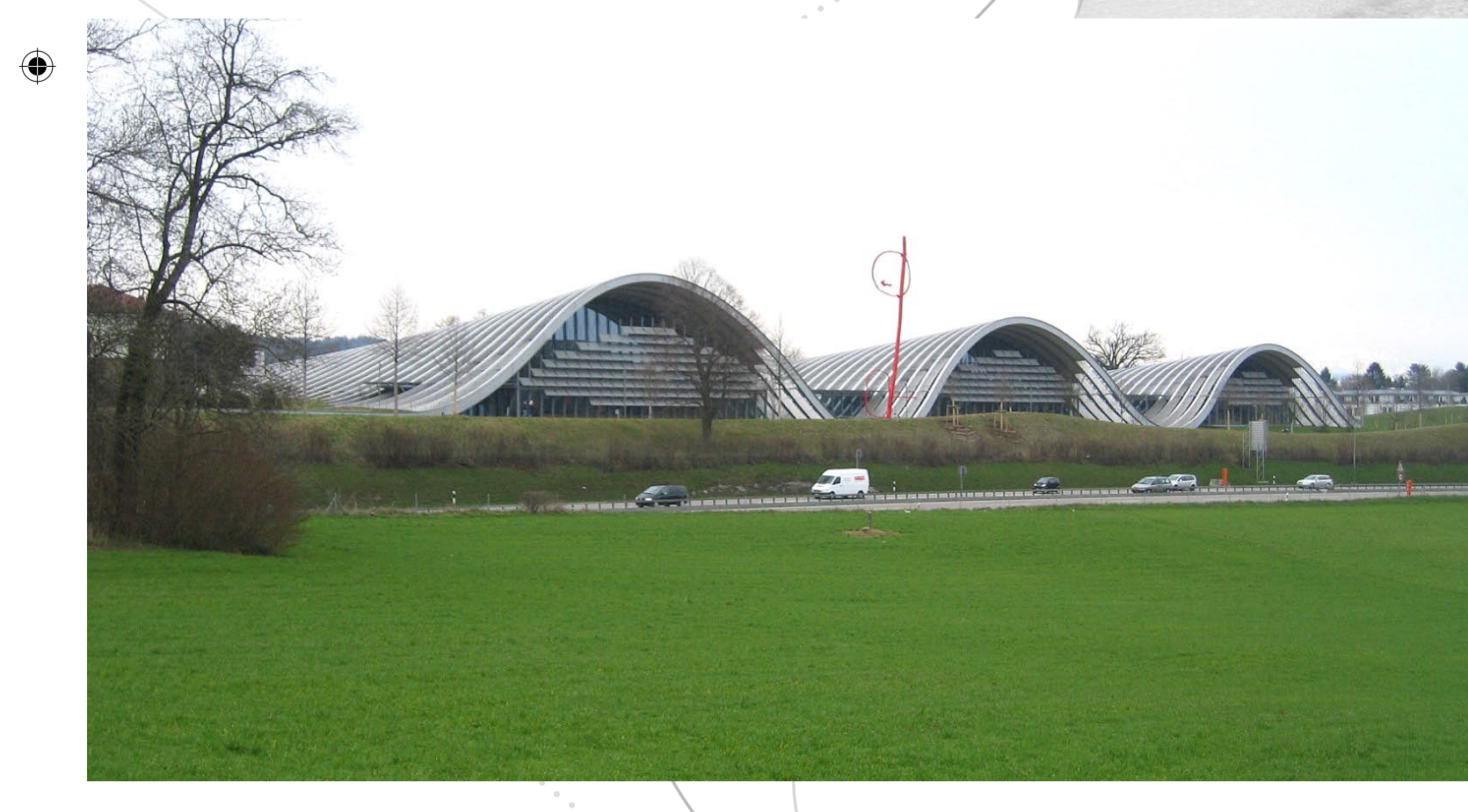

Renzo Piano, Centro Paul Klee, Berna, 2005, (fotografías I.C.). 

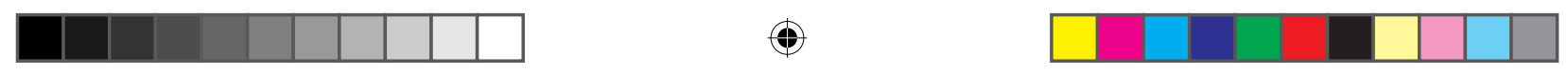

5. Conclusión:Arquitecturas-paisaje surgidas al hilo del tiempo.

complejos, múltiples y en ocasiones efímeros. En Berna, los solapes y transiciones son suaves y fluidos y las referencias formales biológicas y geológicas, son claramente explicitas. Las formas que Renzo Piano trazó en el protegido y estructurado paisaje suizo nos remiten a una arquitectura fluida que busca las referencias en otras disciplinas alejadas de la arquitectura hasta el momento.

Estamos aprovechando este ejemplo para comprobar de qué modo en su formalización, a menudo, esta arquitectura busca una aproximación premeditada a una clara condición orgánica. Esto se debe, sin lugar a dudas a un claro intento de interacción con la naturaleza y el entorno. Paralelamente, esta condición orgánica, además de reflejar la fascinación por los procesos naturales, sirve como denuncia de una normatividad y ortogonalidad rígidas y estáticas; al tiempo que activa, como estamos viendo, procesos de hibridación entre la arquitectura y la natura-

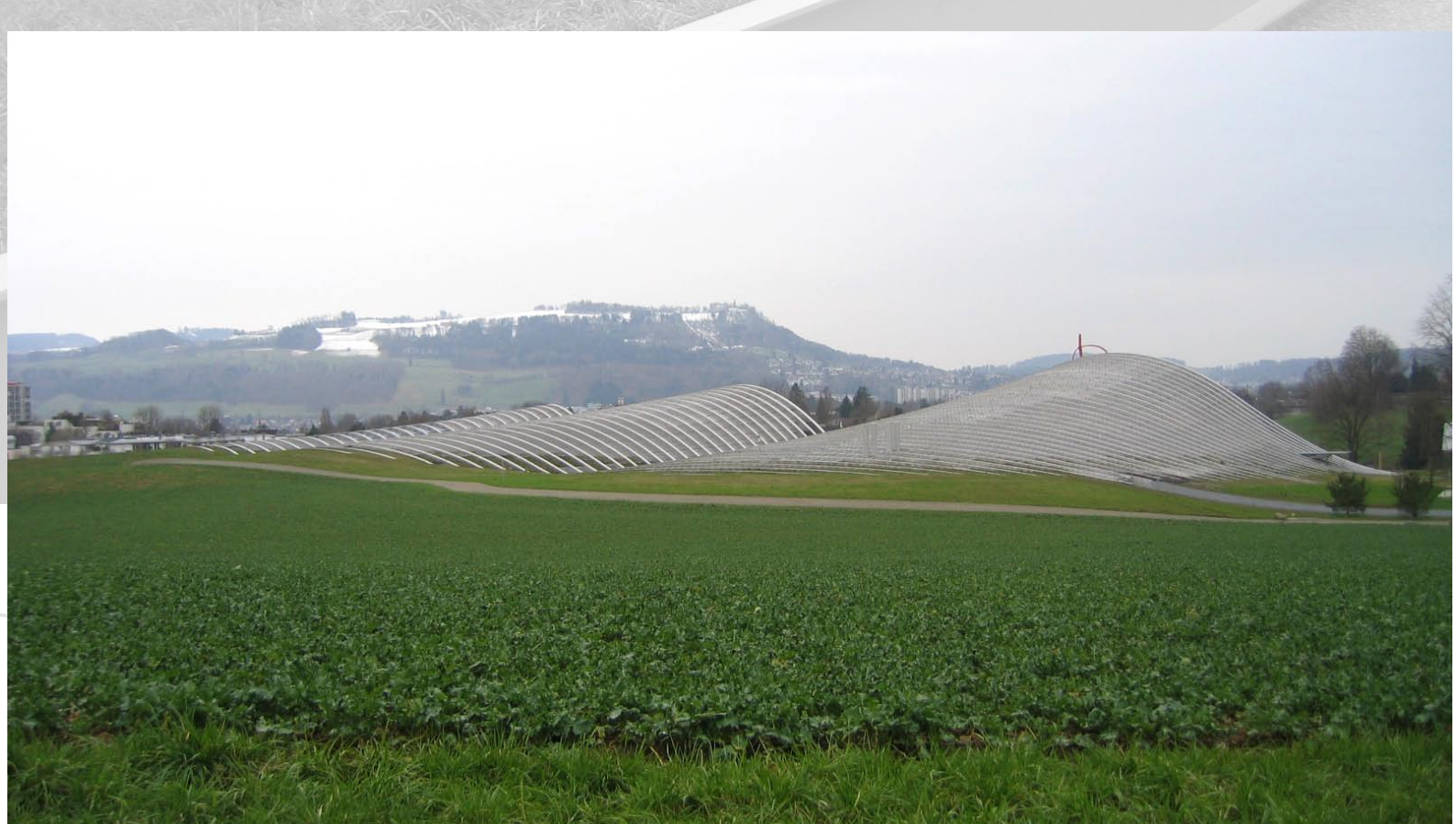




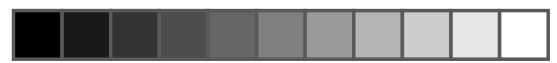

$\oplus$

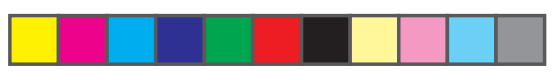

leza que dan lugar a operaciones muy interesantes, si no siempre en sus resultados finales, si en cuanto a la reflexión que plantean.

La actuación de Renzo Piano en el Centro Paul Klee de Berna, no es única (aunque tal vez sea uno de los más satisfactorios ejemplos) en la

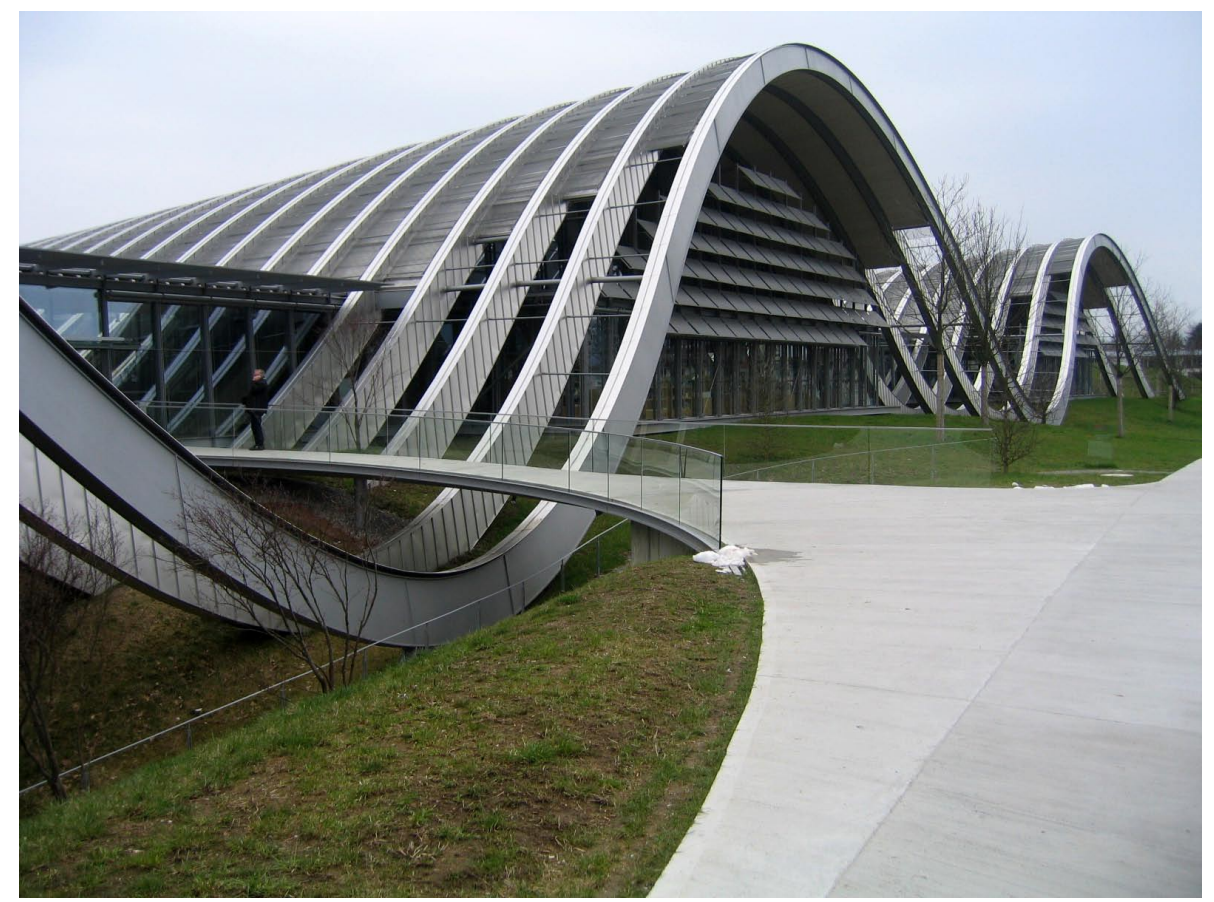

Renzo Piano, Centro Paul Klee, Berna, 2005, (fotografía I.C.).

arquitectura contemporánea. Por el contrario, a comienzos del siglo XXI, proliferan las referencias al mundo vegetal y mineral, como por ejemplo: los pliegues (que a menudo sustituyen a las tradicionales plantas, alzados y secciones creando continuidades en algunos casos sorprendentes); las estructuras arbóreas, con filiaciones más que evidentes; o las vetas e incrustaciones. En ocasiones incluso se llega (aún con el certero riesgo de transformarse en un juego irónico y divertido), a revestirse de tatuajes y camuflajes. Se trata de investigaciones que se sitúan en los límites, en las fronteras, entre naturaleza y artificio, experiencias que buscan dilatar 


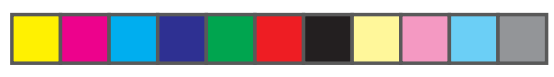

5. Conclusión:Arquitecturas-paisaje surgidas al hilo dèl tiempo.

esas fronteras hasta el límite elástico de rotura.

En estos proyectos se ha producido, en consecuencia, una alteración en la tradicional distinción entre figura y fondo, lo que representa también una de las características más significativas de estos nuevos paisajes. Esta jerarquización, que ha dominado históricamente los procesos proyectuales y creativos ( $\mathrm{y}$ que se ha producido de un modo más férreo en el ámbito de la arquitectura y el urbanismo), ha sido definitivamente puesta en cuestión y posiblemente ya nunca pueda ser retomada con los parámetros en los que se había movido hasta nuestros días. De este modo se están produciendo campos de fuerzas dinámicos de intercambio entre figura y fondo que amplían enormemente las posibilidades de futuro en la ciudad y el territorio contemporáneo.

Los paisajes en movimiento, plantean lo orgánico como proceso formal abierto, indeterminado y evolutivo que reenvía a una concepción intuitiva, individualista y subjetiva de la forma; escapando al análisis sistemático y cartesiano de la misma. Se incorpora así el movimiento y la mutación al proceso, al proyecto, confrontando el elemento vital a la identidad de las formas tipificadas, al tipo en sí mismo. Esta búsqueda de legitimación para/la subjetividad se debe al interés, renovado también, por los aspectos identitarios, lo cual en numerosas ocasiones trasciende el ámbito de la arquitectura y entra de lleno en el terreno del paisaje. La situación, la materia y la forma se convierten en factores clave a la búsqueda de una identidad definida y diferenciadora que se persigue en aras de una seguridad y estabilidad perdidas en un mundo cada vez más interconectado y homogeneizado y por tanto más complejo y extraño. La mayor velocidad impuesta a los cambios y a las transformaciones en el mundo contemporáneo ha impuesto nuevos ritmos a la producción de la arquitectura y la ciudad y no es de extrañar, por tanto, el renovado interés por el paisaje que podemos comprobar en la actualidad. La arquitectura se encuentra cómoda reflejada en el espejo del paisaje ya que de este modo puede tomar partido por la subjetividad que le brinda éste frente a la pretendida objetividad del territorio físico y del emplazamiento con- 

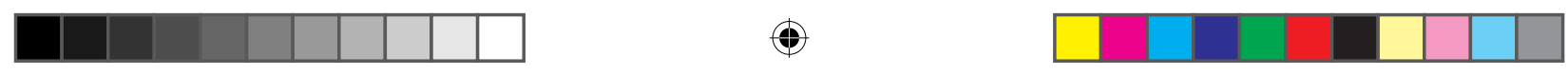

creto, entrando de lleno en la eterna dicotomía subjetividad/objetividad; entre un mundo externo contingente y un mundo intelectual que recoge las percepciones de éste y las interpreta.

Este planteamiento de la arquitectura y de la ciudad como complejos o categorías más abiertas y permeables permite y posibilita influencias transversales provenientes de otras disciplinas y de otros campos artísticos, aportaciones que vienen a enriquecer el discurso y la realidad contemporánea de nuestro entorno. Cada vez en mayor medida, la sociología, la filosofía, la física o las matemáticas están dialogando con aquellas arquitecturas que intentan buscar respuesta a su entorno y su momento histórico sin buscar salidas fáciles, simplistas y carentes, por tanto, de interés.

Hoy en día, como estamos viendo, asistimos gracias a este fructífero intercambio entre disciplinas, a la proliferación de nuevos paisajes contemporáneos. Paisajes surgidos en espacios y entornos donde se funden y confunden los límites entre arquitectura, naturaleza y ciudad. Situaciones y acontecimientos donde lo natural y lo artificial es puesto a menudo en cuestión, en un higiénico y enriquecedor proceso de investigación. De este modo, estos conceptos dejan de responder a categorías abstractas impolutas y excluyentes y pierden todo su carácter antagónico. Hablar en esta nueva situación de edificios resulta, en mi opinión, inadecuado, o al menos insuficiente, para referirnos a arquitecturas que reflejando esa compleja relación de intercambio producida entre el objeto y su entorno generan lo que creo más exacto denominar paisajes en movimiento.

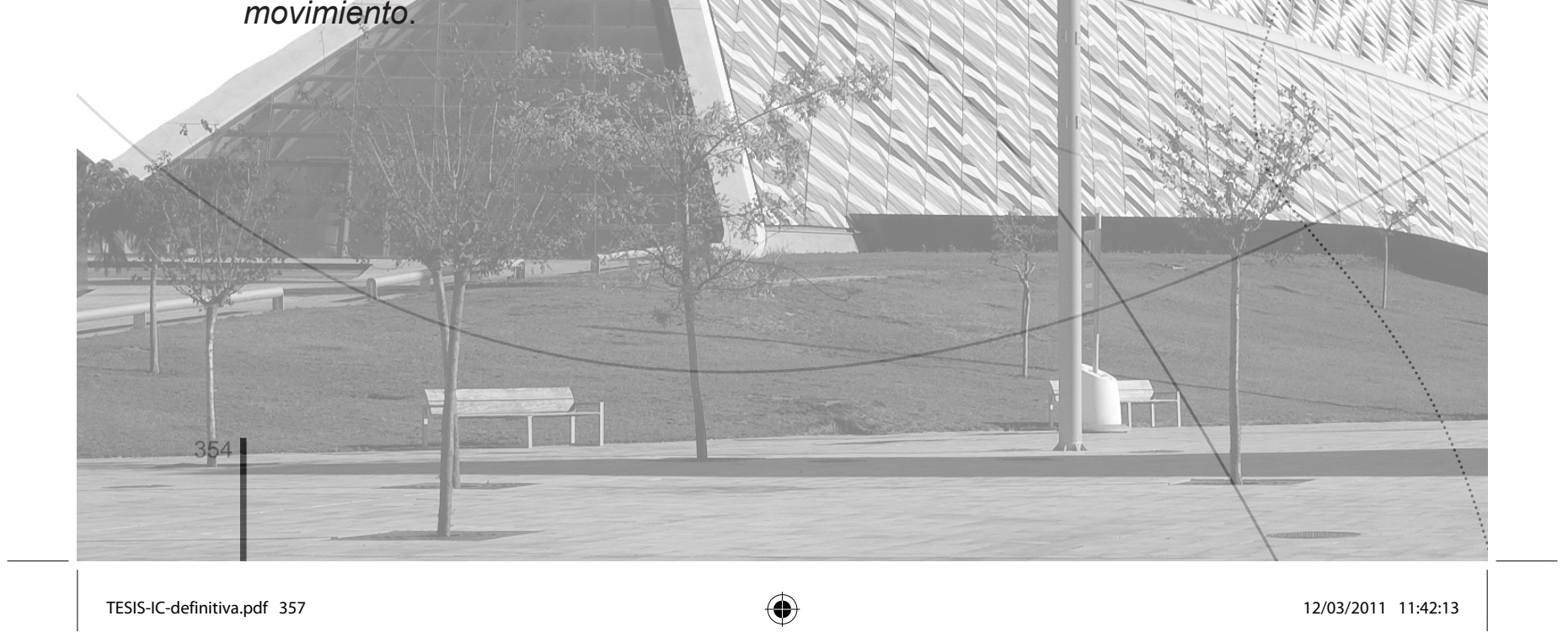




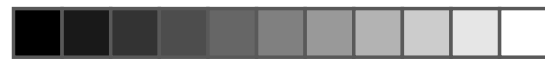

(1)

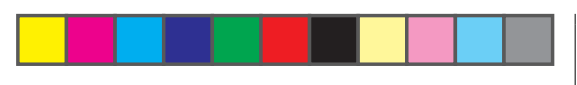

5. Conclusión:Arquitecturas-paisaje surgidas al hilo del tiempo.

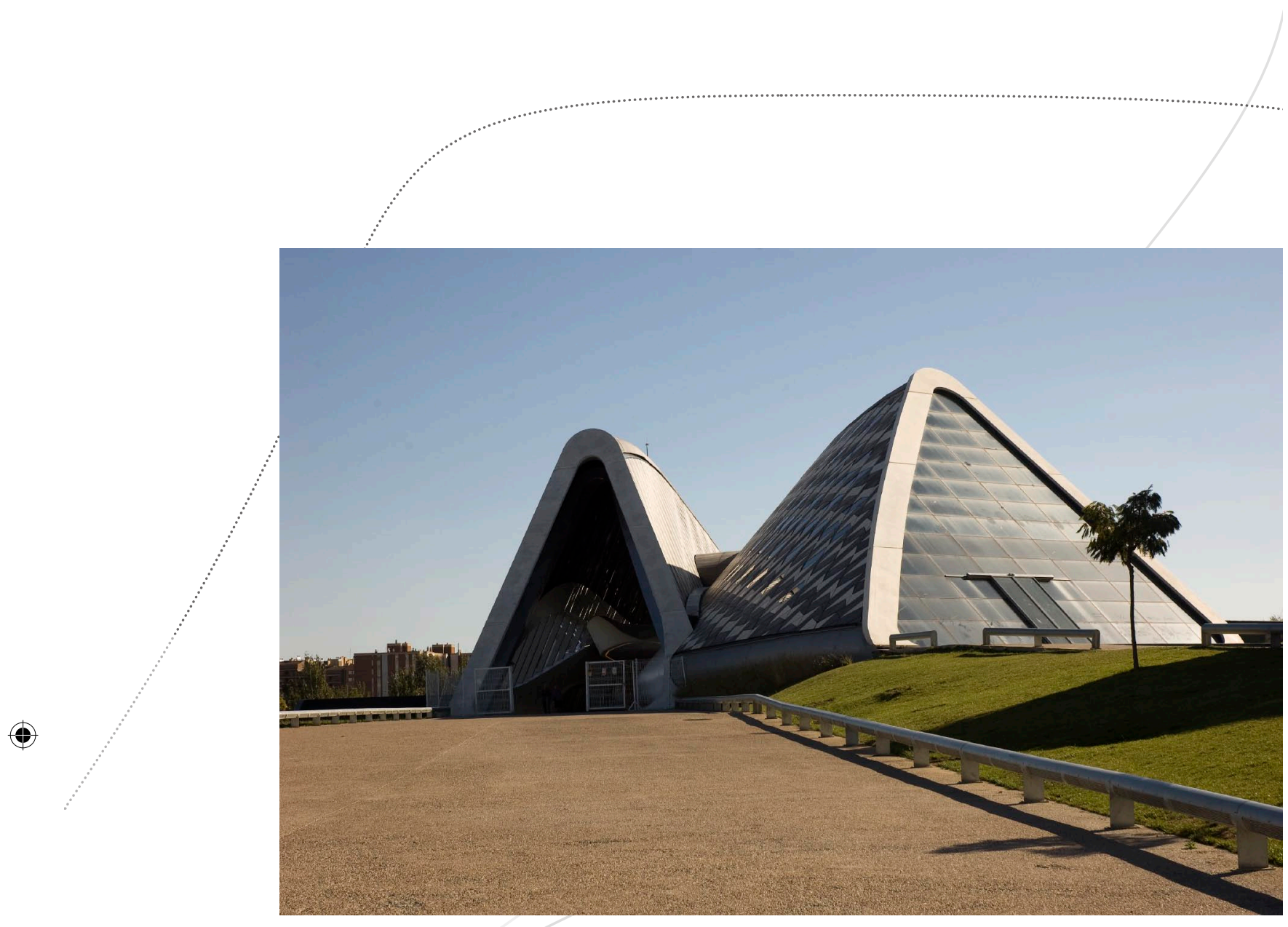

Zaha Hadid, Pabellón-puente, Zaragoza, 2005-08 (fotografía I.C.).

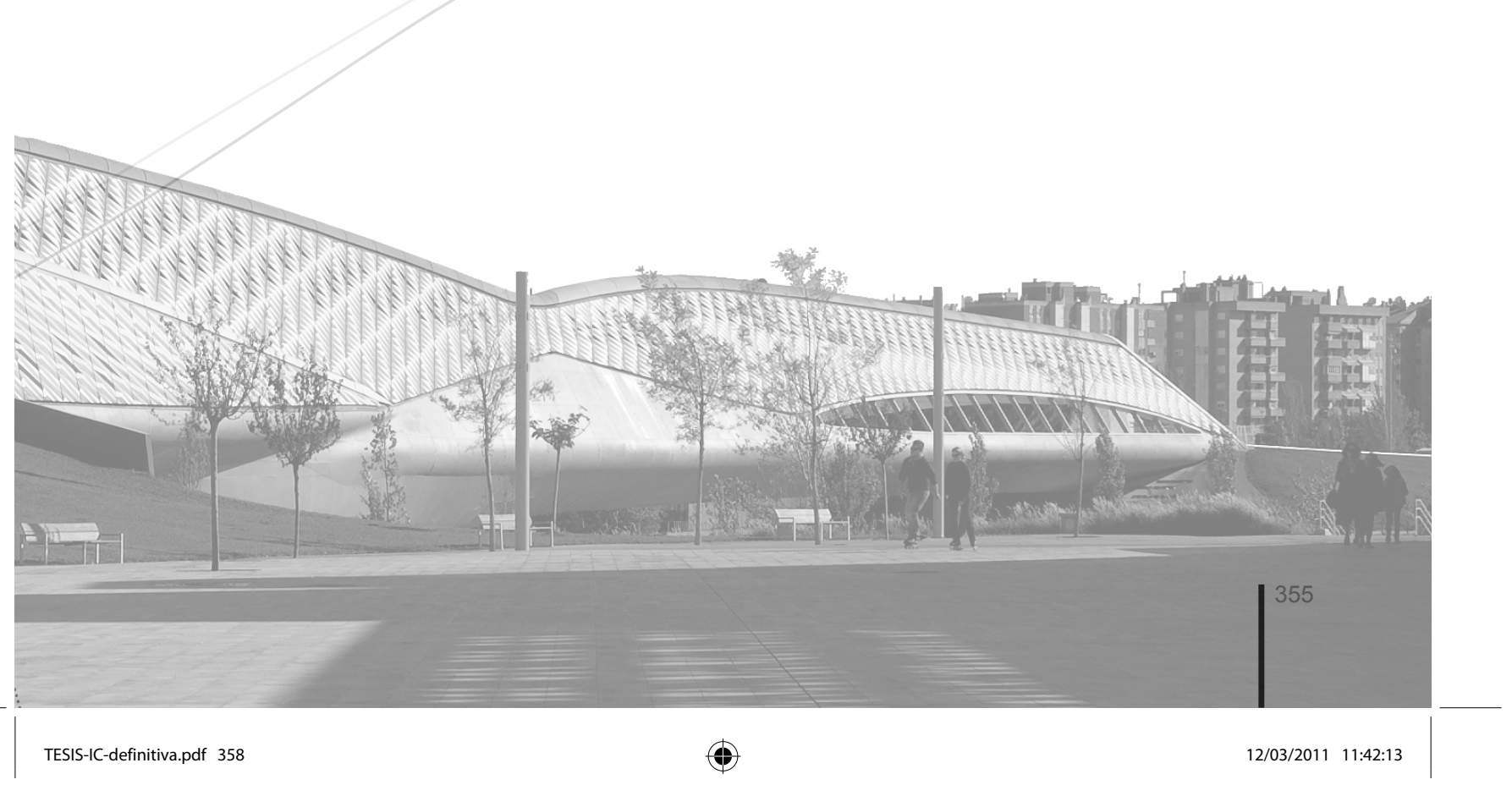




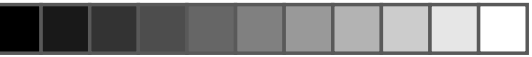

$\oplus$

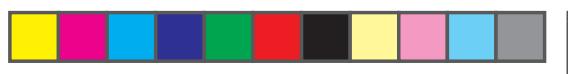

$\oplus$

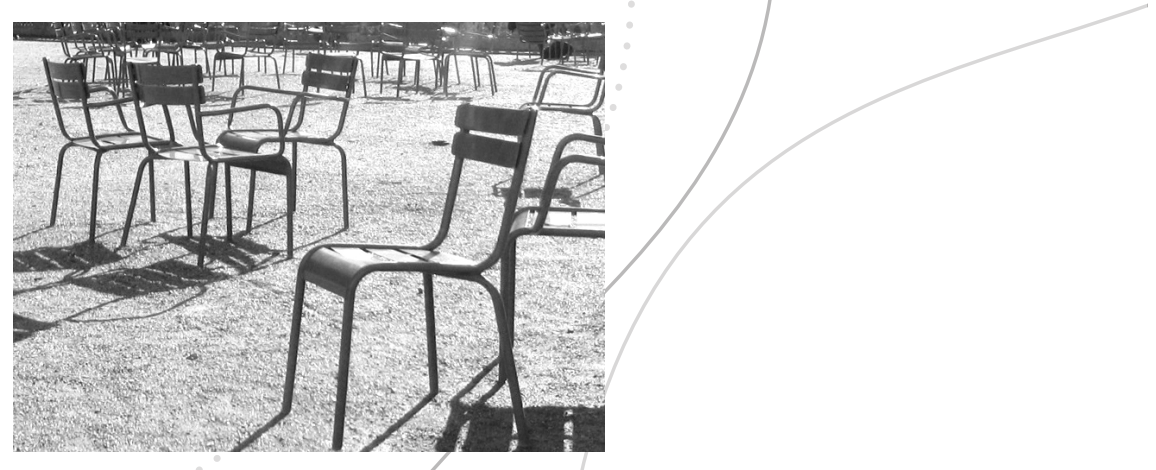



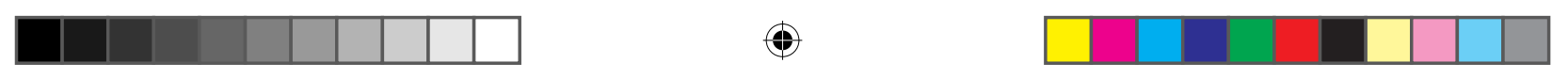

5. Conclusión:Arquitecturas-paisaje surgidas al hilo del tiempo.

Quisiera completar estas conclusiones teóricas acerca de los escenarios urbanos dinámicos de finales del siglo XX y comienzos del siglo $\mathrm{XXI}$ que se sitúan entre el arte y la arquitectura, mediante una aproximación proyectual y arquitectónica personal concreta. Para ello he seleccionado dos intervenciones estrechamente vinculadas con estos paisajes contemporáneos, dos proyectos de muy distinta naturaleza pero complementarios a mi modo de ver. En el primero, un paseo por el espacio urbano nos llevará a Paris; en el segundo, será el recorrido el que entre en el espacio interior de la arquitectura construida para articular una segunda arquitectura efímera que sirva de adecuada escenografía para una exposición de arte contemporáneo.

En el proyecto de Paris me enfrenté, como arquitecto, al reto de crear paisaje desde el caminar por la propia ciudad, en una intervención (más simbólica que ejecutada) que pusiera en práctica, que activara, los mecanismos y procedimientos que hemos ido desglosando a lo largo del camino esbozado desde la introducción, hace ya algunas páginas. En el segundo proyecto me encontré frente al desafío; esta vez en el sentido más físico y tradicionalmente asociado a la arquitectura, de crear una escenografía, un entorno espacial, donde mostrar el interesante proyecto expositivo Malas Calles realizado en el Instituto Valenciano de Arte Moderno (IVAM) ; el cual tenía como objetivo reflexionar acerca del devenir de la calle a lo largo del siglo XX. Dos proyectos entendidos como el haz y el envés de una intervención entre la ciudad y la arquitectura, como experiencias donde continuar y ampliar (y en cierto sentido ejemplificar y completar), la investigación teórica desarrollada por el presente trabajo, cuya tesis se interroga acerca del dinamismo inherente a los espacios urbanos y arquitectónicos de finales de siglo XX y comienzos del XXI. 


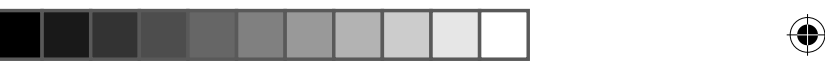

$\varphi$
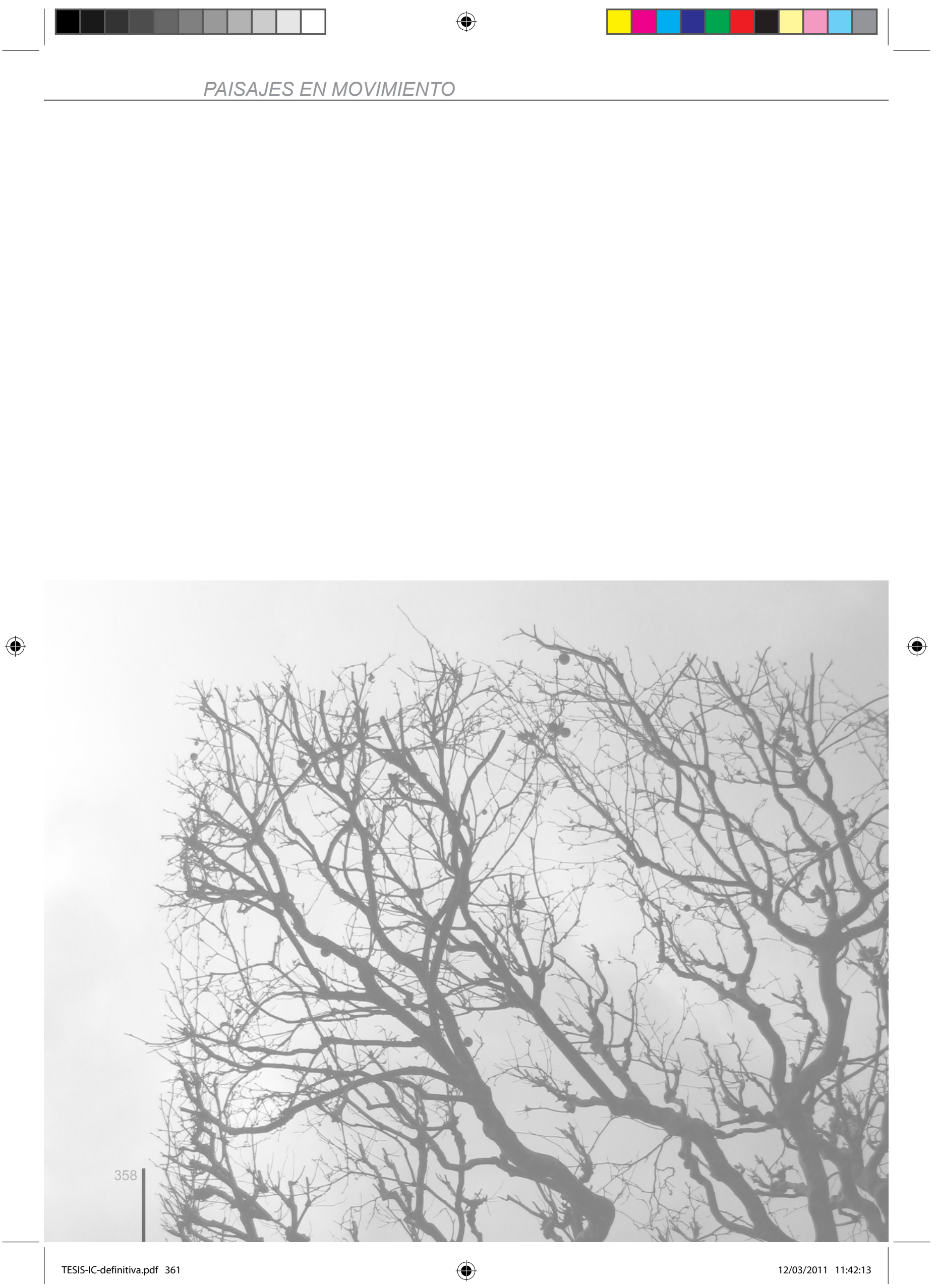
Con estas premisas, salí a pasear por Paris con la única herramienta proyectual de mi mirada y con mi cámara fotográfica como testigo y memoria de dicho caminar. La ciudad elegida fue, como no podía ser de otro modo, Paris, la patria del flâneur, "la ciudad de los pasajes" que fascinara a Louis Aragon o a Walter Benjamin, Y como flâneur me enfrenté a ella, sin mayor objetivo que interpretar y experimentar el paisaje a mi alrededor, creando por lo tanto, y como he querido demostrar a lo largo de la investigación, un paisaje nuevo. Me dispuse a pasear (con Walter Benjamin en el recuerdo), intentando aprender "el arte de extraviarse" del que nos hablara el escritor alemán, sin objetivo aparente más allá del recorrido en sí mismo. Un recorrido que superase las cartografías y pusiese 

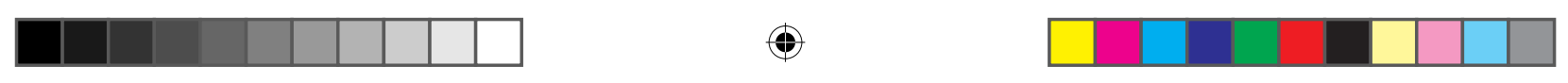

en cuestión el rigor formal y geométrico de la ciudad.

Se trataba, por tanto, de conectar con el carácter efímero y cambiante de la ciudad, o mejor dicho, de sacar a la luz el potencial del ar-

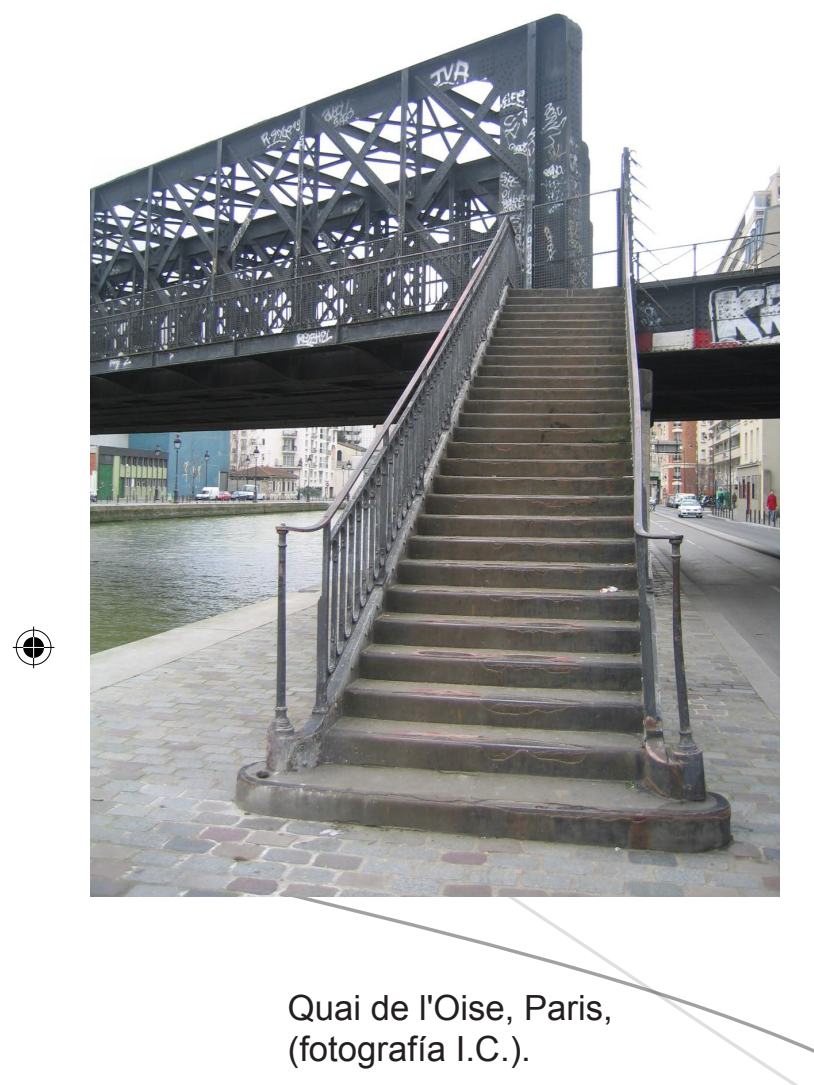
quitecto (en este caso, yo mismo) en cuanto nómada de la propia ciudad, en cuanto habitante que transita por la misma con una mirada lo más desprejuiciada posible. Lo importante del recorrido no era el camino elegido, sino la experiencia fruto del movimiento en sí mismo, de lo que se nos presenta en cada calle, aquello que encontramos al doblar cada esquina. Lo realmente interesante del proyecto es la secuencia, no las imágenes estáticas y mudas y es precisamente esta secuencia del recorrido lo que las fotografías que estamos viendo tratan de plasmar o, al menos, memorizar. La arquitectura se presenta de esta manera como construcción simbólica del espacio, como productora y desencadenante de paisajes dinámicos y cambiantes. El recorrido a través de la ciudad se reivindica como forma estética con un enorme potencial creativo, con una gran capacidad para transformar el modo de representación del espacio urbano gracias al contacto con lo "maravilloso cotidiano" y en consequencia con el propio espacio de la ciudad.

Esta acción de arquitectura, si se me permite la expresión, es gratuita y efímera y no busca dejar huellas permanentes en el espacio urbano sino que reivindica, como decía, la figura del habitante nómada, olvidado pero aún presente en las ciudades contemporáneas. Si hablamos

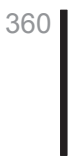




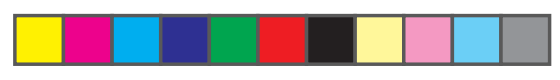

5. Conclusión:Arquitecturas-paisaje surgidas al hilo dèl tiempo.

en términos de paisaje, tal y como veíamos en los primeros capítulos, hablamos de sentimientos, de emociones, de sensaciones, de reconocernos a nosotros mismos en ese territorio físico concreto, bien sea natural o urbano. Recorrer este fragmento de ciudad es recuperar e inventar un nuevo paisaje en movimiento a la búsqueda del conocimiento a través del paseo en sí mismo, creando un sistema de relaciones cambiante y dinámico, potenciador de encuentros fortuitos y casuales, encuentros que nos permiten descubrir y valorar las potencialidades de cada acontecimiento urbano que sale a nuestro encuentro.

El paseo por Paris que presento como parte de las conclusiones de este trabajo de investigación, se sitúa a medio camino entre el recorrido hecho por un viajero romántico que se busca a sí mismo en la ciudad contemporánea y el arquitecto que, en palabras de Stalker "busca un sentido que surja de la experiencia de lo real y sus contradicciones" al espacio urbano que le rodea, intentando con ello crear un nuevo y subjetivo paisaje en movimiento. Por último, creo que resulta necesario anotar que, aunque resulte evidente que, en consecuencia, el punto de inicio y el final del recorrido carecen de verdadero interés (y que se trata por lo tanto únicamente de situarnos), el paseo se inició en el Parque de La Villette, en el extremo Noreste de la ciudad, para terminar algunas horas más tarde en el Jardin des Plantes, en la orilla izquierda del Sena. 


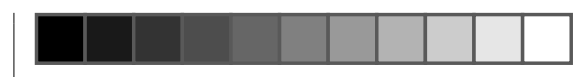

$\oplus$
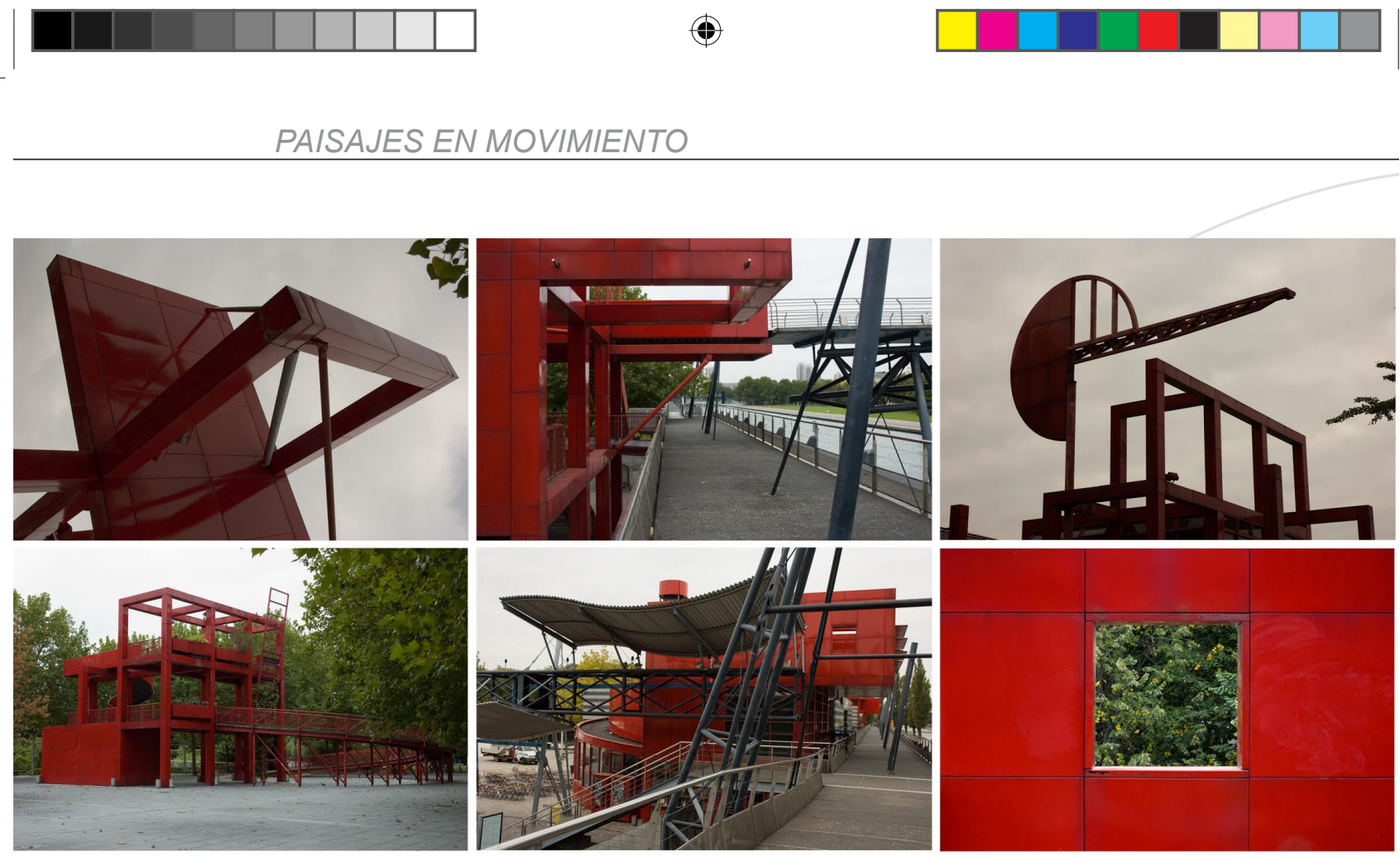

(4)
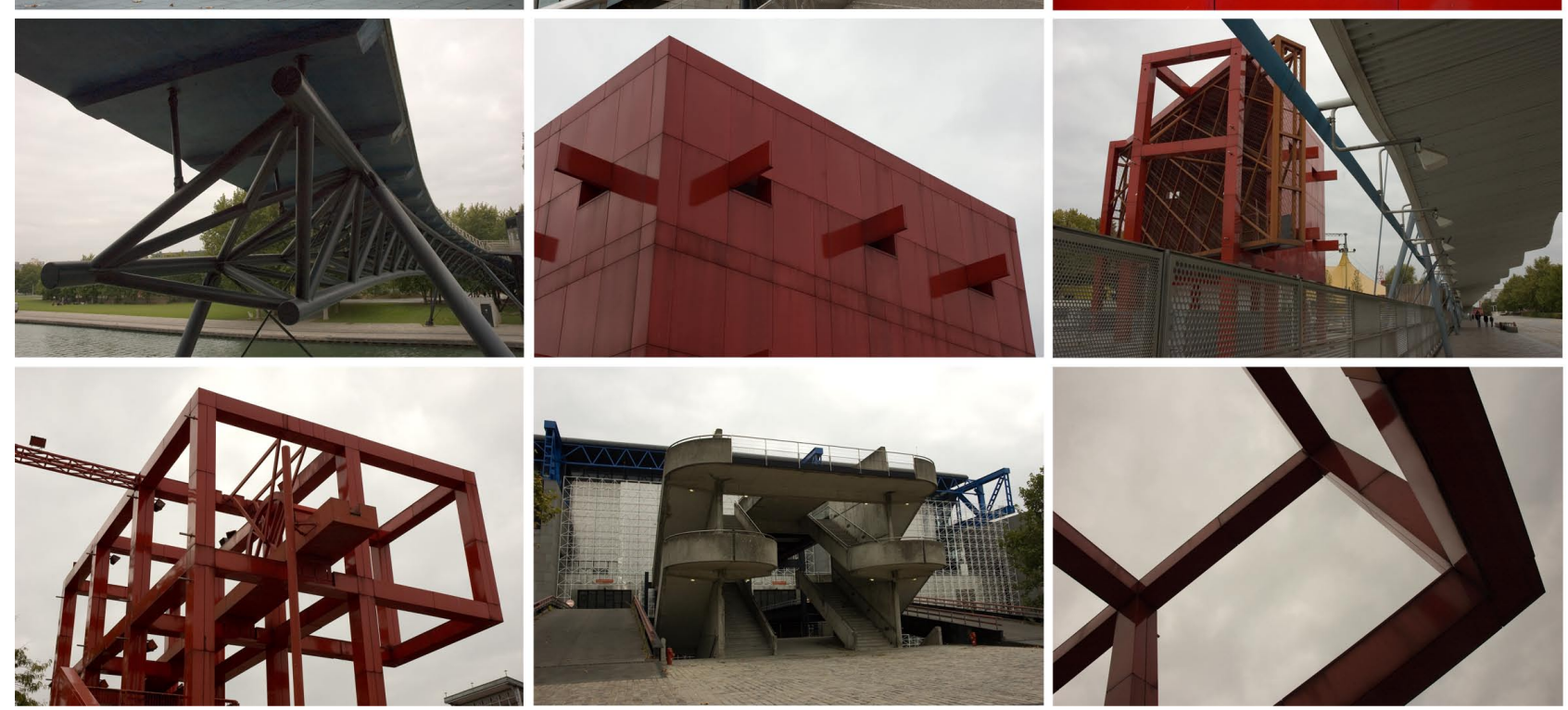

PUNTO DE PARTIDA: La Villette.

Este parque paradigmático de finales del siglo XX, obra de Bernard Tschumi, (quién ganó en concurso en1982) sirvió al arquitecto francés para poner en práctica las ideas de Jacques Derrida. Aquí comenzará nuestro paseo por las calles de Paris. 


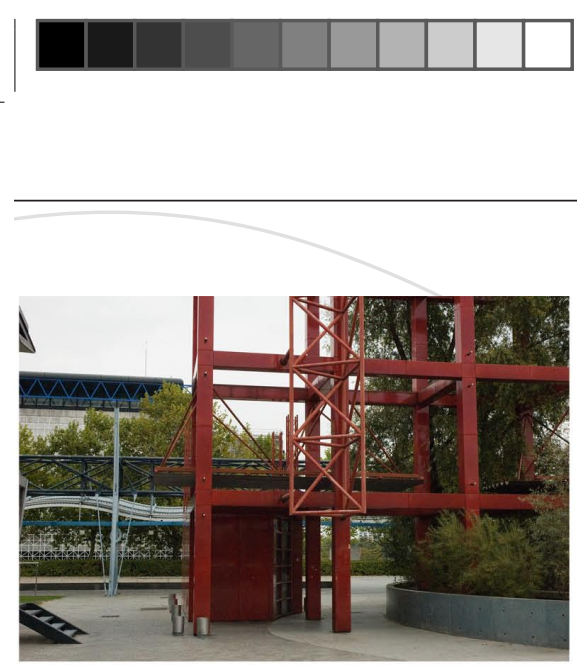

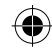
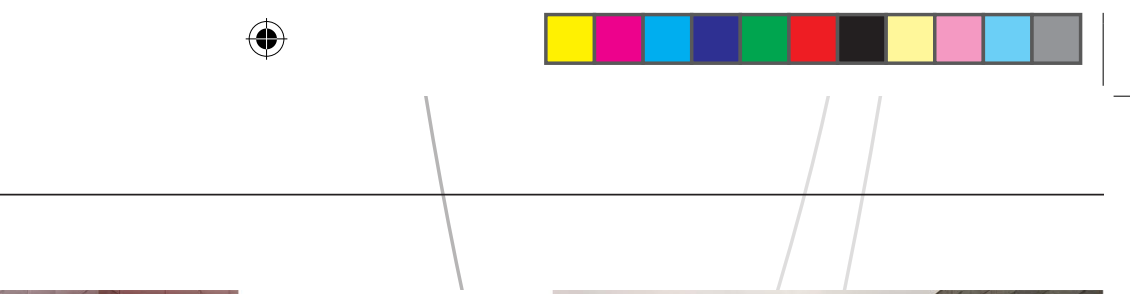

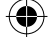
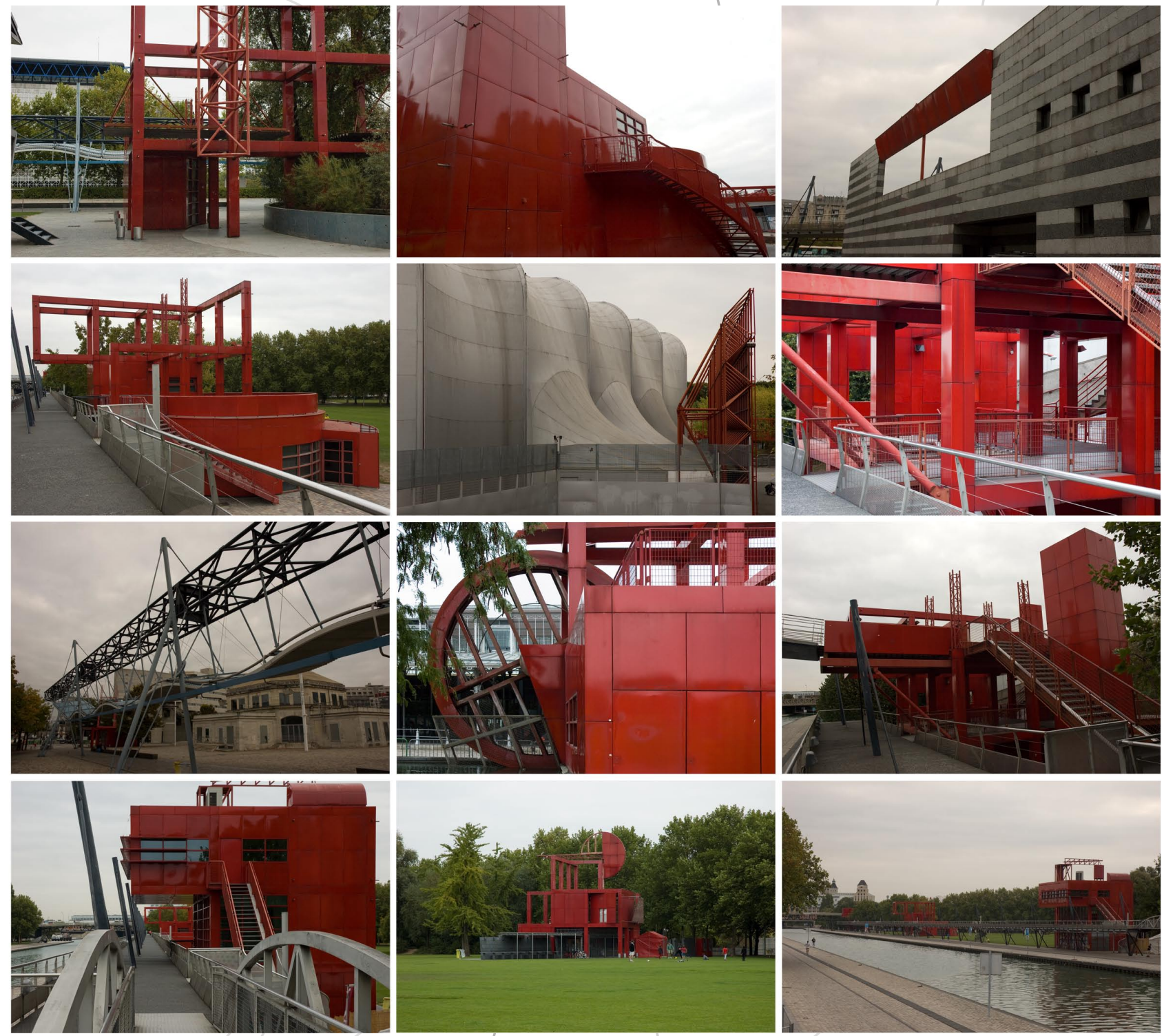

Ignacio Carbó, La Villette, paysage de follies, 2010.

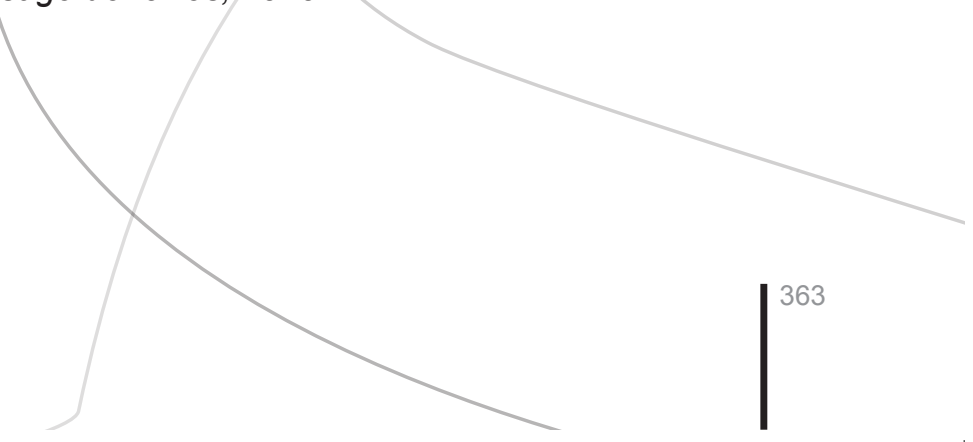




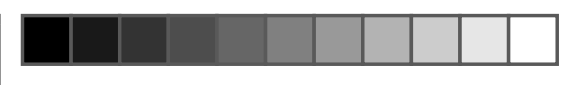

$\oplus$
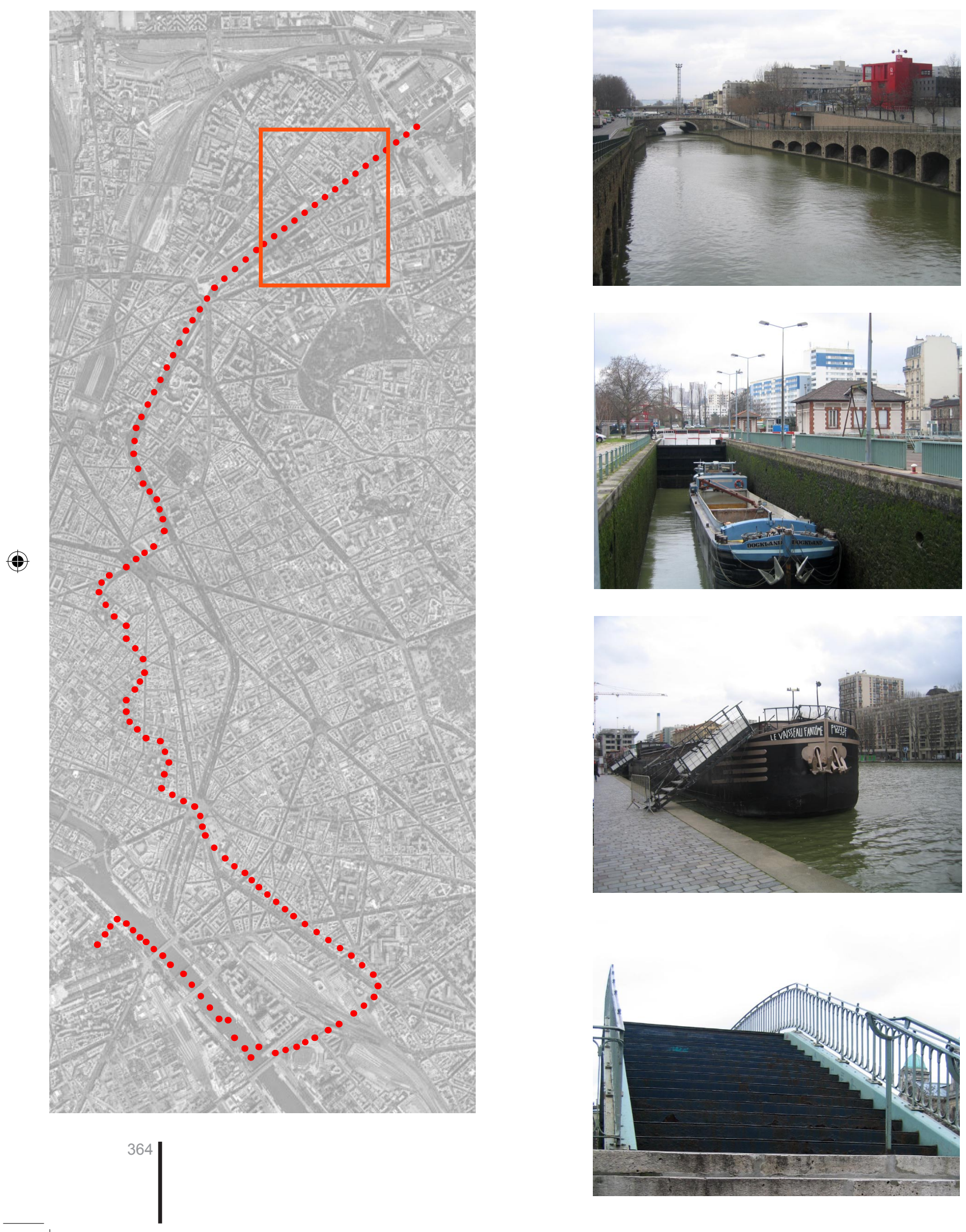


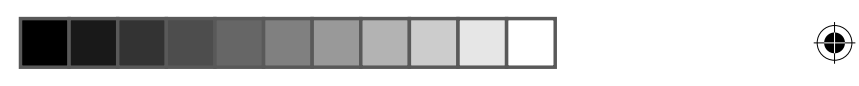

5. Conclusión:Arquitecturas-paisaje surgidas al hilo del tiempo.
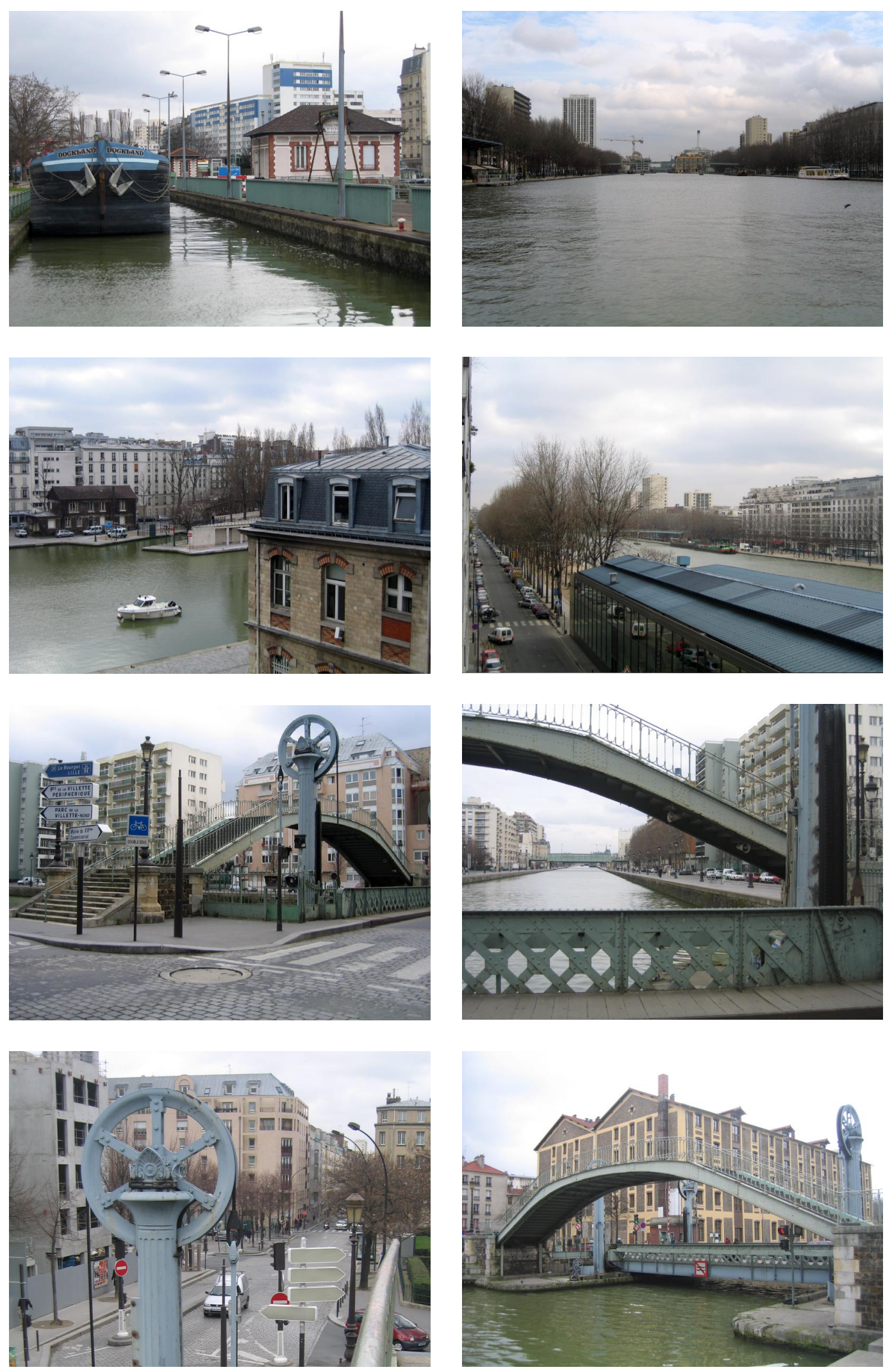


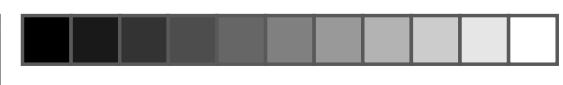

$\oplus$
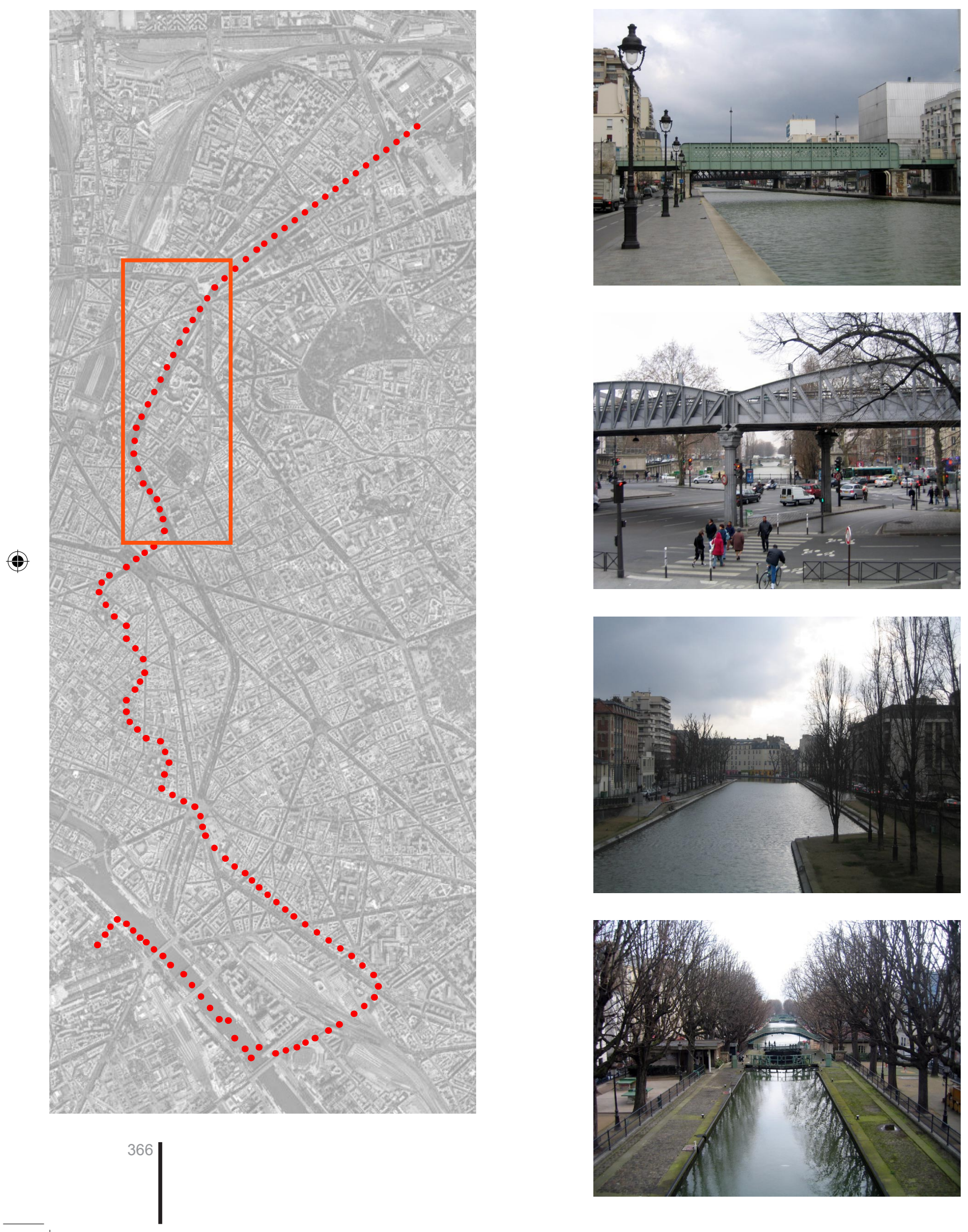


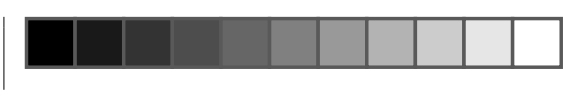

$\oplus$

5. Conclusión:Arquitecturas-paisaje surgidas al hilo del tiempo.



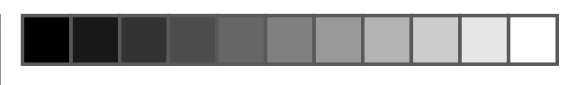

$\oplus$
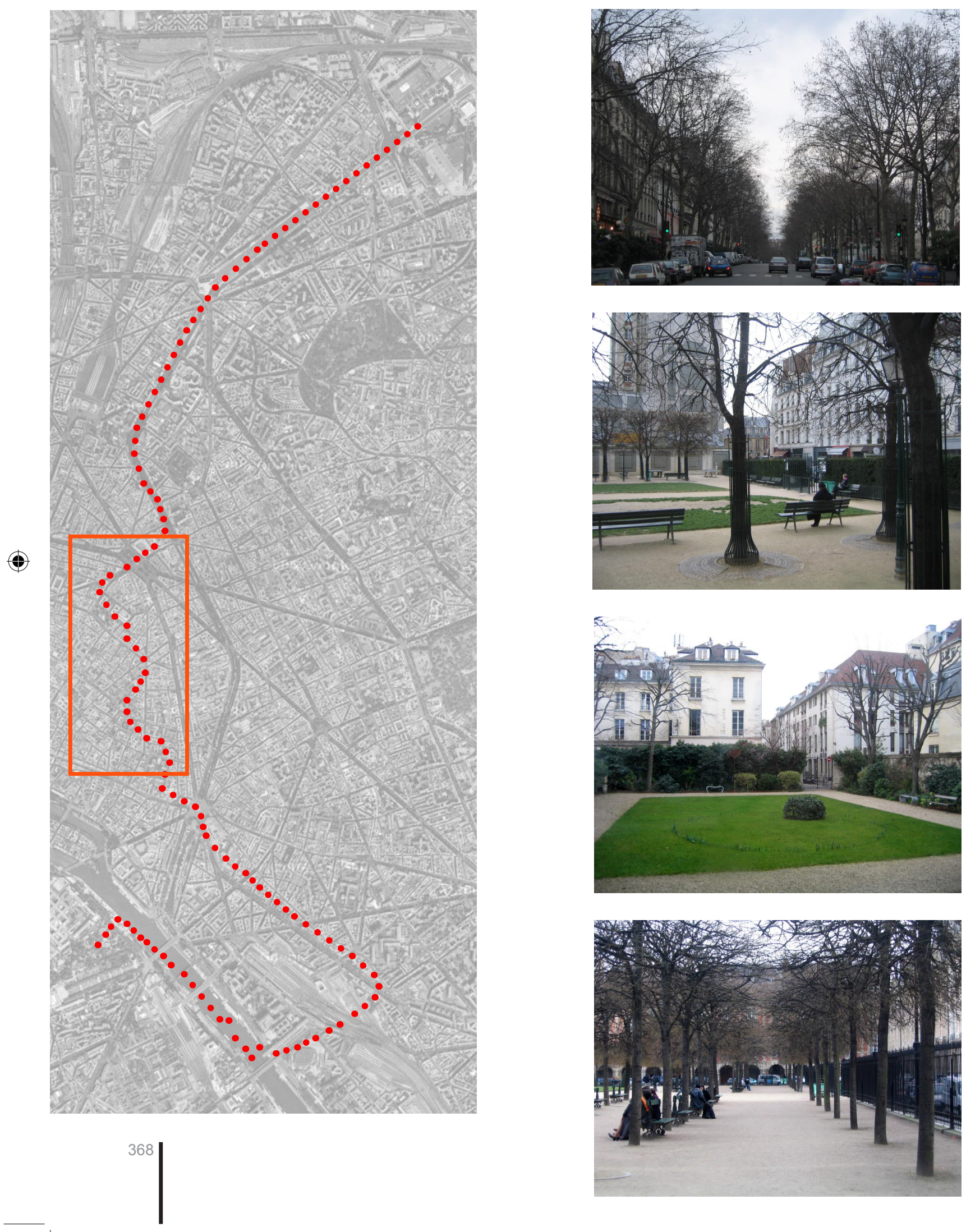


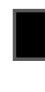

$\oplus$

5. Conclusión:Arquitecturas-paisaje surgidas al hilo del tiempo.
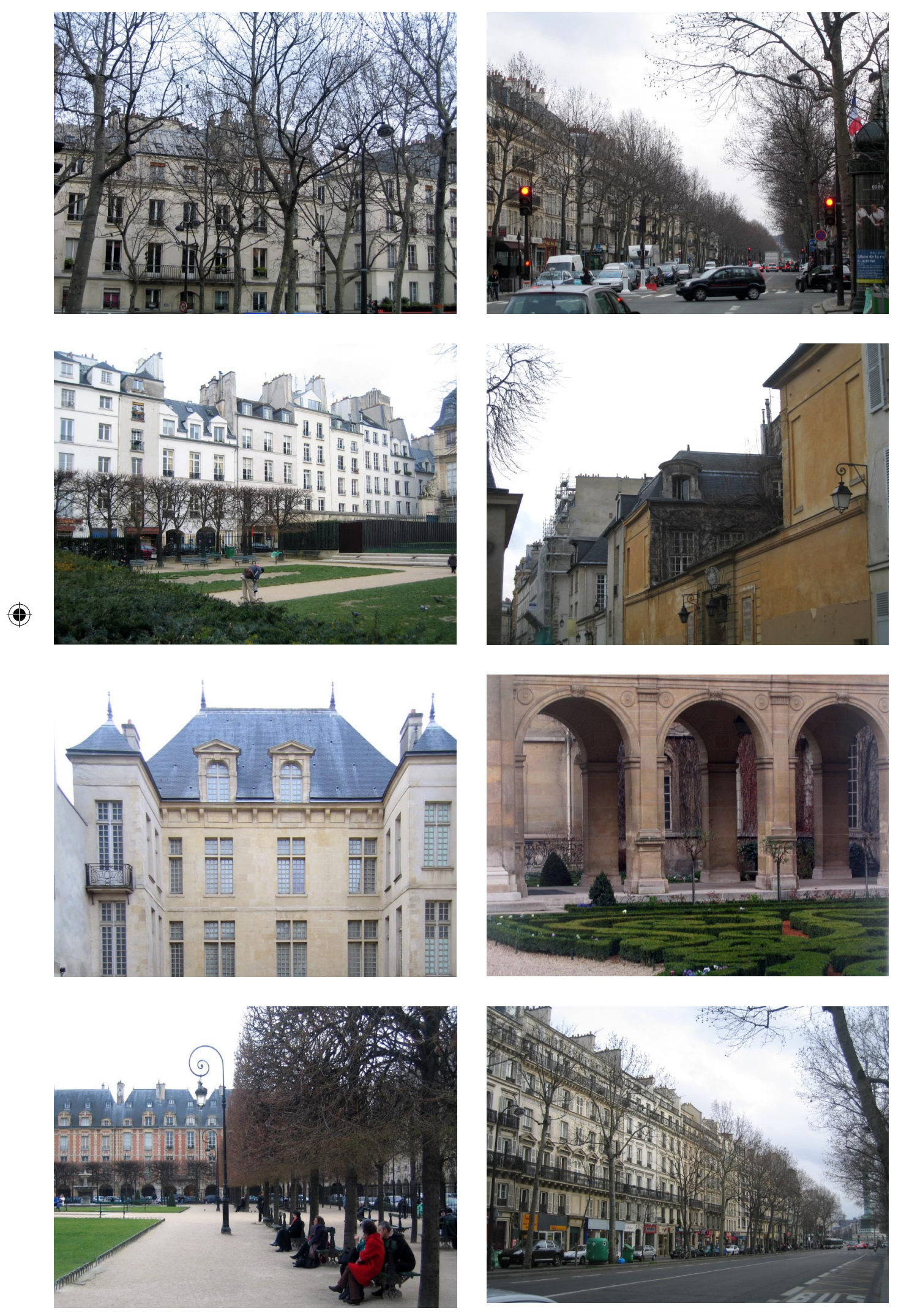


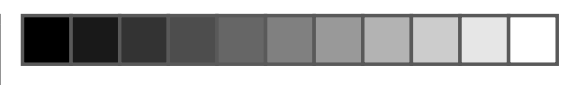

$\oplus$
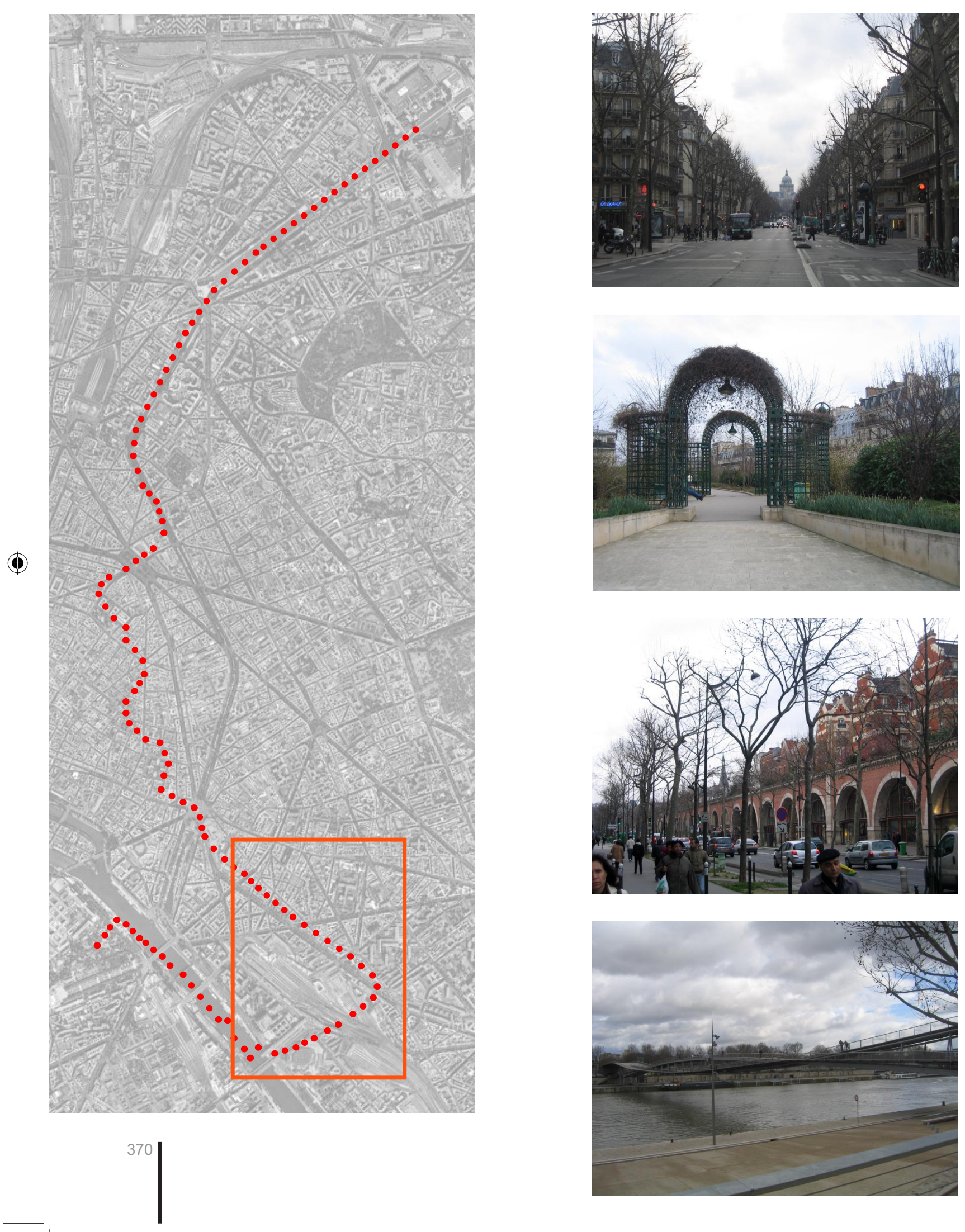


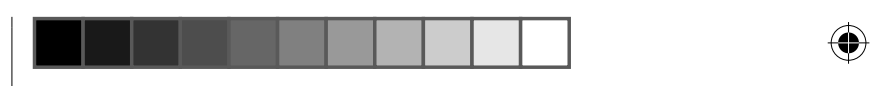

5. Conclusión:Arquitecturas-paisaje surgidas al hilo del tiempo.
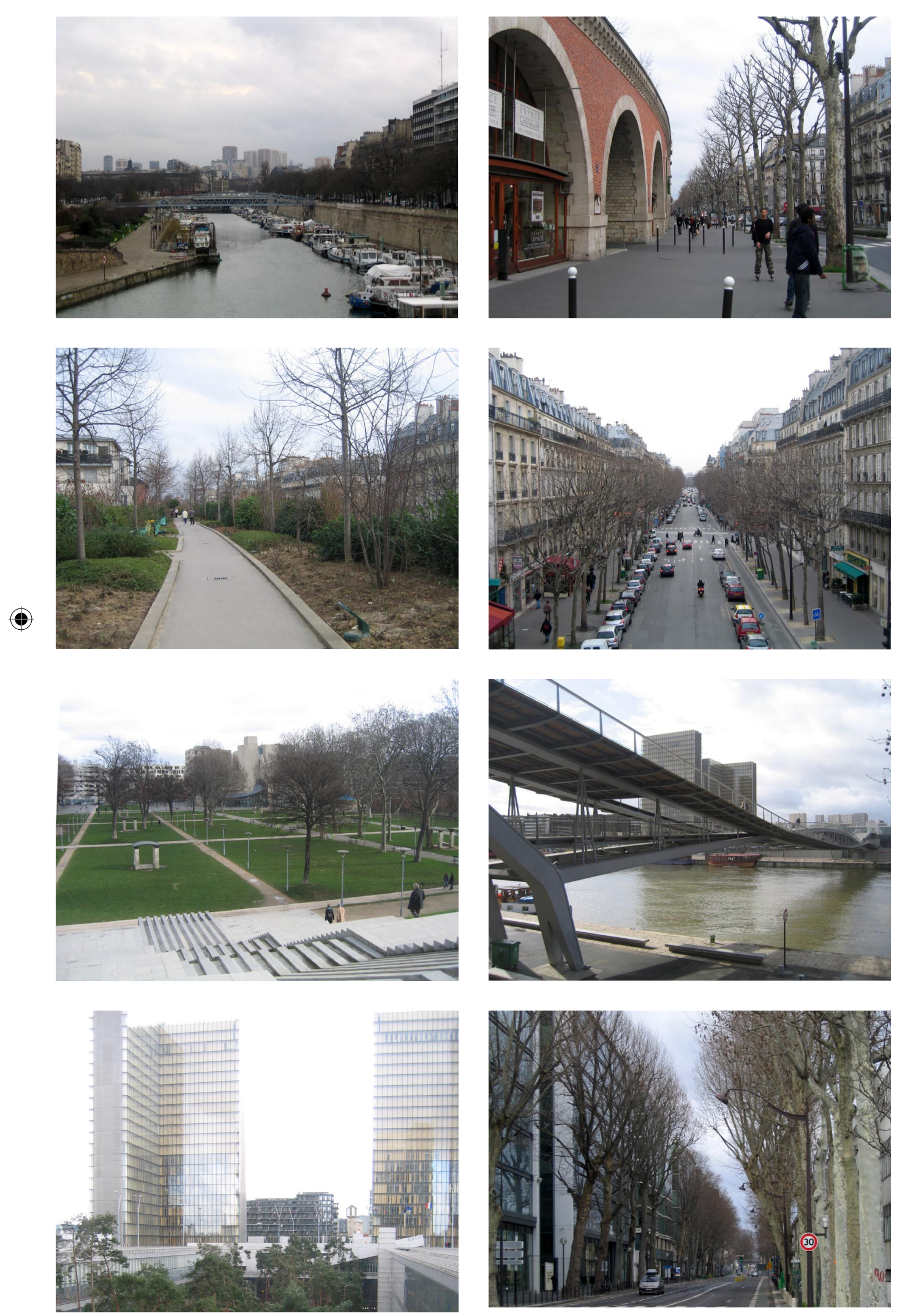


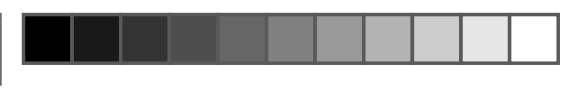

$\oplus$

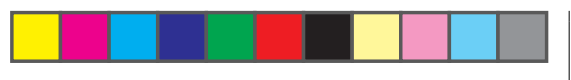

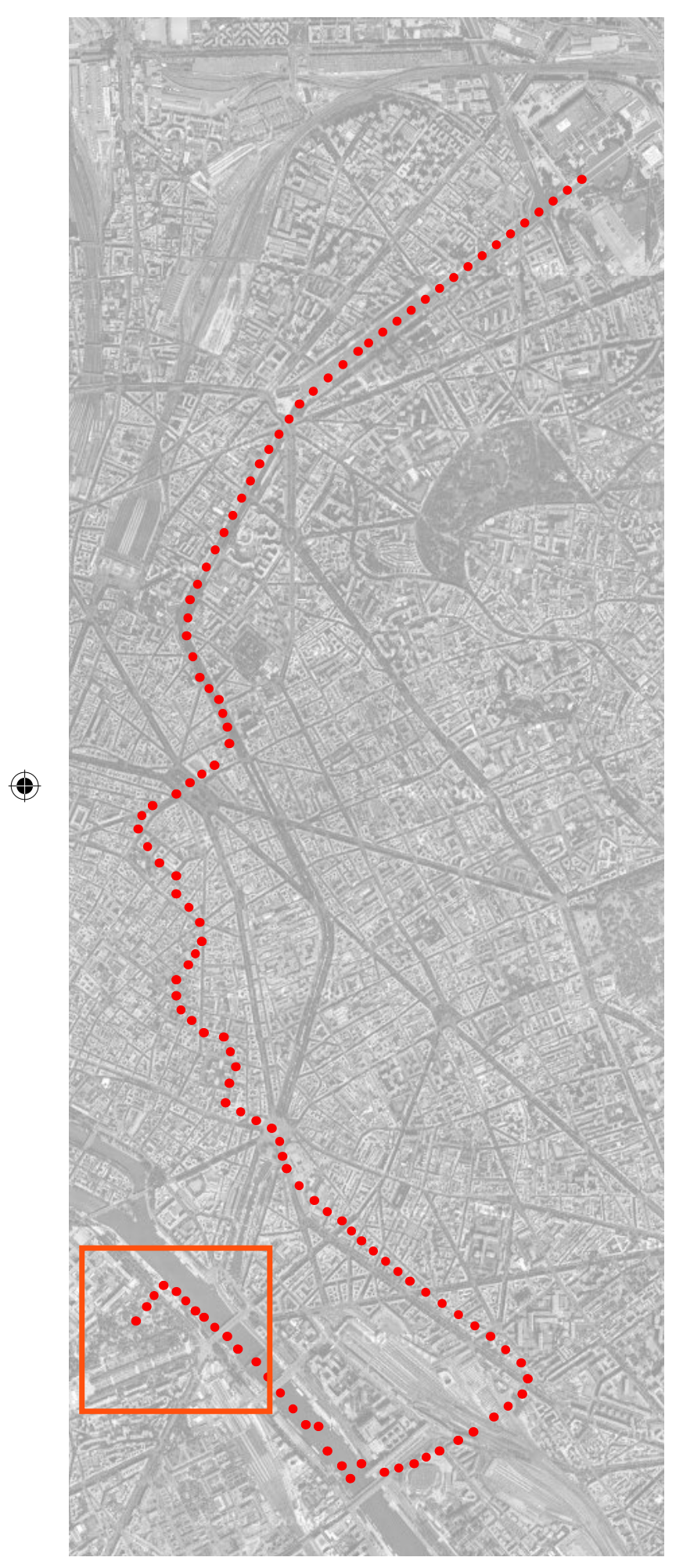

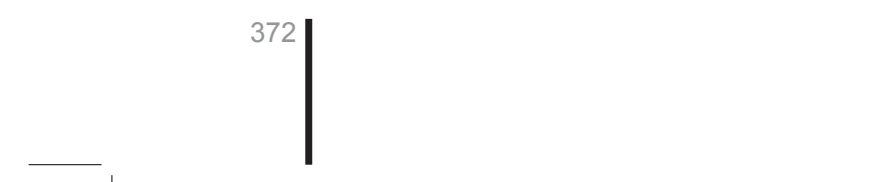

TESIS-IC-definitiva.pdf 375
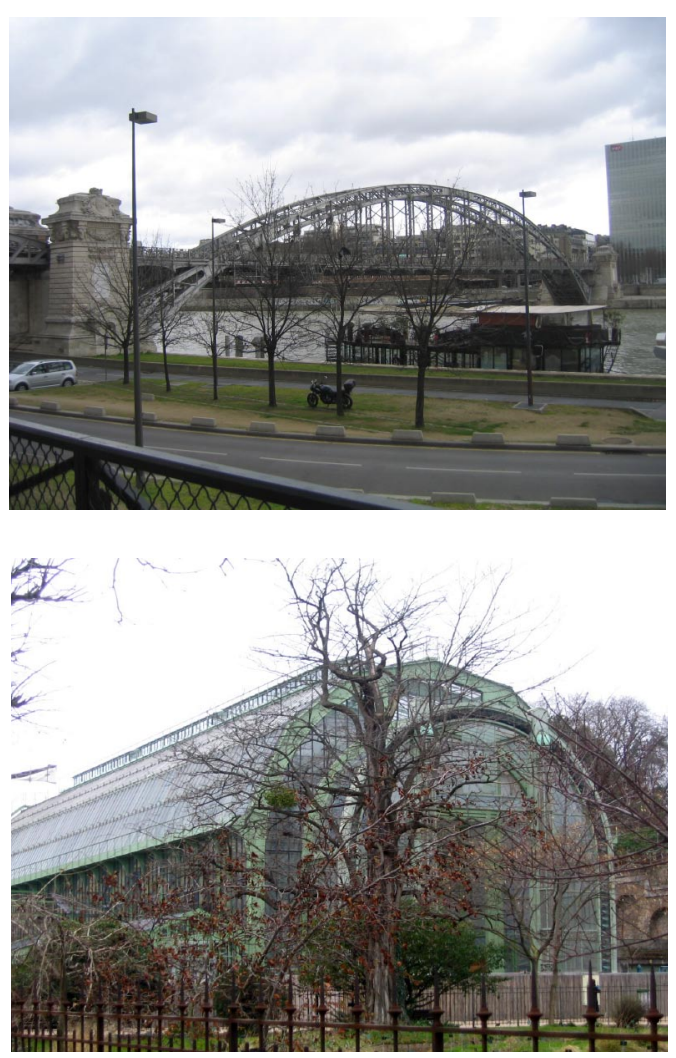

$\oplus$ 


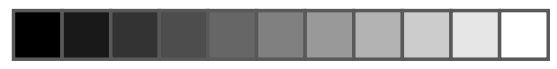

$\oplus$

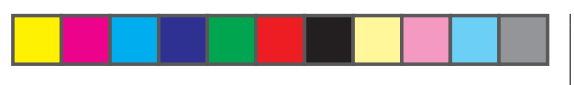

5. Conclusión:Arquitecturas-paisaje surgidas al hilo del tiempo.
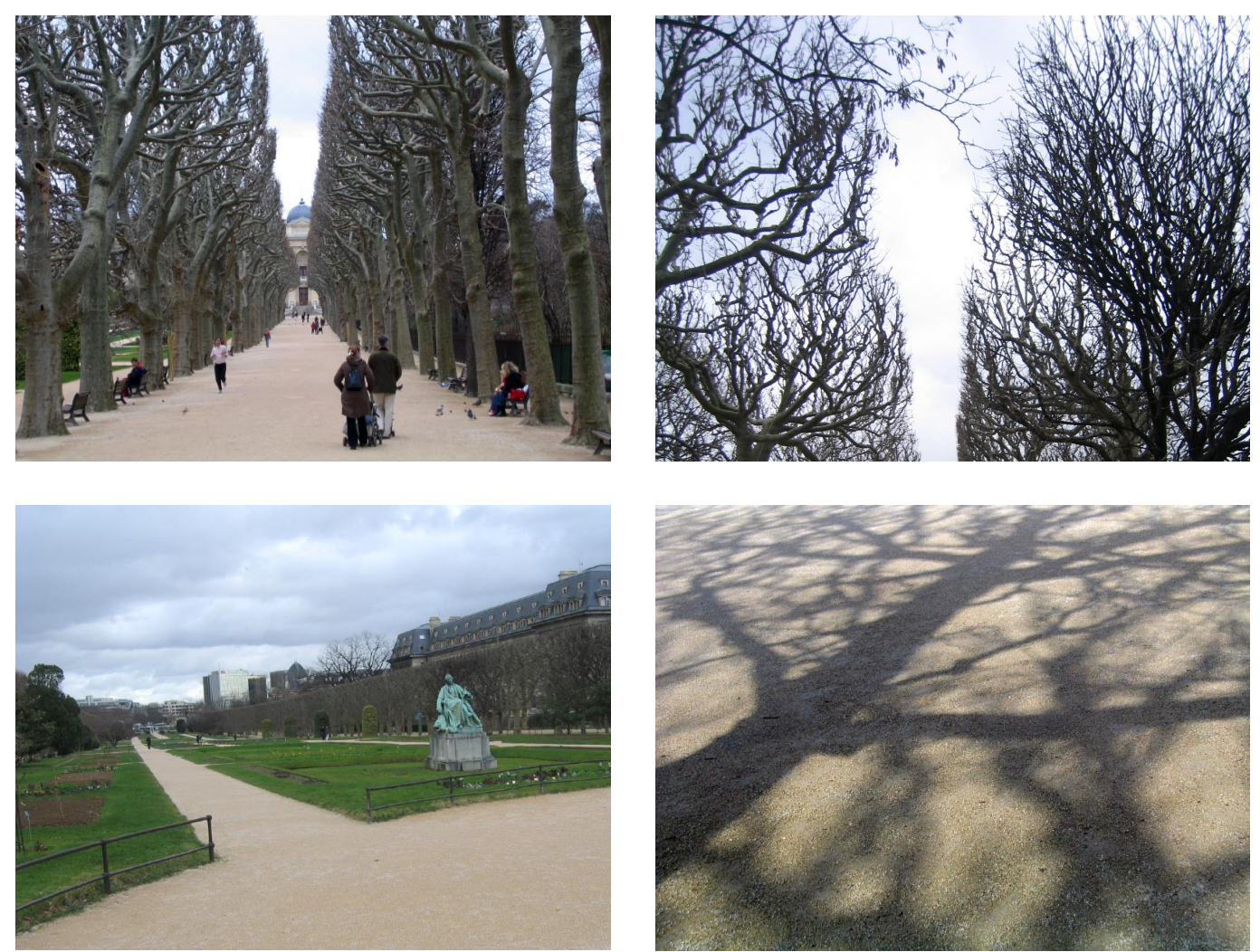

PUNTO DE LLEGADA: Jardin des Plantes.

Este jardín botánico es otro de los jardines paradigmáticos de la ciudad, esta vez de mediados del siglo XVII. Aquí finalizó nuestro recorrido. 


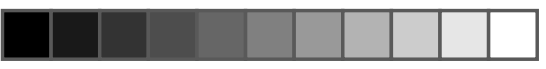

$\oplus$

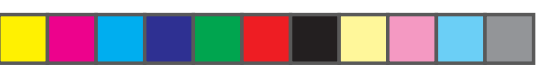

PAISAJES EN MOVIMIENTO

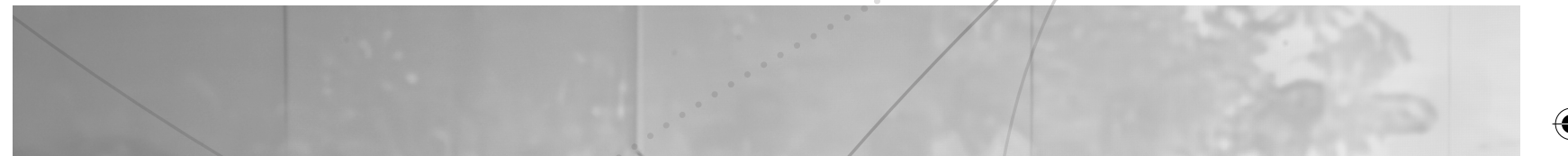

374

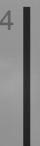




\section{Malas Calles}

La réplica, o mejor dicho el contrapunto, al paseo por Paris la llevé a cabo en el planteamiento de la escenografía para la exposición Malas Calles en el Instituto Valenciano de Arte Moderno (IVAM), un sugerente proyecto expositivo de Jose Miguel G. Cortés. Esta vez no se trataba, como ya he mencionado, de salir a la ciudad para inventar paisajes sino crear un paisaje donde mostrar la ciudad, o al menos, ciertas representaciones de la misma. Así pues, el objetivo de Malas Calles era crear, precisamente, un paisaje dinámico interior que basculase entre el arte y la arquitectura. 

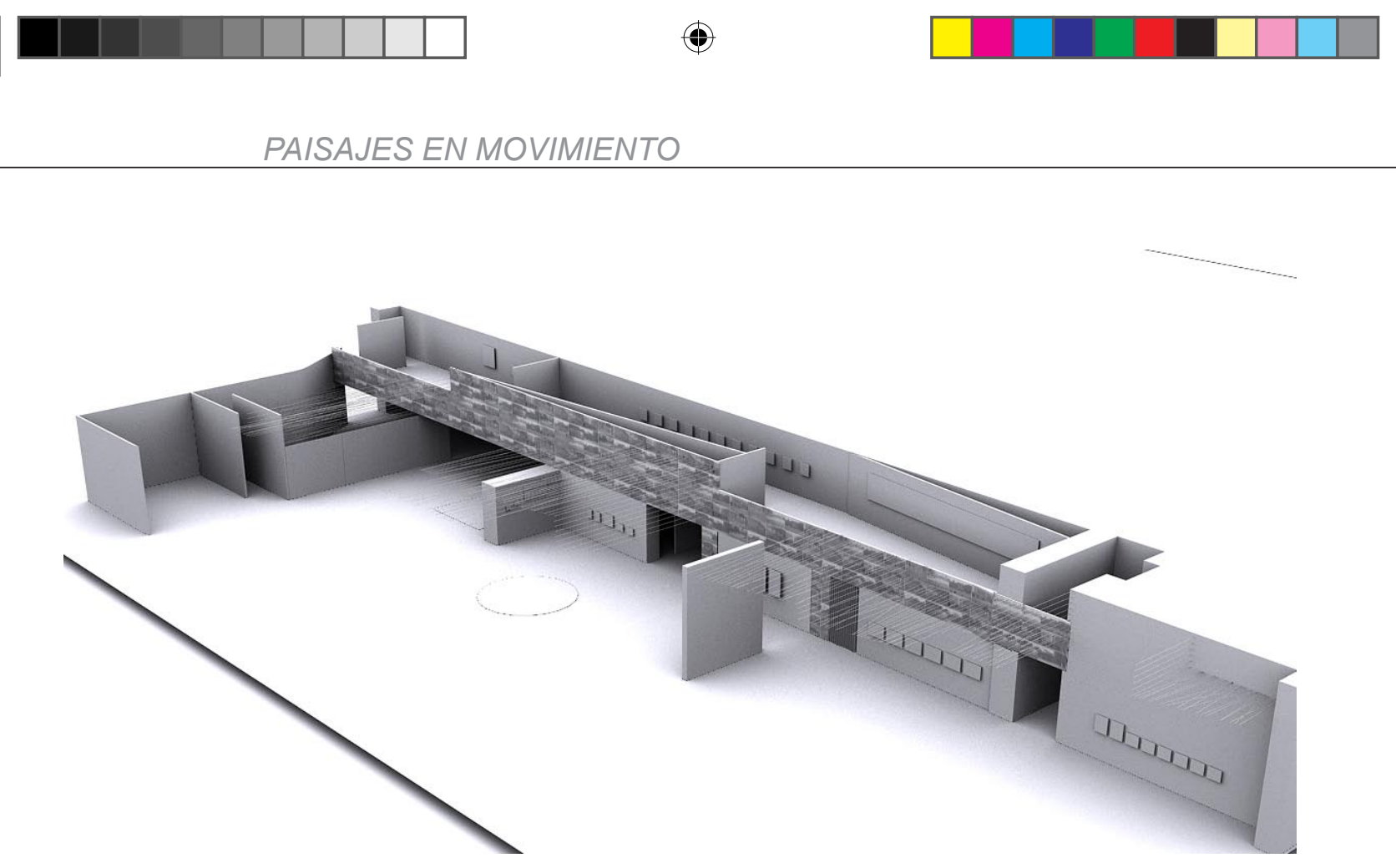

\section{MAQUETA VIRTUAL}

Axonometría seccionada del conjunto de las dos salas. La forma triangular y la acentuada linealidad de la sala superior fueron determinantes en el resultado final del montaje del proyecto. En este caso, las habituales maquetas de trabajo del estudio se sustituyeron por renders, con el objetivo de controlar mejor la luz artificial, fundamental en un proyecto de estas características. Destaca espacialmente el gran Billboard que incorpora a las salas, el paisaje de tres episodios urbanos del Siglo XX fundamentales.

Un primer planteamiento del proyecto nos condujo a idear un espacio para la exposición organizado a partir de un recorrido, de modo que éste guiase el sentido cronológico de las etapas y las obras pensadas por el comisario. Se trataba de evitar que el espectador pasase de obra en obra, contemplando pieza tras pieza desde la entrada a la sala hasta la salida de la misma en un movimiento mecánico y carente de sentido. Para ello se buscó ya desde el comienzo lograr una adecuada transición desde los planos arquitectónicos de las plantas de las salas, es decir de las dos dimensiones, hasta recuperar el volumen gracias al concurso de la sección. Se puede afirmar que la sección fue desde un primer momen- 

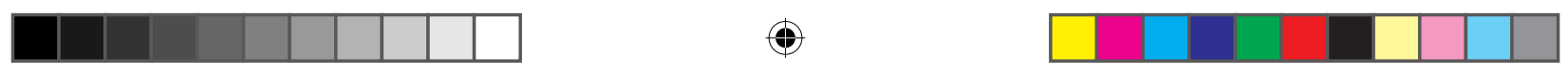

5. Conclusión:Arquitecturas-paisaje surgidas al hilo dèl tiempo.

to determinante para el conjunto de la exposición.

A partir de estas premisas, los planos perpendiculares que salen al encuentro del visitante de la exposición actúan a modo de bambalinas que pautan y ritman todo el recorrido, transformando éste en un paseo a través de distintas representaciones y modos de entender el espacio público a lo largo del siglo XX. Estos paños condicionan la actitud y la velocidad de la visita, creando espacios adecuados a cada una de las cuatro áreas en las que se dividía el "recorrido". Estas cuatro áreas que estructuraban tanto el proyecto expositivo como la publicación de Malas Calles eran, según la secuencia de presentación al visitante: "Se acabó la fiesta", "La calle es nuestra", "Entre la utopía y el desencanto" y "En medio de la multitud".

\section{En "Se aca-} bó la fiesta" se recogían las obras de las décadas más recientes, con piezas que reflejaban, en palabras del propio comisario "el desbordamiento de la propia urbe que engulle el entorno que la rodea"; a continuación "La calle es nuestra", la segunda parte en un recorrido

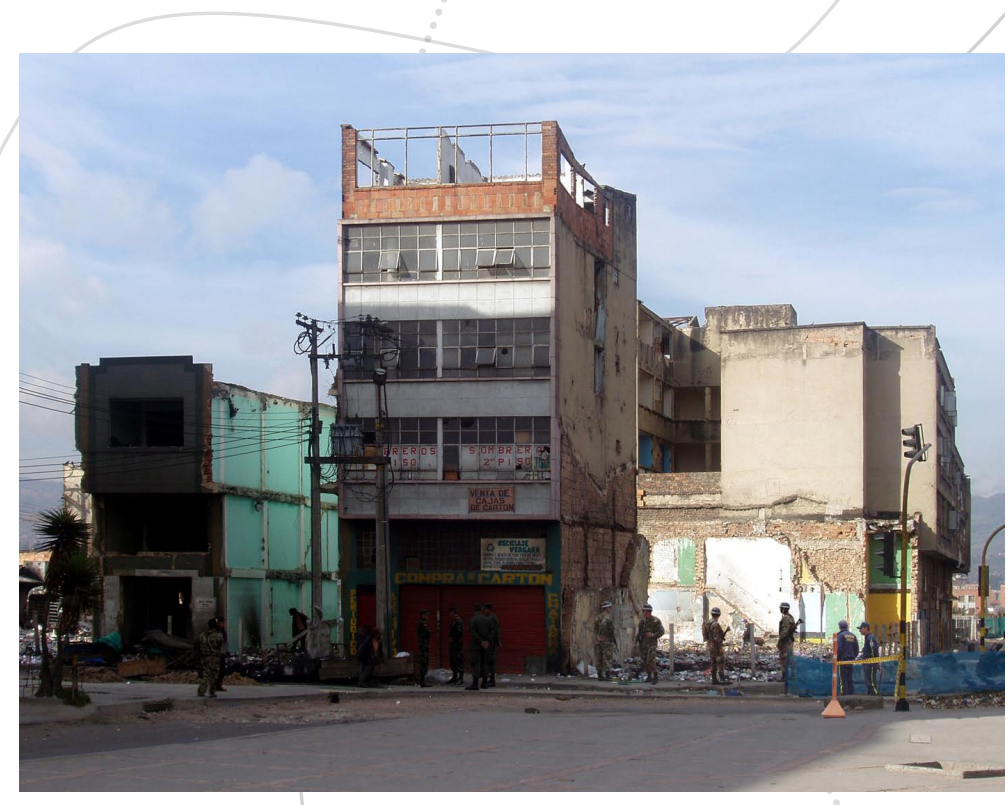

Alexander Apóstol, Avenida Caracas, Bogotá ( $\left.n^{\circ} 4\right)$, 2005. cronológico inverso que avanzaba a medida que retrocedíamos temporalmente hacia comienzos de siglo, se centraba en las décadas de los años sesenta y setenta mostrando una transformación radical del espacio público que señalaba el surgimiento de la auto-reivindicación de sectores sociales negados que 

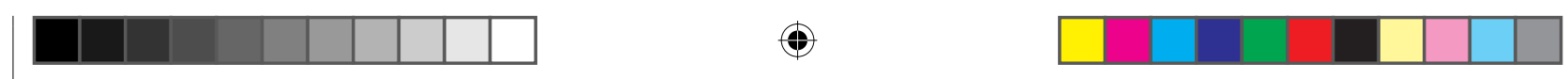

proclamaban el carácter plural de la ciudad. La tercera etapa en nuestro paseo, "Entre la utopía y el desencanto", se desarrollaba a partir de obras que se movían entre el entusiasmo de movimiento utópicos y el desencanto de aquellos que vislumbraban el ascenso de la sociedad de consumo y la consiguiente alineación del ser humano; mientras que la cuarta, "En medio de la multitud", era tal vez la más optimista pues aquí la ciudad ya no era vista como un lugar de pérdida y ruptura sino como un ente liberador; la visión de la ciudad estos años es la de una urbe moderna a comienzos de su expansión, una ciudad convertida en objeto de deseo y que fascinó a creadores de

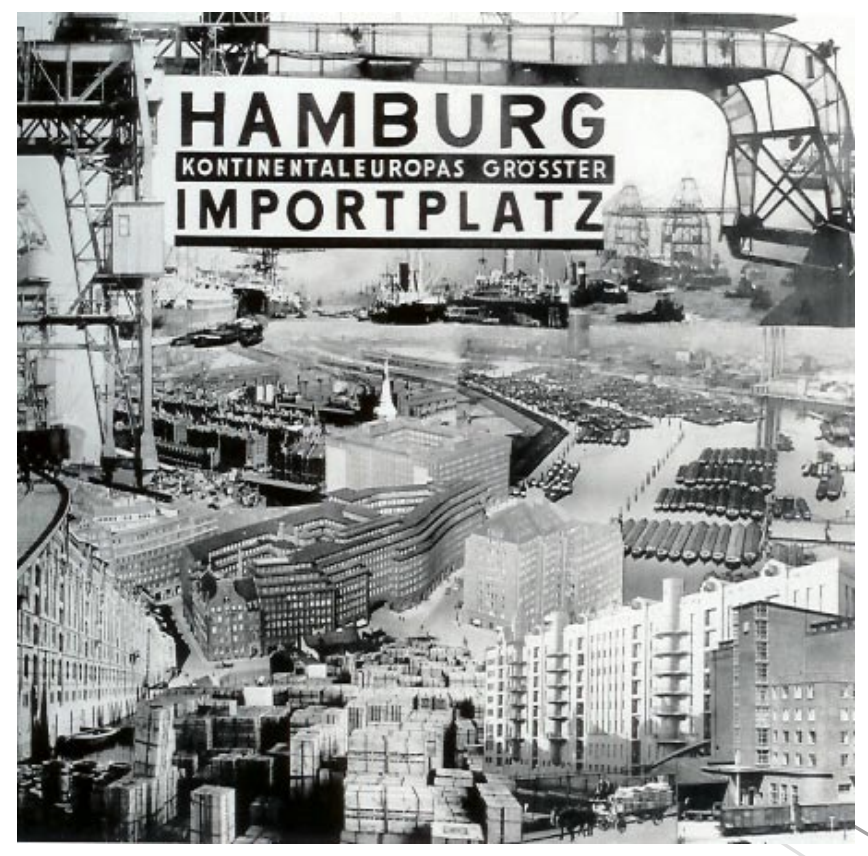
muy diversas disciplinas. ${ }^{3}$

En consecuencia, el espacio proyectado debía convertirse en un paisaje en movimiento que transformara el espacio a medida que avanzáramos y que mantuviera una necesaria continuidad que facilitase una lectura fluida y dinámica, tal y como ha sido la historia del espacio público a lo largo del siglo $X X$. Es aquí donde entraban en juego las líneas tensionadas de hilo de rafia que $\mathrm{di}$ César Domela, Hamburg Importplatz, 1929. bujaban planos quebrados, pliegues y volúmenes fragmentados, acompañando todo el recorrido y ritmándolo, introduciendọ una clara referencia al paisaje urbano de nuestras ciudades. Estas líneas de rafia creaban un interesante, a mi juicio, diálogo con los planos maci3 Véase VV.AA., Malas Calles, Instituto Valenciano de Arte Moderno (IVAM), Valencia, 2010. 

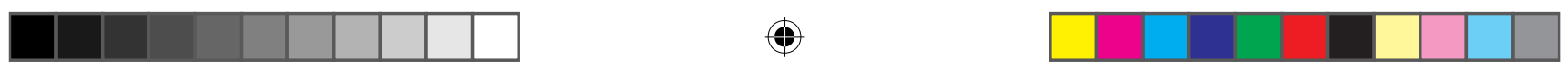

\section{Conclusión:Arquitecturas-paisaje surgidas al hilo del tiempo.}

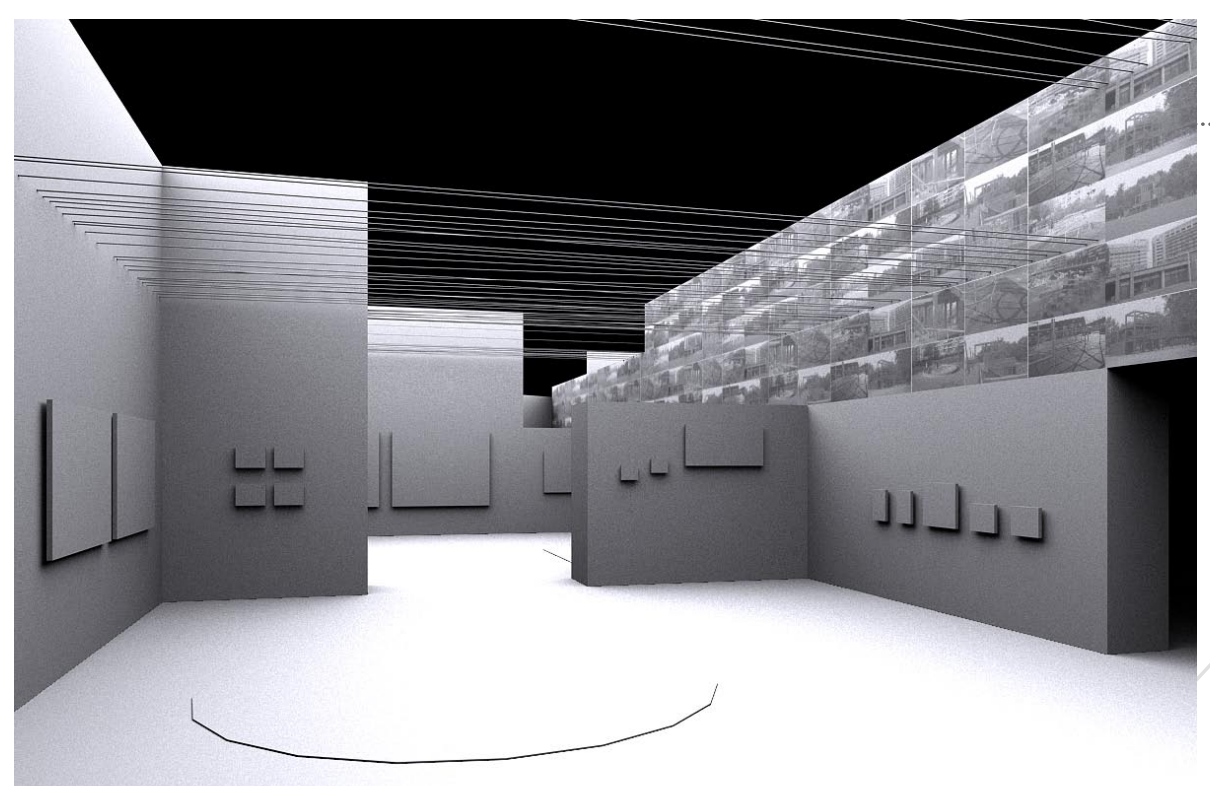

MAQUETA

VIRTUAL

zos donde se mostraban las obras que necesitaban soporte mural para ser expuestas. De algún modo se buscó que mientras que las obras estaban presentes con toda su potencia y rotundidad, la ciudad, la fisicidad del espacio público, estuviese presente de un modo mucho más metafórico y poético.

Estas líneas blancas que redibujaban un paisaje urbano lleno de matices y referencias en el interior del museo, nos acompañaban evitando la fractura en la secuencia entre espacios, al tiempo que hacían alusión a la necesaria condición de continuidad que el paisaje debe de tener para no desestructurarse hasta desaparecer. Esta idea de continuidad viene enfatizada por el gran collage que a modo de billboard (valla publicitaria), en clara referencia también al paisaje suburbano de la ciudad contemporánea, inunda el espacio de la sala de un extremo al otro. En él aparece representado el paisaje urbano fruto de tres experiencias urbanísticas del siglo XX de características muy distintas. Se trataba, también en orden cronológico, del Memorial judío de Berlín, obra de Peter Eisenman, del 


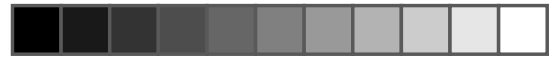

(1)
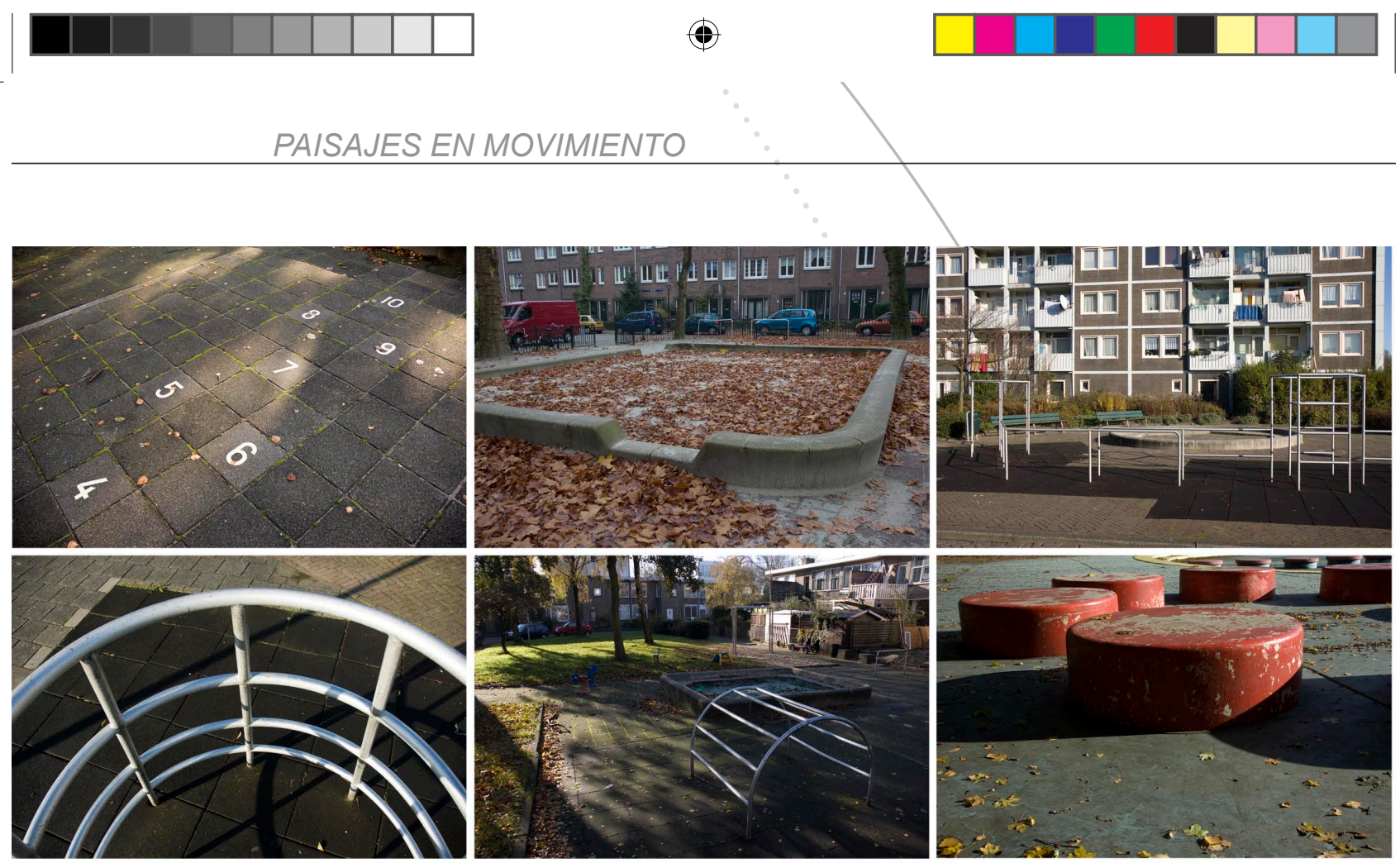

$\oplus$
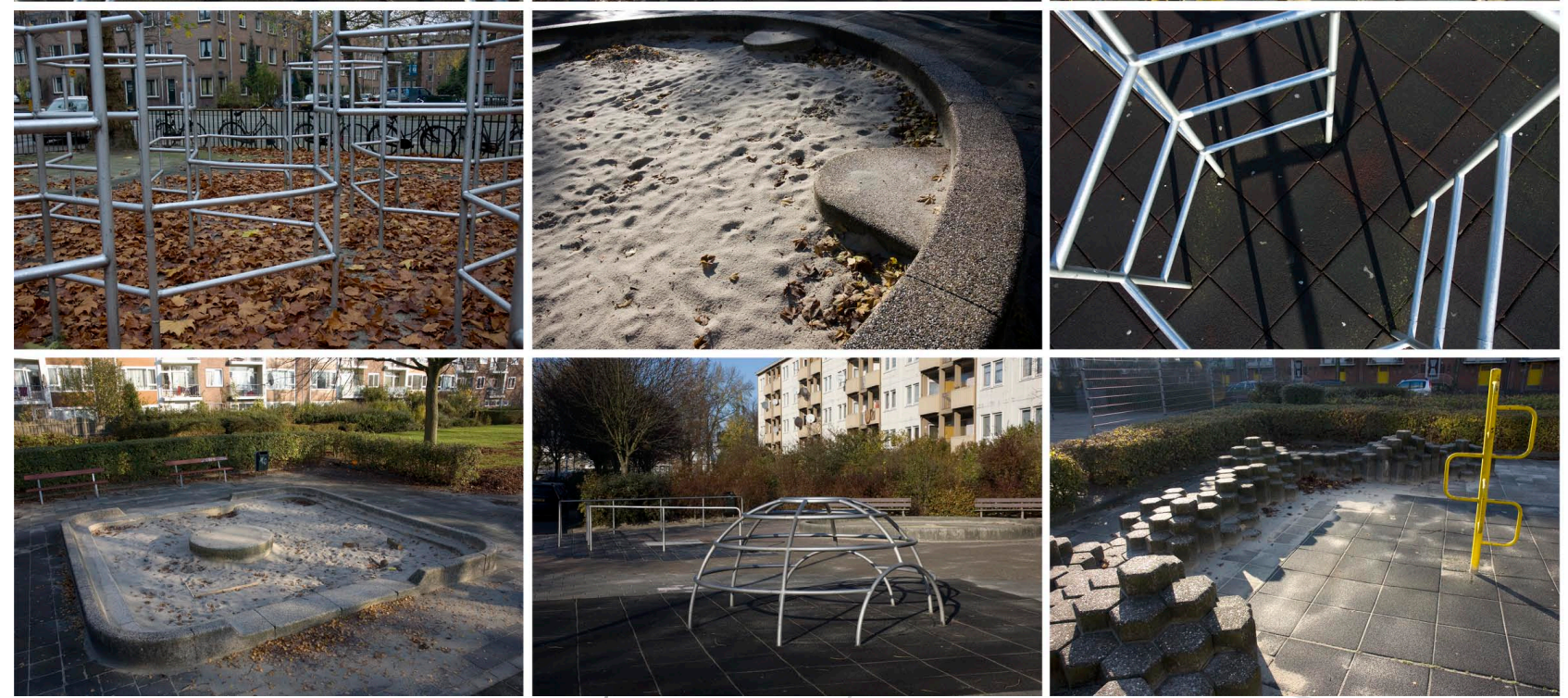

Los Playgrounds que Aldo van Eyck ideó y construyó por todo Amsterdam son esencialmente "paisajes del movimiento" ya que sus formas geométricas abstractas y rotundas se activan con los movimientos y juegos de los niños que se columpian y corren por ellos, que suben y que bajan por esas fantásticas estructuras tubulares, tan caras a los arquitectos del Movimiento Moderno. Sin la presencia de estos niños, el 


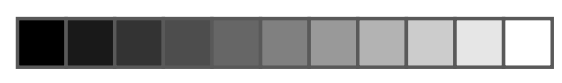

$\oplus$
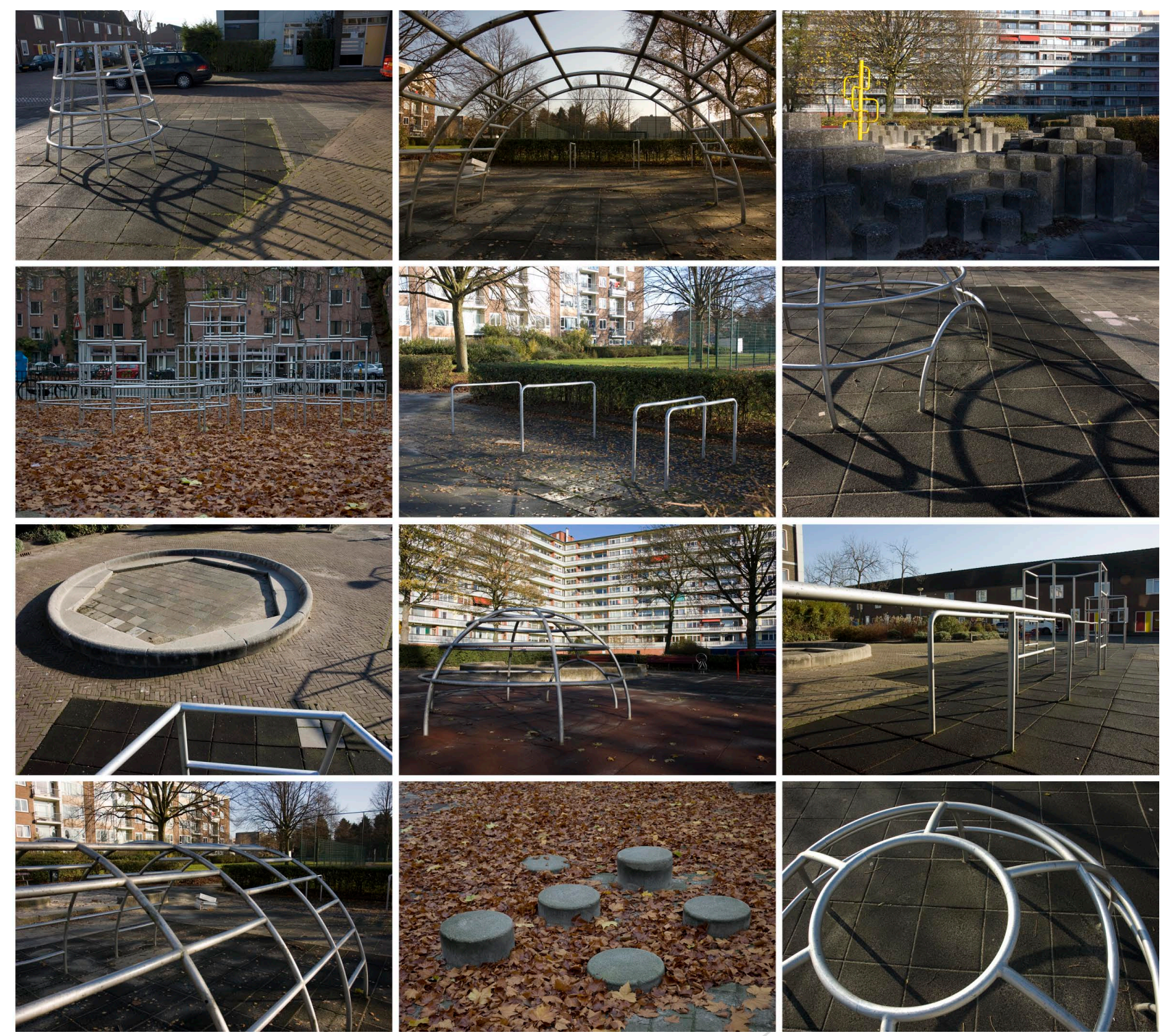

Ignacio Carbó, Playgrounds de Aldo van Eyck, 2010.

tiempo semeja detenido y aparece una fuerte sensación de estrañeza y melancolía. (De los varios centenares de Playgrounds que Aldo van Eyck construyó, tan solo quedan en la actualidad unas decenas. La fotografía es el resultado de un recorrido por estos parques y rincones de la ciudad holandesa). 


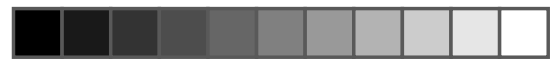

$\oplus$

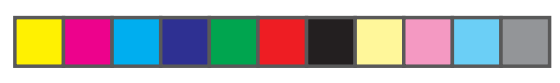

que ya he hablado anteriormente; los Playgrounds para Ámsterdam de Aldo van Eyck (que podríamos traducir como zonas de juegos para niños), espacios para el optimismo en el corazón de la ciudad holandesa; y el Parque de La Villette en Paris, de Bernard Tschumi, lugar de fantasía y utopía desde donde arrancó mi paseo anterior por Paris. En definitiva, el objetivo era traer la ciudad al interior del museo gracias a la reproducción a una escala importante de tres paisajes urbanos (resultado por tanto de la creación de distintos espacios ciudadanos) que hacían referencia a diversos estados de ánimo social, artístico, arquitectónico y que resultaban en consecuencia representativos de las respectivas etapas de la exposición.

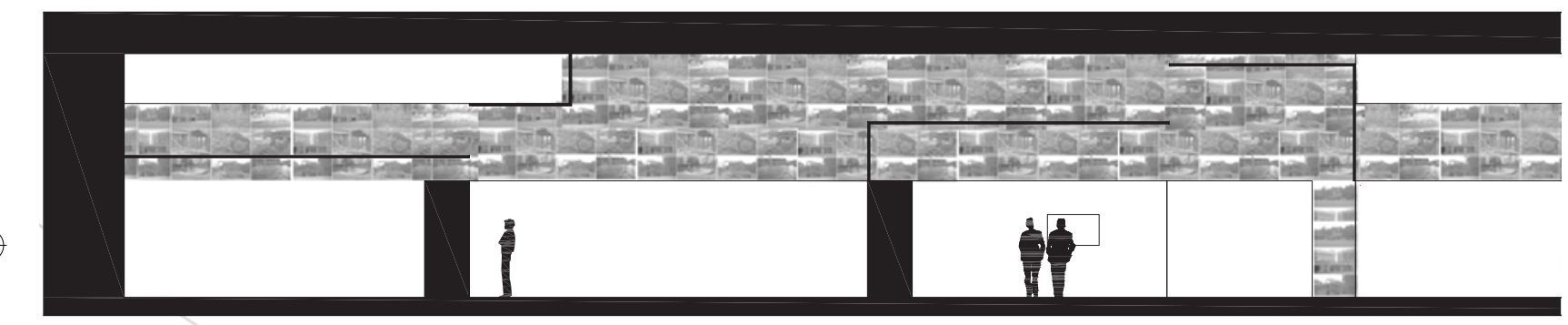

SECCIÓN LONGITUDINAL

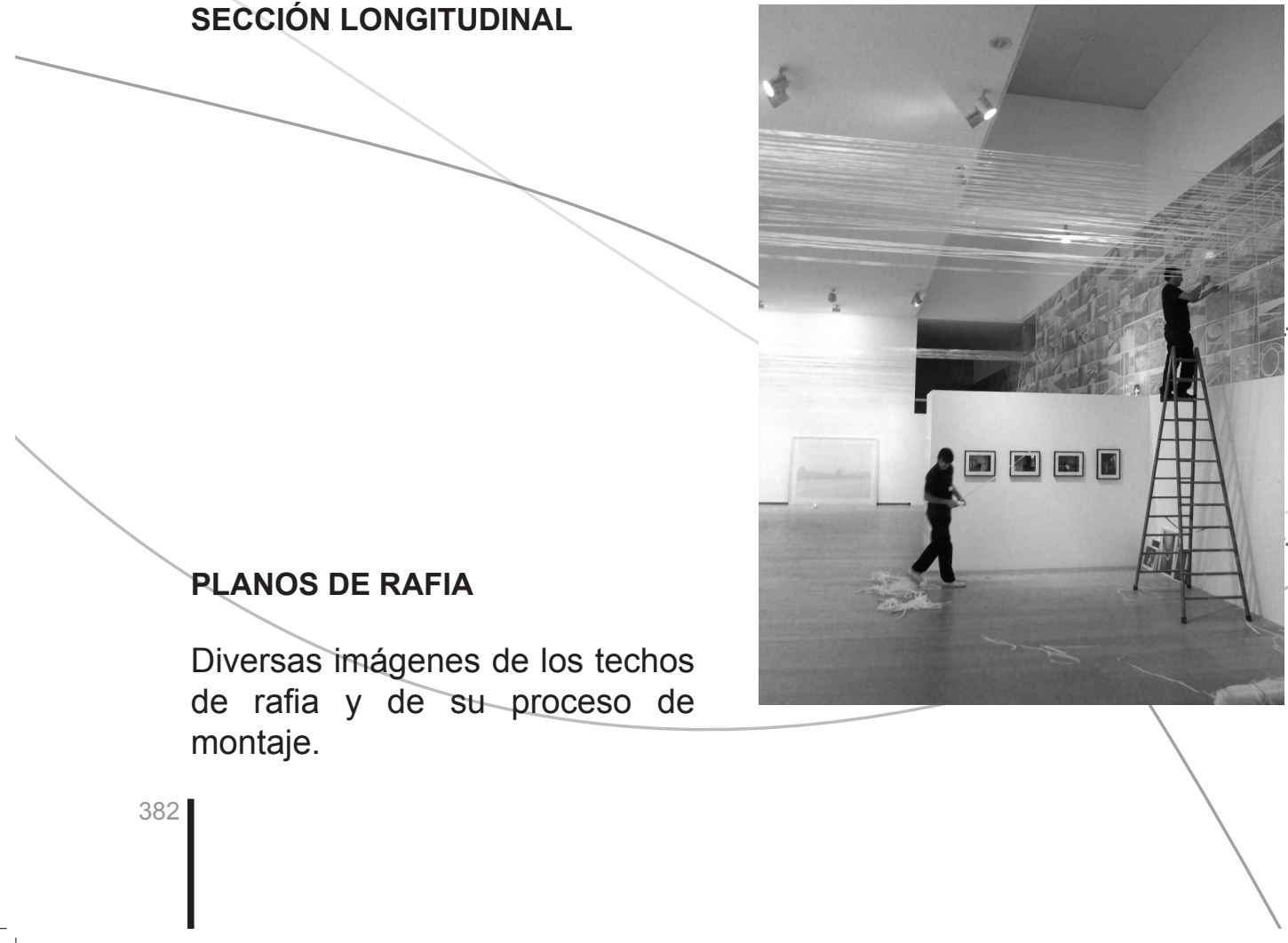



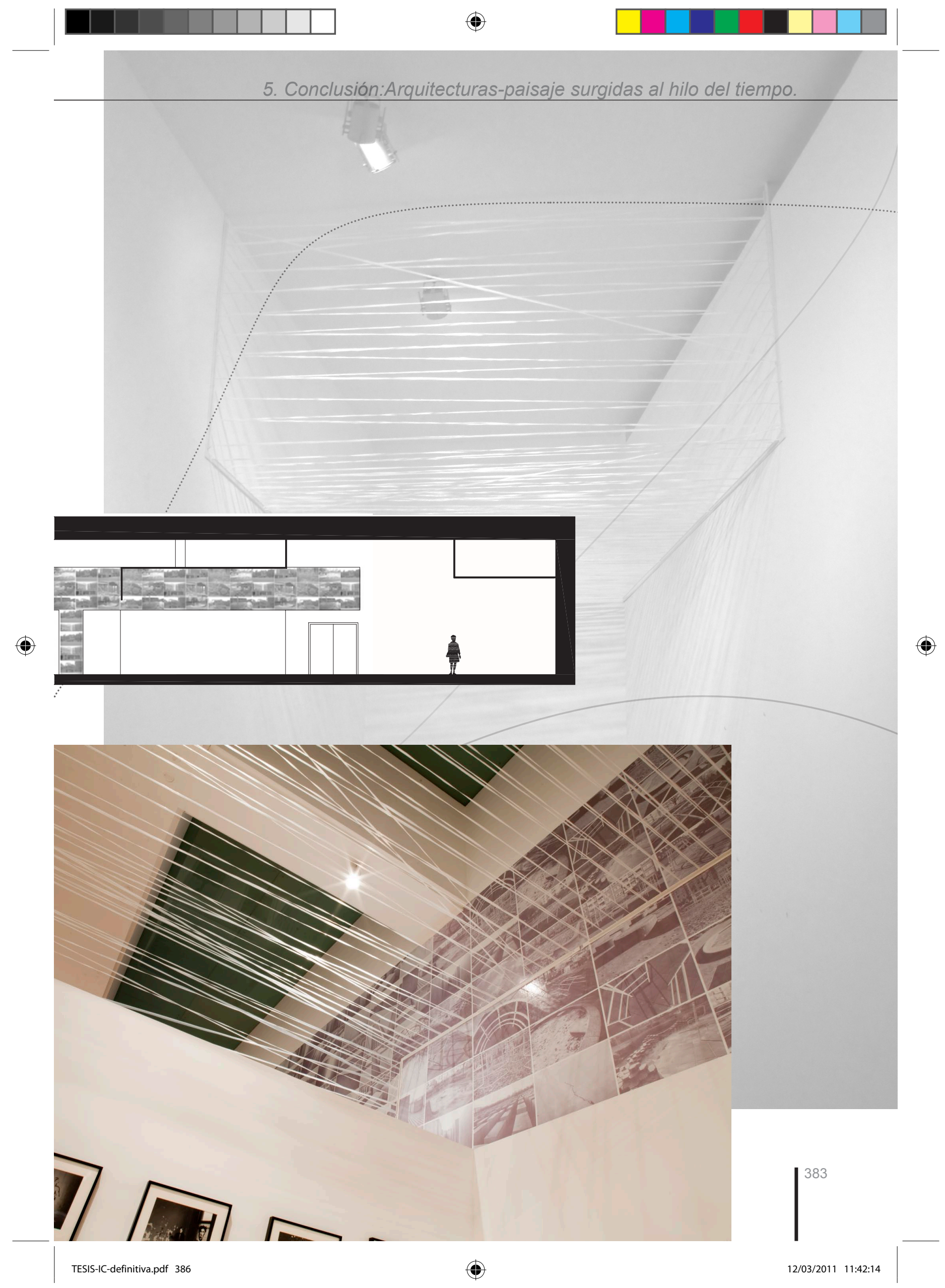


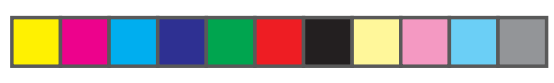

La noción de movimiento que las líneas de rafia introducían en el espacio se tornaba más palpable cuando continuábamos nuestro recorrido y accedíamos a la sala que se encuentra en la planta superior y que albergaba la parte dedicada a comienzos de siglo. Aquí, los "techos" de rafia vibraban con las luces y las sombras producidas por la luz artificial de la sala y el conjunto adquiría un carácter más onírico y poético. La vibración de estos planos horizontales y verticales interrumpidos y huidizos, cubiertas y testeros de una ciudad imaginaria, buscaban acercarnos a un cierto carácter de fragilidad y movimiento suspendido.

\section{PLANOS DE RAFIA}

Planta de trabajo con la situación de los diversos planos fragmentados de hilos de rafia correspondientes con las distintas áreas en las que se dividían las salas. El objeto de esta fragmentación era obtener la pauta correcta en

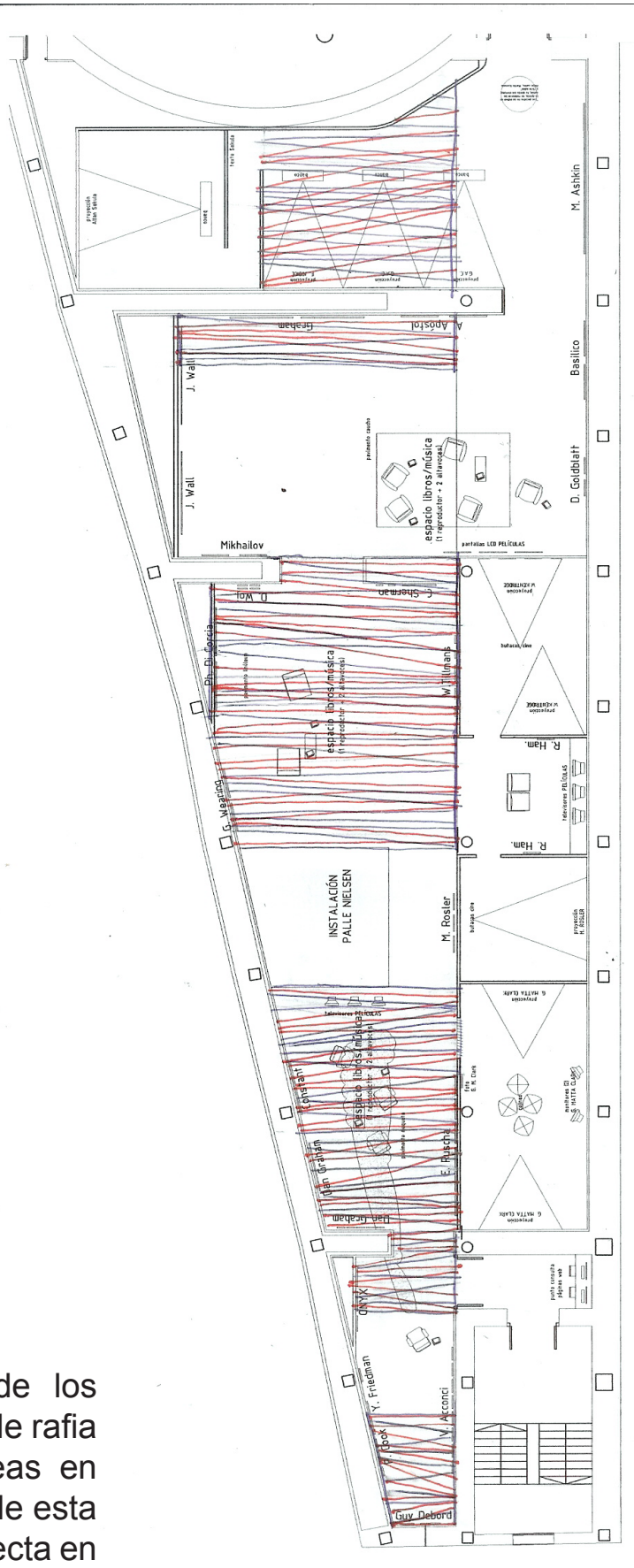
el recorrido de la exposición. 


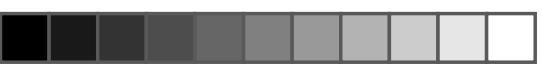

(1)

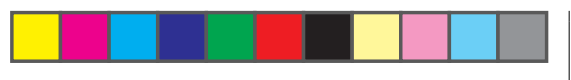

5. Conclusión:Arquitecturas-paisaje surgidas al hilo del tiempo.

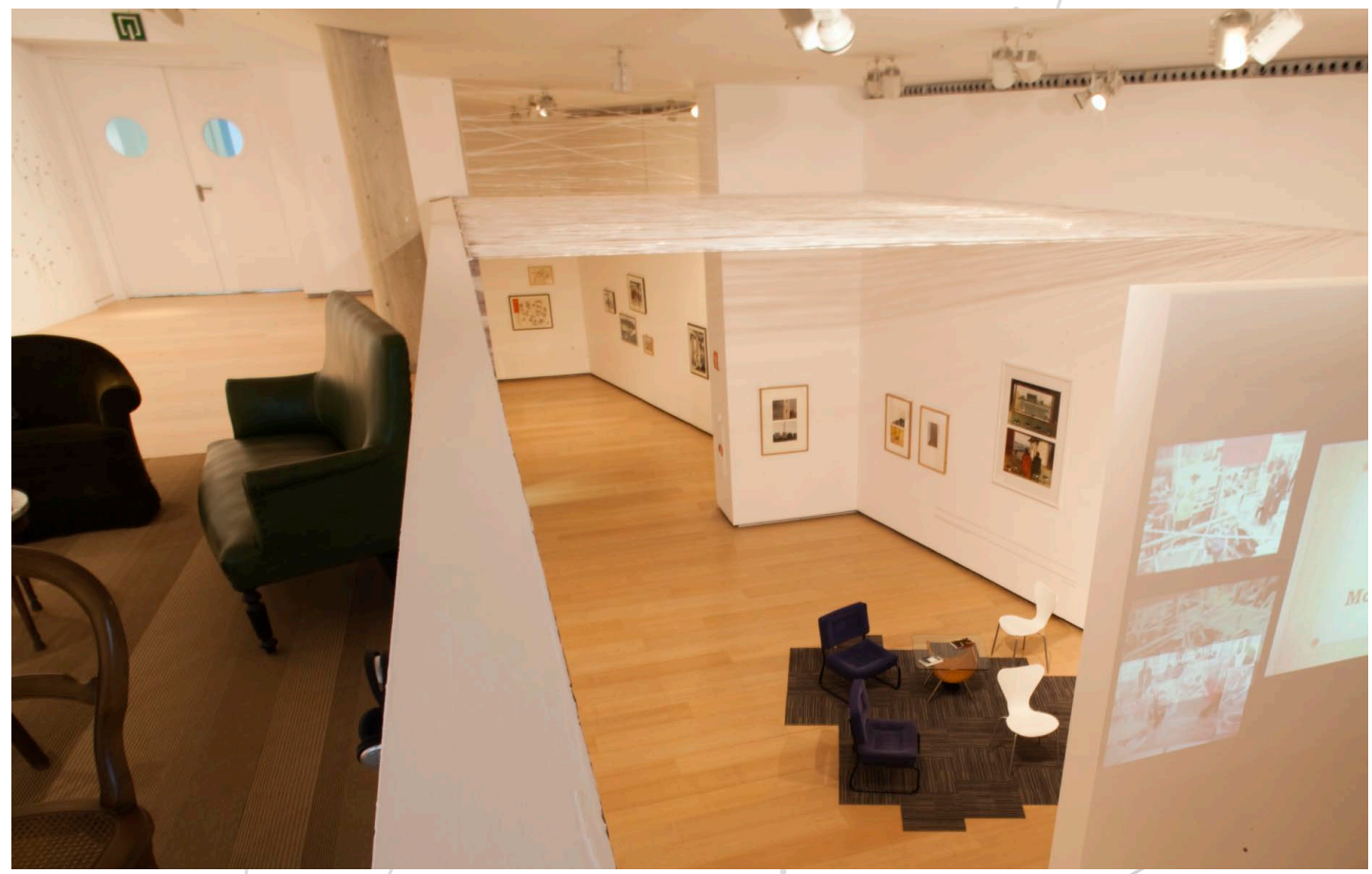

$\oplus$

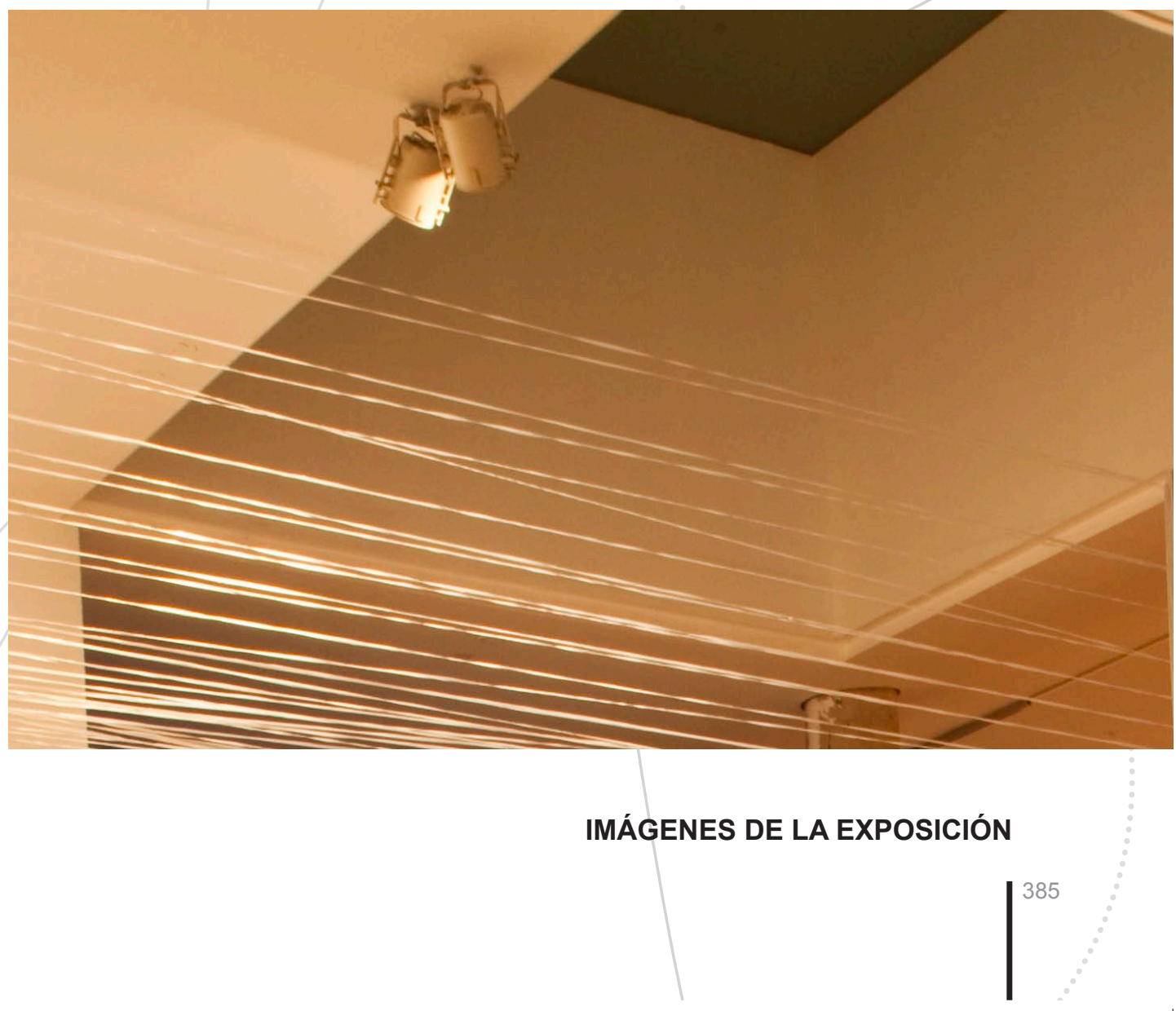




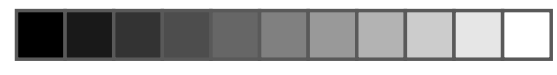

(†)

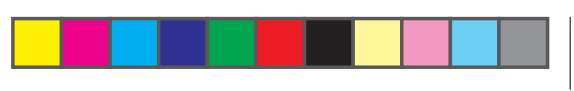

\section{PLANTAS}

Plantas de las dos salas.

Además de las diversas obras, podemos ver los espacios destinados a la lectura y la audición de los libros y canciones representativos de cada etapa, seleccionados por el comisario.

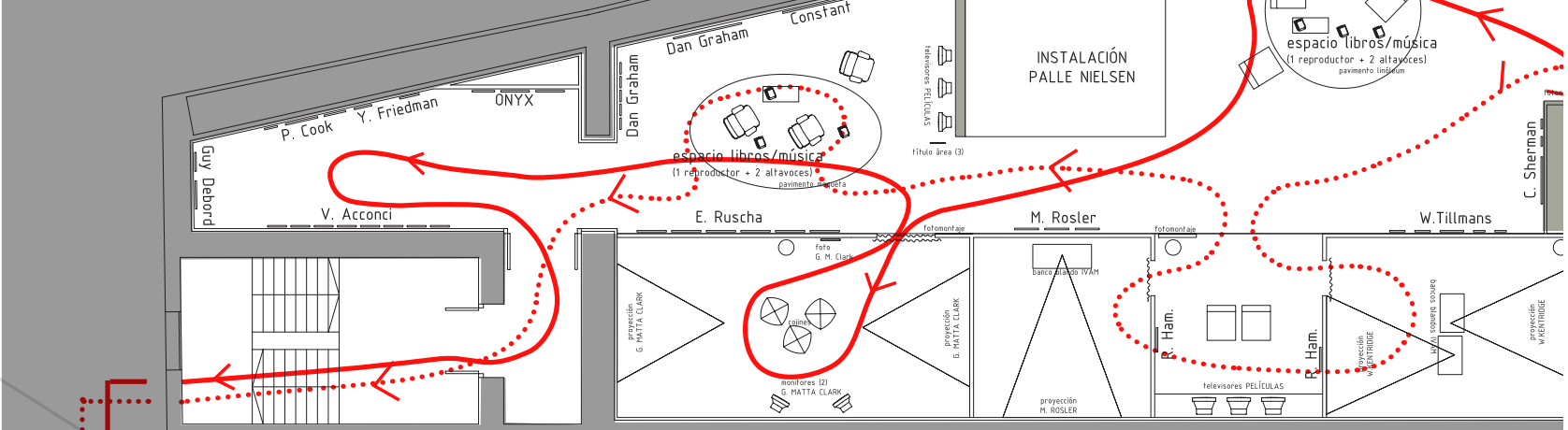




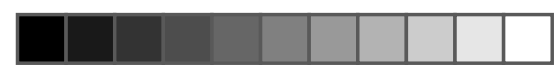

$\oplus$

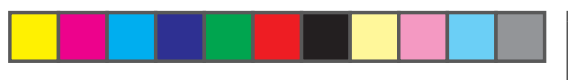

5. Conclusión:Arquitecturas-paisaje surgidas al hilo del tiempo.

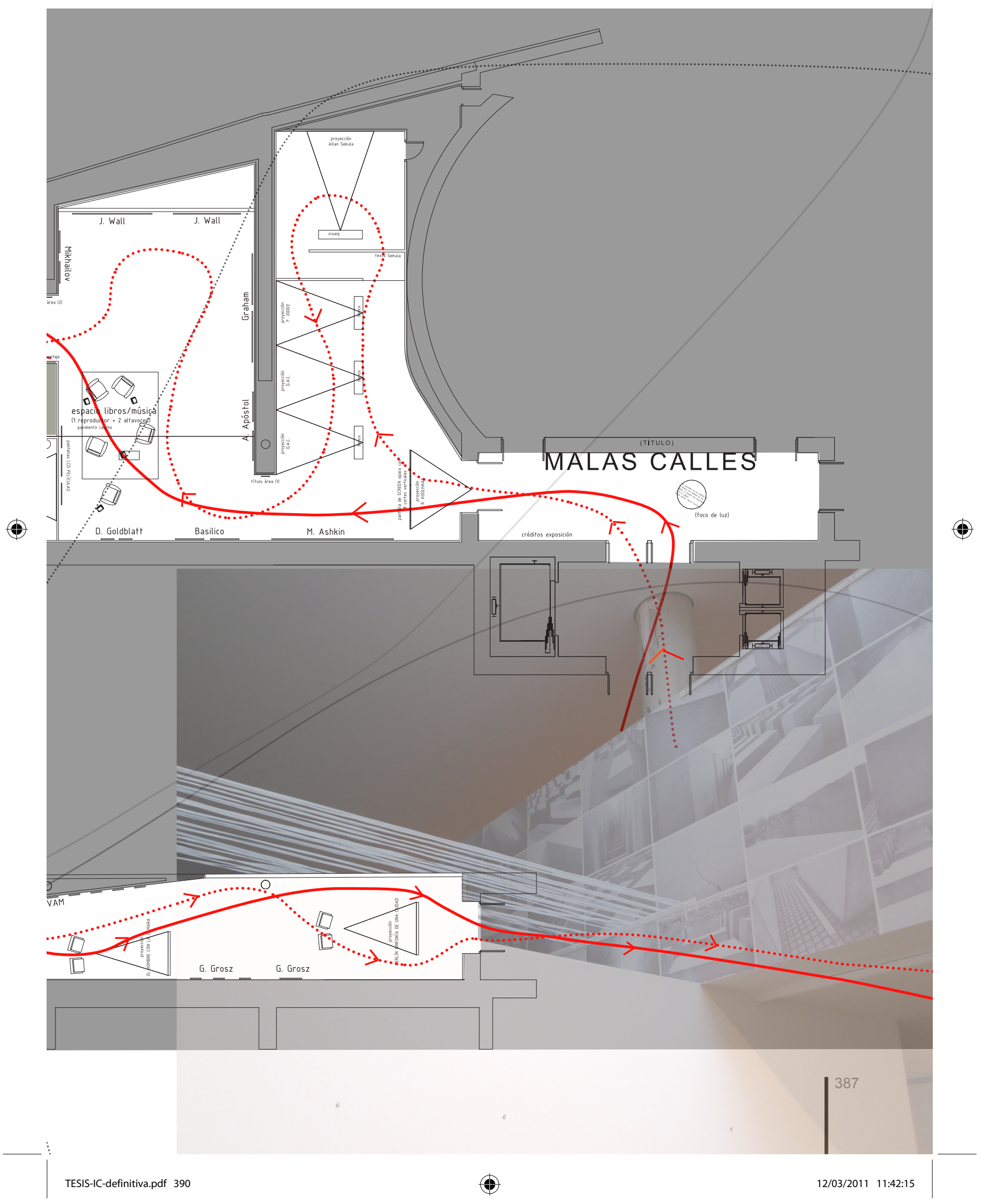




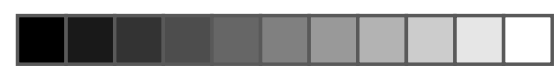

$\oplus$

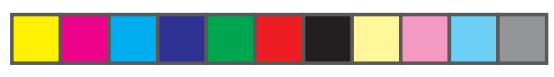

Nuestro caminar por estas Malas Calles, que comenzó en la contemporaneidad al atravesar una pantalla, al "introducirnos" en una proyección del video Lagos Wide \& Close (2002-2004) obra del arquitecto holandés Rem Koolhaas, se detenía tras recorrer la exposición y salir tras la proyección de Berlín sinfonía de una ciudad, Walter Ruttmann (1927), una de las primeras filmaciones acerca de la ciudad a comienzos del siglo $X X$. Dos ciudades, a modo de comienzo y de conclusión del recorrido, dos miradas al paisaje urbano correspondientes a los dos períodos que acotan la exposición y donde el movimiento es pieza clave, tanto de las propias filmaciones como del ritmo de las ciudades representadas.

IMÁGENES DE LA EXPOSICIÓN

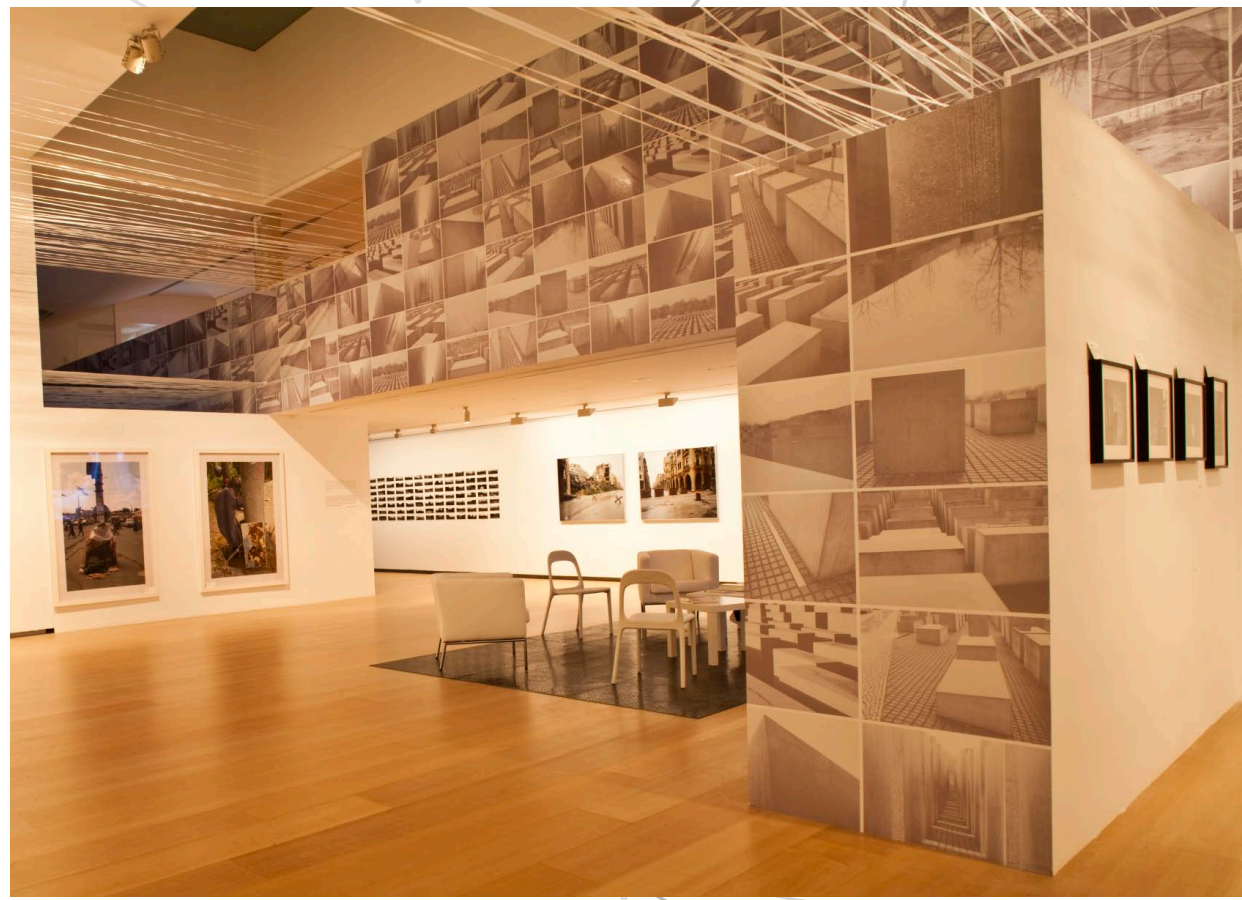




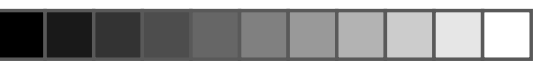

$\oplus$

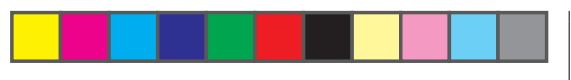

5. Conclusión:Arquitecturas-paisaje surgidas al hilo del tiempo.

MAQUETA VIRTUAL
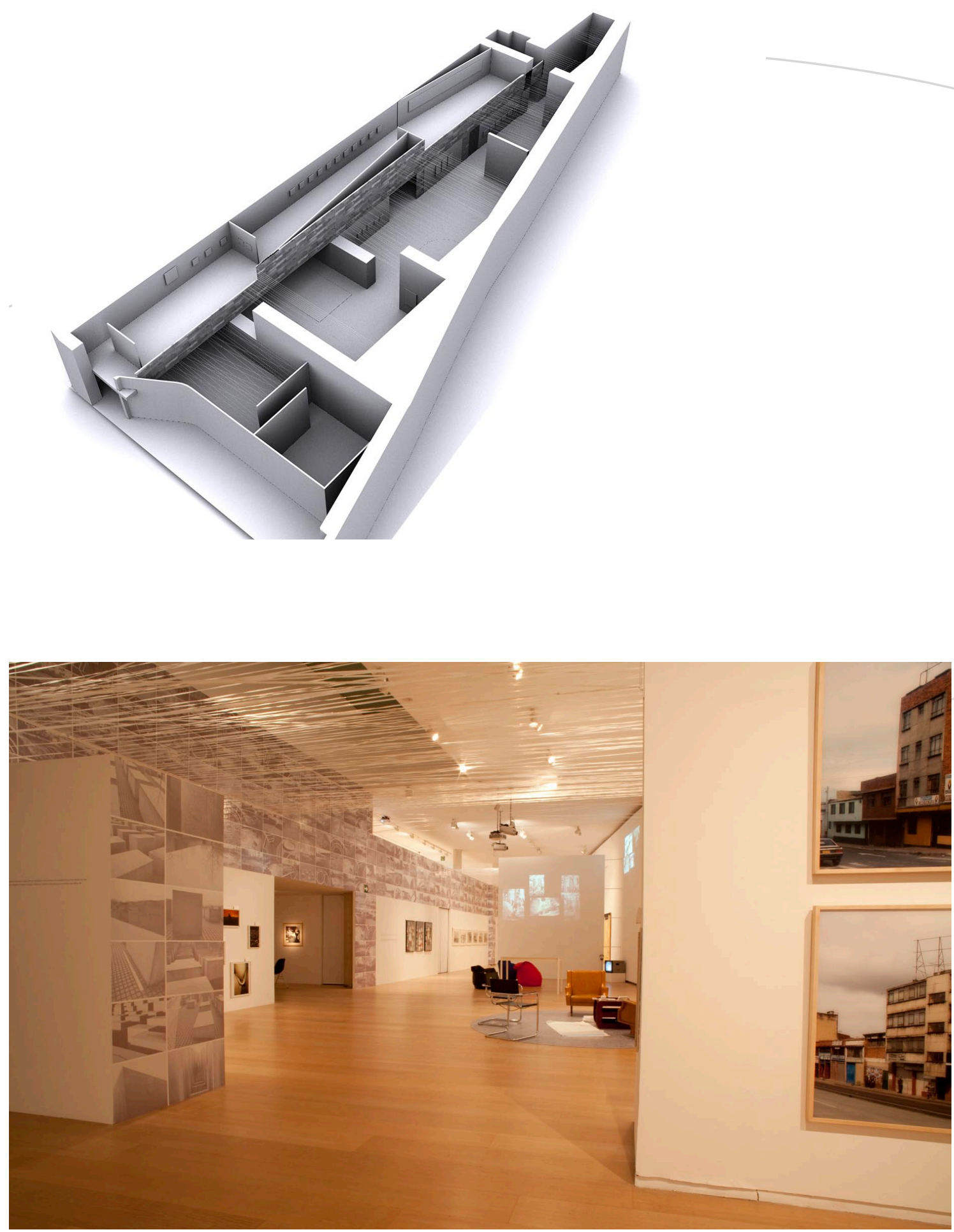


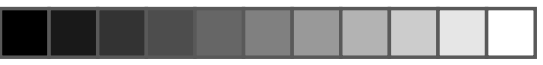

(1)

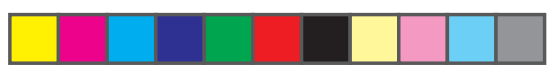

En definitiva, la escenografía para Malas Calles planteaba al visitante un paisaje, un recorrido fluido y dinámico que discurría entre las obras de arte y la arquitectura del museo y que buscaba dar respuesta a las características de las diversas piezas y al proyecto expositivo en su conjunto. Simultáneamente, tenía la pretensión de servir de altavoz y pequeño homenaje para aquellas experiencias arquitectónicas contemporáneas de finales del siglo XX y comienzos del siglo XXI a las que nos hemos aproximado en estas páginas y que, situadas en un lugar difuso y esquivo entre el arte y la arquitectura, nos proponen escenarios urbanos dinámicos, nos proponen esos fascinantes paisajes en movimiento.

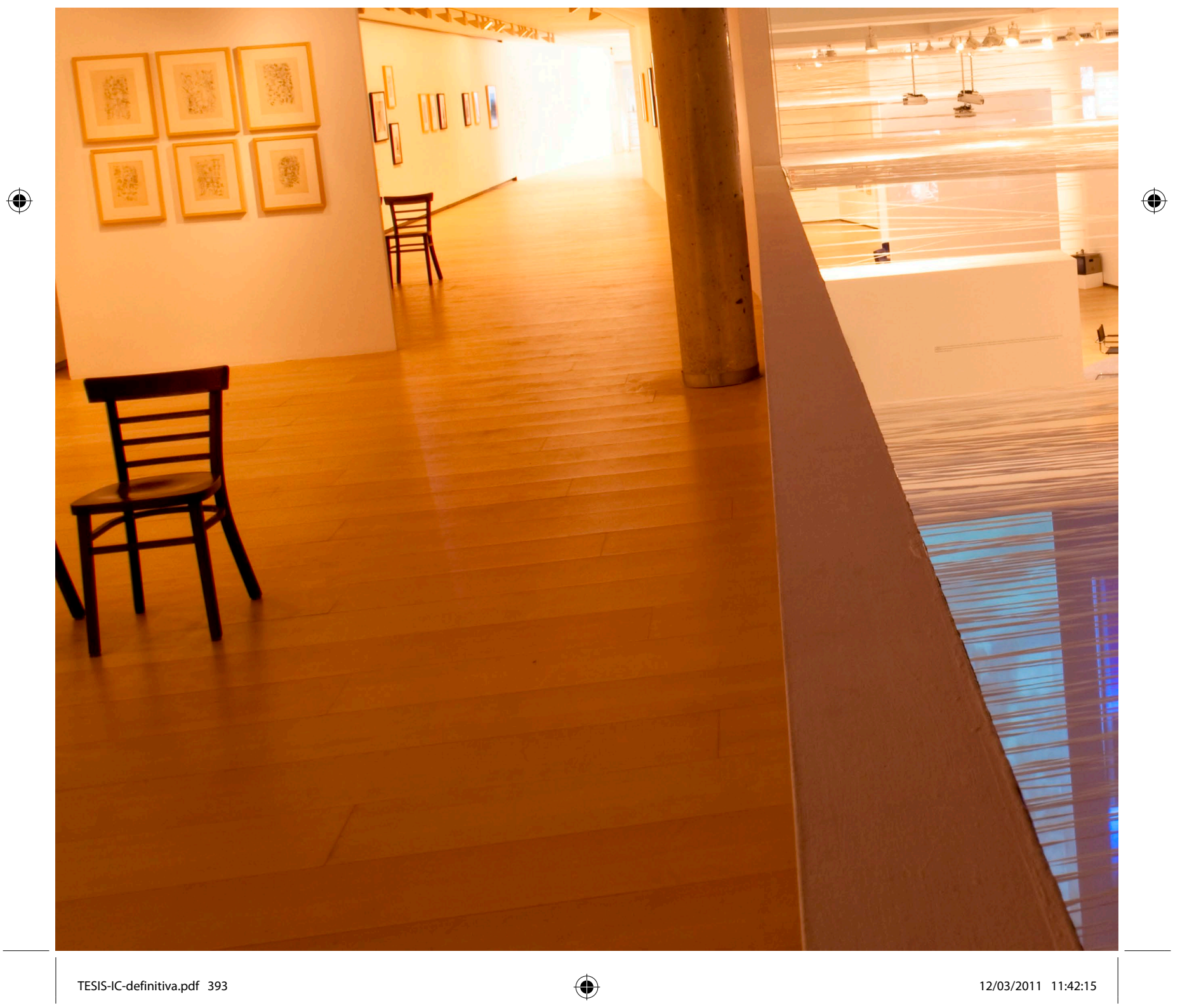




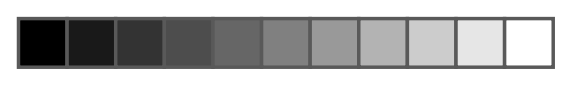

(

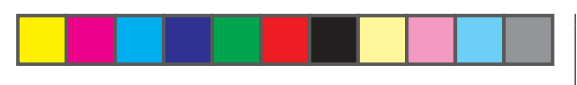

5. Conclusión:Arquitecturas-paisaje surgidas al hilo del tiempo.

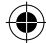
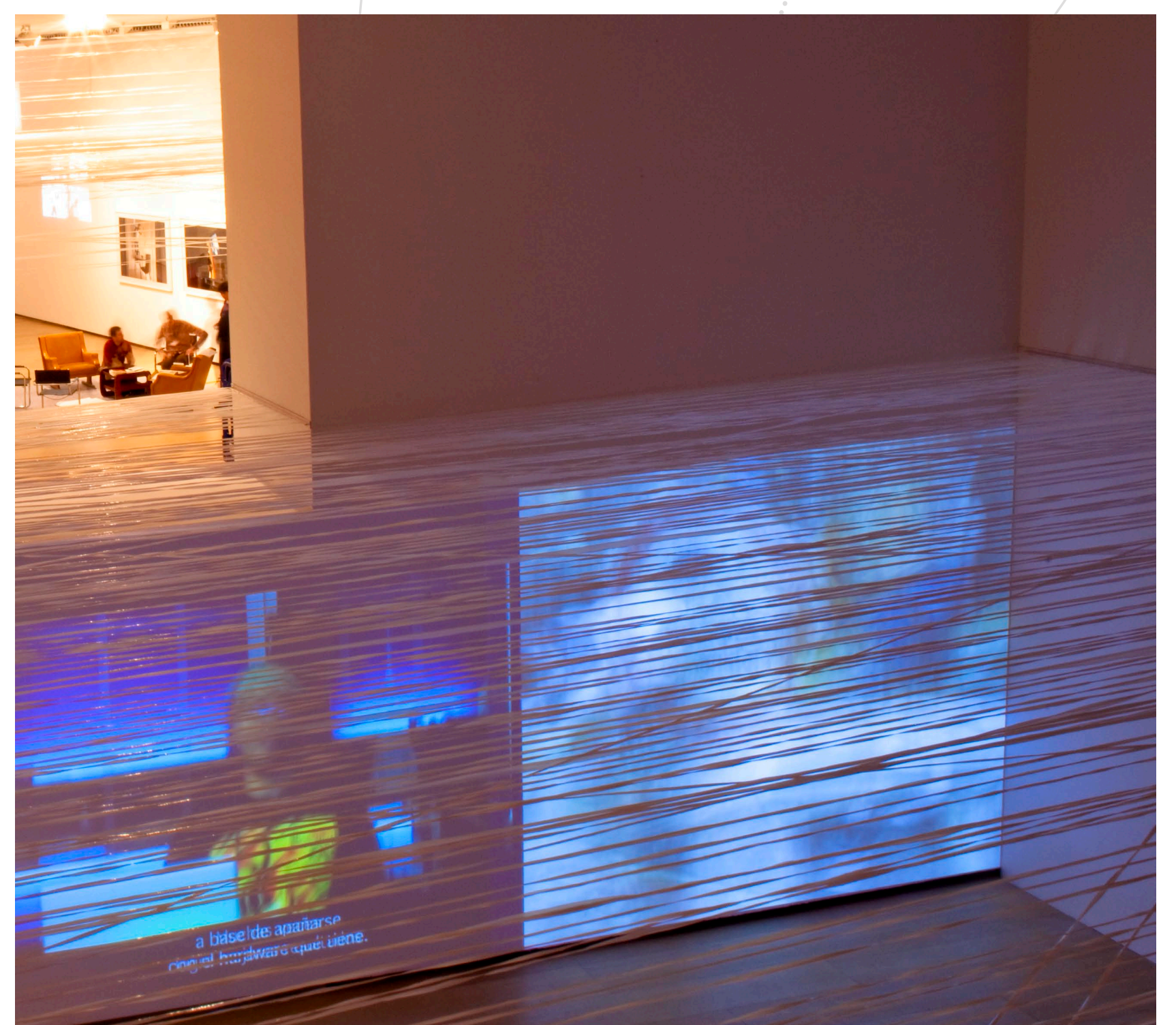


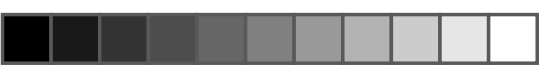

$\oplus$

(

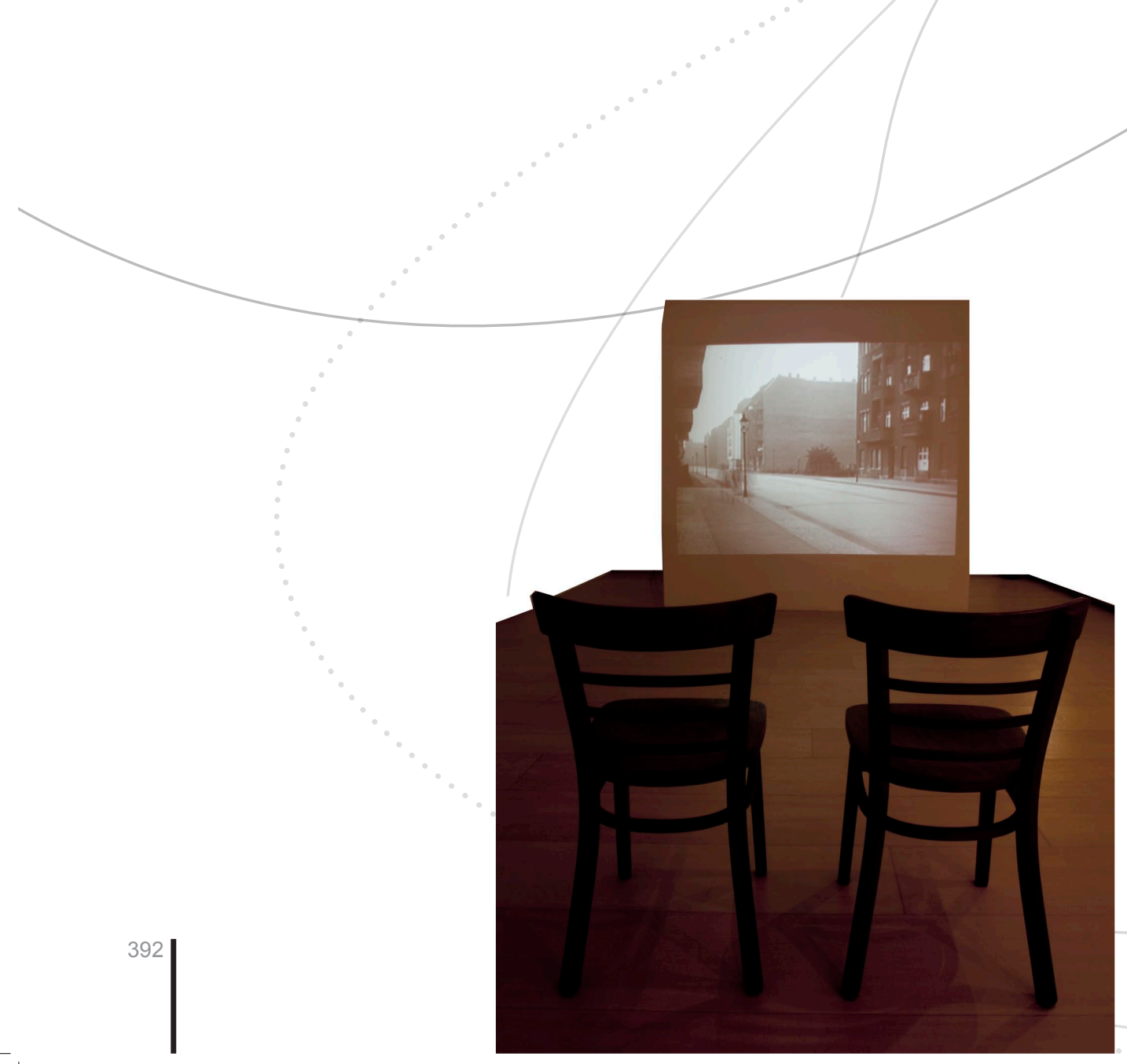




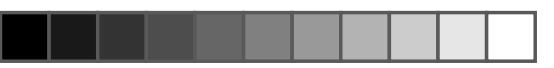

$\oplus$

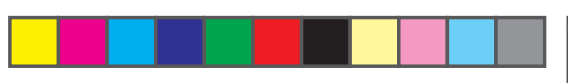

6. Bibliografía.

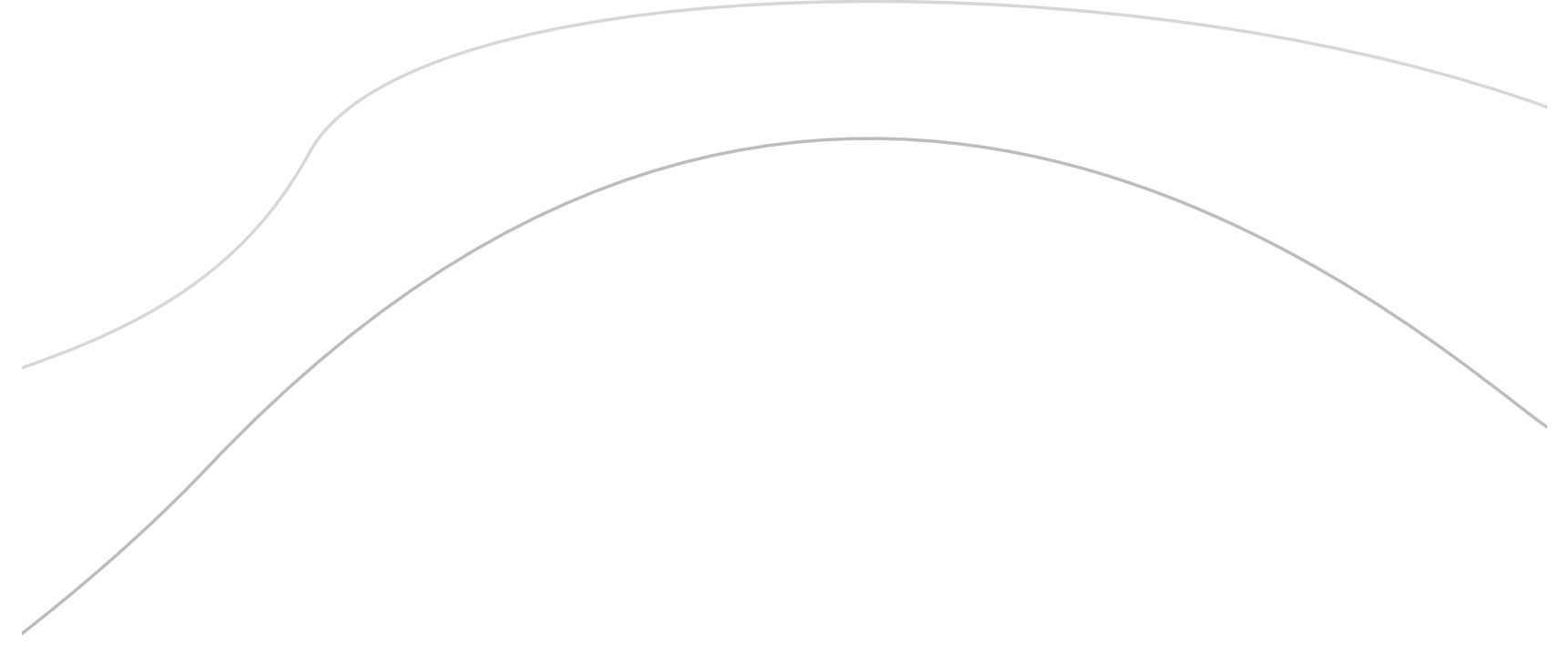

6. BIBLIOGRAFÍA 

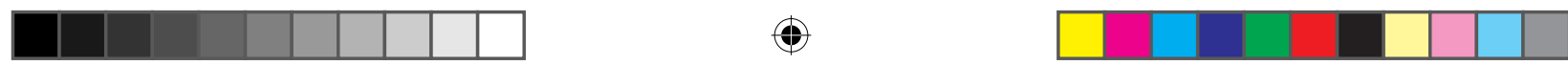

- Albelda, José y Saborit José, La construcción de la naturaleza, Consellería de Cultura, Educació i Ciència, Valencia, 1997.

- Alison, Jane y otros (eds.), Future City. Experiment and Utopia in Architecture. Thames \& Hudson, Londres, 2007.

- Amidon, Jane, Paisajes radicales. Reinventar el espacio exterior, Blume, Barcelona, 2003.

- Andreotti, Libero y Costa, Xavier (eds). Teoría de la deriva y otros textos situacionistas sobre la ciudad, MACBA y ACTAR, Barcelona, 1996.

- Andreotti, Libero y Costa Xavier. Situacionistas. Arte, política, urbanismo, MACBA y ACTAR, Barcelona, 1996.

- Anibarro, Miguel Ángel, La construcción del jardín clásico. Teoría, composición y tipos, Akal, Madrid, 2002.

- Aragon, Louis, El campesino de Paris, Bruguera, Barcelona, 1979.

- Armour, Robert A., Dioses y mitos del Antiguo Egipto, Alianza Editorial, Madrid, 2004.

- Aufrère, Sydney H. (ed.), Description de l'Égypte. Publiée sous les ordres de Napoléon Bonaparte, Bibliothèque de l'image, Tours, 2001.

- Badal, Ferràn, Els peregrins de les Useres, Fills de F. Armengot, Castellón de la Plana, 1974.

- Bearsley, John, Earthworks and Beyond. Contemporary Art in Landscape, Abbeville, Nueva York, 1989.

- Benevolo, Leonardo, La captura del infinito, Celeste ediciones, Madrid, 1994.

- Benjamin, Walter, Poesía y capitalismo lluminaciones II, Altea, Taurus, Alfaguara, SA, Madrid, 1988.

- Berque, Augustin, Les raisons du paysage: de la Chine antique aux environnements de synthèse, Hazan, Paris, 1995.

- Blazwick, Iwona (ed.), Cristina Iglesias, Poligrafa, Barcelona, 2002.

- Borges, Jorge Luis, El aleph, Alianza editorial, Madrid, 2009.

- Borges, Jorge Luis, El libro de los seres imaginarios, Bruguera Alfaguara, Barcelona, 1979. 


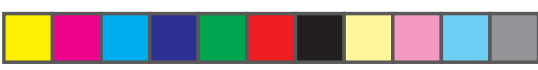

- Borges, Jorge Luis, Nueva antología personal, Editorial Bruguera, Barcelona, 1980.

- Brayer Marie-Ange y Simonot, Beatrice (eds.), Archilab's Earth Buildings:Radical Experiments in Land Architectures, Thames \& Hudson, Londres, 2003.

- Brayer, Marie-Ange y Migayrou, Frédéric, Archilab's Urban Experiments. Radical Architecture, Art and the City, Thames \& Hudson, Londres, 2005.

- Breton, André, Los pasos perdidos, Alianza, Madrid, 1987.

- Careri, Francesco, Walkscapes. El andar como práctica estética, Gustavo Gili, Barcelona, 2003.

- Cauquelin, Anne, L'invention du paysage, Presse Universitaire de France, Paris, 2000.

- Celant, Germano (ed.), Arti et Architettura, 1900/1968, Skira, Milán, 2004.

- Cirlot, Juan Eduardo, Diccionario de símbolos, Siruela, Madrid, 2006.

- Cook, Peter. Archigram, Princeton Architectural Press, Nueva York, 1999.

- Coromina, Beatriz, Doble exposición. Arquitectura a través del arte, Akal, Madrid, 2006.

- Cortés, José Miguel G. (ed.) Contra la arquitectura. La necesidad de (re)pensar la ciudad, Espai d'Art Contemporani de Castelló, Castellón, 2000.

- Cortés, José Miguel G. Políticas del Espacio. Arquitectura, género y control social. ACTAR e Instituto de Arquitectura Avanzada de Cataluña, Barcelona, 2006.

- Cortés, José Miguel G. Espacios diferenciales. LAIMPRENTA CG, Valencia, 2007.

- Cosgrove, Denis, Social Formation and Symbolic Landscape en Les Carnets du paysage número 8, Versailles, 2002.

- Debord, Guy. La sociedad del espectáculo, Pre-textos, Valencia, 2003. 

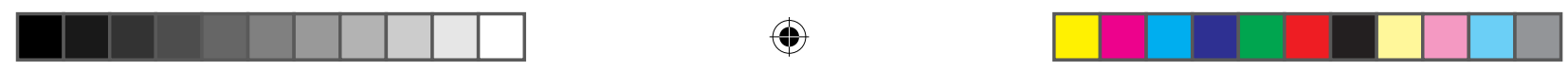

- Doob, Penelope Reed, The Idea of the Labyrinth from Classical Antiquity through the Middle Ages, Cornell University Press, Nueva York, 1990.

- Giedion, Sigfried, El presente eterno: Los comienzos de la arquitectura, Alianza Forma, Madrid, 1986.

- Grimal, Pierre, Diccionario de mitología griega y romana, Paidós, Barcelona, 1994.

- Guasch, Anna Maria, El arte último del siglo XX, Alianza, Madrid, 2000.

- Guilheux, Alain. Archigram, Centre Georges Pompidou, París, 1994.

- Jakob, Michael, Paysage et temps, Infolio éditions, Gollion, 2007.

- Jeannel, Bernard. Le Nôtre, Akal, Madrid, 2003.

- Jellicoe, Geoffrey Susan, El paisaje del hombre. La conformación del entorno desde la prehistoria hasta nuestros días, Gustavo Gili, Barcelona, 1995.

- Eliade, Mircea, Lo sagrado y lo profano, Editorial Labor, Barcelona, 1985.

- Eliade, Mircea, El mito del eterno retorno, Alianza Editorial, Madrid, 2008.

- Espelt, Ramón, Laberints. Llocs, textos, imatges, films. Laertes, Barcelona, 2008.

- Friedman, Yona, La arquitectura móvil, hacia una arquitectura concebida por sus habitantes, Poseidón, Barcelona, 1978.

- Gausa, Manuel (ed.) Otras "naturalezas" urbanas, Espai d'Art Contemporani de Castelló, Castellón, 2001.

- Hamilton Hazlehurst, Franklin, Des jardins d'illusion. Le génie d'André Le Nostre, Somogy éditions d'art, Paris, 2005.

- Hobbs, Robert, Robert Smithson: Sculpture, Cornell University, Londres, 1981.

- Holt, Nancy, The writings of Robert Smithson, New York University Press, Nueva York, 1979.

- Honour, Hugh, El Romanticismo, Alianza Forma, Madrid, 1992. 


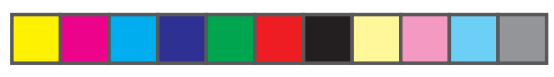

- Ito, Toyo, Escritos, Colegio Oficial de Aparejadores y Arquitectos técnicos de Murcia, Valencia, 2000.

- Jakob, Michael, Paysage et Temps, Infolio, Paris, 2007.

- Maderuelo, Javier, El paisaje, génesis de un concepto, Abada, Madrid, 2005.

- Maderuelo, Javier, La idea de espacio en la arquitectura y el arte contemporáneos, 1960-1989, Akal, Madrid, 2008.

- Marot, Sébastien, Suburbanismo y el arte de la memoria, Editorial Gustavo Gili, Barcelona, 2006.

- Méndez Filesi, Marcos, El laberinto, historia y mito, Alba Editorial, Barcelona, 2009.

- Migayrou, F. y Mennen, Z. Architectures NonStandard, Centre Georges Pompidou, París, 2003.

- Montaner, Josep Mª. Las formas del siglo XX, Gustavo Gili, Barcelona, 2002.

- Neff, Terry, (ed.). A quiet revolution. British Sculpture since 1965, Thames and Hudson, Londres, 1987.

- Nogué, Joan (ed.), La construcción social del paisaje, Biblioteca Nueva, Madrid, 2007.

- Norberg-Schulz, Christian, Existencia, espacio y arquitectura, Editorial Blume, Barcelona, 1975.

- Raquejo,Tonia, Land art, Nerea, Madrid,1998.

- Risselada, Max, Raumplan versus plan libre, 010 Publishers, Rotterdam, 2008.

- Robbins, David (ed.), El Independent Group: La postguerra británica y la estética de la abundancia, Instituto Valenciano de Arte Moderno (IVAM), Valencia, 1990.

- Roche, François, Corrupted Bodies, Damdi Publishing, Londres, 2004.

- Roger, Alain, Guery, François et autres, Maîtres et Protecteurs de la Nature, Champ Vallon, Seyssel, 1996. 

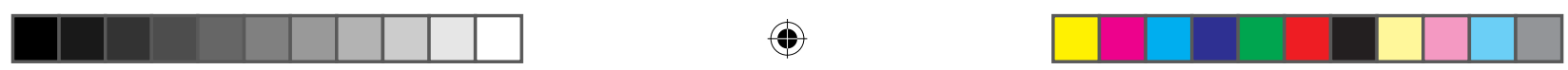

- Roger, Alain, Breve tratado del paisaje, Biblioteca Nueva, Madrid, 2007.

- Rousseau, Jean-Jacques, Ensoñaciones del paseante solitario, Alianza, Madrid, 1979.

- Ruiz de la Puerta, Félix y Sánchez González, Juana, La espiral en la arquitectura, Espacios pictóricos y arquitectónicos, Mairea, Madrid, 2007.

- Sadler, Simon. The Situationist City. The MIT Press, Cambridge, Massachusetts, 1999.

- Schaik, Martin van and Mácel, Otakar (eds.), Exit Utopia. Architectural Provocations 1956-76, Prestel, Munich, 2005.

- Sennet, Richard, Carne y Piedra. El cuerpo y la ciudad en la civilización occidental, Alianza, Madrid, 1997.

- Smithson, Robert. Un recorrido por los monumentos de Passaic, Nueva Jersey, Gustavo Gili, Barcelona, 2006.

- Tortosa, Guy, Stalker à travers les territoires actuels, Jean Michel Place éditeur, París, 2000.

- Walser, Robert, El paseo, Ediciones Siruela, Madrid, 1996.

- Wigley, Mark. Constant's New Babylon. The Hyper-Architecture of Desire, 010 Publishers, Rotterdam, 1998.

- Zellner, Peter, Hybrid Space: New Forms in Digital Architercture, Thames \& Hudson, Londres, 1999.

- VV.AA., Piedras. Richard Long, Ministerio de Cultura, Madrid, 1986.

- VV.AA., Hamish Fulton. Walking Passed, IVAM, Valencia, 1992.

- VV.AA., Krzystof Wodiczko, Fundació Antoni Tàpies, Barcelona, 1992.

- VV.AA., Robert Smithson. El paisaje entrópico. Instituto Valenciano de Arte Moderno (IVAM), Valencia, 1993.

- VV.AA., Cinq propositions pour une théorie du paysage Champ Vallon, Seyssel, 1994.

- VV.AA., Piranesi, Generalitat Valenciana, Valencia, 1996. 


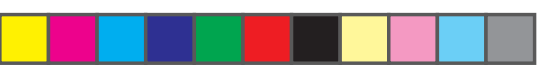

- VV.AA., Zaha Hadid. The Complete Buildings and Projects, Thames \& Hudson, Londres, 1998.

- VV. AA., Mouvance, cinquante mots pour le paysage, Editions de La Villette, Paris, 1999.

- VV. AA., Arquitectes en el Paisatge, Col.legi d'Arquitectes de Catalunya, Girona, 2000.

- VV. AA., Les figures de la marche, Réunion des musées nationaux, Paris, 2000.

- VV.AA., Arquitectura Radical, Generalitat Valenciana, Valencia, 2001.

- VV.AA., Constant, une rétrospective, Musée Picasso Antibes, Antibes, 2001.

- VV.AA., Penser la ville par le paysage, Editions de la Villete, Paris, 2001.

- VV.AA., The Yokohama Project. Foreign Office Architects, Actar, BarceIona, 2002.

- VV.AA., Filogénesis. Las especies de foreign office architects, Actar, Barcelona, 2003.

- VV.AA., Zaha Hadid. Architektur, Hatje Cantz Verlag, Ostfidern-Ruit, 2003.

- VV.AA., Manera de mostrar los jardines de Versalles, Abada editores, Madrid, 2004.

- VV. AA., R. \& Sie...Architects. Spoiled Climate, Arte Prima, Paris, 2004.

- VV.AA., Zaha Hadid. Complete Works (cuatro volúmenes), Thames \& Hudson, Londres, 2004.

- VV.AA., Zaha Hadid 1983-2004, El Croquis, Madrid, 2004.

- V. AA., Paisaje de los Paisajes, Colegio de Arquitectos de la Comunidad Valenciana, Valencia, 2005.

- VV. AA., R \& Sie. I've Heard About..., Musée d'Art Moderne de la Ville de Paris, 2005.

- VV.AA., El espíritu del lugar. Jardín y paisaje en la Inglaterra moderna. Abada, Madrid, 2006. 

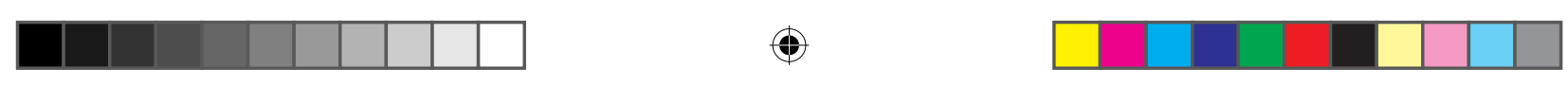

- VV.AA., Nuevas visiones del paisaje, Centro Gallego de Arte Contemporáneo, Santiago de Compostela, 2006.

- VV.AA., Paseantes, Viajeros, Paisajes, Centro gallego de Arte Contemporáneo, Santiago de Compostela, 2007.

- VV.AA., Malas Calles, Instituto Valenciano de Arte Moderno (IVAM), Valencia, 2010.

- VV.VV., El paisaje como idea, proyectos y proyecciones, 1960-1980, Koldo Mitxelena, San Sebastián, 2010.

- VV.AA., Por laberintos, Centre de Cultura Contemporània de Barcelona, Barcelona, 2010. 